Report of Investigations 2008-1

Version 1.0.1

\title{
BRISTOL BAY-ALASKA PENINSULA REGION, OVERVIEW OF 2004-2007 GEOLOGIC RESEARCH
}

\author{
Edited by
}

Rocky R. Reifenstuhl and Paul L. Decker
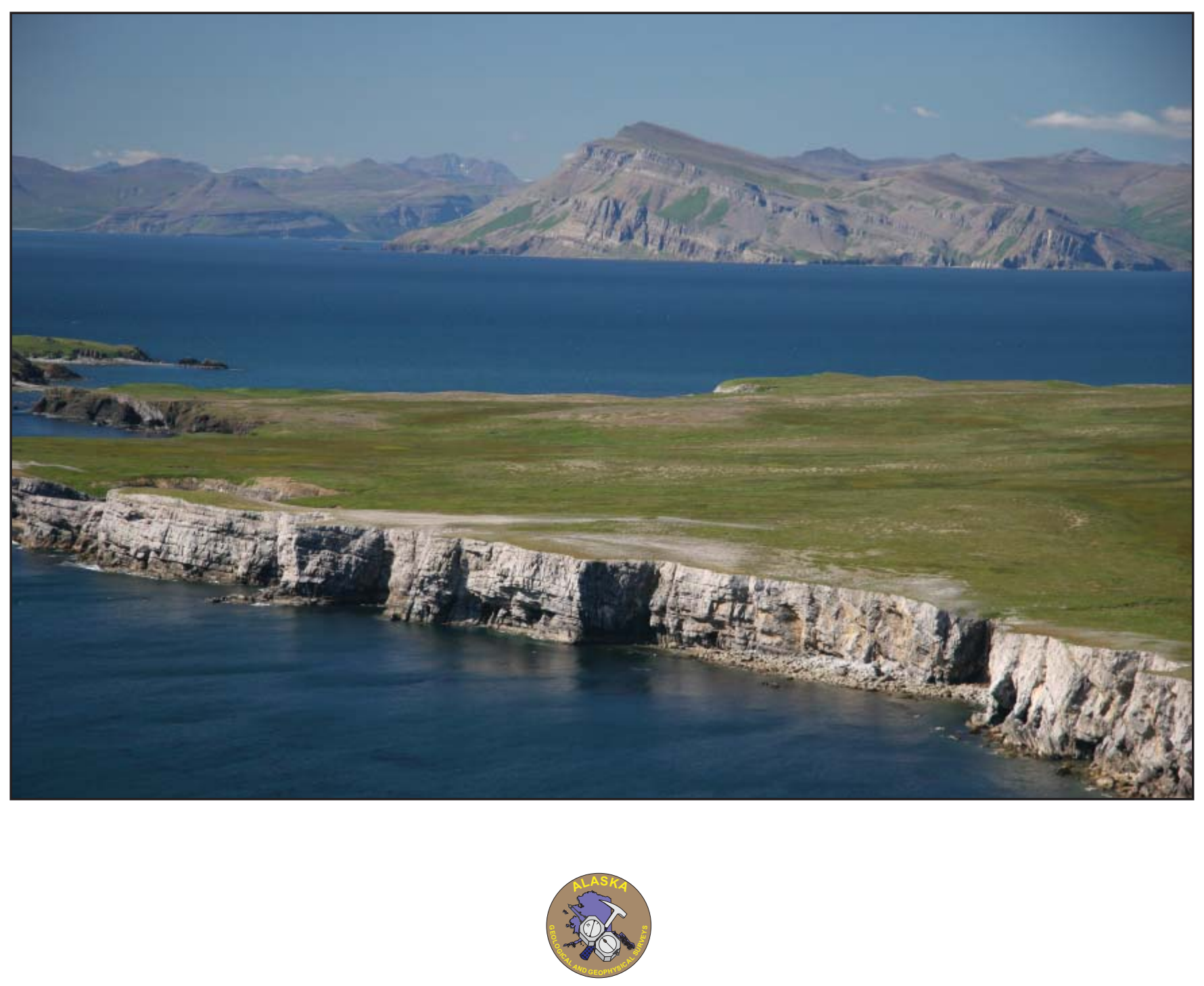

\section{Published by}

STATE OF ALASKA

DEPARTMENT OF NATURAL RESOURCES

DIVISION OF GEOLOGICAL \& GEOPHYSICAL SURVEYS 



\title{
Report of Investigations 2008-1 \\ Version 1.0.1
}

\section{BRISTOL BAY-ALASKA PENINSULA REGION, OVERVIEW OF 2004-2007 GEOLOGIC RESEARCH}

\author{
Edited by \\ Rocky R. Reifenstuhl \\ Alaska Division of Geological \& Geophysical Surveys \\ 3354 College Rd., Fairbanks, Alaska 99709-3707 \\ rocky.reifenstuhl@alaska.gov \\ and \\ Paul L. Decker \\ Alaska Division of Oil \& Gas \\ 550 W. 7th Ave., Suite 800, Anchorage, Alaska 99501-3560 \\ paul.decker@alaska.gov
}

2008

Front cover: View southwest from Cape Kekurnoi across Puale Bay to Cape Aklek, northeast Alaska Peninsula. In the foreground is the shallow-dipping Triassic-age Kamishak Limestone, which contains oil-prone total organic carbon values averaging 1.52 with a maximum of 5.28. Across Puale Bay, the Middle Jurassic-age Shelikof Formation dips beneath the Naknek Formation (just to right of photo). A natural oil seep at Oil Creek, $25 \mathrm{~km}$ southwest of Cape Aklek, flows one-half barrel per day of API $\sim 18$ oil. Photo by R.R. Reifenstuhl.

This DGGS Report of Investigations is a final report of scientific research.

It has received technical review and may be cited as an agency publication. 



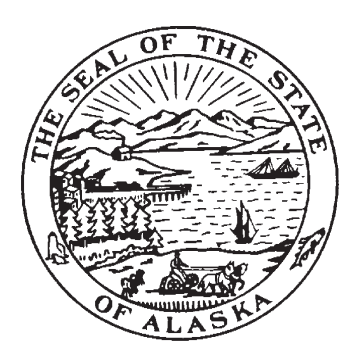

STATE OF ALASKA

Sarah Palin, Governor

DEPARTMENT OF NATURAL RESOURCES

Tom Irwin, Commissioner

\title{
DIVISION OF GEOLOGICAL \& GEOPHYSICAL SURVEYS Robert F. Swenson, State Geologist and Director
}

Publications produced by the Division of Geological \& Geophysical Surveys can be examined at the following locations. To order publications, contact the Fairbanks office.

\author{
Alaska Division of Geological \& \\ \& Geophysical Surveys \\ 3354 College Road \\ Fairbanks, Alaska 99709-3707
}

Elmer E. Rasmuson Library

University of Alaska Fairbanks

Fairbanks, Alaska 99775-1005
Alaska Resource Library \& Information Services (ARLIS)

3150 C Street, Suite 100

Anchorage, Alaska 99503

University of Alaska Anchorage Library

3211 Providence Drive

Anchorage, Alaska 99508

\begin{abstract}
Alaska State Library
State Office Building, 8th Floor

333 Willoughby Avenue

Juneau, Alaska 99811-0571
\end{abstract}

This publication released by the Division of Geological \& Geophysical Surveys was produced and printed in Fairbanks, Alaska, at a cost of $\$ 62$ per copy. Publication is authorized by Alaska Statute 41, which charges the division "to determine the potential of Alaskan land for production of metals, minerals, fuels, and geothermal resources; the location and supplies of groundwater and construction materials; the potential geologic hazards to buildings, roads, bridges, and other installations and structures; and shall conduct such other surveys and investigations as will advance knowledge of the geology of Alaska.” 



\section{CONTENTS}

Executive summary

vii

Rocky R. Reifenstuhl

A. Introduction.

1

Rocky R. Reifenstuhl

B. Mesozoic and Cenozoic source rock-characteristics, Puale Bay outcrops and North Aleutian Shelf COST \#1 Well

Paul L. Decker

C. Reservoir quality of 84 Tertiary sandstones from three exploratory wells, Bristol Bay basin, Alaska Peninsula

Kenneth P. Helmold, Donald W. Brizzolara, and Rocky R. Reifenstuhl

D. Mercury injection capillary pressure and reservoir seal capacity of 26 outcrop samples, Miocene to Triassic age

George W. Bolger and Rocky R. Reifenstuhl

E. Bear Lake Formation microprobe data

Cheryl Hartbauer

F. Structural linkage of major tectonic elements in the Ugashik-Becharof Lakes region, northeastern

Alaska Peninsula

1 folded sheet in envelope

Paul L. Decker, Rocky R. Reifenstuhl, and Robert J. Gillis

G. Kamishak Formation, Puale Bay .....

Michael T. Whalen and Tyler W. Beatty

H. Paleontology and stratigraphy of the Upper Triassic Kamishak Formation in the Puale Bay-

Cape Kekurnoi-Alinchak Bay area, Karluk C-4 and C-5 quadrangle, Alaska Peninsula.

Robert B. Blodgett

I. Revised geologic map and structural model of the Staniukovich Peninsula-Herendeen Bay area.

161

2 folded sheets in envelope

Paul L. Decker, Rocky R. Reifenstuhl, Robert J. Gillis, and Andrea Loveland

J. Fission track geochronology of the North Aleutian COST \#1 Well (OCS-8218), Bristol Bay basin, Alaska

Steven C. Bergman, John Murphy, and Shari Kelley

K. Bibliography of selected references. 



\section{EXECUTIVE SUMMARY}

The Bristol Bay-Alaska Peninsula energy program was a four-year (2004-2007) geological and geophysical research effort funded by the U.S. Department of Energy through the Alaska Energy Technology Development Laboratory (AETDL) of the University of Alaska Fairbanks, and by the Alaska Division of Geological \& Geophysical Surveys (DGGS), the Alaska Division of Oil \& Gas (DOG), and Bristol Bay Native Corporation. DGGS was the lead agency for all field work and outcrop data compilation. In a closely associated effort related to the renewal of oil and gas leasing on the Alaska Peninsula, DOG compiled and distributed uninterpreted, publicly-available geological and geophysical data. Geologists from Purdue University, Bristol Bay Native Corporation (consultant), U.S. Geological Survey, energy companies, and consulting firms also participated in various phases of the project. All data through the 2006 field season have been published previously in peer-reviewed Division of Geological \& Geophysical Surveys reports (available online at www.dggs.dnr.state.ak.us/publications). All rock and data collected during the fieldwork are archived at the DGGS Geologic Materials Center, Eagle River, Alaska.

In addition to an introductory overview and an extended bibliography of relevant geologic literature, this volume contains the final series of nine stand-alone interpretive reports associated with these investigations. This volume does not represent a comprehensive review of all the project's findings or of the region's energy potential. Some important aspects of the project are best documented elsewhere, including previous DGGS publications and other journals.

- Chapter A (Reifenstuhl, this volume) provides a brief overview of the four year project, summarizes the evidence for Cenozoic and Mesozoic petroleum systems, outlines the contributions of the reports contained in this volume and reviews previous geological work in the region, including prior publications associated with this project.

- Chapter B (Decker, this volume) presents new outcrop geochemical data for the Triassic Kamishak and Jurassic Kialagvik Formations at Puale Bay alongside pre-existing data for Tertiary units encountered in the North Aleutian Shelf COST \#1 well. The accompanying analysis characterizes each formation in terms of total organic carbon content, kerogen composition, thermal maturity, and potential for generating and expelling oil and gas. The new data confirm previous descriptions of the Mesozoic source rock units as highly oil prone and are the first to confirm the section's immature to early oil-window thermal maturity previously indicated only by pyrolysis data. The Cenozoic backarc basin fill is dominated by terrestrially-sourced coaly kerogen, and is prospective for natural gas sourced from mature horizons in fault-bounded structural lows.

- Chapter C (Helmold, Brizzolara, and Reifenstuhl this volume) describes the reservoir quality and underlying petrographic characteristics of Alaska Peninsula formations, with particular emphasis on Tertiary sandstones sampled in core from five wells. Data from these samples are augmented by analyses of outcrop samples from a variety of Tertiary and Mesozoic units collected over the course of the project, and from publicly available data collected by industry field programs. Bear Lake and Stepovak Formation sandstones represent the most likely high-quality petroleum reservoirs.

- Chapter D (Bolger and Reifenstuhl, this volume) characterizes the seal capacity that can be expected within Mesozoic and Cenozoic petroleum systems of the region, as defined by mercury injection capillary pressure analyses. Of 26 outcrop samples from the Kamishak, Staniukovich, Tolstoi, Stepovak, and Bear Lake Formations, 12 are shown to be capable of supporting a gas column in excess of $300 \mathrm{~m}(1,000 \mathrm{ft})$ of gas, or an oil column of at least $400 \mathrm{~m}(1,300 \mathrm{ft})$, assuming "standard" reservoir fluid properties. Four of these samples are argillaceous siltstones within the Bear Lake Formation, representing a facies commonly interbedded with high quality potential reservoir sandstones. These are important and encouraging findings, given that seal capacity was identified early in the project as a key uncertainty, particularly for the Cenozoic petroleum system on the Alaska Peninsula.

- Chapter E (Hartbauer, this volume) briefly demonstrates the use of microprobe techniques in assessing variations in composition and alteration of sandstones from the Bear Lake Formation. Applied so far to samples from outcrops near the type section, these techniques show promise for investigating the provenance and diagenetic history of Alaska Peninsula sandstones on a more regional scale.

- Chapter F (Decker, Reifenstuhl and Gillis, this volume) integrates outcrop, well, seismic, and magnetic data to recognize and define several new major tectonic elements in the Ugashik-Becharof Lakes region near the northeastern end of the North Aleutian basin, and interpret how they may have interacted during Cenozoic time. This report provides evidence that the largely Neogene fill of the Ugashik sub-basin was deposited on the formerly upthrown block of the Bruin Bay fault. This occurred as a response to transtensional subsidence made possible by 
upthrown block of the Bruin Bay fault. This occurred as a response to transtensional subsidence made possible by linkage of the Ugashik Lakes fault system with cross faults of the Becharof discontinuity.

- Chapter G (Whalen and Beatty, this volume) and Chapter H (Blodgett, this volume) both describe aspects of the Upper Triassic Kamishak Formation revealed in outcrops near the mouth of Puale Bay. The former describes and interprets lithofacies observed in detailed measured section analyses conducted during 2007. It also includes a brief overview of a subset of the outcrop geochemical data presented in Chapter B (Decker, this volume). Blodgett (this volume) emphasizes paleontological details of the formation gleaned from previously published literature, unpublished U.S. Geological Survey internal reports, and new collections made by the author during field investigations in 2007. Among other findings, both of these papers assert the significance of a probable basal angular unconformity separating the Kamishak Formation from underlying agglomerate, volcaniclastic sandstone, and limestone strata believed to be of Permian age.

- Chapter I (Decker, Reifenstuhl, Gillis, and Loveland, this volume) provides a preliminary geologic map and structural model for the Staniukovich peninsula-Herendeen Bay area south of Port Moller. This mapping covers much of the best exposures within the boundaries of the areawide lease sale, including most of the onshore acreage that received bids in the two sales since 2005. This study resolves major inconsistencies between previous geologic maps and structural interpretations of the area, and provides new understanding of the local geologic framework as it affects oil and gas potential. These results are relevant not only to these tracts and immediately adjacent areas, but also to evaluating regional structural models.

- Chapter J (Bergman, Murphy, and Kelley, this volume) reports the results of zircon and apatite fission track geochronology analyses conducted on Eocene to Miocene core samples from the North Aleutian Shelf COST \#1 well. The authors conclude that this part of the back-arc basin has probably witnessed a simple Tertiary subsidence history with paleo-heat flow akin to the present regime, with a mean geothermal gradient of $31^{\circ} \mathrm{C} / \mathrm{km}$. In addition, patterns of uranium content versus depth suggest the progressive unroofing of an evolving magmatic arc; deeper samples represent more primitive (uranium-depleted) igneous rocks, and shallower samples represent a more evolved (uranium-enriched) igneous suite.

- Chapter K is simply an extended bibliography of geologic literature relevant to the Alaska Peninsula region. It contains all references cited in the other chapters of this volume, in addition to numerous other publications that may be useful to readers of this report. 


\title{
INTRODUCTION
}

\author{
by \\ Rocky R. Reifenstuhl ${ }^{1}$
}

\begin{abstract}
From 2004 through 2007, the Alaska Division of Geological \& Geophysical Surveys led four partial field seasons dedicated to petroleum systems research in the Port Moller, Chignik, Ugashik Lakes, and Puale Bay areas of the Bristol Bay-Alaska Peninsula region. A collaborative effort with the Alaska Division of Oil and Gas and researchers from other organizations, this project has yielded significant new geologic field data, laboratory analyses, and interpretations integrated with subsurface and geophysical data. Our findings document fundamental characteristics of the region's source rocks, reservoir units, seal facies, and structural styles, which collectively determine the oil and gas endowment of the onshore portion of the Bristol Bay - North Aleutian basin. This volume represents the final series of new interpretive reports associated with this four-year project. Some of these chapters contain additional data or observations that supplement or supersede previous findings, but most of the topics covered in previous publications are not included here.

Twenty-eight wells have been drilled since oil and gas exploration began on the Alaska Peninsula over a century ago. The establishment of the Alaska Peninsula areawide oil and gas lease sale in 2005 offered the first access for energy exploration in the region in over two decades. The sale area encompasses 23,470 $\mathrm{km}^{2}$ (5.8 million ac), mostly in the Bristol Bay lowlands on the northwest side of the Alaska Peninsula. Only eleven wells, all drilled between 1959 and 1985, have tested prospects on State lands available for exploration in the areawide sale. Quantitative assessment of the oil and gas resource endowment for the areawide sale is outside the scope of this study. Limited by a critical lack of subsurface data, the 1995 U.S. Geological Survey resource assessment assigned modest oil and gas potential to the onshore Alaska Peninsula. Potential may be greater offshore in federal waters of the North Aleutian basin, where a 2006 resource assessments by the U.S. Minerals Management Service yield mean, technically recoverable resource estimates of 753 million barrels of oil and natural gas liquids, and 244 million $\mathrm{m}^{3}$ (8.6 trillion $\mathrm{ft}^{3}$ [TCF]) of natural gas.

Though past exploration has not yielded commercial production, there are indications that the necessary components of active petroleum systems may be present in both Mesozoic and Cenozoic successions. Source presence and effectiveness are demonstrated by the presence of significant oil and thermogenic gas seeps in Mesozoic units, and by subsurface thermogenic and biogenic gas shows in Tertiary units in wells. Mesozoic sandstones are degraded by zeolites, but may function as tight-gas reservoirs, particularly in the presence of favorable fracture systems, and the carbonates of the Triassic Kamishak Formation may locally develop reservoir quality. Reservoir presence and effectiveness is much more promising in Tertiary formations, in particular the Miocene Bear Lake Formation, as confirmed by petrographic and porositypermeability analyses of outcrop and well samples. The area's complex stratigraphic and structural history suggests that structural and unconformity-related stratigraphic trapping configurations are likely present. Seal capacity studies demonstrate that both Mesozoic and Cenozoic formations could contain significant hydrocarbon columns.
\end{abstract}

\section{PETROLEUM SYSTEMS OVERVIEW}

This volume contains previously unpublished findings from field, office, and laboratory research conducted between 2004 and 2007, focused on petroleum system studies of the Alaska Peninsula. The study area extends from Cathedral River, Pavlov Bay, and Port Moller on the southwest to the Ugashik Lakes and Puale Bay on the northeast (fig. 1). The topical papers presented here have undergone outside peer review, and this entire volume is publicly available on the Division of Geological \& Geophysical Surveys' website (www.dggs.dnr.state.ak.us). The DGGS website has a searchable publications database from which all project reports may be downloaded (no charge) or purchased as paper copies. Information in this report is particularly relevant to hydrocarbon resources and exploration models on lands offered for oil and gas leasing in the Alaska Peninsula areawide lease sale. More information pertinent to this areawide lease sale, including maps and posters illustrating geopolitical, geological, and geophysical data, biostratigraphic interpretations, and other data is available for free download from the Alaska Division of Oil and Gas (DOG) website (http://www.dog.dnr.state.ak.us/oil/products/publications/akpeninsula/ak_peninsula.htm). 
The State of Alaska reopened the frontier Bristol Bay basin (also known as the North Aleutian basin) for oil and gas leasing on State acreage after a two-decade hiatus in 2005. The new areawide sale encompasses some 23,470 km² (5.8 million ac), mostly in the Bristol Bay lowlands on the northwest side of the Alaska Peninsula. Two State-administered Alaska Peninsula areawide oil and gas lease sales have been held to date (October 2005 and February 2007), but at the time of this writing, there are no announced plans for seismic data acquisition or exploratory drilling on State-issued leases in the region. Of the 28 previously-drilled exploration wells and sidetrack holes on the Alaska Peninsula, eleven are within the limits of the areawide sale, all drilled between 1959 and 1985 (fig. 2). Drilling on the Alaska Peninsula began in 1903 with the Costello-1 well (222 m [728 ft] total depth). The most recent well drilled onshore was the Becharof-1, completed in 1985 (2,750 m [9,023 ft] total depth). The offshore North Aleutian Shelf COST-1 well was drilled in 1982-83 (5,229 m [17,155 ft] total depth), bottoming in Eocene-age Tolstoi Formation (Sherwood and others, 2006).
Oil or gas shows were reported in the majority of Alaska Peninsula wells, but no oil or gas has been commercially produced. Citing a critical lack of subsurface information, Magoon and others (1996) estimated that Cenozoic and Mesozoic plays in onshore areas of the Alaska Peninsula have only modest oil and gas endowment. Historically, oil has been the focus of exploration, and little drilling has been devoted to gas, for which potential may be greatest in the Miocene-age Bear Lake Formation (Hite, 2004). Offshore, in federally managed waters of the North Aleutian basin, Sherwood and others (2006, p. 84) estimated mean, undiscovered, technically recoverable nonassociated gas resources in the Bear Lake Formation-Stepovak Formation (Miocene-Oligocene) gas play at 5.473 trillion $\mathrm{ft}^{3}$ (TCF). This represents the most prospective play assessed in the basin, where the total mean, undiscovered, technically recoverable resource for all plays in federal waters is estimated at 753 million barrels of oil and natural gas liquids, and 8.6 trillion $\mathrm{ft}^{3}$ gas (Sherwood and others, 2006, p. 84).

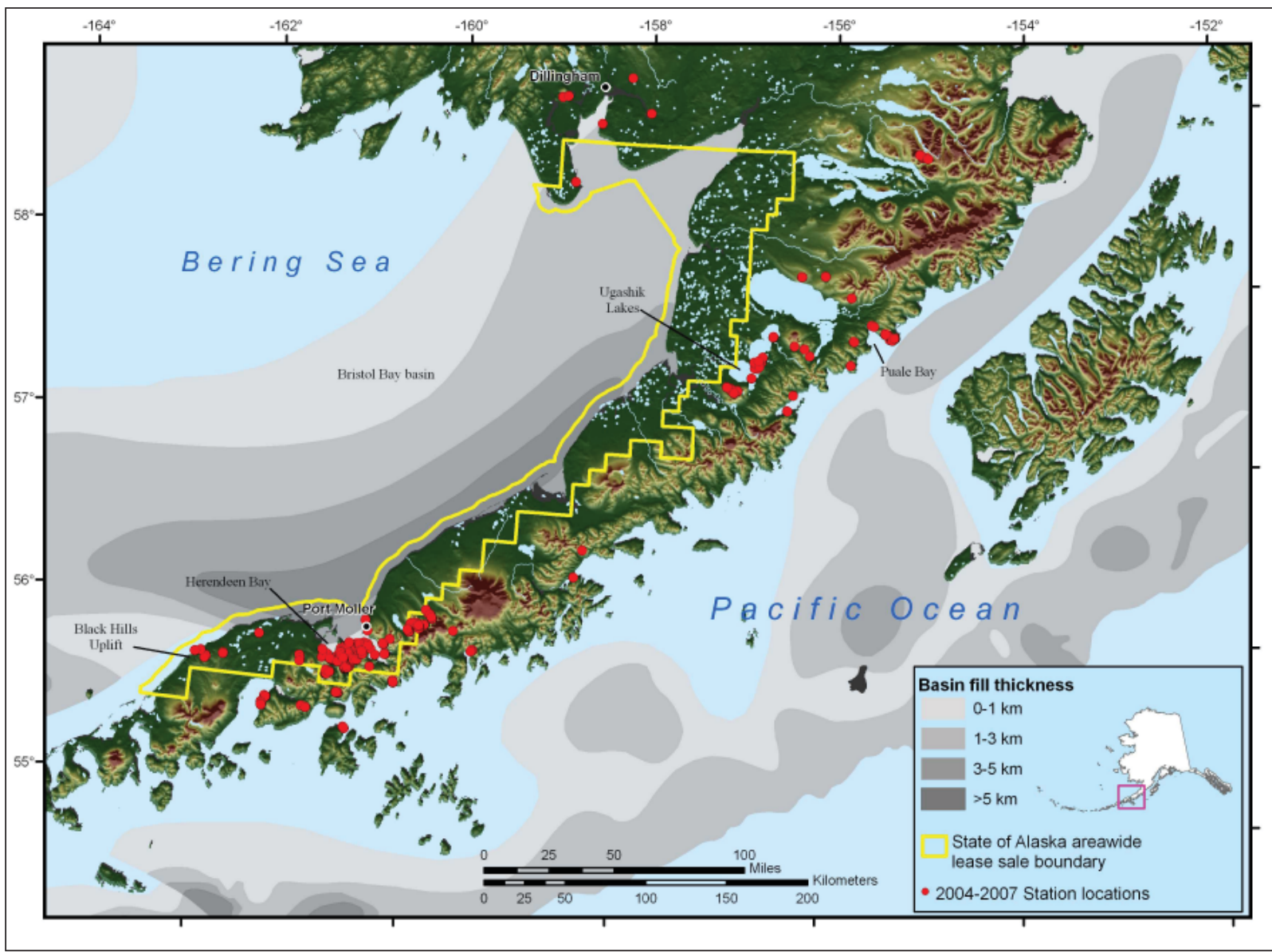

Figure 1. Location map of Alaska Peninsula, State Division of Oil and Gas Areawide Lease Sale, and general location of field stations and samples. 
Most of the research conducted over the course of this project, including several of the studies published in this volume, addressed the geology of State lands on the northwestern side of the Alaska Peninsula, near the thicker, southern edge of the asymmetric Bristol Bay back-arc basin. Cenozoic basin-fill thicknesses range from greater than 4,500 $\mathrm{m}(>15,000 \mathrm{ft})$ below state waters to zero in nearby uplifts (fig. 1). The presence of Mesozoic rocks at oil-window maturity at the surface on the Black Hills uplift $40 \mathrm{~km}(25 \mathrm{mi})$ southwest of Port Moller, and in the Staniukovich peninsula area, $8 \mathrm{~km}$ (5 mi) southwest of Port Moller, indicate substantial local uplift adjacent to the basin's southern margin. A complex subsidence and uplift history introduces elements of both prospectivity and exploration risk to structural and stratigraphic plays in Mesozoic and Cenozoic units along the basin's southern margin (Finzel and others, 2005; Decker, this report).

While neither Mesozoic nor Cenozoic petroleum systems have been proven by significant oil or gas discoveries, there is substantial evidence that all their necessary components exist at various places within the region. Triassic and/or Jurassic source rocks generate oil and gas seeps on the southeastern Alaska Peninsula in the Wide Bay and Oil Creek areas (Magoon and Anders, 1992). One of these seeps flows 18 degree API gravity oil at an estimated rate of one-half barrel per day, along with a small amount of combustible gas. Over time, this flowing seep has created a large asphaltic mat overgrown by surface vegetation (Reifenstuhl and others, 2004; Finzel and others, 2005). Nearby at Puale Bay, Triassic Kamishak Formation limestones and Jurassic Kialagvik Formation mudstones contain excellent oil-prone source rocks, with total organic carbon values of up to 5.3 percent and 3.5 percent, respectively, and hydrogen indices as high as $756 \mathrm{mg} / \mathrm{g}$ and $680 \mathrm{mg} / \mathrm{g}$, respectively (Decker, this volume). These Mesozoic units are the likely source of thermogenic methane that seeps vigorously from the Lower Cretaceous Herendeen Formation near the axis of a major surface anticline in the sale area (Port Moller hot spring, northeastern Staniukovich peninsula; Decker and others, 2005; Decker and others, this report ). Reservoir potential in Jurassic sandstones appears to be regionally degraded by zeolite mineralization (Helmold, Brizzolara, and Reifenstuhl, this volume). Under the most favorable conditions, these low porosity and permeability units

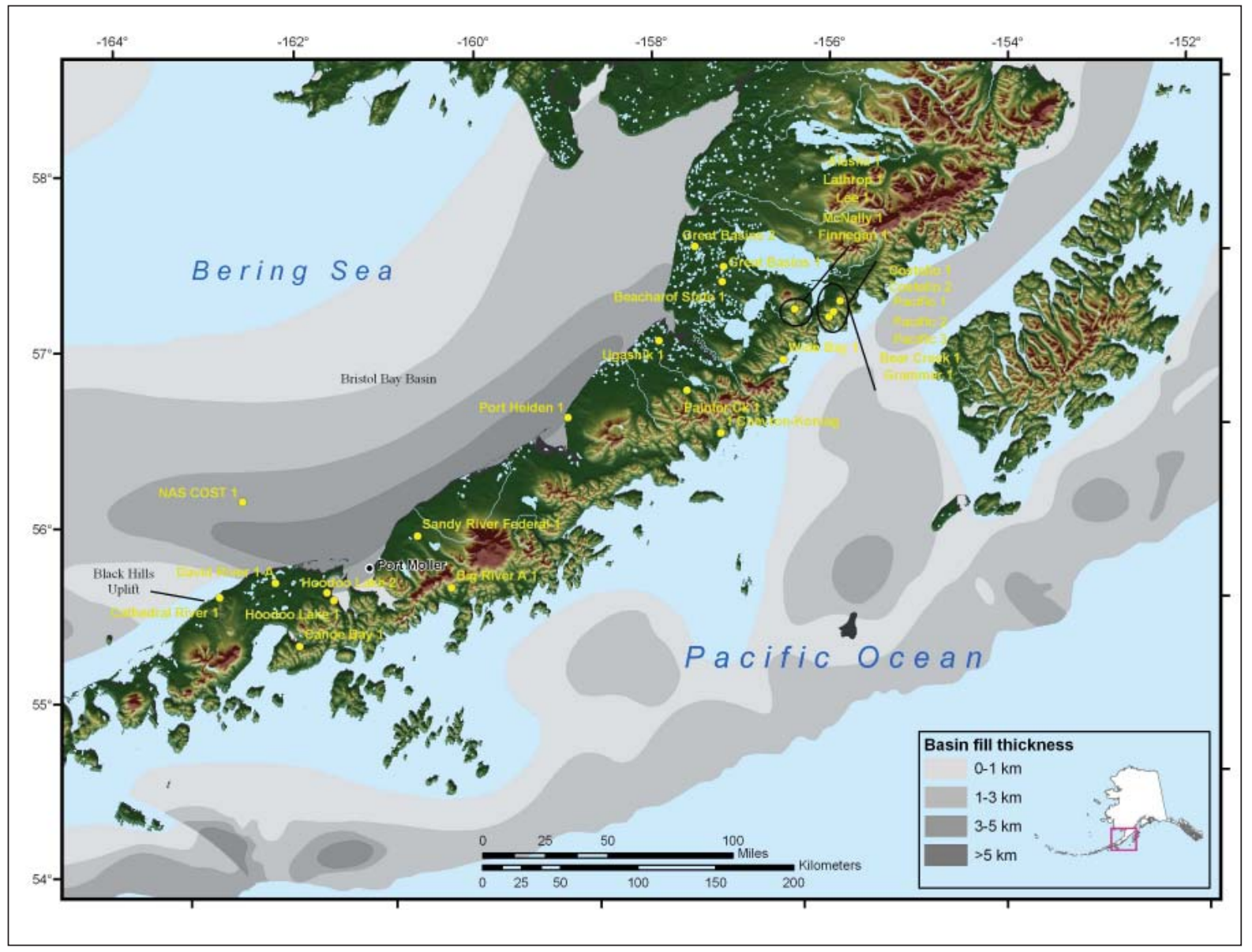

Figure 2. Alaska Peninsula, generalized basin thickness, and wells. 
may constitute gas reservoirs, particularly where highly fractured. Magoon and others (1996), Sralla and Blodgett (2007), and Blodgett and Sralla (2008) speculate that reefoid or biostromal facies of the Kamishak Formation may locally possess reservoir quality in the subsurface. Finally, deformation and erosional events associated with multiple stages tectonism in the region are likely to have generated structural and/or unconformity-related traps. Mesozoic reservoirs may be sealed by marine mudstones of the Lower Cretaceous Staniukovich Formation, which have been shown locally to have good seal capacity (Strauch and others, 2006; Loveland and others, 2007; Helmold, Brizzolara, and Reifenstuhl, this volume; Bolger and Reifenstuhl, this volume).

Source characteristics of the potential Cenozoic petroleum system indicate that the succession filling the back-arc basin is mainly prospective for natural gas. Depending on thermal maturity, Upper Cretaceous to Tertiary coals and carbonaceous mudstones of the Chignik, Tolstoi, Stepovak, and Bear Lake Formations should be excellent sources for either thermogenic or biogenic gas. Rock-Eval and kerogen analyses suggest that Paleogene coals and carbonaceous shales of the Tolstoi Formation may have marginal capacity to generate light oil or condensate, and isotopic- and gas-wetness data support a liquids-associated thermogenic origin for some gas shows encountered in Tertiary sandstones, but their effectiveness as sources of petroleum liquids is probably severely limited by low expulsion efficiency (Decker and others, 2006; Decker, this volume). Several Tertiary sandstones have fair to excellent potential as oil or gas reservoirs, particularly the Miocene Bear Lake Formation and equivalents (Helmold, Brizzolara, and Reifenstuhl, this volume). Nonmarine to marginal marine mudstones interbedded with reservoir sands locally indicate good seal capacity (Bolger and Reifenstuhl, this volume), similar to those in the partially analogous Tertiary system of Cook Inlet.

\section{REVIEW OF PREVIOUS WORK}

As summarized in detail by Detterman and others (1996), the first systematic geologic investigations in the Alaska Peninsula - Bristol Bay region began shortly after the purchase of Alaska from Russia in 1867. Two phases of U.S. Geological Survey explorations are recorded in more than 20 early reports by W.H. Dall, J.E. Spurr, R.W. Stone, W.W. Atwood, S.R. Capps, R.S. Knappen, G.C. Martin, K.P. Mather, S. Paige, W.R. Smith and others published between 1870 and 1930 . Those studies focused on coal, minerals, and petroleum resource potential, but made important inroads toward defining the regional stratigraphic framework. As petroleum exploration progressed, industry geologists documented their field and subsurface geologic observations in internal reports, some of which are now in the public domain.
For example, Hanna and others (1937) reviewed the petroleum geology of the Bear Creek anticline southwest of Puale Bay in a report to the three-company partnership they represented.

Burk (1965) published a detailed monograph accompanied by and maps and measured sections describing the geologic history, stratigraphy, and structure of the Alaska Peninsula southwest of Wide Bay. His report remains one of the most wide-ranging and thorough references for the region. Wisehart (1971) studied the paleo-environment of the upper and middle Mioceneage Bear Lake Formation, followed by Lyle and others (1979), who provided detailed information on the petroleum-reservoir and source-rock potential of Tertiary and Mesozoic rocks on the Alaska Peninsula area. Lower and Middle Jurassic stratigraphic details in the Puale Bay area were defined by Imlay and Detterman (1977).

Wilson and others (1985) recognized the pronounced structural and thermal differences across the Bruin Bay fault, which runs along the center of the northern Peninsula terrane (Silberling and others, 1985). Wilson and others (1985) defined the exposures on the west side of the Alaska Peninsula as the Iliamna subterrane, rocks structurally complex and overmature in terms of oil and gas potential. In contrast, rocks of the Chignik subterrane lie east of the Bruin Bay fault and are only weakly to moderately folded and are well within the thermal range of oil and gas generation (for example, at Puale Bay). Supporting geologic data included geochronology and whole-rock geochemistry (Wilson and others, 1981; 1992; 1994), mapping (Detterman and others, 1981a; 1987; Wilson and others, 1995), and megafossil identifications (Detterman and others, 1981b). Detterman and others (1996) integrated stratigraphic findings from these and other studies, and erected a detailed yet regional stratigraphic framework of the Alaska Peninsula constraining the geologic and depositional history of the Alaska Peninsula. Geologic mapping and regional geology culminated in the compilation of a regional digital geologic map of the Alaska Peninsula at 1:500,000 scale (Wilson and others, 1999). C.M. Molenaar led the Alaska Peninsula portion of the southern Alaska province oil and gas assessment by Magoon and others (1996) as part of a nationwide assessment by the U.S. Geological Survey. Citing a critical lack of subsurface information, that assessment estimated modest oil and gas potential in Tertiary and Mesozoic plays in onshore areas of the Alaska Peninsula.

Kirschner (1988) compiled a map of Alaska's oil and gas basins, including seismic cross sections, two of which depict the North Aleutian and St. George basins. The regional tectonic history of the Bering Sea and Tertiary basins of the Bering shelf was treated in significant detail by Worrall (1991) in a Geological Society of America Special Paper. The tectonic evolution 
of Bristol Bay, in particular, was interpreted by Walker and others (2003).

The North Aleutian Shelf Co-Owned Stratigraphic Test well \#1 (NAS COST\#1) was completed to 3,833 m (17,155 ft) in 1983, and Turner and others (1988) compiled a geological and operational summary. Later, Sherwood and others (2006) produced an updated oil and resource assessment for the Mineral Management Service's North Aleutian planning area. Their report included numerous findings regarding the NAS COST \#1 well as applied to their assessment including all the downhole sampling and tests.

In preparation for the renewal of onshore leasing Alaska Peninsula areawide sale, the Alaska Division of Oil and Gas released a digital compilation that summarized data availability and presents publicly available digital well logs and seismic data (Meyer and others, 2004). The Bristol Bay Native Corporation underwrote and distributed a comprehensive review of the region's exploration history, data availability, stratigraphic and structural framework, petroleum geology, oil and gas potential, and land ownership (Hite, 2004).

The Alaska Division of Geological \& Geophysical Surveys and the Alaska Division of Oil and Gas began field studies in 2004 in the Puale Bay and Wide Bay regions (Reifenstuhl and others, 2004a, 2004b; Reifenstuhl and others, 2005). Field, office, and laboratory studies expanded during 2005, 2006, and 2007 to include the rest of the study area described in this report, as well as both formal and informal collaborations with academic researchers, consultants, and corporate petroleum geologists. Since 2005, this collaboration has directly or indirectly spawned numerous publications other than those included in this volume.

-Finzel and others (2005) reported on the sedimentology, stratigraphy, and hydrocarbon reservoir source rock potential of Tertiary and Mesozoic strata (fig. 3) from outcrop and subsurface samples and offered a detailed interpretation of the Bear Lake Formation based on several measured sections

-Mickey and others (2005) provided a biostratigraphy study of the northwestern Alaska Peninsula and Bristol Bay based on 11 wells including the NAS COST \#1 well

-Blodgett and Clautice (2005) gave an historic account of the oil and gas seeps of the northern Alaska Peninsula

-Decker and others (2005) presented a wide-ranging report covering details of eight measured sections of the Bear Lake, Stepovak, and Tolstoi Formations, the character of the Miocene-Pliocene unconformity, outcrop structure of the Naknek Formation in the Black Hills uplift, and the Bear Lake Formation in Herendeen Bay, organic geochemistry and coal evaluation, isotope geochemistry of thermogenic gas seep in Herendeen Bay, and geochemistry disproving the existence of the historically-reported oil seeps in the greater Dillingham area

-Strauch and others (2006) and Loveland and others (2007) reported reservoir- and seal-quality analyses from outcrop samples based on porosity and permeability and mercury injection capillary pressure data, which indicated good reservoirs within the Bear Lake Formation and good seals locally in Tertiary and Cretaceous rocks

-Decker and others (2006) summarized supporting evidence for potentially functional Mesozoic and Cenozoic petroleum systems on the Alaska Peninsula, and discussed play concepts for reopening the basin to exploration

-Gillis and others (2007) presented preliminary results of petroleum system field studies in the Port Moller area

-Sralla (2007) presented an interpretation of hydrocarbon exploration potential in the Herendeen Bay region

-Sralla and Blodgett (2007) addressed the reservoir potential of the Triassic Kamishak Formation in the Puale Bay area

-Blodgett and Sralla (2008) reviewed and interpret the Permian/Triassic unconformity and hydrocarbon potential in the Puale Bay region

- Blodgett and others (2008) reported and interpreted a suite of Jurassic-Pliocene megafossils

-Gillis and others (2008) outlined implications of new apatite and zircon fission-track thermochronology for Mesozoic and Tertiary basin margin exhumation on the Alaska Peninsula; and

- Finzel and others (in press) detail their observations, interpretations, and implications of the stratigraphic framework, depositional environment, and reservoir characteristics of the Bear Lake Formation in a frontier, gas-prone basin.

\section{KEY FINDINGS, THIS VOLUME}

The following nine chapters represent stand-alone, peer-reviewed treatments of various topics addressed over the course of this project. The final part of this volume is an extended bibliography for the geologic literature of the Bristol Bay-Alaska Peninsula region.

Chapter B (Decker, this volume) presents new outcrop geochemical data for the Triassic Kamishak and Jurassic Kialagvik Formations at Puale Bay alongside pre-existing data for Tertiary units encountered in the North Aleutian Shelf COST \#1 well. The accompanying analysis characterizes each formation in terms of total organic carbon content, kerogen composition, thermal maturity, and potential for generating and expelling oil and gas. The new data confirm previous descriptions of 


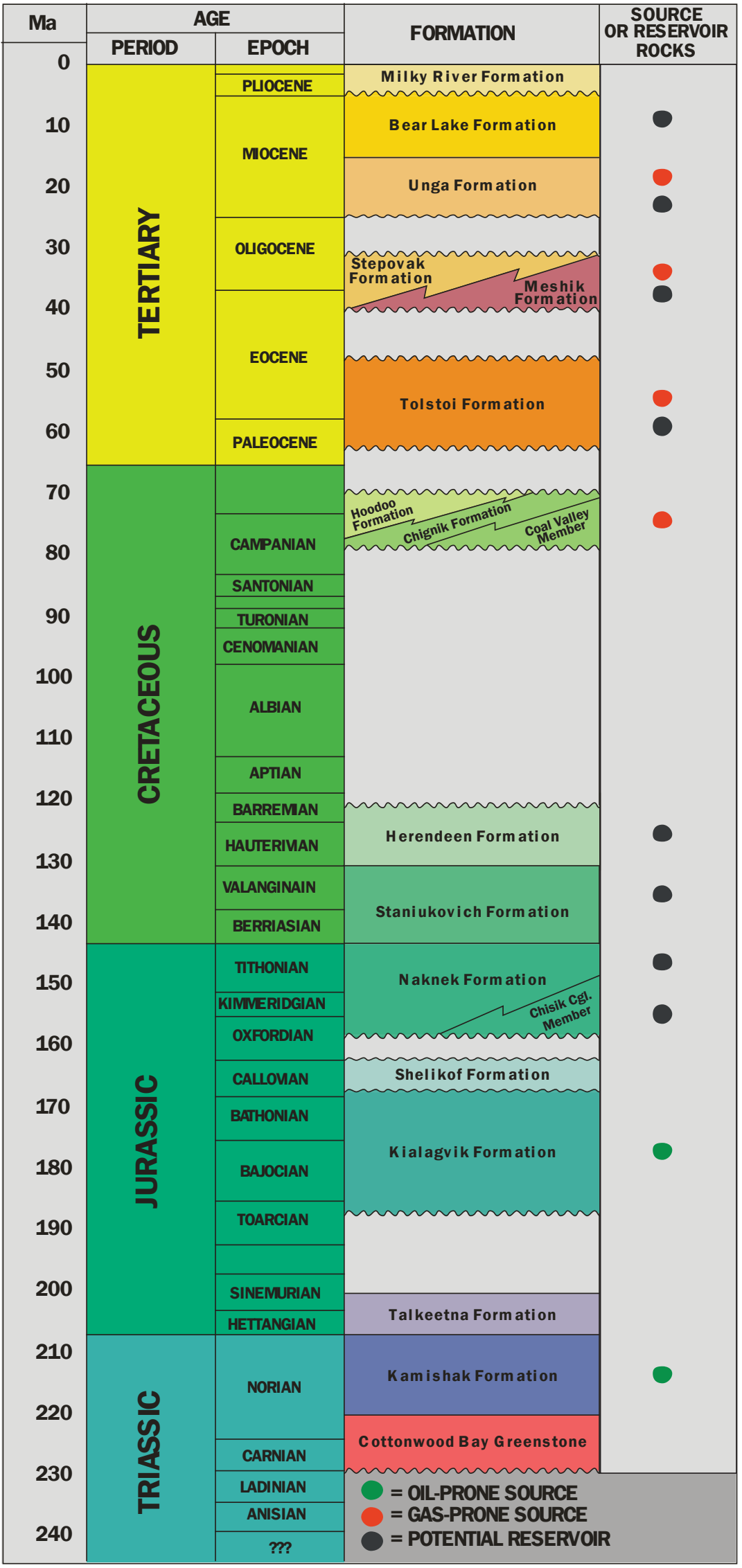

Figure 3. Stratigraphic column for the Alaska Peninsula showing rock formations with generally favorable hydrocarbon source potential (oil prone: green dots; gas prone: red dots) and hydrocarbon reservoir potential (black dots) (modified from Hite, 2004). 
the Mesozoic source rock units as highly oil prone and are the first to confirm the section's immature to early oil-window thermal maturity previously indicated only by pyrolysis data. The Cenozoic backarc basin fill is dominated by terrestrially-sourced coaly kerogen, and is prospective for natural gas sourced from mature horizons in fault-bounded structural lows.

Chapter C (Helmold, Brizzolara, and Reifenstuhl, this volume) describes the reservoir quality and underlying petrographic characteristics of Alaska Peninsula formations, with particular emphasis on Tertiary sandstones sampled in core from five wells. Data from these samples are augmented by analyses of outcrop samples from a variety of Tertiary and Mesozoic units collected over the course of the project, and from publicly available data collected by industry field programs. Bear Lake and Stepovak Formation sandstones represent the most likely high-quality petroleum reservoirs.

Chapter D (Bolger and Reifenstuhl, this volume) characterizes the seal capacity that can be expected within Mesozoic and Cenozoic petroleum systems of the region, as defined by mercury injection capillary pressure analyses. Of 26 outcrop samples from the Kamishak, Staniukovich, Tolstoi, Stepovak, and Bear Lake Formations, twelve are shown to be capable of supporting a gas column in excess of $300 \mathrm{~m}(1000 \mathrm{ft})$ of

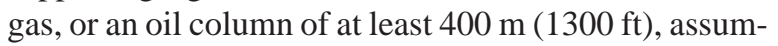
ing "standard" reservoir fluid properties. Four of these samples are argillaceous siltstones within the Bear Lake Formation, representing a facies commonly interbedded with high quality potential reservoir sandstones. These are important and encouraging findings, given that seal capacity was identified early in the project as a key uncertainty, particularly for the Cenozoic petroleum system on the Alaska Peninsula.

Chapter E (Hartbauer, this volume) briefly demonstrates the use of microprobe techniques in assessing variations in composition and alteration of sandstones from the Bear Lake Formation. Applied so far to samples from outcrops near the type section, these techniques show promise for investigating the provenance and diagenetic history of Alaska Peninsula sandstones on a more regional scale.

Chapter F (Decker, Reifenstuhl and Gillis, this volume) integrates outcrop, well, seismic, and magnetic data to recognize and define several new major tectonic elements in the Ugashik-Becharof Lakes region near the northeastern end of the North Aleutian basin, and interpret how they may have interacted during Cenozoic time. This report provides evidence that the largely Neogene fill of the Ugashik sub-basin was deposited on the formerly upthrown block of the Bruin Bay fault. This occurred as a response to transtensional subsidence made possible by linkage of the Ugashik Lakes fault system with cross faults of the Becharof discontinuity.
Chapter G (Whalen and Beatty, this volume) and Chapter $\mathrm{H}$ (Blodgett, this volume) both describe aspects of the Upper Triassic Kamishak Formation revealed in outcrops near the mouth of Puale Bay. The former describes and interprets lithofacies observed in detailed measured section analyses conducted during 2007. It also includes a brief overview of a subset of the outcrop geochemical data presented in Chapter B (Decker, this volume). Blodgett (this volume) emphasizes paleontological details of the formation gleaned from previously published literature, unpublished U.S. Geological Survey internal reports, and new collections made by the author during field investigations in 2007. Among other findings, both of these papers assert the significance of a probable basal angular unconformity separating the Kamishak Formation from underlying agglomerate, volcaniclastic sandstone, and limestone strata believed to be of Permian age.

Chapter I (Decker, Reifenstuhl, Gillis, and Loveland, this volume) provides a preliminary geologic map and structural model for the Staniukovich peninsula-Herendeen Bay area south of Port Moller. This mapping covers much of the best exposures within the boundaries of the areawide lease sale, including most of the onshore acreage that received bids in the two sales since 2005. This study resolves major inconsistencies between previous geologic maps and structural interpretations of the area, and provides new understanding of the local geologic framework as it affects oil and gas potential. These results are relevant not only to these tracts and immediately adjacent areas, but also to evaluating regional structural models.

Chapter J (Bergman, Murphy, and Kelley, this volume) reports the results of zircon and apatite fission track geochronology analyses conducted on Eocene to Miocene core samples from the North Aleutian Shelf COST \#1 well. The authors conclude that this part of the back-arc basin has probably witnessed a simple Tertiary subsidence history with paleo-heat flow akin to the present regime, with a mean geothermal gradient of 31 ${ }^{\circ} \mathrm{C} / \mathrm{km}$. In addition, patterns of uranium content versus depth suggest the progressive unroofing of an evolving magmatic arc; deeper samples represent more primitive (uranium-depleted) igneous rocks, and shallower samples represent a more evolved (uranium-enriched) igneous suite.

\section{REFERENCES CITED}

Blodgett, R.B., and Clautice, K.H., 2005, Oil and gas seeps of the Puale Bay-Becharof Lake-Wide Bay region, northern Alaska Peninsula: Alaska Division of Geological \& Geophysical Surveys Preliminary Interpretive Report 2005-6, 13 p., 1 sheet.

Blodgett, R.B., and Sralla, Bryan, 2008, A major unconformity between Permian and Triassic strata at Cape 
Kekurnoi, Alaska Peninsula; Old and new observations on stratigraphy and hydrocarbon potential, in Haeussler, P.J., and Galloway, J.P., eds., Studies by the U.S. Geological Survey in Alaska, 2006: U.S. Geological Survey Professional Paper 1739-E, 13 p. [http://pubs.usgs.gov/pp/pp1739/e/].

Blodgett, R.B., Finzel, E.S., Reifenstuhl, R.R., Clautice, K.H., Ridgway, K.D., and Gillis, R.J., 2008, Jurassic through Pliocene age megafossil samples collected in 2005 by the Alaska Division of Geological \& Geophysical Surveys from the Bristol Bay-Port Moller area, Alaska Peninsula: Alaska Division of Geological \& Geophysical Surveys Preliminary Interpretive Report 2008-2, 12 p.

Bolger, G.W., and Reifenstuhl, R.R., this volume.

Burk, C.A., 1965, Geology of the Alaska PeninsulaIsland Arc and Continental Margin: The Geological Society of America Memoir 99, 250 p., 3 sheets.

Decker, P.L., this volume.

Decker, P.L., Finzel, E.S., Ridgway, K.D., Reifenstuhl, R.R., and Blodgett, R.B., 2005, Preliminary summary of the 2005 field season; Port Moller, Herendeen Bay, and Dillingham areas, Bristol Bay Basin, Alaska Peninsula: Alaska Division of Geological \& Geophysical Surveys Preliminary Interpretive Report 2005-7, 55 p., 2 sheets.

Decker, P.L., Reifenstuhl, R.R., Finzel, E.S., and Helmold, K.P., 2006, Play concepts for reopening the Bristol Bay basin; Tertiary and Mesozoic petroleum systems of the Alaska Peninsula, (abs): American Association of Petroleum Geologists Bulletin, v. 90, Program Abstracts (digital).

Detterman, R.L., Case, J.E., Miller, J.W., Wilson, F.H., and Yount, M.E., 1996, Stratigraphic framework of the Alaska Peninsula: U.S. Geological Survey Bulletin 1969-A, $74 \mathrm{p}$.

Detterman, R.L., Case, J.E., Wilson, F.H., and Yount, M.E., 1987, Geologic map of the Ugashik, Bristol Bay, and western part of Karluk quadrangles, Alaska: U.S. Geological Survey Miscellaneous Investigations Series Map 1685, 1 plate, scale 1:250,000.

Detterman, R.L., Miller, T.P., Yount, M.E., and Wilson, F.H., 1981a, Geologic map of the Chignik and Sutwik Island quadrangles, Alaska: U.S. Geological Survey Miscellaneous Investigations Series Map 1229, 1 plate, scale 1:250,000.

Detterman, R.L., Yount, M.E., and Case, J.E., 1981b, Megafossil sample locality map, checklists, and stratigraphic sections of the Chignik and Sutwik Island quadrangles, Alaska: U.S. Geological Survey Miscellaneous field Studies Map MF-1053-N, 2 plates, scale 1:250,000.

Finzel, E.S., Reifenstuhl, R.R., Decker, P.L., and Ridgway, K.D., 2005, Sedimentology, stratigraphy, and hydrocarbon reservoir-source rock potential, using surface and subsurface data, of Tertiary and Mesozoic strata, Bristol Bay Basin and Alaska Peninsula: Alaska Division of Geological \& Geophysical Surveys Preliminary Interpretive Report 2005-4, 67 p.

Finzel, E.S., Ridgway, K.D., Reifenstuhl, R.R., Blodgett, R.B., White, J., and Decker, P.L., in press, Stratigraphic framework and estuarine depositional environments of the Miocene Bear Lake Formation, Bristol Bay basin, Alaska: Onshore equivalents to potential reservoir strata in a frontier gas-rich basin: American Association of Petroleum Geologists Bulletin.

Gillis, R.J., Reifenstuhl, R.R., and Decker, P.L., 2008, Implications of new apatite and zircon fission-track thermochronology for Mesozoic and Tertiary basin margin exhumation, upper Alaska Peninsula [abs.], in Garver, J.I., and Montario, M.J., eds., Extended Abstract Volume: FT 2008 - The 11th International Conference on Thermochronometry, Anchorage Alaska, Sept. 15-19, 2008, p. 95, http://www.union. edu/ft2008/Abstract_volume.html.

Gillis, R.J., Reifenstuhl, R.R., Decker, P.L., Strauch, A.L., and Helmold, K.P., 2007, Onshore Alaska Peninsula petroleum system assessment: preliminary summary of outcrop studies of the Port Moller area, 2006 [abs]: American Association of Petroleum Geologists Bulletin, v. 91, Annual Meeting Program Abstracts (digital), http://www.searchanddiscovery. net/documents/2007/07018annual_abs_Ingbch/abstracts/ IbGillis.htm

Hanna, G.D., Leach, C.E., Tallant, R.L., Bryan, J.J., and Scott, E.W., 1937, Preliminary geologic report on the Bear Creek Anticline, Alaska-1937: San Francisco, Tide Water Associated Oil Co.-Standard Oil Co. of California-Union Oil Co. of California internal report, $20 \mathrm{p}$.

Helmold, K.P., and Brizzolara, D.W., 2005, Reservoir quality of Tertiary sandstones from Bristol Bay basin, Alaska Peninsula: preliminary report: Alaska Division of Oil and Gas internal report; http://www. dog.dnr.state.ak.us/oil/products/publications/akpeninsula/ reservoir_quality_report.pdf

Helmold, K.P., Brizzolara, D.W., and Reifenstuhl, R.R., this volume.

Hite, David, 2004, Bristol Bay Native Corporation-Hydrocarbon potential of Native lands in the Bristol Bay area, southern Alaska: BBNC files, Data Set Index No. 774.

Imlay, R.W., and Detterman, R.L., 1977, Some Lower and Middle Jurassic beds in Puale Bay-Alinchak Bay area, Alaska Peninsula: Bulletin of the American Association of Petroleum Geologists, v. 61, no. 4, p. 607-611. 
Kirschner, C.L., 1988, Map showing sedimentary basins of onshore and continental shelf areas, Alaska, U.S. Geological Survey Miscellaneous Investigations Series 1873, 1 plate, scale 1:2,500,000.

Loveland, A.M., Reifenstuhl, R.R., Gillis, R.J., and Decker, P.L., 2007, Outcrop sample results from mercury injection capillary pressure analyses, Bristol Bay, Alaska Peninsula: Alaska division of Geological \& Geophysical Surveys Raw Data File 2007-3, 11 p.

Lyle, W.M., Morehouse, J.A., Palmer, I.F., Jr., and Bolm, J.G., 1979, Tertiary formations and associated Mesozoic rocks in the Alaska Peninsula area, Alaska, and their petroleum reservoir and source-rock potential: Alaska Division of Geological \& Geophysical Surveys Geologic Report 62, 69 p., 19 sheets.

Magoon, L.B., and Anders, D.E., 1992, Oil-to-source rock correlation using carbon-isotopic data and biological marker compounds, Cook Inlet-Alaska Peninsula, Alaska, in Moldowan, J.M., Albrecht, P., and Philip, R.P., eds., Biological Markers in Sediments and Petroleum: Prentice Hall, Englewood Cliffs, New Jersey, p. 241-274

Magoon, L.B., Molenaar, C.M., Bruns, T.R., Fisher, M.A., and Valin, Z.C., 1995, Southern Alaska Province (003), in Gautier, D.L., Dolton, G.L., Takahashi, K.I., and Varnes, K.L., eds., 1995 National Assessment of United States Oil and Gas Resources on CD-ROM: U.S. Geological Survey Digital Data Series 30 (CD-ROM), 21 p.

Meyer, J.F., Jr., Hansen, J.J., Brizzolara, D.W., Pritchard, M.E., Boggess, P.L., Beaty, C.J., Dirks, K.L., Gumpert, J.D., Bolin, K. A., Gibler, K. I., and Phillipson, E.M., 2004, Alaska Peninsula areawide oil and gas lease sale: information and data compilation industry packet: Alaska Division of Oil \& Gas Alaska Peninsula Resource Series (digital, updated 2007).

Mickey, M.B., Haga, H. Boettcher, R.S., and Kling, S.A., 2005, Northwestern Alaska Peninsula-Bristol Bay basin biostratigraphy study: Micropaleo Consultants Job No. 25-104, 287 p., 4 oversize plates, 40 oversize figures, Alaska Division of Oil \& Gas online publication http://www.dog.dnr.state.ak.us/oil/ products/publications/akpeninsula/biostrat.htm

Reifenstuhl, R.R., and McCarthy, Paul, 2004a, Petroleum reservoir characterization, source rock potential, fossil fuel resources, and basin analyses, Bristol Bay Basin, Alaska: AETDL Quarterly Report, October, 2004, 1 p.

Reifenstuhl, R.R., Shafer, D.C., Ryherd, T.J., Brizzolara, D.W., and Blodgett, R.B., 2004b, Summary of May 25-June 4, 2004, field notes and samples, Puale Bay and Wide Bay areas, Alaska Peninsula: Alaska Division of Geological \& Geophysical Surveys Raw Data File 2004-3, 16 p.
Sherwood, K.W., Larson, J., Comer, C.D., Craig, J.D., and Reitmeier, C., 2006, North Aleutian basin OCS planning area assessment of undiscovered technically-recoverable oil and gas: U.S. Minerals Management Service Alaska OCS Region report, 138 p., 4 plates, www.mms.gov/alaska/re/reports/rereport.htm

Silberling, N.J., 1985, Biogeographic significance of the Upper Triassic bivalve Monotis in circum-Pacific accreted terranes, in Howell, D.G., ed., Tectonostratigraphic terranes of the Circum-Pacific region: Circum-Pacific Council for Energy and Mineral Resources Earth Sciences Series No. 1, p. 63-70.

Sralla, Bryan, 2007, Structural geometry, kinematics, and hydrocarbon exploration potential of Sapsuk Lake anticline, Herendeen Bay region, Alaska Peninsula [abs]: Alaska Geology, v. 38, no. 1, p. 1-2.

Sralla, Bryan, and Blodgett, R.B., 2007, Reservoir potential of Late Triassic Kamishak Formation; Puale Bay, Alaska Peninsula [abs.]: American Association of Petroleum Geologists Annual Convention \& Exhibition, Long Beach, CA, 2007, Abstracts, v. 91 (digital), p. 132.

Strauch, A.L., Gillis, R.J., Reifenstuhl, R.R., and Decker, P.L., 2006, 2006 Bristol Bay, Alaska Peninsula field summary and outcrop sample results from porosity \& permeability and mercury injection capillary pressure analyses: Alaska Division of Geological \& Geophysical Surveys Raw Data File 2006-1, 65 p.

Turner, R.F., McCarthy, C.M., Lynch, M.B., Hoose, P.J., Martin, G.C., Larson, J.A., Flett, T.O., Sherwood, K.W., and Adams, A.J., 1988, Geological and operational summary, North Aleutian Shelf COST No. 1 well, Bering Sea, Alaska: Minerals Management Service, Alaska OCS Region, OCS Report MMS 88-089, 256 p., 2 plates.

Walker, K.T., McGeary, S.E., and Klemperer, S.L., 2003, Tectonic evolution of the Bristol Bay basin, southeast Bering Sea: Constraints from seismic reflection and potential field data: Tectonics, v. 22, no. 5, p. 19.

Wilson, F.H., and Shew, N., 1992, Map and tables showing geochronology and whole-rock geochemistry of selected samples, Ugashik and part of Karluk quadrangles, Alaska: U.S. Geological Survey Miscellaneous Field Studies Map MF-1539-E, 12 p., 1 plate, scale 1:250,000.

Wilson, F.H., Detterman, R.L., and Case, J.E., 1985, The Alaska Peninsula terrane; A definition: U.S. Geological Survey Open-File Report 85-450, 17 p. Wilson, F.H., Detterman, R.L., and Case, J.E., 1985, The Alaska Peninsula terrane; A definition: U.S. Geological Survey Open-File Report 85-450, 17 p.

Wilson, F.H., Detterman, R.L., and DuBois, Gregory, 1999, Digital data for the geologic framework of the Alaska Peninsula, sSouthwest Alaska, and the Alaska Peninsula Terrane: U.S. Geological Survey 
Open-File Report 99-317, 41 p., 1 plate, scale 1:500,000, http://wrgis.wr.usgs.gov/open-file/of99-317.

Wilson, F.H., Detterman, R.L., Miller, J.W., and Case, J.E., 1995, Geologic map of the Port Moller, Stepovak Bay, and Simeonof Island quadrangles, Alaska Peninsula, Alaska: U.S. Geological Survey Miscellaneous Investigations Series Map I-2272, 2 plates, scale $1: 250,000$.

Wilson, F.H., Gaum, W.C., and Herzon, P.L., 1981, Maps and tables showing geochronology and whole-rock geochemistry, Chignik and Sutwik Island quadrangles, Alaska: U.S. Geological Survey Miscellaneous Field Studies Map MF-1053-M, 3 plates, scale 1:250,000.
Wilson, F.H., Shew, N., DuBois, G.D., and Bie, S.W., 1994, Sample locality map and analytical data for potassium-argon ages in the Port Moller, Stepovak Bay, and Simeonof Island quadrangles, Alaska Peninsula: U.S. Geological Survey Miscellaneous Field Studies Map MF-2155-E, 18 p., 1 plate, scale $1: 250,000$.

Wisehart, R.M., 1971, Paleoenvironmental analysis of the Bear Lake Formation (upper and middle Miocene), Alaska Peninsula, Alaska: Los Angeles, CA, University of California, M.S. thesis, 112 p.

Worrall, D.M., 1991, Tectonic history of the Bering Sea and the evolution of Tertiary strike-slip basins of the Bering Shelf: Geological Society of America Special Paper 257, 120 p., 1 oversize sheet, 4 plates. 


\title{
MESOZOIC AND CENOZOIC SOURCE-ROCK CHARACTERISTICS, PUALE BAY OUTCROPS AND NORTH ALEUTIAN SHELF COST \#1 WELL
}

\author{
by \\ Paul L. Decker ${ }^{1}$
}

\begin{abstract}
New outcrop geochemical data for Mesozoic source rocks of the Alaska Peninsula are presented alongside similar pre-existing data from Tertiary units of the North Aleutian basin, facilitating direct comparison of key characteristics that determine the type and quantity of expelled petroleum. Consisting of total organic carbon, Rock-Eval pyrolysis, kerogen petrography, and vitrinite reflectance data from samples of Triassic Kamishak and Jurassic Kialagvik Formation exposures at Puale Bay, the new data confirm previous descriptions of these source-rock units as highly oil-prone. More importantly, this dataset establishes important distinctions between the two Mesozoic formations, and provides constraints on the stratigraphic variations and lithofacies associations of the quantity and type of organic matter within each unit. Additionally, the Puale Bay vitrinite reflectance data are the first to confirm the section's immature to early oil-window thermal maturity previously indicated only by pyrolysis data. The same approach applied to Tertiary formations penetrated in the North Aleutian Shelf COST \#1 well and a small population of outcrop coal samples provides details supporting the conclusion reached by previous workers that the Cenozoic backarc basin fill is dominated by terrestrially-sourced coaly kerogen, and is most prospective for natural gas. Though certain facies may possess marginal capability to generate petroleum liquids, particularly carbonaceous mudstones within the Tolstoi Formation and some coals of the Bear Lake Formation, high matrix adsorption effects are likely to limit expulsion efficiency, minimizing the likelihood of significant Tertiary-sourced oil accumulations in the basin.
\end{abstract}

\section{INTRODUCTION}

The Alaska Peninsula hosts potential petroleum systems of both Mesozoic and Cenozoic age (Finzel and others, 2005; Sherwood and others, 2006; Decker and others, 2006; Reifenstuhl and others, 2007), but to date neither has yielded commercial production. A significant difference between these two petroleum systems is that source rocks of the Mesozoic system contain dominantly oil-prone marine organic matter (Wang and others, 1988; Magoon and Anders, 1992), whereas those of the Cenozoic system are dominated by gas-prone terrestrial kerogens (Dow, 1983; Turner and others, 1988; Sherwood and others, 2006).

On the southeastern side of the northern Alaska Peninsula near Wide Bay, Becharof Lake, and Puale Bay, surface petroleum seeps leave no doubt that the Mesozoic petroleum system contains effective oil and gas source rocks. At least 14 historically active seeps of oil or flammable gas in this area have been catalogued by Blodgett and Clautice (2005) as emanating from Jurassic rocks of the Chignik subterrane, the southeastern block of the Alaska Peninsula terrane (fig. 1; Wilson and others, 1985, 1999). Magoon and Anders $(1990,1992)$ presented biomarker and isotopic evidence linking these seeps to the underlying Upper Triassic Kamishak Formation and the mostly Middle Jurassic Kialagvik Formations (fig. 2). Age-equivalent source-rock units extend northeastward beneath much of the Cook Inlet basin, where the Middle
Jurassic Tuxedni Group is the principal source of oil in commercial fields in upper Cook Inlet, and Upper Triassic strata contribute to non-commercial oil occurrences in lower Cook Inlet (Magoon and Claypool, 1981; Magoon and Anders, 1990, 1992; Magoon, 1994).

In contrast, the Quaternary-covered northwestern side of the northern Alaska Peninsula (Bristol Bay Lowlands area) is devoid of active hydrocarbon seeps. There, in the northeast portion of the North Aleutian basin, the three wells that penetrate the full Cenozoic sedimentary and volcanic section of the Ugashik subbasin (fig. 1; Decker, Reifenstuhl and Gillis, this volume) are interpreted to pass directly into Mesozoic igneous and metamorphic basement of the Iliamna subterrane of the Alaska Peninsula terrane (Wilson and others, 1985; 1999), without encountering source-prone Mesozoic sedimentary rocks.

On the southwestern Alaska Peninsula southwest of Port Moller, Chignik subterrane units are uplifted and exposed along the southern margin of the main North Aleutian basin. Thermogenic natural gas seeps vigorously from fractured Cretaceous Herendeen Formation at the Port Moller hot spring (Decker and others, 2005), most likely derived from an underlying Mesozoic source. Minor oil shows occur in Tertiary strata in several wells within and along this edge of the North Aleutian basin, but Sherwood and others (2006) consider it unlikely that

${ }^{1}$ Alaska Division of Oil \& Gas, 550 W. 7th Ave., Suite 800, Anchorage, Alaska 99501 


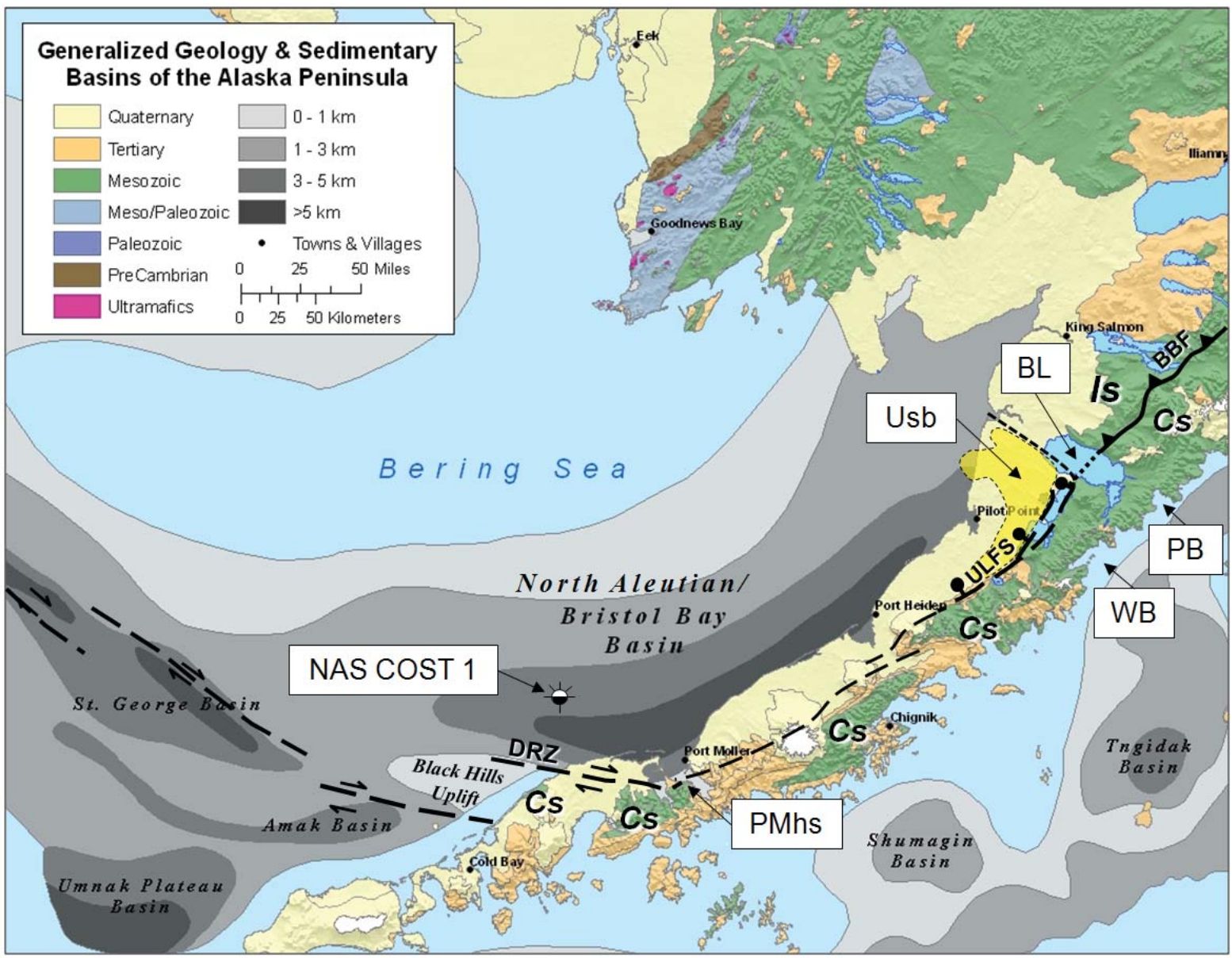

Figure 1. Location map of the Alaska Peninsula showing generalized geologic units, tectonic elements, and localities referred to in text. Abbreviations as follows: $P B=$ Puale Bay, $W B=$ Wide Bay, BL = Becharof Lake, Usb = Ugashik sub-basin, PMhs = Port Moller hot spring (gas seep), Cs =Chignik sub-terrane (in places covered by Cenozoic overlap succession), Is = Iliamna sub-terrane, BBF = Bruin Bay fault, ULFS = Ugashik Lakes fault system, DRZ = David River zone. Geologic age units after Beikman (1980); basin isopachs from Kirschner (1988).

oil-prone Chignik subterrane source-rock units underlie substantial areas of the basin offshore, and view the coaly nonmarine to shallow marine Tertiary section there as primarily prospective for natural gas.

This report presents recently obtained total organic carbon, Rock-Eval pyrolysis, organic petrography, and vitrinite reflectance $\left(R_{0}\right)$ thermal maturity data from outcrops of the Triassic Kamishak and Jurassic Kialagvik formations at Puale Bay (table 1, These data are used to describe their petroleum source-rock characteristics and to draw figs. 3-5).contrasts between them and the Tertiary formations of the North Aleutian basin, mainly as documented using data from the North Aleutian Shelf COST \#1 well (fig. 1; Dow, 1983; Turner and others, 1988; Sherwood and others, 2006). This study is neither a comprehensive overview of regional source rock geochemistry nor an exhaustive compilation or treatment of all the relevant data that might be assembled from a variety of sources. It is intended to present new outcrop data in the context of existing data, and to provide insight into the fundamental differences between the Mesozoic and Cenozoic petroleum systems noted above.

\section{SOURCE-ROCK EVALUATION APPROACH}

The data considered here address the fundamental parameters required to describe a rock's potential and effectiveness as a petroleum source: (1) the quantity or richness of organic matter, (2) the quality or type of organic matter, and (3) the thermal maturity or extent of heating (Tissot and Welte, 1984; Peters and Cassa, 1994). The following overview introduces many of the terms and concepts used in source-rock characterization. Key references for further reading on analytical procedures, applications, and pitfalls of these techniques include Espitalie and others (1977, 1985), Dow (1977), Tissot and Welte (1984), Peters (1986), Langford and BlancValleron (1990), and Peters and Cassa (1994). 


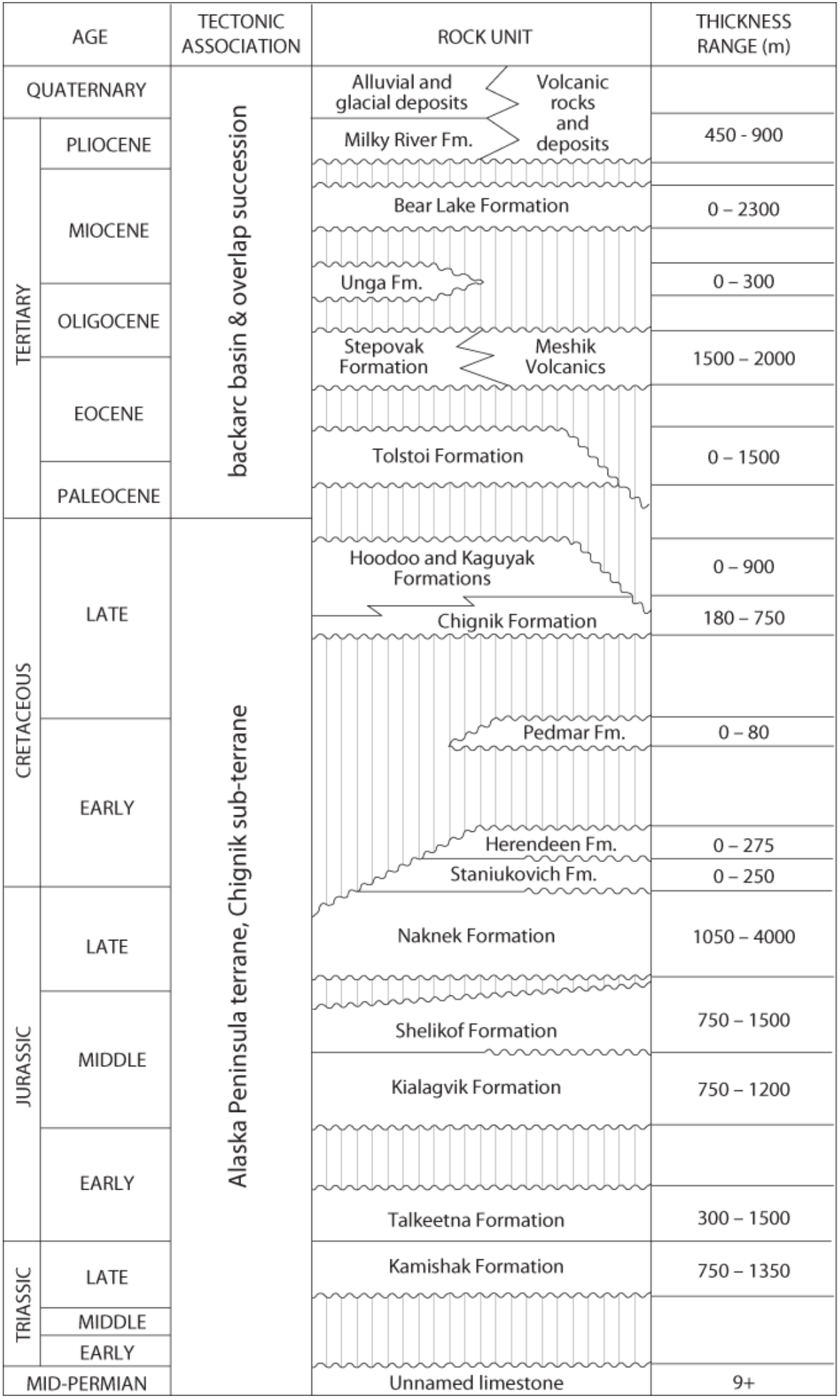

Figure 2. Composite stratigraphic column for the Alaska Peninsula, modified after Beeman and others (1996) and Detterman and others (1996). Metamorphic and plutonic units, including the Iliamna sub-terrane of the Alaska Peninsula terrane, are not depicted. 


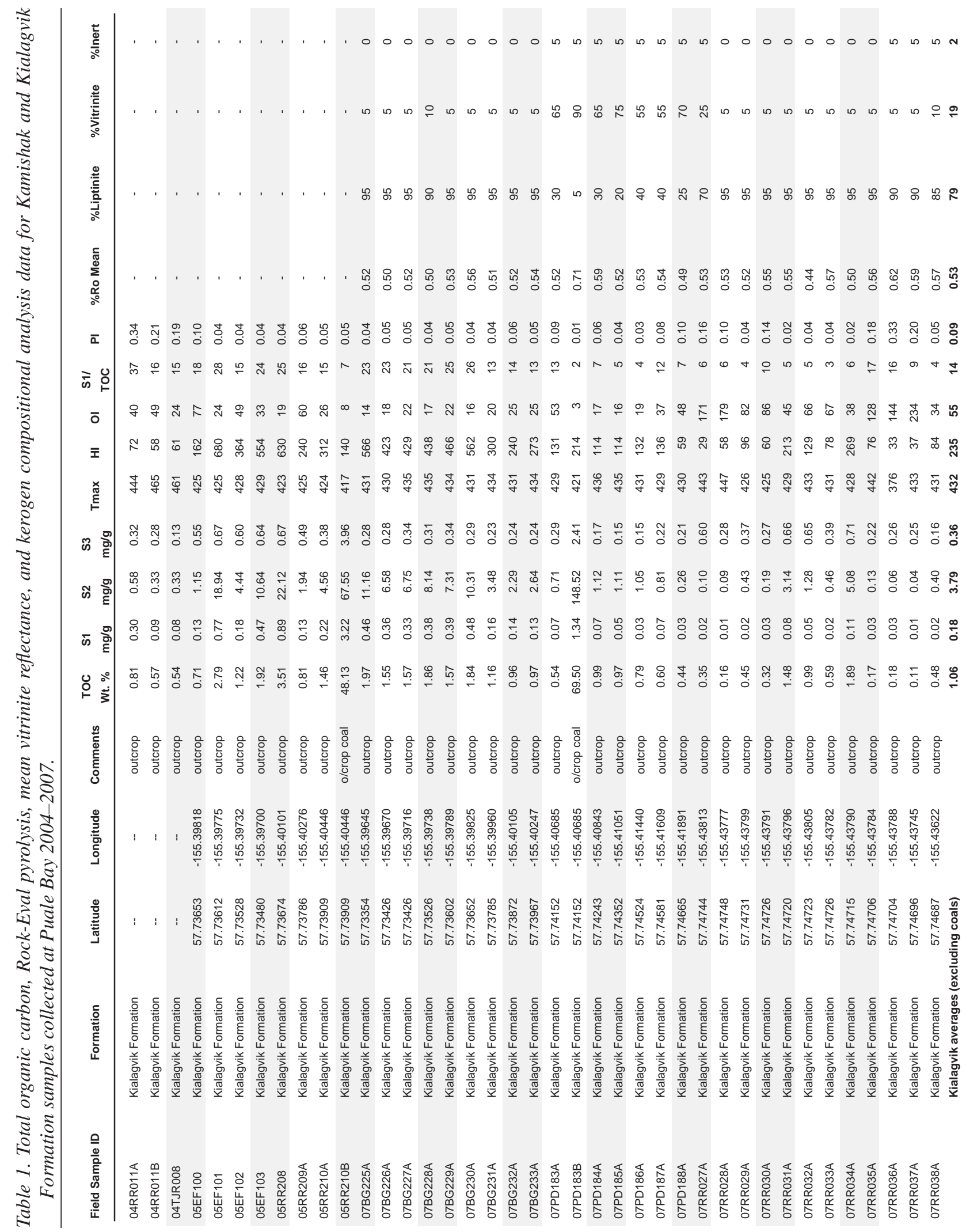




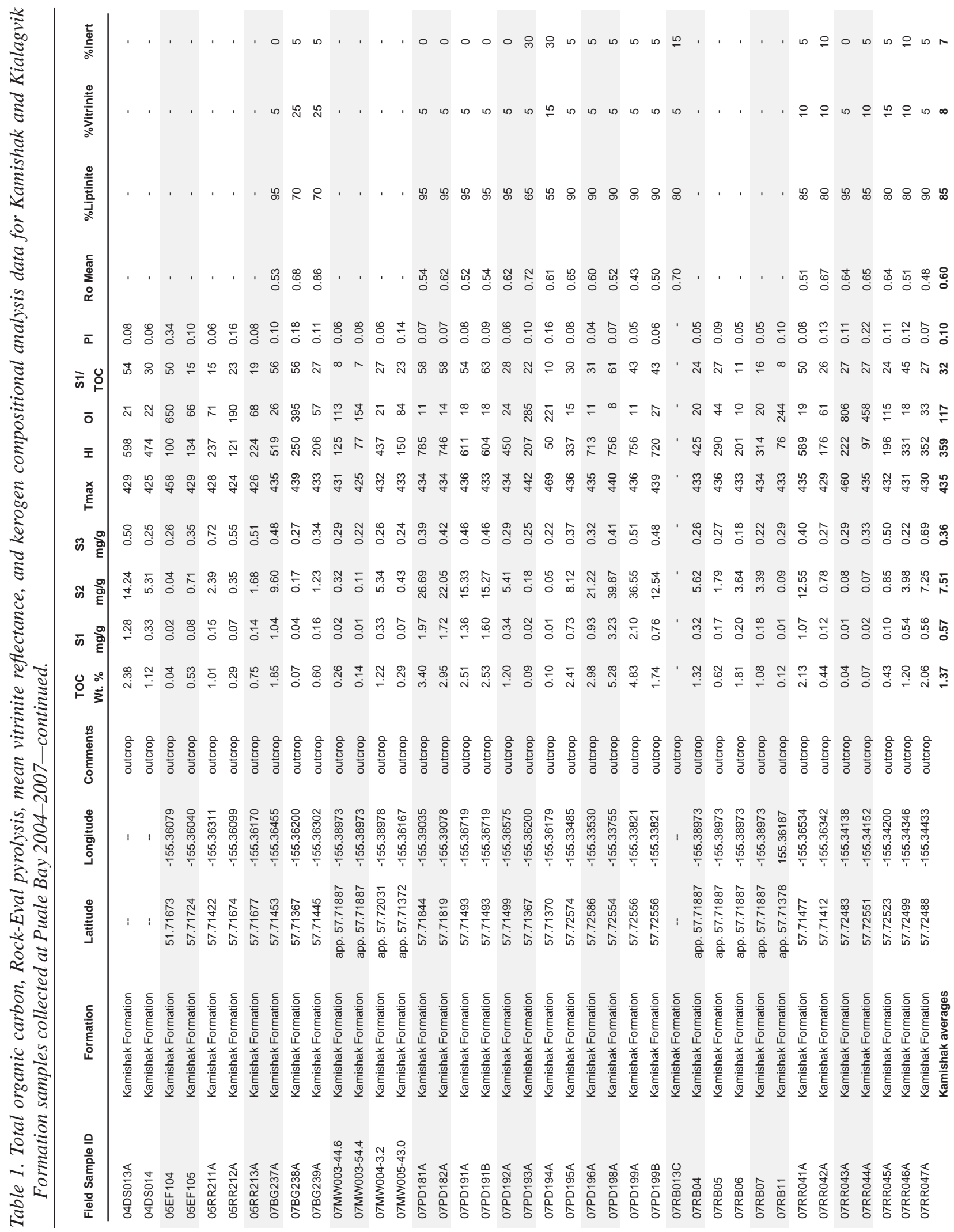




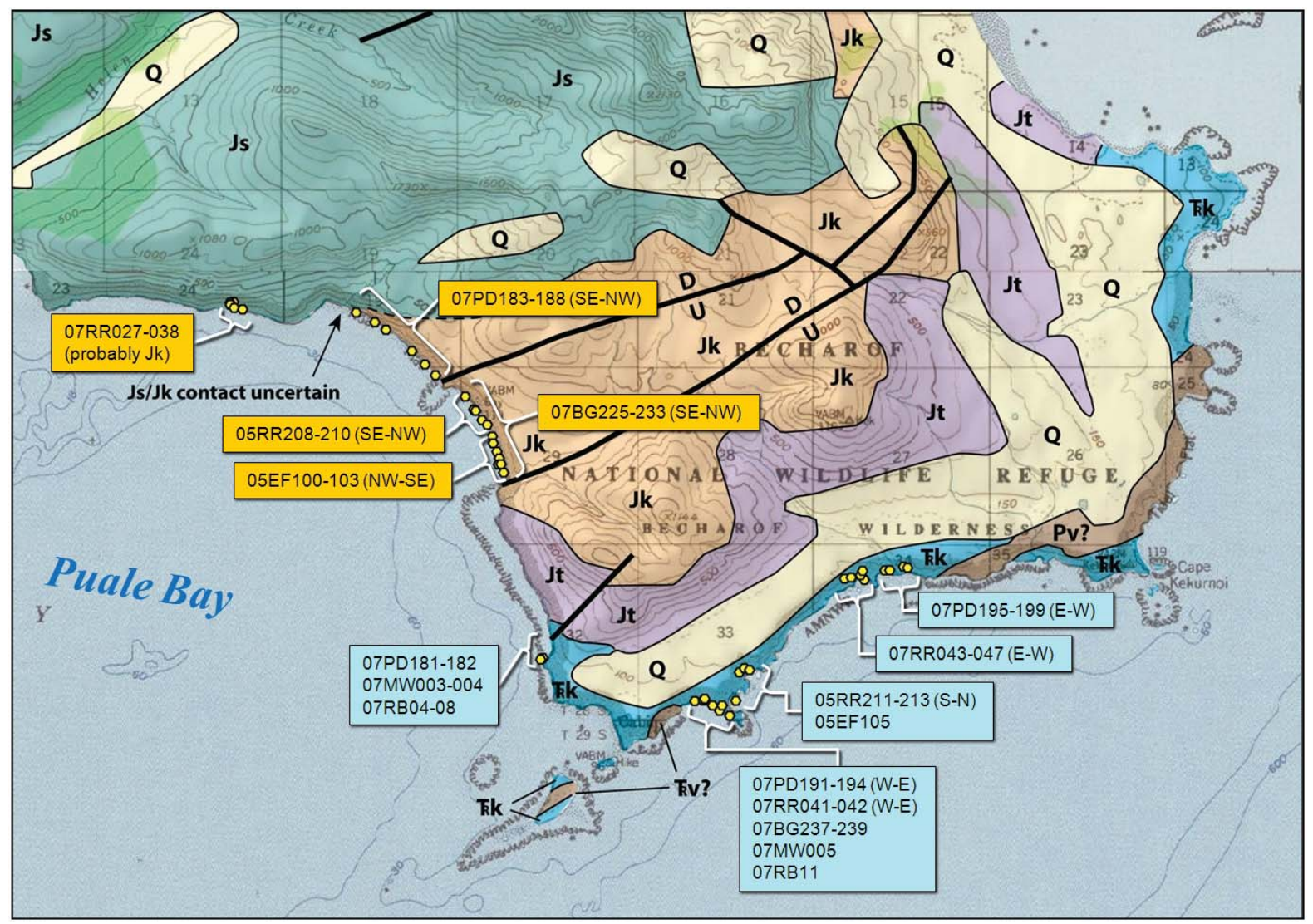

Figure 3. Simplified geology of Puale Bay exposures referred to in text showing location of source rock sampling stations in the Kamishak Formation (blue labels) and Kialagvik Formation (orange labels). Mapping adapted from USGS maps (Detterman and others, 1987; Wilson and others, 1999); some labels modified to reflect uncertainties described in text. Map units as follows: Pv? = Permian(?) volcanic breccia unconformably underlying Triassic Kamishak Formation; Trv? = Triassic(?) volcanic breccia (note that both Pv? and Trv? were mapped by USGS as Trv); Trk = Kamishak Formation; $J t=$ Talkeetna Formation; Jk = Kialagvik Formation; Js = Shelikof Formation; $Q=$ Quaternary, undifferentiated. Js/Jk contact can arguably be placed farther north, immediately overlying the farthest northwest samples, here considered to be from the uppermost part of the Kialagvik Formation.

The quantity of organic matter in a source rock is expressed simply as total organic carbon (TOC) as a percentage of the total sample weight. TOC varies from approximately 0.5 percent in lean source rocks to more than 50 percent in true coals (for example, Peters and Cassa, 1994). Many good to excellent source shales fall in the 1-5 percent range, and carbonaceous shales, siltstones, and other coaly lithologies span the range of TOC up to 50 percent. Modern geochemical laboratories quantify TOC using standardized combustion equipment and techniques.

It is essential to understand the types of kerogen that constitute the organic content because some kerogens are rich enough in hydrogen that they can generate both oil and gas (Types I, II, and II-III mixtures), whereas others contain limited hydrogen and are capable of generating mainly gas (Type III), and others are essentially inert (Type IV). A source rock’s kerogen makeup depends mainly on its depositional environment, which determines both the types of kerogen that are present and their preservation potential. Ideally, kerogen typing should be carried out using complementary techniques, such as optical microscopy examination of the kerogen macerals and elemental analysis to quantify atomic $\mathrm{H} / \mathrm{C}$ (hydrogen/carbon) and O/C (oxygen/carbon) ratios (Tissot and Welte, 1984). These atomic ratios are used to construct traditional van Krevelen diagrams, which, at low thermal maturity, clearly distinguish between hydrogen-rich and hydrogen-poor source rocks. At higher maturity levels, the kerogen type fields converge and overlap due to the progressive depletion of hydrogen and oxygen. The importance of controlling for thermal maturity in source-rock characterization is discussed further in subsequent paragraphs.

For practical reasons, screening studies routinely use efficient but less definitive methods to assess kero- 
gen type. One widely employed technique uses TOC in conjunction with the results of Rock-Eval pyrolysis (Espitalie and others, 1977, 1985) to construct a pseudoor modified van Krevelen diagram. Rock-Eval is a controlled heating procedure that quantifies the amounts of pre-existing volatile hydrocarbon (S1), pyrolyzable hydrocarbon (S2), and carbon dioxide (S3) released from the rock sample over specific temperature ranges. Two key parameters determined by these measurements are hydrogen index (HI=S2/TOC x 100) and oxygen index (OI=S3/TOC x 100), which are typically plotted as proxies for atomic ratios on a modified van Krevelen diagram to distinguish kerogen types. As with true van Krevelen diagrams, the distinction between kerogen types on this sort of plot is greatest in thermally immature samples, and the fields overlap considerably at higher maturity. Normalized to their TOC content, immature sources containing oil-prone Type I and II kerogens yield more hydrocarbon (higher HI) and less carbon dioxide (lower OI) than gas-prone Type III or inert Type IV kerogens. It is important to recognize that a given data point on either traditional or modified van Krevelen diagrams reflects the weighted average of all the kerogen types present in that sample, and that samples typically contain mixtures rather than consisting purely of oil-prone or gas-prone end-member kerogens (M. McCaffrey, 2008, written commun.). Peters (1986) cautioned that pyrolysis techniques commonly overestimate the liquid hydrocarbon generative potential of samples containing Type III coaly kerogen. Elemental analyses (atomic $\mathrm{H} / \mathrm{C}$ and $\mathrm{O} / \mathrm{C}$ ratios) and organic petrography should supplement Rock-Eval and TOC data in determining whether sufficient oil-prone kerogen is present for coals and carbonaceous shales to be effective oil source rocks (Peters, 1986). Effective oil-prone coals not only have $\mathrm{HI}$ in excess of $200 \mathrm{mg} / \mathrm{g}$, but they also have atomic H/C ratio of at least $0.8-0.9$ and liptinitic kerogen content of at least 15-20 percent (Hunt, 1991; Powell and Boreham, 1994; Peters and Cassa, 1994).

Langford and Blanc-Valleron (1990) argued the merits of an alternative means of kerogen characterization by applying linear regression analysis to graphs of S2 vs. TOC. There is error in the measurement of S2 due to retention of some of the pyrolyzed hydrocarbon within the rock matrix (Katz, 1983; Espitalie and others, 1985; Peters, 1986; Langford and Blanc-Valleron, 1990). The smaller the TOC, the larger this error becomes. This in turn leads to low-side bias in the calculation of hydrogen index from individual samples with low TOC, causing organically lean samples to appear to contain more gasprone Type III kerogen than they actually do. According to Langford and Blanc-Valleron (1990), because HI is defined as S2/TOC x 100, the true average hydrogen index of a given sample population is best determined from the slope of the S2 vs. TOC regression line, not by the arithmetic mean of the individual HI values. Furthermore, the $\mathrm{x}$-intercept of the regression line represents the threshold organic content required for that source rock to generate and release measurable hydrocarbon upon pyrolysis. The y-intercept directly indicates the hydrocarbon adsorption capacity, showing the amount of hydrocarbon that is retained within the source-rock matrix upon pyrolysis. Langford and Blanc-Valleron (1990) maintained that the regression approach thus provides true average $\mathrm{HI}$ at the same time as it corrects for and quantifies the adsorptive effect, providing a meaningful basis for distinguishing among source-rock populations that may appear very similar on traditional (H/C vs. O/C) or modified (HI vs. OI) van Krevelen diagrams.

During natural generation of oil and gas, kerogens mature (convert) into hydrocarbons across a range of temperatures, with the kerogen composition controlling the rate of generation at any given temperature. Knowledge of the thermal maturity level is critical to source-rock evaluation both for determining how much oil or gas may have been generated, and for understanding whether the measured TOC, atomic ratios, and hydrogen index correctly reflect the original generative potential. The organic carbon and pyrolyzable hydrocarbon content of high thermal maturity source rocks is reduced compared to their original (pre-maturation) values, much of it having already been spent in generating hydrocarbons. Therefore, at advanced maturity levels, even good source rocks will yield analytical results similar to poor or non-source samples.

Thermal maturity can be quantified in various ways. Rock-Eval yields a general maturity parameter $\mathrm{T}_{\max }$, the temperature $\left({ }^{\circ} \mathrm{C}\right)$ at which the maximum release of pyrolyzable hydrocarbon (S2 peak) occurs during pyrolysis. More robust thermal maturity measurements can be derived from careful microscopy techniques, including vitrinite reflectance $\left(\mathrm{R}_{\mathrm{o}}\right)$, thermal alteration index (TAI), and conodont alteration index (CAI). The vitrinite reflectance scale is the most widely employed in petroleum maturation studies. It measures the percentage of light reflected from vitrinite kerogen macerals. $\mathrm{R}_{\mathrm{o}}$ values are typically reported as the mean value for the in-situ vitrinite population in a given sample (excluding depositionally reworked vitrinite and any evident sample contamination). In many cases, and for the purposes of this study, a mean $\mathrm{R}_{0}$ value of 0.6 percent is taken as an approximation for the onset of oil generation (for example, Peters and Cassa, 1994). Where greater precision is required, it is important to investigate reaction kinetics, which govern the transformation of kerogen to hydrocarbon in a given source rock, and varies as a function of lithology and kerogen composition. 


\section{STRATIGRAPHIC OVERVIEW OF TRIASSIC-JURASSIC SOURCE-ROCK SUCCESSION PUALE BAY}

Lower Mesozoic units of the Chignik subterrane are well exposed at the entrance and northeast shore of Puale Bay (figs. 3-5). Previous work in this area has yielded varied lithologic descriptions, and there are significant differences of opinion regarding the position and nature of formation contacts (for example, Hanson, 1957; Wang and others, 1988; Detterman and others, 1996; Wilson and others, 1999; Blodgett and Sralla, 2008). Detterman and others (1983, 1987, and 1996) were the first to extend the geographic range of the Upper Triassic Kamishak and Lower Jurassic Talkeetna formations from Cook Inlet to Puale Bay, and established a local reference section of the Lower and Middle Jurassic Kialagvik Formation there in recognition of important differences relative to the unit's type section at Wide Bay. These formations are locally faulted and gently folded, but most beds strike northeast and dip $15-30^{\circ}$ to the northwest.

Kamishak Formation. Wang and others (1988) described an approximately 700-m-thick succession at Puale Bay, consisting in ascending order of coral biomicrite, carbonate conglomerate, bedded spicular chert, and volcanic breccia. Most of this section is now assigned to the Upper Triassic Kamishak Formation, but the upper part may extend into the Lower Jurassic Talkeetna Formation as mapped by Detterman and others (1987). Detterman and others (1996) measured $800 \mathrm{~m}(2,625 \mathrm{ft})$ of Kamishak Formation in the same exposures. They described the bulk of the formation above the corralline bioclastic facies as consisting of thin- to medium-bedded gray limestones, with no mention of bedded chert.
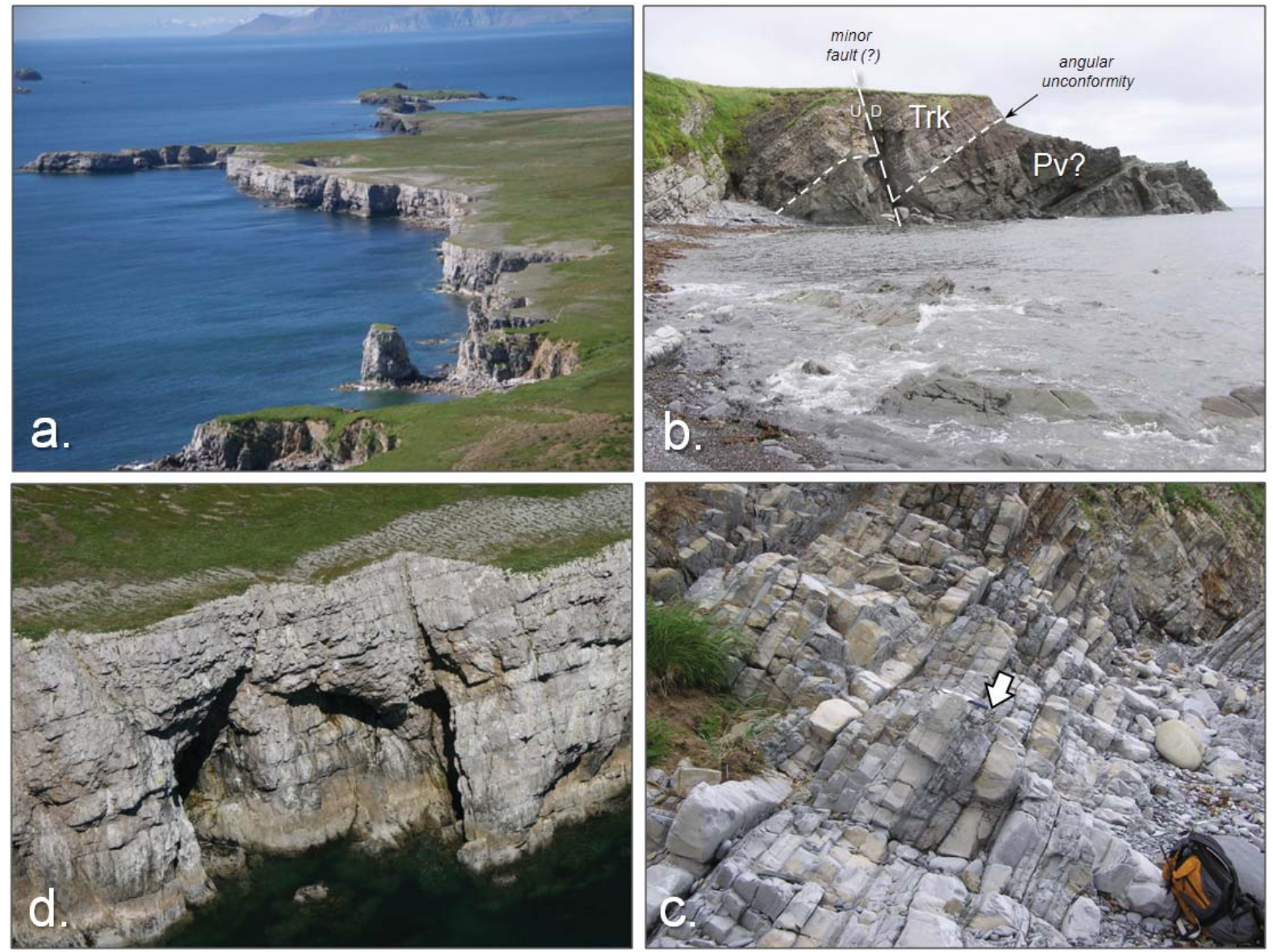

Figure 4. Outcrop photographs of the Upper Triassic Kamishak Formation limestone near the entrance of Puale Bay. (a) View to west of lower part of formation on south-facing shoreline west of Cape Kekurnoi and east entrance to Puale Bay. (b) Angular unconformity $2.2 \mathrm{~km}$ west of Cape Kekurnoi; basal Kamishak overlies volcanic breccia of probable Permian age (see text for discussion). (c) Thinly laminated to medium-bedded finely crystalline limestone from lower Kamishak Formation. Sample 07PD198a, collected in the subfissile, laminated bed indicated by arrow, is an excellent oil-prone source rock $(\mathrm{TOC}=5.28 \%, \mathrm{HI}=756 \mathrm{mg} / \mathrm{g})$. (d) Thick-bedded bioclastic limestone facies is represented by poor to non-source lithologies, and is of more interest as potential reservoir facies. 
Observations recorded by DGGS and DOG geologists are more consistent with those of Blodgett and Sralla (2008), who describe much of the formation at Puale Bay as consisting of "thinly-bedded, dark brown to gray, argillaceous limestone and silty, calcareous shale.”

Wang and others (1988) considered the base of the Triassic section to be truncated by faulting within the coral facies. Hanson (1957), Blodgett and Sralla (2008), and Blodgett (this volume) placed the base of the Triassic section farther east at an angular unconformity (fig. 4b). Blodgett and Sralla (2008) considered volcanic agglomerates immediately beneath the unconformity to be of probable Permian age due to their lithologic similarity to volcanic breccias that are apparently interbedded with Middle Permian limestones (Hanson,
1957) on small islands near the entrance to Puale Bay. Detterman and others (1987; 1996, fig. 6) and Wilson and others (1999) considered the volcanic breccias to be part of the Triassic section, and extended the outcrop belt of lower Kamishak Formation still farther east to Cape Kekurnoi (fig. 3). To the northwest, the gradational upper contact of the Kamishak with the overlying Lower Jurassic volcanic and volcaniclastic deposits mapped as Talkeetna Formation (Detterman and others, 1987; 1996; Wilson and others, 1999) has been placed where clastic sediments become predominant over limestone (Detterman and others, 1996).

During the 2007 DGGS field program, Whalen and Beatty (this volume) and Blodgett (this volume) made detailed measurements and reinterpretations of parts of
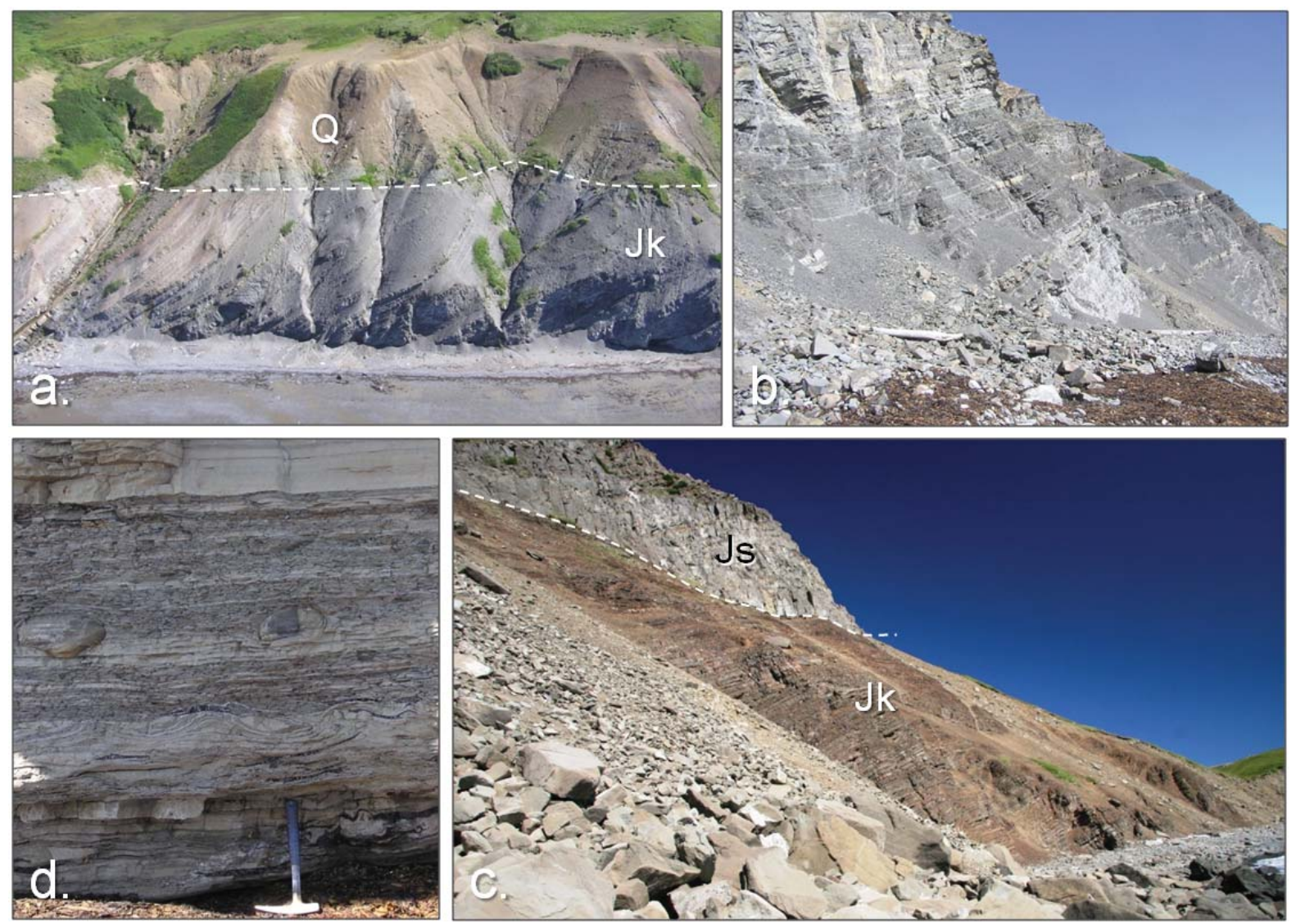

Figure 5. Outcrop photographs of the mainly Middle Jurassic Kialagvik Formation sandstones and siltstones on the northeast shore of Puale Bay. (a) Much of the lower portion of the Kialagvik is rhythmically bedded, dark gray fissile siltstone. Quaternary unconformity (dashed line) is overlain by unconsolidated deposits (Q). (b) Generally upward-coarsening and upward-thickening succession from the middle to upper Kialagvik Formation. The finest-grained intervals consist of rhythmically bedded blocky siltstone and fine sandstone. (c) Twelve source rock samples (07RR027-038) were collected from reddish-brown weathering siliceous siltstone and sandstone interpreted here as uppermost Kialagvik (Jk) just below the contact with the overlying Shelikof Formation (Js) at the base of the cliff-forming light gray sandstone (dashed line). (d) Laminated to medium-bedded sandstones from the upper part of the section shown in photograph b contain abundant carbonaceous laminae and thin, commonly deformed coal lenses in addition to common carbonate concretions. Deposition of the middle to upper Kialagvik Formation in this area likely occurred near a deltaic sediment source, possibly under marginal marine conditions. 
the Kamishak Formation interval described by Wang and others (1988) and Detterman and others (1996). The source-rock samples discussed in this report include a number collected in these re-described intervals, but also represent other parts of the formation, including the lowermost Kamishak section farther east near the purported basal unconformity recognized by Hanson (1957) and Blodgett and Sralla (2008). The overlying Talkeetna-equivalent section was not sampled for source-rock evaluation.
Kialagvik Formation. Containing megafauna ranging from late Toarcian to Callovian age (Imlay, 1984; Detterman and others, 1996), the Kialagvik Formation is largely time-equivalent to the Middle Jurassic Tuxedni Group, the source rock for most of the oils in upper Cook Inlet (Magoon and Anders, 1992). Detterman and others (1996) described the 790-m-thick Kialagvik section at Puale Bay as dominated by rhythmically interbedded siltstone and sandstone of deepwater affinity, with local intervals of massive, disorganized conglomerate. They

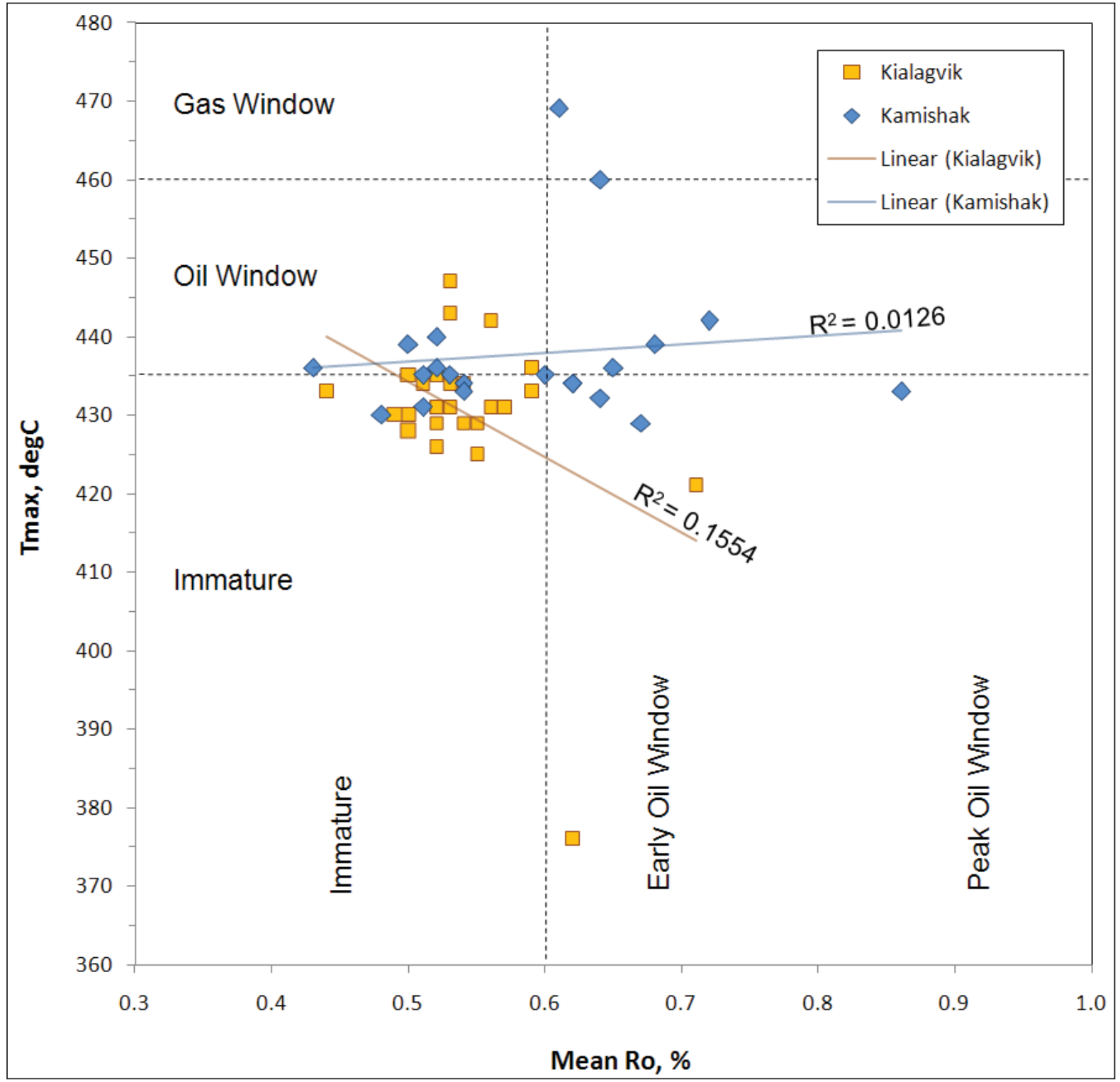

Figure 6. Cross-plot of Rock-Eval $T_{\max }$ vs. mean $R_{o}$ for Kamishak and Kialagvik Formation source rock samples from Puale Bay outcrops. In general, these thermal maturity parameters would be expected to show a reasonably strong positive correlation. However, the low correlation coefficient for the Kamishak regression $\left(R^{2}=0.0126\right)$ indicates a weak correlation, and the negative slope of the Kialagvik regression line suggests an unlikely inverse correlation. This suggests the $T_{\max }$ data should not be relied on to define the thermal maturity of individual samples. Considered as a group, and ignoring outliers, the $T_{\max }$ data correctly describe the Puale Bay source rocks as mostly immature to early oil window maturity. 
noted the lithologic similarity of this section to the upper part of the unit's principal reference section at Wide Bay. In contrast, the lower part of the Wide Bay section consists of nearshore marine deposits. Significant lithology changes occur within short distances in the Kialagvik Formation, and fossils are required to make robust correlations (Imlay, 1984). The Puale Bay exposures are poorly fossiliferous relative to other exposures, leading to a lack of confident correlations between the Wide Bay and Puale Bay exposures, and with the section penetrated in the Bear Creek \#1 well between the two outcrop areas (Detterman and others, 1996).

At Puale Bay, the contact with the underlying Talkeetna Formation is a conglomerate-mantled erosional unconformity. Detterman and others (1996) considered the contact with the overlying Shelikof Formation to be conformable at Puale Bay but unconformable at Wide Bay. This upper contact has been revised repeatedly, most recently by Allaway and others (1984). The formation is locally transected by subvertical dikes, and cut by steep faults with various amounts of displacement. Truncation surfaces, channel profiles, and clinoforms or lateral accretion surfaces in the rhythmically interbedded siltstones and sandstones above the massive conglomerates in the lower to middle part of the formation suggest complex deepwater depositional patterns, possibly accompanied by local slumping.

Cursory observations during geochemical sampling suggest that, with the exception of local conglomeratic packages, lithologies of the Kialagvik Formation at Puale Bay may reflect a general upward gradation to more proximal, probably shallower water deposition (fig. 5). The dark gray, fissile siltstones of the lower portion transition upward to medium to light gray, blocky siltstones and interbedded sandstones of the middle portion, where some beds contain deformed lenses of coal 0-3 $\mathrm{cm}$ thick. Continuing upsection, this interval becomes increasingly lighter gray with thicker carbonaceous to coaly sandstone beds. The upper part of the formation consists of reddish-gray to reddish-brown weathering, siliceous siltstone and sandstone that form steep, south-facing slopes on the northeast side of Puale Bay. It is unclear to this author whether the Kialagvik-Shelikof contact as mapped there by Detterman and others (1987) and Wilson and others (1999) is consistent with the redefinition of the contact by Allaway and others (1984) or the lithologic descriptions of this stratigraphic interval by Detterman and others (1996). Twelve samples assigned in this report to the uppermost Kialagvik Formation (07RR027a through 07RR038a) were collected in the thick, red-weathering, silicified interval at the northwestern end of the sampling traverse (fig. 5a). This interval was mapped by Detterman and others (1987) as the lowermost portion of the Shelikof Formation.

\section{STRATIGRAPHIC OVERVIEW OF CENOZOIC FORMATIONS, NAS COST \#1 WELL}

Drilled in 1982-83 to a total depth of 5,229 m $(17,155 \mathrm{ft})$, the North Aleutian Shelf COST \#1 well penetrated clastic strata of Eocene through Pleistocene age in the North Aleutian back-arc basin without reaching lithologic or acoustic basement (Turner and others, 1988; Mickey and others, 2005). Composed of sandstone, conglomerate, siltstone, mudstone, and coal, the well's nonmarine to shallow marine succession was initially divided into five major seismic sequences (I-V) and subdivided into 11 zones defined by lithologic, depositional, diagenetic, seismic, and petrophysical characteristics (Turner and others, 1988). More recent studies have assigned formation names to the well (Finzel and others, 2005; Sherwood and others, 2006; Decker and others, 2006). Three of the interpretive formation tops used in this report correspond to sequence-bounding seismic horizons defined by Turner and others (1988). In the absence of condensed marine shales or carbonates, the lithologies of greatest interest as potential source rocks include coals, carbonaceous mudstones, and siltstones.

Tolstoi Formation. The interval from 3,164 m $(10,380 \mathrm{ft})$ to the base of the well at 5,229 $\mathrm{m}(17,155 \mathrm{ft})$ measured depth in the NAS COST \#1 well corresponds to seismic sequence V of Turner and others (1988). This interval is considered to be entirely Eocene in age (Mickey and others, 2005) and is assigned to the Tolstoi Formation (Sherwood and others, 2006). This thickness of more than 2,000 m (nearly 6,800 ft) represents only a partial penetration of the formation. Older strata are present in the 1,355-m-thick reference section at Ivanof Bay on the Alaska Peninsula, where the Tolstoi includes a rainforest megaflora assemblage of Late Paleocene age (Detterman and others, 1996). Interpretation of publicly available seismic data (Turner and others, 1988; Finzel and others, 2005; Sherwood and others, 2006) indicates the COST well penetrated one of several grabens that accommodated or preserved the early basin-filling sequence. In outcrop, the Tolstoi Formation varies from dominantly shallow marine strata at its type section on Pavlof Bay to progressively more nonmarine environments toward the northeast near Chignik Bay. In the well, most of the formation consists of nonmarine volcaniclastic sandstone, conglomerate, siltstone, carbonaceous mudstone, and abundant coal, with transitional marine deposits restricted to approximately the upper hundred meters (Turner and others, 1988). The base and top of the formation are unconformable onshore (Detterman and others, 1996), and probably also offshore (Worrall, 1991). Two abrupt lithologic breaks are present in the lower part of the Tolstoi interval drilled in the COST well (seismic horizons E and F). Turner and others (1988) 
interpreted these surfaces as possible unconformities, presumably generated by drops in relative sea level associated with the basin's early faulting history. Sherwood and others (2006) have reinterpreted at least one of these breaks as a fault with significant stratigraphic separation.

Stepovak, Bear Lake, and Milky River Formations. The Late Eocene through Pliocene interval of the NAS COST \#1 well records an overall trend toward increasingly marine conditions (Turner and others, 1988, fig. 90). The Eocene to Oligocene Stepovak Formation is here assigned to the interval from 1,730 to $3,164 \mathrm{~m}$ (5,675 to $10,380 \mathrm{ft}$ ) measured depth, corresponding to seismic sequences III and IV of Turner and others (1988). Their seismic sequence II between 765 and $1,730 \mathrm{~m}$ (2,510 and 5,675 ft) measured depth, which probably spans late Oligocene to late Miocene time (Turner and others, 1988; Mickey and others, 2005), is interpreted as a relatively continuous offshore depositional record of the depositional cycles represented onshore by the Unga sandstone and Bear Lake Formation.

Nonmarine fluvial-deltaic sandstone, conglomerate, finer clastics, and coals dominate the lower part of the Stepovak Formation (seismic sequence IV), whereas microfossil assemblages (Turner and others, 1988) indicate that the upper Stepovak (seismic sequence III) was deposited in inner to middle shelf environments. These conditions continued during deposition of the lower part of the Bear Lake-Unga cycle before yielding to marginal marine intertonguing of diatomaceous marine strata and lignite-bearing nonmarine to delta-plain environments during deposition of the upper Bear Lake Formation.

The unconformity separating the Bear Lake and Milky River formations shows only subtle discordance in seismic data within the backarc basin (Finzel and others, 2005, fig. 4.7), but it becomes profoundly angular in the outcrop belt northeast of Port Moller (Decker and others, 2005). Microfossils from the Pliocene Milky River Formation in the COST well (interpreted here as the interval between 476 and $765 \mathrm{~m}$ (1,563 and 2,510 $\mathrm{ft}$ ) measured depth are interpreted to reflect cold water conditions with slight deepening from the middle to the outer shelf (Turner and others, 1988). Unconsolidated Quaternary glaciomarine deposits constitute the section above $476 \mathrm{~m}$ (1,563 ft) measured depth (Turner and others, 1988; Mickey and others, 2005).

\section{MESOZOIC SOURCE-ROCK CHARACTERISTICS}

DGGS and DOG geologists collected 38 samples from the Kamishak Formation and 39 samples from the Kialagvik Formation for source-rock evaluation at Puale Bay during 2004, 2005, and 2007 (fig. 3). TOC, Rock-Eval, mean vitrinite reflectance, and kerogen composition data from these samples are presented in table 1. This sample suite represents various lithologies from the lower, middle, and upper parts of each unit, but time constraints prohibited achieving a uniform stratigraphic sample distribution in either formation. Most samples are not precisely positioned relative to the measured sections of Whalen and Beatty (this volume), Wang and others (1988), or Detterman and others (1996).

Thermal maturity. In mapping patterns of thermal maturity on the Alaska Peninsula, Molenaar (1996) lacked outcrop vitrinite reflectance data from the Puale Bay-Wide Bay area. He described the Middle Jurassic rocks in the area as undermature $\left(\mathrm{R}_{0}<0.6\right.$ percent) based on reflectance data from the nearby Bear Creek 1 and Wide Bay 1 wells, and the Upper Triassic outcrop section as immature to barely mature based on Rock-Eval $\mathrm{T}_{\max }$ data (Magoon and Anders, 1992; Wang and others, 1988). Table 1 presents new outcrop vitrinite reflectance results from the Kamishak Formation (23 samples) and the Kialagvik Formation (28 samples) at Puale Bay. These samples yield mean $\mathrm{R}_{0}$ values ranging from 0.43 to 0.86 percent (averaging 0.60 percent) in the Kamishak and from 0.44 to 0.71 percent (averaging 0.54 percent) in the Kialagvik. This confirms the interpretations of previous workers that overall, the Puale Bay section is at immature to early oil window thermal maturity levels. Given this low thermal maturity, the Kamishak and Kialagvik formations' source characteristics revealed by TOC and Rock-Eval analyses are believed to approximate their original generative potential, little biased by loss of organic carbon and hydrogen content that would accompany greater maturation.

Figure 6 is a cross-plot of $T_{\max }$ versus mean $R_{0}$ for all Kamishak and Kialagvik Formation samples collected in 2007. Note that despite the normally strong positive correlation between these pyrolysis-based and microscopy-based maturity measures (for example, Peters, 1986; Peters and Cassa, 1994), the regression line for the Kamishak data has a very low correlation coefficient, and the Kialagvik regression actually has a negative slope, implying an unlikely inverse correlation. As noted by Peters (1986), $\mathrm{T}_{\max }$ is a crude and often unreliable indicator of the thermal maturity of individual samples. In this case, the poor correlation between $\mathrm{T}_{\max }$ and mean $\mathrm{R}_{0}$ is driven mainly by high and low outliers in the $\mathrm{T}_{\text {max }}$ data. Even so, the $\mathrm{T}_{\text {max }}$ data as a whole aptly characterize the overall population as mainly immature to early oil window maturity.

Molenaar (1996) observed that, despite paleo-burial to depths estimated in excess of 4,000 m, the Triassic-Jurassic section at Puale Bay remains only early mature. He concluded that the geothermal gradient during Late Cretaceous-Paleogene maximum burial must have been significantly lower than the present-day geothermal 
gradient defined by wells in the Ugashik sub-basin, where the 0.6 percent $\mathrm{R}_{0}$ isograd (approximating the top of the oil window) is reached at about $3,000 \mathrm{~m}$.

Kerogen type and total organic carbon. Given the low thermal maturity of the Puale Bay outcrop samples, a modified van Krevelen plot is useful for considering kerogen type (fig. 7). More than half of the Kamishak samples plot near the highly oil-prone Type I and II kerogen curves, many of which yield hydrogen indices in the 700-800 mg/g range. Approximately 15 percent of the Kamishak samples appear to be oil- and gas-prone Type II-III kerogen mixtures, and about one-third appear to contain mostly gas-prone Type III kerogen, including several highly oxidized samples (oxygen indices above $200 \mathrm{mg} / \mathrm{g}$ ) that are off-scale, and not shown on the plot.

Organic petrography analysis of 20 Kamishak Formation samples documents the relative abundance of oil-prone liptinite, gas-prone vitrinite, and inert kerogen types. Liptinitic kerogen is overwhelmingly dominant, averaging 85 percent of the organic matter, and representing 90-95 percent in approximately two-thirds of the samples analyzed (table 1). Vitrinite makes up an average of 8 percent and inert kerogen an average of
7 percent. Samples from the coral-rich bioclastic facies contained the highest proportions of vitrinite (up to 25 percent), and inert kerogen (up to 30 percent) and the lowest proportion of liptinite (55-65 percent). These results are broadly consistent with the pyrolysis-based kerogen determinations for the Kamishak illustrated by figure 7 .

Kialagvik Formation pyrolysis data (fig. 7) suggest that its overall kerogen composition is only slightly less oil-prone than that of the Kamishak. Nearly 30 percent of the Kialagvik samples plot near the Type I and II curves with HI values greater than $300 \mathrm{mg} / \mathrm{g}$, reaching a maximum HI of $680 \mathrm{mg} / \mathrm{g}$. More than one-third plot as Type II-III mixtures. The remaining one-third or so appear from figure 6 to consist of gas-prone Type III or inert Type IV kerogens.

Organic petrography analyses of 28 Kialagvik Formation samples indicate that, on average, liptinite constitutes 79 percent and vitrinite represents 19 percent of the organic matter, with the remaining 2 percent being inert kerogen (table 1). Liptinite makes up 90 percent or more of the kerogen in approximately two-thirds of the samples. Vitrinite constitutes 55-90 percent of the kerogen in one-fourth of the samples. These are siltstones
Figure 7. Modified van Krevelen diagram, showing kerogen type determination from Rock-Eval pyrolysis data. See text for caveats of typing kerogens from coaly strata using this approach.

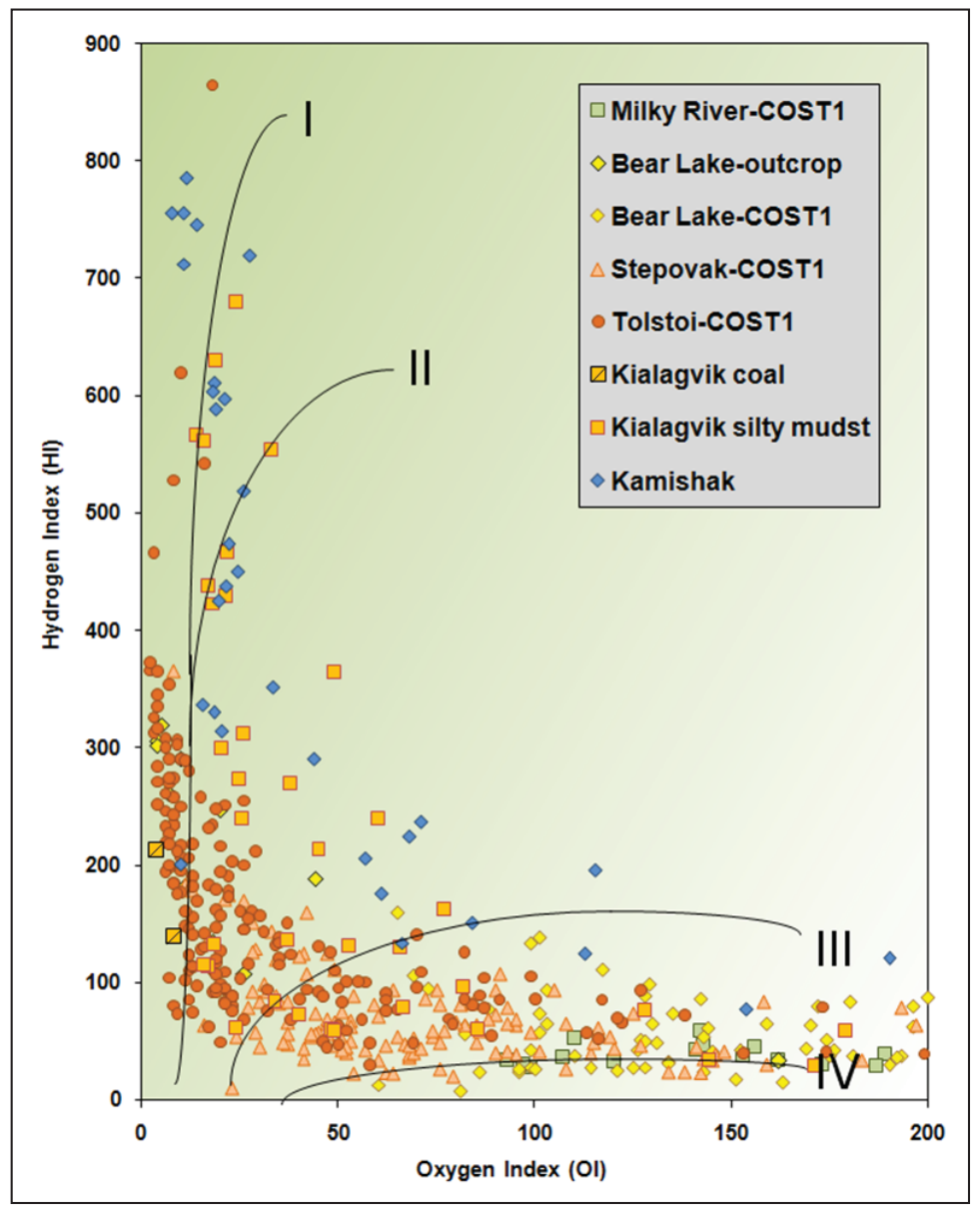


and a thin coal from exposures near the middle of the formation. These Kialagvik organic petrography results are broadly consistent with the kerogen type determinations inferred from the pyrolysis data. However, many of the samples with very high liptinite:vitrinite ratios do not have correspondingly high HI values associated with good Type I and II source rocks.

Figure 8 is a graph of hydrogen index vs. total organic carbon, an effective means of screening sourcerock samples for both the quantity and type of organic matter present. The colored fields in the background are loosely defined and non-unique, but they suggest the hydrocarbon products that would be expected to generate from samples as they mature. They also reflect a suite of interrelated characteristics including kerogen type, lithology, depositional environment, and thermal maturity. Both TOC and HI decrease with increasing maturity as described above, so the fields would not accurately reflect the original characteristics of highly mature source rocks. The data show a strong correlation between TOC and HI, with samples richer in organic content appearing to consist of the more oil-prone kerogens. However, Langford and Blanc-Valleron (1990) cautioned that pyrolysis experiments systematically under-predict the S2 (and thus HI) values of low-TOC samples. This is due largely to matrix adsorption effects, discussed in the subsequent section.

Considering the uncorrected pyrolysis results at face value, fully half of the Kamishak Formation limestones plot as good to excellent oil source rocks with TOC values in the 1-5 percent range and $\mathrm{HI}$ values greater than $300 \mathrm{mg} / \mathrm{g}$. A few Kamishak samples fall in the lean oil or gas source categories, and about one-third contain less than 0.5 percent TOC, probably too lean to consider source-prone. These correspond to the one-third of samples that are typed as Type III kerogen from the modified van Krevelen plot (fig. 7), marked by low HI and elevated OI.

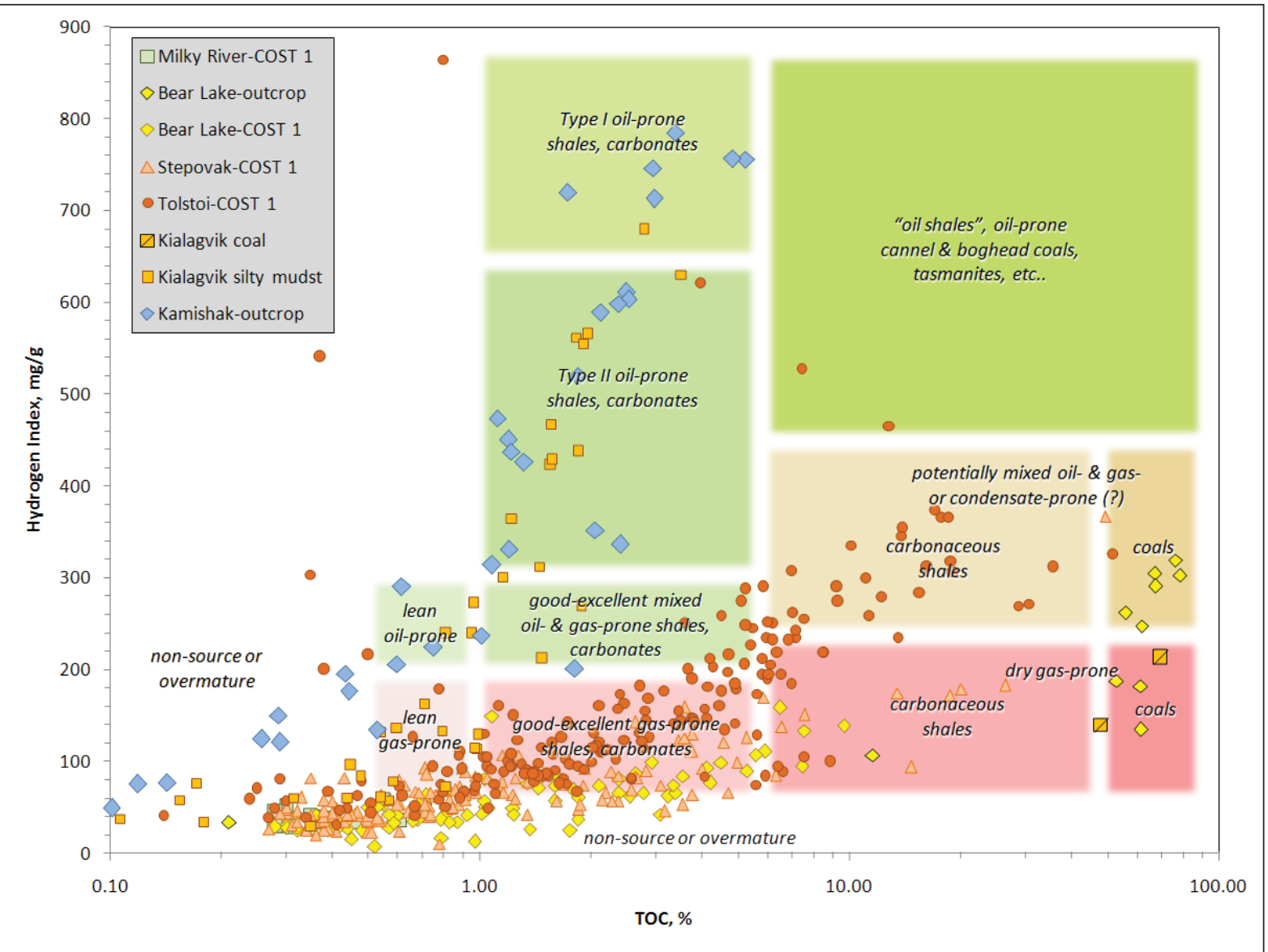

Figure 8. Both the quantity and type of organic matter are readily apparent in a plot of hydrogen index (HI) versus total organic carbon (TOC). Samples are plotted on loosely defined fields that suggest expected hydrocarbon products and reflect other characteristics such as kerogen type, lithology, depositional environment, and maturity. These fields are non-unique, and should be considered in light of other available information, particularly in the case of coals and other rocks containing coaly kerogens. 
The silty mudstones of the Kialagvik Formation follow a trend similar to the Kamishak samples on the plot of HI vs. TOC (fig. 8). More than one-third of the Kialagvik mudstones have good to excellent TOC values in the 1-4 percent range; most of these have HI values in the range associated with oil-prone Type II kerogen (300-650 mg/g). Nearly 15 percent of Kialagvik mudstones rank a step lower in terms of source-rock quality. With TOC values in the $0.8-2$ percent range and $\mathrm{HI}$ values ranging from $200-300 \mathrm{mg} / \mathrm{g}$, these samples would likely generate gas-oil mixtures. Almost 20 percent of the Kialagvik mudstones plot as lean to fair gas source rocks, and about 30 percent rank here as nonviable hydrocarbon sources. Nonviable source rocks may be too lean in organic matter, thermally overmature, contain too much inert kerogen, or have high matrix adsorption capacity. Two coaly Kialagvik samples are clearly differentiated from the Kialagvik mudstones in figure 8 by their high TOC values (48 and 70 percent). Considering their moderate HI values $(<215 \mathrm{mg} / \mathrm{g})$ and high vitrinite content (90 percent in sample 07PD183B), the thin lenses of coal observed in outcrop in the middle part of the Kialagvik Formation are expected to contribute mainly dry gas. Because of their low OI values $(<10 \mathrm{mg} / \mathrm{g})$, these coals plot misleadingly in the lower-left part of the modified van Krevelen diagram (fig. 7), an area normally associated with high-maturity sources. This illustrates the point made by Peters (1986) that pyrolysis data often fail to characterize coaly sources correctly.

Average hydrogen index and hydrocarbon adsorption capacity. Figure 9 presents graphs of pyrolyzable hydrocarbon (S2) versus TOC, in which source-rock sample populations plot in distinct linear trends suited to regression analysis (Langford and Blanc-Valleron, 1990). Figure 9a plots the entire data range for Mesozoic and Cenozoic samples, including coals and carbonaceous shales; figure 9b plots a more restricted data range (TOC $<20$ percent, $\mathrm{S} 2<50 \mathrm{mg} / \mathrm{g}$ ) necessary to resolve the bulk of the samples and to analyze the differences in their regression lines.

The Kamishak regression line has the steepest slope, corresponding to a "true average" HI (in the sense of Langford and Blanc-Valleron; 1990) of $745 \mathrm{mg} / \mathrm{g}$, suggesting a strong predominance of Type I kerogen in the formation. This is substantially higher than the arithmetic average of the individual HI values, which was calculated at $359 \mathrm{mg} / \mathrm{g}$ for the same population of samples. This is presumably because of the adsorption of much of the pyrolyzed hydrocarbon from low TOC samples. The regression for the Kialagvik mudstones has a slightly lower slope that indicates an average HI of 654 $\mathrm{mg} / \mathrm{g}$. This falls near the Type I-II boundary, and is also much higher than the corresponding arithmetic mean $\mathrm{HI}$ of $235 \mathrm{mg} / \mathrm{g}$. The y-intercepts of these regressions indicate the Kamishak limestones have an adsorptive capacity of $2.663 \mathrm{mg}$ of pyrolyzable hydrocarbon per gram of source rock, compared to $3.145 \mathrm{mg} / \mathrm{g}$ for the Kialagvik mudstones, consistent with the observation of Langford and Blanc-Valleron (1990) that clay matrix is more adsorptive than carbonate matrix.

Mesozoic source facies summary and stratigraphic relationships. Figure 10 summarizes TOC, HI, and mean $R_{0}$ variations in the stratigraphic succession at Puale Bay. Because the samples are not tied to a complete measured section, these three parameters are plotted here as a function of longitude. This serves as a proxy for relative stratigraphic position, since the samples are from a generally northwest-dipping succession. Sampling gaps are clearly evident in this plot, as they are on the map (fig. 3), particularly in the Kamishak Formation. Although the data are not uniformly distributed, the Kamishak data reveal multiple, high-frequency fluctuations in sourcerock richness and apparent kerogen type.

The highest-quality source rocks from the Kamishak Formation represent a range of limestone lithologies. They were described in outcrop as light to medium gray or tan weathering, medium to dark gray, brown, or black fresh, micritic to finely crystalline, subfissile to blocky, planar- and ripple-laminated to medium bedded, argillaceous, fossiliferous to coquinoid limestone, typically with fetid odor. The bioclastic and adjacent knobby-weathering, nodular limestone facies include marginally gas-prone to non-source lithologies. The new organic carbon content and pyrolysis data from the Kamishak Formation agree relatively well with the results from 41 samples analyzed by Wang and others (1988, fig. 4). That paper does not present tabular data, but graphs indicate that approximately half of the samples from that study exceeded 1 percent TOC, and at least 80 percent of the samples were identified as consisting of Type I or II kerogen.

The Kialagvik TOC and HI data suggest a more systematic trend of upward-decreasing source-rock quality, with rich oil-prone facies (fissile, dark gray siltstones) in the lower part of the unit giving way to leaner gas-prone facies (blocky medium gray siltstones) in the middle, and highly variable oxidized and silicified lithologies at the top dominated by non-source and gasprone samples. Liptinitic kerogen makes up 90 percent or more of the organic matter in all nine of the samples analyzed by organic petrography from the lower part of the formation, whereas vitrinite accounts for 55-90 percent of the kerogen from the seven samples analyzed near the middle part of the formation. This pattern is consistent with the possible upward-coarsening and/or shoaling trend noted in observations of the Kialagvik Formation at this locality. Interestingly, liptinite is the dominant kerogen type in the uppermost part of the formation, but the source-rock quality of this interval appears limited due to low total organic content, high adsorptive capacity, perhaps compounded by diagenetic alteration. 

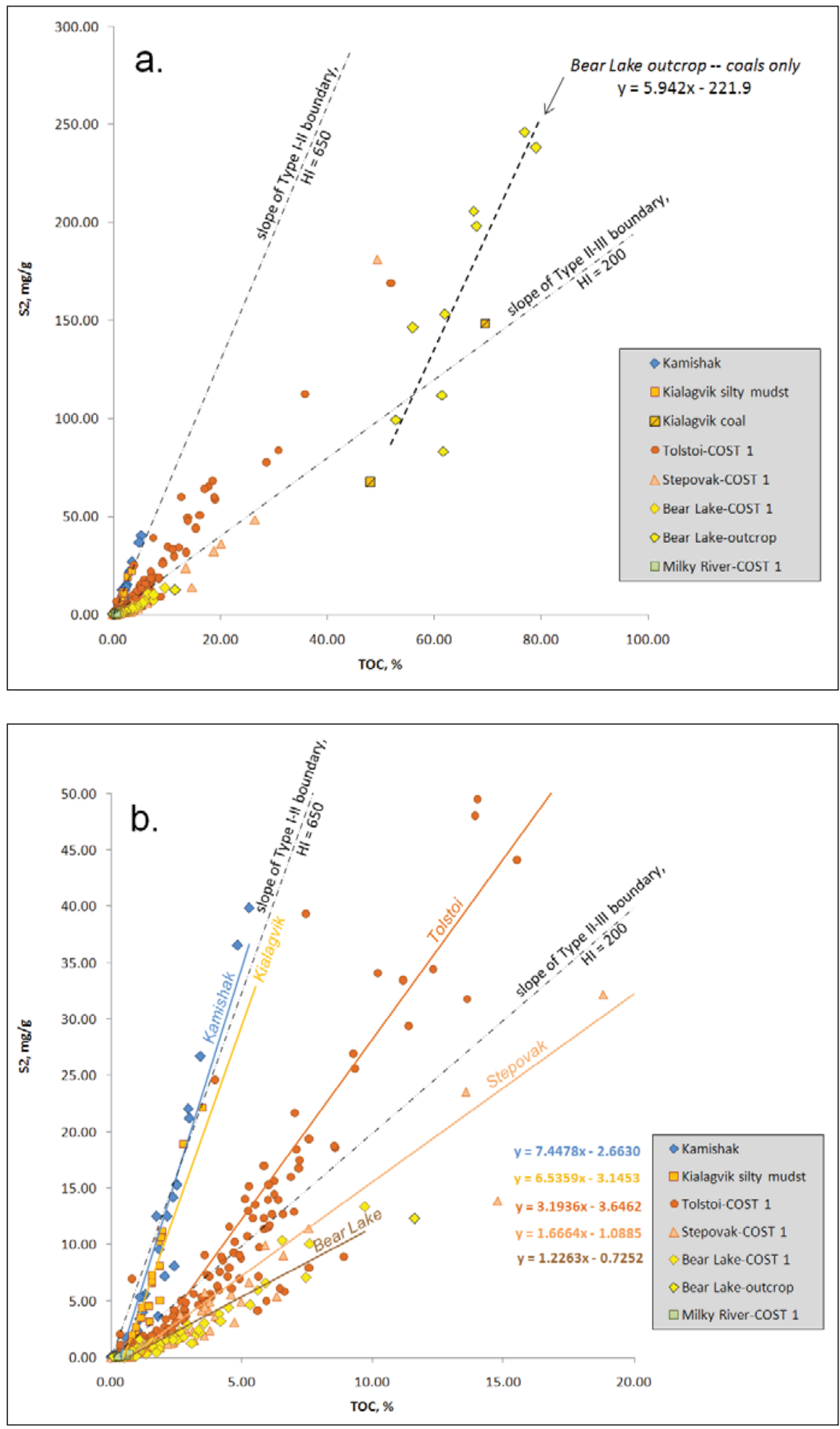

Figure 9. Graphs of hydrolyzed hydrocarbon (S2) versus total organic carbon (TOC), following the analytical logic of Langford and Blanc-Valleron (1990). Stratigraphic order in legend is inverted to maximize visibility of all data series on plot. (a) Full data range, including coals and highly carbonaceous mudstones. See text for discussion of interpretations of regression through Bear Lake outcrop coals. (b) Restricted data range, for resolution of populations with TOC $<20 \%$ and $S 2<50 \mathrm{mg} / \mathrm{g}$. Linear regression equations determine true average HI (slope x 100) and hydrocarbon adsorptive capacity (y-intercept) of each sample population. Type I-II boundary shown corresponds to HI = 650 (slope = 6.5), a compromise between the boundary values suggested by Langford and Blanc-Valleron (1990) and Peters and Cassa (1994). 


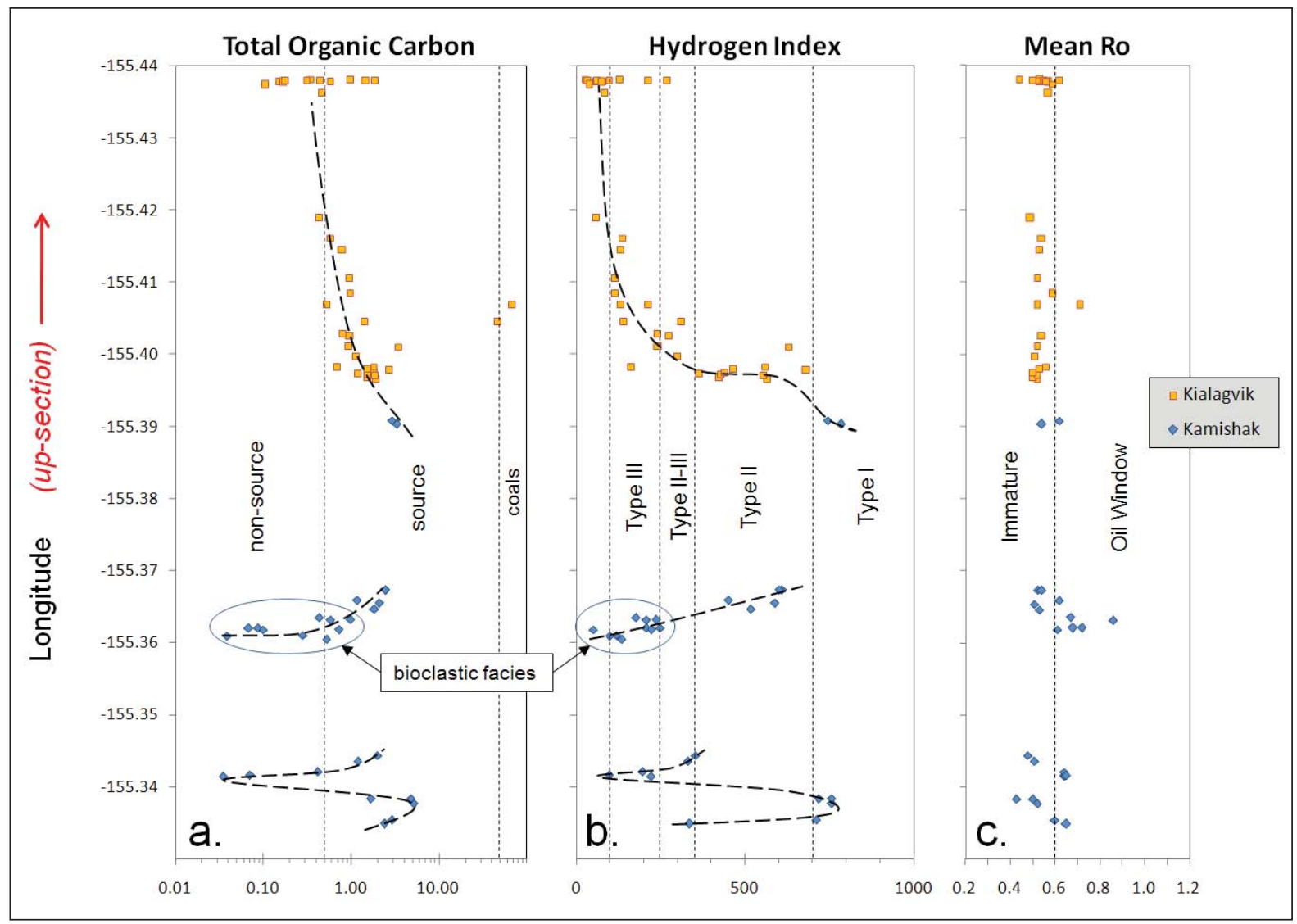

Figure 10. TOC, HI, and mean $R_{o}$ of Kamishak and Kialagvik Formation samples from Puale Bay. Samples are plotted as a function of longitude, a proxy for relative stratigraphic position since these samples are from a generally northwest-dipping succession. The relationship to stratigraphic thickness is variable, depending on local fluctuations in dip magnitude and direction. Detterman and others (1996) report a 404-m-thick section of Lower Jurassic Talkeetna Formation strata between the Kamishak and Kialagvik Formations at this location. Dashed black curves are highly smoothed, visually-fit trends through the TOC and HI data, reflecting relatively high-frequency fluctuations in organic richness and apparent kerogen type throughout Kamishak deposition, versus a more systematic upward trend of decreasing source rock quality in the Kialagvik Formation. Vitrinite reflectance values average 0.60 in the Kamishak Formation and 0.54 in the Kialagvik Formation. These marginal maturity values indicate that the TOC and HI data approximate the original generative potential, with little bias attributable to transformation of organic matter to hydrocarbon.

\section{CENOZOIC SOURCE-ROCK CHARACTERISTICS}

Most of the Tertiary samples considered here are from the NAS COST \#1 well, where more than 420 TOC and Rock-Eval analyses and 120 elemental analyses (Sherwood and others, 2006, Appendix 2) represent the Tolstoi, Stepovak, Bear Lake (including the possible Unga-equivalent interval), and Milky River Formations. Previous analyses of the well data (Dow, 1983; Turner and others, 1988; Sherwood and others, 2006) have reached many of the same conclusions supported by this report, clearly demonstrating the Tertiary section of the North Aleutian basin to be predominantly gas-prone. Nonetheless, many of these well data are presented here to facilitate direct comparison with the data from the Mesozoic outcrops at Puale Bay. Results from 12 additional Bear Lake Formation outcrop samples collected by DGGS geologists during 2004 and 2005, nine of which are coals with more than 50 percent TOC, are plotted as a discrete data series on the graphs of figures 7-9, distinct from the Bear Lake samples from the well. Populations of outcrop samples collected by DGGS workers from other Tertiary units are probably too small to stand alone as the basis of meaningful observations, and are omitted from this discussion in favor of examining the larger datasets available from the well. As in the preceding section, thermal maturity is considered first because of its impact on the interpretation of other source characteristics. 
Thermal maturity. Figure 11 is a plot of vitrinite reflectance vs. depth from the NAS COST \#1 well, showing a well-defined linear maturity gradient. A significant offset in the profile at $761 \mathrm{~m}(15,620 \mathrm{ft})$ measured depth in the Tolstoi Formation is attributable either to erosion at an intra-formational unconformity or omission of section by normal faulting (Sherwood and others, 2006, fig. 17). Based on this gradient, the main oil generation window (0.6 to 1.35 percent $\mathrm{R}_{\mathrm{o}}$ ) extends from approximately $-3,750 \mathrm{~m}(-12,300 \mathrm{ft})$ subsea $(\sim 3,780 \mathrm{~m} / \sim 12,400 \mathrm{ft}$ measured depth) to about $-5,640 \mathrm{~m}$ (-18,500 ft) subsea, below the well's total depth. Thus, while much of the Tolstoi Formation is mature for hydrocarbon generation at this location, the overlying Stepovak, Bear Lake, and Milky River Formations are all thermally immature. Only the deeper parts of the Tolstoi Formation may have originally had significantly more organic carbon and hydrogen content (more oil-generating potential) than their TOC and Rock-Eval measurements described below would indicate. Substantial gas generation is expected to have occurred from carbonaceous and coaly source intervals that are at oil window or greater maturity in the middle and lower portions of the Tolstoi Formation (Boreham and Powell, 1993; Sherwood and others, 2006). Ongoing dry gas generation is expected within the lowest part of the sedimentary section in this graben. Burial history modeling (Sherwood and others, 2006, fig. 30) estimates that Tolstoi strata at the floor of the graben entered the main oil window during latest Eocene or earliest Oligocene time ( $\sim 34 \mathrm{Ma}$ ), and passed into the main gas generation window during latest Oligocene time ( 24 Ma).

Sherwood and others (2006) described complications in defining a single geothermal gradient that is appropriate for the entire NAS COST \#1 well. Their burial history modeling suggested a geothermal gradient of 30.4 to $31.0^{\circ} \mathrm{C} / \mathrm{km}$ (1.67 to $1.7^{\circ} \mathrm{F} / 1,000 \mathrm{ft}$ ) for the interval below $\sim 1,500 \mathrm{~m}(4,900 \mathrm{ft})$ measured depth. This is virtually identical to the $31^{\circ} \mathrm{C} / \mathrm{km}$ gradient calculated for the well as a whole by Turner and others (1988) and Bergman, Murphy, and Kelley (this volume). Molenaar (1996) derived somewhat higher present-day geothermal gradients from onshore wells, averaging $34.6^{\circ} \mathrm{C} / \mathrm{km}$ near the edge of the backarc basin onshore in the Bristol Bay Lowlands, and averaging $36.5^{\circ} \mathrm{C} / \mathrm{km}$ in the volcanic arc and outcrop belt. Seismic, biostratigraphic, and fission-track data (Turner and others, 1988; Sherwood and others, 2006; Bergman, Murphy, and Kelley, this volume) support the interpretation that the backarc basin, and in particular the graben drilled by the COST well, has experienced a simple subsidence history, reaching maximum temperatures in the recent past.

Kerogen type and total organic carbon. Taken at face value without regard to the previously discussed caveats about using pyrolysis techniques for kerogen characterization in coaly organic matter, the modified van Krevelen plot (fig. 7) would suggest that the Cenozoic samples include a wide range of kerogen macerals,

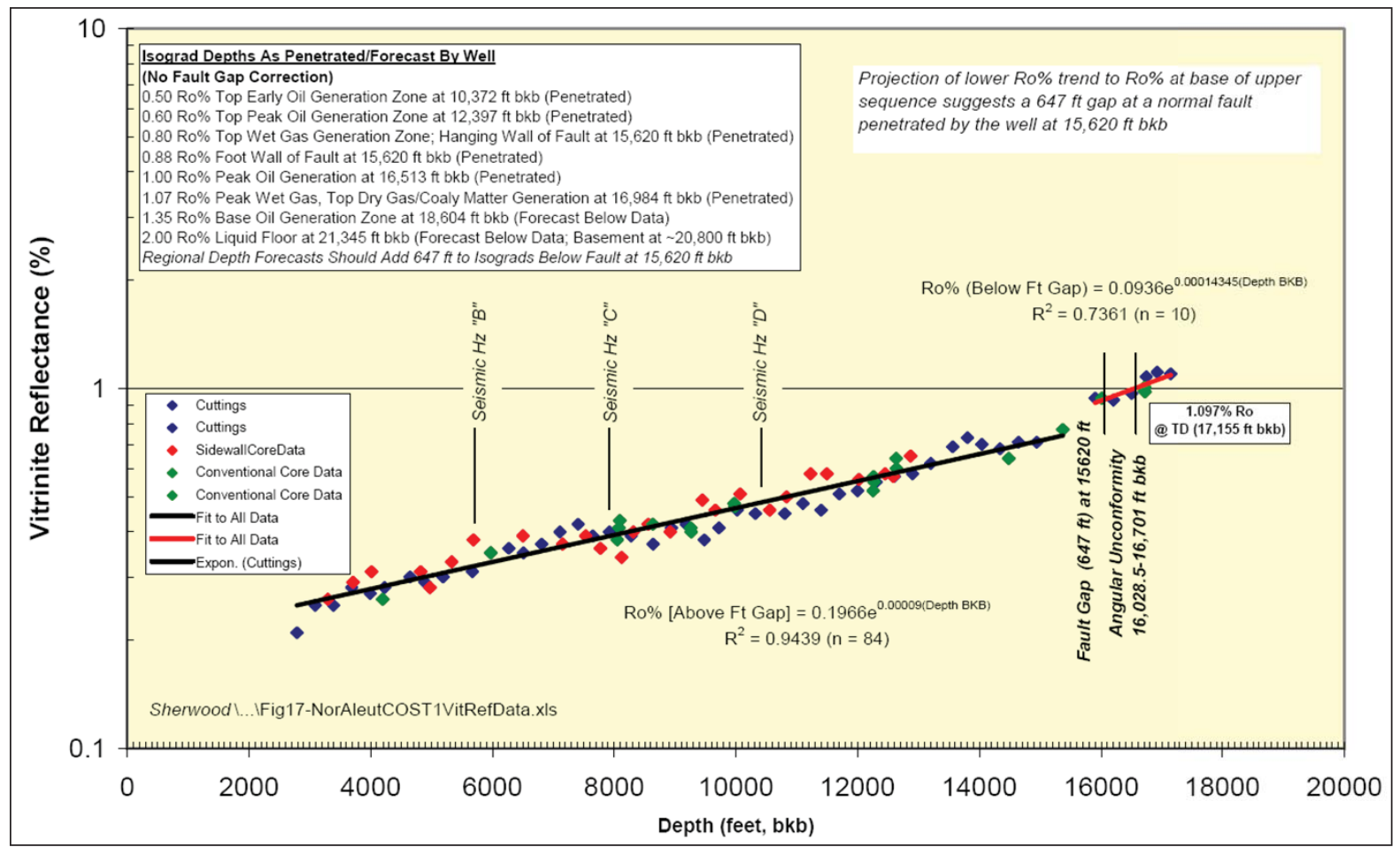

Figure 11. Vitrinite reflectance profile for NAS COST 1 well from Sherwood and others, 2006. 
including inert (Type IV), gas-prone (Type III), and possibly liquid-prone (Type I-II and II-III) forms. Given the shallow marine to nonmarine depositional setting in the North Aleutian basin, it is not surprising that many of the well samples, including nearly all from the Stepovak, Bear Lake, and Milky River Formations appear to consist mostly of gas-prone or inert kerogens. However, there is a large number of Tolstoi Formation samples and a small group of coals from the Bear Lake outcrop belt that have elevated HI values (>200 mg/g) and low OI values ( $<25 \mathrm{mg} / \mathrm{g})$. These merit further discussion as to whether they should be considered potential liquid-prone source rocks, particularly those with HI in excess of 300 $\mathrm{mg} / \mathrm{g}$. Most of the Tolstoi samples with HI values above $200 \mathrm{mg} / \mathrm{g}$ are from between 3,660 and 4,785 m (12,000 and 15,700 ft) measured depth (Sherwood and others, 2006, fig. 21).

Kerogen typing from organic microscopy in the NAS COST \#1 well (Turner and others, 1988, fig. 93) indicates that much of the Tolstoi interval with $\mathrm{HI}$ in excess of $200 \mathrm{mg} / \mathrm{g}$ also contains 15-25 percent liptinitic kerogen as a mix of amorphous (Type I algal, sapropelic or structureless) and exinite (Type I-II structured herbaceous, lipid-rich) macerals. Atomic ratio data are also available for a subset of the samples from the well (Dow, 1983; Sherwood and others, 2006). Most of the samples with HI values greater than $200 \mathrm{mg} / \mathrm{g}$ that were also analyzed for elemental composition have $\mathrm{H} / \mathrm{C}$ ratios between 0.8 and 1.0. Considered together, their HI, petrographic characteristics, and elemental compositions place these Tolstoi samples in the marginal range for oil expulsion (Hunt, 1991; Powell and Boreham, 1994; Peters and Cassa, 1994), albeit near the Type III curve on a true van Krevelen diagram (Sherwood and others, 2006, fig. 22).

The HI vs. TOC plot (fig. 8) suggests correctly that the Tertiary succession consists of a mix of lithologies, including non-source sandstones and siltstones as well as source-prone mudstones, carbonaceous shales ( $\sim-50$ percent TOC), and true coals ( $>50$ percent TOC). There is significant overlap between samples of the Stepovak, Bear Lake, and Milky River Formations. Above about 1 percent TOC, most Tolstoi samples define a substantially higher HI trend than the younger formations (fig. 9b). All but a few of the Tertiary samples with $\mathrm{HI}>200 \mathrm{mg} / \mathrm{g}$ also have TOC values above 3-4 percent; those with HI ranging 300 to $400 \mathrm{mg} / \mathrm{g}$ are mostly carbonaceous shales of the Tolstoi Formation and a few of the coals from the Bear Lake outcrop belt. Several Tolstoi samples have $\mathrm{HI}$ greater than $450 \mathrm{mg} / \mathrm{g}$ paired with widely scattered TOC values; a few with TOC elevated above 4 percent could potentially represent either restricted marine or lacustrine shales (fig. 8). The high HI values of those with low TOC values may result from spuriously low TOC measurements, since HI is defined by the S2/TOC ratio. These exceptions and caveats notwithstanding, the distinctly higher HI vs. TOC trend of the main Tolstoi population relative to most samples from the other Tertiary formations is noteworthy.

Average hydrogen index and hydrocarbon adsorption capacity. S2 vs. TOC regression lines for the Tolstoi, Stepovak, and Bear Lake sample populations from the NAS COST \#1 well are shown on the graph of figure 9b. The smaller Milky River population, besides being statistically less robust, is of little consequence as a potential thermogenic or biogenic source in the North Aleutian basin (shallow burial, organically lean), and is not subjected to regression analysis. The small group of true coals from outcrops of the Bear Lake Formation is analyzed independently (non-coal outcrop samples excluded) in figure 9a.

The Tertiary sample populations cluster into relatively distinct trends in these S2 vs. TOC cross plot of figure 9b. The Tolstoi regression has the steepest slope, equating to a true average $\mathrm{HI}$ of $319 \mathrm{mg} / \mathrm{g}$, consistent with a substantial Type II kerogen content. A single sidewall core sample from the lower part of the Stepovak Formation at 2,534 $\mathrm{m}(8,314 \mathrm{ft})$ measured depth plots as an outlier near the center of figure $9 a$ (TOC $=49.5$ percent, $\mathrm{S} 2=181 \mathrm{mg} / \mathrm{g})$. This sample is excluded from the Stepovak regression, since it is for all practical purposes a coal, whereas the other samples represent a range of muddy to sandy clastic lithologies. The resulting regression reveals that non-coal sources of the Stepovak Formation have a true average HI of $167 \mathrm{mg} / \mathrm{g}$. The non-coal population from the Bear Lake interval in the COST well has a still lower slope, representing a true average HI of $123 \mathrm{mg} / \mathrm{g}$. Both of these are below the $200 \mathrm{mg} / \mathrm{g}$ HI boundary suggested as an approximate upper limit for gas-prone Type III kerogen (Langford and Blanc-Valleron, 1990; Peters and Cassa, 1994).

The regression-based true average $\mathrm{HI}$ values suggest that the Stepovak and Bear Lake formations would be expected to generate only dry gas, but the Tolstoi Formation could potentially generate light hydrocarbon liquids in addition to gas. Coals and coaly organic matter are now well accepted as the source of oil accumulations in Australia, Indonesia, and other areas (Clayton, 1993; Powell and Boreham, 1994; Fleet and Scott, 1994; Peters and Cassa, 1994). Multiple lines of geochemical evidence demonstrate that coals from the Eocene Kulthieth Formation may source some of the natural oil seeps in the Gulf of Alaska region (Van Kooten and others, 2002).

The limiting factor in the effectiveness of coaly strata as oil source rocks is commonly their low expulsion efficiency (Fleet and Scott, 1994), largely a function of high hydrocarbon adsorption capacity. As an illustration, consider the regression through the small dataset of coals from Bear Lake Formation outcrops (fig. 9a). Although 
the steep slope of the regression indicates that these coals have a high average $\mathrm{HI}(594 \mathrm{mg} / \mathrm{g}$ ) consistent with the potential for generating liquid petroleum, the regression line is shifted far to the right, with a large negative y-intercept. The adsorptive capacity of the Bear Lake outcrop coals is $222 \mathrm{mg}$ of hydrocarbon per gram of source rock, nearly two orders of magnitude higher than that of the Kamishak carbonates, meaning that relatively little of the hydrocarbon generated would be expelled.

Cenozoic source facies summary. Taken together, the TOC, Rock-Eval pyrolysis data, organic microscopy, atomic ratio, and thermal maturity data from the NAS COST \#1 well indicate that the Tertiary succession of the North Aleutian basin contains abundant gas-prone source facies in the Tolstoi, Stepovak, and Bear Lake Formations. However, only the deeper portions of the basin below about $-3,750 \mathrm{~m}(-12,300 \mathrm{ft})$ subsea are expected to have experienced significant thermogenic generation. Some coaly siltstones, carbonaceous mudstones, and shales of the Tolstoi Formation penetrated in the well between 3,660 and 4,785 m (12,000-15,700 ft) measured depth may meet the criteria (Hunt, 1991; Powell and Boreham, 1994; Peters and Cassa, 1994) for coaly sources that are at least marginally capable of generating and expelling light hydrocarbon liquids. This is in keeping with the findings of Sherwood and others (2006) that the minor oil shows from the lower part of the NAS COST \#1 well yield carbon isotope values, pristane/phytane ratios, and biomarker signatures tying them to Tertiary terrigenous source facies rather than the marine source rocks of the Jurassic and Triassic units.

\section{DISCUSSION AND CONCLUSIONS}

Despite major lithologic contrasts between the carbonate-dominated Triassic Kamishak Formation and the siliciclastic mudstones, siltstones, and sandstones of the Jurassic Kialagvik Formation, Rock-Eval, TOC, and kerogen petrography analyses indicate that both units contain highly oil-prone source facies. True average hydrogen indices (HI) in the 650-750 mg/g range determined from S2-TOC regressions reflect the strong predominance of Type I-II kerogen, consistent with liptinite contents averaging approximately 80 to 85 percent in both units, despite the local occurrence of thin vitrinitic coals in the Kialagvik Formation.

Although there is no evidence that these Mesozoic source rocks underlie substantial offshore portions of the North Aleutian basin, the outcrop distribution of Chignik subterrane units suggests they may locally source onshore and nearshore plays on acreage offered in Alaska Peninsula areawide lease sales. The importance of the Middle Jurassic Tuxedni Group (Kialagvik equivalent) as the source of commercial oil in upper Cook Inlet fields is well established from geochemical evidence (Magoon and Claypool, 1981; Magoon and Anders, 1990, 1992; Magoon, 1994), and Upper Triassic rocks (Kamishak equivalent) have been identified as a co-source of oils in lower Cook Inlet (Magoon and Anders, 1990, 1992). Future outcrop study of these Mesozoic source rocks should strive to integrate pyrolysis data with measured section thicknesses in order to quantify source potential index (Demaison and Huizinga, 1994). This parameter is valuable in constraining basin models, as it represents the maximum quantity of hydrocarbons that can be generated per square meter of a source rock unit's areal extent.

In contrast, the Cenozoic formations penetrated at the NAS COST \#1 well are considerably more gas-prone, in keeping with the shallow marine to nonmarine depositional environment and corresponding predominance of terrestrially-derived coaly kerogen. Although interpreted as mostly nonmarine at this location, the Eocene Tolstoi Formation's true average hydrogen index of $319 \mathrm{mg} / \mathrm{g}$ suggests that portions of its carbonaceous shale facies with elevated liptinitic kerogen content and $\mathrm{H}$ :C ratio may possess marginal capability to generate petroleum liquids in addition to natural gas. Because the middle and lower parts of the Tolstoi are thermally mature for hydrocarbon generation, their original TOC and HI values (and thus liquids-generation potential) would have been somewhat higher still. However, the high adsorptive capacity associated with coaly kerogens may have limited the unit's expulsion efficiency. A small population of Miocene Bear Lake Formation coals collected in outcrop has a true average HI of nearly 600 $\mathrm{mg} / \mathrm{g}$, but their adsorptive capacity is nearly two orders of magnitude higher than those of the other units. Any liquid hydrocarbons generated are unlikely to have migrated out of these Bear Lake coals. The Bear Lake Formation and Eocene-Oligocene Stepovak Formation shales and carbonaceous shales from the COST well nearly all appear capable of generating only dry gas upon thermogenic maturation. However, at least in the deep graben penetrated by the well, the zone of thermogenic generation potential lies entirely within and below the Tolstoi Formation.

\section{ACKNOWLEDGMENTS}

Field work and analyses for this study were conducted during 2004, 2005, and 2007 with funding from multiple sources, including a U.S. Department of Energy grant from the Arctic Energy Technology Development Laboratory at the University of Alaska Fairbanks to Rocky Reifenstuhl (program head) and Paul McCarthy (principal investigator, UAF); Bristol Bay Native Corporation; and Division of Geological \& Geophysical Surveys and Division of Oil and Gas operating and capital improvement project budgets. Field samples were 
collected by Rocky Reifenstuhl, Robert Gillis, Emily Finzel, and Karen Clautice (DGGS); the author, David Shafer, and Timothy Ryherd, (DOG); Michael Whalen (UAF); and Robert Blodgett (consulting geologist). The text and figures benefited greatly from insightful reviews by Mark McCaffrey and Art Banet.

\section{REFERENCES CITED}

Allaway, W.H., Jr., Detterman, R.L, Miller, J.W., and Magoon, L.B., 1984, Stratigraphic clarification of the Shelikof Formation, Alaska Peninsula, in Stratigraphic notes, 1983: U.S. Geological Survey Bulletin 1537-A, p. A21-A27.

Beeman, W.R., Obuch, R.C., and Brewton, J.D., 1996, Digital map data, text, and graphical images in support of the 1995 National Assessment of United States Oil and Gas Resources: U.S. Geological Survey Digital Data Series DDS-35, 1 disk, http://pubs. usgs.gov/dds/dds-035/DDS-35.html

Beikman, H.M., 1980, Geologic map of Alaska: U.S. Geological Survey Professional Paper 171, 1 plate, scale 1:2,500,000.

Bergman, S.C., Murphy, John, and Kelley, Shari, this volume.

Blodgett, R.B., this volume.

Blodgett, R.B., and Clautice, K.H., 2005, Oil and gas seeps of the Puale Bay-Becharof Lake-Wide Bay region, northern Alaska Peninsula: Alaska Division of Geological \& Geophysical Surveys Preliminary Interpretive Report 2005-6, 13 p., 1 sheet.

Blodgett, R.B., and Sralla, Bryan, 2008, A major unconformity between Permian and Triassic strata at Cape Kekurnoi, Alaska Peninsula; Old and new observations on stratigraphy and hydrocarbon potential, in Haeussler, P.J., and Galloway, J.P., eds., Studies by the U.S. Geological Survey in Alaska, 2006: U.S. Geological Survey Professional Paper 1739-E, 13 p. [http://pubs.usgs.gov/pp/pp1739/e/].

Boreham, C.J., and Powell, T.G., 1993; Petroleum source rock potential of coal and associated sediments - qualitative and quantitative aspects, in Law, B.E., and Rice, D.D., eds., Hydrocarbons from coal: American Association of Petroleum Geologists Studies in Geology 38, p. 133-157.

Clayton, J.L., 1993, Composition of crude oils generated from coals and coaly organic matter in shales, in Law, B.E., and Rice, D.D., eds., Hydrocarbons from coal: American Association of Petroleum Geologists Studies in Geology 38, p. 185-201.

Decker, P.L., Finzel, E.S., Ridgway, K.D., Reifenstuhl, R.R., and Blodgett, R.B., 2005, Preliminary summary of the 2005 field season; Port Moller, Herendeen Bay, and Dillingham areas, Bristol Bay Basin, Alaska Peninsula: Alaska Division of Geological \&
Geophysical Surveys Preliminary Interpretive Report 2005-7, 55 p., 2 sheets.

Decker, P.L., Reifenstuhl, R.R., and Gillis, R.J., this volume.

Decker, P.L., Reifenstuhl, R.R., Finzel, E.S., and Helmold, K.P., 2006, Play concepts for reopening the Bristol Bay basin; Tertiary and Mesozoic petroleum systems of the Alaska Peninsula [abs.]: American Association of Petroleum Geologists Bulletin, v. 90, Program Abstracts (digital).

Demaison, G., and Huizinga, B.J., 1994, Genetic classification of petroleum systems using three factors; Charge, migration and entrapment, in Magoon, L.B., and Dow, W.G., eds., The petroleum system-from source to trap: American Association of Petroleum Geologists Memoir 60, p.73-89.

Detterman, R.L., Case, J.E., Wilson, F.H., Yount, M.E., and Allaway, W.H., Jr., 1983, Generalized geologic map of the Ugashik, Bristol Bay, and part of Karluk quadrangles, Alaska: U.S. Geological Survey Miscellaneous Field Studies Map 1539-A, 1 plate, scale 1:250,000.

Detterman, R.L., Case, J.E., Wilson, F.H., and Yount, M.E., 1987, Geologic map of the Ugashik, Bristol Bay, and western part of Karluk quadrangles, Alaska: U.S. Geological Survey Miscellaneous Investigations Series Map 1685, 1 plate, scale 1:250,000.

Detterman, R.L., Case, J.E., Miller, J.W., Wilson, F.H., and Yount, M.E., 1996, Stratigraphic framework of the Alaska Peninsula: U.S. Geological Survey Bulletin 1969-A, 74 p.

Dow, W.G., 1977, Kerogen studies and geological interpretations: Journal of Geochemical Exploration, v. 7, p. 79-99.

Dow, W.G., 1983, Geochemical analysis of North Aleutian Shelf Cost No. 1 well, Alaska: Minerals Management Service public well files - Robertson Research Report No. 823/135, 315 p.

Espitalié, J., Laporte, J.L., Madec, M., Marquis, F., Leplat, P., Paulet, J., Boutefeu, A., 1977, Methode rapide de caracterisation des roches meres, de leur potential petrolier et de leur degree d'evolution: Revue de l’Institut Français du Pétrole, v. 32, p. 23-42.

Espitalié, J., Deroo, G., and Marquis, F., 1985, La pyrolyse Rock-Eval et ses applications: Revue de l'Institut Français du Pétrole, v. 40, p. 563-579 and 755-784.

Finzel, E.S., Reifenstuhl, R.R., Decker, P.L., and Ridgway, K.D., 2005, Sedimentology, stratigraphy, and hydrocarbon reservoir-source rock potential, using surface and subsurface data, of Tertiary and Mesozoic strata, Bristol Bay basin and Alaska Peninsula: Alaska Division of Geological \& Geophysical Surveys Preliminary Interpretive Report 2005-4, 67 p. 
Fleet, A.J., and Scott, A.C., 1994, Coal and coal-bearing strata as oil-prone source rocks; An overview, in Scott, A.C., and Fleet, A.J., eds., Coal and coalbearing strata as oil-prone source rocks?: Geological Society Special Publication No. 77, p. 1-8.

Hanson, B.M., 1957, Middle Permian limestone on Pacific side of Alaska Peninsula: American Association of Petroleum Geologists Bulletin, v. 41, no. 10, p. 2,376-2,378.

Hunt, J.M., 1991, Generation of gas and oil from coal and other terrestrial organic matter: Organic Geochemistry, v. 17, p. 673-680.

Imlay, R.W., 1984, Early and middle Bajocian (Middle Jurassic) ammonites from southern Alaska: U.S. Geological Survey Professional Paper 1322, 38 p., 2 plates.

Katz, B.J., 1983, Limitations of 'Rock-Eval' pyrolysis for typing organic matter: Organic Geochemistry, v. 4, p. 195-199.

Kirschner, C.L., 1988, Map showing sedimentary basins of offshore and continental shelf areas, Alaska: U.S. Geological Survey Miscellaneous Investigations Series 1873, 1 plate, scale 1:2,500,000.

Langford, F.F., and Blanc-Valleron, M.-M., 1990, Interpreting Rock-Eval pyrolysis data using graphs of pyrolyzable hydrocarbons vs. total organic carbon: American Association of Petroleum Geologists Bulletin, v. 74, p. 799-804.

Magoon, L.B., 1994, Tuxedni-Hemlock(!) petroleum system in Cook Inlet, Alaska, U.S.A., in Magoon, L.B., and Dow, W.G., eds., The petroleum system-from source to trap: American Association of Petroleum Geologists Memoir 60, p. 359-370.

Magoon, L.B., and Anders, D.E., 1990, Oil-source rock correlation using carbon isotope data and biological marker compounds, Cook Inlet-Alaska Peninsula [abs.]: American Association of Petroleum Geologists Bulletin, v. 74, p. 711.

Magoon, L.B., and Anders, D.E., 1992, Oil-to-source rock correlation using carbon-isotopic data and biological marker compounds, Cook Inlet-Alaska Peninsula, Alaska, in Moldowan, J.M., Albrecht, P., and Philip, R.P., eds., Biological Markers in Sediments and Petroleum: Prentice Hall, Englewood Cliffs, New Jersey, p. 241-274.

Magoon, L.B., and Claypool, G.E., 1981, Petroleum geology of Cook Inlet basin; an exploration model: American Association of Petroleum Geologists Bulletin, v. 65, p. 1,043-1,061.

Mickey, M.B., Haga, H. Boettcher, R.S., and Kling, S.A., 2005, Northwestern Alaska Peninsula-Bristol Bay basin biostratigraphy study: Micropaleo Consultants Job No. 25-104, 287 p., 4 oversize plates, 40 oversize figures, Alaska Division of Oil \& Gas online publication http://www.dog.dnr.state.ak.us/oil/ products/publications/akpeninsula/biostrat.htm

Molenaar, C.M., 1996, Thermal-maturity patterns and geothermal gradients on the Alaska Peninsula, in Johnsson, M.J., and Howell, D.G., eds., Thermal evolution of sedimentary basins in Alaska: U.S. Geological Survey Bulletin 2142, p. 11-19.

Peters, K.E., 1986, Guidelines for evaluating petroleum source rock using programmed pyrolysis: American Association of Petroleum Geologists Bulletin, v. 70, p. 318-329.

Peters, K.E., and Cassa, M.R., 1994, Applied source rock geochemistry, in Magoon, L.B., and Dow, W.G., eds., The petroleum system-from source to trap: American Association of Petroleum Geologists Memoir 60, p. 93-117.

Powell, T.G., and Boreham, C.J., 1994, Terrestrially sourced oils; Where do they exist and what are our limits of knowledge? - A geochemical perspective, in Scott, A.C., and Fleet, A.J., eds., Coal and coalbearing strata as oil-prone source rocks?: Geological Society Special Publication No. 77, p. 11-29.

Reifenstuhl, R.R., Decker, P.L., Gillis, R.J., Helmold, K.P., and Strauch, A., 2007, Hydrocarbon systems, basin analyses, and 2006 field and subsurface data; Bristol Bay, Alaska Peninsula, Frontier Basin [abs.]: American Association of Petroleum Geologists Bulletin, v. 91, Program Abstracts (digital).

Sherwood, K.W., Larson, J., Comer, C.D., Craig, J.D., and Reitmeier, C., 2006, North Aleutian basin OCS planning area assessment of undiscovered technically-recoverable oil and gas: U.S. Minerals Management Service Alaska OCS Region report, 138 p., 4 plates, www.mms.gov/alaska/re/reports/rereport.htm.

Tissot, B.P., and Welte, D.H., 1984, Petroleum formation and occurrence, 2nd ed.: Berlin, Springer-Verlag, $699 \mathrm{p}$.

Turner, R.F., McCarthy, C.M., Lynch, M.B., Hoose, P.J., Martin, G.C., Larson, J.A., Flett, T.O., Sherwood, K.W., and Adams, A.J., 1988, Geological and operational summary, North Aleutian Shelf COST No. 1 well, Bering Sea, Alaska: Minerals Management Service, Alaska OCS Region, OCS Report MMS 88-089, 256 p., 2 plates.

Van Kooten, G.K., Short, J.W., and Kolak, J.J., 2002, Low-maturity Kulthieth Formation coal; A possible source of the polycyclic aromatic hydrocarbons in benthic sediments of the northern Gulf of Alaska: Environmental Forensics, v. 3, p. 227-241.

Wang, Jason, Newton, C.R., and Dunne, L., 1988, Late Triassic transition from biogenic to arc sedimentation on the Peninsular terrane, Puale Bay, Alaska Peninsula: Geological Society of America Bulletin, v. 100 , no. 9, p. 1,466-1,478. 
Whalen, M., this volume.

Wilson, F.H., Detterman, R.L., and Case, J.E., 1985, The Alaska Peninsula terrane; A definition: U.S. Geological Survey Open-File Report 85-450, 17 p.

Wilson, F.H., Detterman, R.L., and DuBois, Gregory, 1999, Digital data for the geologic framework of the Alaska Peninsula, Southwest Alaska, and the
Alaska Peninsula Terrane: U.S. Geological Survey Open-File Report 99-317, 41 p., 1 plate, http://wrgis. wr.usgs.gov/open-file/of99-317.

Worrall, D.M., 1991, Tectonic history of the Bering Sea and the evolution of Tertiary strike-slip basins of the Bering Shelf: Geological Society of America Special Paper 257, 120 p., 1 oversize sheet, 4 plates. 



\title{
RESERVOIR QUALITY OF 84 TERTIARY SANDSTONES FROM THREE EXPLORATORY WELLS, BRISTOL BAY BASIN, ALASKA PENINSULA
}

\author{
by
}

Kenneth P. Helmold ${ }^{1}$, Donald W. Brizzolara ${ }^{1}$, and Rocky R. Reifenstuhl ${ }^{2}$

\section{INTRODUCTION}

The State of Alaska began holding areawide oil and gas lease sales for the Alaska Peninsula on October 26, 2005 (fig. 1). The Department of Natural Resources (DNR) has instituted several studies aimed at providing data necessary for the resource evaluation. This report documents one of these studies undertaken by DOG to determine the quality of potential Tertiary sandstone reservoirs.

Eighty-four thin sections of siltstone and sandstone were examined from three exploratory wells: Arco North Aleutian COST \#1 (30 km [18.6 mi] offshore), Amoco Becharof State \#1, and General Petroleum Great
Basins \#1, on the Alaska Peninsula (fig. 1). The wells were chosen for study because conventional cores or conventional core chips were readily accessible. Wells with only cuttings were excluded from study but may be examined in future efforts. The North Aleutian COST \#1 well was sampled at the ConocoPhillips Bayview core facility in Anchorage, Alaska, by Division of Geological \& Geophysical Surveys (DGGS) personnel. The Becharof State \#1 and Great Basins \#1 wells were sampled at the Alaska Geologic Materials Center (GMC) in Eagle River, Alaska. Where possible (Becharof State \#1 and North Aleutian COST \#1), 2.5-cm- (1-inch-) diameter

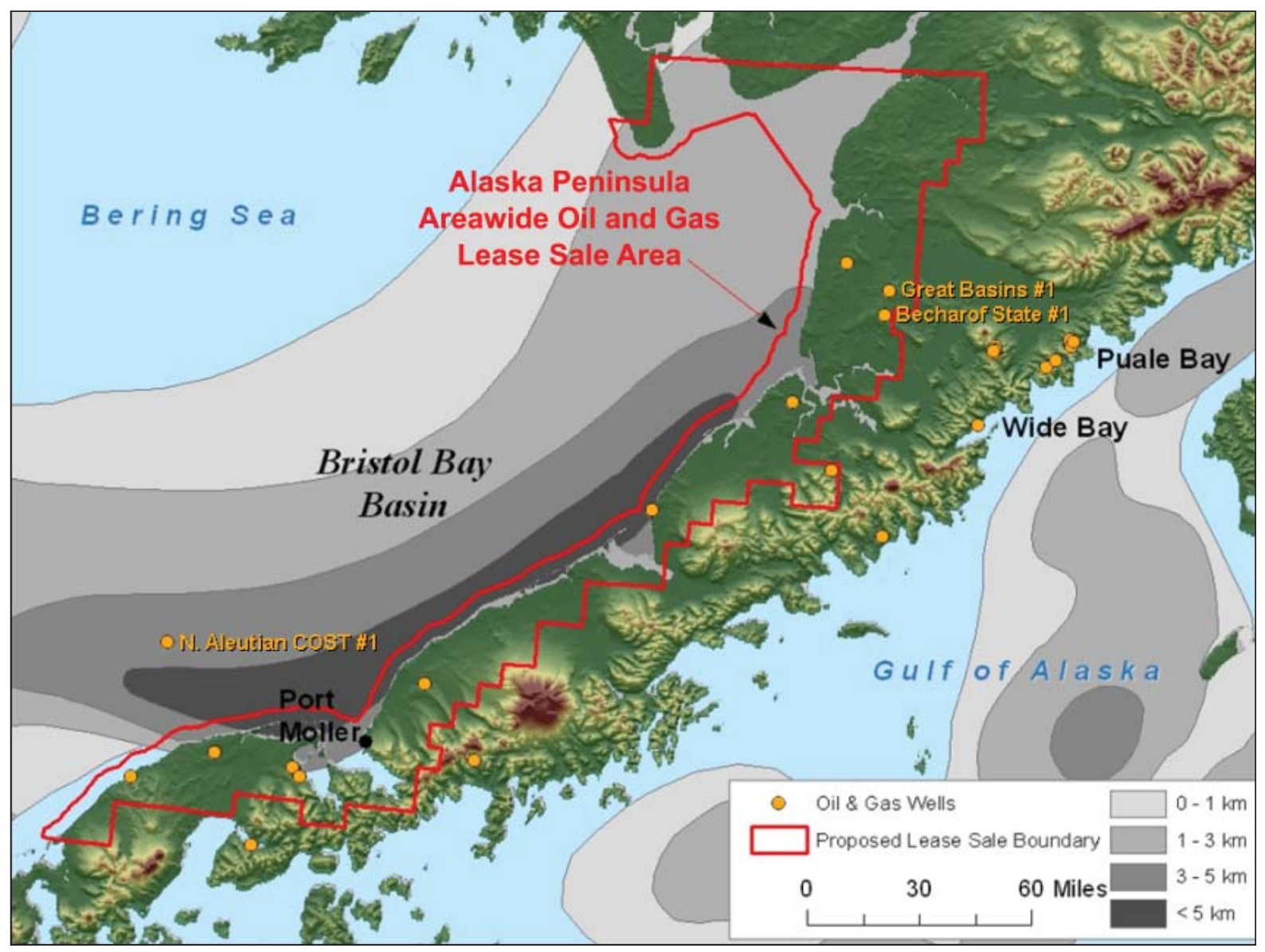

Figure 1. Shaded relief map of the Alaska Peninsula showing the lease sale area and location of oil and gas wells.

${ }^{1}$ Alaska Division of Oil \& Gas, 550 W. 7th Ave., Suite 800, Anchorage, Alaska 99501

${ }^{2}$ Alaska Division of Geological \& Geophysical Surveys, 3354 College Rd., Fairbanks, Alaska 99709-3707 
plugs were drilled from the conventional cores to obtain thin sections and porosity-permeability $(\varphi-\mathrm{k})$ measurements from the same sample. Only small core chips were available for the Great Basins \#1 well, so no $\varphi-k$ measurements could be obtained. Routine $\varphi-\mathrm{k}$ data for exploratory wells on the Alaska Peninsula were compiled from the State of Alaska Division of Oil \& Gas's (DOG) well files to augment data collected during this study. Additional previously-reported porosity and permeability data from Tertiary and Mesozoic outcrop samples (Reifenstuhl and others, 2005; Strauch and others, 2006) are included for comparison (table 4).

The samples are primarily from the upper Paleogene and Neogene portion of the stratigraphic section. They encompass the Oligocene Stepovak, Miocene Bear Lake (including the Unga Member), and Pliocene Milky River Formations (fig. 2). These units were purposefully chosen for initial investigation because of their high likelihood for containing reservoirs of good to excellent quality due to their relatively young age.

Detailed modal (point-count) analyses were performed on 47 samples to obtain quantitative estimates of detrital and authigenic mineralogies. X-ray diffraction (XRD) and scanning electron microscope (SEM) analyses were conducted on 19 samples to identify and quantify the clay mineralogy of the sandstones. The SEM micrographs are also useful for estimating the type and distribution of porosity and cements. This report is primarily intended to release these data in a timely manner for use in the evaluation of the basin's petroleum potential with the hope they might encourage future exploration. As such, detailed interpretation of the data and evaluation of regional trends of reservoir quality are limited. Recent work by DGGS documents various aspects of the structural geology, sedimentology, stratigraphy, and petroleum geology of Bristol Bay and the Alaska Peninsula (Reifenstuhl and others, 2005; Finzel and others, 2005; Decker and others, 2005; Strauch and others, 2006; Loveland and others, 2007).

\section{METHODS}

\section{THIN SECTIONS}

All samples were impregnated with bluedyed epoxy in a vacuum for 30 minutes followed by the application of high pressure (1,500-2,000 pounds per square inch or psi) for at least 8 hours. This procedure ensures complete impregnation of even the most impermeable samples and facilitates the recognition of pore types. All thin sections were stained for K-feldspar with potassium cobaltinitrate (Laniz and others, 1964) and for carbonates with a combination of alizarin red $\mathrm{S}$ and potassium ferricyanide (Dickson, 1965, 1966; Lindholm and Finkelman, 1972). Thin sections were prepared by Mark Mercer (Petrographic Services, Montrose, Colorado). Point-count analyses consisting of 300 points per sample for composition and 200 detrital grains for size were conducted by Michael D. Wilson (Wilson \& Associates, Lakewood, Colorado). Petrographic results are provided in tables 1 and 2 .

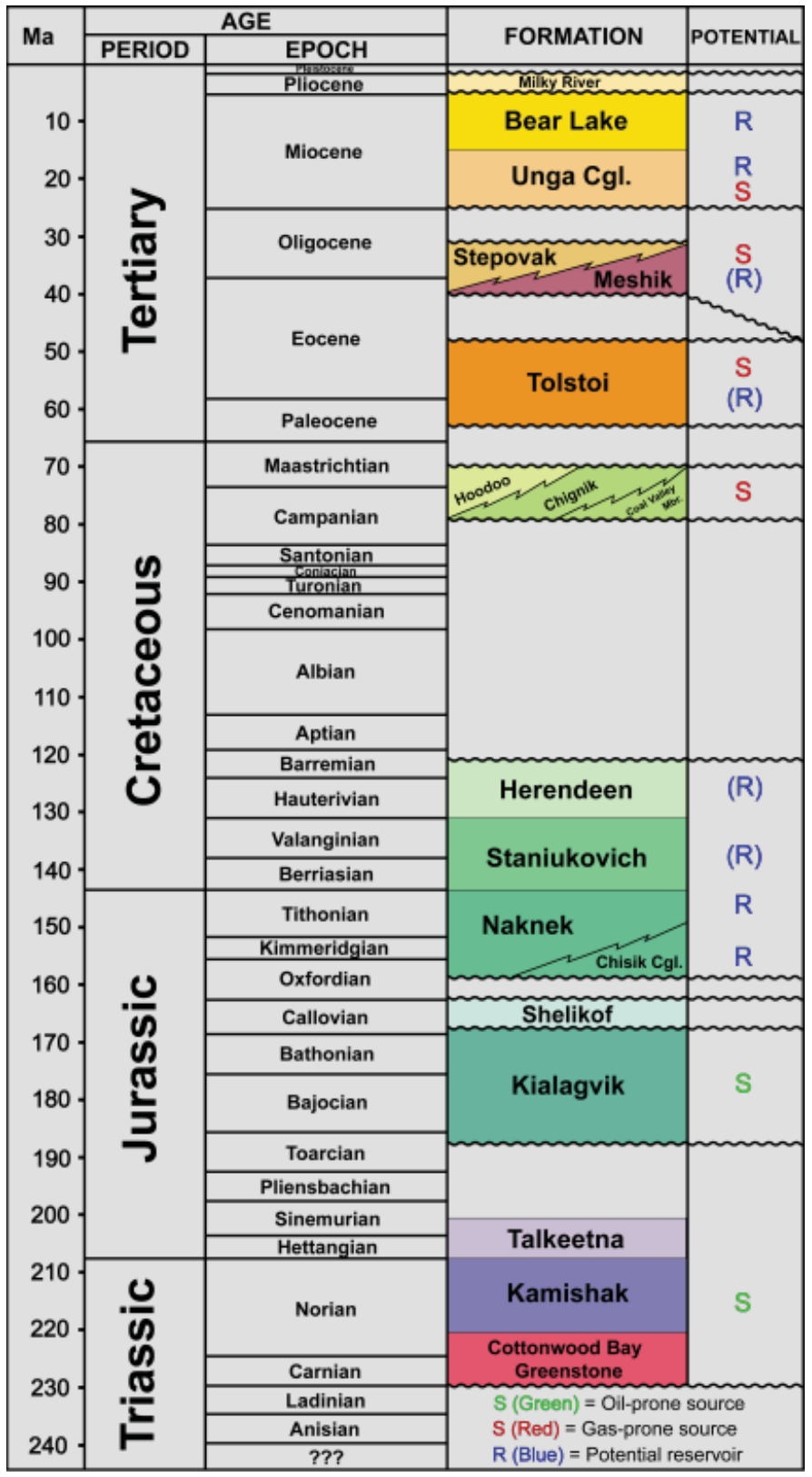

Figure 2. Composite stratigraphic column of Bristol Bay and the Alaska Peninsula (modified from Burk, 1965, and Detterman and others, 1996). 


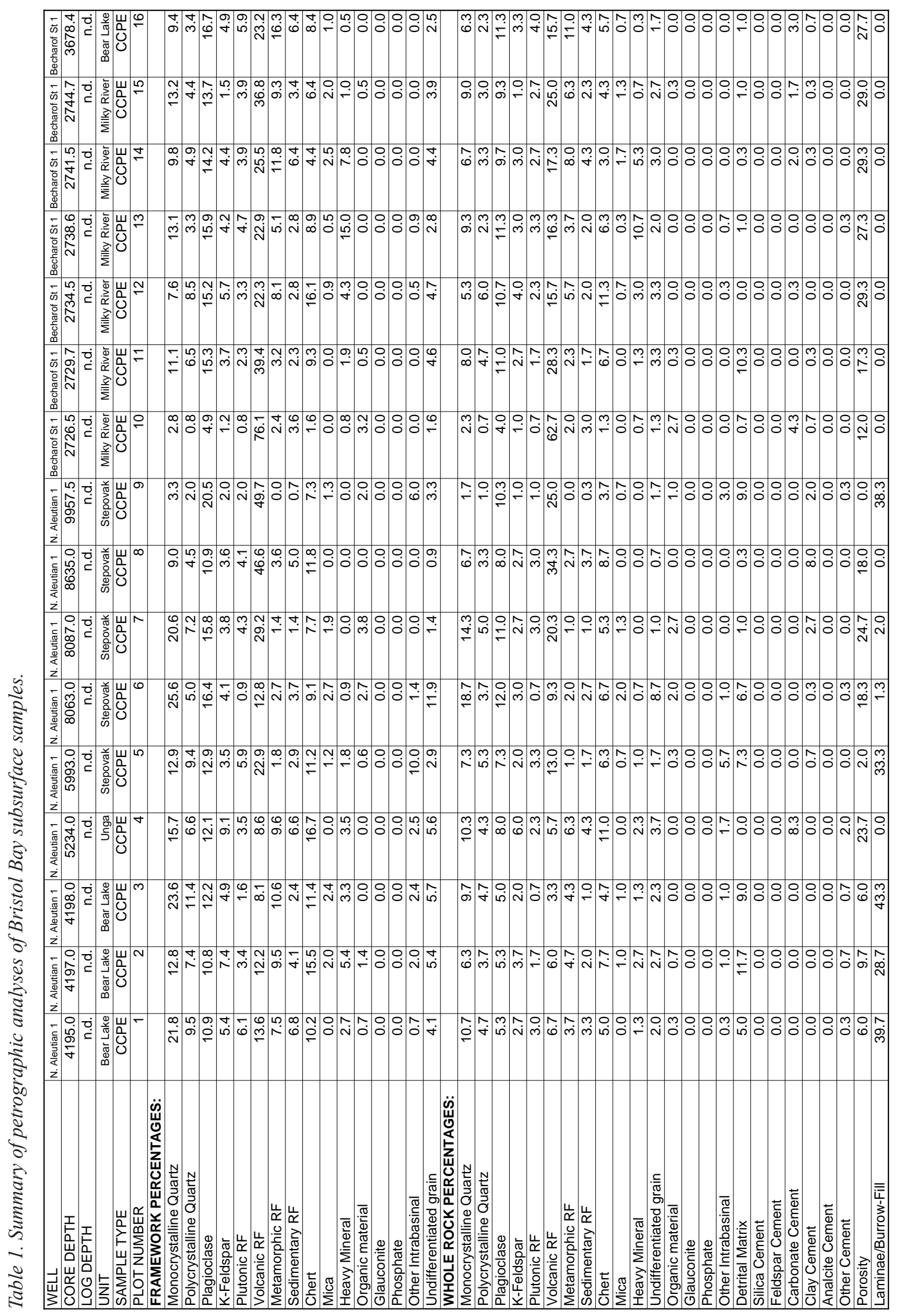




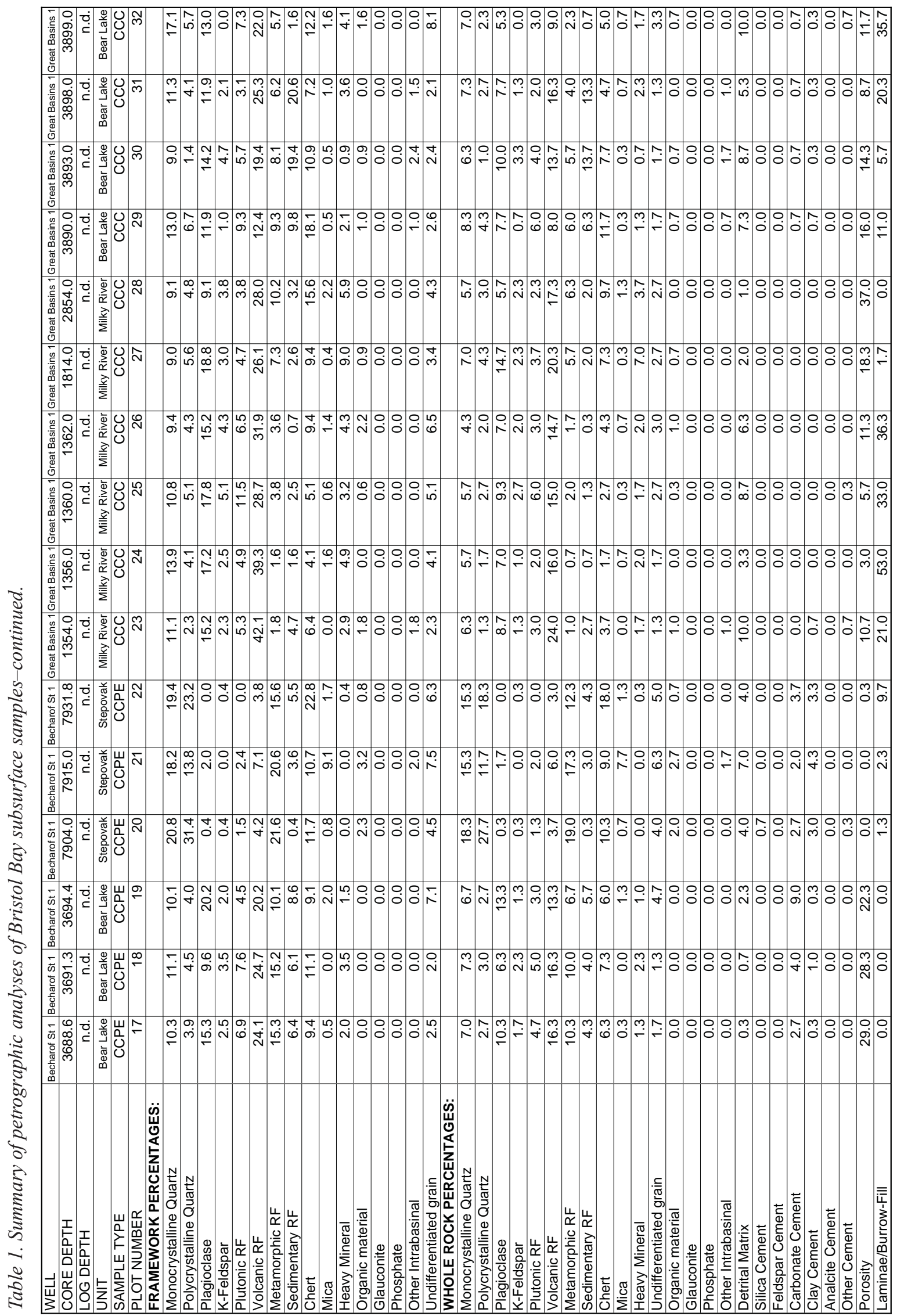




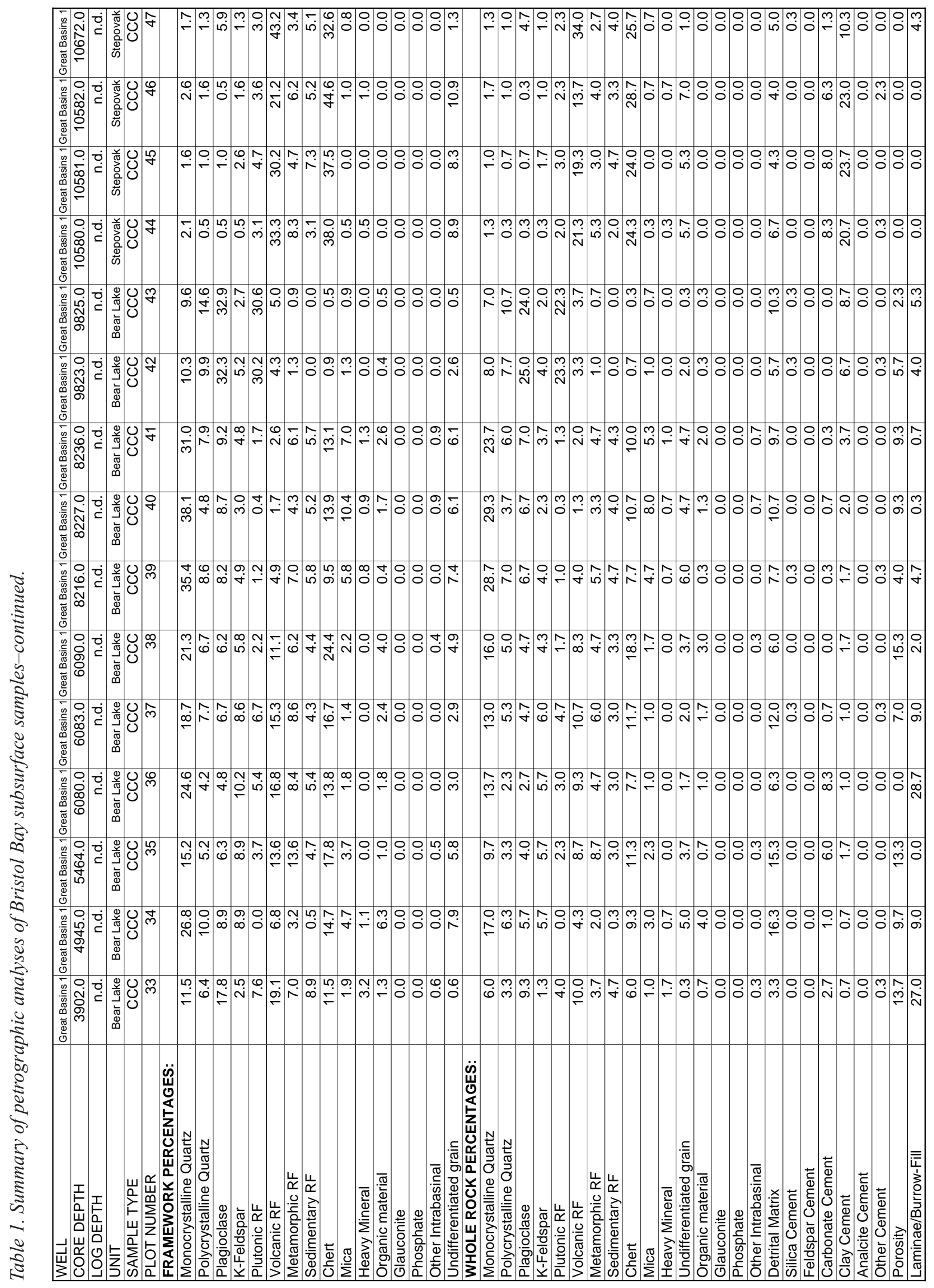




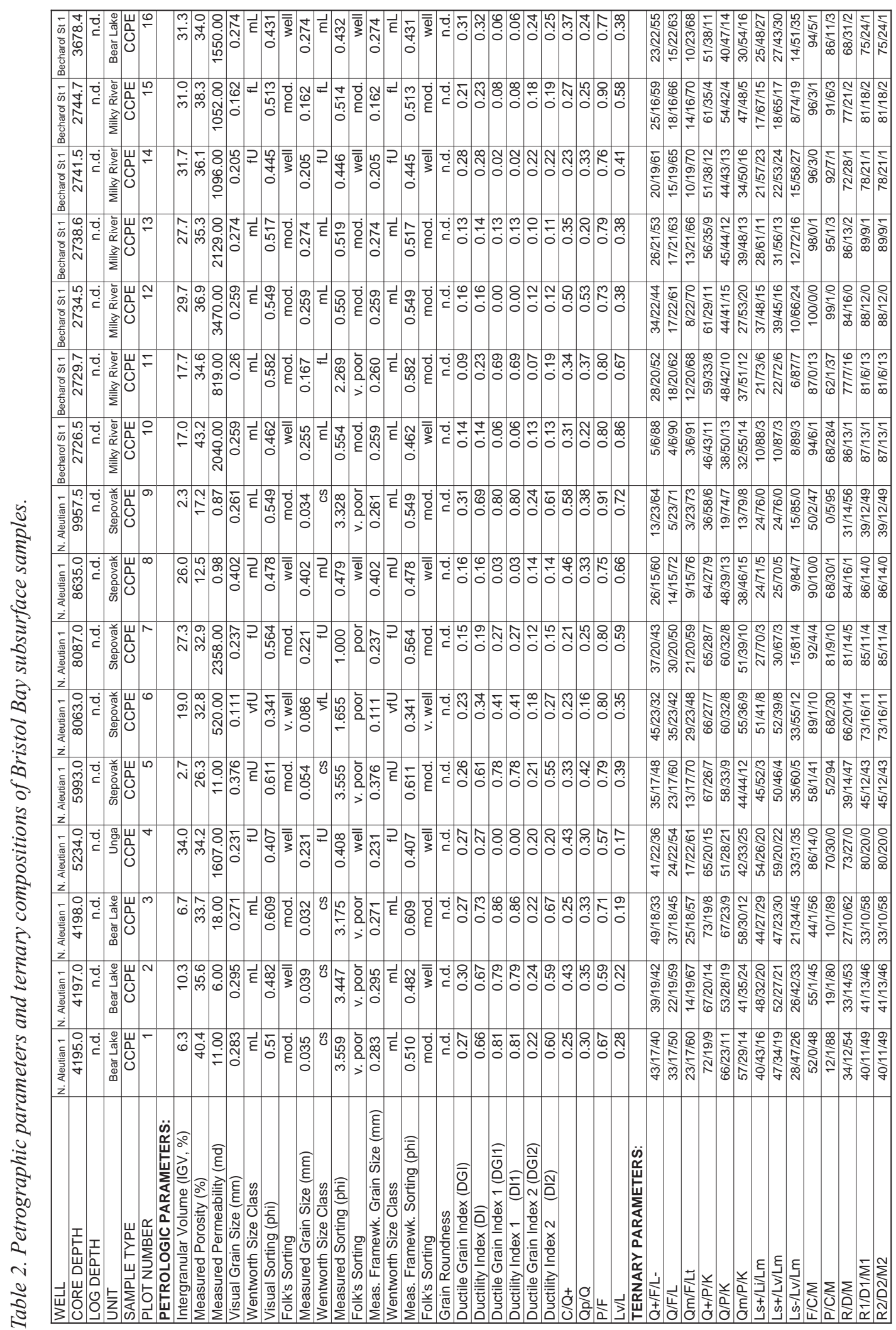




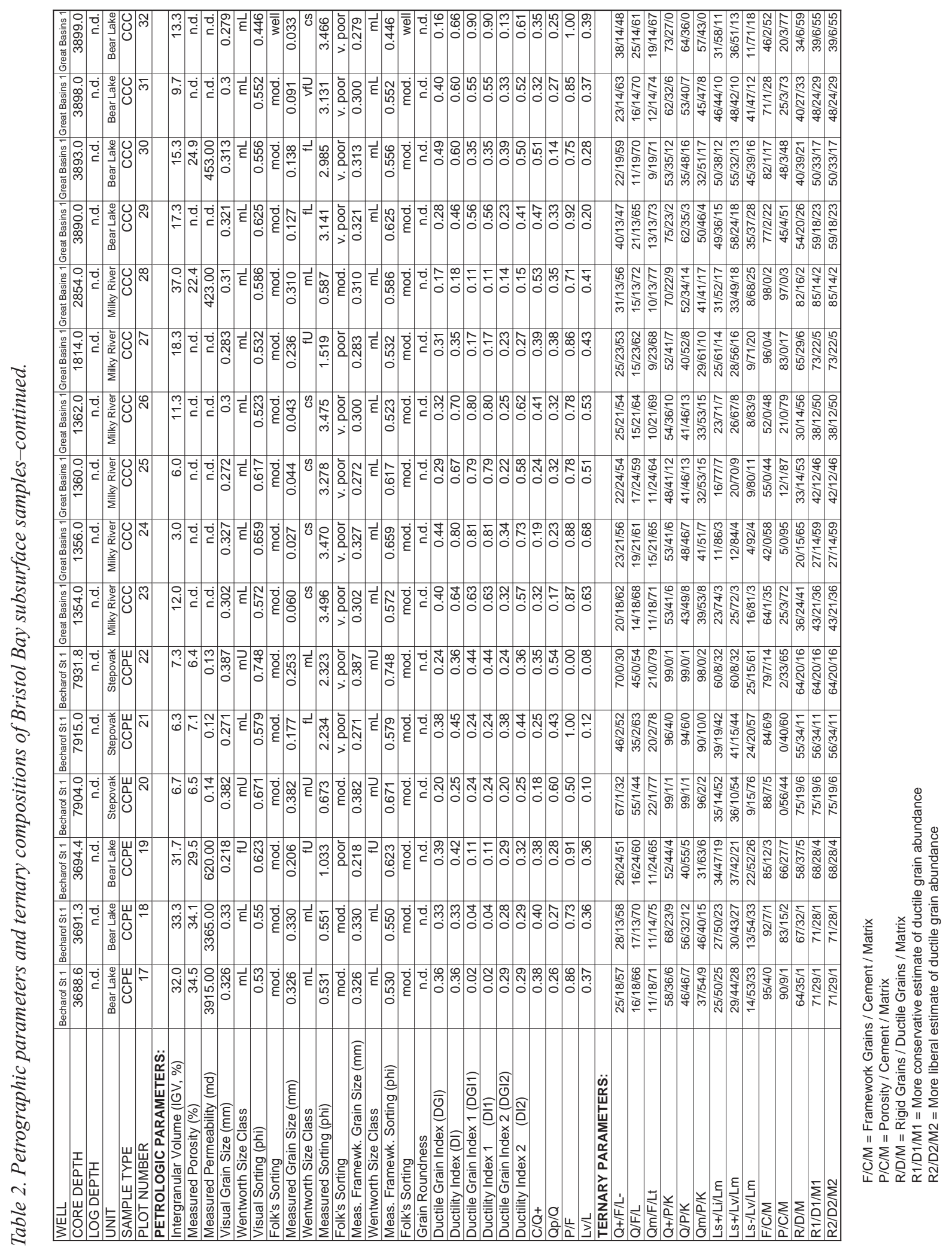




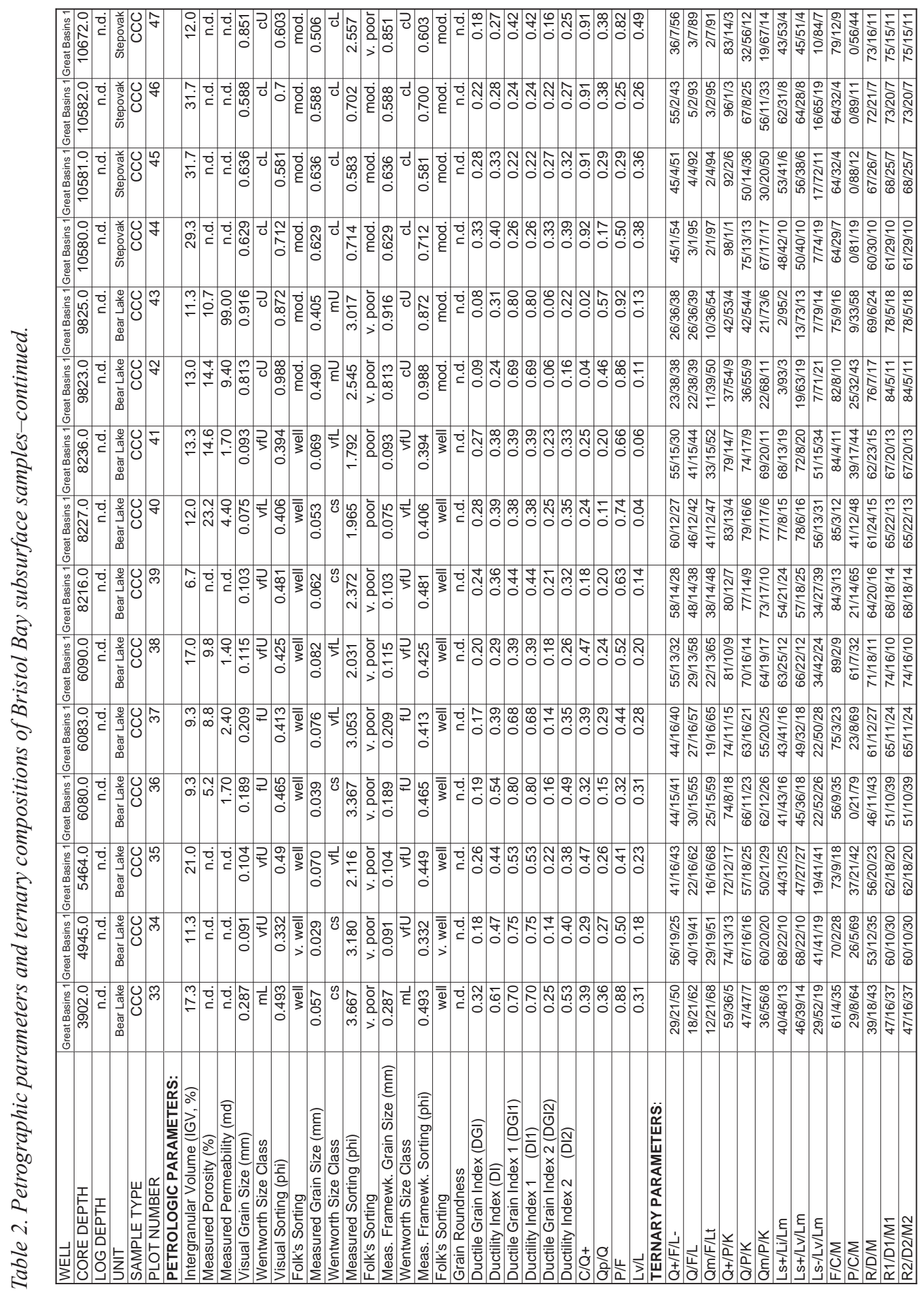




\section{X-RAY DIFFRACTION (XRD)}

Samples submitted for whole rock and clay mineral XRD analyses were cleaned of obvious contaminants and disaggregated in a mortar and pestle. A split of each sample was transferred to deionized water and pulverized using a McCrone micronizing mill. The resultant powder was dried, disaggregated, and pressure-packed into an aluminum sample holder to produce random whole-rock mounts. A separate split of each sample was dispersed in a dilute sodium phosphate solution using a sonic probe. The suspensions were centrifugally size fractionated to isolate clay-size $(<4$ micron equivalent spherical diameter) materials for a separate clay mount. A $<4$ micron cutoff was employed to include all authigenic clays, some of which, particularly kaolinite, are coarser than 2 microns. The suspensions were vacuumdeposited on nylon membrane filters to produce oriented clay mineral aggregates. Membrane mounts were attached to glass slides and exposed to ethylene glycol vapor for a minimum of 24 hours.

X-ray diffraction analyses of the samples were performed using a Rigaku automated powder diffractometer equipped with a copper $\mathrm{X}$-ray source $(40 \mathrm{kV}, 35 \mathrm{~mA})$ and a scintillation X-ray detector. The whole rock samples were analyzed over an angular range of 2 to $65^{\circ} 2 \Theta$ at a scan rate of one degree per minute. The glycol-solvated oriented clay mounts were analyzed over an angular range of 2 to $50^{\circ} 2 \Theta$ at a rate of $1.5^{\circ}$ per minute.

Semiquantitative determinations of whole-rock mineral amounts were obtained utilizing integrated peak areas (derived from peak-decomposition/profile-fitting methods) and empirical reference intensity ratio (RIR) factors determined specifically for the diffractometer used in data collection. The total phyllosilicate (clay and mica) abundance of the samples was determined on the whole-rock XRD patterns using combined $\{001\}$ and $\{\mathrm{hkl}\}$ clay mineral reflections and suitable empirical RIR factors.

X-ray diffraction (XRD) patterns from glycolsolvated clay-fraction samples were analyzed using techniques similar to those described above. The relative amounts of phyllosilicate minerals were determined from the patterns using profile-fitted integrated peak intensities and combined empirical and calculated RIR factors. Determinations of mixed-layer clay ordering and expandability were made by comparing experimental diffraction data from the glycol-solvated clay aggregates with simulated one-dimensional diffraction profiles generated using the program NEWMOD written by R.C. Reynolds (Moore and Reynolds, 1989). Sample preparation, analyses and interpretations were performed by James B. Talbot (K/T GeoServices, Inc., Argyle, Texas; see www.ktgeo.com for details of analytical procedure). $\mathrm{X}$-ray diffraction results are provided in table 3 .

\section{SCANNING ELECTRON MICROSCOPY (SEM)}

A split of sandstones that were X-rayed were also examined with an ISI DS-130 scanning electron microscope (SEM) to aid in the identification of authigenic components, particularly clay minerals, and to better visualize pore geometries (figs. 13-16). Standardless energy dispersive analyses of X-rays (EDX) were performed on several grains and pore-filling cements to confirm initial identifications based on crystal morphology. The analyses were conducted using a Kevex Delta 5 system attached to the SEM. This work was performed at the Advanced Instrumentation Laboratory, University of Alaska Fairbanks.

\section{RESULTS \\ INTERPRETATION OF TERNARY DIAGRAMS}

The composition of the sandstones determined via point-count analyses (tables 1 and 2) are summarized on a suite of ternary diagrams (fig. 3). The QFL (Quartz-Feldspar-Lithic) diagram (fig. 3A) is used to illustrate the composition of the major detrital components. In this diagram monocrystalline quartz $(\mathrm{Qm})$ and polycrystalline quartz (Qp) are apportioned to the Q-pole to highlight chemical and mechanical stability. All feldspars (potassium-feldspar and plagioclase) are apportioned to the F-pole, with the remaining lithic components (including chert) plotted at the L-pole. Chert is included with the lithics to emphasize its sedimentary origin. In a break from tradition (Dickinson, 1970; Dickinson and Suczek, 1979), intrabasinal components (that is, glauconite, phosphate, and pellets) are included with the lithics due to their potential for compaction, which negatively affects reservoir quality. In this diagram, the closer a sandstone plots towards the Q-pole, the greater its mineralogical maturity. The QmPK diagram (fig. 3B) is intended to show the composition of the monocrystalline components (quartz and feldspar) of the rocks, therefore all lithic fragments (including $\mathrm{Qp}$ ) are excluded from the diagram. As in the QFL diagram, the closer a sandstone plots towards the Q-pole, the greater its mineralogical maturity.

The LsLvLm diagram (fig. 3C) shows the composition of the aphanitic polycrystalline (lithic) components of the rock. Sedimentary rock fragments (SRF) including chert are included at the Ls-pole. Volcanic rock fragments (VRF) are apportioned to the Lv-pole, while metamorphic rock fragments (MRF) are included at the Lm-pole. Phaneritic plutonic rock fragments (for example, granite and diorite) are excluded from this diagram. The PCM diagram (fig. 3D) portrays the 







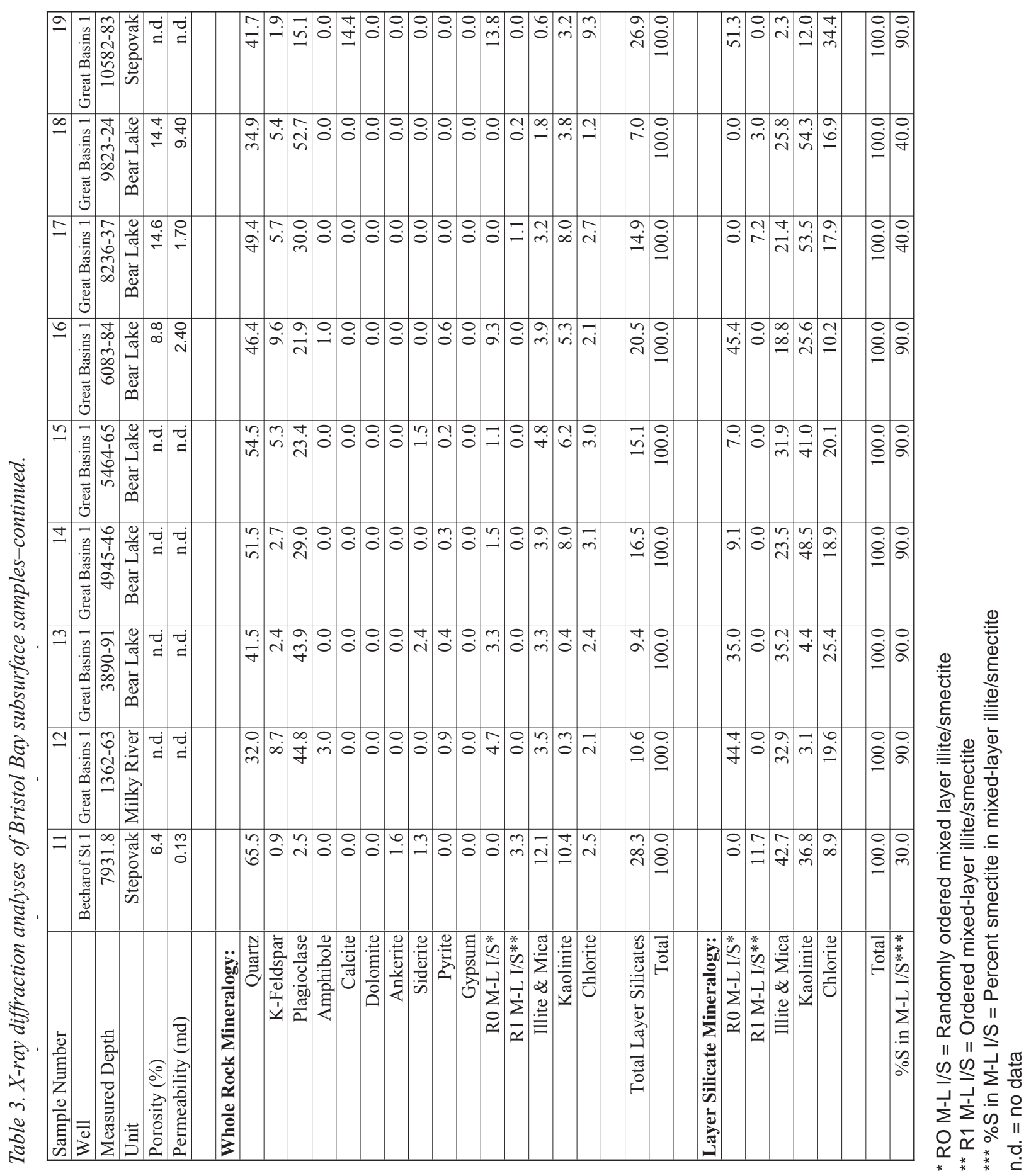




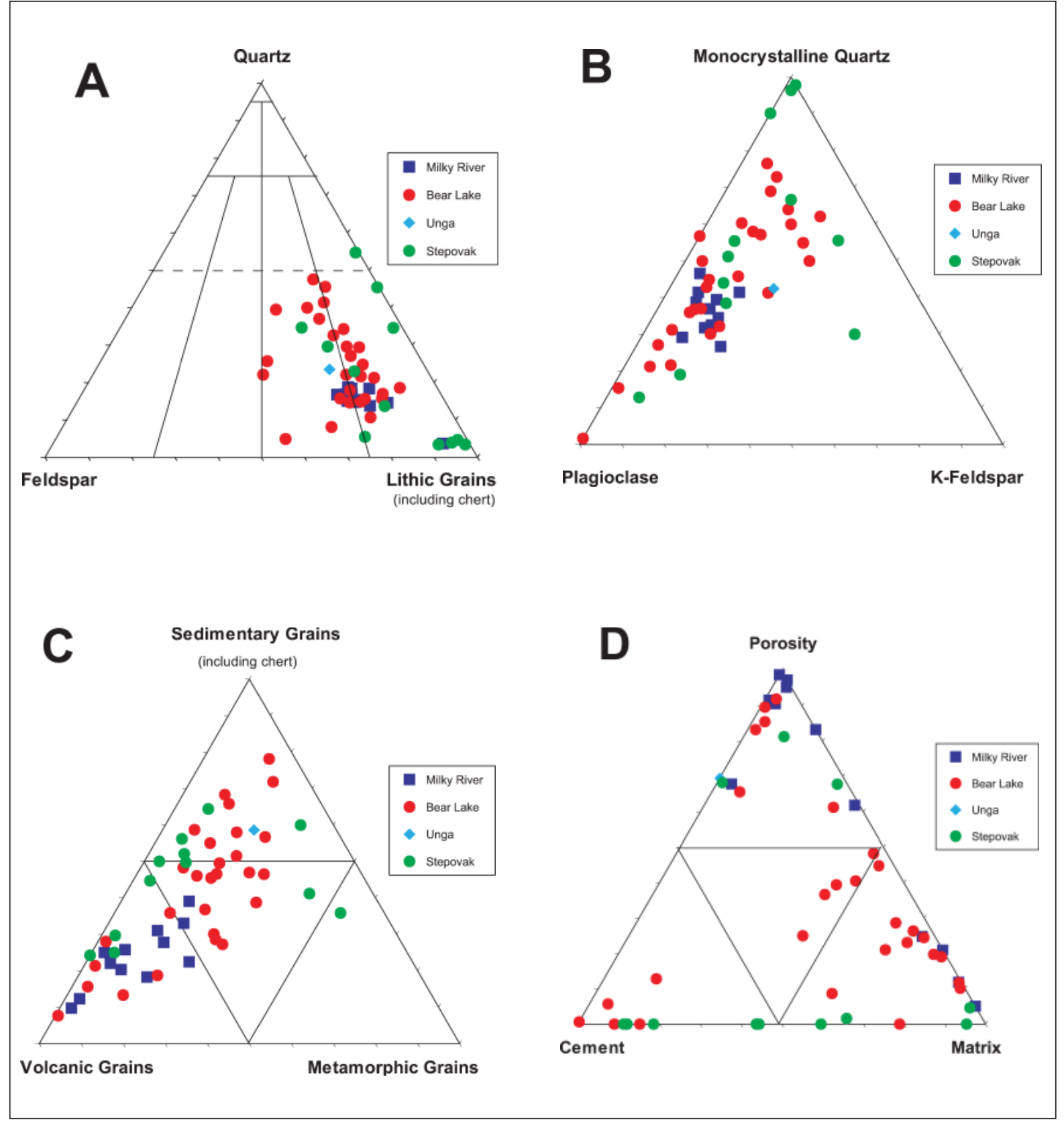

Figure 3. Ternary diagrams showing composition of Bristol Bay sandstones. A. QFL (Quartz-Feldspar-Lithics) diagram showing composition of detrital grains comprising the rock framework. All the sandstones are enriched in lithic grains. B. QmPK (Monocrystalline Quartz-Plagioclase-K-Feldspar) diagram showing monocrystalline composition of Bristol Bay sandstones. The sandstones are enriched in quartz and plagioclase with relatively less K-Feldspar. C. Ls $+L v L m$ (Sedimentary Lithics +Chert-Volcanic Lithics-Metamorphic Lithics) diagram showing lithic composition of Bristol Bay sandstones. Milky River sandstones are typically enriched in volcanic lithics. D. PCM (Porosity-Cement-Matrix) diagram showing composition of the intergranular components of the sandstones. Detrital matrix is present in some of the sandstones and is a primary factor controlling permeability in those rocks. Tables 1 and 2 list all data included in these diagrams. 
composition of the intergranular components (that is, porosity, cements, and matrix) of the rock. The higher the ratio of porosity to cement plus matrix, the better the reservoir quality of the rock.

\section{TERTIARY SANDSTONES}

The Tertiary sandstones vary in grain size from lower very fine grained (fL, $70 \mu \mathrm{m}$ ) to upper coarsegrained $(\mathrm{cU}, 920 \mu \mathrm{m})($ table 2$)$. The framework grains are moderately to very well sorted $(0.33-0.99$ standard deviation in phi units of just the framework grains; Measured Framework Sorting in table 2) but the presence of detrital matrix results in some rocks having very poor overall sorting $(>2.0$ standard deviation in phi units of entire rock, framework grains + matrix; Measured Sorting in table 2). In general, the finer-grained sandstones tend to be better sorted (fig. 4). The sandstones are highly lithic with an average framework composition of $\mathrm{Q}_{22} \mathrm{~F}_{16} \mathrm{~L}_{61}$ (fig. 3A). Monocrystalline quartz (Qm, 15 percent) is more common than polycrystalline (Qp, 7 percent) varieties. Feldspar is common with plagioclase (12 percent) dominant over K-feldspar (4 percent). The average lithic composition of the sandstones is $\mathrm{Ls}_{41} \mathrm{Lv}_{43} \mathrm{Lm}_{16}$ with grains consisting of felsic and mafic volcanic fragments, chert, phyllite, schist, quartzite, felsic plutonic fragments, mudstone, and siltstone (table 1). The Milky River samples are more volcanogenic than the other Tertiary sandstones with an average composition of $\mathrm{Ls}_{24} \mathrm{Lv}_{65} \mathrm{Lm}_{11}$. Micas average 2 percent of the framework fraction and consist of chlorite, muscovite, and biotite. Amphibole, pyroxene, epidote, and garnet are the most common heavy minerals and are indicative of an immature, labile suite.

Detrital matrix varies in abundance, comprising from 0 to 16 percent of the sandstones (table 1). It is particularly common in many of the Bear Lake samples (fig. 3D). The matrix consists predominantly of clay minerals with lesser amounts of detrital silt. Clay laminae are common in many of the samples, particularly the Milky River and Bear Lake sandstones (table 1). Together, detrital matrix and clay laminae account for more than 40 percent of the bulk volume of several sandstones. $\mathrm{X}$-ray diffraction analyses suggest these clays largely consist of illite and mixed-layer illite/smectite (table 3). The mixed-layer clay consists dominantly of smectite with only 10 percent illite layers. Because these clays are highly smectitic, the matrix could exhibit significant swelling if exposed to fresh water.

The majority of the sandstones generally lack significant cement (table 1; figs. 7-12). Quartz cement occurs in minor amounts in a few samples, due in part to the lack of nucleation sties and relatively low abundance of detrital quartz. The extensive matrix in some of the samples also retards cementation by inhibiting nucleation of overgrowths. Carbonate cement, particularly siderite and calcite, occur in variable amounts (up to 10.5 percent of bulk rock) in a few samples but generally has little effect on reservoir quality in the majority of samples. Authigenic, pore-filling kaolinite (fig. 15) occurs in several samples and is probably related to feldspar altera-

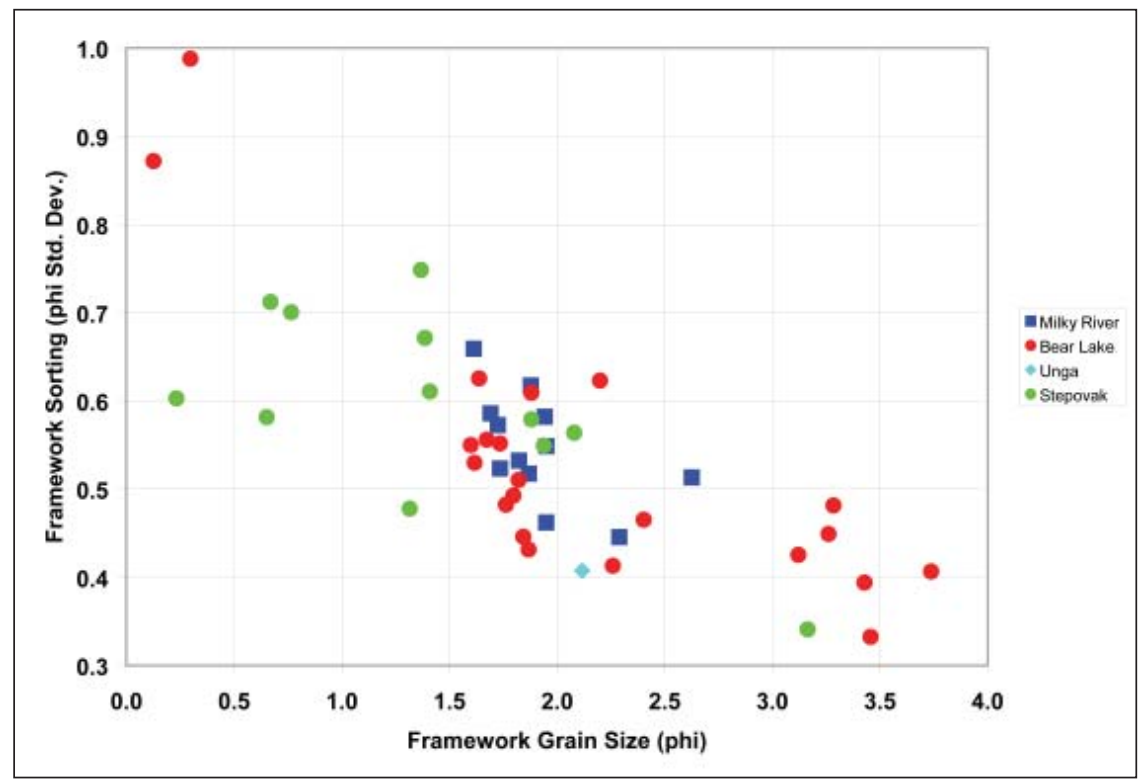

Figure 4. Grain size-sorting scatter plot of Bristol Bay sandstones by formation. Data are for grains greater than $30 \mu \mathrm{m}$ in diameter and therefore exclude clay and very fine to medium silt. In general, the finer-grained rocks tend to be better sorted (note grain size is shown in phi units). Pearson correlation coefficient is -0.77 . 
tion. In a few sandstones where it comprises more than 10 percent of the rocks, kaolinite significantly degrades reservoir quality. Representative photomicrographs are presented in figures 7-12.

\section{RESERVOIR QUALITY}

Reservoir quality of the Tertiary sandstones varies from excellent $(\varphi>30$ percent, $k>100 \mathrm{md})$ to poor $(\varphi<10$ percent, $\mathrm{k}<1 \mathrm{md})$. In order to illustrate the regional porosity-permeability trend, data for Tertiary and Mesozoic sandstones were plotted together (fig. 5). Most of the high-quality sandstones are Tertiary subsurface samples; the majority of low-quality rocks are from Mesozoic outcrops. Using an economic cutoff of 10 percent porosity and $1 \mathrm{md}$ permeability (suitable for liquid hydrocarbons), the majority of samples could be effective hydrocarbon reservoirs. Using lower $\varphi-\mathrm{k}$ cutoffs ( 7 percent porosity and $0.1 \mathrm{md}$ permeability), a significant number of additional samples could be effective gas reservoirs.
There is a fairly systematic relationship between reservoir quality (porosity-permeability) and depth (fig. 6). Porosities in excess of 20 percent and permeabilities higher than $10 \mathrm{md}$ are present at depths approaching 10,000 feet. It should be noted that much of the data are from the North Aleutian COST \#1 well that was drilled offshore in a deep portion of the basin. It is unclear if similar trends exist for the shallower, onshore portion of the basin. Additional data are needed before regional porosity-depth and permeability-depth trends can be established with certainty.

\section{CONCLUSION}

Based on detailed point-count analyses, conventional core analyses, and SEM examination of samples from three exploratory wells, sandstones with favorable reservoir properties are present in the Milky River, Bear Lake, and Stepovak Formations and may yield economically viable petroleum reservoirs. Sandstones in older, more deeply buried strata are likely to be of lower reservoir quality.

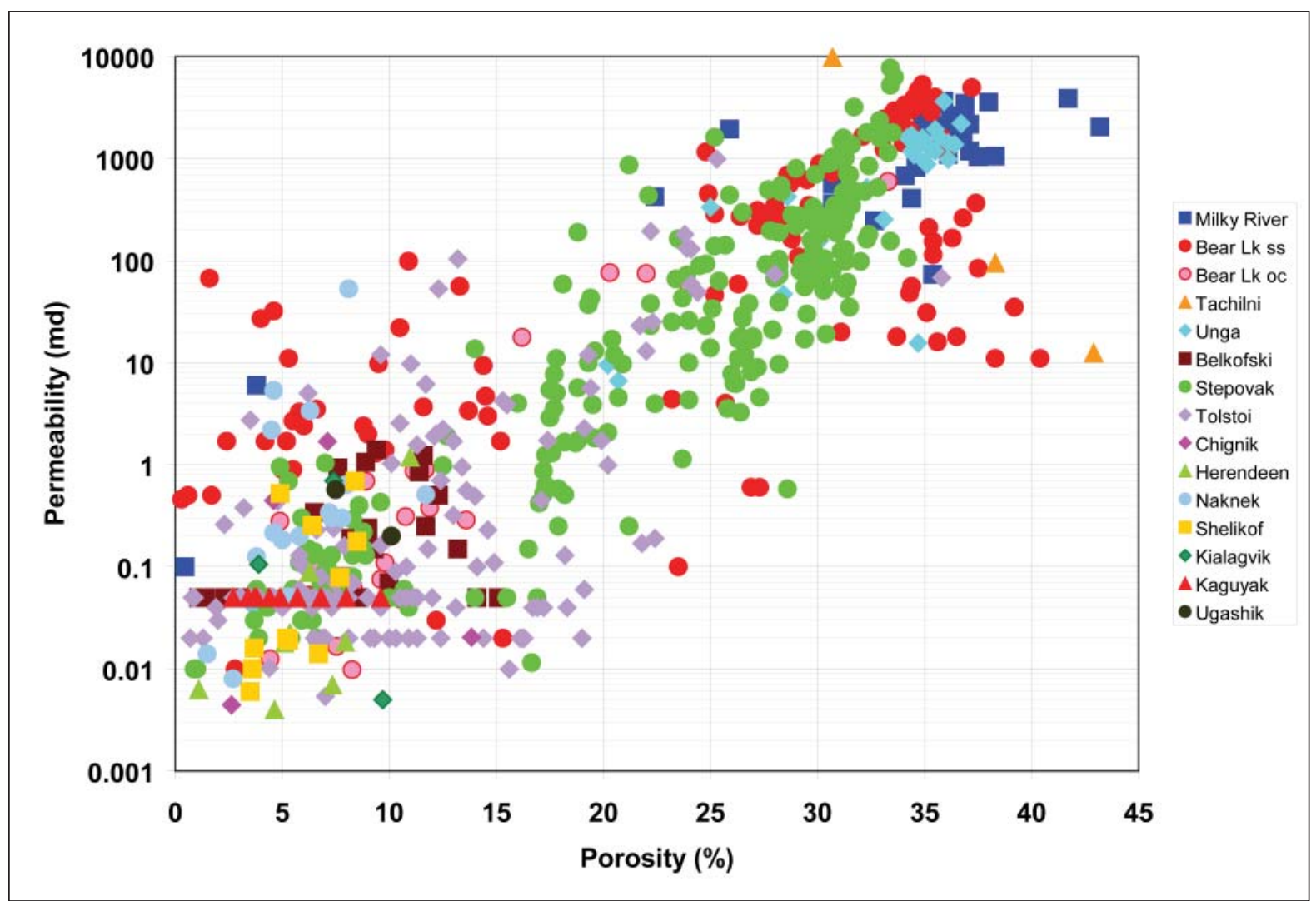

Figure 5. Porosity-permeability scatter plot of Bristol Bay sandstones by formation. Using a cutoff of 10 percent porosity and $1 \mathrm{md}$ permeability, a large proportion of the samples have good to excellent reservoir quality. Most of the high-quality rocks are Tertiary subsurface samples while the majority of low-quality rocks are from Mesozoic outcrops. Table 4 lists all data included in this plot. 


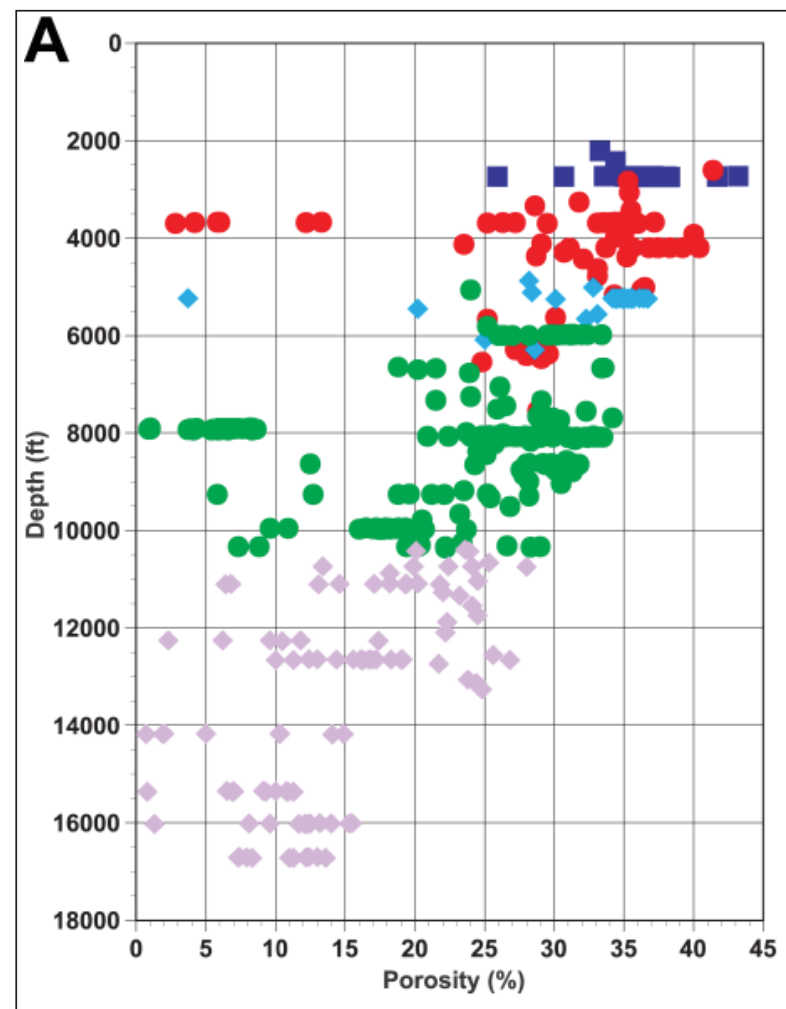

Milky River Bear Lake Unga Stepovak $\diamond$ Tolstoi

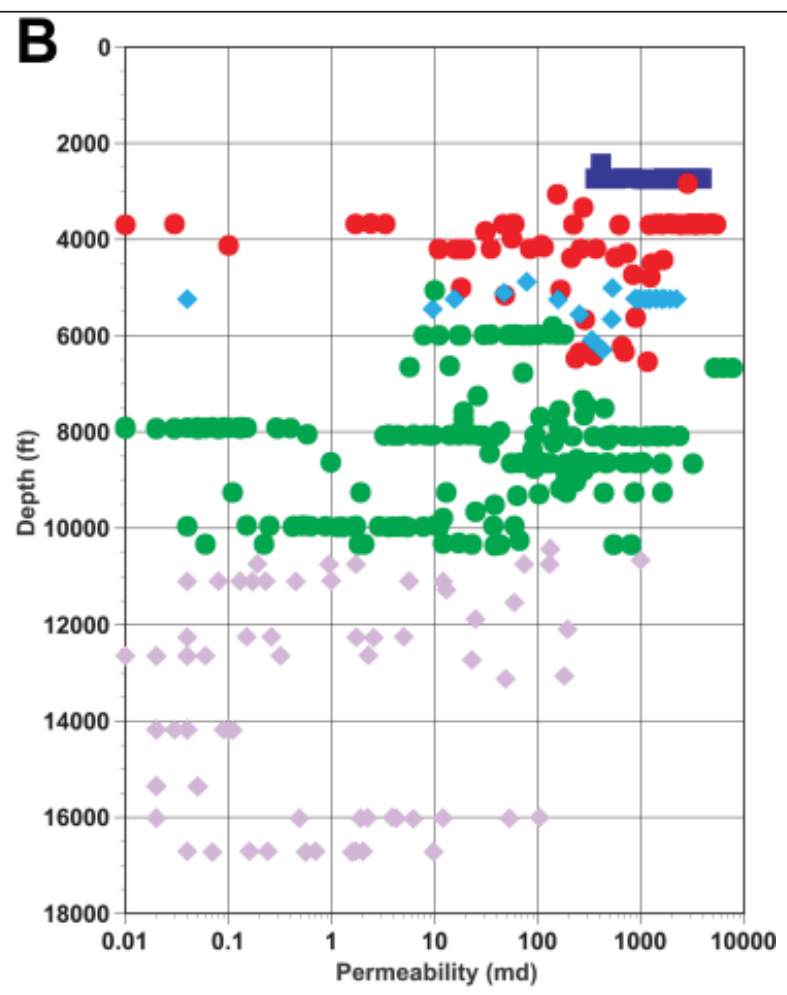

Milky River Bear Lake Unga Stepovak $\bullet$ Tolstoi

Figure 6. Reservoir quality-depth scatter plots of Bristol Bay sandstones by formation. A. Porosity-depth trend. B. Permeability-depth trend. Table 4 lists data included in this plot.

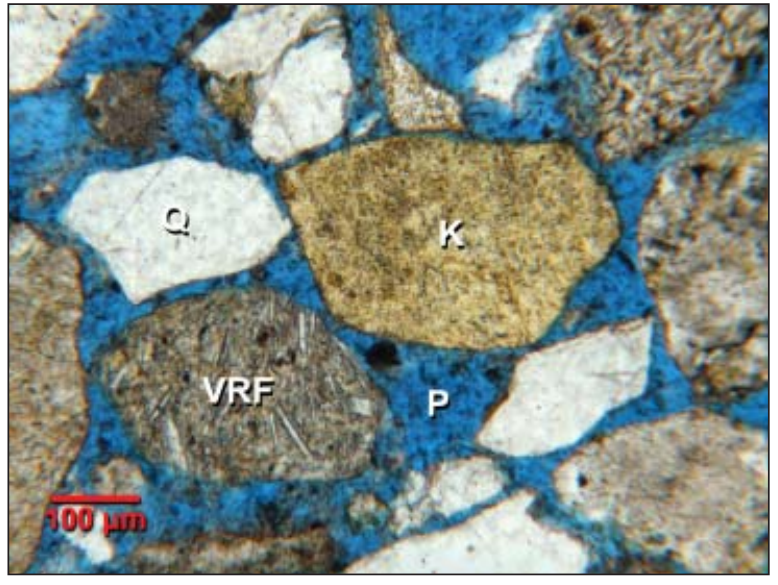

Figure 7. Photomicrograph of Milky River sandstone showing well-developed intergranular porosity $(P)$. Framework grains include quartz (Q), K-feldspar $(K)$, and volcanic rock fragments (VRF). Becharof State \#1, 2,734.5', $\varphi=$ 36.9 percent, $k=3,470 \mathrm{md}$.

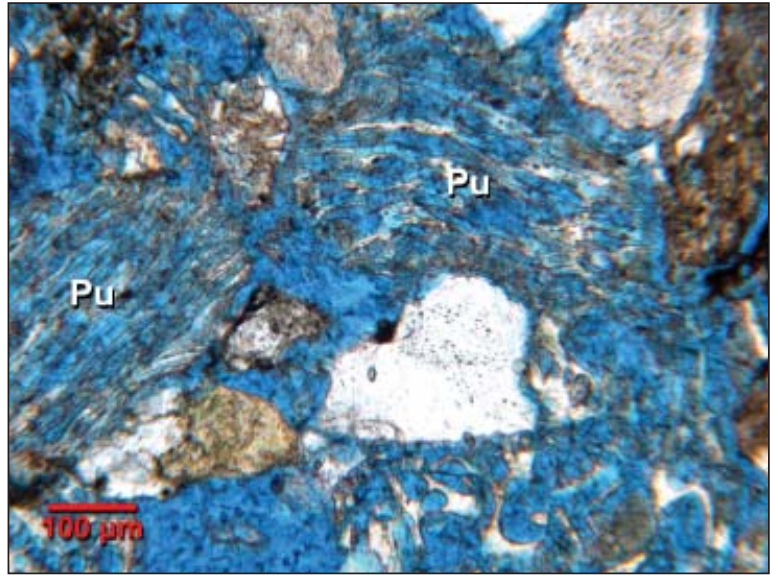

Figure 8. Photomicrograph of Milky River sandstone showing substantial mesoporosity in vesicular pumice fragments (Pu). Becharof State \#1, 2,726.5', $\varphi=43.2$ percent, $k=$ 2,040 md. Sample contains much pumice. 


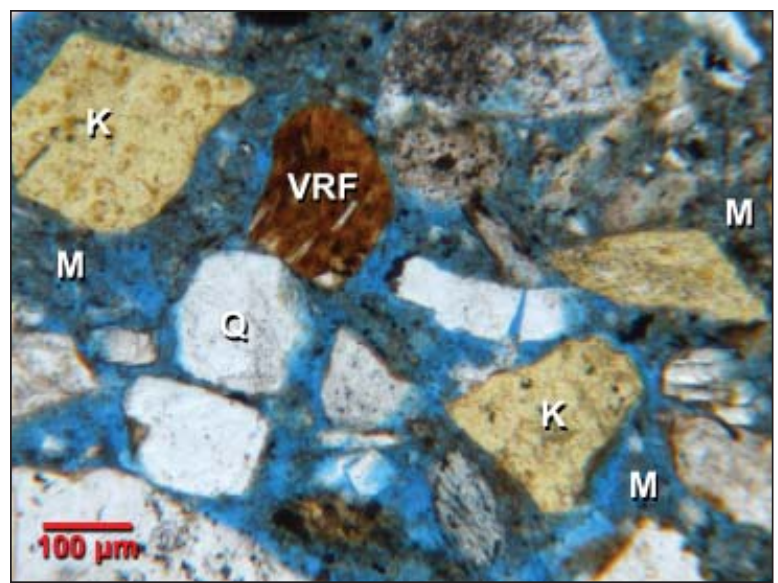

Figure 9. Photomicrograph of Bear Lake sandstone showing detrital clay matrix (M) partially occluding intergranular pores. Framework grains include quartz (Q), K-feldspar $(K)$, and volcanic rock fragments (VRF). North Aleutian COST \#1, 4,197.0', $\varphi=35.6$ percent, $k=16 \mathrm{md}$. Low permeability is the result of extensive clay matrix.

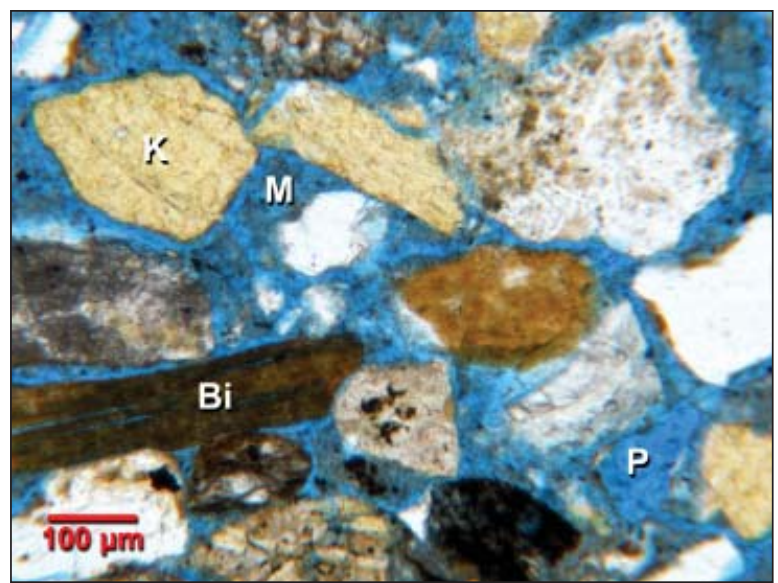

Figure 10. Photomicrograph of Bear Lake sandstone showing clay matrix $(M)$ sporadically filling intergranular pores (P). Framework grains include $K$-feldspar $(K)$ and biotite (Bi). North Aleutian COST \#1, 2,734.5', $\varphi=33.7$ percent, $k=18 \mathrm{md}$. Low permeability is the result of extensive clay matrix.

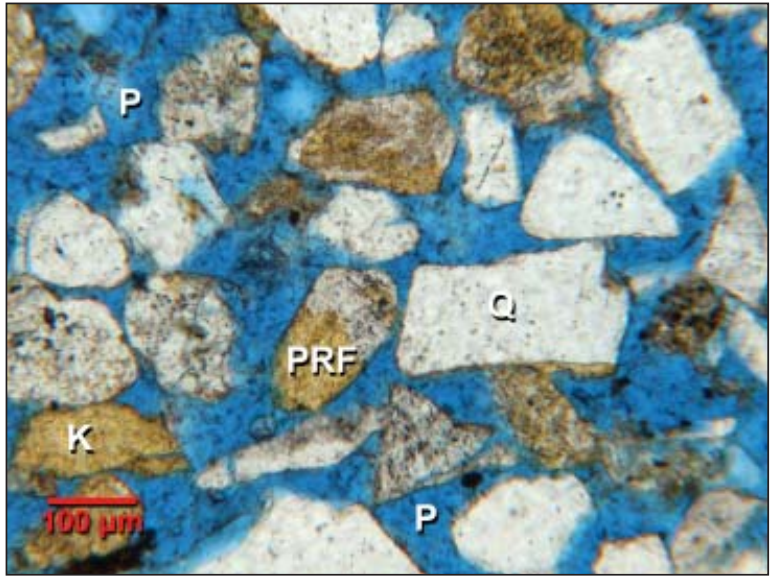

Figure 11. Photomicrograph of Stepovak sandstone showing well-developed intergranular porosity $(P)$. Framework grains include quartz (Q), K-feldspar (K), and plutonic rock fragments (PRF). North Aleutian COST \#1, 8,087.0', $\varphi=32.9$ percent, $k=2,358 \mathrm{md}$.

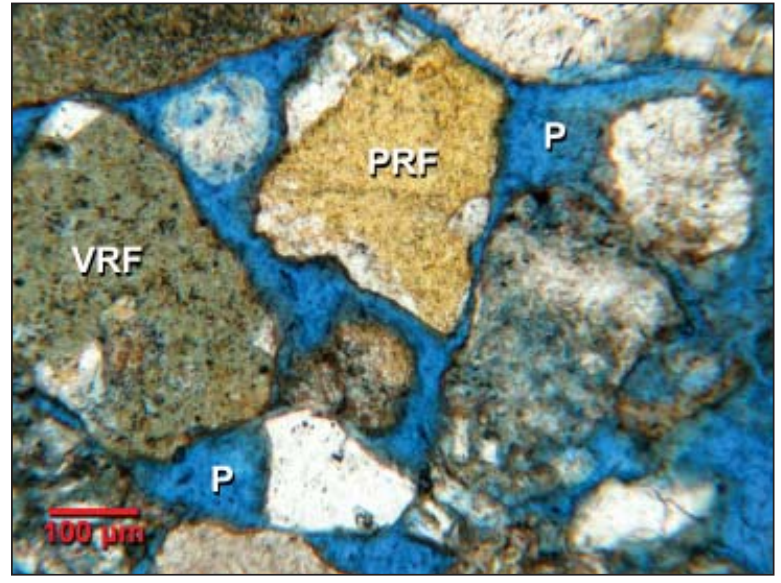

Figure 12. Photomicrograph of Stepovak sandstone showing both point and long contacts between grains. Intergranular porosity $(P)$ is common. Framework grains include volcanic (VRF) and plutonic (PRF) rock fragments. North Aleutian COST \#1, 8,635.0', $\varphi=31.4$ percent, $k=709 \mathrm{md}$. 


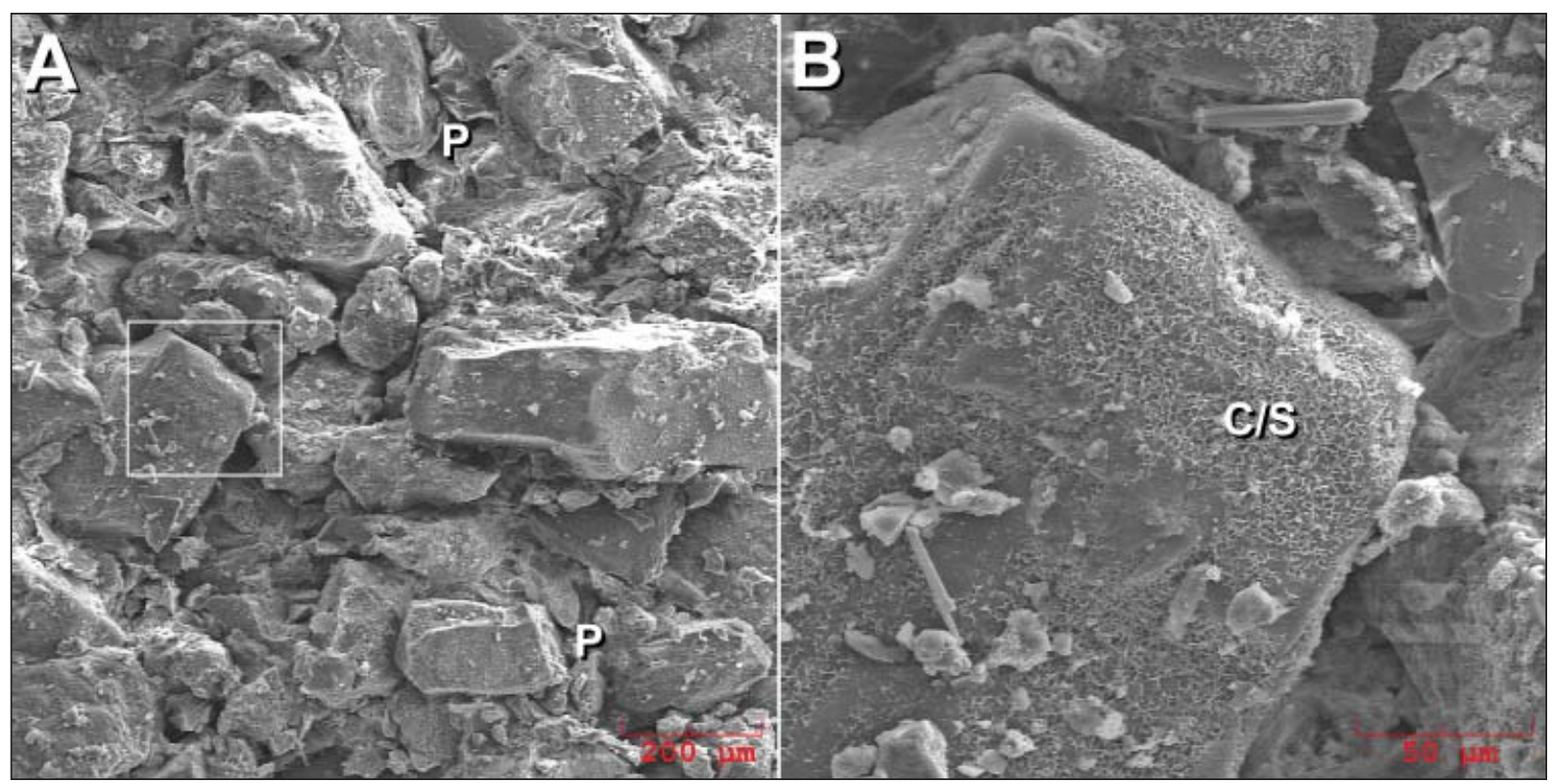

Figure 13. SEM photomicrograph of sandstone from the Milky River Formation, Amoco Becharof State \#1, 2, 735.5'. A. General view showing angular nature of detrital grains and abundant intergranular porosity $(P)$. B. Enlarged view of outlined area showing authigenic clay, probably mixed-layer chlorite-smectite (C/S), coating detrital grain.

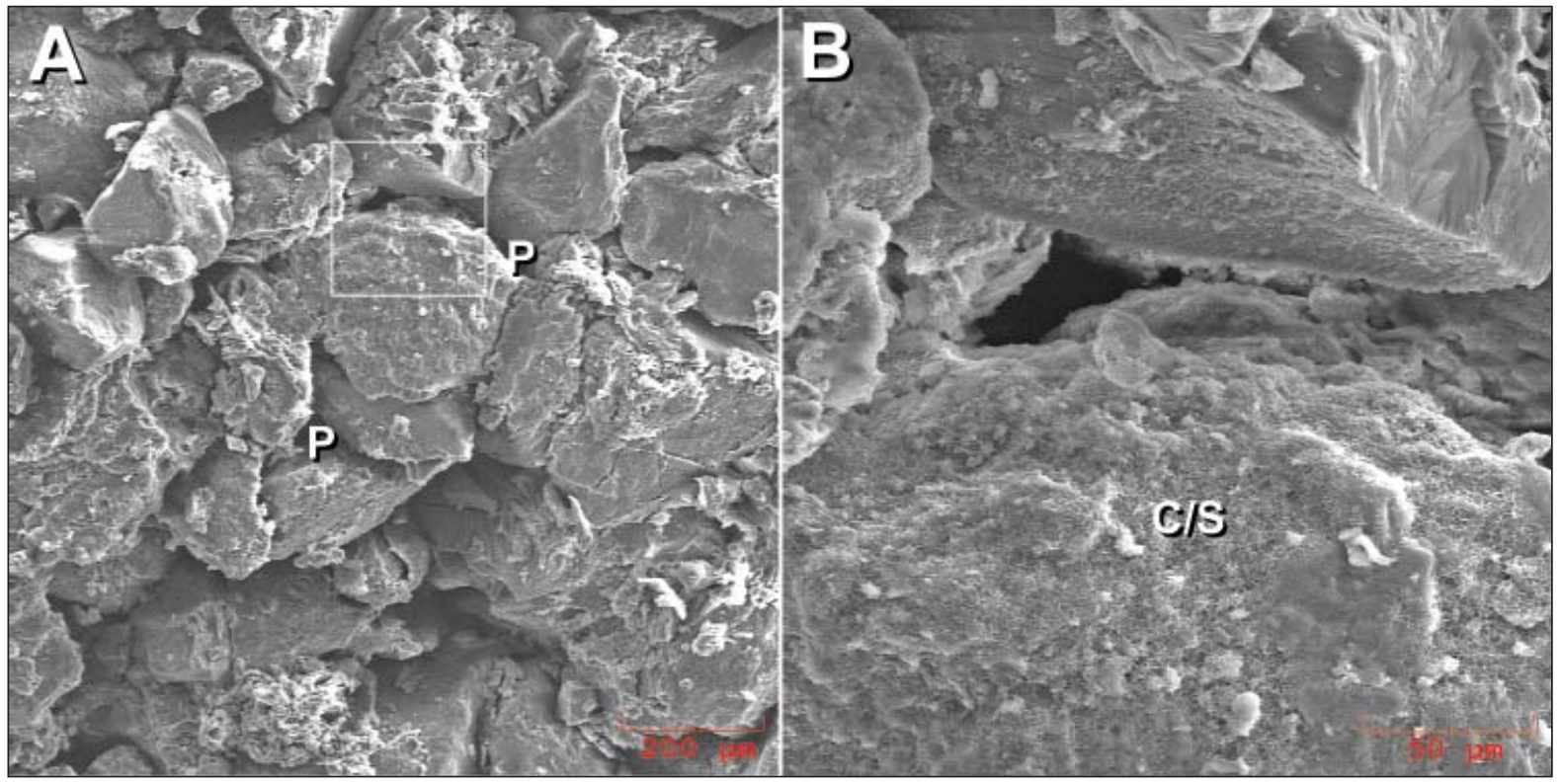

Figure 14. SEM photomicrograph of sandstone from the Bear Lake Formation, Amoco Becharof State \#1, 3, 678.4'. A. General view showing abundant intergranular pores connected by open pore throats $(P)$. B. Enlarged view of outlined area showing authigenic clay, probably mixed-layer chlorite-smectite $(C / S)$, coating detrital grain and lining intergranular pore. 


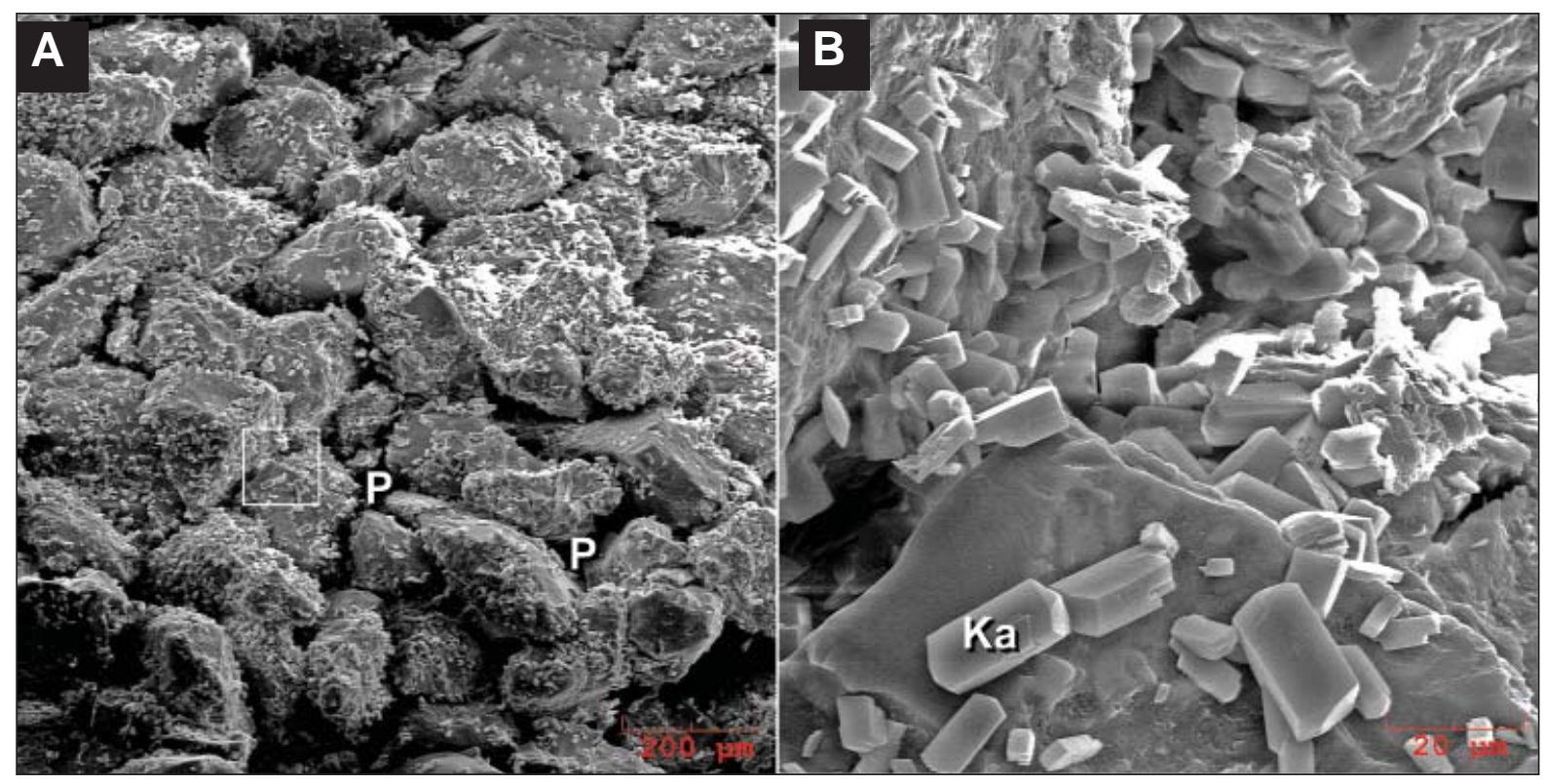

Figure 15. SEM photomicrograph of sandstone from the Unga Formation, ARCO North Aleutian COST \#1, 5,234.0'. A. General view showing abundant intergranular porosity $(P)$ and detrital grains coated with kaolinite. B. Enlarged view of outlined area showing authigenic kaolinite (Ka) filling intergranular pore. Microporosity is common between clay platelets.

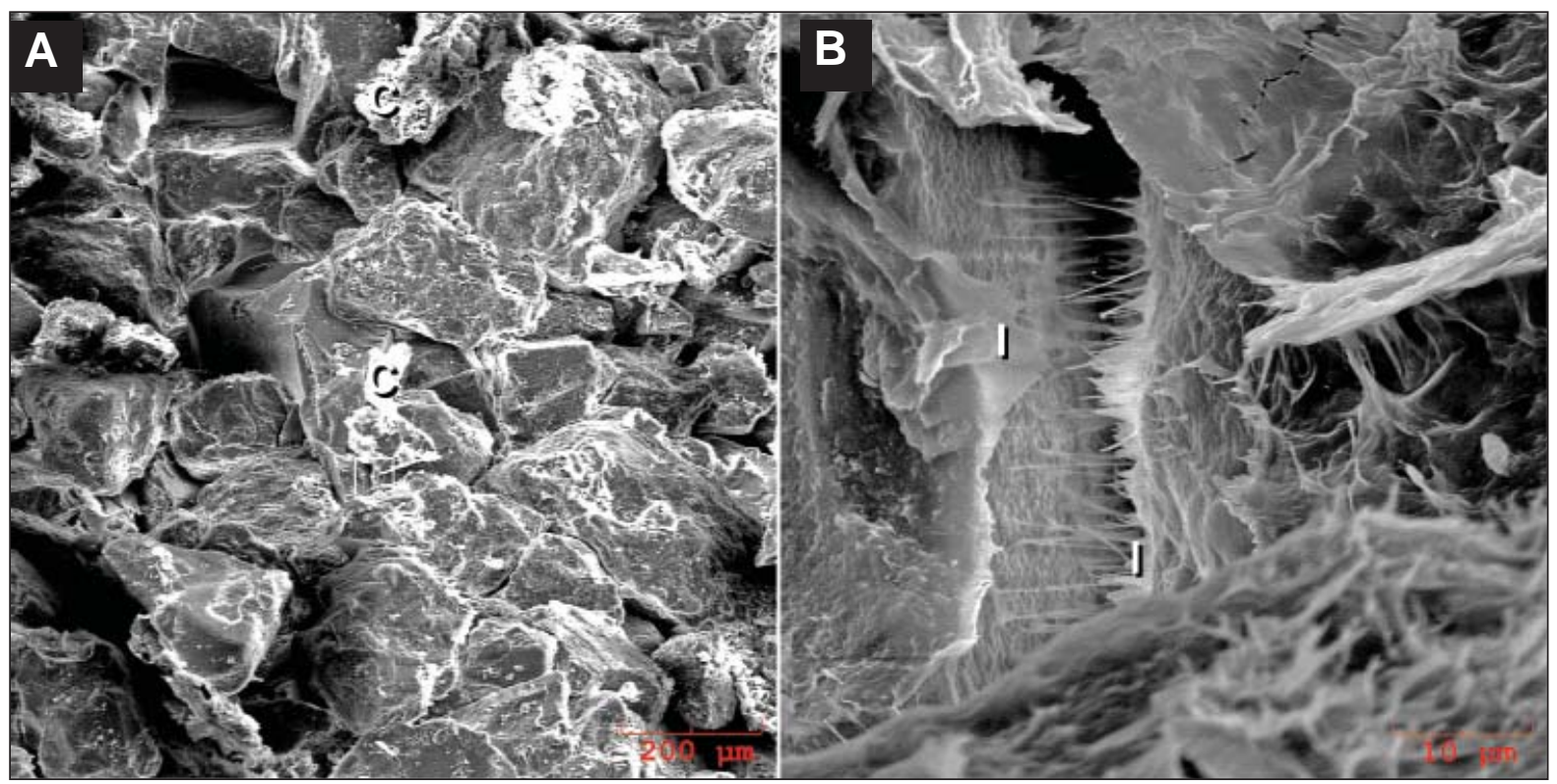

Figure 16. SEM photomicrograph of sandstone from the Stepovak Formation, ARCO North Aleutian COST \#1, 8,087.0'. A. General view showing angular nature of detrital grains. Bright patches are small areas of authigenic clay (C) coating grains. B. Enlarged view of outlined area showing fibrous authigenic clay, probably illite (I), lining small intergranular pore. 


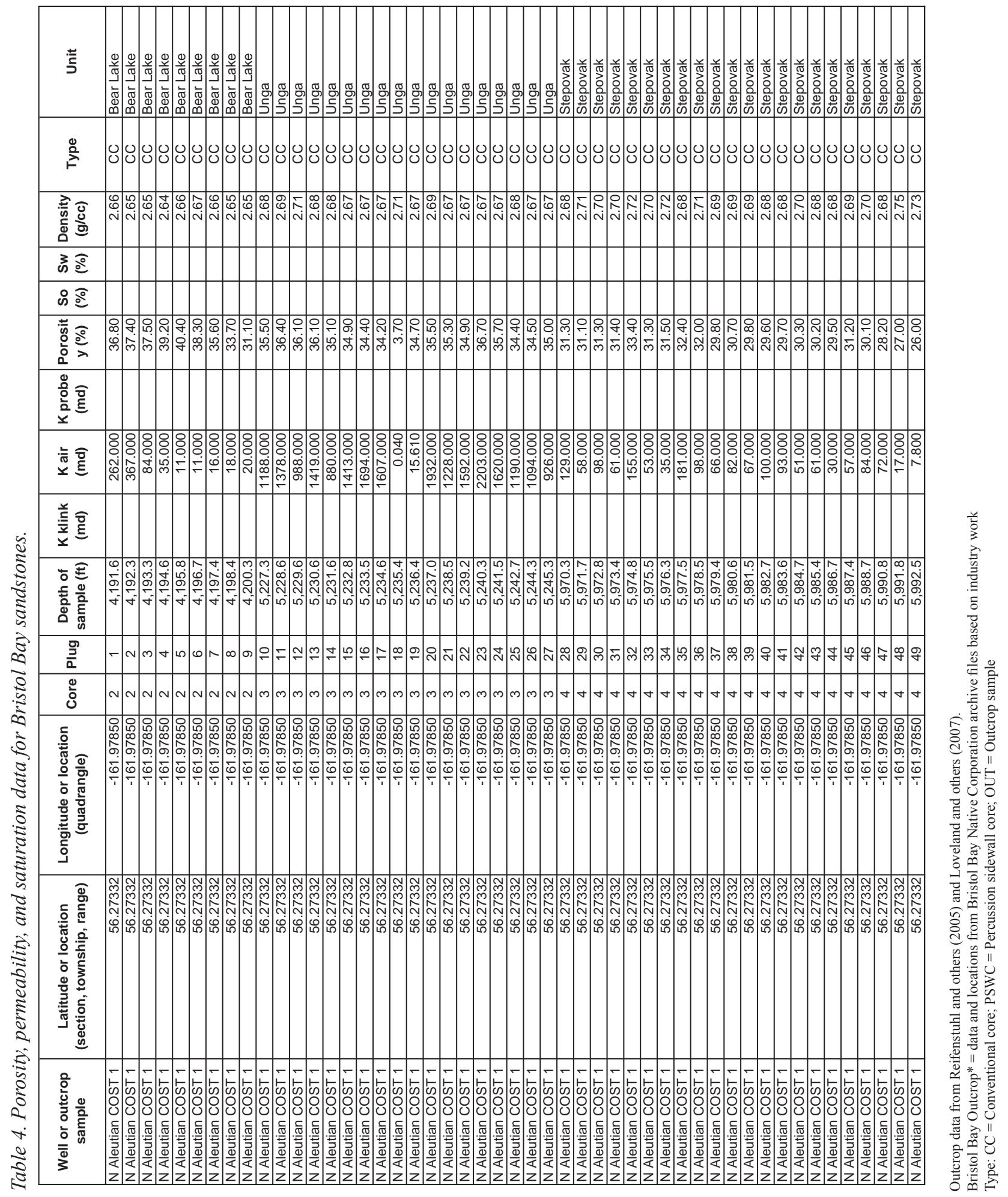




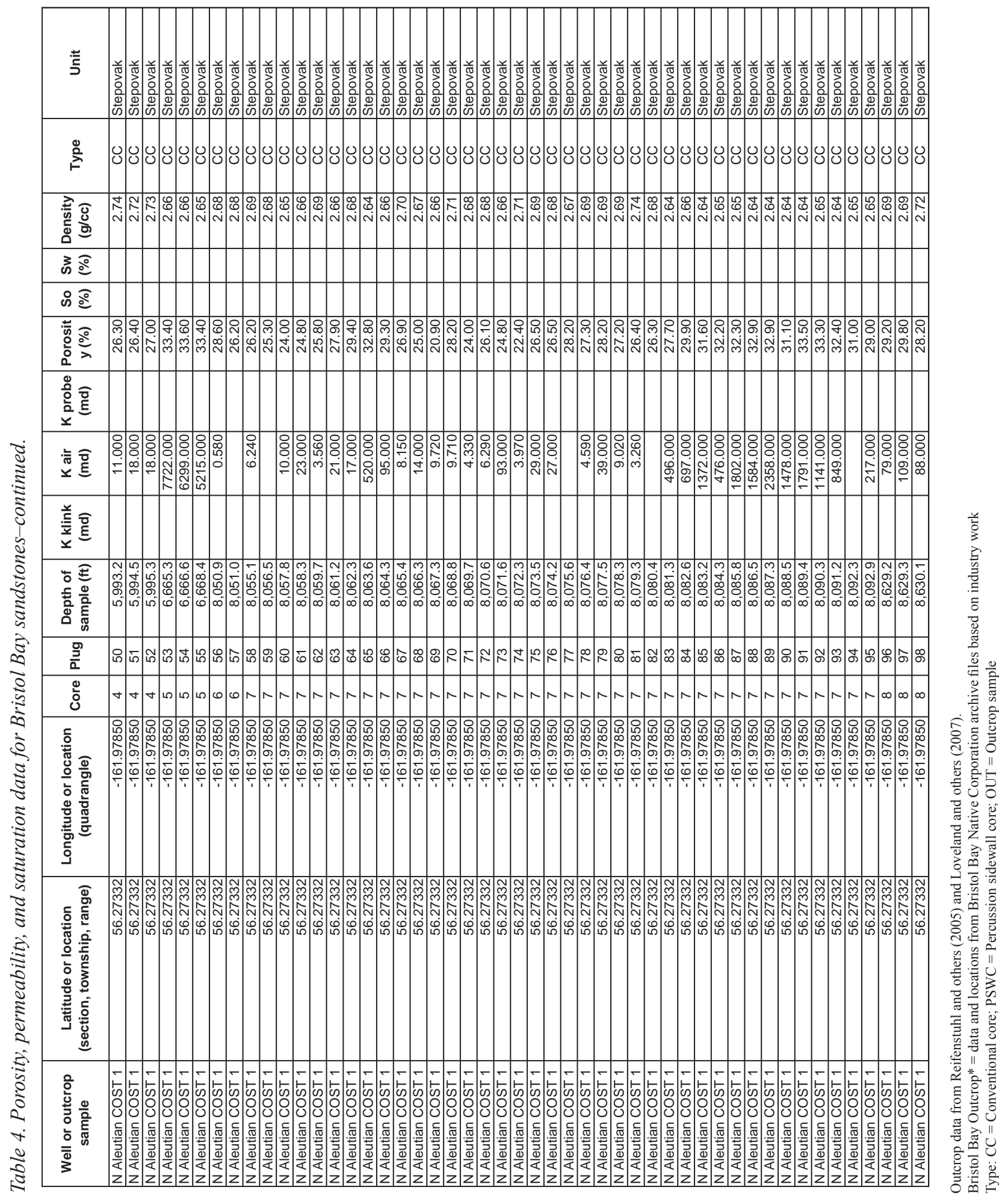




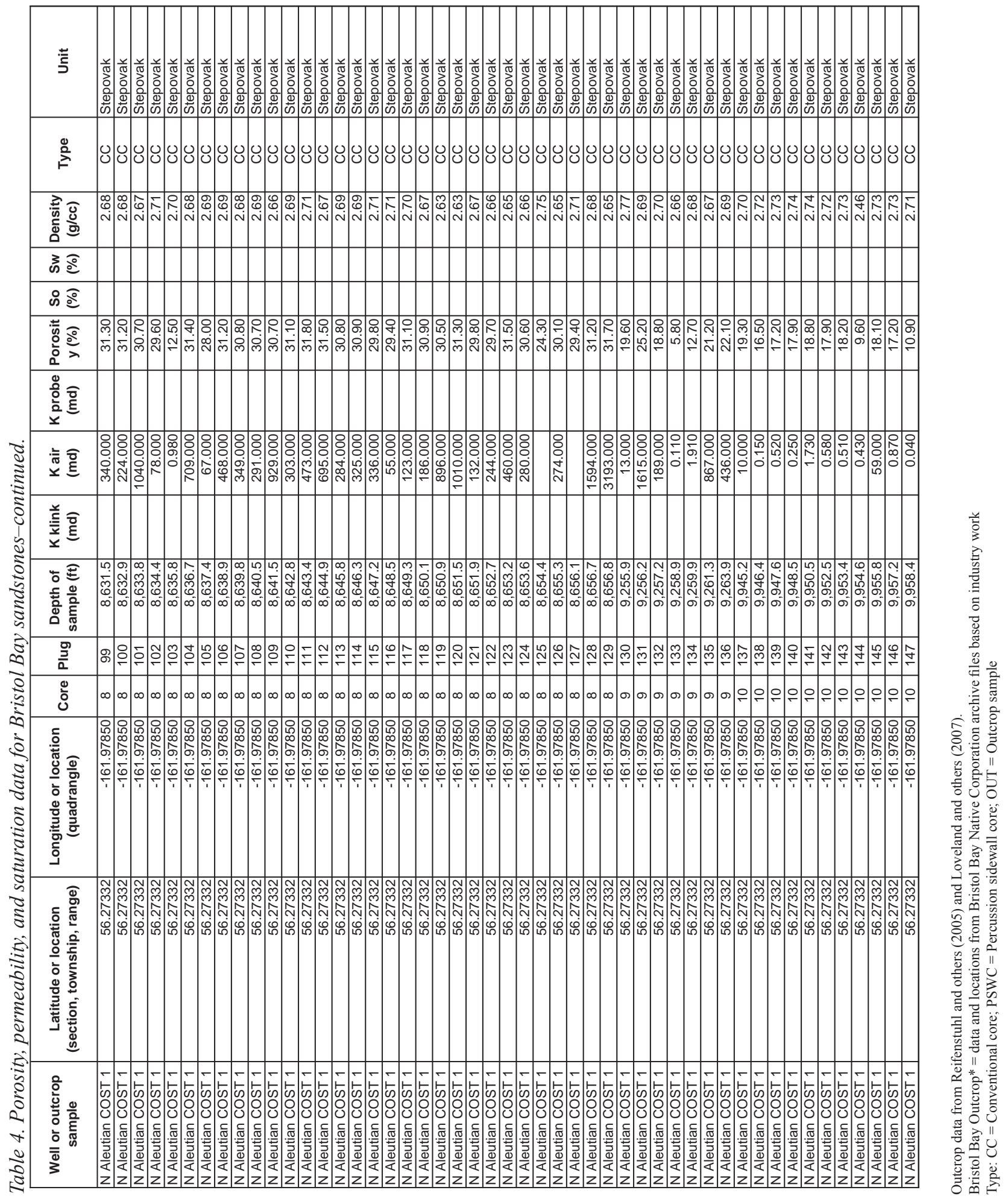




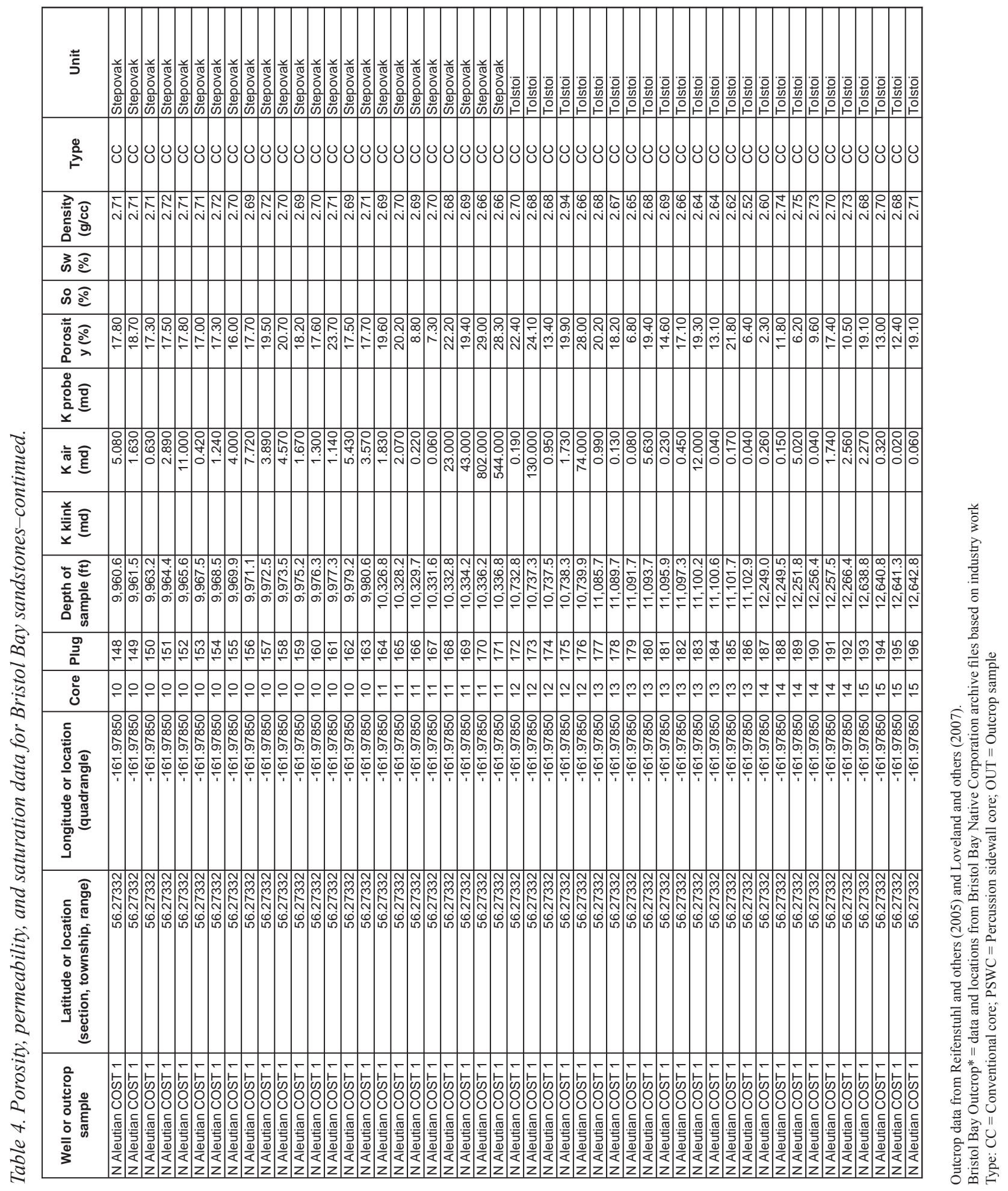




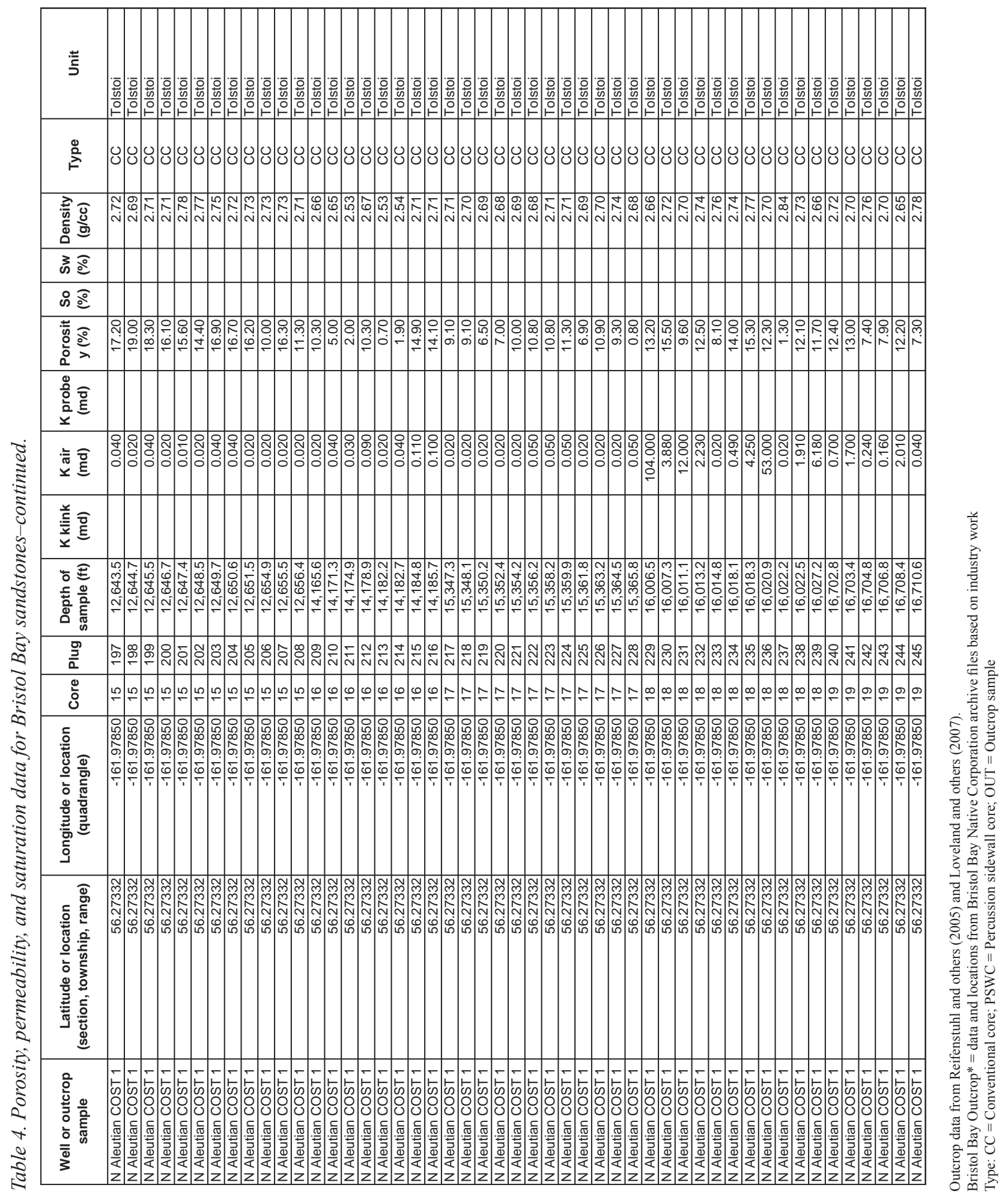




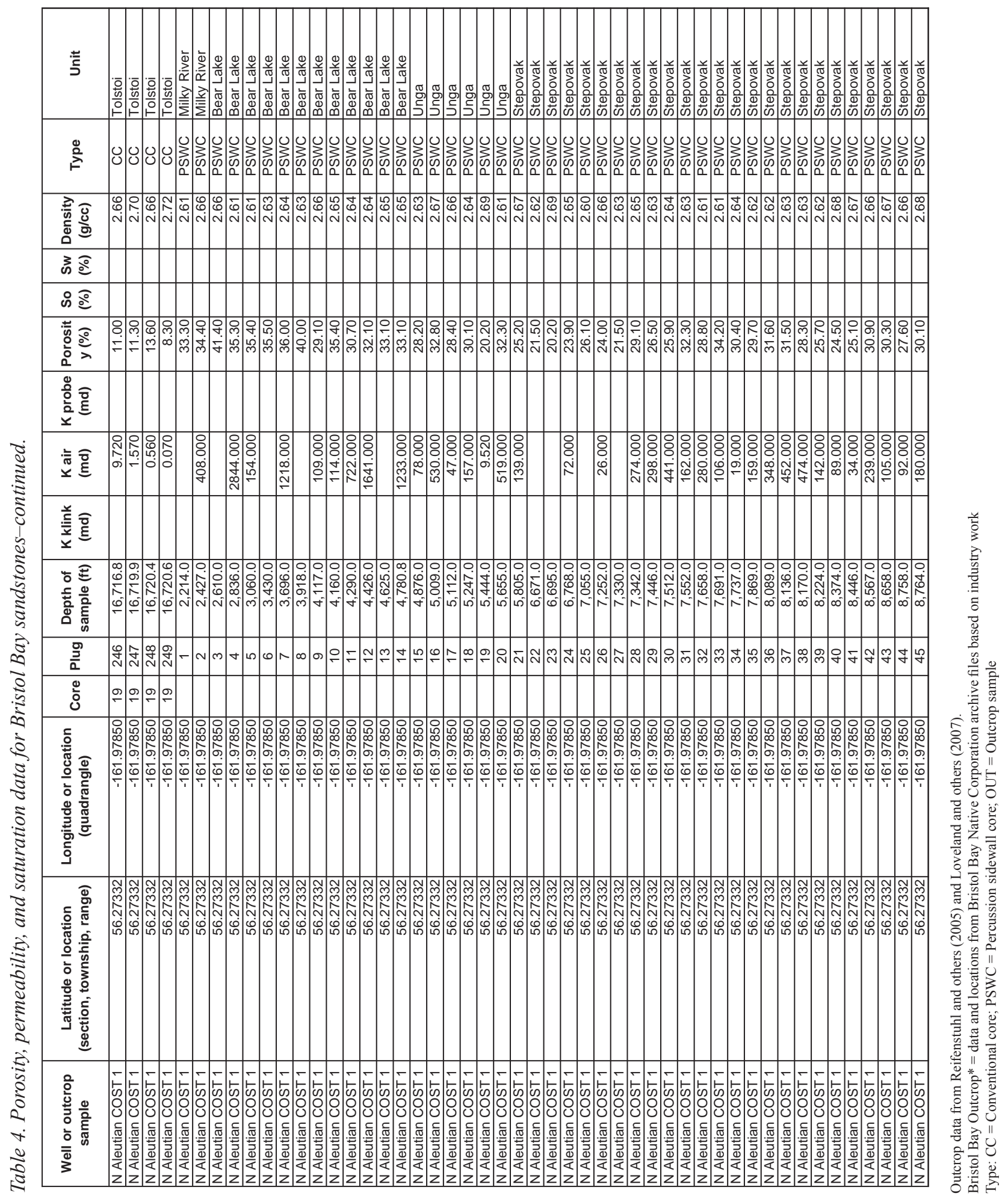




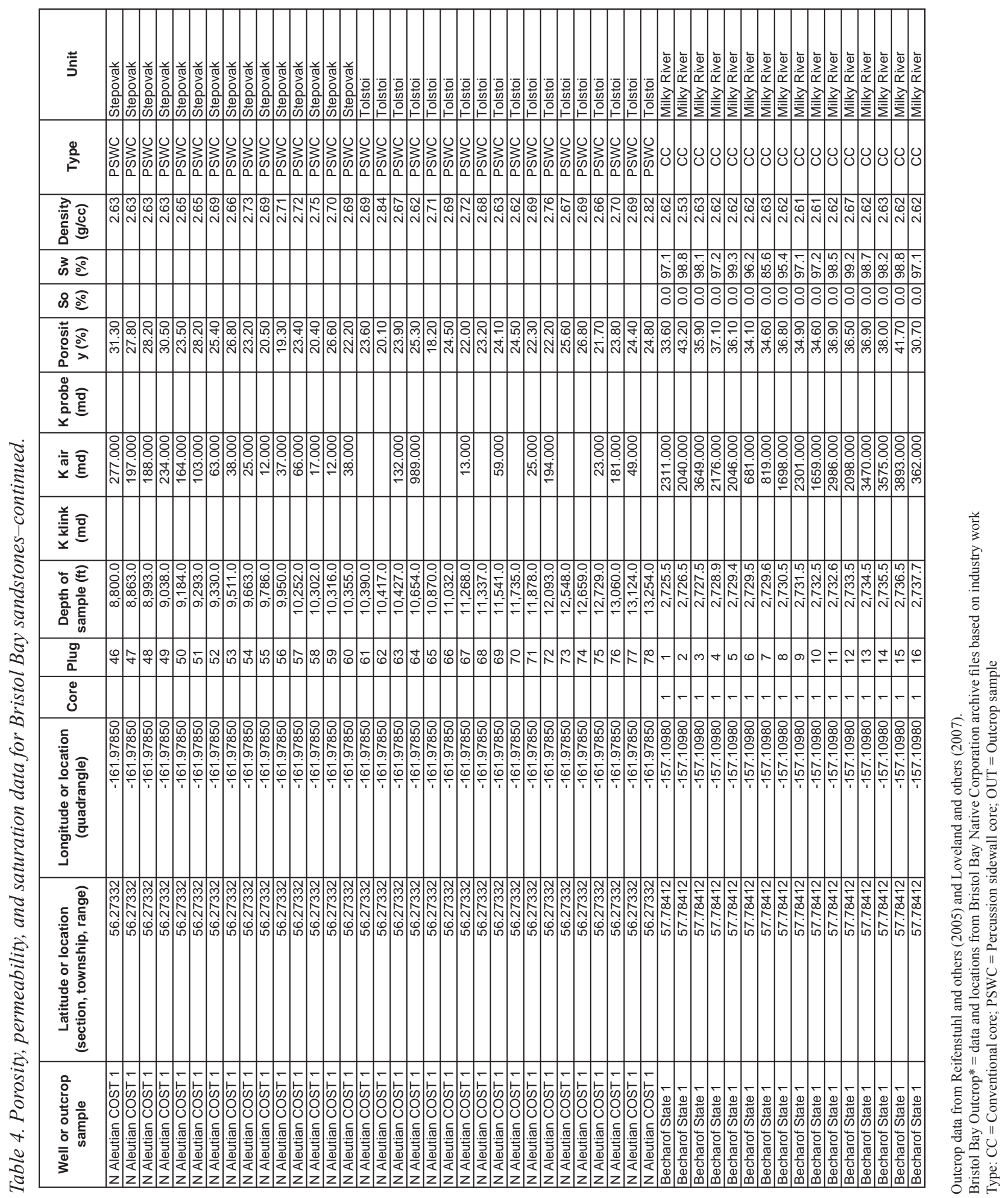




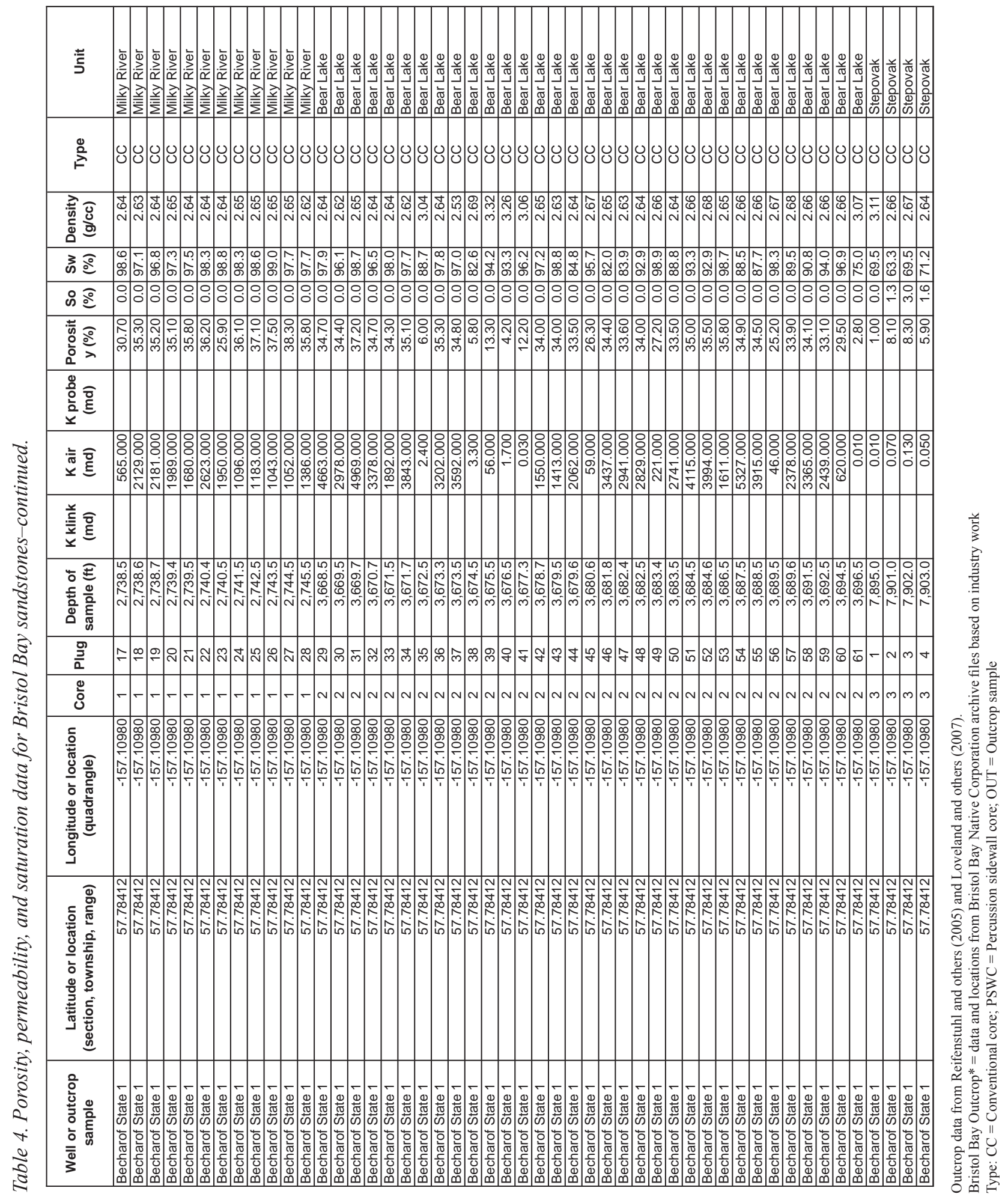




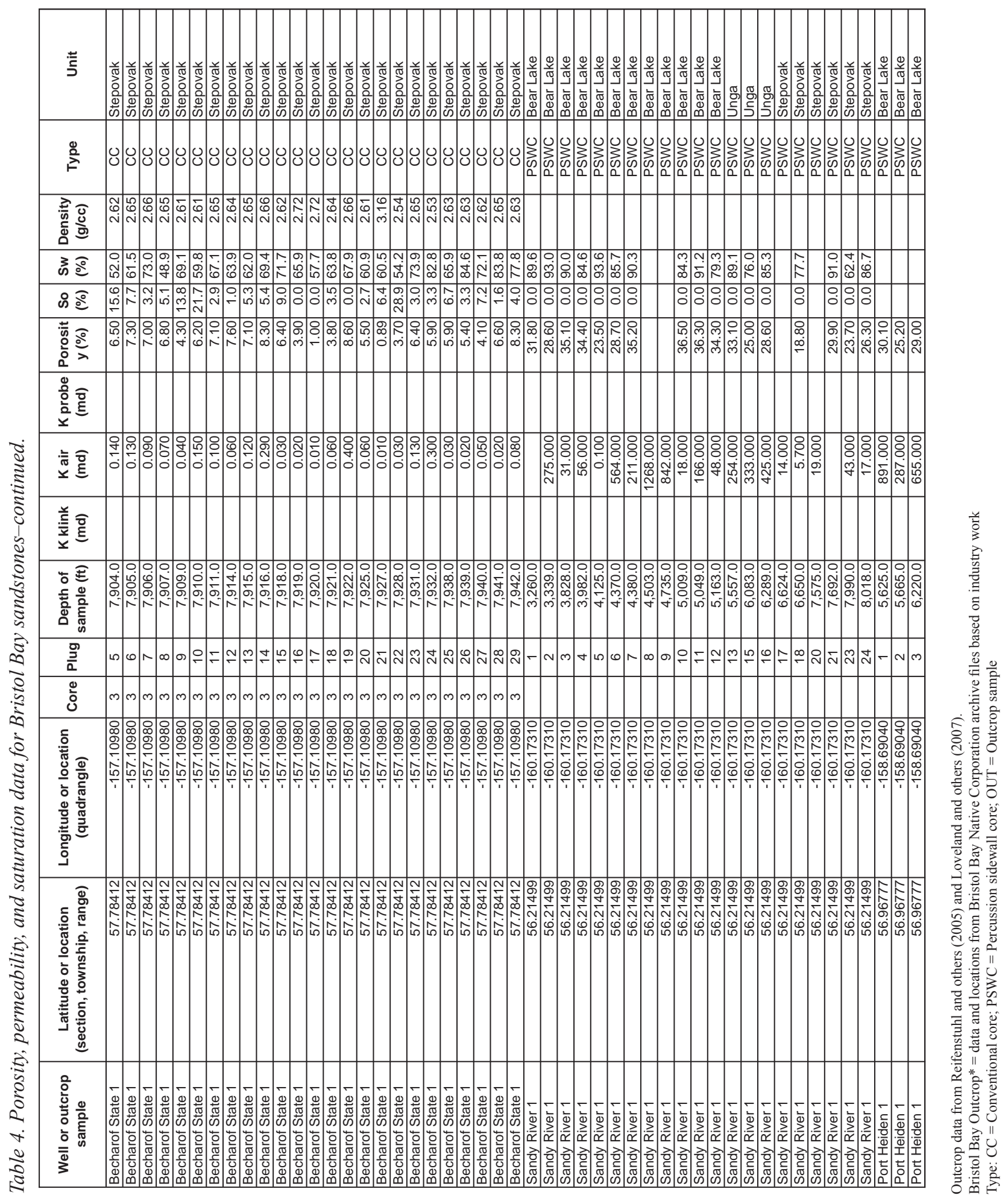




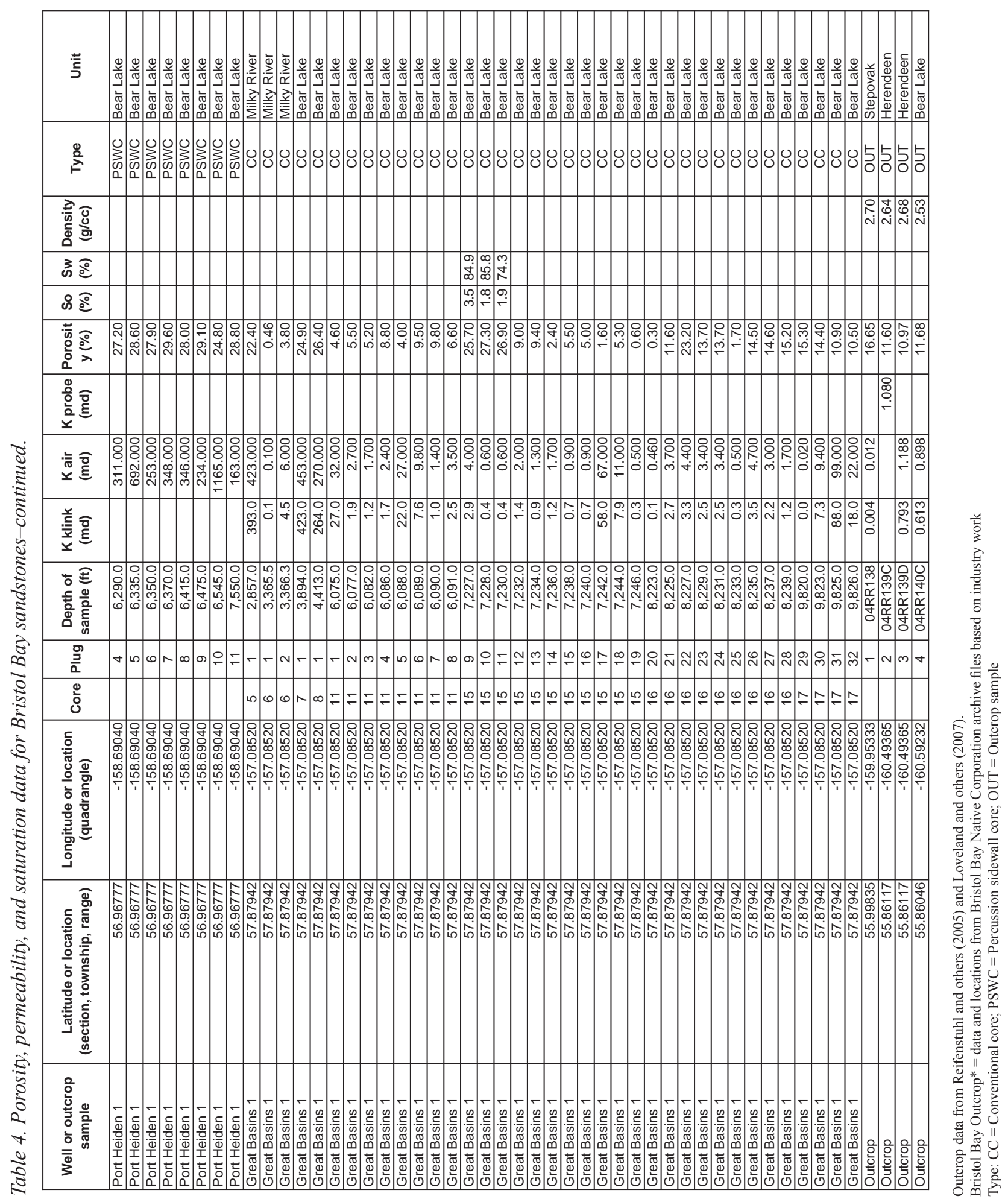




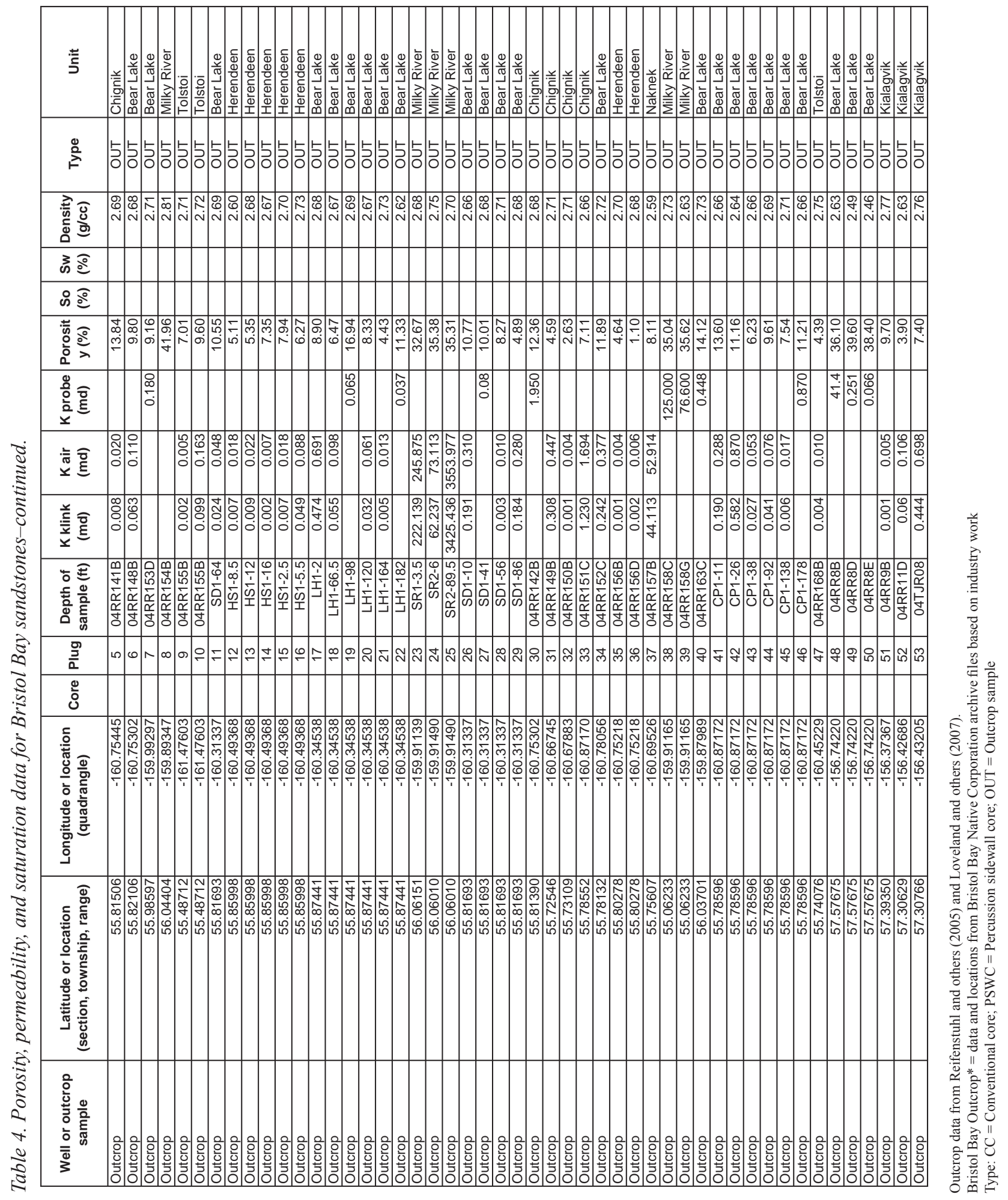




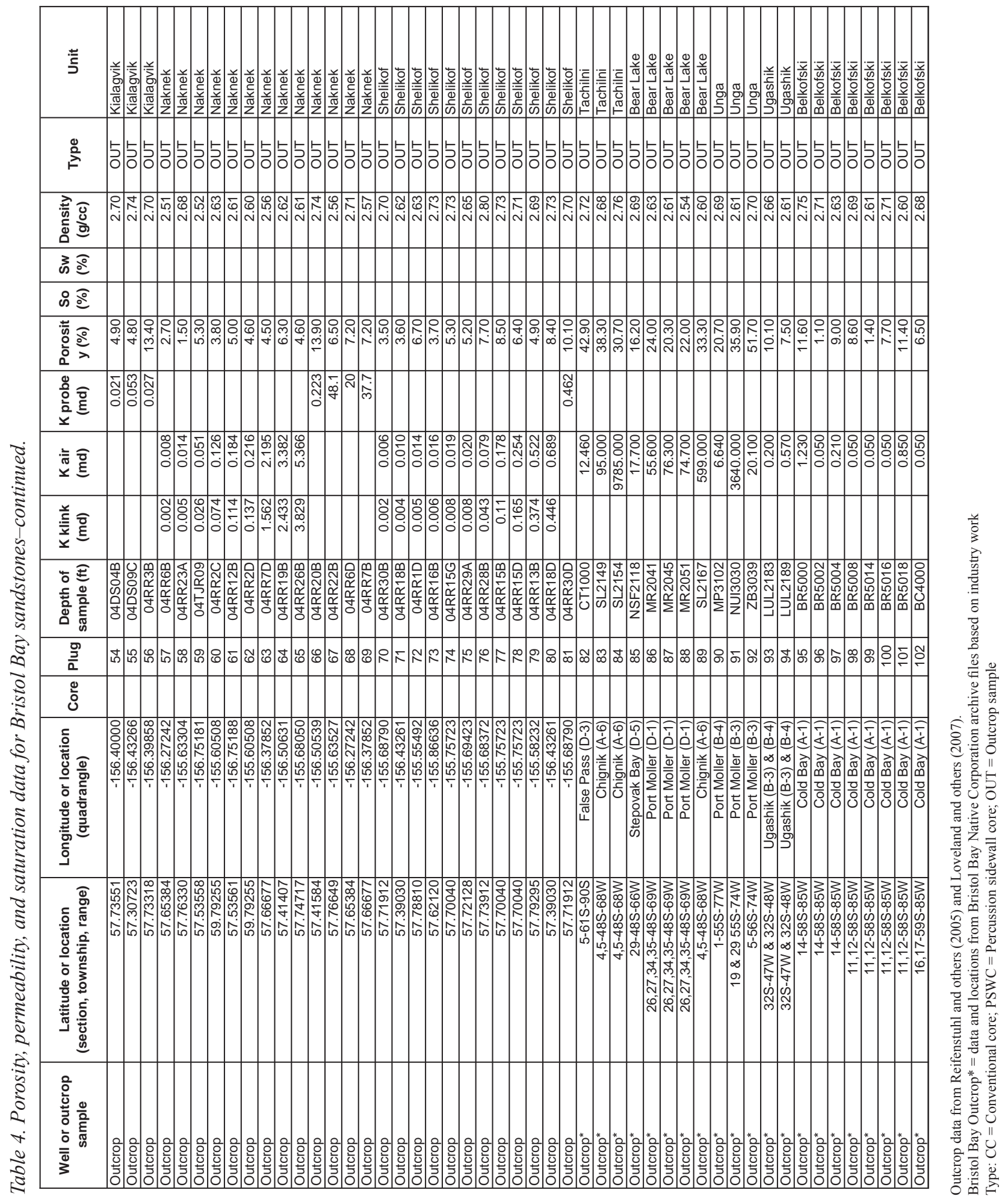




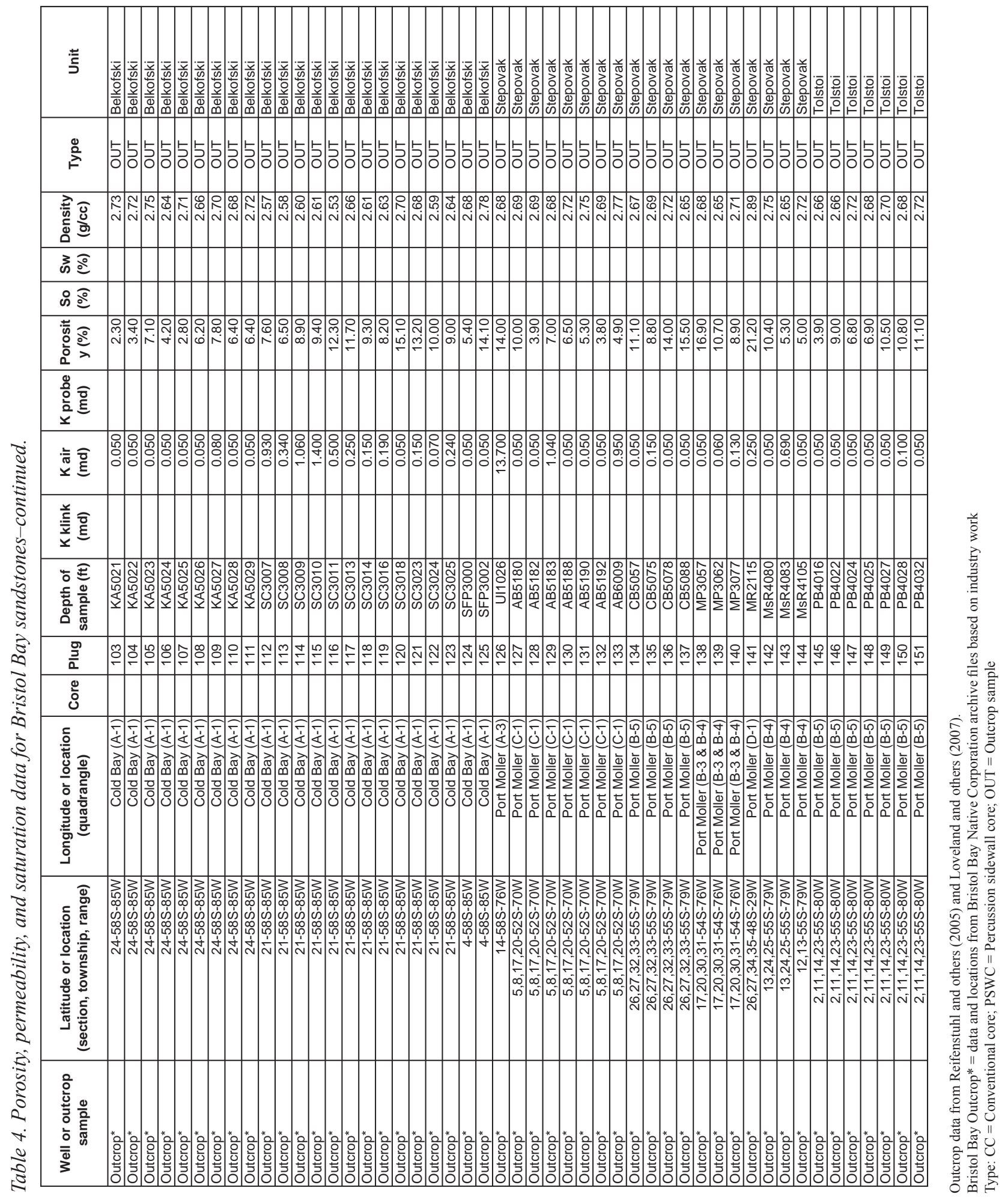




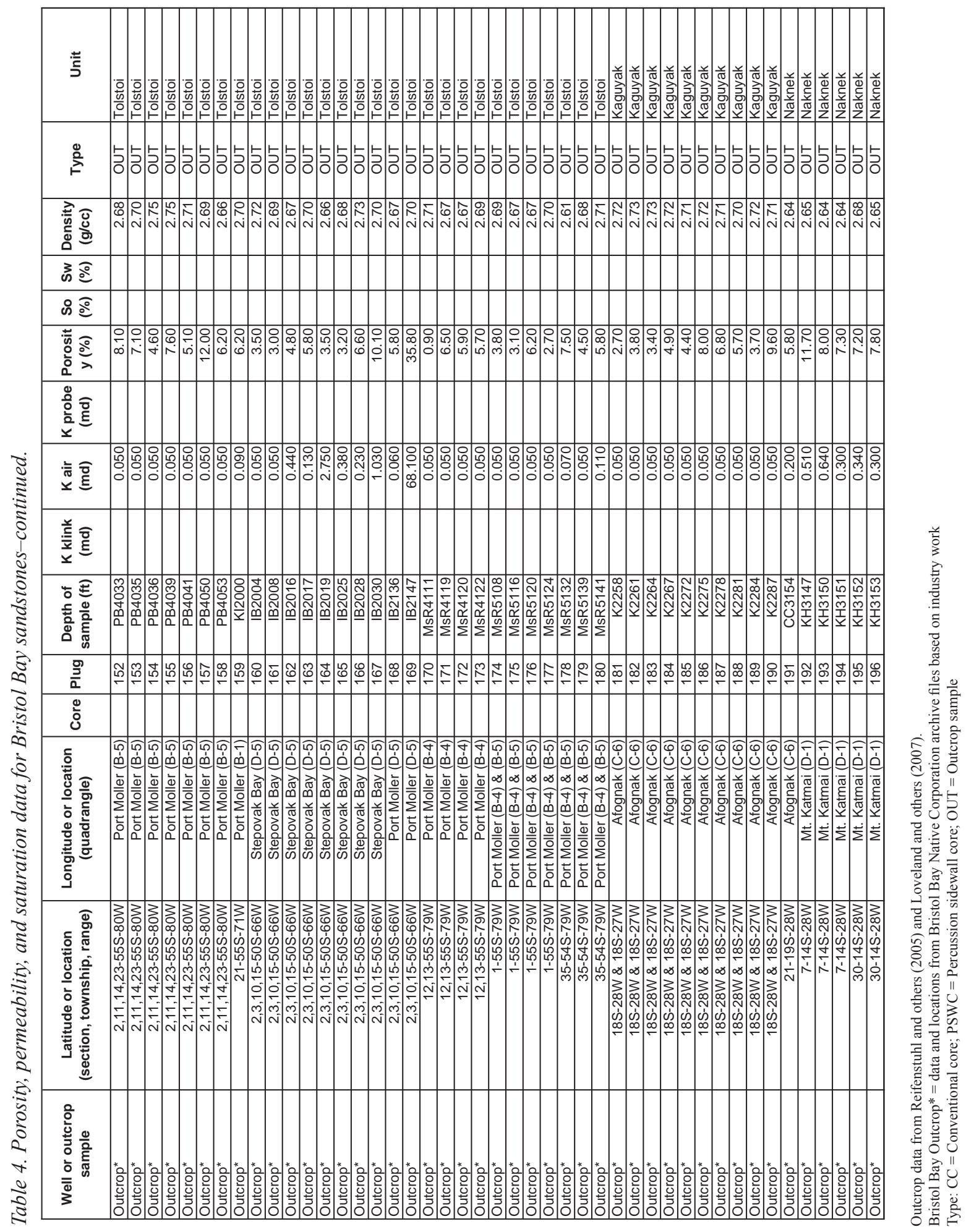




\section{REFERENCES CITED}

Burk, C.A., 1965, Geology of the Alaska Peninsula-Island Arc and Continental Margin: The Geological Society of America Memoir 99, 250 p., 3 sheets.

Decker, P.L., Finzel, E.S., Ridgway, K.D., Reifenstuhl, R.R., and Blodgett, R.B., 2005, Preliminary summary of the 2005 field season; Port Moller, Herendeen Bay, and Dillingham areas, Bristol Bay Basin, Alaska Peninsula: Alaska Division of Geological \& Geophysical Surveys Preliminary Interpretive Report 2005-7, 55 p., 2 sheets.

Detterman, R.L., Case, J.E., Miller, J.W., Wilson, F.H., and Yount, M.E., 1996, Stratigraphic framework of the Alaska Peninsula: U.S. Geological Survey Bulletin 1969-A, $74 \mathrm{p}$.

Dickinson, W.R., 1970, Interpreting detrital modes of graywacke and arkose, Journal of Sedimentary Petrology, v. 40, p. 695-707.

Dickinson, W.R. and Suczek, C.A., 1979, Plate tectonics and sandstone compositions: American Association of Petroleum Geologists, v. 63, p. 2,164-2,182.

Dickson, J.A.D., 1965, A modified staining technique for carbonates in thin section: Nature, v. 205, p.587.

Dickson, J.A.D., 1966, Carbonate identification and genesis as revealed by staining: Journal of Sedimentary Petrology, v. 36, p. 491-505.

Finzel, E.S., Reifenstuhl, R.R., Decker, P.L., and Ridgway, K.D., 2005, Sedimentology, stratigraphy, and hydrocarbon reservoir-source rock potential, using surface and subsurface data, of Tertiary and Mesozoic strata, Bristol Bay Basin and Alaska Peninsula: Alaska Division of Geological \& Geophysical Surveys Preliminary Interpretive Report 2005-4, 67 p.
Laniz, R.V., Stevens, R.E., and Norman, M.B., 1964, Staining of plagioclase feldspar and other minerals: U.S. Geological Survey Professional Paper 501-B, p. B152-B153.

Lindholm, R.C., and Finkelman, R.B., 1972, Calcite staining; Semiquantitative determination of ferrous iron: Journal of Sedimentary Petrology, v. 42, p. 239-242.

Loveland, A.M., Reifenstuhl, R.R., Gillis, R.J., and Decker, P.L., 2007, Outcrop sample results from mercury injection capillary pressure analyses, Bristol Bay, Alaska Peninsula: Alaska Division of Geological \& Geophysical Surveys Raw Data File 2007-3, 11 p.

Moore, D.M., and Reynolds, R.C., Jr., 1989, X-ray diffraction and the identification and analysis of clay minerals: Oxford University Press, 332 p.

Reifenstuhl, R.R., Bailey, R.D., and Finzel, E.S., 2005, Bristol Bay and Alaska Peninsula 2004; Fieldwork and sample analyses compilation report: Alaska Division of Geological \& Geophysical Surveys Preliminary Interpretive Report 2005-1, 20 p.

Strauch, A.L., Gillis, R.J., Reifenstuhl, R.R., and Decker, P.L., 2006, 2006 Bristol Bay, Alaska Peninsula field summary and outcrop sample results from porosity \& permeability and mercury injection capillary pressure analyses: Alaska Division of Geological \& Geophysical Surveys Raw Data File 2006-1, 65 p. 



\title{
MERCURY INJECTION CAPILLARY PRESSURE AND RESERVOIR SEAL CAPACITY OF 26 OUTCROP SAMPLES, MIOCENE TO TRIASSIC AGE
}

\author{
by \\ George W. Bolger ${ }^{1}$ and Rocky R. Reifenstuhl ${ }^{2}$
}

\begin{abstract}
Twenty-six outcrop samples from Alaska Peninsula formations (Bear Lake, 11 samples; Stepovak, two samples; Tolstoi, five samples; Staniukovich, four samples; and Kamishak, four samples) were selected from the stratigraphic section as prospective hydrocarbon seals (fig. 1). These samples were analyzed using mercury injection capillary pressure (MICP). Formations were sampled based on reservoir seal position within prospective petroleum play concepts. Outcrop lithologies with the greatest perceived seal capacity were sampled.

The best quality seals (Sneider Seal Classification, Sneider, 1997) in the sample set are Sneider Type A and are present in the Bear Lake, Kamishak, and Tolstoi Formations (table 1). Overall, the Type A seals represent approximately 40 percent of the samples collected (11 of 26) and largely consist of rock visually characterized as claystone and limestone (Kamishak limestone), but also include a few of the argillaceous siltstone and argillaceous sandstone samples. The porosity in the Type A seals ranges from 1.22 percent (Kamishak limestone) to 20.2 percent (Bear Lake argillaceous siltstone); in all cases the rocks have a finescale pore structure that supports high capillary pressures.

Type $\mathrm{C}$ seals are the next most common and account for approximately 30 percent of the samples. For the most part, they are moderately argillaceous to argillaceous siltstones. Porosity ranges from 4.82 percent (Stepovak Formation) to 18.2 percent (Bear Lake Formation). A majority of the Type $\mathrm{C}$ seal rocks have a bimodal pore structure and the lower capillary pressures associated with the larger, initial pore aperture population generally control the seal capacity. Where the Type $C$ seals have a laminated fabric that creates the bimodality, the seal quality may be higher if the laminations are oriented perpendicular, or at a high angle, to the hydrocarbon migration direction.

The Staniukovich Formation samples include one calcareous siltstone with cemented to partially-open fractures and one well-compacted sandstone; both are Type B seals. Porosity is 8.30 percent and 4.98 percent, respectively. These rocks have bimodal pore structures that do not appear to be related to the depositional fabric.

The data provided by the MICP analysis show that a significant portion of the rock types sampled as potential sealing facies represent good quality Type A and Type B seals.
\end{abstract}

\section{INTRODUCTION AND METHODOLOGY}

Public data were not previously available on the quality of potential sealing facies in the onshore Bristol Bay petroleum system. Additionally, there has been some concern as to whether good quality seals exist within the depositional settings proposed for these rocks. In order to provide an initial database to address these issues, 26 Alaska Peninsula outcrop samples were collected to test their reservoir seal capacity (fig. 1; table 1). These rock samples were selected from the stratigraphic section (fig. 2) based on the likelihood that they might act as capillary seals for a subsurface reservoir in an oil or gas play on the Alaska Peninsula or near-shore Bristol Bay basin. Formations sampled include:
- Bear Lake (Miocene; 11 samples)

- Stepovak (Oligocene; two samples)

- Tolstoi (Eocene; five samples)

- Staniukovich (Early Cretaceous; four samples)

- Kamishak (Triassic; four samples).

Seals are defined as generally ductile rocks with a very high capillary entry pressure that can dam up or stop hydrocarbon migration. Petrophysical and petrographic studies of conventional and sidewall cores from known seal-reservoir couplets of hydrocarbon-producing reservoirs provide a basis to quantify the capacity of a rock to seal a hydrocarbon column (Sneider, 1997). The most

${ }^{1}$ PetroTech Associates, 11767 Katy Freeway, Suite 320, Houston, Texas 77079

${ }^{2}$ Alaska Division of Geological \& Geophysical Surveys, 3354 College Rd., Fairbanks, Alaska 99709-3707 
important property of a seal is its pore-size distribution as measured in thin section, scanning electron microscope, and high pressure (up to 60,000 psi) air-mercury capillary pressure curves determined across bedding surfaces. Using the density difference of normal saline water and 35 degree API oil as a standard, an arbitrary scale of seal types has been developed (Sneider, 1997).

The outcrop samples collected from the measured sections, or geologic mapping grab-samples to be used for seal evaluation, were forwarded to Petrotech Associates (Houston, Texas). The pieces of rock in each sample were examined using a reflected light microscope (magnifications of $5 \mathrm{X}$ to $50 \mathrm{X}$ ) and a brief description of the rock properties was made (table 1 ). A representative portion of the bulk sample was selected for capillary pressure analysis and trimmed to a size that would fit the sample holder. The sample was then placed in a low-temperature convection oven and dried to a constant weight.

The high-pressure mercury injection capillary pressure (MICP) analysis was carried out using a Micromeritics 9420 mercury porosimeter. Penetrometers with 15 cc sample chambers were used for all analyses. Each test utilized a pressure table containing 118 separate pressure points from 1.5 to 59,500 psia, and the volume of mercury injected was measured at each point. The collected data were corrected for closure, that is, intrusion related only to the mercury conforming to the sample surface. The complete detailed analytical data set for each sample and coordinates for each sample location are presented in tabular and graphical formats in RDF 2007-3 (Loveland and others, 2007) available by contacting the State of Alaska Division of Natural Resources, Division of Geological \& Geophysical Surveys (www.dggs.dnr.state.ak.us; 3354 College Road, Fairbanks, Alaska; 907-451-5020).

The air/mercury capillary pressure data were converted to gas/water and oil/water systems assuming a gas/water surface tension of 50 dynes/cm and an oil/ water interfacial tension of $30 \mathrm{dynes} / \mathrm{cm}$. Subsequent conversion to equivalent height was made using the values in table 2 . These values are used to reflect interpreted reservoir conditions.

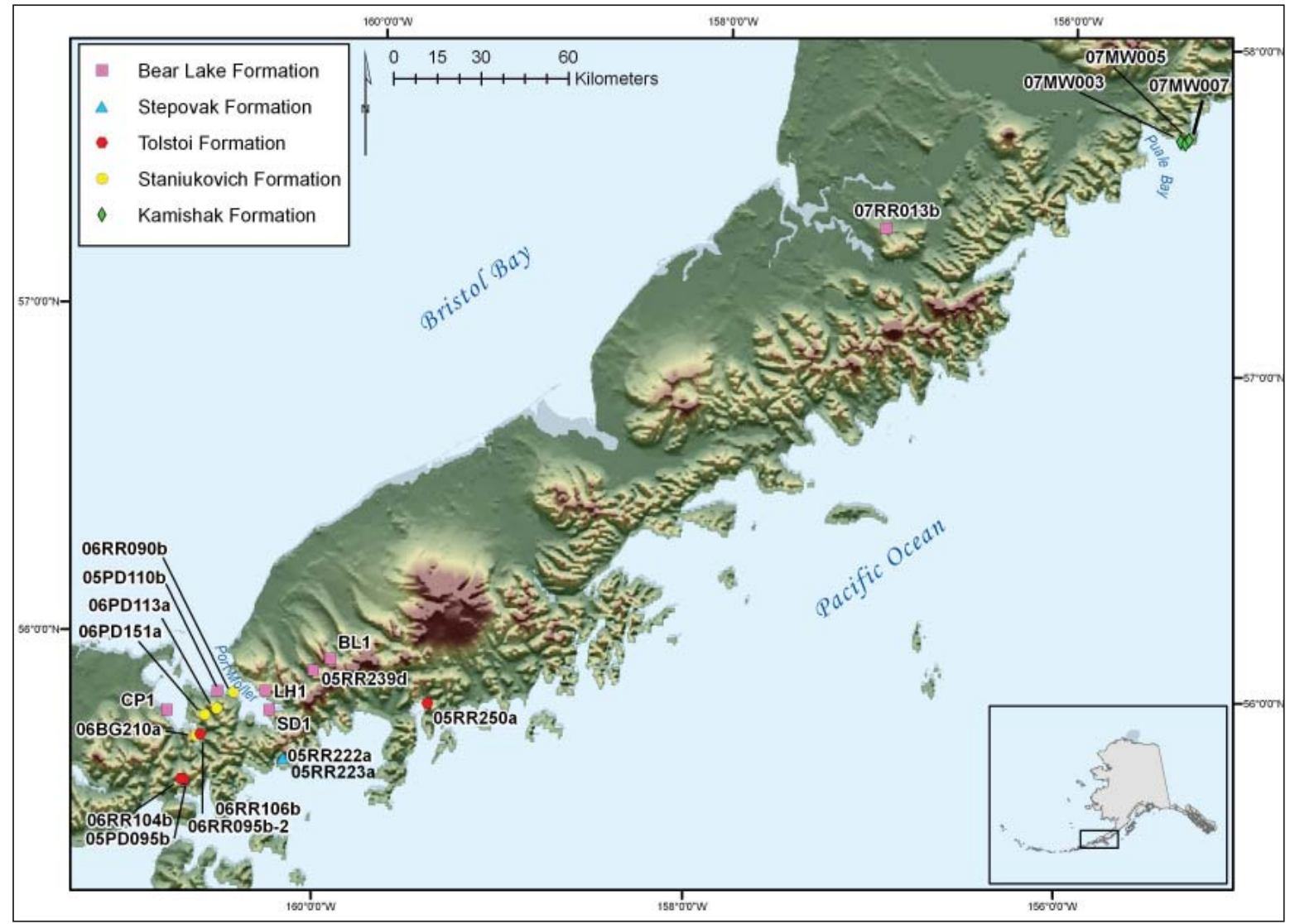

Figure 1. Map of the Alaska Peninsula showing the location of 26 outcrops sampled for mercury injection capillary pressure analyses. Samples are from the Port Moller, Puale Bay, and Ugashik Lake areas. 
Table 1. Porosity and permeability and Sneider (1997) hydrocarbon seal type derived from mercury injection capillary pressure analyses for 26 Alaska Peninsula outcrop samples. See text for discussion of Sneider seal type.

\section{Sample and Formation}

\section{Bear Lake Formation}

BL - 3

CP1 - 182

SD1 - 16

SD1 - 90

BL - 18

CP1 - 0.5

LH1 - 115

07RR013B

05PD110B

LH1 - 27.5

05RR239D

\section{Stepovak Formation}

05RR223A

05RR222A

Tolstoi Formation

05RR250A

06PD095b

06RR104b

06RR095b-2

06RR106b

Staniukovich Formation

06PD113a

06BG210

06PD151a

06RR090b

Kamishak Formation

07MW003 - 7.5

07MW005 - 50

07MW007 - 27.2

07MW003 - 46.8
MICP Derived

$\begin{array}{ccc}\text { Porosity } & \text { Permeability } & \begin{array}{c}\text { Sneider } \\ \text { (\%) }\end{array} \\ \text { (md) } & \text { Seal Type }\end{array}$

A

A

A

A

C

C

C

$\mathrm{D}$

D

E

none

\section{Description}

siltstone, argillaceous

claystone

sandstone, argillaceous, variable sandstone/siltstone/claystone, laminated, hard

siltstone, laminated argillaceous/ clean

siltstone, moderately argillaceous siltstone/sandstone, argillaceous

siltstone, laminated argillaceous/ clean

siltstone/sandstone, laminated sandstone, slightly argillaceous sandstone, reservoir (?) rock

sandstone, compacted

sandstone, argillaceous matrix

claystone

claystone

claystone

sandstone, compacted, matrix?

claystone, organic-rich, coaly

siltstone, calcareous, fractures sandstone, argillaceous, compacted siltstone, moderately argillaceous

C sandstone, argillaceous

\begin{tabular}{|c|c|c|c|}
\hline 8.3 & 0.0064 & B & siltstone, calcareous, fractures \\
\hline 4.98 & 0.0002 & B & $\begin{array}{l}\text { sandstone, argillaceous, } \\
\text { compacted }\end{array}$ \\
\hline 12.6 & 0.048 & $\mathrm{C}$ & siltstone, moderately argillaceous \\
\hline 9.33 & 0.0088 & $\mathrm{C}$ & sandstone, argillaceous \\
\hline
\end{tabular}

sandstone, compacted, cemented limestone, crystalline limestone, crystalline limestone, crystalline 
Figure 2. Stratigraphic column for the Alaska Peninsula showing rock formations with generally favorable hydrocarbon source potential (oil prone: green dots; gas prone: red dots) and hydrocarbon reservoir potential (black dots) (modified from Hite, 2004).

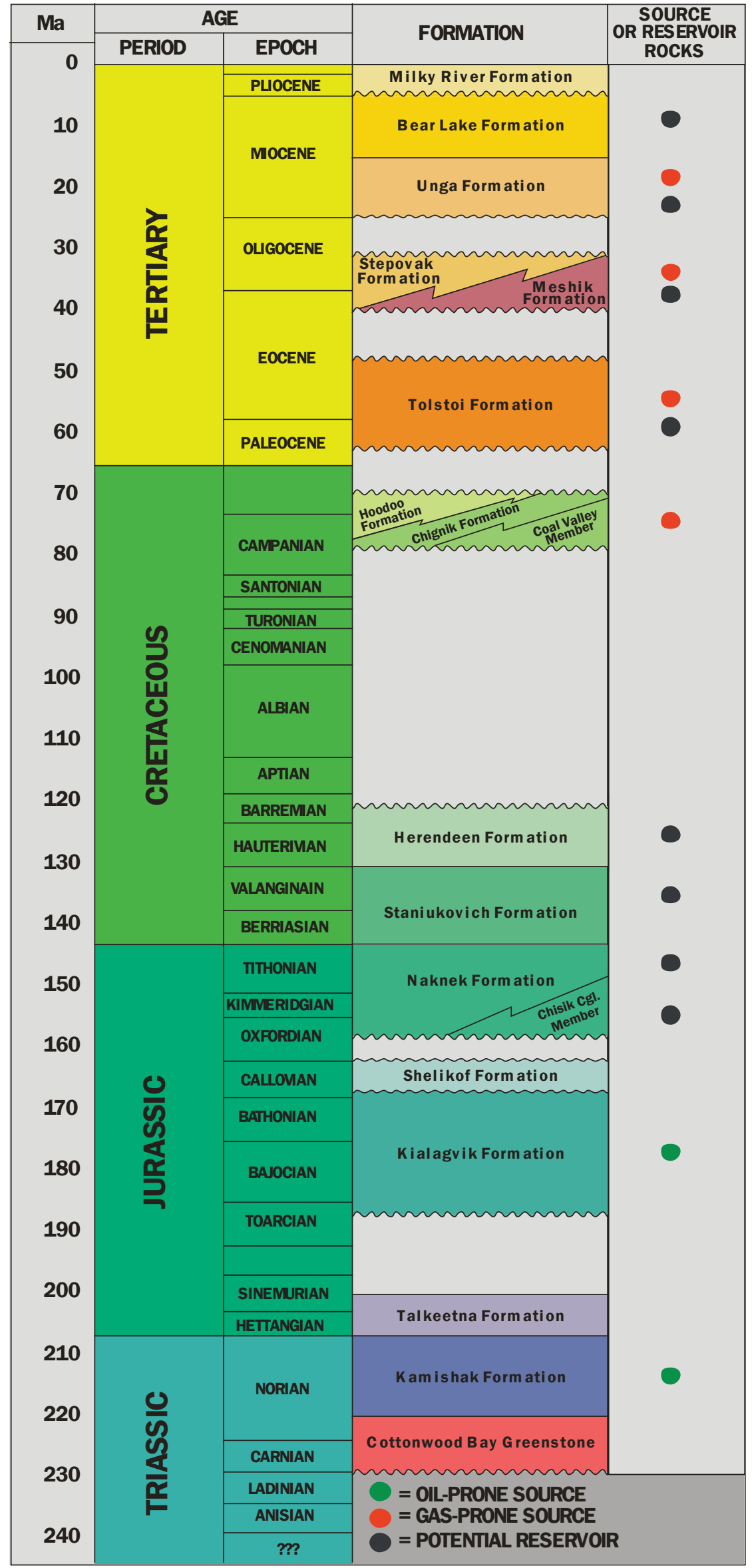




$\begin{aligned} & \text { Table 2. Values used for conversion to equivalent height } \\
& \text { of oil and gas based on the mercury injection capil- } \\
& \text { lary pressure (MICP) analyses. }\end{aligned}$
\begin{tabular}{llc} 
Water Density & Oil Density & Gas Density \\
$1.016 \mathrm{~g} / \mathrm{cc}$ & $0.28 \mathrm{~g} / \mathrm{cc}$ & $0.69 \mathrm{~g} / \mathrm{cc}$ \\
\hline
\end{tabular}

Calculations of potential seal capacity (hydrocarbon column held) were made for hydrocarbon saturations in the seal of 0 percent (entry), 5 percent, 7.5 percent, and 10 percent and are part of the available database.

Porosity and permeability values were generated for each of the samples using the MICP data. The porosity is measured using an Archimedes bulk volume and the pore volume based on the closure-corrected volume of mercury injected. Permeability is calculated using the Swanson Equation (Swanson, 1981).

\section{ROCK TYPES}

Twenty-six samples (see table 1) representing various facies and rock types were analyzed for their potential seal capacity. The samples were collected from the following formations: Bear Lake (11 samples), Stepovak (two samples), Tolstoi (five samples), Staniukovich (four samples), and Kamishak (four samples).

The appearance of the samples while being examined under reflected light microscopy indicates that they include a variety of rock types and depositional fabrics (table 1). A majority of the rocks have a grainrich character and include sandstones (nine samples), siltstones (six samples) and mixtures of the two (two samples). The grain-rich samples appear to contain limited to high levels of clay, with moderately argillaceous to argillaceous fabrics common. Samples that exhibit a more clay-rich character (that is, claystones) are less common and were primarily collected from the Tolstoi Formation. Samples containing distinctly laminated fabrics are from the Bear Lake Formation. Rock properties creating the laminae range from changes in grain size (sand to silt or silt to clay) to, more commonly, variations in clay mineral content (clean to argillaceous). Limestones that appear to have been originally slightly fossiliferous mudstones are the dominant rock in the outcrop samples from the Kamishak Formation. Locally there is visual evidence that higher levels of compaction have occurred. Only rarely do the rocks appear to have been highly cemented.

\section{PORE STRUCTURE}

The porosity and permeability based on the MICP data are listed in table 1 and displayed in figures 3 and 4, identified by formation and seal type, respectively. There is a large range in both porosity (1.22 to 37.0 percent) and permeability (0.00001 to $1.30 \mathrm{md}$ ), with the most scatter in the Bear Lake Formation samples. The higher porosity rock types tend to be argillaceous siltstones and cleaner sandstones that retain some open intergranular pore space. The lowest porosity rocks are the Kamishak Formation limestones (average 1.65 percent), followed by claystones (average 5.18 percent) and the compacted sandstones (5.53 percent) that are present in each of the formations. In the samples with the higher permeability values, a portion of the rock generally has a grain-supported fabric that contains remnant, primary intergranular pore space. However, these rocks are often laminated, resulting in inferred anisotropy.

The pore structure in the sandstones and laminated siltstone/sandstones generally exhibits some degree of bimodality; that is, there are two separate populations in the pore aperture size distribution that control access to the pore space. The two modes reflect the aperture size differences created by the change in grain size (for example, sand, silt) or open intergranular pore space versus microporous clay. The claystones, limestones, and more uniform argillaceous grain-rich rocks have relatively well defined, unimodal pore structures. This is largely a function of the more homogeneous rock fabric that produces a narrower pore aperture size distribution.

\section{SEAL QUALITY}

An assessment of seal capacity is provided by the Sneider Seal Classification (Sneider, 1997). This classification is a qualitative system for ranking seals, and is based on the mercury capillary entry pressure. Seal type, corresponding mercury capillary entry pressure, and equivalent column height for a "standard” oil water system are compiled in table 3.

The best quality seals (Sneider, 1997) in the sample set are Sneider Type A and are present in the Bear Lake, Kamishak, and Tolstoi Formations (table 4). Overall, the Type A seals represent approximately 40 percent of the samples collected (11 of 26) and largely consist of rock visually characterized as claystone and limestone, but also include a few of the argillaceous siltstone and argillaceous sandstone samples. The porosity in the Type A seals ranges from 1.22 percent (Kamishak limestone) to 20.2 percent (Bear Lake argillaceous siltstone); in all cases the rocks have a fine-scale pore structure that supports high capillary pressures. 


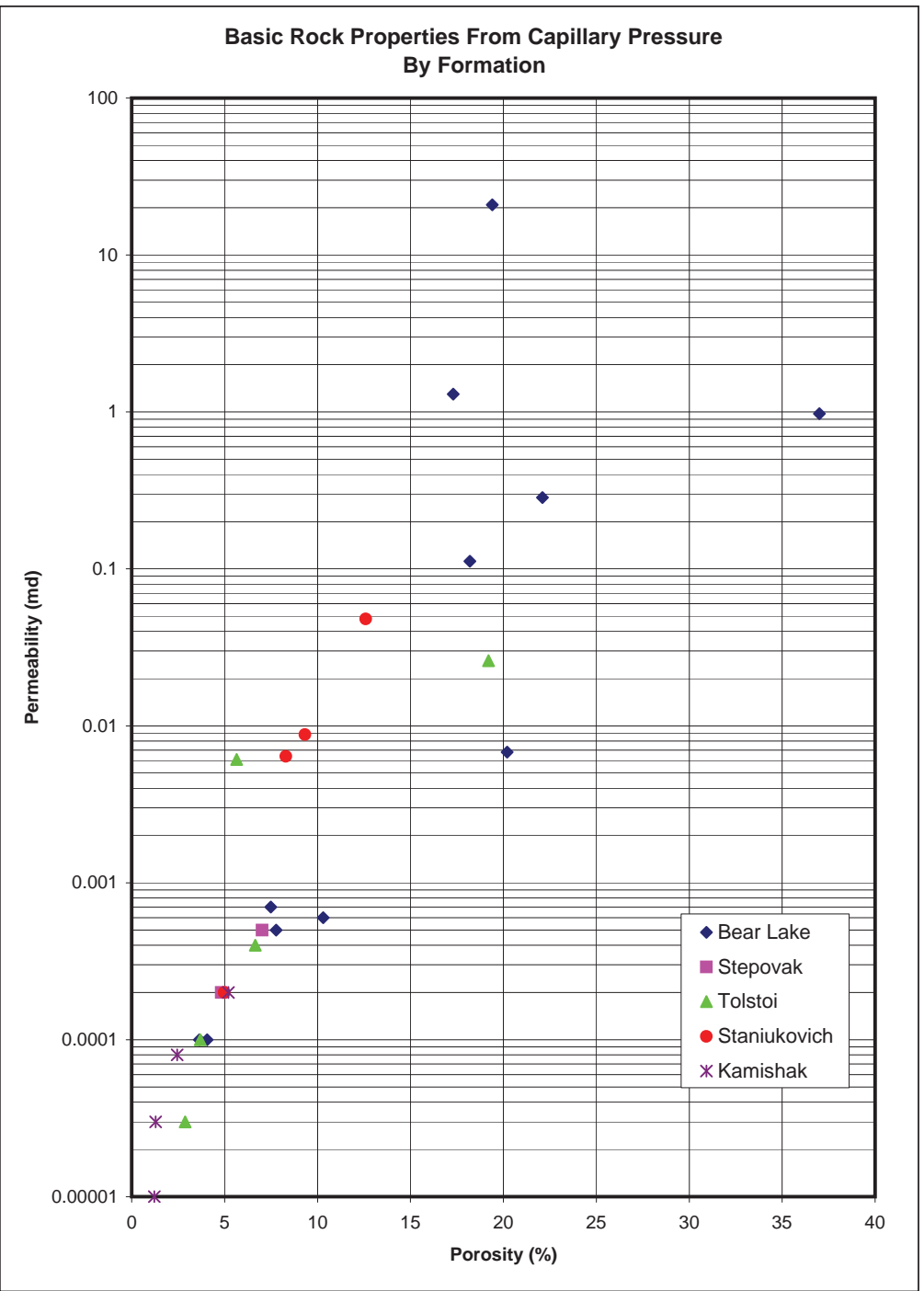

Figure 3. Porosity and permeability derived from mercury injection capillary pressure analyses of 26 Alaska Peninsula outcrop samples. Samples are plotted using symbology corresponding to their stratigraphic formation and show significant variability due to rock type changes and petrophysical differences within the individual formations.

Table 3. Sneider (1997) hydrocarbon seal types, mercury entry pressure, and range in oil column held based on mercury injection capillary pressure (MICP) analyses.

\begin{tabular}{ccc} 
Seal Type & $\begin{array}{c}\text { Entry Pressure (pounds } \\
\text { per square inch) }\end{array}$ & $\begin{array}{c}\text { Oil Column Held (feet; } \\
\text { one meter } ~ 3.1 \text { feet) }\end{array}$ \\
$\mathrm{A}+$ & $>6,868$ & $>5,000$ \\
$\mathrm{~A}$ & $1,373-6,868$ & $1,000-5,000$ \\
$\mathrm{~B}$ & $687-1,373$ & $500-1,000$ \\
$\mathrm{C}$ & $137-687$ & $100-500$ \\
$\mathrm{D}$ & $69-137$ & $50-100$ \\
$\mathrm{E}$ & $14-69$ & $<50$ \\
$\mathrm{~F}$ & $<14$ & Waste Zone \\
\hline
\end{tabular}


Figure 4. Porosity and permeability derived from mercury injection capillary pressure analyses of 26 Alaska Peninsula outcrop samples. Samples are plotted using symbology corresponding to their Sneider (1997) hydrocarbon seal type (see text and table 3 for details).

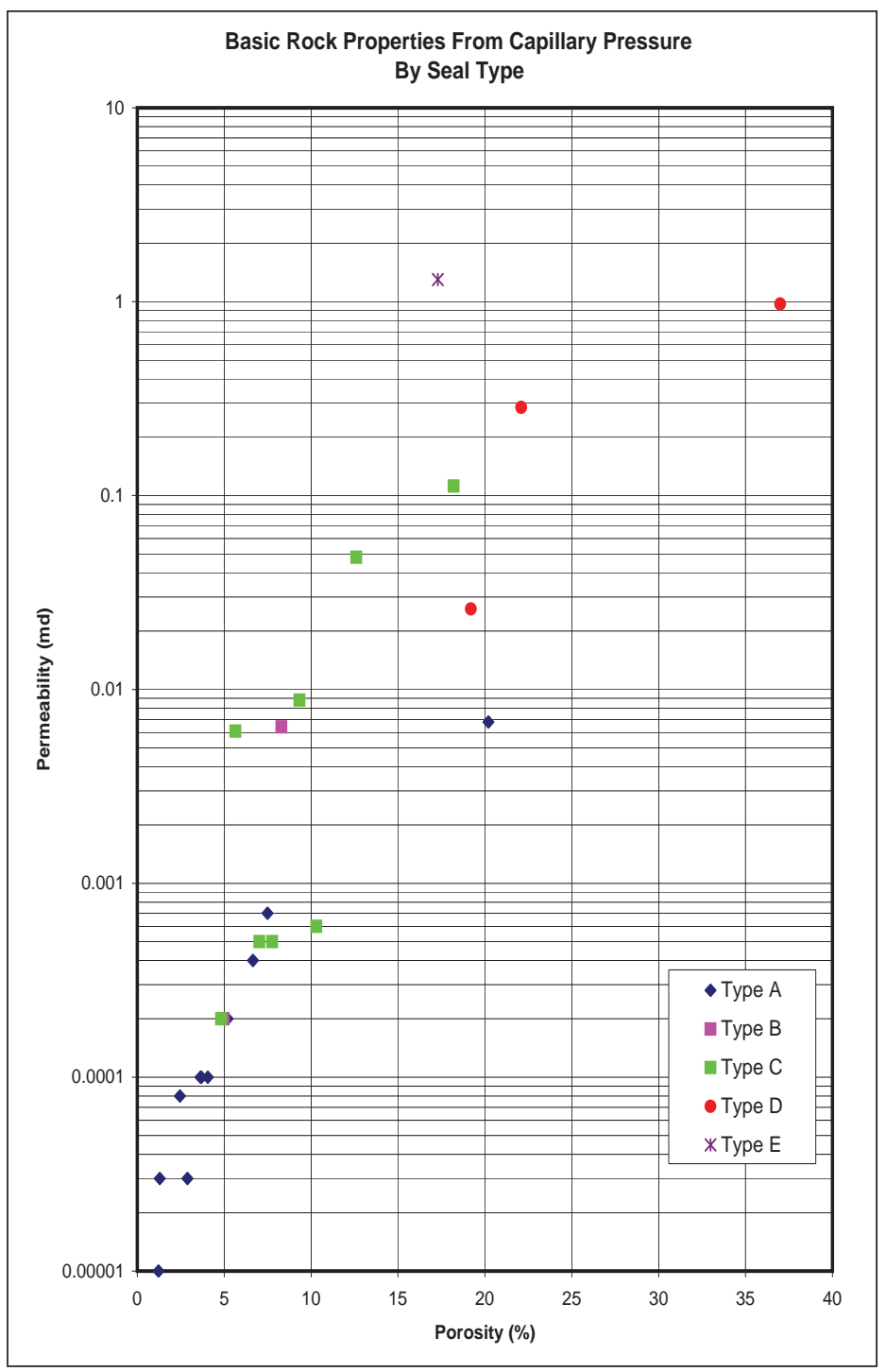

Table 4. Sneider (1997) hydrocarbon seal types, Alaska Peninsula formations sampled and hydrocarbon column height values for oil and gas based on mercury injection capillary pressure (MICP) analyses.

\section{Seal Formations \\ Type Present}

A Bear Lake

Kamishak

Tolstoi

B Staniukovich

C Bear Lake

Staniukovich

Stepovak

Tolstoi

D Bear Lake

Tolstoi

E

Bear Lake
Column height range (feet; 1 meter $~ 3.1$ feet)

\section{Oil}

$2,170-4,984$

$798-1,360$

$199-661$

$117-151$

61
Column height average (feet; 1 meter $~ 3.1$ feet )

Oil Gas

3,257

2,404

1,079

796

$589-1,004$

$147-488$

417

308

$87-111$

136

101 
Type $\mathrm{C}$ seals are the next most common and account for approximately 30 percent of the samples. They are present in all of the formations except the Kamishak and, for the most part, are moderately argillaceous to argillaceous siltstones. A majority of the Type $\mathrm{C}$ seal rocks have a bimodal pore structure and the lower capillary pressures associated with the larger, initial pore aperture population generally control the seal capacity. Where the Type $C$ seals have a laminated fabric that creates the bimodality, the seal quality may be higher if the laminations are oriented perpendicular, or at a high angle, to the hydrocarbon migration direction, like a top seal that is conformable with the reservoir. Porosity ranges from 4.82 percent (Stepovak Formation) to 18.2 percent (Bear Lake Formation).

The Staniukovich Formation samples include a calcareous siltstone with cemented to partially open fractures, and a well compacted sandstone that are both Type B seals. Porosity is 8.30 percent and 4.98 percent, respectively. These rocks have bimodal pore structures that do not appear to be related to the depositional fabric.

A small portion of the samples collected represent Type D and E quality seals. The Bear Lake Formation rocks within these lower seal capacity ranges, for the most part, have grain-supported fabrics and appear to contain an amount of open intergranular pore space that makes them borderline reservoir rock, rather than seals. They also have high porosity (17.3 to 37.0 percent) and permeability (0.285 to $1.30 \mathrm{md})$. However, as with the Type $C$ seals, laminated fabrics and bimodal pore structures present the potential for higher seal quality if the laminations are perpendicular to the migration direction. In the Tolstoi Formation an apparently organic-rich, almost coaly, claystone was sampled that has high porosity (19.2 percent) and a heterogeneous pore structure that produces capillary properties consistent with a Type D seal.
The seal capacity (hydrocarbon column held) can be quantified based on an assumption of the hydrocarbon saturation present in the seal at the leak point. The air/mercury capillary pressure needed to generate the assumed saturation is converted to equivalent height for the specific hydrocarbon/water system being evaluated. The common range in values is from 5 to 10 percent non-wetting phase saturation. The value at 7.5 percent saturation is used here to indicate the point at which the hydrocarbon content in the seal is sufficient to form a phase continuous enough to cause the seal to leak. Potential seal capacities for this saturation level, grouped by formation, are plotted in figures 5 and 6 for oil and gas, respectively.

It is apparent from the seal capacity data in figures 5

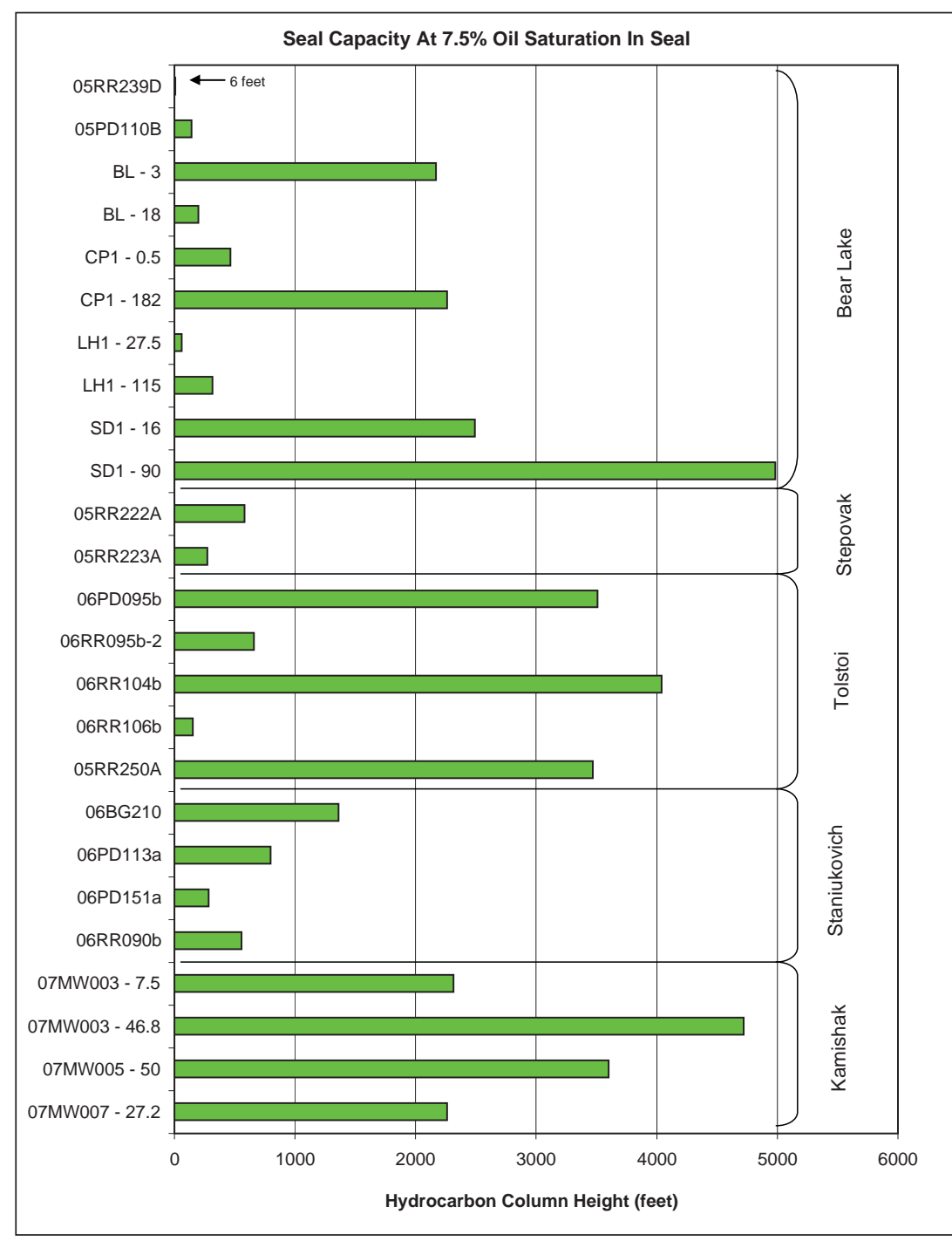

Figure 5. Seal capacity (at 7.5 percent oil saturation in seal) for 26 Alaska Peninsula outcrop samples. Mercury injection capillary pressure analyses show significant variability in the potential column heights for the rock types sampled as well as within the individual formations. 
and 6 that there is significant variability in the potential column heights for the rock types sampled and also within the individual formations. Table 4 illustrates the range in potential column heights for both oil and gas referenced to the Sneider Seal Types.

\section{CONCLUSIONS}

The results of the mercury injection analysis show that there are rock types that represent good quality capillary seals present in Miocene- to Triassic-age formations of the Alaska Peninsula (onshore Bristol Bay petroleum system). The highest quality seals are found in the Kamishak, Tolstoi, and Bear Lake Formations, and the poorest in the Stepovak and Staniukovich. However, as sampled, there is also significant variability within some of the formations, with some of the poorest quality seals also coming from the Bear Lake and Tolstoi Formations.

The rock types analyzed include siltstone, sandstone, claystone, and crystalline limestone. Porosity ranges from 1.22 to 37.0 percent and permeability from 0.00001 to $1.30 \mathrm{md}$. The siltstones and sandstones are commonly moderately argillaceous to argillaceous, and are thinly laminated in the Bear Lake Formation. The laminae are developed by changes in particle size and/or clay mineral content.

Nearly half (40 percent) of the rocks analyzed are Type A seals (Sneider Classification System) that comprise crystalline limestones (Kamishak Formation), claystones (Tolstoi and Bear Lake Formations), and compacted/cemented sandstones (Bear Lake and Kamishak Formations). Using "standard" reservoir fluid parameters, the average capillary properties of the Type A seals are capable of holding oil columns of 3,200 ft and gas columns of 2,400 ft. Lower quality Type B seals are represented by compacted/cemented sandstone and siltstone (Staniukovich Formation) with slightly more open pore structures, or that contain partially open fractures.

Type C seals are the second most common seal type and compose about 30 percent of the samples. As with most depositional systems, an increase in the grain content of the rock generally results in a decrease in seal quality, especially where the rock fabrics develop a grain-supported framework. In this study, the more grain-rich rocks, sampled from the Bear Lake, Staniukovich, Stepovak, and Tolstoi Formations, include siltstones and sandstones that contain varying amounts of matrix clay. Additionally, a portion of the Type $C$ seals have laminated fabrics that commonly result in bimodal pore structures; where the more permeable lami-
Figure 6. Seal capacity (at 7.5 percent gas saturation in seal) for 26 Alaska Peninsula outcrop samples. Mercury injection capillary pressure analyses show the significant variability in the potential column heights for the rock types sampled and also within the individual formations. 
nae with larger pore apertures control the seal quality. As tested, the Type $\mathrm{C}$ seals can trap potential oil columns of $400 \mathrm{ft}$ and gas columns of $300 \mathrm{ft}$. However, in the laminated rocks, seal quality should improve if the laminae are oriented perpendicular, or at high angles, to the direction of hydrocarbon migration, like a top seal that is conformable with the reservoir.

The most grain-rich rock sampled, including those with open intergranular pore structures more comparable to reservoir rock, make up the limited number of Type $\mathrm{D}$ and E seals.

\section{REFERENCES CITED}

Loveland, A.M., Reifenstuhl, R.R., Gillis, R.J., and Decker, P.L., 2007, Outcrop sample results from mercury injection capillary pressure analyses, Bristol Bay, Alaska Peninsula: Alaska Division of Geological \& Geophysical Surveys Raw Data File 2007-3, 11 p.

Sneider, R.M., 1997, Petrophysical properties of seals, in Surdam, R.C., ed., Seals, traps and the petroleum system: Tulsa, OK, American Association of Petroleum Geologists Memoir 67, 317 p.

Swanson, B.F., 1981, A simple correlation between permeabilities and mercury capillary pressures: Journal of Petroleum Technology, p. 2,498-2,504. 


\title{
BEAR LAKE FORMATION MICROPROBE DATA
}

\author{
by
}

Cheryl Hartbauer ${ }^{1}$

Microprobe data were collected as part of a study to test the hypotheses that the composition of the Bear Lake Formation (fig. 1) reflects progressive erosion of Tertiary and Mesozoic units of the Alaska Peninsula, and that diagenetic minerals present in the Bear Lake Formation reflect conditions implied by thermal maturity indicators. Five samples were analyzed in order to characterize the composition of volcanic rock fragments, other framework clasts, and diagenetic minerals. These samples are all sandstones from outcrops of the Bear Lake Formation in the Port Moller area of the Alaska Peninsula (fig. 2). Major oxide compositions were measured using the Cameca SX-50 electron microprobe at the Advanced Instrumentation Laboratory at the University of Alaska Fairbanks.

Three samples were taken from measured stratigraphic sections and were analyzed using a 2-micron beam with $15 \mathrm{KeV}$ and $10 \mathrm{nA}$. Pore-lining clay of a sodic illite composition and pore-filling zeolites were identified in sample BL2-176 (fig. 3). Chemical composition and cursory XRD analysis suggest that these zeolites are heulandite. Other minerals identified in these samples include plagioclase (An1-68), potassium feldspar, hornblende, glauconite, and smectite. Albite (An1-5) occurs as a pore-filling mineral and replaces plagioclase of higher anorthite content. Samples BL5-92 and BL2176 contain both zeolite and albite.

Analysis of two additional samples focused on classifying volcanic rock fragments. A 20-micron beam was used with $15 \mathrm{KeV}$ and $10 \mathrm{nA}$. Individual phenocrysts in each clast were analyzed and averaged with measurements of the groundmass to approximate a whole-rock composition. For fragments with phenocrysts smaller than 20 microns, individual points that included a combination of phenocryst and groundmass were measured and averaged to approximate a whole-rock composition.

Forty-six volcanic rock fragments were analyzed from sample 04RR163b. Both felsic and intermediate volcanic fragments were identified, with a notable absence of mafic fragments (fig. 4). Classification based on comparison with average major-oxide compositions of volcanic rock types agrees extremely well with classification based on the total alkali-silica diagram. Phenocrysts identified include pyroxene, hornblende, and plagioclase (fig. 5). Both clinopyroxene and orthopyroxene were identified, with clinopyroxene being the more prevalent of the two. Anorthite content of the plagioclase ranges from An44 to An69. In addition, some quartz phenocrysts were identified in the felsic volcanic fragments.

Twenty-six volcanic rock fragments were analyzed from sample 04RR152b. The majority of these fragments have been altered to the point that their compositions no longer resemble those of volcanic rocks. Groundmass has been replaced by clay, and in some fragments plagioclase is albitized or replaced by calcite (fig. 6). Compositionally, a number of fragments still appear volcanic, but the total alkali-silica diagram could not be used to classify these fragments due to mobility of $\mathrm{Na}$ and $\mathrm{K}$. Instead, the data were compared to average volcanic rock compositions with emphasis on the relatively non-mobile elements Si and Ti. These fragments were found to be of intermediate and felsic composition, ranging from basaltic andesite to rhyolite (fig. 7).

In general, microprobe analysis of these five samples from the Bear Lake Formation shows that volcanic fragments are slightly to severely altered, and of felsic and intermediate composition. This characterization will aid in provenance identification. Recognition of compositional variations and refinement of provenance interpretation for the Bear Lake Formation will provide a foundation for interpreting the tectonic dynamics of the Alaska Peninsula during the Miocene. The identification of pore-filling and replacement minerals, such as zeolite and albite, helps to characterize the diagenetic mineralogy of the Bear Lake Formation. Considering this mineralogy in conjunction with existing thermal maturation data will aid in understanding the diagenetic conditions that this formation has experienced in the Port Moller area.

\section{REFERENCES}

Reifenstuhl, R.R., Shafer, D.C., Ryherd, T.J., Brizzolara, D.W., and Blodgett, R.B., 2004, Summary of May 25-June 4, 2004, field notes and samples, Puale Bay and Wide Bay areas, Alaska Peninsula: Alaska Division of Geological \& Geophysical Surveys Raw Data File 2004-3, 16 p.

Streckeisen, A., 1976, To each plutonic rock its proper name: Earth Science Review, v. 12, p. 1-33.

${ }^{1}$ University of Alaska, Department of Geology \& Geophysics, P.O. Box 757320, Fairbanks, Alaska 99775-7320; fsclr2@uaf.edu 


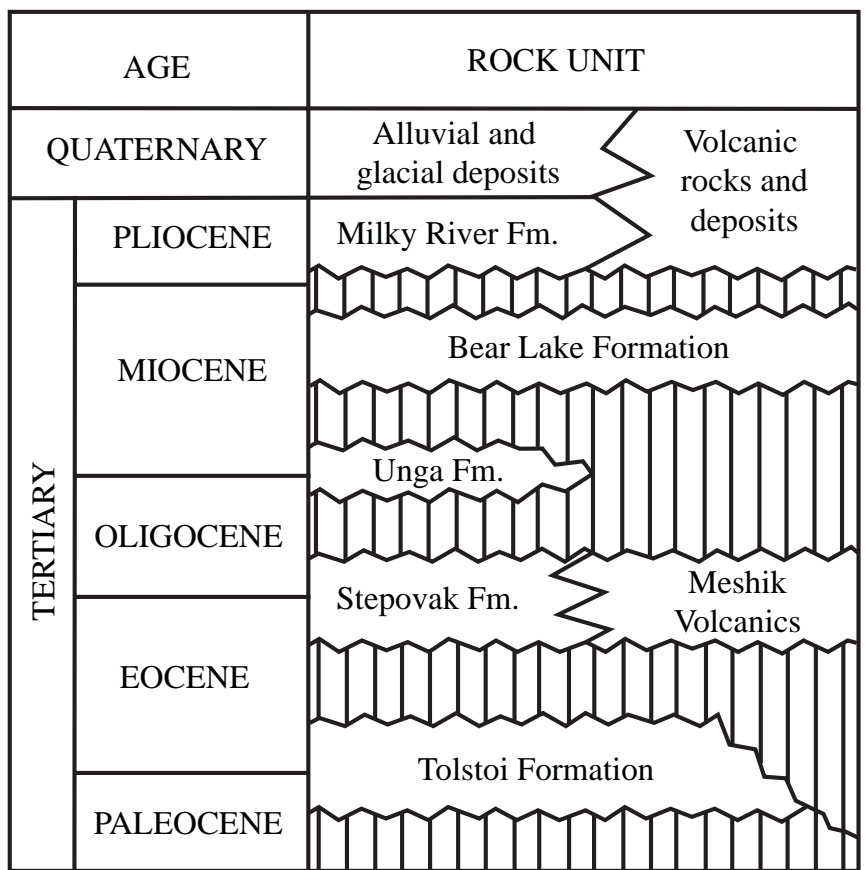

Figure 1. Tertiary stratigraphic column for the Alaska Peninsula (modified from Reifenstuhl and others, 2004).

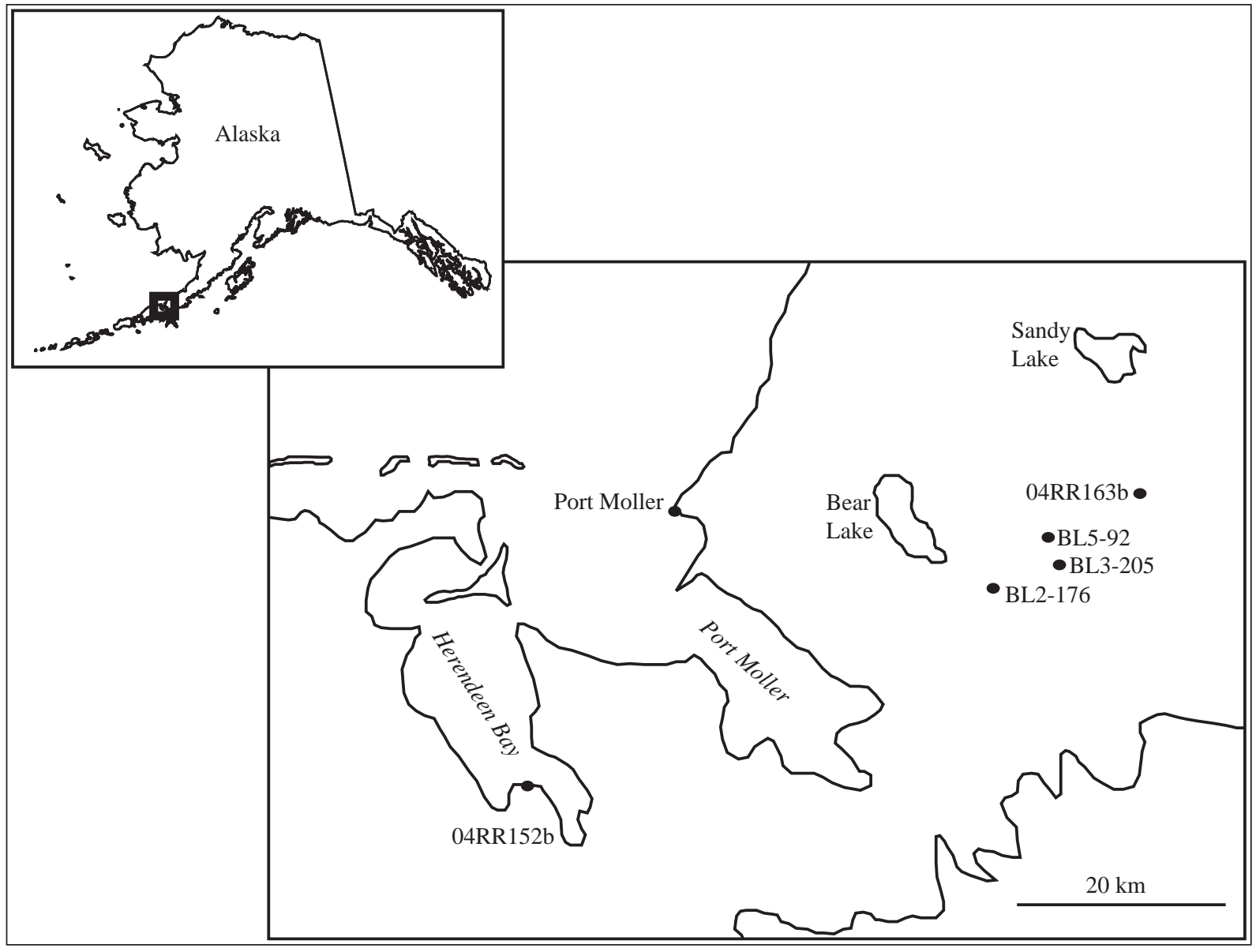

Figure 2. Location of Bear Lake Formation outcrop samples used in microprobe analysis. BL prefix indicates samples from measured stratigraphic sections. 
Figure 3. Photomicrograph of pore-lining illite (arrow) and pore-filling zeolite $(\mathrm{Z})$ in sample BL2-176.

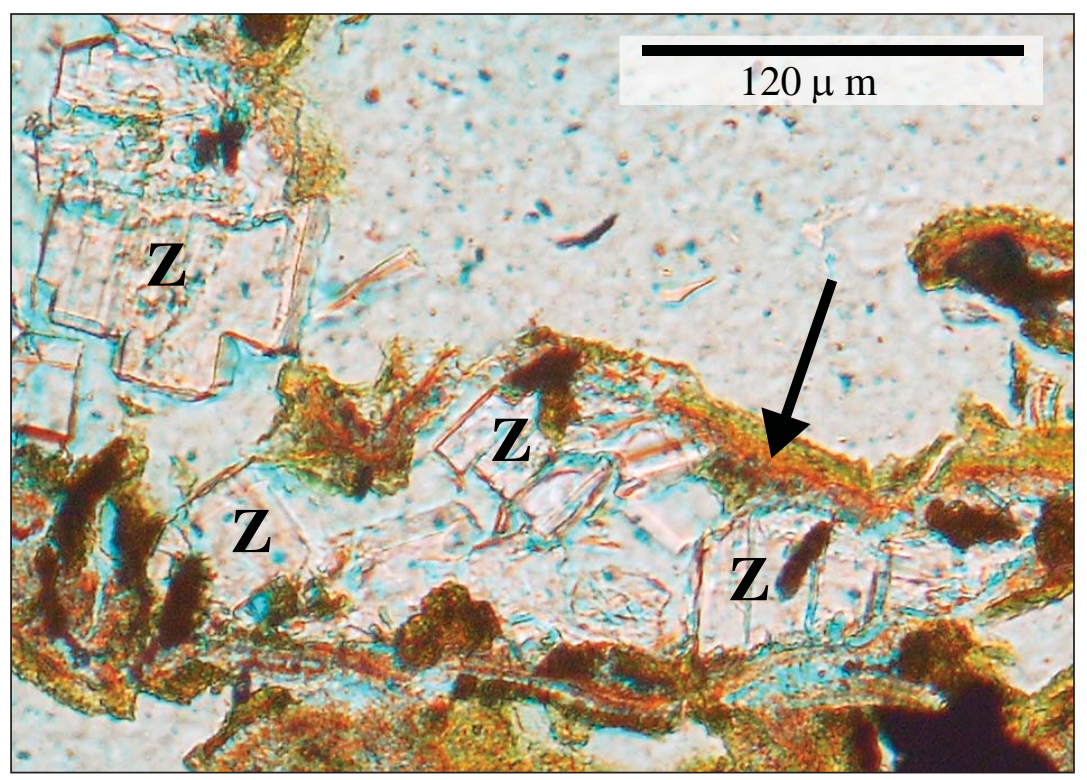

\section{Classification of Volcanic Rock Fragments Sample 04RR163b}

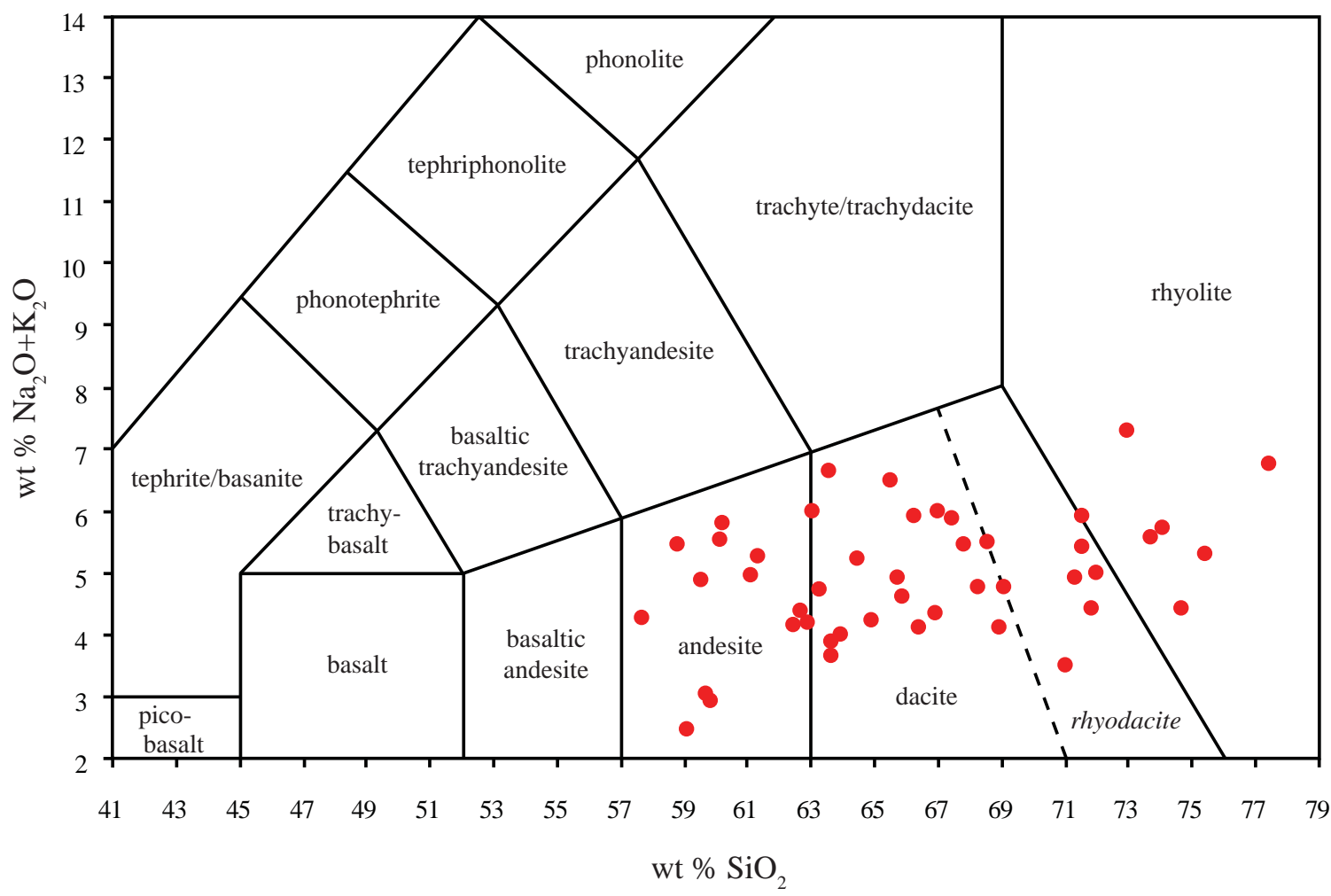

Figure 4. Total alkali-silica plot for volcanic rock fragments analyzed in sample 04RR163b. 


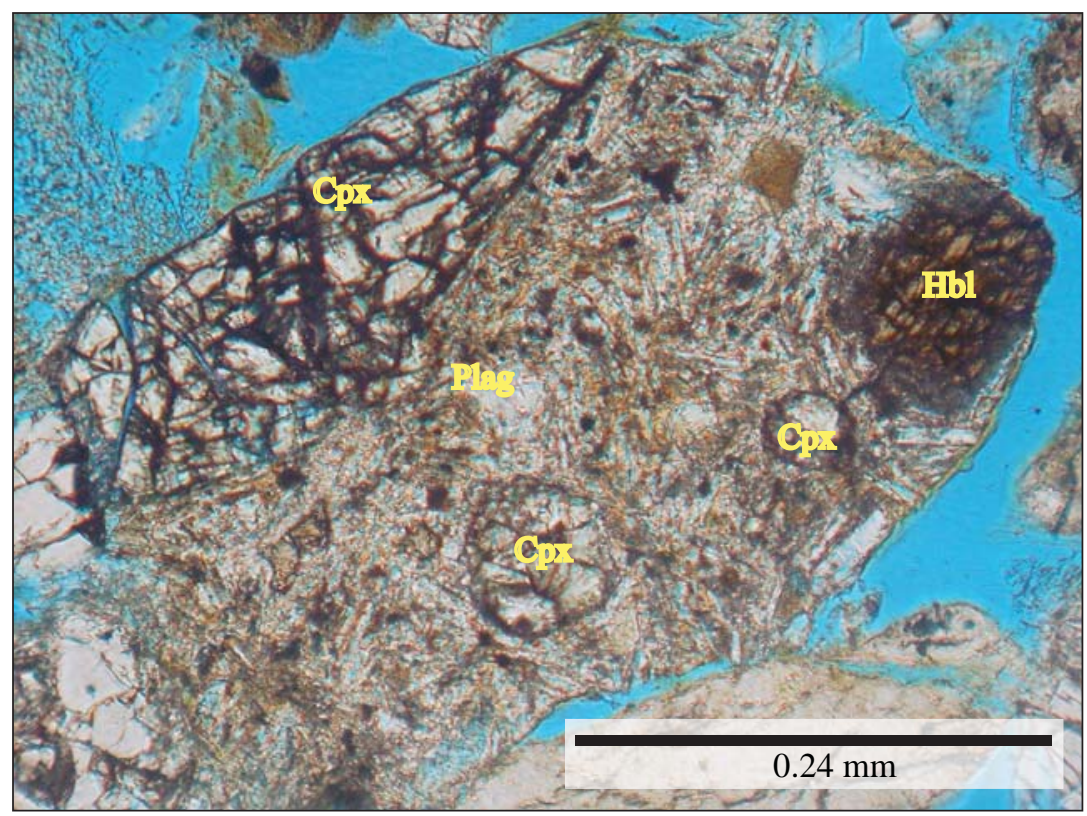

Figure 5. Photomicrograph of volcanic rock fragment in sample 04RR163b with hornblende ( $\mathrm{Hbl})$, clinopyroxene (Cpx), and plagioclase (Plag) (An56) phenocrysts.

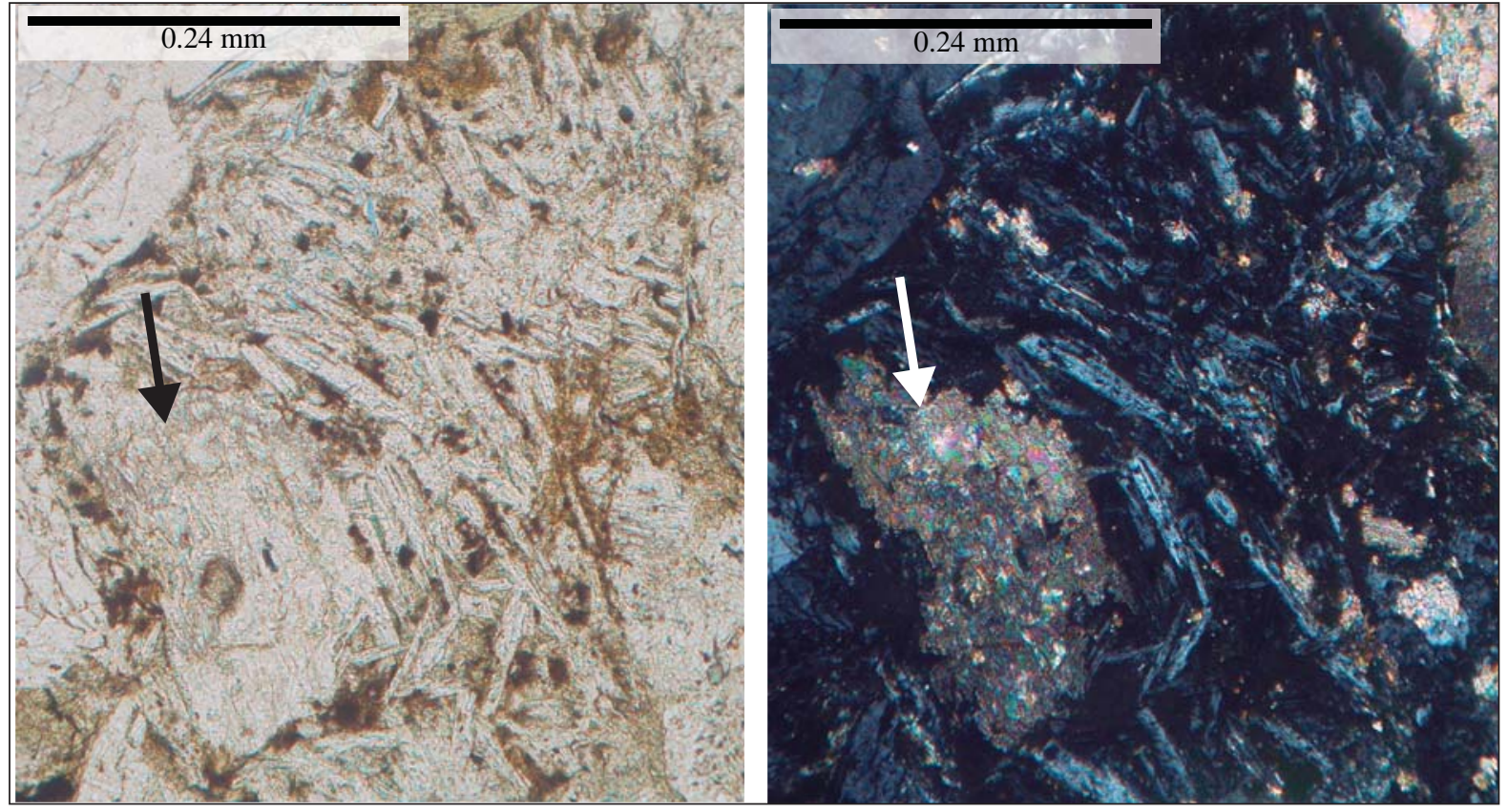

Figure 6. Photomicrograph of volcanic rock fragment in sample 04RR152b with calcite-altered plagioclase (arrow). Shown in plane-polarized light (left) and with crossed polars (right). 


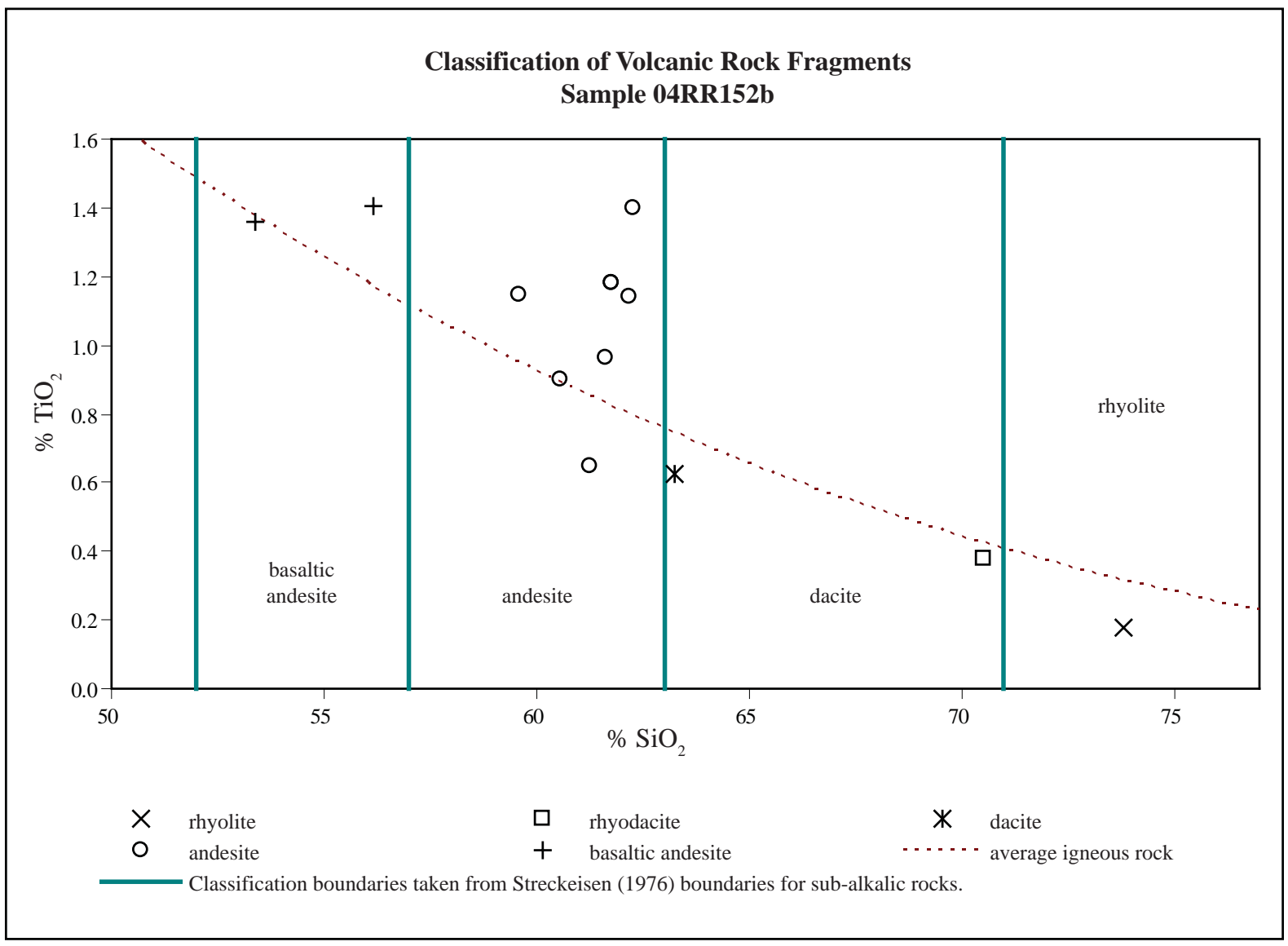

Figure 7. $\mathrm{SiO}_{2}$ vs $\mathrm{TiO}_{2}$ plot for selected altered volcanic rock fragments analyzed in sample 04RR152b. Classification boundaries are taken from Streckeisen (1976) boundaries for sub-alkalic rocks. The dashed curve is an average trend for 18,170 relatively unaltered igneous rocks. 



\title{
STRUCTURAL LINKAGE OF MAJOR TECTONIC ELEMENTS IN THE UGASHIK-BECHAROF LAKES REGION, NORTHEASTERN ALASKA PENINSULA
}

\author{
by \\ Paul L. Decker ${ }^{1}$, Rocky R. Reifenstuhl², and Robert J. Gillis²
}

\begin{abstract}
In the Ugashik Lakes-Becharof Lake region of the Alaska Peninsula, the northeastern end of the North Aleutian basin approaches the southernmost outcrops of the upthrown block of the regional Bruin Bay fault. Subsidence in this segment of the Tertiary backarc was probably in part coeval with reverse or reverse-oblique uplift along the Bruin Bay fault system, but details of the spatial and temporal interaction between these features are not well documented. This report identifies three previously unnamed tectonic elements that are important in clarifying the region's tectonic history: the Ugashik sub-basin, the Ugashik Lakes fault system, and the Becharof discontinuity. The Ugashik sub-basin is the northeastern segment of the North Aleutian backarc basin, separated from the main basin by a major Eocene-Oligocene extrusive complex in the Port Heiden area. The sub-basin is further distinguished by the timing of the onset of major subsidence, best expressed by differential thickening of the Miocene Bear Lake Formation. This significantly postdates the Eocene or older onset of subsidence recorded by the Tolstoi Formation in the heart of the backarc basin to the southwest near Port Moller. The Ugashik sub-basin is bounded on the southeast by the Ugashik Lakes fault system, a northeast-trending set of down-to-northwest faults mapped previously from limited outcrop information. The northeast margin of the sub-basin is the Becharof discontinuity, a northwest-trending zone of crustal weakness interpreted from geophysical data, volcanic activity, and modern seismicity. Focal mechanism solutions from the region are consistent with largely strike-slip motion in a present-day stress regime dominated by a nearly north-south-trending, subhorizontal axis of maximum compressive stress. Assuming similar stress orientations during Neogene time, subsidence of the Ugashik sub-basin may represent a local transtensional response to sinistral displacement along the Ugashik Lakes fault system, possibly contemporaneous with transpressional uplift on the Bruin Bay fault farther north. Additional studies of the timing, sense, and magnitude of Bruin Bay fault displacement will provide valuable constraints on this hypothesis.
\end{abstract}

\section{INTRODUCTION}

This report attempts to clarify the timing and mechanisms of subsidence in the northeastern part of the North Aleutian basin beneath the Ugashik and Becharof Lakes region of the Alaska Peninsula (fig. 1). We devote particular emphasis to a set of faults in the Ugashik Lakes area that likely represent the largely concealed tectonic boundary separating the Tertiary-aged North Aleutian backarc basin to the northwest from the structurally elevated belt of Jurassic and older strata along the Pacific coast on the southeast. We also speculate on the nature of the equally cryptic boundary that separates the northeast end of the backarc basin from the arc batholith and metamorphic basement that makes up the upthrown northwestern block of the Bruin Bay fault. Drawing on new field observations, legacy geologic mapping, well correlations, and newly interpreted aeromagnetic data, seismic surveys, and earthquake focal mechanism solutions, we describe major tectonic elements in the region, and present a simple model of their possible kinematic interactions during late Tertiary time. This hypothesis may have significant implications with respect to hydrocarbon exploration within the basin and the broader tectonic history of southwestern Alaska.

\section{MAJOR TECTONIC ELEMENTS}

Several major tectonic elements are central to this report, including the Bruin Bay fault and three previously unnamed features: the Ugashik Lakes fault system, the Ugashik sub-basin, and the Becharof discontinuity. We briefly introduce these elements here before moving on to provide a more in-depth description and interpretation of the Ugashik Lakes fault system, and conclude by incorporating all the major elements into a Neogene kinematic model.

\section{BRUIN BAY FAULT}

The northeast-trending Bruin Bay fault (Detterman and Hartsock, 1966; Detterman and others, 1976; Detterman and Reed, 1980; Detterman and others, 1987) is among the major structures of southern Alaska. It constitutes a system of several fault strands that extends some $515 \mathrm{~km}$ (320 miles) (Detterman and others, 1976) from at least Becharof Lake (fig. 1A) to its intersection with the Castle Mountain fault, the northern margin of the upper Cook Inlet basin. On the west side of lower Cook Inlet, the Bruin Bay fault has been shown to have up-to-northwest reverse stratigraphic separation of more than 3,000 $\mathrm{m}(10,000 \mathrm{ft})$, and possible left-lateral

${ }^{1}$ Alaska Division of Oil \& Gas, 550 W. 7th Ave., Suite 800, Anchorage Alaska 99501-3560

${ }^{2}$ Alaska Division of Geological \& Geophysical Surveys, 3354 College Rd., Fairbanks, Alaska 99709-3707 
movement of 10 to $19 \mathrm{~km}$ (6-12 mi; Detterman and Hartsock, 1966; Detterman and others, 1976). Major movement on the Bruin Bay fault system is thought to have occurred during middle to late Tertiary time, ending in the Miocene (Detterman and Reed, 1980). It may have been responsible for uplift and erosion of the Alaska-Aleutian Range batholith as early as the Late Jurassic, coincident with the deposition of arkosic sandstones and granitic conglomerates of the Naknek Formation (fig. 2; Detterman and Reed, 1980, p. B71). The southern limit of the Bruin Bay fault trace has been plotted differently on various geologic maps. Wilson and others (1999) ended the fault beneath Becharof Lake (fig. 1B). Detterman and others (1987) speculated that the Bruin Bay fault extends much farther southwest in the subsurface, following an aeromagnetic anomaly pattern that we believe relates more directly to the Ugashik Lakes fault system (fig. 3).

\section{UGASHIK LAKES FAULT SYSTEM}

A north-northeast-trending fault zone, referred to here as the Ugashik Lakes fault system (ULFS, figs. 1B and 3), is constrained by outcrop relationships at just two localities. These locations are approximately $21 \mathrm{~km}$ (13 mi) apart, located north and south of Lower Ugashik Lake (Detterman and others, 1987; Wilson and others, 1999). This fault system juxtaposes a large region of broadly folded and highly faulted Jurassic Naknek Formation and older rocks on the east with limited exposures of Tertiary Bear Lake Formation, the northeastern-most exposures of the North Aleutian backarc basin (figs. 1A and 2). Relative ages clearly indicate the northwestern side of the ULFS is downthrown in a relative sense. However, fault attitudes and kinematics have not been documented previously; normal, reverse, strike-slip, and/or reactivational displacements along this system are all permissible interpretations of the fault patterns as represented on legacy geologic maps. Much of this report pertains to our observations and interpretations

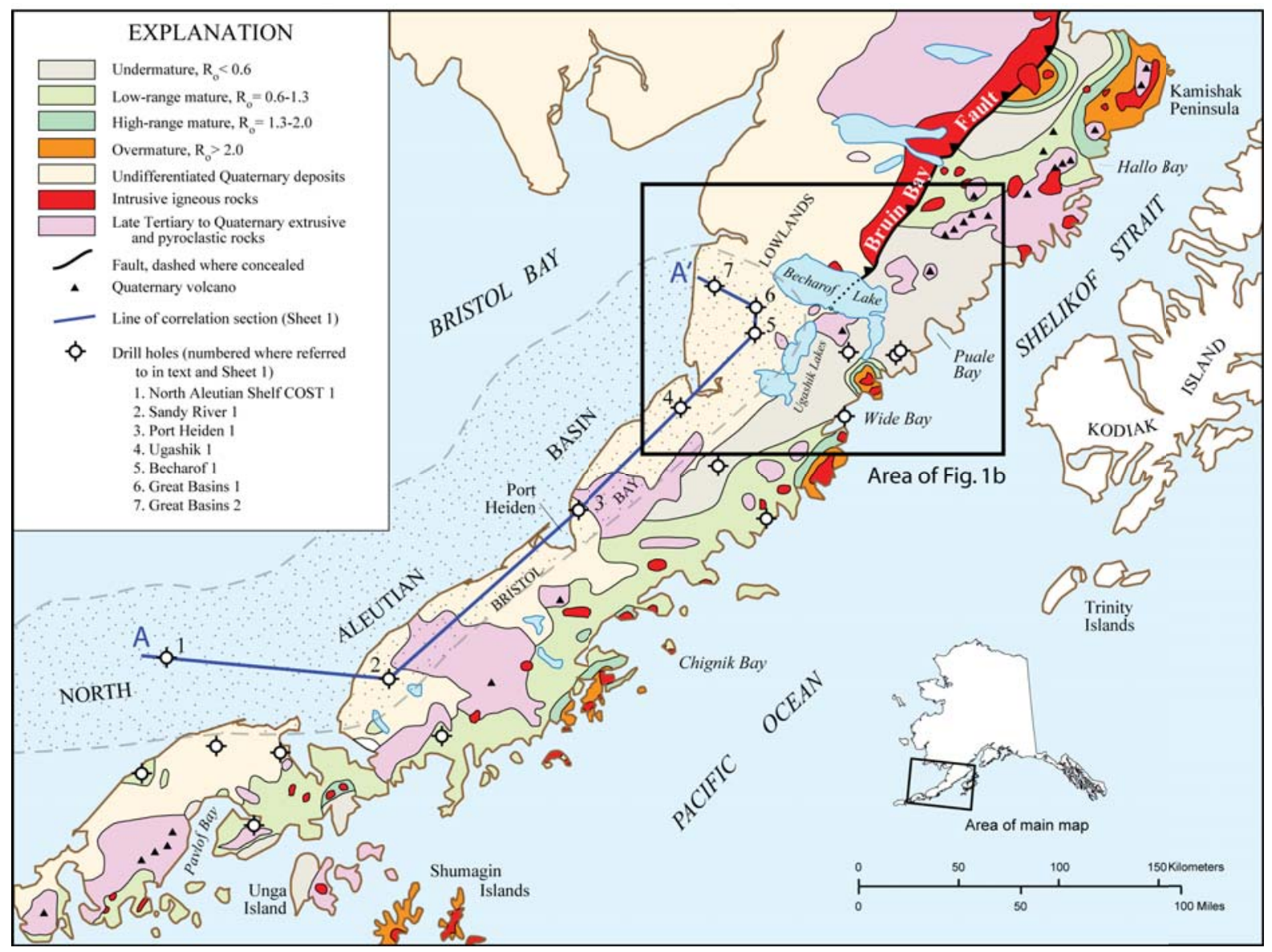

Figure 1A. Location map of the Alaska Peninsula, modified from surface thermal maturity map of Molenaar (1996). Inset shows area of this study, shown in more detail in geologic map, figure 1B. Note line of section A-A'(sheet 1) through numbered wells, approximate outline of North Aleutian basin, Becharof Lake, Ugashik Lakes, and the Bruin Bay fault. 
of the ULFS relative to the mapped formation boundaries shown in figure 3 (Detterman and others, 1987) and to the northeast-trending, relatively short-wavelength aeromagnetic anomalies shown in figure 4 (Saltus and others, 1999; Meyer and others, 2004; Meyer, 2007).

\section{UGASHIK SUB-BASIN}

Interpretation of subsurface well and seismic data, in conjunction with aeromagnetic and surface geologic mapping, strongly suggests the presence of a faultcontrolled Neogene depocenter beneath the Bristol Bay lowlands west of Ugashik Lakes and southwest of Becharof Lake. As shown in the regional well log correlation panel of Sheet 1, sedimentary strata of the Ugashik sub-basin are separated from the main backarc depocenter to the southwest by a thick, extensive sequence of Meshik Formation lavas penetrated in the Port Heiden 1 and Ugashik 1 wells. Sherwood and others
(2006, p. 20) recognized this segmentation of the North Aleutian basin and interpreted the intervening Meshik sequence as a massive Eocene to Oligocene extrusive complex. Figure 5 shows a time-structure interpretation at or near the base of the Bear Lake Formation from publicly released two-dimensional (2-D) seismic data. A variety of fault trends are interpreted to have accommodated differential subsidence within the sub-basin. Evidence that the Ugashik sub-basin has a younger subsidence history than the southern part of the North Aleutian basin is presented in context of our Neogene tectonic model later in this report.

\section{BECHAROF DISCONTINUITY}

Several independent lines of evidence suggest that an important and previously unrecognized crustal boundary cuts across the Alaska Peninsula trending northwest near the south shore of Becharof Lake. Referred to here as the

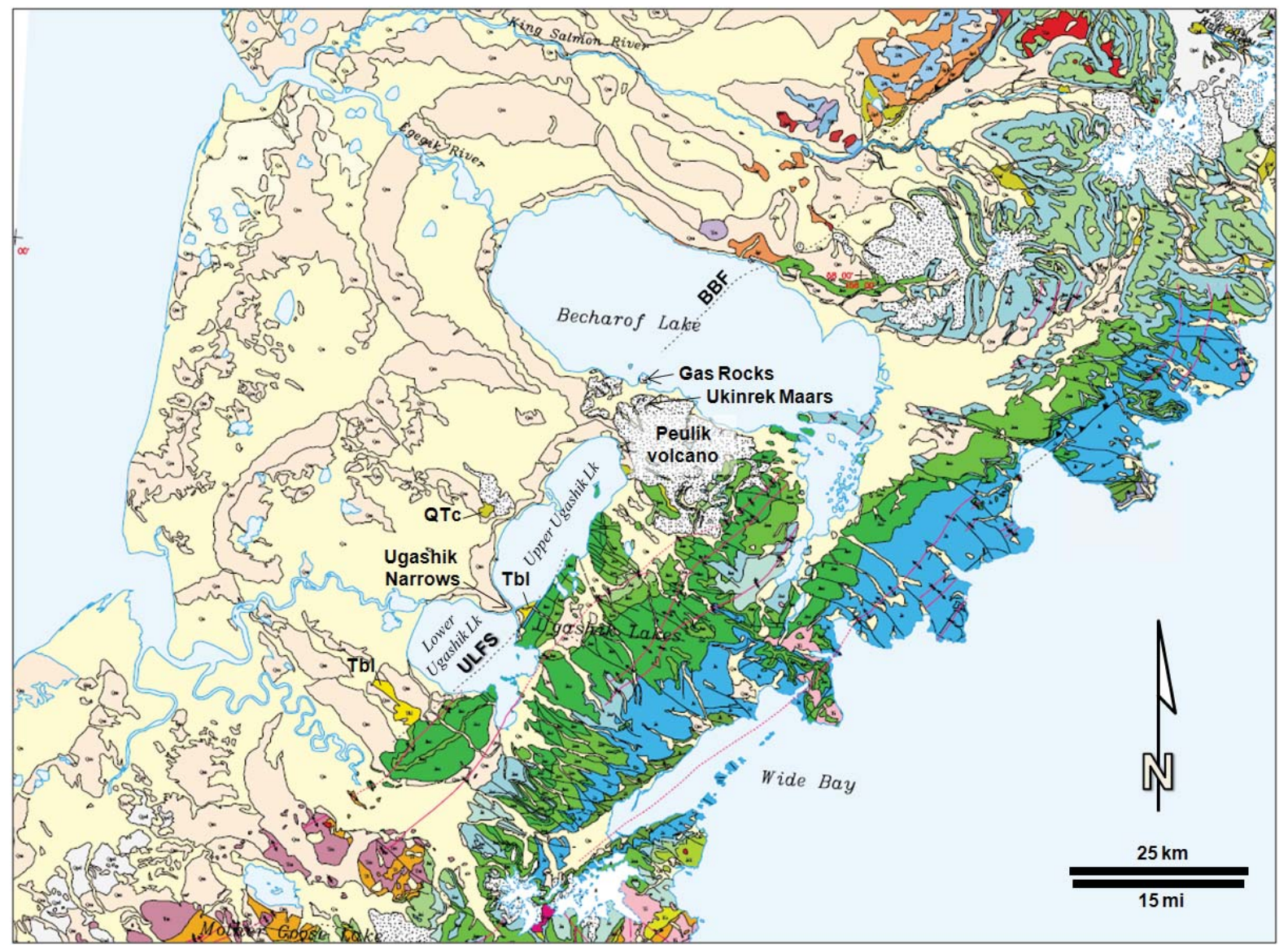

Figure 1B. Excerpt from regional geologic map of Wilson and others (1999) with labels of geologic and geographic features added for visibility. The northeasternmost exposures of Miocene Bear Lake Formation (darkyellow, Tbl) occur in the Ugashik Narrows area (between Upper and Lower Ugashik Lakes) and south of Lower Ugashik Lake, where they are juxtaposed by faults of the down-to-west Ugashik Lakes fault system (ULFS) with Jurassic Shelikof (blue) and Naknek (various shades of green) Formations to the southeast. Quaternary or Tertiary contact metamorphic unit (greenish-yellow, QTc) west of Upper Ugashik Lake is labeled here to avoid confusion with Bear Lake Formation. 
Becharof discontinuity, this boundary can be observed in the unfiltered aeromagnetic data (fig. 4). In the lowlands west of the lake, the Becharof discontinuity manifests as a broad magnetic gradient. On the northeast is an area of high magnetic intensity corresponding to the uplifted arc-batholith basement in the hangingwall of the Bruin Bay fault (the Iliamna subterrane of Wilson and others [1985]). To the southwest is an area of low magnetic intensity corresponding to the sediment-filled Ugashik sub-basin. Interpretation near the base of the sedimentary section in the northeastern part of the sub-basin reveals a set of down-to-southwest Neogene faults that parallel the contours of this magnetic gradient (figs. 4 and 5). Hence, the magnetic gradient corresponds to the structural gradient on the top of the basement complex.

The Becharof discontinuity has a different magnetic expression beneath southern Becharof Lake itself, where banded, short wavelength anomalies with distinctly

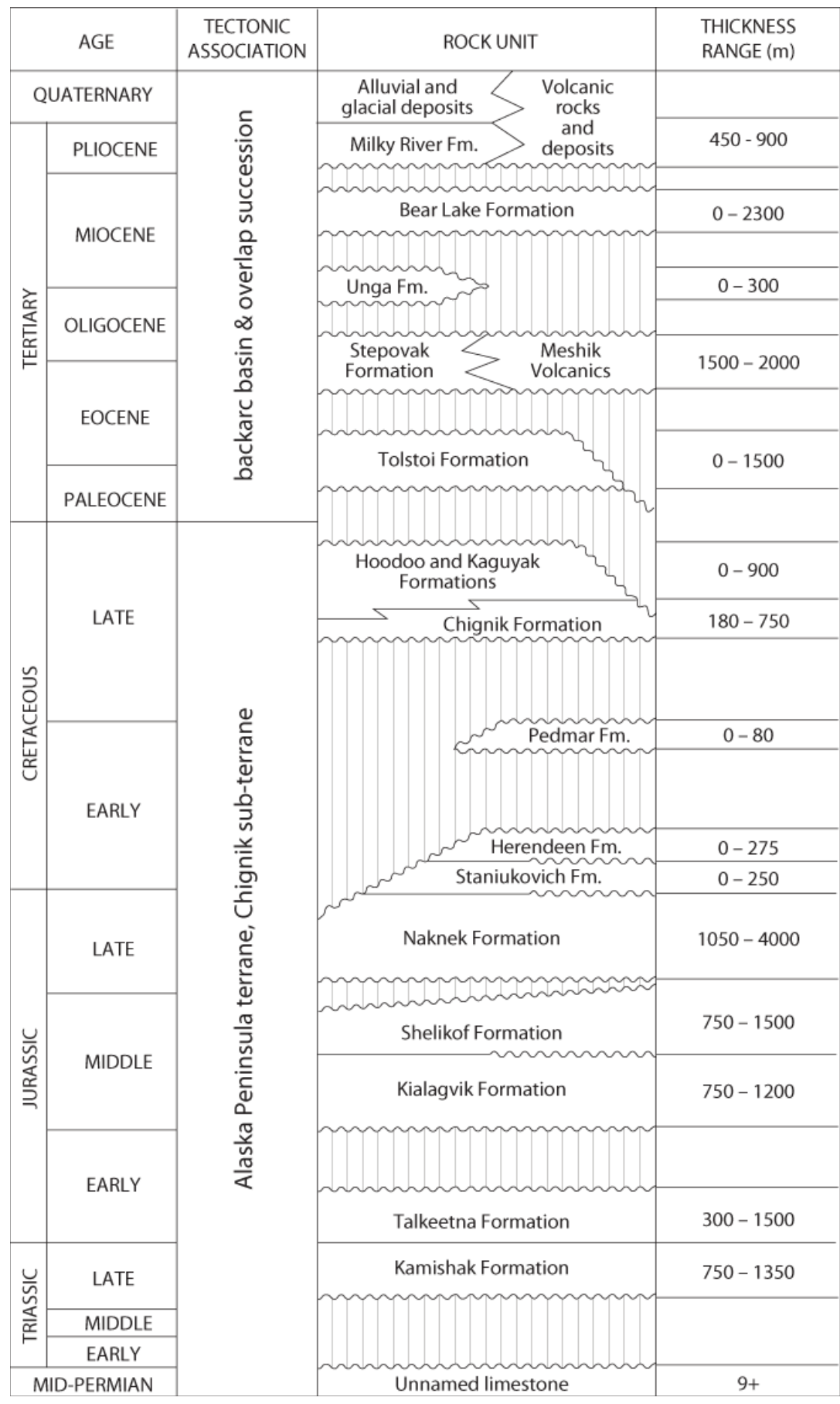

Figure 2. Composite stratigraphic column for the Alaska Peninsula, modified after Beeman and others (1996) and Detterman and others (1996). Metamorphic and plutonic units, including the Iliamna sub-terrane of the Alaska Peninsula terrane, are not depicted. 
different trends approach from either side and terminate near the south shore of the lake. The linear anomalies on the north side are clearly related to the Bruin Bay fault, whereas we relate the more arcuate southern anomalies to the ULFS, as discussed in more detail below. Their point of intersection coincides closely with the prolific vents of mantle-derived carbon dioxide at Gas Rocks (fig. 1B; Symonds and others, 1997). Close by are the Ukinrek Maars, two craters formed in 1977 by mantlelinked phreatomagmatic eruptions (Barnes and McCoy, 1979; Motyka and others, 1993). A swarm of strong, shallow earthquakes recorded during May to October
1998 was concentrated beneath the western part of Becharof Lake along the same discontinuity (McGimsey and others, 2003). Considered along with evidence of recent inflation of Mount Peulik volcano located on the same trend immediately to the southeast (fig. 1B; C. Nye, written commun., January 18, 2007), these observations suggest that the Becharof discontinuity marks a persistent zone of weakness in the upper lithosphere that may remain active today. This zone is tectonically significant because it may explain the decoupling of the Bruin Bay fault from the Ugashik Lakes fault system, allowing uplift to the north and subsidence to the south.

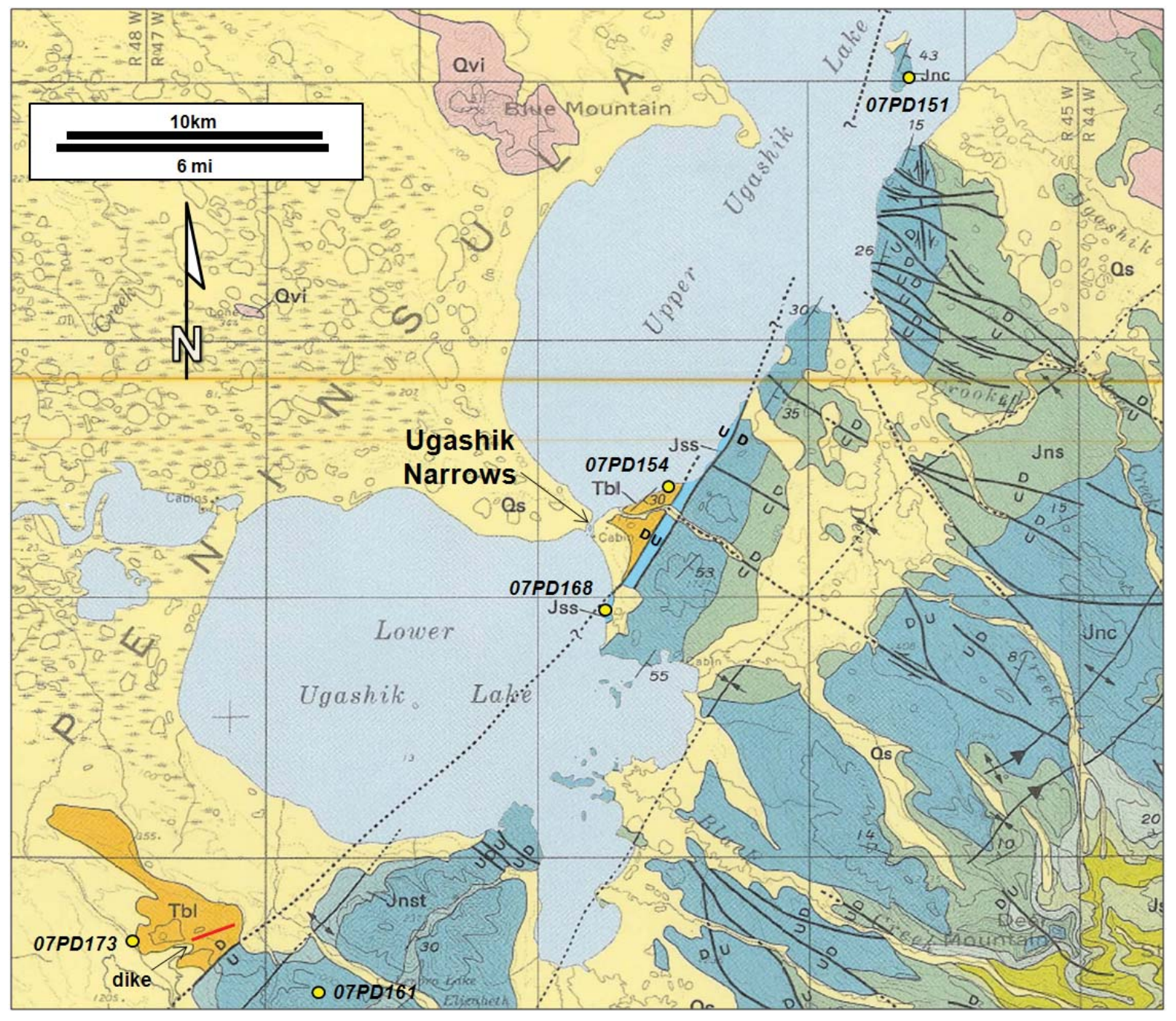

Figure 3. Excerpt from 1:250,000-scale geologic map adapted from Detterman and others (1987) showing key outcrop relationships in the Ugashik Lakes area. Relevant unit abbreviations: Bear Lake Formation (Tbl), Naknek Formation (Jnc, Jnst, Jns), and Shelikof Formation (Jss). Yellow dots labeled in italics are stations with structural fabric measurements shown in figure 10. Also added to map is the trace of a previously unmapped dike southwest of Lower Ugashik Lake, discussed in text. 


\section{INVESTIGATIONS OF THE UGASHIK LAKES FAULT SYSTEM}

Prior to conducting field work in the Ugashik Lakes area, we recognized the Ugashik sub-basin and speculated as to the existence of the Becharof discontinuity. We hypothesized that the ULFS represents at least two major, down-to-west normal or normal-oblique faults that helped accommodate Neogene subsidence and sedimentation in the Ugashik sub-basin. The map traces of these controlling faults, including their covered reaches, were predicted to correspond closely with the arcuate bands of the short-wavelength aeromagnetic anomaly observed in the (unfiltered) total field aeromagnetic data (fig. 4). An important part of this study is to test this hypothesis by (1) field checking outcrop relationships presented in legacy geologic maps, (2) relating those field relationships to aeromagnetic boundaries, and (3) collecting outcrop structural data relevant to interpreting the attitude, kinematics, and movement history of the main fault or faults that make up the system. The following discussion presents our findings in each of these three areas.

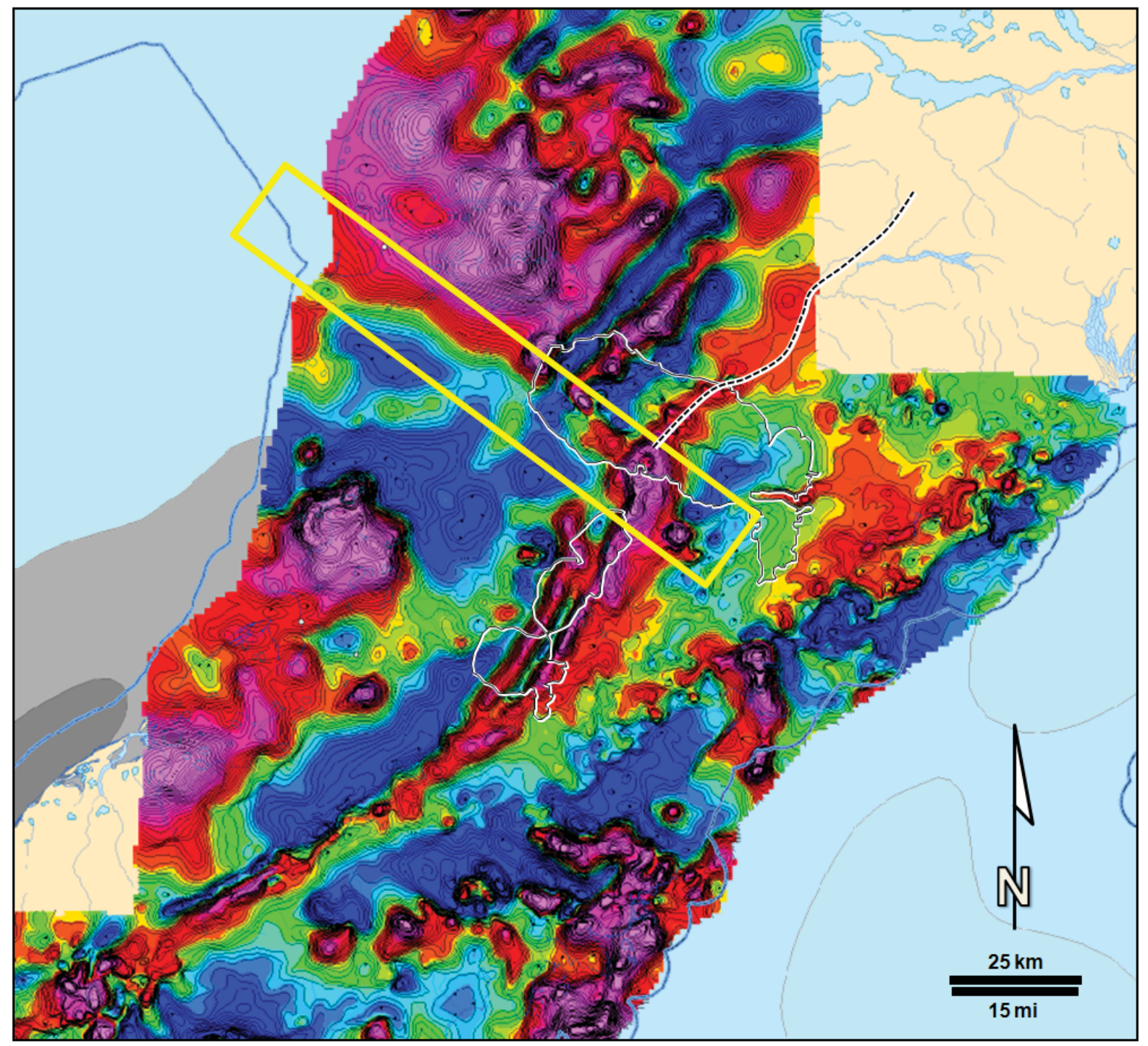

Figure 4. Total field aeromagnetic anomaly of the region surrounding Becharof Lake and the Ugashik Lakes (overlaid for geographic reference in black and white lines), excerpted and modified from Meyer (2007), after Meyer and others (2004) and Saltus and others (1999). Warm colors (violet, red, orange, and yellow) are positive magnetic anomalies; cool colors (greens and blues) are negative magnetic anomalies. Yellow rectangle marks the Becharof magnetic discontinuity referred to in text; dashed black line is the trace of the Bruin Bay fault from Wilson and others (1999). 


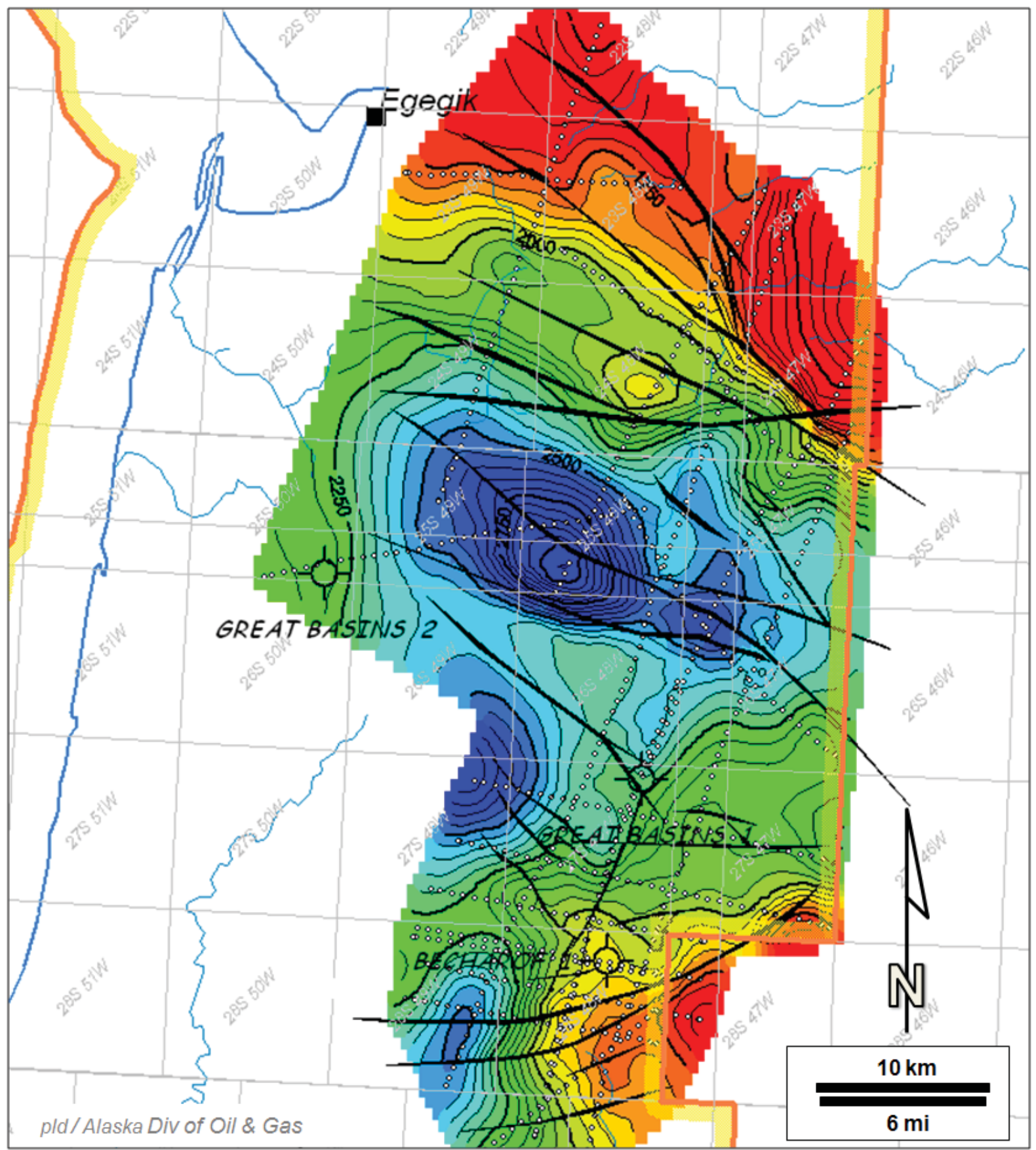

Figure 5. Preliminary time-structure interpretation near the base of the Bear Lake Formation from publicly available seismic data in the western part of the Ugashik sub-basin, west of Becharof Lake. West-northwest-trending faults appear to control subsidence from the structurally highest area along the Becharof discontinuity in the north (red) into the structurally lowest part of the sub-basin (blue). Contour interval: 50 milliseconds two-way time. Seismic lines are shown by small white circles (shotpoints). Orange and yellow border marks Alaska Peninsula areawide lease sale boundary. Refer to figure 8 for location relative to geologic map. 


\section{LEGACY MAPPING AND OUTCROP RELATIONSHIPS}

Without recognizing the magnetic contrasts and other criteria cited above that define the Becharof discontinuity, Detterman and others (1987) cited aeromagnetic data in suggesting that the Bruin Bay fault continues in the subsurface far to the southwest beyond Ugashik Lakes. Wilson and others (1999) later adopted a more restrictive view, ending the trace near the middle of Becharof Lake, thus setting the Bruin Bay fault apart from the ULFS as we describe it. Detterman and others (1987) initially mapped the Bruin Bay fault with a continuous queried line some $30 \mathrm{~km}(20 \mathrm{mi})$ farther south into Upper Ugashik Lake, where they show it in cross section as a west-dipping normal fault. They offered no explanation of how or why this major fault's reverse movement would transition laterally into major normal displacement across Becharof Lake. Nor did they present evidence that the fault dips to the west in the Ugashik Lakes area, presumably making the assumption that the fault maintains the same general attitude as the Bruin Bay fault to the north. Nonetheless, because we realized that major structural changes might occur across the Becharof discontinuity, we sought field evidence to evaluate other possible fault orientations. For example, might the faults at Ugashik Lakes consist of northwestverging reverse or thrust faults linked to compressional deformation of the Mesozoic rocks to the east? Alternatively, could the faults be nearly vertical and have substantial strike-slip displacement?

In the immediate vicinity of Ugashik Lakes, our field observations confirmed the general distribution of rock units as mapped (fig. 3; Detterman and others, 1987), including the close juxtaposition of Jurassic and Tertiary formations (see outcrop photos of key units in figure 6). However, in many places, actual outcrop is far less extensive and surficial cover is more extensive than shown. The area of Bear Lake outcrop is heavily overrepresented in previous mapping, both near the Ugashik Narrows (the small stream connecting Upper and Lower Ugashik lakes, figs. 1B and 3) and in the upland area south of Lower Ugashik Lake. However, we did locate an additional Bear Lake outcrop immediately northwest of the Narrows where the shoreline was previously mapped as Quaternary. Overall, we believe the bedrock units mapped by Detterman and others (1987) near the ULFS are mostly accurately portrayed, even if the area of their outcrop is simplified.

Unfortunately, our field investigations revealed no exposures of the surfaces of the controlling faults of the ULFS. Although Detterman and others (1987) and Wilson and others (1999) mapped the ULFS with solid lines near Ugashik Narrows and in the uplands south of Lower Ugashik Lake, our investigations found the faults to be universally covered by either surficial deposits, dense vegetation, or the lakes themselves. This lack of exposure leaves considerable uncertainty regarding the number, attitude, sense of movement, and cumulative displacement of the major faults in this zone. Minor faults, shear joints, and fractures are abundant in some exposures near the mapped fault traces, and provide at least some basis for inferring the attitude of the associated major faults. We present and interpret outcrop fabric data in a subsequent section below.

Our work corroborates other key geologic map relationships shown in figure 3 that are relevant to integrating the aeromagnetic data into the structural interpretation of the ULFS. The island in the northern part of Upper Ugashik Lake and most of the eastern shoreline of the Ugashik Lakes are underlain by moderately east-dipping conglomerates and sandstones of the Upper Jurassic Naknek Formation, as mapped by Detterman and others (1987). The Naknek is rich in plutonic detritus shed from the Jurassic arc batholith complex (fig. 6A), and thus is likely to yield a strong positive aeromagnetic signature. Detterman and others (1987) also mapped a narrow, continuous strip of Middle Jurassic Shelikof Formation in the low hills at the base of much higher and steeper terrain just east of Ugashik Narrows (fig. 3). We tentatively confirm the presence of Shelikof Formation in this area (fig. 6B), based on our observations of basaltic conglomerate beds in sandstones that bear a diverse molluscan assemblage, including the diagnostic Callovian ammonite Cadoceras in addition to broad-ranging bivalves and belemnites (R. Blodgett, oral commun., August 12, 2007). Detterman and others (1987) portrayed this sliver of Shelikof Formation as a horse caught between two apparently steep faults, both marked by parallel, solid lines. The Shelikof is juxtaposed against Bear Lake Formation at the western fault (down-to-west) and against Naknek Formation at the eastern fault (up-to-west). We found much less extensive bedrock exposure of the Shelikof than mapped previously, and we found no exposures of either of the two faults, but corresponding topographic lineaments are consistent with this structural interpretation for the Ugashik Narrows area.

\section{RELATIONSHIPS OF CONTACTS TO AEROMAGNETIC BOUNDARIES}

We recognize that aeromagnetic anomalies do not necessarily closely coincide with the distribution of buried magnetic bodies (e.g., Vacquier, 1963). However, in certain cases, the correlation between well-defined magnetic anomalies and exposed bedrock units is compelling enough to warrant fairly literal interpretation of the shallow subsurface. For example, Saltus and others (2001) filtered a high-resolution aeromagnetic dataset in the Tertiary Cook Inlet basin at various wavelengths, and successfully related the shorter wavelength anomalies 
to structurally-defined geologic contacts at or very near the surface.

Where faults of the ULFS are constrained by outcrop, they coincide closely with two sharply-defined strands of alternating high and low magnetic intensity in the unfiltered aeromagnetic map of figure 4 (Saltus and others, 1999; Meyer and others, 2004; Meyer, 2007). These bands define a pair of arcuate, northeast-trending, short-wavelength magnetic anomalies. The eastern strand extends farther north than the western strand, intersecting the Becharof discontinuity at Gas Rocks on the south shore of Becharof Lake, and runs south near the east shore of Upper and Lower Ugashik lakes.
The western anomaly terminates northward just west of Upper Ugashik Lake, passes just west of Ugashik Narrows, and merges with the eastern anomaly in the uplands south of Lower Ugashik Lake. This merged band of high magnetic intensity continues southwest for at least $75 \mathrm{~km}$ (50 mi) as a fairly well-defined linear feature (fig. 4).

Many of the Jurassic and younger sedimentary formations on the Alaska Peninsula possess significant magnetic susceptibility due to the presence of magnetite and/or other magnetic minerals derived from the Jurassic, Tertiary, and Quaternary magmatic arcs. Where exposed in the Ugashik Lakes area, Jurassic Naknek
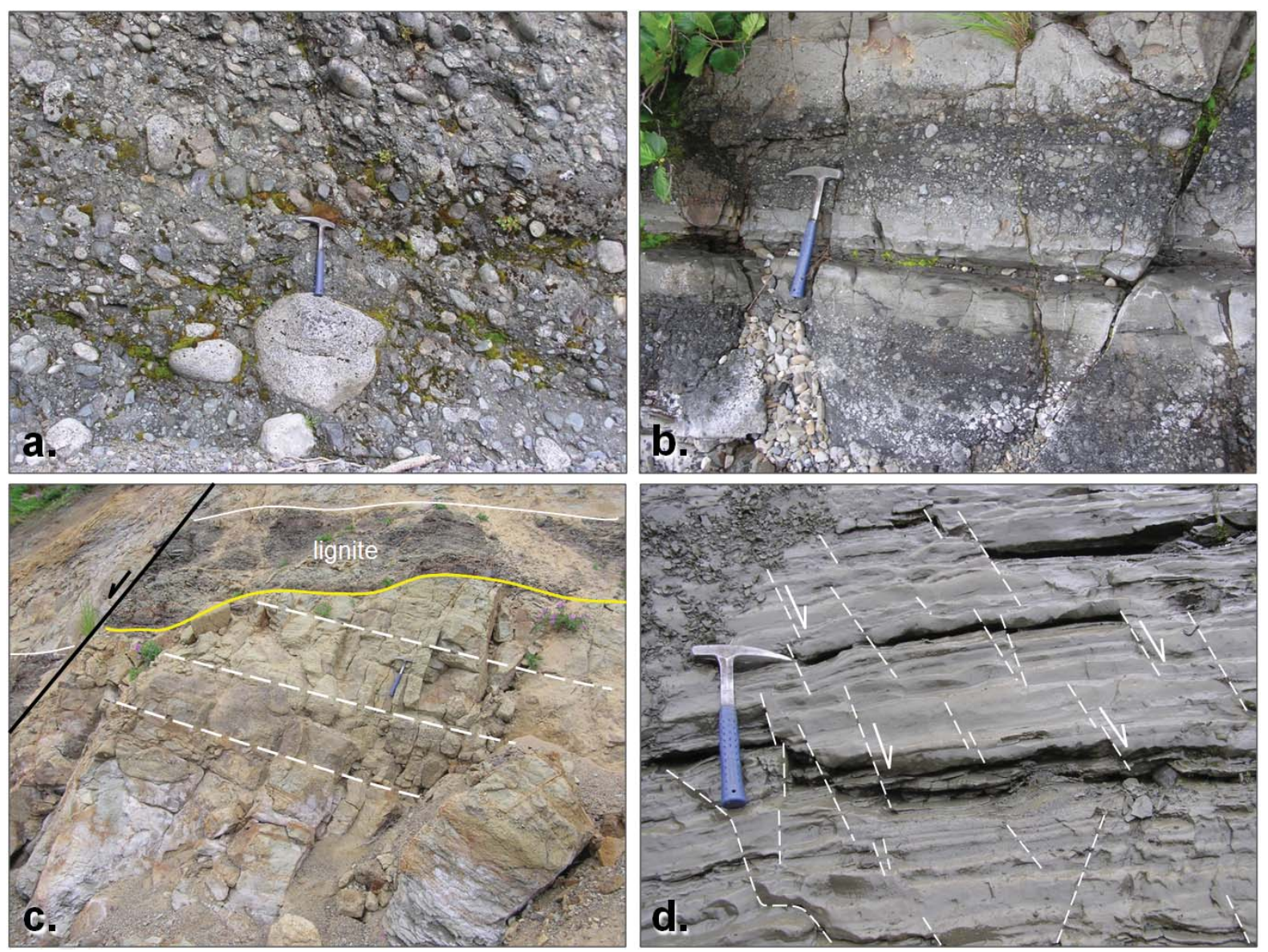

Figure 6. Field photographs of rock units in the vicinity of the Ugashik Lakes fault system (see figure 3 for station locations). Hammer for scale in all photos. (A) Naknek Formation conglomerates with abundant plutonic cobbles and boulders on shoreline of island in Upper Ugashik Lake at station 07PD151. (B) View looking downward at moderately east-dipping sandstone and basaltic conglomerate beds in Shelikof Formation on east shore of Upper Ugashik Lake north of station 07PD154. This unit contains abundant magnetic minerals within basaltic clasts and as detrital heavy mineral grains. (C) View to east-southeast of Bear Lake Formation conglomeratic sandstone and lignite north of Ugashik Narrows on the east shore of Upper Ugashik Lake at station 07PD154. Syndepositional fault rotation is implied by intraformational truncation of sandstone beds below lignite horizon. Both units are offset by later down-to-north fault at left, one of numerous minor northwest-striking faults exposed in outcrops in this area. (D) View to southwest of abundant penecontemporaneous microfaults and shear fractures in lightly consolidated lacustrine(?) silt of Bear Lake Formation south of Lower Ugashik Lake at station 07PD173. 
and Shelikof outcrops consistently underlie the eastern band of strongly positive magnetic signature. This is particularly clear along the eastern shorelines of Upper and Lower Ugashik lakes, for example, immediately east of the Ugashik Narrows (figs. 4 and 7). The outcrops of Bear Lake Formation occur within bands of negative magnetic signature between and to the west of the positive lineaments. Bear Lake outcrops near Ugashik Narrows are bounded by linear, highly positive strands on both east and west, whereas Bear Lake outcrops south of Lower Ugashik Lake occur west of the intersection of the two positive strands. Continuing farther southwest, the merged, single-stranded positive anomaly corresponds mainly with outcrops of Eocene-Oligocene Meshik volcanics (fig. 7).

Where exposure is sufficient to map with reasonable confidence (particularly near the Ugashik Narrows), the fault contacts between Bear Lake and Jurassic units occur at fairly obvious, qualitatively assessed boundaries between relatively short-wavelength positive and negative aeromagnetic anomalies. We infer from this that the aeromagnetic boundaries can, in fact, be used to extend these rock units and fault traces into areas of thin surficial cover. The magnetic patterns imply that there are likely two major faults that accommodated or preserved Bear Lake deposits on their western downthrown blocks (labeled A and B in figs. 8 and 9). According to the conceptual model of figure 9, Bear Lake outcrops near the Ugashik Narrows are preserved on the downthrown side of the eastern fault (A). This fault contact is inferred to continue northward, immediately west of the island of Naknek conglomerates in Upper Ugashik Lake. The Bear Lake outcrops south of Lower Ugashik Lake are likely downthrown to a separate western fault (B) parallel to the western magnetic boundary. Shown in figure 8, this model revises the mapping of Detterman and others (1987), which connected the Bear Lake fault contacts north and south of Lower Ugashik Lake with a single fault trace (fig. 3), despite the fact that it cuts obliquely across the well-defined, banded magnetic anomalies (fig. 7). Future geologic mapping in the Ugashik Lakes region may benefit from the computation of horizontal gradients and identification of linear features from the aeromagnetic data (e.g., linear maximum gradient analysis of Saltus and others, 2001) to define magnetic boundaries and locate covered fault contacts with greater precision.

\section{STRUCTURAL FABRIC}

Lacking exposures of the controlling faults themselves, we collected orientation data on fracture and minor fault planes from Jurassic and Tertiary outcrops at five locations in and near the ULFS, listed from north to south in table 1 and located on the map of figure 3 . Between 41 and 66 planes were measured at each station to shed light on the orientation, variability, and kinematic history of faults in the zone, and to weigh the hypothesis that its major structures are westerly-dipping normal faults. Slickenlines, fault steps, and other measurable indicators of true slip direction were unfortunately rare. Evidence for normal stratigraphic separation is much more common than reverse separation, but the lack of true slip indicators made it difficult to assess the magnitude of potential strike-slip.

Figure 10 shows fabric diagrams summarizing the attitudes of planes from each measurement station. Lower hemisphere stereographic projections illustrate the variations in both strike and dip of fractures and minor fault planes. Superimposed rose diagrams provide a quick statistical comparison of the dominant fracture strike orientations; the outer circle represents 15 percent of the data in each population. All five stations show multiple fault and fracture sets, and in four of the five datasets, one strike orientation dominates over the others, though the dominant orientation varies with location. Steep, north-northeast-striking planes form a recognizable or predominant set in all but the southernmost station; in most cases, fractures of this strike dip toward the west-northwest. We interpret these as minor faults and associated shear fractures parallel (synthetic) to the major faults of the ULFS (i.e., we interpret the major faults as northwest-dipping). Planes with similar strike but dipping the opposite direction (east-southeast) are interpreted as antithetic faults and shear joints. In the contractionally-deformed Jurassic units (stations 07PD151, 07PD 161, and 07PD168), fractures with

Table 1. Fracture and minor fault measurement stations

\begin{tabular}{llll}
\hline Station & Formation & \multicolumn{1}{c}{ Lithology } & \multicolumn{1}{c}{ Location Description } \\
07PD151 & Naknek & Conglomerate, sandstone & Island in Upper Ugashik Lake \\
07PD154 & Bear Lake & Sandstone, siltstone, coal & Shoreline, northeast of Ugashik Narrows \\
07PD168 & Shelikof & Sandstone & Shoreline, southeast of Ugashik Narrows \\
07PD161 & Naknek & Conglomerate & Highland slope, south of Lower Ugashik Lake \\
07PD173 & Bear Lake & Silty sandstone & Upland stream, south of Lower Ugashik Lake \\
\hline
\end{tabular}


this orientation could plausibly relate to either reverse or normal faulting. In the Bear Lake Formation (stations 07PD154 and 07PD173), the preponderance of normal offsets indicates the fabric is extensional in origin (figs. 6C and D).
In the Bear Lake exposures north of the Ugashik Narrows at 07PD154, minor normal faults have two predominant attitudes (fig. 10). Measurements there may have been statistically biased by the north-northeast trend of the bluff face-parallel to the controlling faults

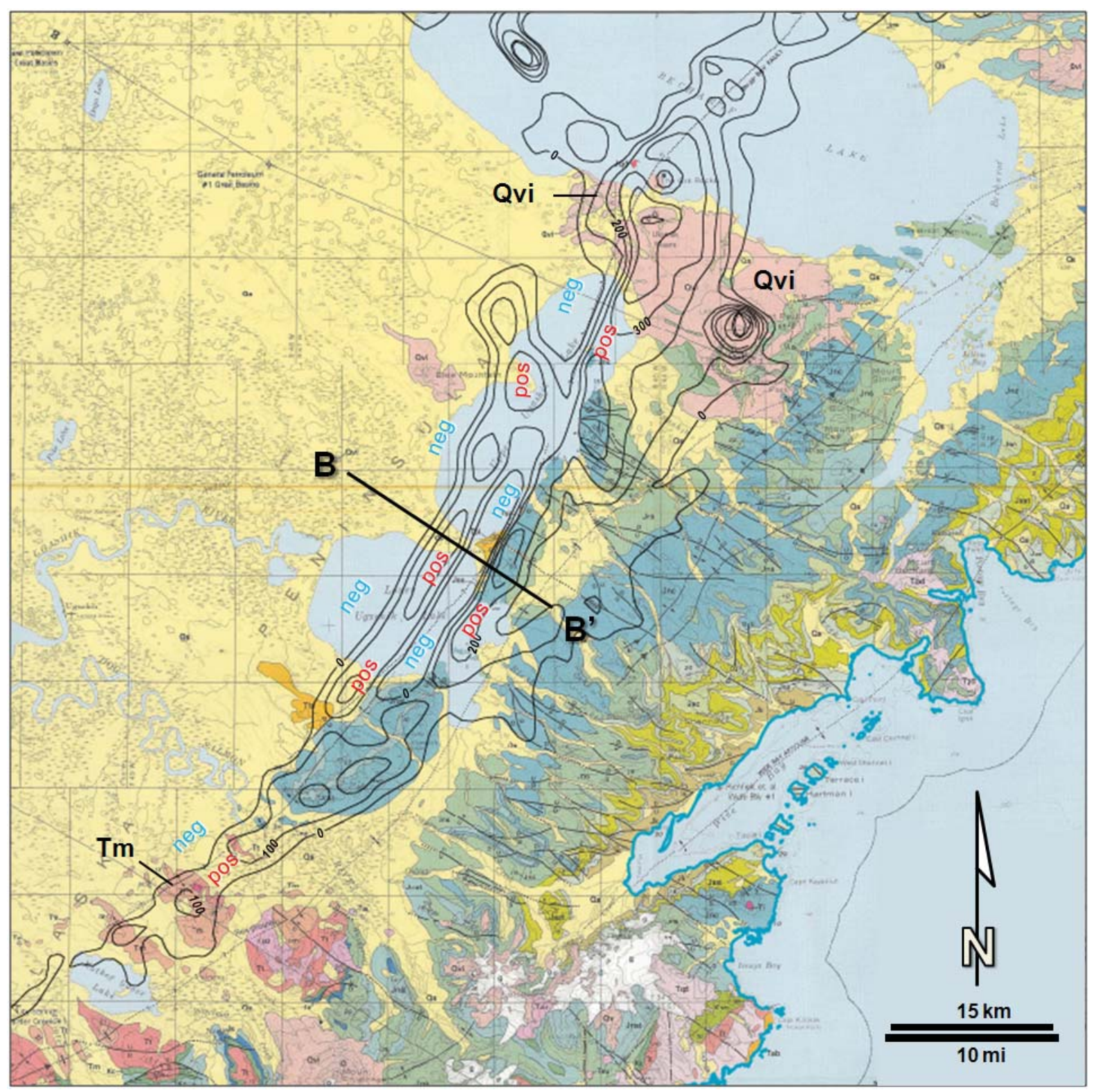

Figure 7. Excerpt from geologic map of Detterman and others (1987) overlain by contours of positive aeromagnetic anomalies most relevant to the Ugashik Lakes and Bruin Bay fault systems (contour interval $100 \mathrm{nT}$, outside contour $=0 \mathrm{nT}$ ) from Meyer and others (2004) after Saltus and others (1999). Bear Lake Formation exposures occur in bands of negative total magnetic intensity (labeled “neg”). Band of positive magnetic intensity (labeled "pos”) along the east shore of the Ugashik Lakes corresponds to Jurassic exposures. To the north between Upper Ugashik Lake and Becharof Lake, this positive anomaly is complicated by Quaternary volcanics and shallow intrusive bodies associated with Mount Peulik volcano, The Gas Rocks, and Ukinrek Maars (Qvi). In the southwestern part of the map, the positive magnetic anomaly relates mainly to outcrops of Meshik volcanics (Tm). Line B-B' shows location of schematic model in figure 9. See figure 3 for more geologic detail in Ugashik Lakes area. 
of the ULFS—but down-to-northeast, northwest-striking faults are abundant in this outcrop, and exhibit evidence of syndepositional movement (fig. 6c). Detterman and others (1987) mapped numerous northwest-striking cross faults in the folded Mesozoic rocks east of the Ugashik Lakes. Fractures and normal faults of this general orientation having displacements on the decimeter to meter scale are abundant in the outcrops we visited (e.g., in the Shelikof Formation at station 07PD168, and in the Bear Lake Formation at station 07PD154, fig.10), recording Miocene or younger arc-parallel extension in addition to subsidence of the backarc basin itself. Other planes of similar strike are nearly vertical (or perpendicular to bedding). In Mesozoic units, some of these may represent extension joints formed during earlier contractional deformation.

At the southernmost station south of Lower Ugashik Lake (07PD173), the Bear Lake Formation consists of finely layered, locally contorted, lightly consolidated silty claystones interpreted as lacustrine deposits. These beds are cut by numerous discontinuous shear planes that have a strong preferred orientation with east-northeast $\left(\sim 070^{\circ}\right)$ strike and steep north-northwest dip. These planes are conspicuous in outcrop as closely spaced microfaults with down-to-northwest normal displacement of approximately 1-2 cm (fig. 6D). Many of these shears die out into small-scale drag folds, consistent with faulting of semi-consolidated sediments. The attitude and characteristics of these structures are consistent with syndepositional Neogene subsidence in the area of the Ugashik sub-basin west of Ugashik Lakes. A fracture set with similar attitude is apparent in the nearby Naknek Formation (fig. 10, station 07PD161), suggesting similar extensional stresses also affected the much more indurated Mesozoic rocks near the ULFS in the area.

Due to widespread cover in the hills south of Lower Ugashik Lake, we were unable to determine the precise location of any significant faults of the ULFS between the Bear Lake and Naknek exposures just described, notwithstanding the solid fault trace shown in previous

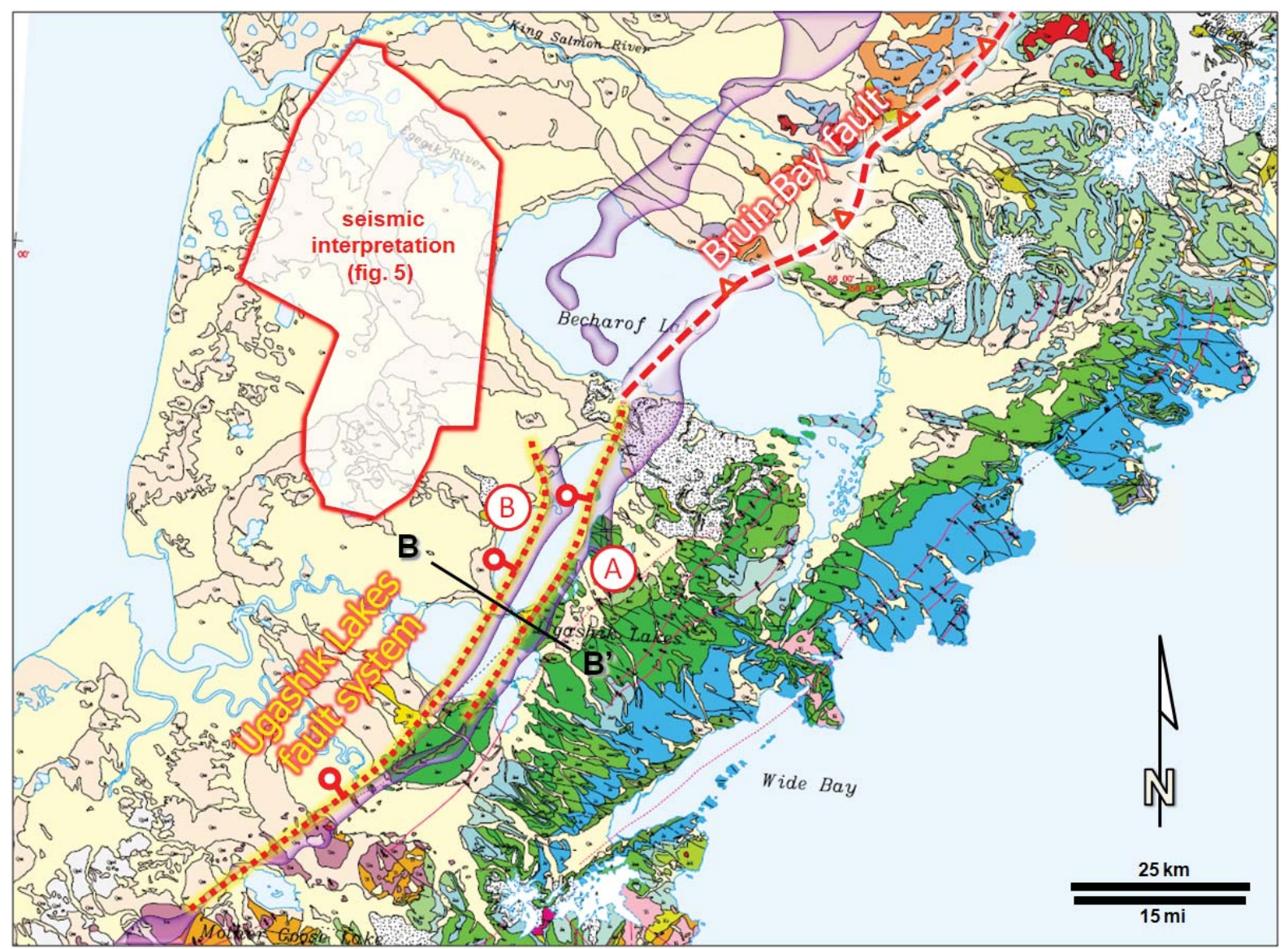

Figure 8. Map showing the reinterpreted traces for the mostly covered controlling faults of the Ugashik Lakes fault system as yellow-highlighted dotted traces (bar and ball on downthrown side). Trace of the Bruin Bay fault is white-highlighted dashed trace (teeth on upthrown side). Strongly positive short-wavelength aeromagnetic anomalies are generalized here as transparent purple areas. Line B-B' refers to the conceptual model of figure 9. 


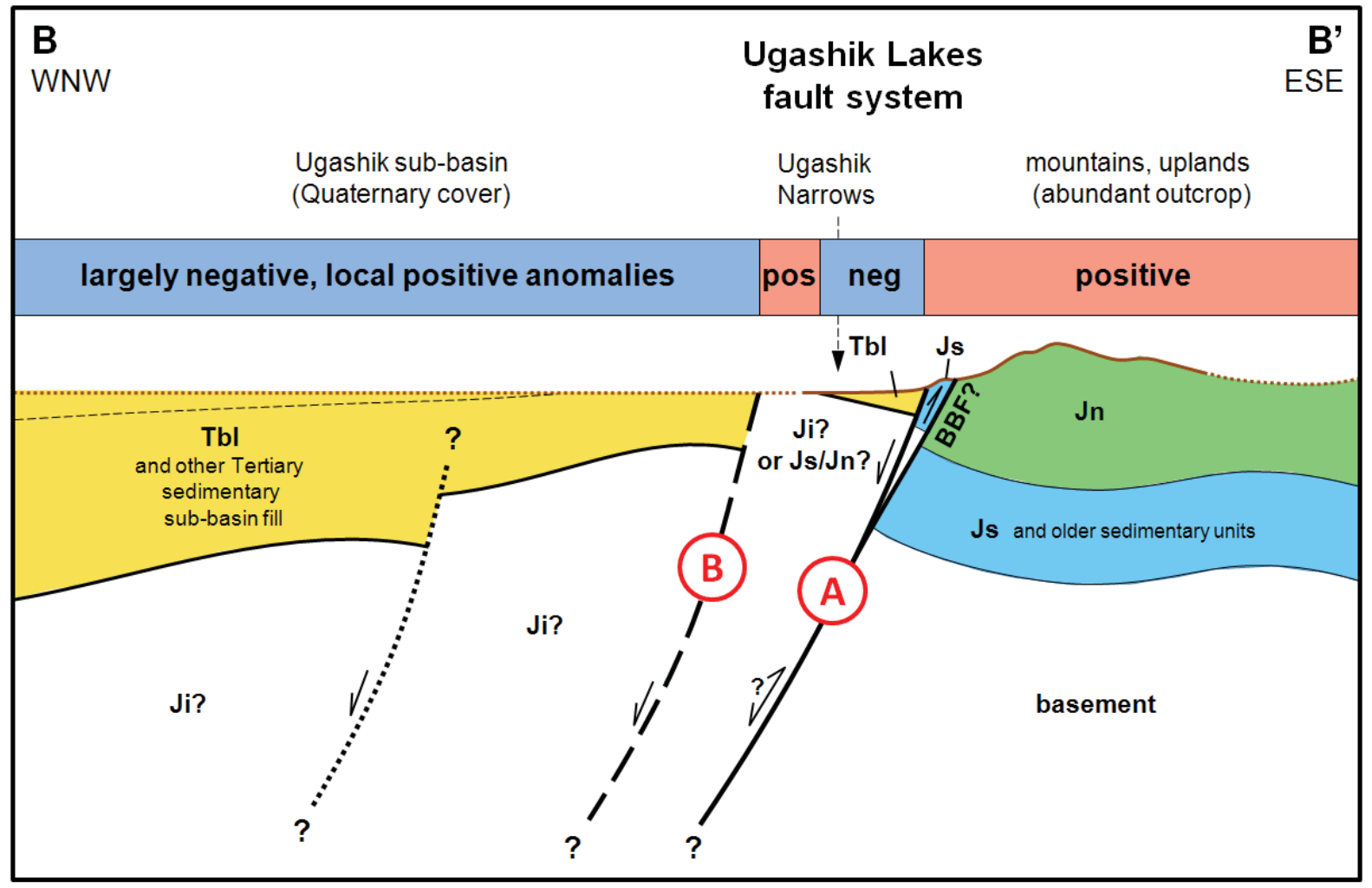

Figure 9. Conceptual model showing relationship of aeromagnetic anomaly pattern to inferred bedrock structure along line $B-B$ 'shown in figures 7 and 8. Surface profile is represented by dotted brown line where bedrock is completely obscured by surficial cover (unknown thickness not represented). Tertiary Bear Lake Formation (Tbl) outcrops coincide with negative magnetic anomalies; Jurassic Naknek (Jn) and Shelikof (Js) exposures coincide with strong positive anomalies. Jurassic batholith (Ji) is probable basement west of ULFS. Faults labeled A and B discussed in text; "BBF?" fault may be a relict segment of the reverse-displacement Bruin Bay fault, and may merge with fault A at depth. Additional down-to-northwest faults in Ugashik sub-basin inferred from seismic data. Not to scale.

mapping (Detterman and others, 1987; Wilson and others, 1999). We did locate a previously unmapped, intermediate-composition porphyritic dike in the general area where the fault(s) would be expected; this dike has been added to the map in figure 3 . The dike itself is erosionally resistant, forming a ridge that trends $070^{\circ}$, but we found no nearby bedrock of the intruded sedimentary unit(s). Detterman and others (1987) mapped this ridge as Bear Lake Formation, placing the main fault nearby to the southeast. The dike has not been radiometrically dated, and without certainty as to which formation(s) it intrudes, we are unable to constrain its age beyond post-Late Jurassic. However, its strike-parallel to the Neogene extensional fabric in the nearest Bear Lake outcrop-suggests a genetic link to the north-northwest/south-southeast extension direction in the ULFS in this area. It is possible that the dike intruded during extensional movement along the surface of one of the system's significant faults.

\section{SUMMARY OF FINDINGS ON THE UGASHIK LAKES FAULT SYSTEM}

Our field observations confirm the overall distribution of Jurassic and Tertiary bedrock units as mapped by Detterman and others (1987) and Wilson and others (1999) in the vicinity of Ugashik Lakes, though we disagree locally with the continuity of exposure shown in their maps. Our integration of the aeromagnetic data (Saltus and others, 1999; Meyer and others, 2004; Meyer, 2007) suggests the ULFS consists of at least two poorly exposed faults that have a different and more extensive map expression than shown on existing geologic maps. Fabric populations indicate a variety of fault and fracture trends that are consistent with the controlling faults of the ULFS being steep, northwest-dipping normal or normal-oblique faults.

Just east of Ugashik Narrows, Detterman and others' (1987) interpretation of two parallel, closely spaced, north-northeast-striking faults with opposite senses of displacement (fig. 3) is a viable explanation of the bedrock map units there, but we were unable to locate 


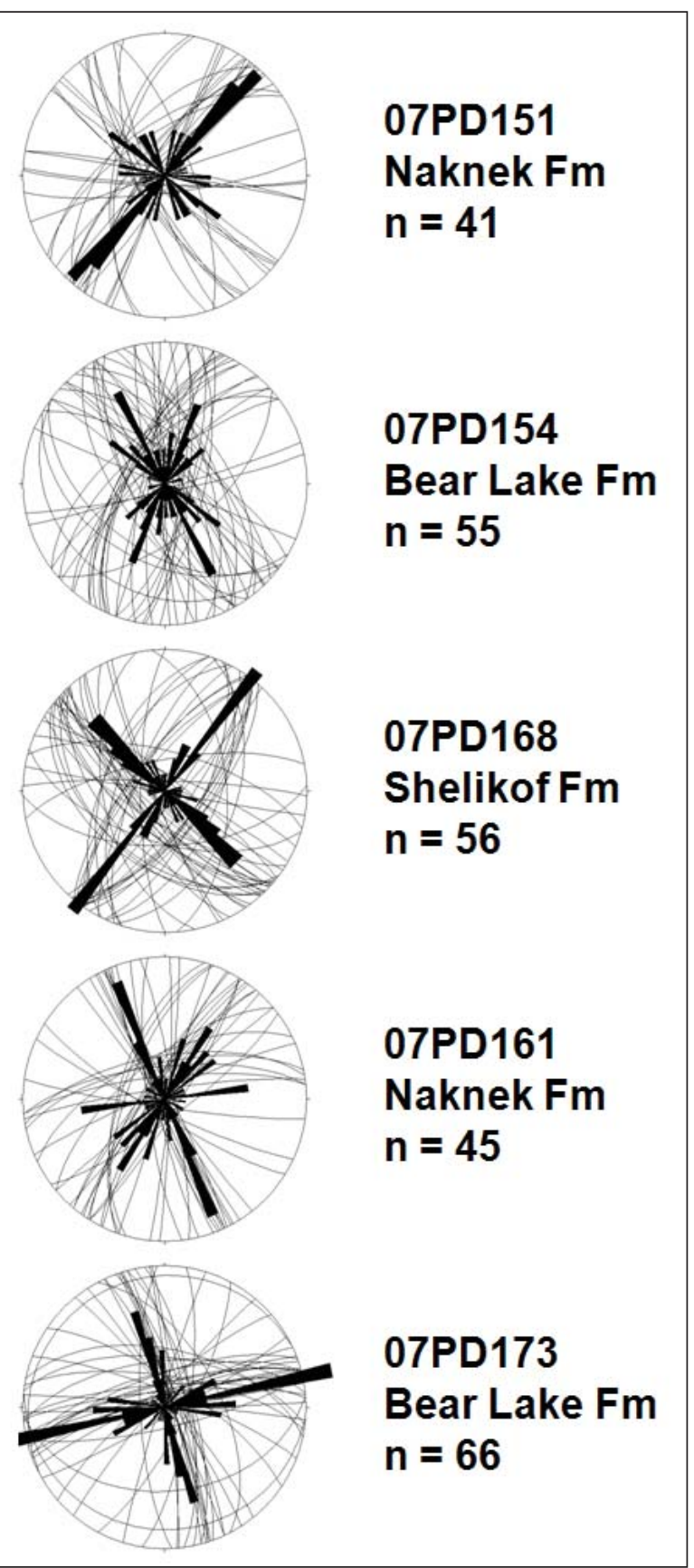

Figure 10. Structural fabric diagrams of fractures and minor faults in the vicinity of the Ugashik Lakes fault system. Stations are arranged from north at the top to south at the bottom; locations are shown in figure 3. Lower hemisphere stereographic projections show strike and dip of planes. Superimposed rose diagrams show their strike and relative abundance; outer circle represents 15 percent of the population in each plot. any exposures of these fault surfaces to document their attitude or examine them for kinematic indicators. The eastern of these two faults has a component of up-towest displacement, placing a sliver of Middle Jurassic Shelikof Formation against Upper Jurassic Naknek Formation (fig. 3). Its dip is not well constrained, but as an up-to-west fault, it may be closely related to the Bruin Bay reverse fault system, and may represent its southernmost relict surface trace. Thus, it is possible that the down-to-west faults of the ULFS represent a down-to-west extensional (or transtensional) reactivation of the up-to-west compressional (or transpressional) system. The western of the two faults mapped near Ugashik Narrows (fault A in figs. 8 and 9) is clearly down-to-west. It marks Miocene or younger faulting that accommodated and/or preserves the northeasternmost occurrences of Bear Lake Formation. The eastern short-wavelength magnetic anomaly coincides closely with the fault contact between Tertiary strata on the west and Jurassic rocks on the east.

The outcrops of Bear Lake Formation south of Lower Ugashik Lake are also believed to be bounded by one or more normal faults, but this contact coincides more closely with the south end of the western short-wavelength magnetic anomaly. We interpret it as a separate western fault strand (B in figs. 8 and 9), distinct from either of the two faults near Ugashik Narrows, whereas Detterman and others (1987) connected the two Bear Lake fault contacts with a dotted line that cut obliquely across the banded magnetic anomalies in Lower Ugashik Lake. East-northeast-trending, down-to-northwest microfaults in the southern Bear Lake outcrops document Miocene or younger extension that would allow subsidence of the Ugashik sub-basin. A nearby dike with nearly the same strike as the Bear Lake microfaults may be genetically linked to this subsidence. Better knowledge of the age and spatial relationship of this dike to the unexposed fault contact nearby could be important in documenting the age and kinematics of the ULFS.

The amount and sense of strike-slip along the ULFS is not well constrained by our investigations. Most of the regional fault systems in southern Alaska are believed to have major right lateral offsets, but Detterman and Hartsock (1966) interpreted the offset of Mesozoic contacts in the Lower Cook Inlet region as evidence the Bruin Bay fault may have had up to 19 $\mathrm{km}$ (12 mi) of left lateral movement during middle to late Tertiary time. The Bruin Bay fault intersects the right-lateral Lake Clark/Castle Mountain fault system at an angle of more than $30^{\circ}$, and it may represent an antithetic (conjugate) structure with the opposite sense of strike-slip. Furthermore, most of the available focal mechanism solutions for recent earthquakes imply generally north-south-oriented maximum compressive stress in the Becharof-Ugashik Lakes region 


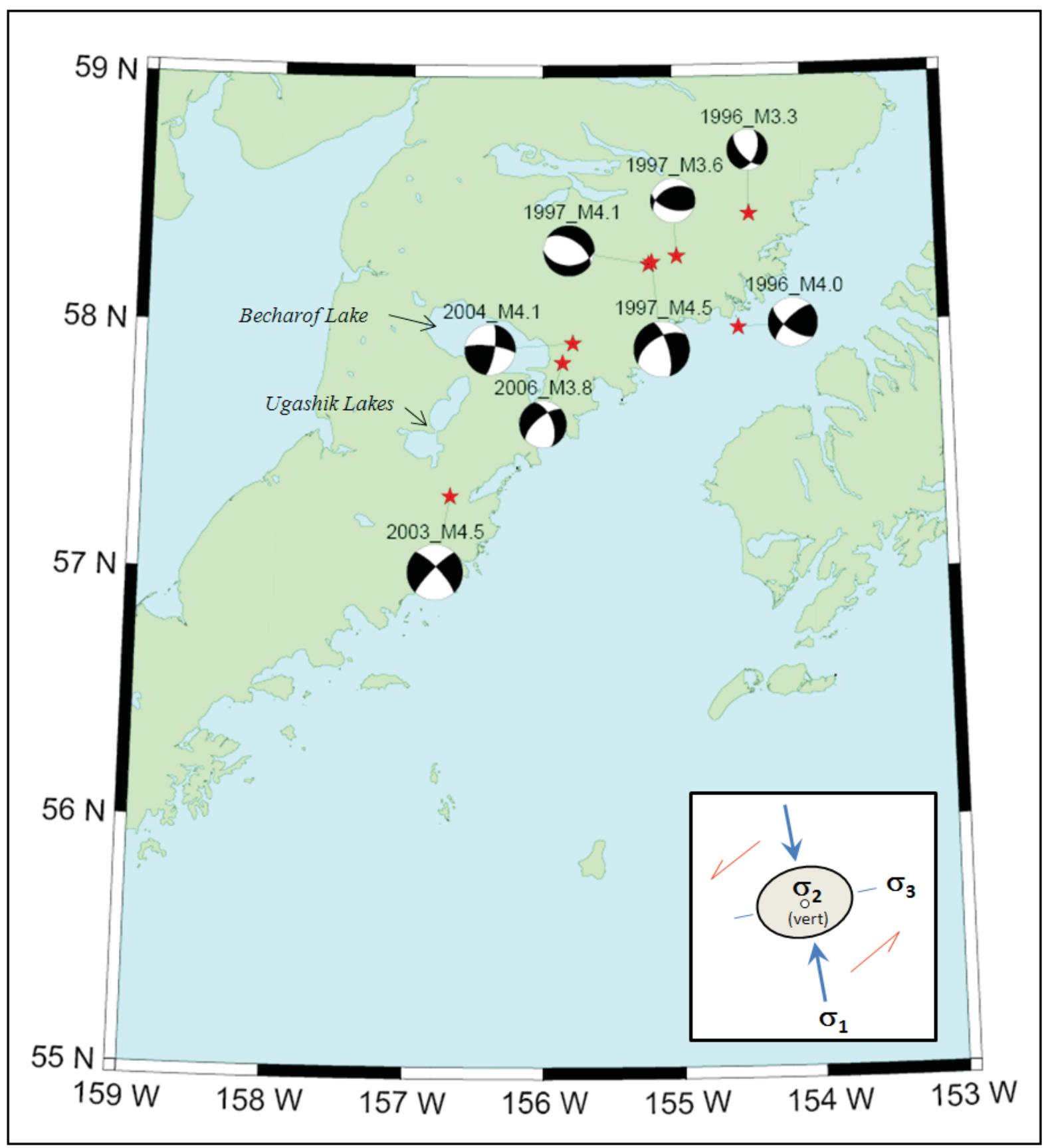

Figure 11. Focal mechanisms in the northern Alaska Peninsula region spanning the years 1996-2006. All the events shown are located southeast of both the Ugashik Lakes and Bruin Bay fault systems. Several epicenters coincide closely with Holocene volcanoes in the Katmai area. Most of these events are consistent with a large component of either left lateral strike-slip on northeast-striking faults or right lateral strike-slip on northwest-striking cross faults, with a generally north-south-trending, subhorizontal axis of maximum compressive stress $\left(\sigma_{H}=\sigma_{1}\right.$, bisecting white quadrants), subvertical intermediate stress $\left(\sigma_{v}=\sigma_{2}\right)$, and subhorizontal, generally east-west-trending minimum compressive stress $\sigma_{h}=\sigma_{3}$. Plot courtesy of Natalia Ruppert, Alaska Earthquake Information Center. 
(fig. 11; N. Ruppert, written commun., June 11, 2007). If similar stress orientations existed during middle to late Tertiary movement on the northeast-southwest-trending Bruin Bay and Ugashik Lakes fault systems, it would have favored a component of sinistral slip.

\section{NEOGENE KINEMATIC MODEL}

\section{SUBSIDENCE HISTORY OF THE UGASHIK SUB-BASIN}

As alluded to in a previous section, well correlations indicate that the northeastern end of the North Aleutian basin-the Ugashik sub-basin-has a younger subsidence history than the main backarc depocenter, and is separated from it by an extensive volcanic center in the area of the Port Heiden 1 and Ugashik 1 wells. This subbasin is illustrated at the right (northeast) end of Sheet 1 , a structurally datumed well log correlation panel that extends northeast from the heart of the backarc at the North Aleutian Shelf COST 1 well to the Great Basins 2 well west of Becharof Lake (fig. 1A). Formation tops and internal correlation markers used in these correlations are guided by a combination of biostratigraphic control (Mickey and others, 2005) and well log character.

The offshore North Aleutian COST 1 well was deliberately drilled in a structural low to penetrate as much stratigraphic section as possible, including thick intervals of Eocene Tolstoi and Eocene to Early Oligocene Stepovak Formations deposited during the early stages of backarc subsidence. Wells drilled onshore to the east and northeast penetrated the basin closer to its southern edge, where the Tolstoi thins and pinches out. The volcaniclastic deposits of the Stepovak maintain a thickness of $\sim 1,400 \mathrm{~m}(4,500 \mathrm{ft})$ offshore to $\sim 1,800 \mathrm{~m}(6,000 \mathrm{ft})$ onshore at the Sandy River 1 well before interfingering to the northeast (proximally) with primary lavas of the Meshik volcanics. These lavas are structurally elevated and reach a thickness of at least 1,800 m (6,000 ft) in the vicinity of the Port Heiden 1 and Ugashik 1 wells, interpreted as the locus of Oligocene extrusive activity (Sherwood and others, 2006).

The Ugashik sub-basin lies northeast of this Meshik high, in the area penetrated by the Becharof 1 and Great Basins 1 and 2 wells (sheet 1). Lacking any biostratigraphic evidence for pre-Tertiary sedimentary units, Mickey and others (2005) interpreted the basal strata in the area as uppermost Stepovak Formation volcaniclastics, presumably shed from the Meshik volcanic complex to the southwest. Consisting of nonmarine to marginal marine conglomerate, sandstone, and coal, this interval ranges from 0 to $400 \mathrm{~m}(0-1,400 \mathrm{ft})$ thick, implying that accommodation remained limited here through Oligocene time. Compelling log correlations in these three wells show differential thickening of the lower Bear Lake Formation in Great Basins 1, the well nearest the center of the sub-basin. Log markers and biostratigraphic picks indicate more uniform thicknesses in the upper Bear Lake and the overlying Pliocene Milky River Formation (sheet 1), constraining the phase of major differential subsidence to a brief span of Miocene time.

\section{FAULT CONTROLS ON UGASHIK SUB-BASIN SUBSIDENCE}

Seismic mapping northwest of Ugashik Lakes and southwest of the Becharof discontinuity indicate an important element of fault control on the Ugashik subbasin. Figure 5 is a preliminary structure contour map (contoured in seismic two-way time) near the base of the base Bear Lake Formation. An interpretation of the publicly available ANM and ARD seismic surveys (Alaska Division of Oil and Gas, 2004), it covers a limited area of the coastal plain at, and southwest of, the Becharof discontinuity, well to the west of Ugashik Lakes. The most conspicuous features of this seismic interpretation are (1) a west-northwest-trending structural low with a maximum two-way travel time of more than 3 seconds, estimated at more than 4,350 $\mathrm{m}(14,300 \mathrm{ft})$ deep, and (2) northwest- and west-northwest-trending faults that appear to have controlled subsidence into this trough. A faulted zone of steep structural gradient rises from this low on the northeast side up to less than 1.4 seconds, equivalent to approximately $1,500 \mathrm{~m}(5,000 \mathrm{ft})$. This structural gradient coincides closely with the magnetic gradient and other features that define the northwest trend and location of the Becharof discontinuity.

Most of the seismically imaged faults along the Becharof discontinuity offset reflections in the Bear Lake Formation, but only occasionally persist upward into the Pliocene Milky River Formation. As such, they reflect a component of extension parallel to the arc during Miocene time, and are presumably linked genetically to the outcrop-scale cross faults we observed in the Bear Lake Formation near the Ugashik Narrows, and to the numerous cross faults mapped by Detterman and others (1987) in the Mesozoic units east of the Ugashik Lakes. Modern seismicity, (McGimsey and others, 2003), the Ukinrek Maars phreatomagmatic eruptions (Barnes and McCoy, 1979; Motyka and others, 1993), the venting of mantle-derived CO2 at Gas Rocks (Symonds and others, 1997), and evidence of inflation of Mount Peulik volcano (C. Nye, written commun., January 18, 2007), suggest that the Becharof magnetic discontinuity has been a zone of weakness in the upper lithosphere since at least Miocene time, and that subsidence of the northeast margin of the Ugashik sub-basin may continue today.

We consider the ULFS the southeastern margin of the Ugashik sub-basin. Faults with north-northeast trends similar to that of the northern part of the ULFS 
are essentially absent from the seismic interpretation (fig. 5), but may be present east of the seismic survey, closer to Ugashik Lakes. The seismic interpretation indicates a series of arcuate faults near the south end of the dataset that strike east-northeast and are downthrown to the northwest. These faults appear to reflect the same extension as the microfault fabric in the Bear Lake Formation lacustrine deposits at station 07PD173 (fig. 10) and the dike nearby in the uplands south of Lower Ugashik Lake.

Field evidence for mid to late Tertiary left lateral strike-slip on the Bruin Bay fault (Detterman and Hartsock, 1966; Detterman and others, 1976; Detterman and Reed, 1980) is highly relevant to subsidence of the Ugashik sub-basin. This is particularly true in recognition of the Becharof discontinuity as a Neogene tectonic element that can explain the mechanical decouplingand thus the contrasting orientations and movement directions - between the linear, up-to-northwest Bruin Bay fault and the arcuate, down-to-northwest faults of the ULFS. If regional stress orientations were similar during the Neogene to those suggested by recent focal mechanism solutions, movement on the Bruin Bay fault should have been sinistral-reverse, as has been described. However, in a sinistral displacement field, the jog in fault trends at the Becharof discontinuity would become a left-stepping releasing bend, and the ULFS on the eastern side of the sub-basin can be readily interpreted as a transtensional or pull-apart margin (fig. 12). Under such a stress regime, these tectonic elements may have interacted to allow sinistral-reverse transpression north of Becharof Lake coeval with major Neogene subsidence in the adjacent Ugashik sub-basin.

\section{CONCLUSIONS}

Our field investigations in the Ugashik Lakes area corroborate certain critical outcrop relationships represented on USGS geologic maps, but we propose that the traces of two main faults in the Ugashik Lakes fault system should be interpreted differently in covered areas (mostly below the lakes themselves) to more closely follow the contours of curvilinear, short-wavelength aeromagnetic anomalies. Where constrained by outcrop,

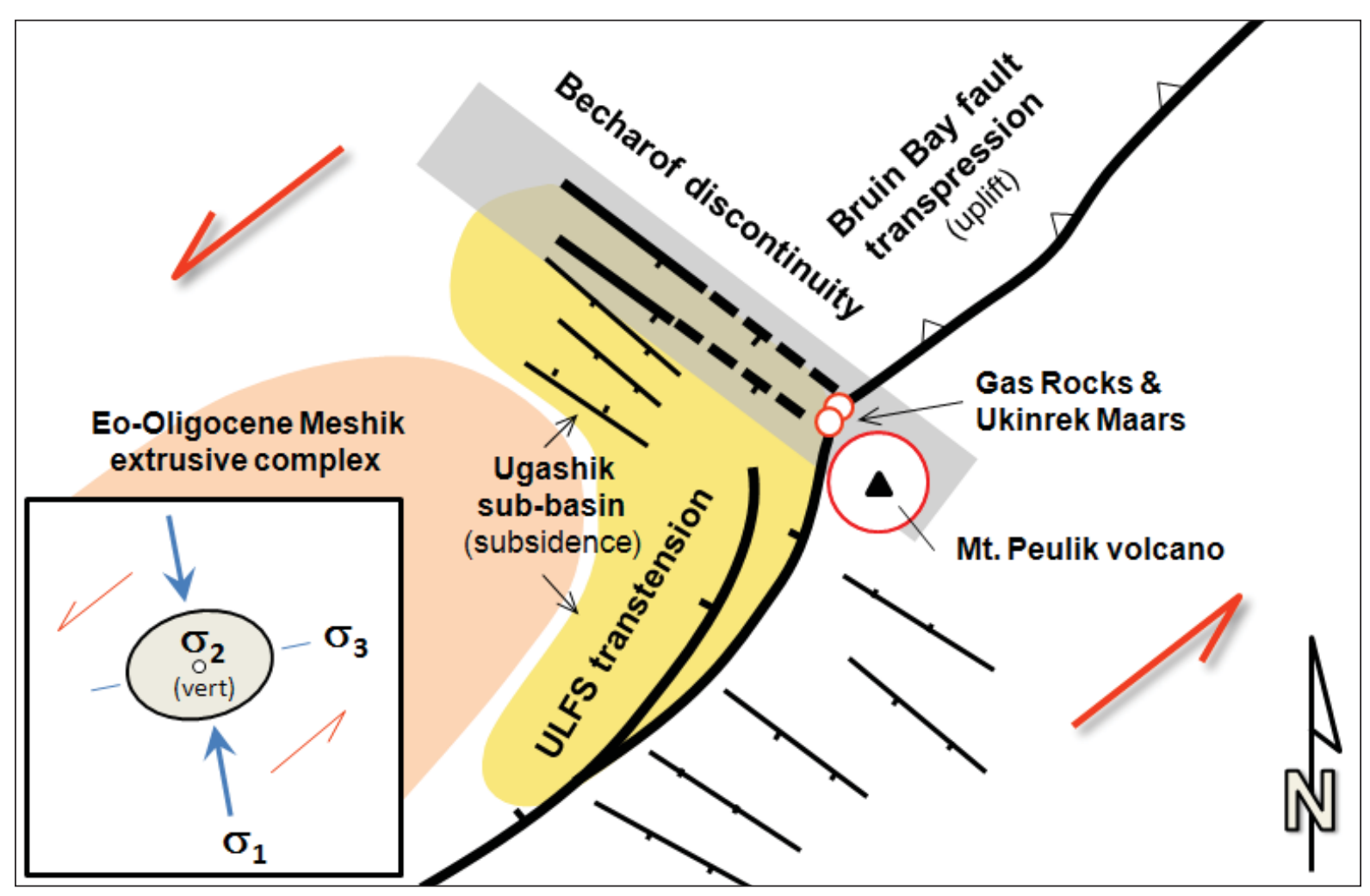

Figure 12. Cartoon of possible structural linkage of the Bruin Bay fault, the Ugashik Lakes fault system, the Ugashik subbasin, and the Becharof discontinuity. Critical geometries include the jog in fault trends and cross faults at the Becharof discontinuity. Neogene stress orientations similar to the modern regime inferred from the majority of focal mechanism solutions would have induced a left-lateral shear couple consistent with reverse-oblique movement (transpressive uplift) on the Bruin Bay fault, normal-oblique movement (transtension) along ULFS, and pull-apart subsidence of the Ugashik sub-basin. Refer to figure 11 for explanation of stress axes. 
the bands of negative magnetic intensity correspond with the Miocene Bear Lake Formation, containing sediments of mostly non-igneous origin; narrow bands of strongly positive magnetic intensity correspond to the Jurassic Naknek and Shelikof and Tertiary formations, which contain abundant detritus from the Jurassic magmatic arc. Where most sharply defined, the boundaries of these narrow magnetic anomalies coincide with mapped faults having Bear Lake Formation in the downthrown western blocks, and we consider it likely that the same holds true where these fault traces are obscured by the lakes and surficial cover.

Measurements of fractures and outcrop-scale faults along the ULFS define a complex fabric that at most stations includes prominent sub-populations of steep, west-northwest-dipping planes considered to mimic the attitude of the fault system's major north-northeast-striking structures. We thus interpret the controlling faults of the ULFS as west-northwest dipping with a significant component of normal displacement, rather than as eastsoutheast-dipping thrust or reverse faults. Accordingly, planes with similar strike but steep east-southeast dip probably represent genetically related antithetic shears. Subpopulations corresponding to northwest-striking minor faults reflect Miocene or younger arc-parallel extension.

An early phase of reverse movement on the Bruin Bay fault may have persisted at least as far south as the Ugashik Narrows, where a sliver of Middle Jurassic Shelikof Formation is juxtaposed by faulting with Upper Jurassic Naknek Formation. Elsewhere south of Becharof Lake, evidence for up-to-northwest movement related to the Bruin Bay fault has been erased by down-to-northwest movement on the ULFS, perhaps largely due to reactivation of pre-existing faults. South of Lower Ugashik Lake, the Bear Lake Formation hosts a dominant set of fractures and microfaults that dip steeply north-northwest, striking east-northeast parallel to a prominent nearby dike; both the structural fabric and the dike are consistent with extensional subsidence of the Ugashik sub-basin to the northwest.

We identify the Becharof discontinuity as a significant zone of Neogene and younger weakness oriented transverse to the Alaska Peninsula. This tectonic element accommodates some amount of arc-parallel extension, and may account for the abrupt change in strike and stratigraphic separation between the Bruin Bay fault to the north and the Ugashik Lakes fault system to the south. The mantle-sourced volcanism and $\mathrm{CO} 2$ venting at the intersection of these faults and the Becharof discontinuity are evidence that, at least locally, this weakness may extend through the entire thickness of the crust. South of the Becharof discontinuity, well correlations and seismic interpretation define the subsurface structure of the Ugashik sub-basin, set apart from the main North Aleutian backarc basin by a structurally elevated volcanic center drilled in the Port Heiden 1 and Ugashik 1 wells. Differential subsidence of the sub-basin apparently began during Miocene deposition of the lower Bear Lake Formation. The sub-basin is bounded by cross faults of the Becharof discontinuity to the northeast, and presumably by faults of the ULFS to the southeast.

A component of left-lateral strike slip on the Bruin Bay and Ugashik Lakes fault systems during Tertiary time is consistent with geologic map patterns in the western Cook Inlet region and with the modern stress regime interpreted from recent earthquake focal mechanisms. Neogene cross faulting at the Becharof discontinuity may have severed the southern end of the Bruin Bay fault system and allowed the blocks to the north and south to respond independently to an oblique-slip regime. The left-stepping kink in the fault trends at this discontinuity between the Bruin Bay and Ugashik Lakes fault systems would favor transtensional subsidence in the Ugashik sub-basin west of the ULFS yet allow either earlier or coeval transpressional shortening on the Bruin Bay fault. This may have important implications for the type and orientations of potential subsurface hydrocarbon traps along the Alaska Peninsula margin of the North Aleutian basin, particularly within the Ugashik sub-basin at its northeast end. Additional studies of the timing, sense, and magnitude of movement on the Bruin Bay fault would provide valuable constraints on this tectonic model.

\section{ACKNOWLEDGMENTS}

Field studies during 2007 were funded by the Alaska Division of Oil and Gas and the Alaska Division of Geological \& Geophysical Surveys. The text and figures benefited from the thorough and insightful reviews by Thomas Homza and Paige Delaney.

\section{REFERENCES CITED}

Alaska Division of Oil \& Gas, 2004, Alaska Peninsula areawide oil and gas lease sale and Bristol Bay basin exploration license area, information and data compilation: Alaska Division of Oil \& Gas, Alaska Peninsula oil and gas resource series, 3 volume CD-ROM.

Barnes, I., and McCoy, G.A., 1979, Possible role of mantle-derived $\mathrm{CO}_{2}$ in causing two "phreatic" explosions in Alaska: Geology, v. 7, p. 434-435.

Beeman, W.R., Obuch, R.C., and Brewton, J.D., 1996, Digital map data, text, and graphical images in support of the 1995 National Assessment of United States Oil and Gas Resources: U.S. Geological Survey Digital Data Series DDS-35, 1 disk, http://pubs. usgs.gov/dds/dds-035/DDS-35.html 
Detterman, R.L., and Hartsock, J.K., 1966, Geology of the Iniskin-Tuxedni region, Alaska: U.S. Geological Survey Professional Paper 512, 78 p., 6 plates, scale 1:63,360.

Detterman, R.L., and Reed, B.L., 1980, Stratigraphy, structure, and economic geology of the Iliamna Quadrangle, Alaska: U.S. Geological Survey Bulletin 1368-B, 86 p., 1 plate, scale 1:250,000.

Detterman, R.L., Case, J.E., Wilson, F.H., and Yount, M.E., 1987, Geologic map of the Ugashik, Bristol Bay, and western part of Karluk quadrangles, Alaska: U.S. Geological Survey Miscellaneous Investigations Series Map 1685, 1 plate, scale 1:250,000.

Detterman, R.L., Hudson, Travis, Plafker, George, Tysdal, R.G., and Hoare, J.M., 1976, Reconaissance geologic map along Bruin Bay and Lake Clark faults in Kenai and Tyonek quadrangles, Alaska: U.S. Geological Survey Open-File Map 76-477, 4 p., 1 plate.

McGimsey, R.G., Neal, C.A., and Girina, O., 2003, 1998 volcanic activity in Alaska and Kamchatka: summary of events and response of the Alaska Volcano Observatory: U.S. Geological Survey Open-File Report 03-423, 35 p.

Meyer, J.F., Jr., 2007, Total intensity magnetic anomaly for the Bristol Bay region and Alaska Peninsula: Alaska Department of Natural Resources, Division of Oil \& Gas, Alaska Peninsula Oil and Gas Field Map Series, plate 3 of 3, scale 1:500,000.

Meyer, J.F., Jr., Hansen, J.J., Brizzolara, D.W., Pritchard, M.E., Boggess, P.L., Beaty, C.J., Dirks, K.L., Gumpert, J.D., Bolin, K.A., Gibler, K.I., and Phillipson, E.M., 2004, Alaska aeromagnetic compilation, Ugashik quadrangle: Alaska Department of Natural Resources, Division of Oil \& Gas, Alaska Peninsula Resource Series, plate 10 of 19, scale 1:250,000.

Mickey, M.B., Haga, H. Boettcher, R.S., and Kling, S.A., 2005, Northwestern Alaska Peninsula-Bristol Bay basin biostratigraphy study: Micropaleo Consultants Job No. 25-104, 287 p., 4 oversize plates, 40 oversize figures, Alaska Division of Oil \& Gas online publication http://www.dog.dnr.state.ak.us/oil/ products/publications/akpeninsula/biostrat.htm
Molenaar, C.M., 1996, Thermal-maturity patterns and geothermal gradients on the Alaska Peninsula, in Johnsson, M.J., and Howell, D.G., eds., Thermal evolution of sedimentary basins in Alaska: U.S. Geological Survey Bulletin 2142, p. 11-19.

Motyka, R.J., Liss, S.A., Nye, C.J., and Moorman, M.A., 1993, Geothermal resources of the Aleutian Arc, Alaska: Alaska Division of Geological \& Geophysical Surveys Professional Report 114, 17 p.

Saltus, R.W., Connard, G.G., and Hill, P.L., 1999, Alaska aeromagnetic compilation-digital grids and survey data: U.S. Geological Survey Open-File Report 99-502, CD-ROM.

Saltus, R.W., Haeussler, P.J., Bracken, R.E., Doucette, J.P., and Jachens, R.C., 2001, Anchorage Urban Region Aeromagnetics (AURA) Project - preliminary geophysical results: U.S. Geological Survey OpenFile Report 01-0085, 21 p.

Sherwood, K.W., Larson, J., Comer, C.D., Craig, J.D., and Reitmeier, C., 2006, North Aleutian basin OCS planning area assessment of undiscovered technically-recoverable oil and gas: U.S. Minerals Management Service Alaska OCS Region report, 138 p., 4 plates, www.mms.gov/alaska/re/reports/rereport.htm

Symonds, R.B., Ritchie, B.E., McGimsey, R.G., Ort, M.H., Poreda, R.J., Evans, W.C., and Janik, C.J., 1997, Investigations of gas seeps and springs in the vicinity of The Gas Rocks, south shore Becharof Lake, Alaska: U.S. Geological Survey Open-File Report 97-0127, 27 p.

Vacquier, V., 1963, General principles, in Vacquier, V., Steenland, N. C., Henderson, R.G., and Zietz, I., Interpretation of aeromagnetic maps: Geological Society of America Memoir 47, 151 p., 14 plates.

Wilson, F.H., Detterman, R.L., and Case, J.E., 1985, The Alaska Peninsula terrane; A definition: U.S. Geological Survey Open-File Report 85-450, 17 p.

Wilson, F.H., Detterman, R.L., and DuBois, Gregory, 1999, Digital data for the geologic framework of the Alaska Peninsula, Southwest Alaska, and the Alaska Peninsula Terrane: U.S. Geological Survey OpenFile Report 99-317, 41 p., 1 plate, scale 1:500,000, http://wrgis.wr.usgs.gov/open-file/of99-317. 



\title{
KAMISHAK FORMATION, PUALE BAY
}

\author{
by \\ Michel T. Whalen ${ }^{1}$ and Tyler W. Beatty ${ }^{1}$
}

\begin{abstract}
Four partial stratigraphic sections of the Kamishak Formation, near Puale Bay on the Alaska Peninsula, were examined for this study. Lithostratigraphic and petrographic analyses prompted subdivision of the Kamishak Formation into biostromal, nodular limestone and conglomerate, rhythmically bedded limestone, and siliceous limestone units. Sedimentary structures, biota, and ichnofabrics indicate that the biostromal unit was deposited in relatively shallow normal marine environments in a middle to inner carbonate ramp setting. The nodular limestone and conglomerate unit, with evidence of synsedimentary folding and mass movement processes, was deposited along a distally steepened slope of the carbonate ramp. The rhythmically bedded unit, with no evidence of wave or current structures, was deposited below storm wave base in a basinal setting. The siliceous limestone unit, with evidence of turbidite or tempestite deposition and abundant ichnofauna, indicates deposition above storm wave base on an outer carbonate ramp.

Organic geochemical data demonstrate that the Kamishak Formation contains good to very good source rocks with best source potential within the siliceous limestone and rhythmically bedded units. Kerogen types in the Kamishak Formation include Type I, II, and III with average values plotting as oil prone (Type II). Rock-Eval data indicate that Kamishak source rocks are near the boundary between immature and mature. The reservoir potential of the portion of the Kamishak Formation examined for this study is, in general, poor but some facies within the nodular limestone and conglomerate unit display macro- and micro-scale porosity. Secondary fracture porosity and dolomitization in the biostromal unit may also provide some reservoir potential.
\end{abstract}

\section{INTRODUCTION}

The Kamishak Formation, exposed near Puale Bay (figs. 1-3), is a relatively complete but slightly deformed Triassic and Jurassic succession in south-central Alaska (Imlay and Detterman, 1977; Detterman and Reed, 1980; Wang and others, 1988; Detterman and others, 1996). The Upper Triassic to Lower Jurassic Kamishak Formation comprises about $800 \mathrm{~m}$ of marine, dominantly carbonate, rocks that are interbedded with basaltic volcanic and volcaniclastic rocks in the upper portion of the section (Wang and others, 1988; Detterman and others, 1996).

The purpose of this study is to evaluate the Kamishak Formation in the Puale Bay area in light of other recent work (Detterman and others, 1996; Sralla and Blodgett, 2007; Blodgett and Sralla, 2008) and provide insight into the lithofacies, depositional environment, and source rock and reservoir potential of the unit.

\section{STRATIGRAPHIC CONTEXT}

Contact relations of the Upper Triassic Kamishak Formation at Puale Bay are not well understood. Wang and others (1988) considered the base of the Triassic section to be truncated by faulting and that was confirmed, at least on a local basis, during this study. Volcaniclastic conglomerates and breccias exposed just to the west of Cape Kekurnoi (07MW001) have been variably inter-

preted and this issue will be addressed further below.

Wang and others (1988) evaluated the Upper Triassic portion of the section near Puale Bay that records the geological evolution of a volcanic island arc. Imlay (1981) documented the presence of Lower Jurassic Hettangian age rocks and Newton (1989) contended that the Triassic-Jurassic (T-J) boundary section was complete. Pálfy and others (1999) studied the uppermost Triassic and lower Jurassic portion of the section and demonstrated that Hettangian rocks were present but that the $\mathrm{T}-\mathrm{J}$ boundary was missing due to minor faulting. The upper contact of the Kamishak Formation is gradational with the overlying Talkeetna or Bidarka Formation and is associated with a decrease in carbonate content at the expense of fine-grained siliciclastic material (Detterman and others, 1996; Pálfy and others, 1999)

\section{METHODS}

Stratigraphic sections within the Kamishak Formation were measured in the field with a Jacob's staff and compass. Lithofacies were identified and logged at sub-meter resolution noting lithology, color, bedding character, sedimentary structures, trace fossils, and body fossils. At major changes in lithofacies, samples were collected for thin section, Total Organic Carbon (TOC), Rock-Eval pyrolysis, and/or reservoir seal analyses.

${ }^{1}$ Department of Geology and Geophysics, Universityof Alaska, P.O. Box 755780 Fairbanks, Alaska 99775-5780 


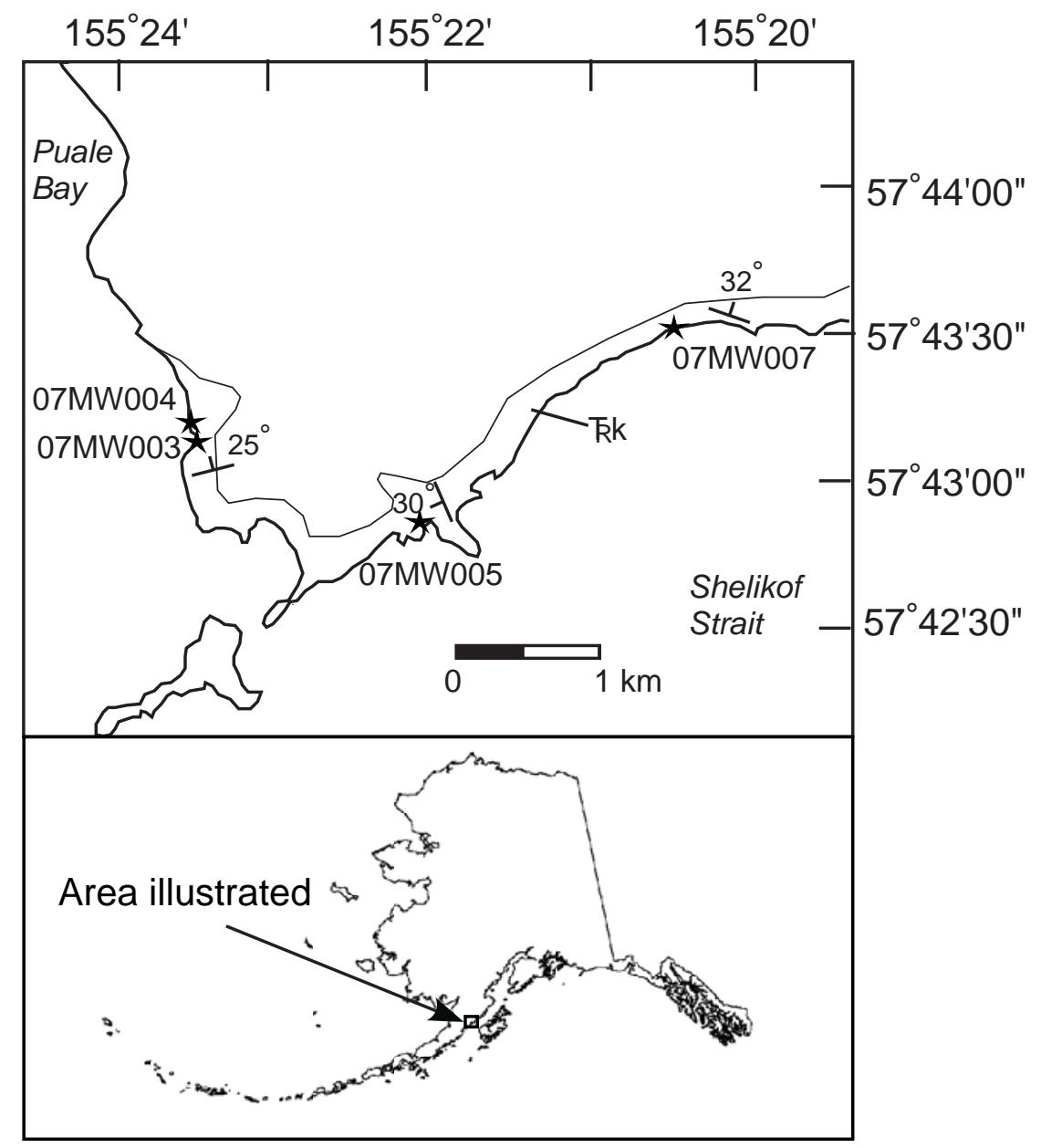

Figure 1. Location map. Map of Cape Kekurnoi located to the east of Puale Bay, illustrating the distribution and attitude of the Kamishak Formation (TR k) and the locations (labeled stars) of measured stratigraphic sections (modified from Detterman and others, 1996; Wilson, and others, 1999; Decker, this volume).

Samples for TOC and Rock-Eval pyrolysis were processed by Baseline Resolution, Inc. (143 Vision Park Blvd., Shenandoah, Texas 77384) while those for seal analysis were evaluated by George Bolger, PetroTech Associates (11767 Katy Freeway, Suite 320, Houston, Texas 77079). Thin sections were stained for calcite with Alizarin Red-S and vacuum impregnated with blue epoxy to help evaluate porosity. Thin sections were examined with a Nikon Optiphot petrographic microscope and digitally imaged using an Olympus Q-color camera and Q-capture software. Descriptions of carbonate-dominated lithofacies will follow the carbonate classification of Dunham (1962) as modified by Embry and Klovan (1972). Bedding thicknesses are classified as laminated ( $<1 \mathrm{~cm}$ thick), thin ( $1-10 \mathrm{~cm}$ thick), medium $(11-50 \mathrm{~cm}$ thick), and thick bedded (51-100 cm thick), or massive $(>100 \mathrm{~cm}$ thick).

\section{MEASURED SECTIONS}

Four partial stratigraphic sections, totaling $156 \mathrm{~m}$ of section, within the Upper Triassic part of the Kamishak Formation were measured during this study and 41 samples were collected within the unit (table 1, fig. 1). Blodgett (this report) provides biostratigraphic and paleontologic information concerning these sections. Section 07MW005 (fig. 4) is the lowest within the stratigraphic succession beginning approximately $35 \mathrm{~m}$ above the base of the exposed section, which is truncated by a fault (Wang and others, 1988). This section begins within what was identified as a coral biomicrite unit and continues up through a carbonate conglomerate (unit 1 of Detterman and others, 1996) and the lowermost bedded chert facies of Wang and others (1988; lower part, unit 2 of Detterman and others, 1996). Section 07MW007 (fig. 5) is in part laterally equivalent with section 07MW005. It begins within lateral equivalents of the coral biomicrite 


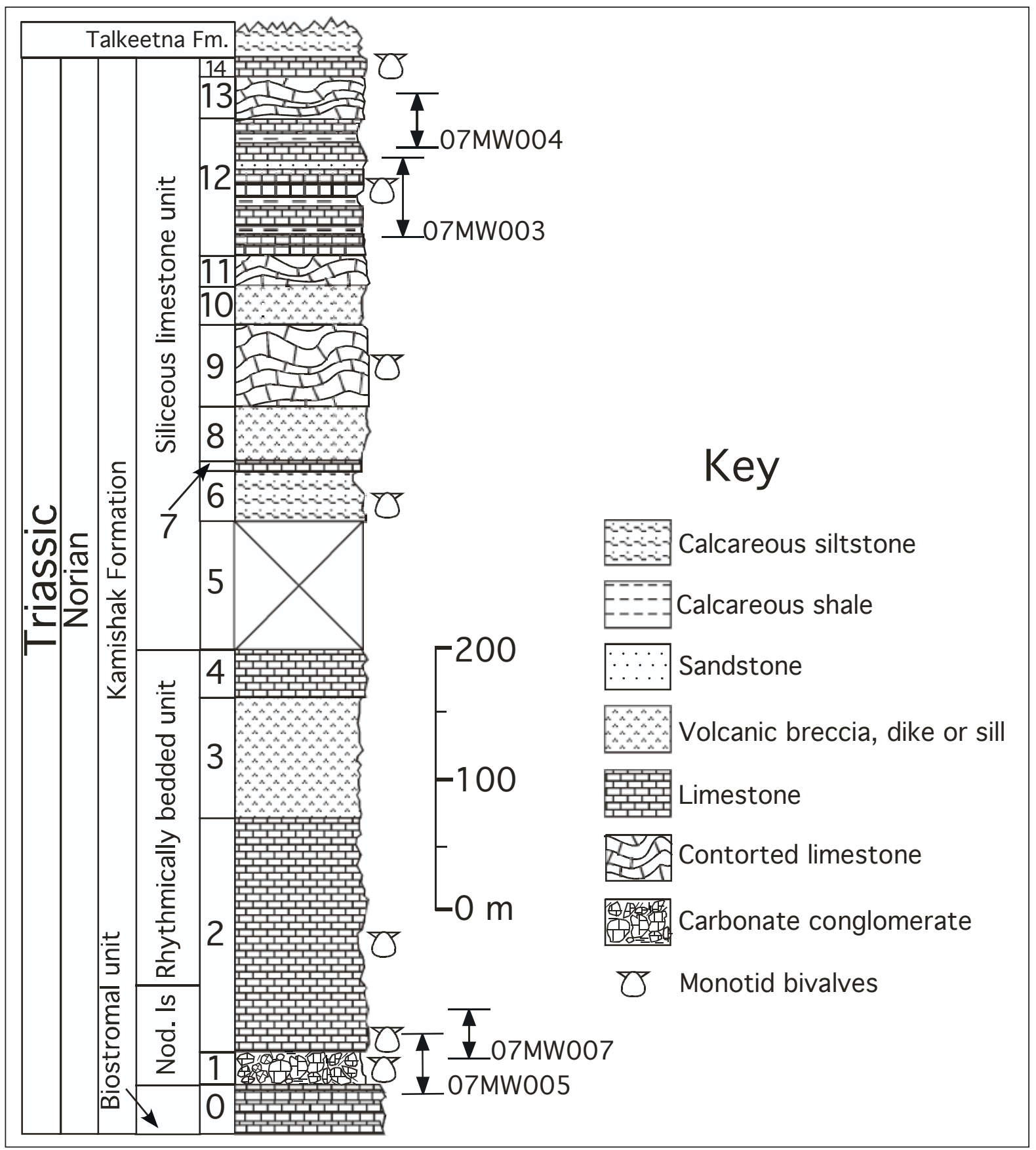

Figure 2. Composite stratigraphic section of the Kamishak Formation near Puale Bay (after Wang and others, 1988; Detterman and others, 1996; this study). Diagram illustrates the age, lithologies, units defined in this study, and thickness in meters (m) of the Kamishak Formation near Puale Bay. Numbers in the column to the left of the lithologic column indicate units of Detterman and others (1996). The stratigraphic position of measured sections from this study (figs. 4-7) is indicated to the right of the lithologic column. Nod. Is = Nodular limestone and conglomerate unit. 


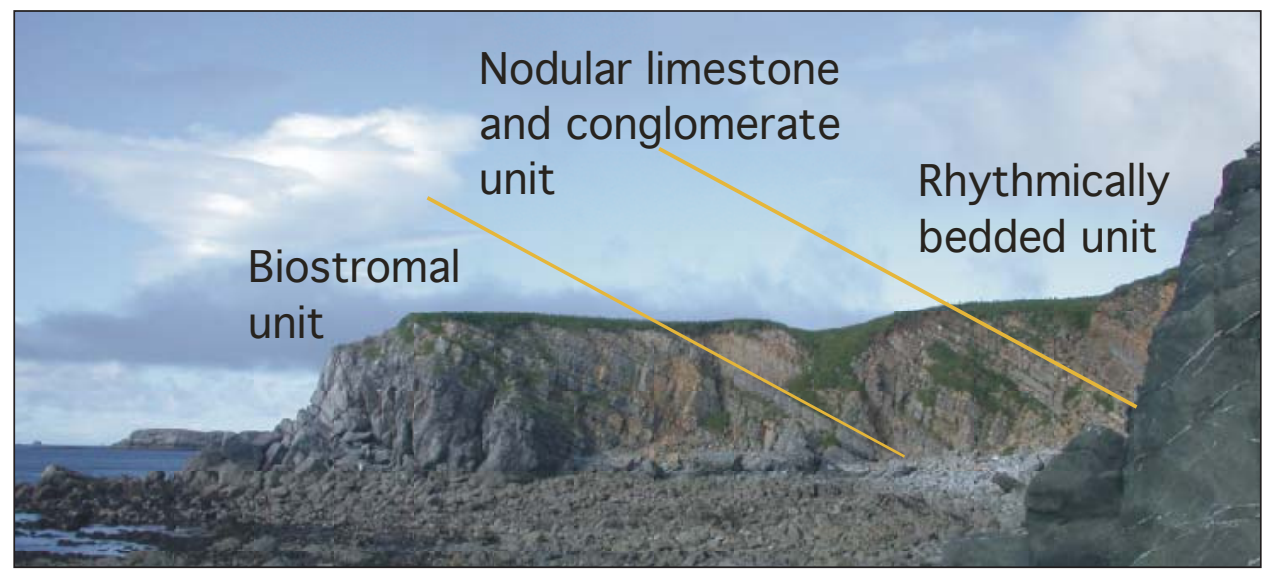

Figure 3. Outcrop photograph of the lower portion of the Kamishak Formation exposed near Puale Bay, illustrating the biostromal, nodular limestone and conglomerate, and lower portion of the rhythmically bedded unit.

Table 1. Measured stratigraphic sections in the Kamishak Formation. Section number, latitude and longitude of the base of the section, general attitude of the rocks, and thickness of each measured section are outlined.

\begin{tabular}{cccc} 
Measured Section & Latitude/Longitude & Strike/Dip & Thickness \\
07MW003 & N57.71887, W155.38973 & N74, $25^{\circ} \mathrm{NW}$ & $60 \mathrm{~m}$ \\
07MW004 & N57.72031, W155.38978 & N67, $8^{\circ} \mathrm{NW}$ & $13 \mathrm{~m}$ \\
$07 \mathrm{MW005}$ & $\mathrm{N} 57.71372, \mathrm{~W} 155.36167$ & $\mathrm{~N} 156^{\circ}, 30^{\circ} \mathrm{SW}$ & $52 \mathrm{~m}$ \\
$07 \mathrm{MW007}$ & $\mathrm{N} 57.72525, \mathrm{~W} 155.34082$ & $\mathrm{~N} 110^{\circ}, 32^{\circ} \mathrm{NE}$ & $31 \mathrm{~m}$ \\
\hline
\end{tabular}

and continues through the carbonate conglomerate facies (unit 1 of Detterman and others, 1996) and lower bedded chert unit of Wang and others (1988; lower part of unit 2 of Detterman and others, 1996). Sections 07MW003 (fig. 6) and 004 (fig. 7) are in the upper part of the Upper Triassic portion of the section and would be entirely within the upper part of Wang and others' (1988) bedded chert facies (units 12-13 of Detterman and others, 1996).

Reference to the facies described by Wang and others (1988) and Detterman and others (1996) are presented here as a guide to readers wishing to place this report in context with previously published work. A somewhat different facies classification and interpretation of the depositional setting of these Upper Triassic rocks resulted from field analysis, hand specimen examination, and thin section petrography conducted during this study.

\section{UNITS AND FACIES}

Lithostratigraphic, facies, and microfacies analyses provide evidence of four different lithostratigraphic units, each of which contains several individual facies.
Lithostratigraphic units described here include: (1) biostromal, (2) nodular limestone and conglomerate, (3) rhythmically bedded, and (4) siliceous limestone units. Following the unit designations will be a description of the ichnology of the siliceous limestone unit, which contributes to depositional and paleoenvironmental interpretations. Interpretations of depositional environment and comparison with earlier interpretations follow in the subsequent section.

\section{BIOSTROMAL UNIT}

This unit is equivalent to the coral biomicrite of Wang and others (1988) who documented the unit to be about $45 \mathrm{~m}$ thick. Approximately $10 \mathrm{~m}$ of the upper portion of the unit were examined for this study at measured section 07MW005 (fig. 4). The unit consists of medium-bedded to massive carbonate rocks that weather light gray and medium brown and are mottled medium brown and white on fresh surfaces (figs. 8,9). Thinner lateral equivalents crop out at section 07MW007 (fig. 5) but are interbedded with nodular limestones similar to rocks that overlie the biostromal unit at section 07MW005. 

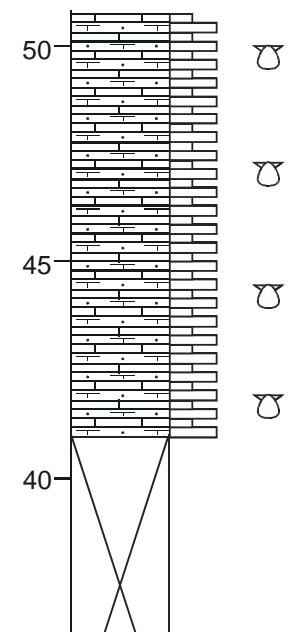

\section{Key}

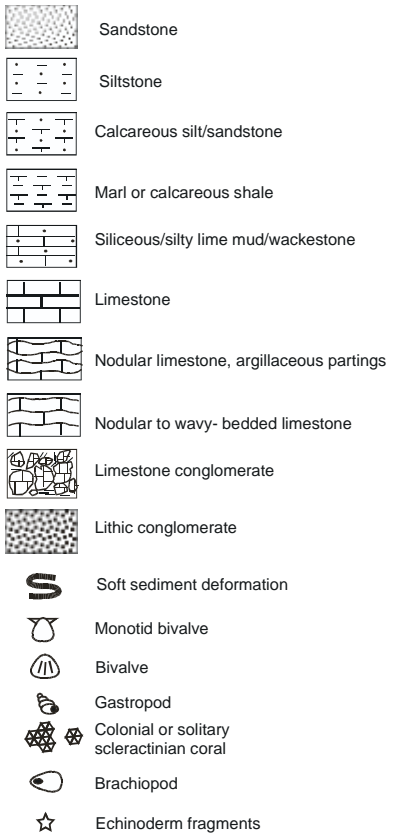

Figure 4. Measured stratigraphic section 07MW005 that exposes the upper biostromal unit, nodular limestone and conglomerate, and lower rhythmically bedded unit. Diagram illustrates lithologies, units defined in this study, thickness in meters $(m)$, average grain size $(C=$ clay, $S t=$ silt, $S d=$ sand, $G=$ gravel, $B=$ boulder), and common body fossils. 


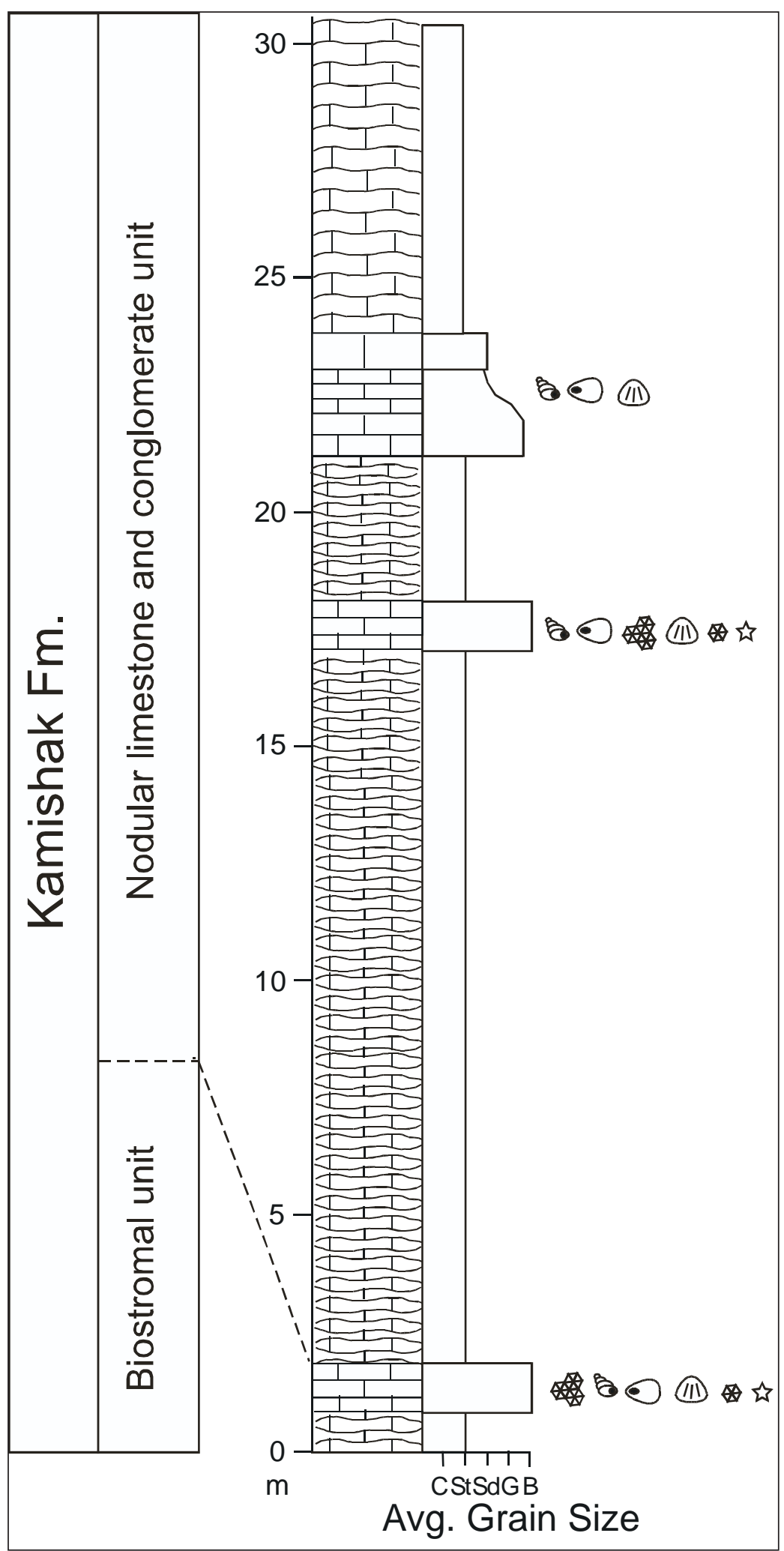

Figure 5. Measured stratigraphic section 07MW007 records the upper portion of the biostromal unit and the lower part of the nodular limestone and conglomerate unit. Diagram illustrates lithologies, units defined in this study, thickness in meters $(m)$, average grain size $(C=$ clay, $S t=$ silt, $S d=$ sand, $G=$ gravel, $B=$ boulder $)$, and common body fossils. See figure 4 for key to lithologies and other symbols. 


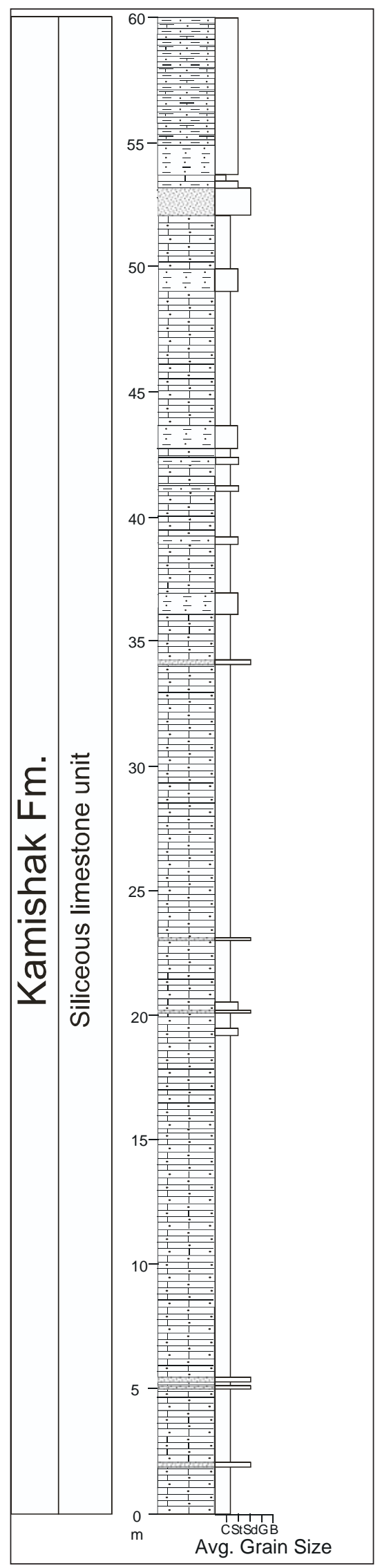

Figure 6. Measured stratigraphic section 07MW003 exposes part of the siliceous limestone unit. Diagram illustrates lithologies, units defined in this study, thickness in meters $(m)$, average grain size ( $C=$ clay, $S t$ $=$ silt, $S d=$ sand, $G=$ gravel, $B=$ boulder), and common body fossils. See figure 4 for key to lithologies and other symbols.

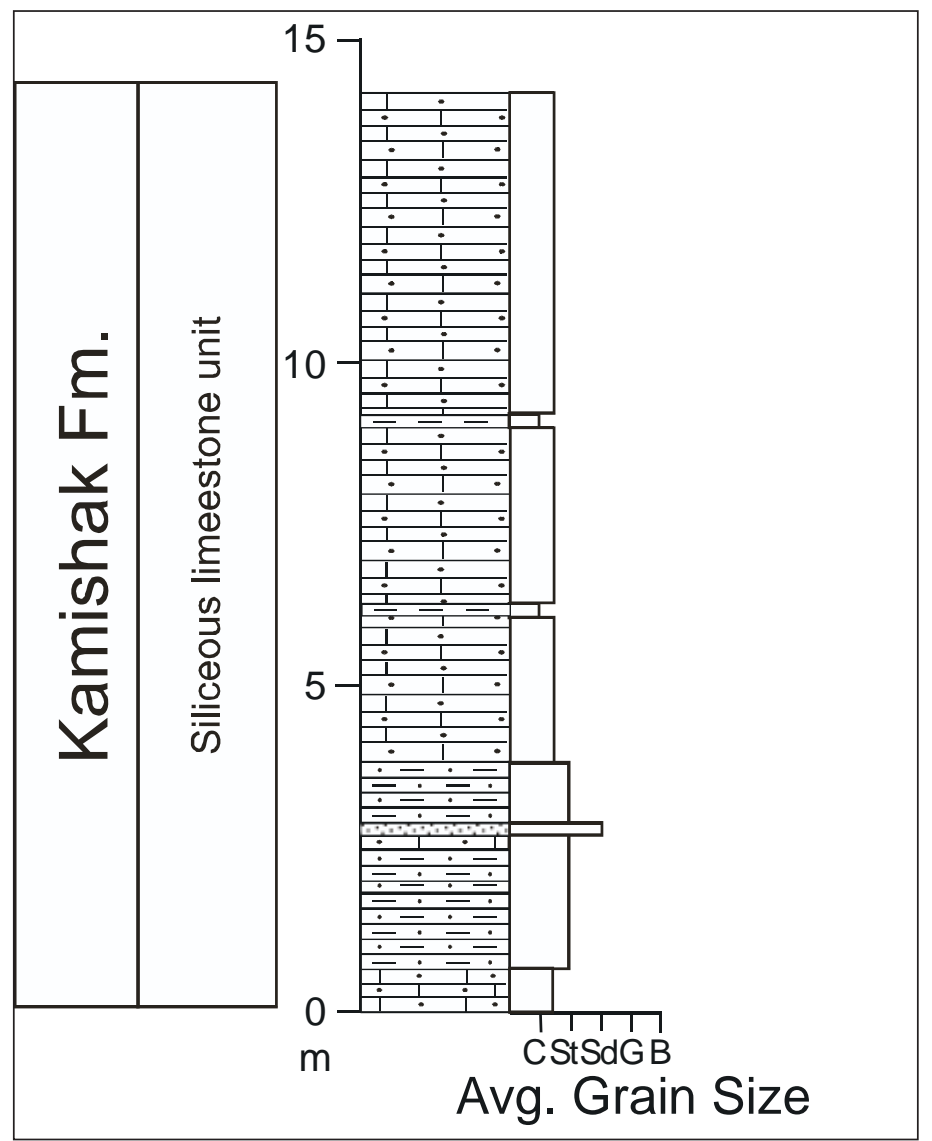

Figure 7. Measured stratigraphic section 07MW004 records part of the siliceous limestone unit. Diagram illustrates lithologies, units defined in this study, thickness in meters $(m)$, average grain size $(C=$ clay, $S t=$ silt, $S d=$ sand, $G=$ gravel, $B=$ boulder), and common body fossils. See figure 4 for key to lithologies and other symbols. 

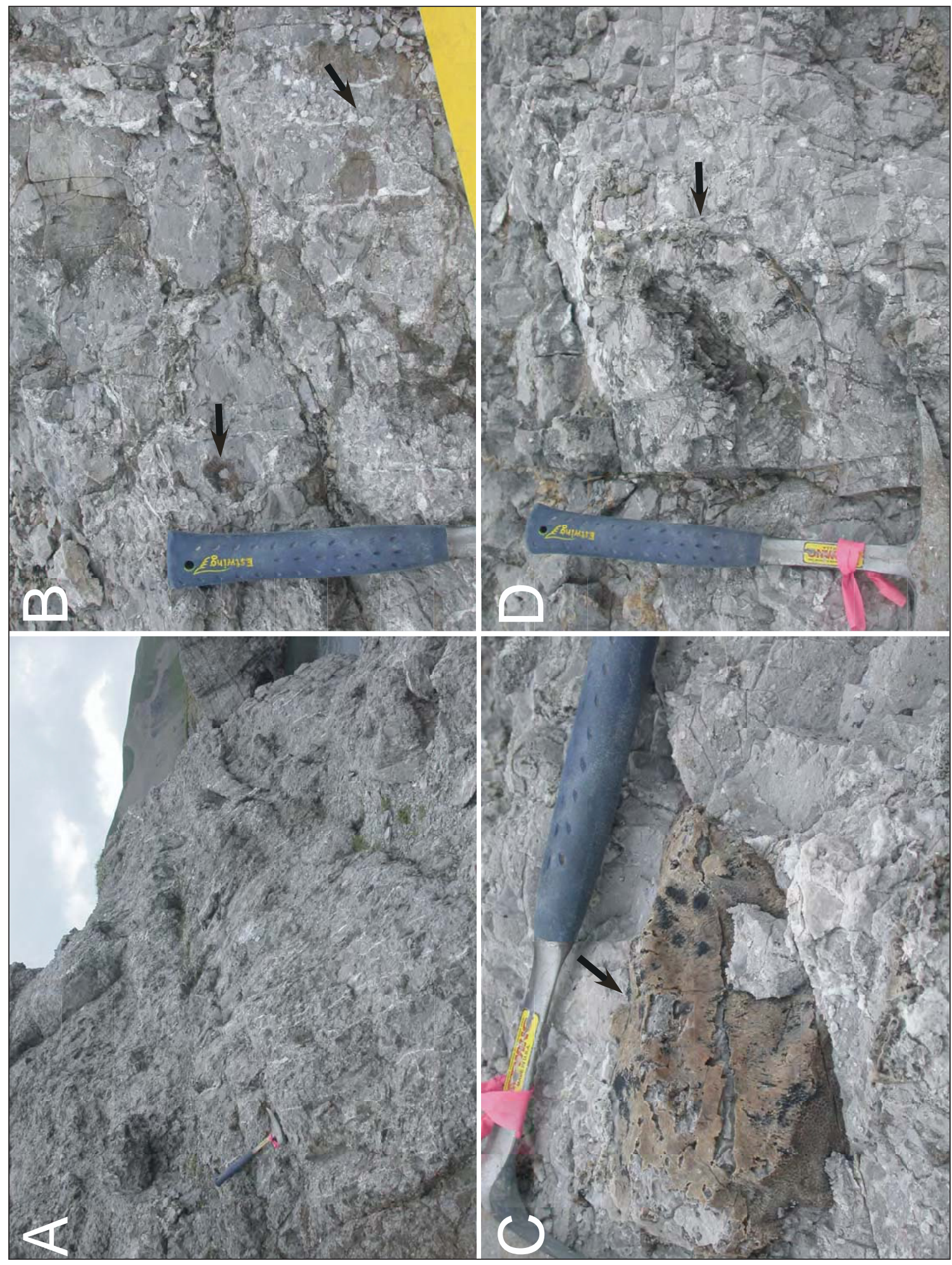

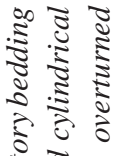

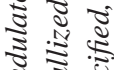

赵

究

ปे $\frac{1}{2}$

$\delta \equiv$

ปี

:

웅

ร రิ อ

ปิ โ

‥ ‥

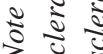

$\stackrel{5}{\sigma}$

ฐ

हิ ปั

ริ ฮ

.ั)

苂

范。

के चे

ㅎํㄴ

ป ई है

का

곤

๓

षี ริ

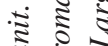

施ن

हี :

ड़े

능

₹

ऽ

के के

ธิ ป

¿ $\frac{0}{0}$

ล. ڤ

ปั

ปัฐ

$\infty$ है :

ڤ

곤 
The biostromal unit contains a mixture of bioclastic wackestone, packstone, floatstone, and rudstone with abundant colonial scleractinian corals, spongiomorphs, and terebratulid brachiopods (figs. 8-10) (Wang and others, 1988; this study) and common gastropods, bivalves, echinoderm fragments (echinoid spines and crinoid ossicles), and solitary scleractinian corals. Most bioclasts appear to be transported including colonial coral heads, more than $20 \mathrm{~cm}$ in diameter, some of which are completely overturned (fig. 8).

The facies within this unit are highly fractured, partially dolomitized, and partly silicified. Within the portion of the biostromal unit examined for this study, 50-500 $\mu \mathrm{m}$ planar euhedral to subhedral dolomite rhombs are fabric destructive and replace both grains and lime mud matrix. Based on visual estimates, dolomite does not make up more than 25 percent of any of the facies examined and no increase in secondary porosity is associated with the dolomite. Petrographic observations indicate that the dolomite is cross cut by younger coarsely crystalline calcite fracture-filling cement. Microcrystalline quartz and spherulitic chalcedony replaces some grains, matrix, and late stage calcite cement.

\section{NODULAR LIMESTONE AND CON- GLOMERATE UNIT}

The nodular limestone and conglomerate unit overlies the biostromal unit and is dominantly composed of light gray-brown weathering bioclastic wackestone carbonate nodules that are medium gray on fresh surfaces (figs. 4, 5, 9 and 11). The lower $25 \mathrm{~m}$ was previously described as a depositional carbonate conglomerate (Wang and others, 1988). It is equivalent to unit 1 of Detterman and others (1996) but they provide no detailed lithologic description. The clasts in the conglomerate are very similar to nodules that make up the bulk of the overlying nodular limestone. The nodules are surrounded by dark gray (weathering and fresh) argillaceous to silty wackestone to packstone. The nodules contain a diverse fauna of corals, bivalves, ammonoids, nautiloids, and gastropods (figs. 9, 10) (Wang and others, 1988; this study). The base of this unit is quite complex and comprises several facies, one of which is similar to Wang and others' (1988) carbonate conglomerate. This conglomerate contains cobble-size clasts that are identical to the nodules described above and the matrix of the conglomerate is similar to the material interbedded with the nodules (figs. 9, 11). At the main exposure of these units, the conglomerate directly overlies the biostromal unit; however, a small exposure to the northeast (fig. 11), that is not visible from the main exposure, provides evidence of additional facies deposited above the biostromal unit and lends insight into the genesis of the conglomerate.
At this secondary exposure there is a thin package that includes the following facies (fig. 4): (1) $40 \mathrm{~cm}$ of light gray weathering (medium gray fresh) laminated to thin-bedded lime mudstone, (2) $45 \mathrm{~cm}$ of nodular limestone overlain by (3) $20 \mathrm{~cm}$ of light gray-brown weathering, reverse graded rudstone with sand to pebble-size, greenish volcanic clasts and medium gray weathering carbonate lithoclasts in a packstone matrix (fig. 11), (4) $60 \mathrm{~cm}$ of nodular limestone overlain by (5) $20 \mathrm{~cm}$ of medium gray (weathering and fresh) finegrained, laminated packstone overlain by approximately (6) $2 \mathrm{~m}$ of nodular cobble conglomerate (fig. 11). The nodular limestone unit overlies this succession and becomes less conglomerate-like upsection. The laminated packstone and immediately overlying and underlying units illustrate the complex history of this interval. A small-scale asymmetric syncline/anticline pair, with an amplitude of about $1 \mathrm{~m}$, contorts these units (fig. 11). Primary bedding in the laminated packstone unit is preserved within the limbs of the fold but the texture of the rock was largely destroyed in the fold axes where the laminated packstone, rudstone, and nodular cobble conglomerate units are all deformed (fig. 11). The overlying nodular cobble conglomerate (\#6 above) also contains clasts of the packstone and rudstone units.

At locality 07MW007 this deformed unit is not present above the biostromal unit. Instead, there are thick beds of nodular limestone and lithoclastic/bioclastic floatstone and rudstone interbedded with tabular beds of bioclastic wackestone and packstone similar to the underlying biostromal unit (figs. 5, 9).

\section{RHYTHMICALLY BEDDED UNIT}

This unit consists of rhythmically interbedded brownish weathering argillaceous mud/wackestone or calcareous shale and light gray weathering silty mud/ wackestone. A thick package of volcaniclastic rocks is interbedded with this unit (fig. 2). The rhythmically bedded unit is equivalent to the lower portion of Wang and others' (1988) bedded chert unit and the upper portion of unit 2 and units 3 (volcaniclastic) and 4 of Detterman and others (1996; fig. 2). The argillaceous or shaly lithofacies are usually laminated, thin bedded, and fissile. The silty mud/wackestone lithofacies is more resistant and thin to medium bedded. Both are medium to dark gray on fresh surfaces and contain abundant well-preserved Monotid bivalves and rare gastropods. The unit overlies the nodular limestone and conglomerate unit (figs. 4, 5, and 12). The contact between the two is separated by a $7 \mathrm{~m}$ covered interval in measured section 07MW005 (fig. 4). The contact is exposed at section 07MW007 that records a gradational change from nodular limestone to the rhythmically bedded unit (fig. 12).

At two localities just to the west of Cape Kekurnoi the rhythmically bedded unit is associated with greenish 


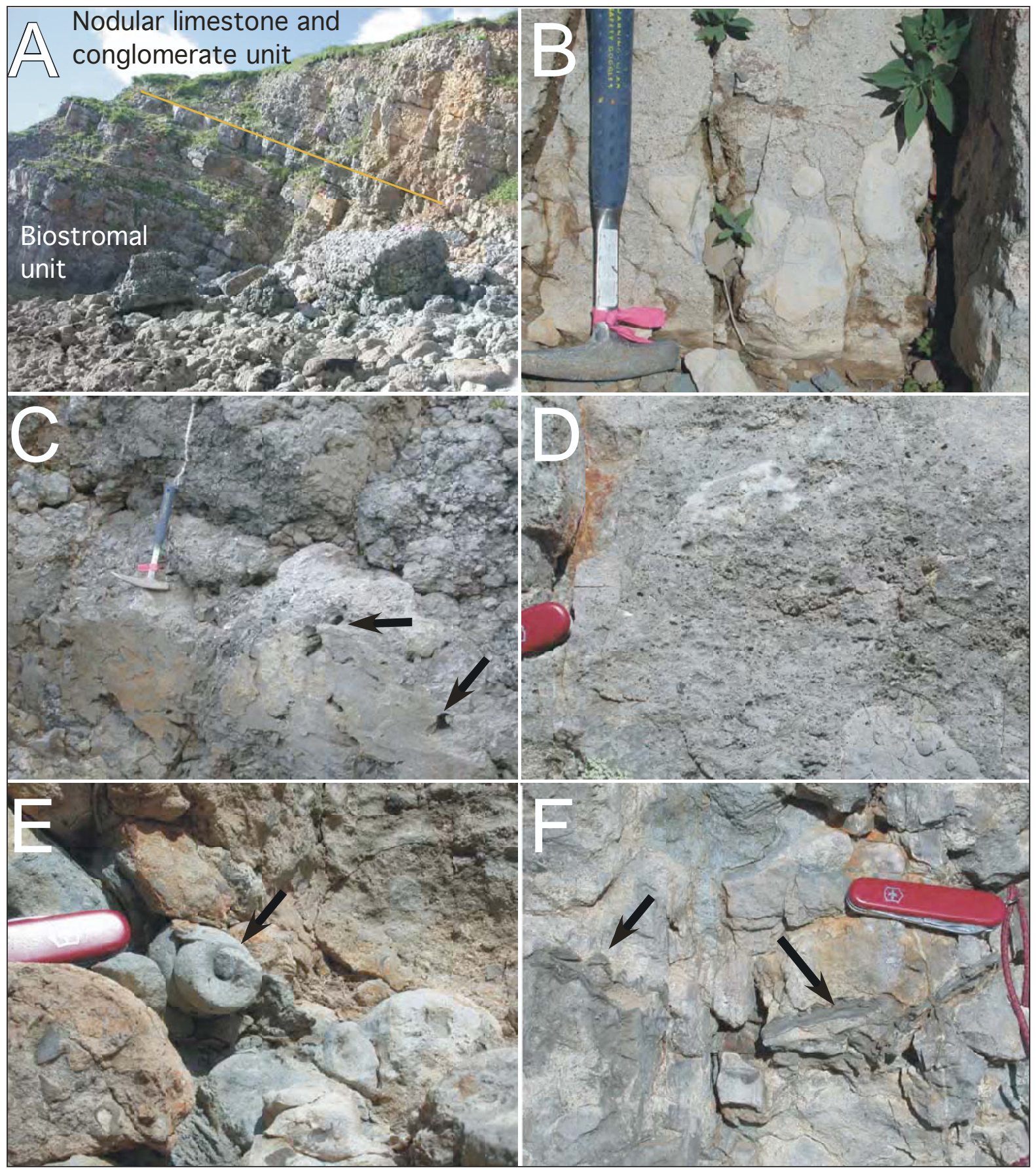

Figure 9. Biostromal and nodular limestone and conglomerate units. A. Outcrop photograph at locality 07 MW007 illustrating the contact between the biostromal and nodular limestone and conglomerate units. B. Floatstone in the lower nodular limestone and conglomerate unit with cobble-size subrounded carbonate lithoclasts within a bioclastic-lithoclastic matrix. C. Lower portion of the nodular limestone and conglomerate unit illustrating nodular texture and large-scale dissolution vugs (arrows). D. Millimeter-scale vugs within a floatstone in the lower nodular limestone and conglomerate unit. E. Large, high-spired gastropod steinkern (arrow) and rounded carbonate lithoclasts in a rudstone in the lower nodular limestone and conglomerate unit. F. Carbonate lithoclasts and thick shelled oysters (arrows) in a rudstone, nodular limestone and conglomerate unit. 

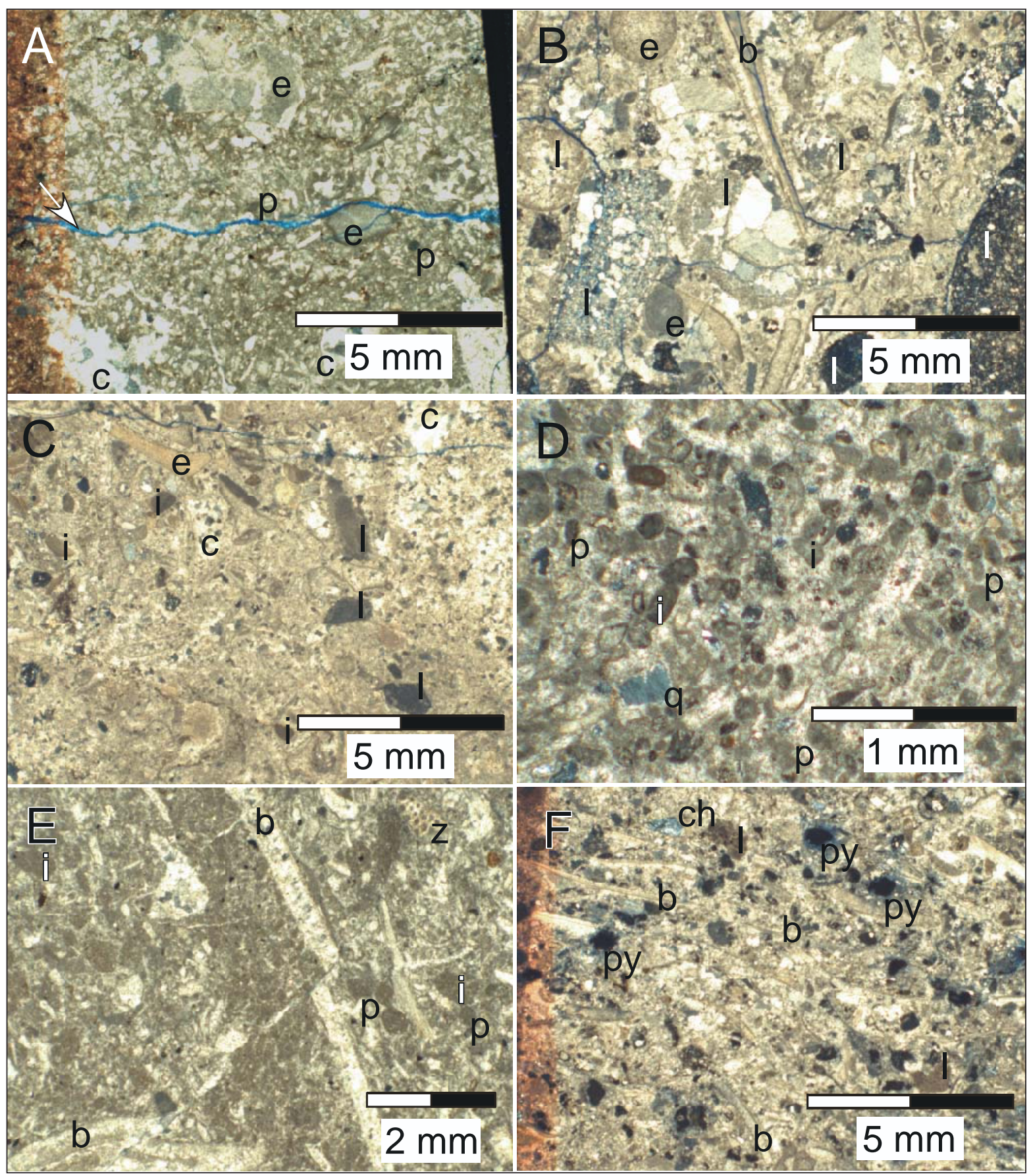

Figure 10. Photomicrographs of the Kamishak Formation biostromal and nodular limestone and conglomerate units. All photomicrographs taken under crossed polars. A. Bioclastic packstone from the upper part of the biostromal in measured section 07MW005 unit with echinoderm fragments (e), fine-grained unidentifiable skeletal grains, local peloids (p), and interstitial lime mud. Primary pores are filled with blocky calcite cement (c) and the only remaining porosity is within fractures (arrow) now filled with blue epoxy. B. Lithoclastic-bioclastic rudstone from the lower portion of the deformed interval near the base of the nodular limestone and conglomerate unit in measured section 07MW005. Note the abundant lithoclasts (l), thin-shelled bivalves (b), and echinoderm grains (e). Lithoclasts vary in composition and include volcaniclastic sandstone, carbonate mud-wackestone, and silty lime mud-wackestone. C. Bioclastic-lithoclastic rudstone from the lower part of the nodular limestone and conglomerate unit in measured section 07MW007. Note the abundant skeletal grains, including bivalve (b), echinoderm (e), an unidentifiable fine-grained component, lithoclasts (l), and intraclasts (i). Lithoclasts are dominated by subangular to subrounded lime mudstone clasts. Minor primary porosity was filled with calcite cement (c). D. Peloidal-intraclastic pack-grainstone in the lower nodular limestone unit in measured section 07MW007. Peloids (p) and intraclasts (i) dominate this facies that locally contains lime mud. E. Bioclastic-intraclastic packstone from the middle nodular limestone and conglomerate unit. Bivalve fragments (b), intraclasts (i), peloids (p), and bryozoan (z) fragments are illustrated. F. Bioclastic-lithoclastic rudstone in the upper nodular limestone and conglomerate unit in measured section 07MW007. Not the thin-shelled bivalves (b), chert lithoclasts (ch), and pyrite (py). Also note the minor dissolution-related porosity (blue epoxy) around corroded pyrite crystals. 

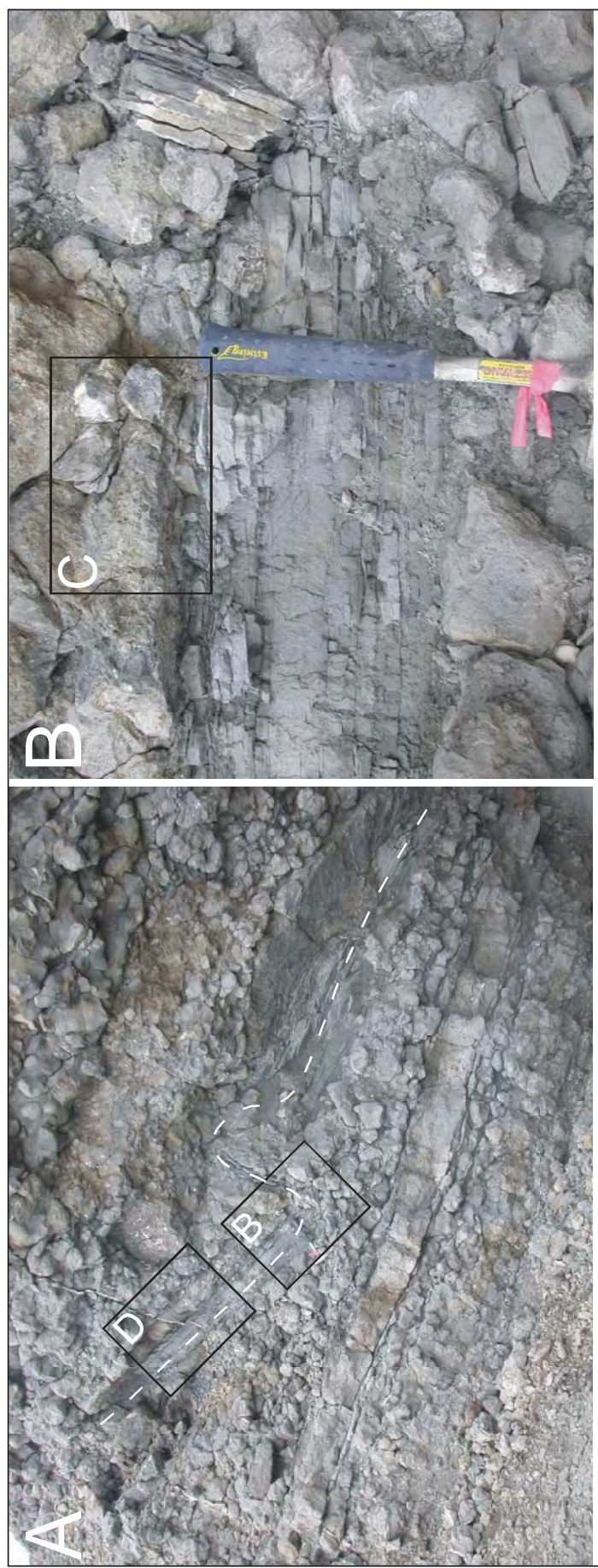
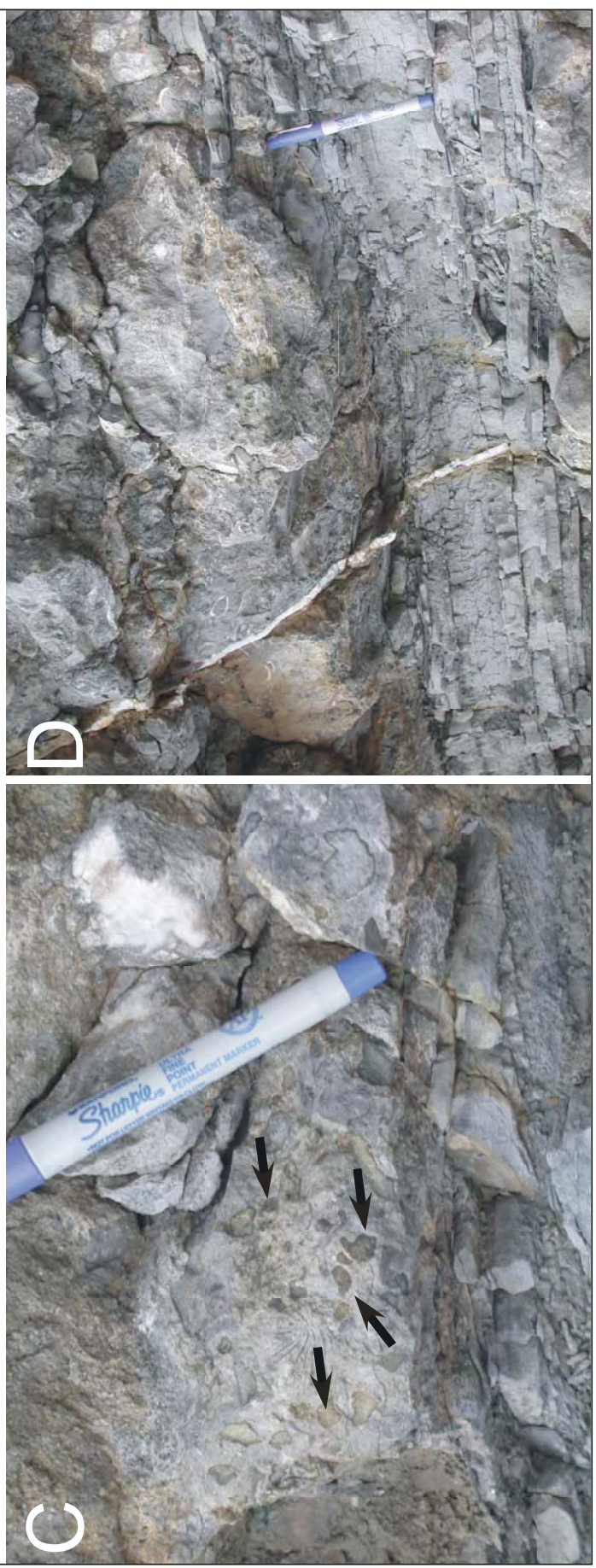

ซี ฐ ฐ

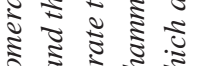

万ั

ठ 屯ै

ปี

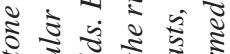

प 항 웡

है ₹ ะ ป ะ

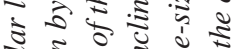

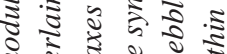

¿ वे है

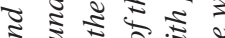

व $0.5 \%$

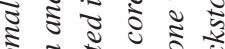

โ ฐ

ชิ

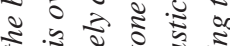

ป क

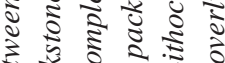

उै के

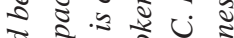

응 สำ

ว

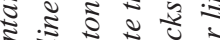

ฐ $\vdots$ :

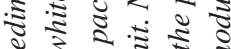

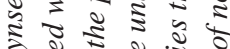

के

ते वे

ปี

- ₹ิ วิ 0

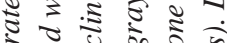

ह छ :

ㄱำ

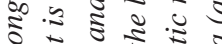

ป ฐ

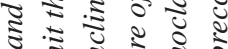

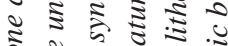

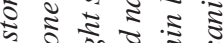

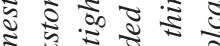

$\exists$ ธี

ప 2 ป

च छे छ

$\approx$ s $\approx$ \&

ป ปิ

क क

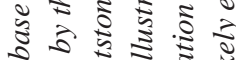

ะ $\overrightarrow{0}:$ :

z

ซ

ธี

ริ ธิธี

$\Xi \approx$ क

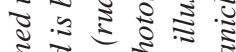

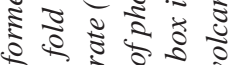

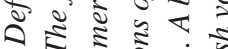

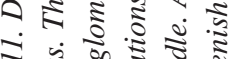

ๆ

空 


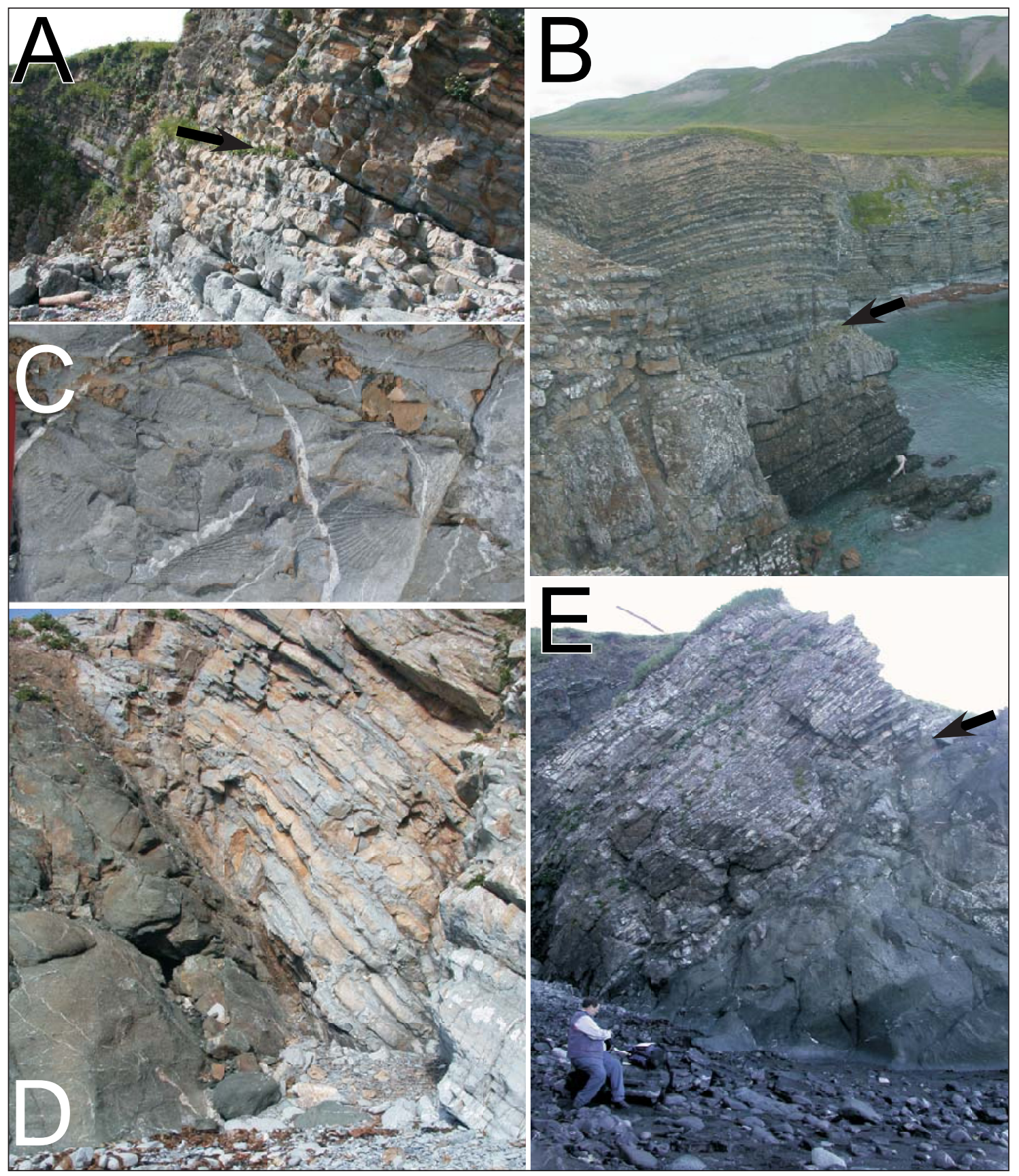

Figure 12. Outcrop photographs of the rhythmically bedded unit. A. Contact (arrow) between the nodular limestone and conglomerate unit and rhythmically bedded unit at locality 07MW007. Note the more nodular character of beds below the contact and more tabular bedding above. B. Contact (arrow) between the nodular limestone and conglomerate unit and the rhythmically bedded unit at the top of measured section 07MW005. The thick-bedded unit just beneath the arrow is the rudstone unit at $31 \mathrm{~m}$ in figure 4. C. Monotid bivalves in the rhythmically bedded unit in measured section 07MW005. D. Fault contact between the greenish volcanic breccias and rhythmically bedded unit at locality 07MW001. The high-angle contact is characterized by several centimeters of fault gouge. E. Rhythmically bedded unit in apparent depositional contact (arrow) with the volcanic breccia unit at locality 07MW001. The outcrop is just to the east of the fault contact illustrated in $D$. 
volcaniclastic breccias (Burk, 1965; Hill, 1979; Wang and others, 1988; Detterman and others, 1996; this study). Similar greenish volcaniclastic breccias are also interbedded with rocks herein categorized as the rhythmically bedded unit on the eastern side of the mouth to Puale Bay (Wang and others, 1988). These dark gray-green volcaniclastic lithologies contain breccia or conglomerate beds up to $50 \mathrm{~cm}$ thick and clasts up to 20 $\mathrm{cm}$ in diameter (Hill, 1979; this study). Sandy beds are 5-30 cm thick with local planar and trough cross-beds. At one locality near Cape Kekurnoi (07MW001) these breccias appear to be in depositional contact with the Kamishak Formation (fig. 12E). Overlying facies of the rhythmically bedded unit contain abundant monotid bivalves and are clearly Upper Triassic in age. However, in cliff exposures farther to the east there appears to be an angular unconformity between the breccias and the overlying Kamishak Formation (Hanson, 1957; Hill, 1979; Blodgett and Sralla, 2008). At a small outcrop (07MW006) farther to the west the greenish volcaniclastics are in fault contact with the overlying Monotis-bearing rhythmically bedded unit (fig. 12D).

\section{SILICEOUS LIMESTONE UNIT}

Dominantly 5-50-cm-thick beds of very hard, medium gray to yellowish weathering (dark gray fresh) planar to locally wavy bedded lime mud/wackestone and fine-grained bioclastic packstone, much of which is siliceous, comprise this unit (figs. 6,7 and 13). There are both a basalt flow and volcaniclastic rocks interbedded with this unit (fig. 2). The siliceous limestone is equivalent to the upper bedded chert unit of Wang and others (1988) and units 9 and 11-14 of Detterman and others (1996; fig. 2). While these rocks are relatively siliceous they are also very carbonate rich and do not display the typical vitreous luster or conchoidal fracture of bedded cherts. They were correctly identified as siliceous limestones by Newton (1983). Siliceous components include radiolaria, sponge spicules, and chalcedony and microcrystalline quartz cement and replacement material (fig. 14). Foraminifera, echinoderm fragments, and calcitized radiolaria are the most common carbonate clasts (fig. 14). The rocks of this unit are commonly fractured and locally brecciated. Calcite fills most fractures and cements some breccias.

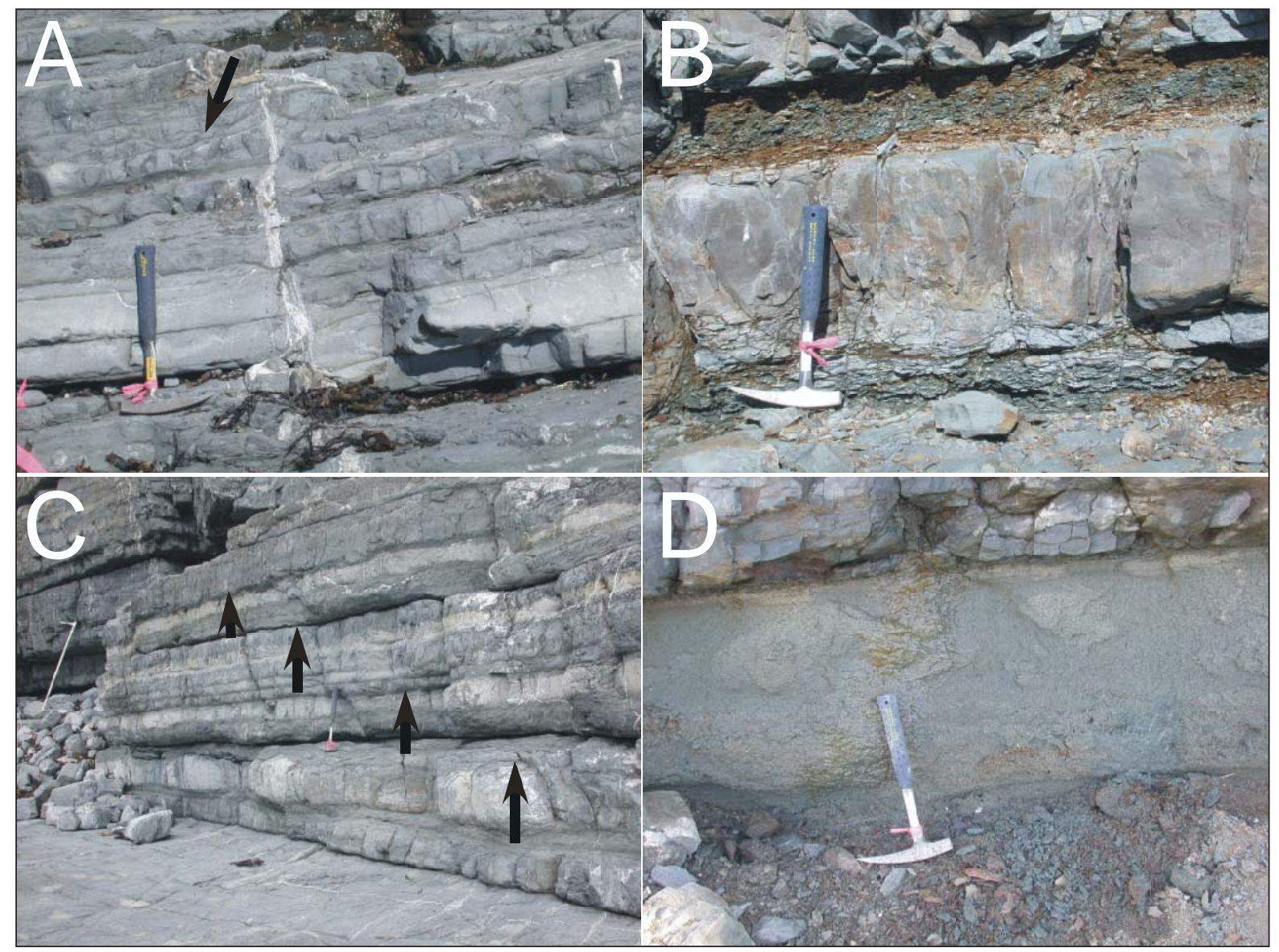

Figure 13. Outcrop photographs of the siliceous limestone unit. A. Thin to medium planar to wavy (arrow) bedded siliceous limestone in measured section 07MW003. B. Interbedded calcareous shale and medium-bedded siliceous limestone in measured section 07MW003. C. Several cycles (arrows) thicken and coarsen upward from mudstone to packstone in measured section 07MW003. D. Medium thick greenish volcaniclastic sandstone bed in measured section 07MW003. 


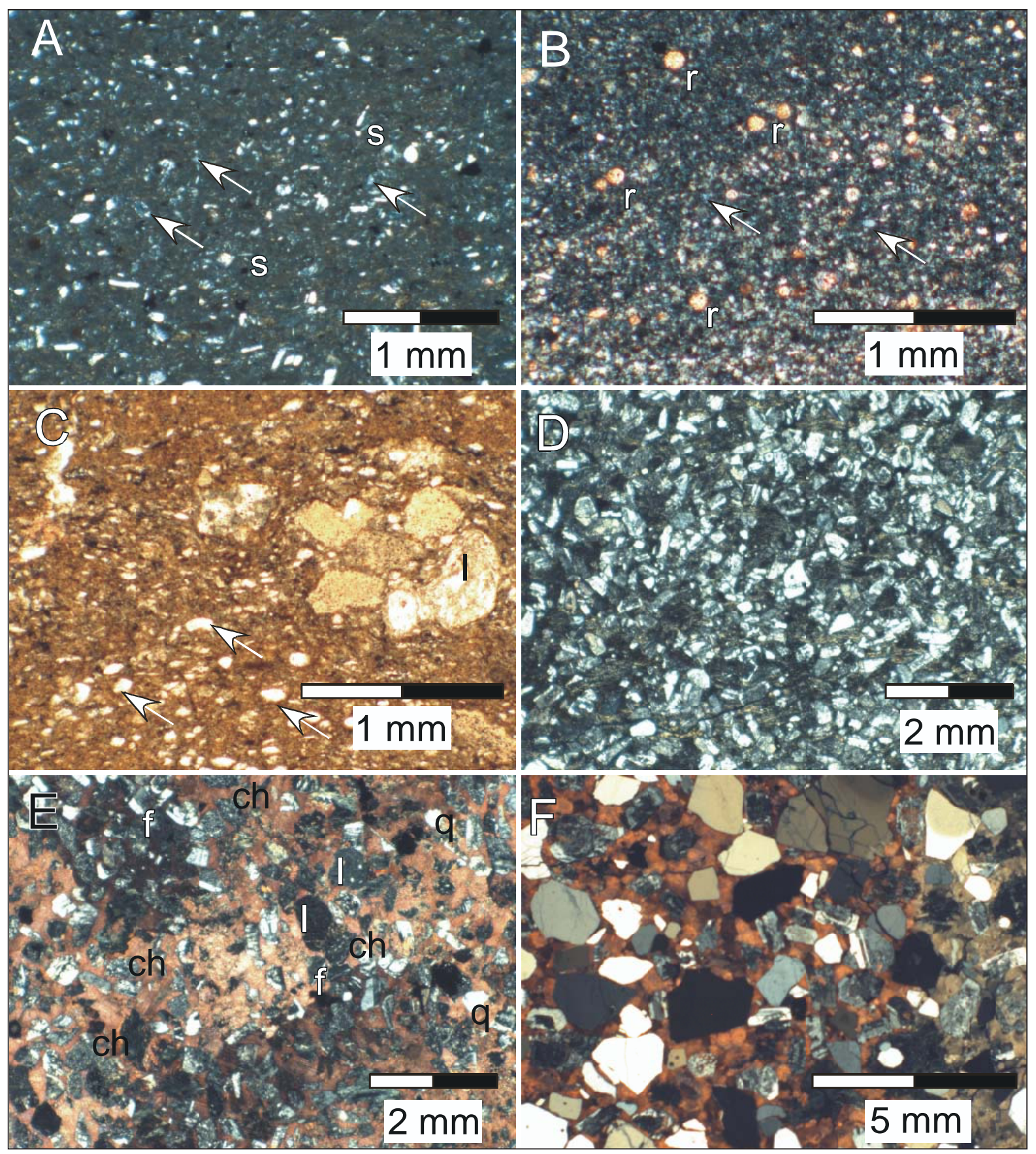

Figure 14. Photomicrographs of the siliceous lime mudstone unit and interbedded volcaniclastic and sandstone facies, Kamishak Formation, measured section 07MW003. All photomicrographs taken under crossed polars except where noted. A. Siliceous lime mudstone with quartz and feldspar silt, siliceous spicules (s), and microcrystalline quartz cement (arrows). B. Siliceous wackestone with calcitized radiolaria ( $r$ ) that are stained red with Alizarin Red-S, fine-grained quartz, and microcrystalline quartz cement (arrows). C. Wackestone with volcaniclastic lithics, individual mineral grains, and glass shards (arrows). Plane-polarized light. D. Volcaniclastic arenite with subangular to subrounded partially altered plagioclase and orthoclase feldspars, quartz, lithics, and minor clay matrix. E. Calcite-cemented quartzo-feldspathic, lithic arenite. Major framework grains include subangular to rounded plagioclase feldspar, quartz, and chert (ch) and lime mud-wackestone lithics (I). Calcite cement is stained red with Alizarin Red-S. F. Calcite-cemented quartz arenite with subangular to rounded, dominantly monocrystalline quartz and minor quantities of plagioclase feldspar and chert lithics. Interstitial calcite cement stained with Alizarin Red-S. 
Beds within this unit commonly thicken and coarsen upward in packages 10 to $50 \mathrm{~cm}$ thick. Planar-bedded units are locally laminated, sharp-based with scours, and grade upward from packstone to mudstone. Some of the wavy-bedded units appear to display hummocky cross stratification with low-angle laminated wackestone that downcuts into underlying mudstone. Most facies within the unit are highly bioturbated with abundant Rosellia rotatus, Cylindrichnus isp., and Thallasinoides isp., common Chondrites isp., and a variety of other traces described in more detail in the next section (fig. 15).

The above lithology is intercalated with several other medium to dark gray-brown weathering, thin-bedded facies including argillaceous or silty mud/wackestone and calcareous siltstone and gray-green weathering sandstone (figs. 13, 14). These interbedded facies are usually recessive. The sandstone interbeds are commonly sharp based, with small-scale basal scours, and are normally graded (fig. 13). Sandstones include volcaniclastic arenites and quartzo-feldspathic lithic arenites with abundant plagioclase feldspar, quartz, and chert and lime mud-wackestone lithics (fig. 14). Thickening and coarsening upward packages are most commonly made up of thin-bedded argillaceous or silty mudstone or calcareous siltstone and medium-bedded lime mud/ wackestone (fig. 13).

The siliceous limestone unit represents the upper portion of the Upper Triassic Kamishak Formation and is interbedded with contorted and faulted limestones (Wang and others, 1988; Detterman and others, 1996) that appear to be similar lithologically. Where siliceous limestones are interbedded with silty mud/wackestone or calcareous siltstone the unit resembles the rhythmically bedded unit; however, thick successions of homogenous siliceous limestone and thin interbedded sandstones set this unit apart.

\section{ICHNOLOGY}

Trace fossils are very abundant and diverse in the siliceous limestone unit (table 2). Ichnofossils were not readily apparent in the other units of the Kamishak Formation although the texture of the nodular limestones could have been influenced by bioturbation (Tucker and Wright, 1990; Flügel, 2004).

Figure 15. Outcrop photographs of trace fossils and bioturbation in the siliceous limestone unit. A. Two truncation/colonization (dashed and dotted lines) surfaces are apparent in this photo. Below the first surface (dashed line) is a suite of Rosellia socialis developed in a light gray wackestone. These suspension-feeder trace fossils indicate fully marine, typically lower shoreface to offshore transition conditions. Re-burrowing of a Rosellia mud ball, by Palaeophycus and Planolites (or possibly Chondrites) is evident within the dashed polygon. Above the truncation surface are two graded beds. The first comprises laminated fine-grained sediments that are relatively unbioturbated with a mudstone at the top colonized by a low-density Planolites community. A Chondrites-Cylindrichnus suite with a distinctive light-grey infill more extensively colonizes the second graded bed. These are both deposit feeding traces and indicate a lack of food delivered in suspension thus a deeper environment (for example, distal offshore or deeper). A Thalassinoides suite with a distinctive yellow-grey infill overprints this suite. Thalassinoides burrow walls are sharp, suggesting they were developed in a firm substrate. Based on color, the burrow-fill of the Chondrites-Cylindrichnus suite appear genetically linked to the sediments above the second truncation surface and suggest post-truncation colonization of this bedding surface. The Thalassinoides infill suggests later colonization and may indicate a lacuna (Glossifungites) surface above. B. This photo documents three similar cycles that coarsen upward from a thin darker-colored mudstone to thicker-bedded lighter-colored wackestone. All three cycles display similar colonization patterns dominated by suspension-feeding organisms (such as Cylindrichnus, Anchonichnus) but the basal mudstones likely represent lower sedimentation rates and are colonized by a higher degree of deposit-feeding organisms. C. This bedding surface illustrates extensive colonization by an organism forming mud-lined burrows. Superficially, these burrows appear to belong to Thalassinoides, however lack of continuity, funnel shapes instead of Y-branches and concentric fill in some burrows (see arrow Rot) suggest these belong to Rosellia, although these specimens appear to be oriented oblique to bedding rather than vertical, which is typical for Rosellia. D. Photograph illustrates a Zoophycos-like burrow that deviates from the archetype in that it does not appear to revolve around a central shaft. It instead forms a series of branching lobes that, in isolation, exhibit morphology approaching that of Rhizocorallium. Definitive identification would require a more complete specimen. From close inspection an open outer tube is visible on the side of one of the lobes (arrow), indicating a J-shaped, causative burrow in the sense of Wetzel and Werner (1980); this indicates relatively well oxygenated conditions. E. Photograph illustrates Planolites isp. The burrow density appears highest within muddy facies and suggests exploitation of this as a food resource. Some of these burrows show branching and are transitional to a Chondrites-like form. F. The main burrow illustrated is Chondrites, likely formed by a single organism. Note the circular and mud-filled burrows suggesting an open burrow system filled from above. Close inspection reveals sediments were previously bioturbated by Palaeophycus. G. This incomplete specimen is likely Rhizocorallium, a causative burrow that is best developed along the top edge. Spreitenate fill is visible throughout. This may be part of a multi-lobed structure similar to that illustrated in D. H. Photograph illustrates a bedding plane similar to that in C. Many of the burrows appear to be Rosellia rotatus. The large, linear burrow in the center of the photograph is either Thalassinoides or Planolites. 


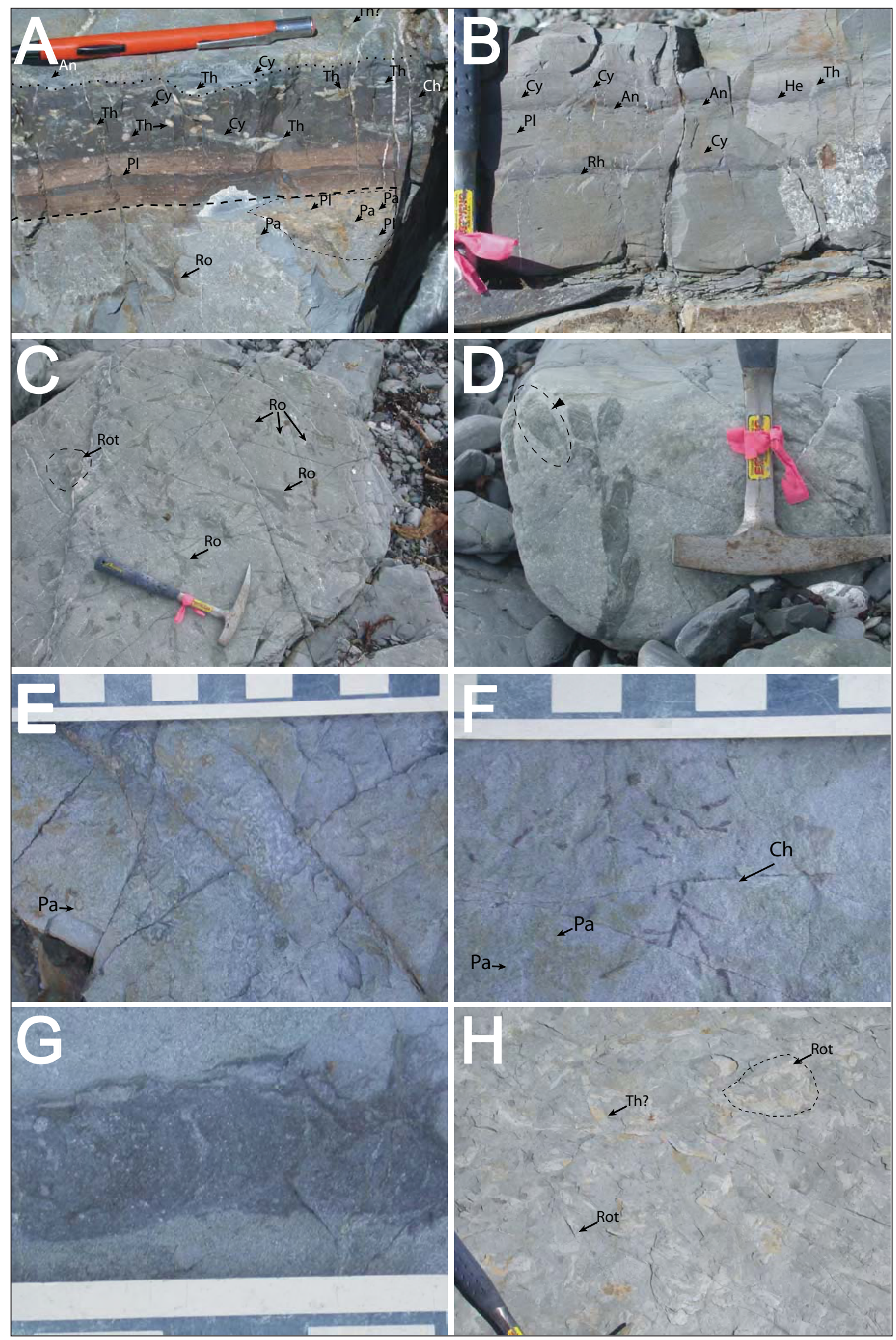


Thin to medium beds of light gray mud/wackestones in the siliceous limestone unit display two different common ichnofaunal associations. One consists mainly of Rosellia rotatus, Rosellia socialis, and Thalassinoides isp.; Planolites, Palaeophycus, Cylindrichnus, and Chondrites dominate another (table 2; fig. 15). There are examples of superposition of ichnocoenese or multiple colonization events with traces like Rosellia socialis reburrowed by Palaeophycus and Planolites, and Chondrites and Cylindrichnus overprinted by Thalassinoides (table 2; fig. 15). These patterns are likely controlled by variations in the type of substrate, rates of sedimentation including delivery of suspended organic matter, and redox conditions. Traces such as Rosellia socialis and those resembling Zoophycos or Rhizocorallium are indicative of well-oxygenated conditions while Chondrites is commonly interpreted to indicate a dysoxic environment (table 2; fig. 15). Associations of Chondrites-Cylindrichnus are mainly deposit feeding traces indicating relatively distal offshore environments while those like Rosellia socialis were produced by suspension feeders near the shoreface to offshore transition.

\section{DEPOSITIONAL INTERPRETATIONS BIOSTROMAL UNIT}

While some of the biostromal unit can accurately be classified as a packed biomicrite or wackestone (Wang and others 1988), this categorization is misleading in the sense that these facies would normally indicate deposition in relatively calm waters where carbonate mud accumulated under little influence from waves or currents. As noted by Wang and others (1988, p. 1468), the lower part of the section represents deposition in a relatively shallow water carbonate environment based on the presence of "calcareous green algae, meteoric diagenesis resulting in dissolution of aragonitic grains, lack of any pelagic components, and presence of colonial scleractinian corals with characteristics of modern shallow-water hermatypic corals" (fig. 8). The biostromal unit does not contain boundstone facies or any other evidence of rigid reefal framework. The chaotic arrangement of bioclasts including the relatively large overturned coral colonies (fig. 8C, D) indicates that this unit was deposited either in an area of some wave or

Table 2. Trace fossils identified from the siliceous limestone unit. Table lists ichnotaxa, abbreviations (see fig. 15), and descriptions of different trace fossils from the siliceous limestone unit.

\begin{tabular}{|c|c|c|}
\hline $\begin{array}{r}\text { Ichnotaxa } \\
\text { Anchonichnus isp. }\end{array}$ & $\begin{array}{l}\text { Abbreviation } \\
\text { An }\end{array}$ & $\begin{array}{l}\quad \text { Description } \\
\text { Small, smooth, irregularly meandering trails, usually with a } \\
\text { dark core surrounded by a lighter halo; not limited to bedding } \\
\text { planes }\end{array}$ \\
\hline Chondrites isp. & $\mathrm{Ch}$ & $\begin{array}{l}\text { Complex, dendritic system of regularly branching, non- } \\
\text { interpenetrating tunnels of uniform diameter. Commonly } \\
\text { interpreted as indicative of dysoxic substrate conditions }\end{array}$ \\
\hline Cylindrichnus isp. & $\mathrm{Cy}$ & $\begin{array}{l}\text { Vertical or inclined, straight or weakly curved, unbranched } \\
\text { tubes with an exterior hall of multiple concentric layers }\end{array}$ \\
\hline Palaeophycus tubularis & $\mathrm{Pa}$ & Smooth, unornamented, and thinly lined burrows \\
\hline Planolites montanus & $\mathrm{Pl}$ & $\begin{array}{l}\text { Smooth, unlined, and unbranched burrows, straight to curved. } \\
\text { Burrow fill differs in color and/or texture from the host rock }\end{array}$ \\
\hline Rosellia socialis & Ro & $\begin{array}{l}\text { Gently curved lower burrow with upper funnel-shaped opening. } \\
\text { Back-filled shaft and lower funnel. Indicative of well- } \\
\text { oxygenated, fully marine environment characteristic of the } \\
\text { proximal Cruziana ichnofacies (Eckdale and others, 1984) }\end{array}$ \\
\hline Rosellia rotatus & Rot & $\begin{array}{l}\text { Vertical or inclined, straight or curved cylindrical tube that is } \\
\text { enlarged to a funnel shape in upper parts; the funnel comprises } \\
\text { finer-grained sediment with intensively developed, crescentric } \\
\text { backfill structures formed by rotary movements of the tube } \\
\text { within the funnel }\end{array}$ \\
\hline Thalassinoides isp. & Th & $\begin{array}{l}\text { Cylindrical burrows forming three-dimensional branching } \\
\text { systems comprising horizontal networks connected to the } \\
\text { surface by vertical shafts. }\end{array}$ \\
\hline cf. Zoophycos & Zo & Spreitenate burrow \\
\hline
\end{tabular}


current agitation or possibly on the slope. The abundant shallow water fauna argues against a slope environment but deposition on a storm-influenced middle to outer carbonate ramp could explain the juxtaposition of muddy facies and transported bioclasts.

Wang and others (1988) document dissolved aragonitic grains and Sralla and Blodgett (2007) observed coarsely crystalline dolostones and collapse breccias in the lower portion of the biostromal unit that they attributed to an episode of subaerial exposure and meteoric diagenesis prior to deposition of the upper portion of the unit. Unfortunately, the lower $35 \mathrm{~m}$ of this unit were inaccessible due to high tide while we were conducting our fieldwork at this locality and we were unable to examine that part of the section. It should be noted that more recent research indicates that submarine dissolution of aragonitic grains is much more common than previously believed (Melim and others, 1995; 2002) and it would be worth re-examining the lower portion of the biostromal unit in this light.

\section{NODULAR LIMESTONE AND CAR- BONATE CONGLOMERATE}

The nodular limestone and carbonate conglomerate unit is entirely equivalent to the carbonate conglomerate of Wang and others (1988) and Detterman and others (1996). The lower part of this unit is conglomeratic as described above. However, the complex underlying deformed package indicates that the conglomerate was most likely produced by synsedimentary deformation and soft sediment folding that caused mass movement of partially lithified nodules (fig. 11). The inclusion of greenish volcanic clasts within the deformed interval implies that greenish volcanic breccias were locally exposed to erosion and redeposition during deposition of the lowermost nodular limestone and carbonate conglomerate unit. The unit becomes less conglomeratic upsection at 07MW005 and displays a nodular texture (fig. 11). At section 07MW007, nodular facies are interbedded at $\mathrm{m}$-scale with carbonate rudstones and floatstones with abundant lithoclasts and bioclasts (figs. 5, 9).

Nodular textures are in part produced by patchy submarine cementation and burrowing, followed by differential compaction, transport and redeposition of partly cemented limestones, or shear processes affecting limestone-shale alternations (Tucker and Wright, 1990; Flügel, 2004). Nodules commonly develop during early diagenesis via anaerobic, bacterial catabolysis of organic matter that results in carbonate cementation (Gluyas, 1984). Other researchers cite the influence of pressure solution on the final form of the nodules (Möller and Kvingan, 1988). Nodular facies are quite common in carbonate slope and outer carbonate ramp environments including examples in the Ordovician, Silurian (Gluyas, 1984; Möller and Kvingan, 1988), Devonian (Whalen and others, 2000), Carboniferous (Gluyas, 1984; Dumoulin and others, 2008), and Jurassic (Gluyas, 1984). A carbonate slope interpretation is also supported by the deformation that likely resulted from gravitational mass movement during deposition and loading of the overlying nodular limestone. The indication of slope deposition in the nodular limestone unit implies that the Kamishak carbonate ramp was distally steepened, at least during deposition of the lower part of the succession.

\section{RHYTHMICALLY BEDDED UNIT}

The laminated and thin-bedded character (fig. 12) and the lack of any sedimentary structures indicative of wave or current energy indicate that the rhythmically bedded unit was deposited in a relatively quiet water setting below storm wavebase. This interpretation is supported by the presence of abundant, well-preserved, thin-shelled Monotid bivalves (fig. 12C). On the basis of its stratigraphic position above the nodular limestone unit, it would appear that this unit was deposited in more seaward slope or basinal environments. The rhythmically bedded unit records progressive deepening over the slope environment indicated by the underlying nodular limestone.

The greenish volcanic breccia unit is clearly interbedded with the rhythmically bedded unit near the mouth of Puale Bay (Wang and others, 1988; Detterman and others, 1996). The stratigraphic relationships to the east, near Cape Kekurnoi, are less clear but the volcanic breccias outcrop below Monotis-bearing limestones that are clearly Upper Triassic in age although locally the contact is faulted (Hall, 1979; this study; fig. 11D) or an angular unconformity (Hanson, 1957; Hall, 1979; Blodgett and Sralla, 2008).

Hall (1979), Wang and others (1988), and Detterman and others (1996) considered the volcaniclastic rocks to be Triassic in age, and interbedded with limestones of the Kamishak Formation. Hanson (1957) inferred that they are Permian in age, underlying an angular unconformity with the Triassic limestones, an interpretation adopted by Blodgett and Sralla (2008). Greenish clasts within various Kamishak Formation units imply that these volcaniclastic breccias were, at least in part, exposed throughout deposition of much of the Kamishak.

These rocks were equated with the Shuyak Formation on Kodiak Island where Upper Triassic fossils were reported (Burk, 1965; Moore, 1967; Hill, 1979). Alternatively they were interpreted to be equivalent to the Triassic Cottonwood Bay Greenstone but no direct evidence for this age, from the Puale Bay area, was cited (Detterman and Reed, 1980; Detterman and others, 1996; Wilson and others, 1999). The Permian age is based on 
middle Permian fossils, identified by Jeffords in Hanson (1957), from a limestone on a small island approximately $5.5 \mathrm{~km}$ to the southwest of the rocks exposed on the mainland near Cape Kekurnoi. The stratigraphic context of the limestone is uncertain. Nowhere is the Permian limestone observed as interbedded with the volcanics and there is no direct evidence of age cited from the volcaniclastic or volcanic rocks themselves (Hanson, 1957; Blodgett and Sralla, 2008). Hill (1979) draws a distinction between the volcaniclastic rocks on the islands that contain reddish andesitic clasts from those on the mainland that are dominated by greenish basaltic clasts. The age of these volcaniclastic rocks thus remains in question although Blodgett and Sralla (2008) and Blodgett (this volume) concur with Hanson's (1957) Permian age assignment and Decker (this volume, figs. 3 and 4) tentatively depicts the volcaniclastic rocks as probably Permian in age. Based on the stratigraphic relationships observed during this study and previously published work the more parsimonious interpretation seems to be that these volcaniclastic rocks are Upper Triassic in age and interbedded with the Kamishak Formation (Hill, 1979; Wang and others, 1988; Detterman and others, 1996).

\section{SILICEOUS LIMESTONE UNIT}

The siliceous limestone unit displays wavy bedding surfaces and potentially hummocky cross stratification (HCS) that would indicate deposition under the influence of storm waves. The scours and normal grading of packstone to mudstone packages and some of the interbedded sandstones (figs. 13, 14) indicates unidirectional traction transport in a waning current. The lack of other abundant sedimentary structures implies that this unit was largely deposited below fairweather wave base. The graded beds and HCS are likely storm deposits and the depositional setting would have been above storm wave base in a lower shoreface to offshore or outer carbonate ramp environment. This interpretation is supported by ichnofossils, such as Rosellia socialis, which are commonly interpreted as indicators of similar environments (fig. 15). Sedimentologic and ichnofauna indicate that the unit fluctuates between somewhat deeper offshore and shallower lower shoreface settings recorded in numerous thickening and coarsening upward cycles. The sedimentologic and ichnofabric data imply that the siliceous limestone unit records a general shoaling compared to the slope and possibly basinal units in the underlying nodular limestone and conglomerate and rhythmically bedded units. The interbedded sandstones with plagioclase and greenish volcanic lithic grains indicate that greenish volcanic breccias were locally exposed to erosion and redeposition during deposition of the siliceous limestone unit. This unit makes up the bulk of the Kamishak Formation and more detailed stratigraphic data throughout the unit will be necessary to better define its overall depositional history.

\section{REGIONAL PALEOGEOGRAPHY}

The facies of the Kamishak Formation record deposition on a carbonate ramp in middle to outer ramp and ramp slope/basin environments. The biostromal unit is interpreted as a middle to outer ramp deposit, the nodular limestone and conglomerate unit as upper slope facies, the rhythmically bedded unit as slope or basin deposits, and the siliceous limestone as indicating an outer carbonate ramp environment. The presence of slope-deposited units indicates that the carbonate ramp was distally steepened at least through deposition of the nodular limestone and conglomerate unit. It is unclear whether this distally steepened profile remained during deposition of the rhythmically bedded and siliceous limestone units.

The basal depositional contact of the Kamishak Formation is not exposed where the lowermost Kamishak crops out (locality 07MW005). The exposure documented at locality 07MW001 records the onlap of the Kamishak onto an erosional surface atop the volcaniclastic rocks. Lithologically these onlapping Kamishak facies appear similar to the siliceous limestone unit. Thin greenish sandstone beds are found in the Kamishak exposed above the underlying greenstone at 07MW001 and similar sandstones were documented in section 07MW003 and 4 and greenish clasts were noted in the deformed unit at the base of the nodular conglomerate in section 07MW005. This would indicate that the underlying volcaniclastic unit formed a topographic high that was at least partly exposed to subaerial or submarine erosion during deposition of much of the Kamishak. Units overlying the biostromal unit all indicate deeper water environments indicating active subsidence and/or relative sea level rise. However, the underlying volcaniclastics served a local source of greenish sand and clasts through deposition of the siliceous limestone unit. This implies that the volcanic/volcaniclastic edifice remained partially emergent or was locally uplifted during deposition of the Kamishak. The common fault contact of the Kamishak with the underlying volcaniclastics and the deformed unit between the biostromal and nodular limestone and conglomerate units supports the interpretation that the rocks were undergoing active Upper Triassic synsedimentary tectonic deformation.

\section{SOURCE ROCK POTENTIAL}

Organic geochemical analyses conducted included total organic carbon (TOC) and Rock-Eval pyrolysis. TOC is the sum of the total kerogen (insoluble, disseminated organic matter) and bitumen (soluble, disseminated organic matter) in a rock (Waples, 1981) and the con- 
centration is directly related to source-rock quality. Rock-Eval is a method used to determine the types of kerogen and the quality of the organic matter that relate to the source rock potential (Peters, 1986). Rock-Eval analyses measure several parameters other than TOC: $\mathrm{S} 1, \mathrm{~S} 2$, and $\mathrm{S} 3$ are parameters measured with respect to values obtained from one gram of rock. S1 indicates milligrams of hydrocarbons that can be thermally distilled; $\mathrm{S} 2$ represents milligrams of hydrocarbons generated by pyrolytic degradation of kerogen; and S3 indicates milligrams of CO2 generated during pyrolysis (Peters, 1986). Tmax is the temperature at which the greatest amounts of S2 hydrocarbons are generated. Potential petroleum source rocks will have at least 0.5 percent TOC and very good source rocks are characterized by $>2$ percent (Peters, 1986). Peters (1986) and Espitalié and others (1985) also use the S2 value to gain insight into source rock potential with values of 5 to $10 \mathrm{mg}$ hydrocarbon $/ \mathrm{g}$ rock indicating good to very good potential. Tmax and the production index (PI) can be used to estimate thermal maturity, with Tmax and PI values less than 435C and 0.1 respectively, indicating immature rocks (Peters, 1986). Espitalié and others (1977) pioneered the use of Rock-Eval data to evaluate types of kerogen similar to atomic $\mathrm{H} / \mathrm{C}$ vs. $\mathrm{O} / \mathrm{C}$ diagrams. They defined and cross plotted the hydrogen index $(\mathrm{HI}=[\mathrm{S} 2 / \mathrm{TOC}] \times 100)$ and oxygen index $(\mathrm{OI}=[\mathrm{S} 3 / \mathrm{TOC}] \times 100$ to describe the types of organic matter within samples.

The following summarizes the organic geochemical data for Kamishak Formation samples. For a more detailed analysis of the organic geochemistry of Kamishak and other Bristol Bay samples see Decker (this report). The mean TOC value of all Kamishak Formation samples collected was 1.52 percent with a high of 5.28 percent (table 3). Eighteen of 31 Kamishak samples had TOC values $>1.0$ percent, indicating that many of the lithofacies are potential source rocks; only 10 samples had $>2$ percent TOC, indicating very good source potential (table 3). The best source rocks appear to be within the rhythmically bedded and siliceous limestone units (table 3). The mean S2 for all Kamishak samples is $8.41 \mathrm{mg} \mathrm{HC} / \mathrm{g}$ with a range of 0.05 to 39.87 , indicating a wide range of source potential (table 3 ). Tmax measurements from samples with $\mathrm{S} 2$ values of $<0.2 \mathrm{mg} \mathrm{HC} / \mathrm{g}$ are often inaccurate (Peters, 1986) and were omitted when calculating the average Tmax of $434^{\circ} \mathrm{C}$ for Kamishak samples (table 3 ). Mature source rocks generally have Tmax values between 435 and $470^{\circ} \mathrm{C}$ (Peters, 1986) so the Kamishak appears to be near the boundary of immature and mature source rocks. This is supported by the relatively low PI values, averaging 0.09 . Values derived from Rock-Eval can be affected by the types of included organic matter or rock-matrix adsorption of hydrocarbons liberated by pyrolysis and should be verified by other methods such as vitrinite reflectance or gas chromatography (Katz, 1983; Espitalié and others, 1985; Peters, 1986; Langford and Blanc-Valleron, 1990). HI values range from 8 to 785 (mean 380) and OI values range from 8 to 806 (mean of 108). Kamishak Formation samples display a wide distribution on a van Krevelen diagram, indicating that kerogen ranges from Type 1 (very oil prone) to Type III (gas prone) (fig. 16). Average values plot as Type II (oil prone) kerogen. These data support previous organic geochemical analyses reported in Wang and others (1988).

\section{RESERVOIR POTENTIAL}

Very few of the facies examined during this study contain any significant porosity that would indicate reservoir rock potential. The only facies that appear to have some macroscale porosity occur within the conglomerates (rudstones and floatstones) of the nodular limestone and conglomerate unit. At section 07MW007, centimeter-scale vugs occur within a rudstone bed near the base section and millimeter-scale vugs were documented in a rudstone unit several meters above (fig. 9). This indicates meter-scale units with some reservoir potential but the lateral extent of these units was not documented. At the microscopic scale there is almost no observable primary and very minor secondary porosity in the form of unfilled fractures (fig. 10A) and small dissolution vugs associated with pyrite diagenesis (fig. 10F). Dolomite observed in the biostromal unit was relatively fine crystalline replacement dolomite and was not associated with secondary porosity. Some fractures within the biostromal unit appeared open in outcrop but all fractures observed in thin section were filled with calcite. More detailed analyses would be necessary to determine the timing and mode of dolomitization in these rocks. Sralla and Blodgett (2007) report porous sucrosic dolomite from lower levels within the biostromal unit near section 07MW007 and from subsurface wells but that texture was not observed in outcrop samples or thin sections examined for this study. While this outcrop analysis does not point to very good reservoir potential, subsurface data from the Kamishak Formation indicates significant permeability (average 15.5 millidarcies), and reservoir quality rocks in the nearby subsurface (Sralla and Blodgett, 2007; Blodgett and Sralla, 2008).

\section{CONCLUSIONS}

The Upper Triassic portion of the Kamishak Formation was examined for this study to lend insight into the lithofacies, stratigraphy, depositional environments, and source and reservoir rock potential. Four partial stratigraphic sections were measured and samples were collected for thin section, TOC, Rock-Eval pyrolysis, and/or reservoir seal analyses. Stratigraphic and petrographic analyses identified four lithostratigraphic units 
including a biostromal, nodular limestone and conglomerate, rhythmically bedded, and siliceous limestone unit. Bedding characteristics, sedimentary structures, and trace fossils indicate that the biostromal unit was deposited on a middle to outer carbonate ramp possibly above fair weather wave base. The nodular limestone and carbonate conglomerate was, as Wang and others (1988) interpreted, likely deposited on a distally steepened slope of the carbonate ramp. The folded unit, identified at the base of the nodular limestone and conglomerate, implies that the overlying carbonate conglomerate was formed through synsedimentary deformation and downslope movement. The rhythmically bedded unit displays no evidence of wave or current transport and implies deposition below storm wave base, likely in a deep slope or basin environment. The overlying siliceous limestone unit records a general shoaling and deposition in relatively deep offshore to offshore-shoreface transition environments on an outer carbonate ramp. Trace fossil assemblages in the siliceous limestone support this interpretation.

The base of the Kamishak Formation is commonly a fault contact (Wang and others, 1988; Detterman and others, 1996) but locally the unit appears to onlap an angular unconformity atop the underlying greenish volcaniclastic unit (Hanson, 1957; Blodgett and Sralla,

Table 3. Organic geochemical data for Kamishak Formation samples.

\begin{tabular}{|c|c|c|c|c|c|c|c|c|c|c|}
\hline \multirow[b]{2}{*}{ Latitude } & \multirow[b]{2}{*}{ Longitude } & \multirow{2}{*}{$\begin{array}{c}\text { TOC } \\
\text { Wt. } \\
\% \\
\end{array}$} & \multirow{2}{*}{$\begin{array}{c}\mathrm{S} 1 \\
\mathrm{mg} / \mathrm{g}\end{array}$} & \multirow{2}{*}{$\begin{array}{c}\mathrm{S} 2 \\
\mathrm{mg} / \mathrm{g}\end{array}$} & \multirow{2}{*}{$\frac{\mathrm{S} 3}{\mathrm{mg} / \mathrm{g}}$} & \multirow[b]{2}{*}{ Tmax } & \multirow[b]{2}{*}{ HI } & \multirow{2}{*}{ OI } & \multirow{2}{*}{$\begin{array}{c}\text { S1/ } \\
\text { TOC }\end{array}$} & \multirow[b]{2}{*}{ PI } \\
\hline & & & & & & & & & & \\
\hline 57.71453 & -155.36455 & 1.85 & 1.04 & 9.60 & 0.48 & 435 & 519 & 26 & 56 & 0.10 \\
\hline 57.71367 & -155.362 & 0.07 & 0.04 & 0.17 & 0.27 & 439 & 250 & 395 & 56 & 0.18 \\
\hline 57.71445 & -155.36302 & 0.60 & 0.16 & 1.23 & 0.34 & 433 & 206 & 57 & 27 & 0.11 \\
\hline 57.71844 & -155.39035 & 3.40 & 1.97 & 26.69 & 0.39 & 434 & 785 & 11 & 58 & 0.07 \\
\hline 57.71819 & -155.39078 & 2.95 & 1.72 & 22.05 & 0.42 & 434 & 746 & 14 & 58 & 0.07 \\
\hline 57.71493 & -155.36719 & 2.51 & 1.36 & 15.33 & 0.46 & 436 & 611 & 18 & 54 & 0.08 \\
\hline 57.71493 & -155.36719 & 2.53 & 1.60 & 15.27 & 0.46 & 433 & 604 & 18 & 63 & 0.09 \\
\hline 57.71499 & -155.36575 & 1.20 & 0.34 & 5.41 & 0.29 & 434 & 450 & 24 & 28 & 0.06 \\
\hline 57.71367 & -155.362 & 0.09 & 0.02 & 0.18 & 0.25 & 442 & 207 & 285 & 22 & 0.10 \\
\hline 57.7137 & -155.36179 & 0.10 & 0.01 & 0.05 & 0.22 & 469 & 50 & 221 & 10 & 0.16 \\
\hline 57.72574 & -155.33485 & 2.41 & 0.73 & 8.12 & 0.37 & 436 & 337 & 15 & 30 & 0.08 \\
\hline 57.72586 & -155.3353 & 2.98 & 0.93 & 21.22 & 0.32 & 435 & 713 & 11 & 31 & 0.04 \\
\hline 57.72554 & -155.33755 & 5.28 & 3.23 & 39.87 & 0.41 & 440 & 756 & 8 & 61 & 0.07 \\
\hline 57.72556 & -155.33821 & 4.83 & 2.10 & 36.55 & 0.51 & 436 & 756 & 11 & 43 & 0.05 \\
\hline 57.72556 & -155.33821 & 1.74 & 0.76 & 12.54 & 0.48 & 439 & 720 & 27 & 43 & 0.06 \\
\hline 57.71477 & -155.36534 & 2.13 & 1.07 & 12.55 & 0.40 & 435 & 589 & 19 & 50 & 0.08 \\
\hline 57.71412 & -155.36342 & 0.44 & 0.12 & 0.78 & 0.27 & 429 & 176 & 61 & 26 & 0.13 \\
\hline 57.72483 & -155.34138 & 0.04 & 0.01 & 0.08 & 0.29 & 460 & 222 & 806 & 27 & 0.11 \\
\hline 57.72523 & -155.342 & 0.43 & 0.10 & 0.85 & 0.50 & 432 & 196 & 115 & 24 & 0.11 \\
\hline 57.72499 & -155.34346 & 1.20 & 0.54 & 3.98 & 0.22 & 431 & 331 & 18 & 45 & 0.12 \\
\hline 57.72488 & -155.34433 & 2.06 & 0.56 & 7.25 & 0.69 & 430 & 352 & 33 & 27 & 0.07 \\
\hline 57.7201 & -155.38948 & 1.32 & 0.32 & 5.62 & 0.26 & 433 & 425 & 20 & 24 & 0.05 \\
\hline 57.7201 & -155.38948 & 0.62 & 0.17 & 1.79 & 0.27 & 436 & 290 & 44 & 27 & 0.09 \\
\hline 57.7201 & -155.38948 & 1.81 & 0.20 & 3.64 & 0.18 & 433 & 201 & 10 & 11 & 0.05 \\
\hline 57.7201 & -155.38948 & 1.08 & 0.18 & 3.39 & 0.22 & 434 & 314 & 20 & 16 & 0.05 \\
\hline 57.7201 & -155.38948 & 0.12 & 0.01 & 0.09 & 0.29 & 433 & 76 & 244 & 8 & 0.10 \\
\hline 57.7201 & -155.38948 & 0.26 & 0.02 & 0.32 & 0.29 & 431 & 125 & 113 & 8 & 0.06 \\
\hline 57.7201 & -155.38948 & 0.14 & 0.01 & 0.11 & 0.22 & 425 & 77 & 154 & 7 & 0.08 \\
\hline 57.7201 & -155.38948 & 1.22 & 0.33 & 5.34 & 0.26 & 432 & 437 & 21 & 27 & 0.06 \\
\hline 57.7201 & -155.38948 & 0.29 & 0.07 & 0.43 & 0.24 & 433 & 150 & 84 & 23 & 0.14 \\
\hline 57.725511 & -155.34152 & 0.07 & 0.02 & 0.07 & 0.33 & 435 & 97 & 458 & 27 & 0.22 \\
\hline
\end{tabular}




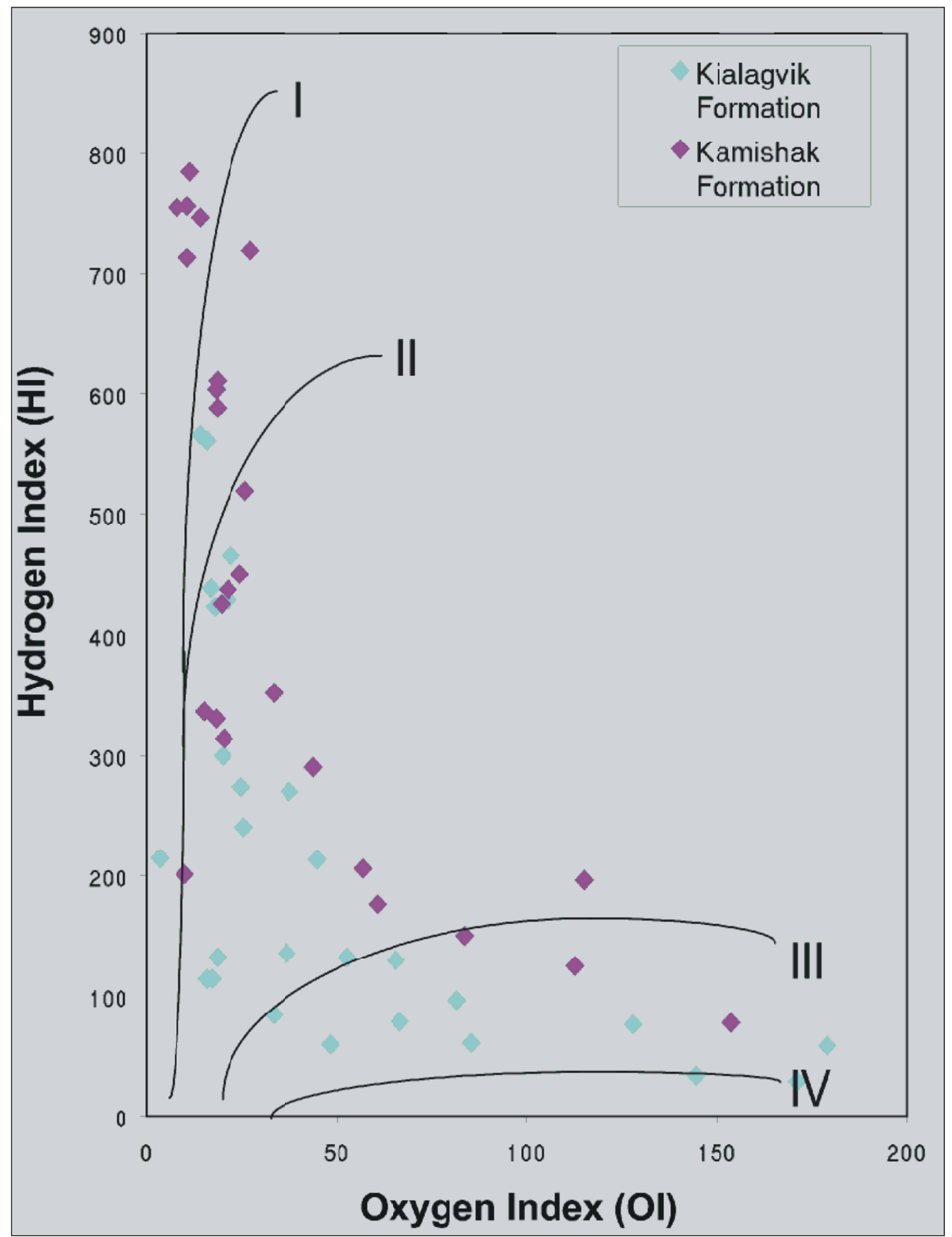

Figure 16. Modified Van Krevelen diagram based on analyses of Kamishak and Kialagvik formation samples. Note the wide range of Kamishak values ranging from Type I (very oil prone) to Type III (gas prone) kerogen. Average Kamishak values fall within Type II (oil prone) kerogen. Diagram courtesy of A. Loveland. See Decker (this report) for more detailed information on source rock analysis. 
2008). Greenish clasts identified in the deformed interval at the base of the nodular limestone and conglomerate unit and greenish sands within the siliceous limestone unit indicate that the volcaniclastics were locally exposed to erosion during deposition of much of the Kamishak Formation. This, along with the synsedimentary folds within the nodular limestone and conglomerate unit (fig. 11) and several deformed limestones in the upper Kamishak (fig. 2), implies that the area was undergoing active tectonic deformation during deposition of the Kamishak Formation.

TOC and Rock-Eval pyrolysis data indicate that some facies in the Kamishak Formation are potential source rocks that are immature to barely mature. Hydrogen Index and Oxygen Index data from kerogen in the Kamishak Formation indicates that it is both oil and gas prone (fig. 16). Very few facies contain the requisite porosity to serve as potential reservoir rocks although some rudstone beds within the nodular limestone and conglomerate unit contain macroscopic secondary porosity. Overall the reservoir potential is poor.

\section{REFERENCES CITED}

Blodgett, R.B., this volume.

Blodgett, R.B., and Sralla, Bryan, 2008, A major unconformity between Permian and Triassic strata at Cape Kekurnoi, Alaska Peninsula; Old and new observations on stratigraphy and hydrocarbon potential, in Haeussler, P.J., and Galloway, J.P., eds., Studies by the U.S. Geological Survey in Alaska, 2006: U.S. Geological Survey Professional Paper 1739-E, 13 p. [http://pubs.usgs.gov/pp/pp1739/e/].

Burk, C.A., 1965, Geology of the Alaska PeninsulaIsland Arc and Continental Margin: The Geological Society of America Memoir 99, 250 p., 3 sheets.

Decker, P.L., this volume.

Detterman, R.L., and Reed, B.L., 1980, Stratigraphy, structure, and economic geology of the Iliamna Quadrangle, Alaska: U.S. Geological Survey Bulletin 1368-B, 86 p., 1 plate, scale 1:250,000.

Detterman, R.L., Case, J.E., Miller, J.W., Wilson, F.H., and Yount, M.E., 1996, Stratigraphic framework of the Alaska Peninsula: U.S. Geological Survey Bulletin 1969-A, 74 p.

Dumoulin, J.A., Whalen, M.T., and Harris, A.G., 2008, Lithofacies, age, and sequence stratigraphy of the Carboniferous Lisburne Group in the Skimo Creek area, central Brooks Range, in Haeussler, Peter J., and Galloway, John P., eds., Studies by the U.S. Geological Survey in Alaska, 2006: U.S. Geological Survey Professional Paper 1739-B, 64 p. [http://pubs. usgs.gov/pp/pp1739/b/].

Dunham, R.J., 1962, Classification of carbonate rocks according to texture, in Ham, W.E., ed., Classifica- tion of carbonate rocks: American Association of Petroleum Geologists Memoir 1, p. 108-121.

Eckdale, A.A., Bromley, R.G., and Pemberton, S.G., 1984, Ichnology trace fossils in sedimentology and stratigraphy: Society of Economic Paleontologists and Mineralogists Short Course 15, $317 \mathrm{p}$.

Embry, A.F., and Klovan, J.E., 1972, Absolute water depth limits of late Devonian paleoecological zones: Geological Research, v. 61, p. 672-686.

Espitalié, J., Deroo, G., and Marquis, F., 1985, La pyrolyse Rock-Eval et ses applications: Revue de 1'Institut Français du Pétrole, v. 40, p. 563-579 and 755-784.

Espitalié, J., Madec, M., and Tissot, B., 1977, Source rock characterization method for petroleum exploration: Proceedings of the 9th Annual Offshore Technology Conference, v. 3, p. 439-448.

Flügel, E., 2004, Microfacies of carbonate rocks; Analysis, interpretation, and application: BerlinHeidelberg, Springer-Verlag, 976 p.

Gluyas, J.G., 1984, Early carbonate diagenesis within Phanerozoic shales and sandstones of the northwest European shelf: Clay Minerals, v. 19, p. 309-321.

Hanson, B.M., 1957, Middle Permian limestone on Pacific side of Alaska Peninsula: American Association of Petroleum Geologists Bulletin, v. 41, no. 10, p. 2,376-2,378.

Hill, M.D., 1979, Volcanic and plutonic rocks of the Kodiak-Shumagin shelf, Alaska; Subduction deposits and near-trench magmatism: Santa Cruz, CA, University of California Santa Cruz, Ph.D. Dissertation, $259 \mathrm{p}$.

Imlay, R.W., 1981, Early Jurassic ammonites from Alaska: U.S. Geological Survey Professional Paper 1190,40 p.

Imlay, R.W., and Detterman, R.L., 1977, Some Lower and Middle Jurassic beds in Puale Bay-Alinchak Bay area, Alaska Peninsula: Bulletin of the American Association of Petroleum Geologists, v. 61, no. 4, p. 607-611.

Katz, B.J., 1983, Limitations of 'Rock-Eval' pyrolysis for typing organic matter: Organic Geochemistry, v. 4, p. 195-199.

Langford, F.F., and Blanc-Valleron, M.-M., 1990, Interpreting Rock-Eval pyrolysis data using graphs of pyrolizable hydrocarbons vs. total organic carbon: American Association of Petroleum Geologists Bulletin, v. 74, p. 799-804.

Melim, L.A., Swart, P.K., and Maliva, R.G., 1995, Meteoric like fabrics forming in marine waters; Implications for the use of petrography to identify diagenetic environments: Geology, v. 23, p. 755-758.

Melim, L.A., Westphal, H., Swart, P.K., Eberli, G.P., and Munnecke, A., 2002, Questioning carbonate diage- 
netic paradigms; Evidence from the Neogene of the Bahamas: Marine Geology, v. 185, p. 24-54.

Möller, N.K., and Kvingan, K., 1988, The genesis of nodular limestones in the Ordovician and Silurian of the Oslo Region (Norway): Sedimentology, v. 35, p. 405-420.

Moore, G.W., 1967, Preliminary geologic map of the Kodiak Islands and vicinity: U.S. Geological Survey Open File Report 271, 1 plate, scale 1:250,000.

Newton, C.R., 1983, Paleozoogeographic affinities of Norian bivalves from the Wrangellian, Peninsular, and Alexander terranes, northwestern North America, in Stevens, C.H., ed., Pre-Jurassic rocks in western North American suspect terranes: Society of Economic Paleontologists and Mineralogists Symposium, Sacramento, CA, 1983, p. 37-48.

Newton, C.R., 1989, Triassic-Jurassic boundary section at Puale Bay, Alaska Peninsula; Comparative diversity patterns of skeletal faunas and trace fossils: American Association of Petroleum Geologists Bulletin, v. 74, p. 730.

Pálfy, József, Smith, P.L., Mortensen, J.K., and Friedman, R.M., 1999, Integrated ammonite biochronology and U-Pb geochronometry from a basal Jurassic section in Alaska: Geological Society of America Bulletin, v. 111, no. 10, p. 1,537-1,549.

Peters, K.E., 1986, Guidelines for evaluating petroleum source rock using programmed pyrolysis: American Association of Petroleum Geologists Bulletin, v. 70, p. 318-329.

Sralla, Bryan, and Blodgett, R.B., 2007, Reservoir potential of Late Triassic Kamishak Formation; Puale
Bay, Alaska Peninsula [abs.]: American Association of Petroleum Geologists Annual Convention \& Exhibition, Long Beach, CA, 2007, Abstracts, v. 91 (digital), p. 132.

Tucker, M.E., and Wright, V.P., 1990, Carbonate Sedimentology: Oxford, England, Blackwell Publishing, $482 \mathrm{p}$.

Wang, Jason, Newton, C.R., and Dunne, L., 1988, Late Triassic transition from biogenic to arc sedimentation on the Peninsular terrane, Puale Bay, Alaska Peninsula: Geological Society of America Bulletin, v. 100 , no. 9 , p. $1,466-1,478$.

Waples, D., 1981, Organic geochemistry for exploration geologists: Minneapolis, Minnesota, Burgess Publishing Company, $151 \mathrm{p}$.

Wetzel, A., and Werner, F., 1980, Morphology and ecological significance of Zoophycos in deep-sea sediments off northwest Africa: Palaeogeography, Palaeoclimatology, Palaeoecology, v. 32, p. 185-212.

Whalen, M.T., Eberli, G.P., van Buchem, F.S.P., Mountjoy, E.W., and Homewood, P.W., 2000, Bypass margins, basin-restricted wedges and platform-tobasin correlation, upper Devonian, Canadian Rocky Mountains; Implications for sequence stratigraphy of carbonate platform systems: Journal of Sedimentary Research, v. 70, p. 913-936.

Wilson, F.H., Detterman, R.L., and DuBois, Gregory, 1999, Digital data for the geologic framework of the Alaska Peninsula, Southwest Alaska, and the Alaska Peninsula Terrane: U.S. Geological Survey OpenFile Report 99-317, 41 p., 1 plate, scale 1:500,000, http://wrgis.wr.usgs.gov/open-file/of99-317. 



\title{
PALEONTOLOGY AND STRATIGRAPHY OF THE UPPER TRIASSIC KAMISHAK FORMATION IN THE PUALE BAY-CAPE KEKURNOI-ALINCHAK BAY AREA, KARLUK C-4 AND C-5 QUADRANGLE, ALASKA PENINSULA
}

by

Robert B. Blodgett ${ }^{1}$

\begin{abstract}
This report summarizes the paleontological character and stratigraphy of the Kamishak Formation in the Puale Bay-Cape Kekurnoi-Alinchak Bay area, Karluk C-4 and C-5 quadrangle, Alaska Peninsula. This 799.5-m- (2,625-ft-) thick strata succession has long been of interest to petroleum explorationists and has been considered to be the most likely source of the hydrocarbons found in oil and gas seeps in the greater Becharof Lake region. Paleontological data presented here are derived from published literature, unpublished internal paleontological reports of the U.S. Geological Survey, and new collections made by the author during the course of fieldwork conducted by the Alaska Division of Geological \& Geophysical Surveys (DGGS) in August 2007. Data are presented on various megafaunal groups found in this unit as well as for a single conodont element (conodonts have previously been unreported from Kamishak exposures on the Alaska Peninsula and lower Cook Inlet region). Biodiversity is highest in the lowermost biostromal limestone and overlying nodular limestone beds (each assigned to separate informal members here) limited in exposure to the headland area near the eastern entrance into Puale Bay, where a diverse fauna of bivalves, brachiopods, gastropods, scleractinian corals, and nautiloids is noted. To the northeast along the shoreline between this headland and Cape Kekurnoi, these lowermost beds are laterally replaced by deeper-water limestone and shale (referred to in this report as the limestone and shale member), which are characterized by an abundance of monotid bivalves (most of which belong to the species Monotis [Pacimonotis] subcircularis Gabb) and hydrozoan genus Heterastridium. The limestone and shale member also directly overlies the biostromal limestone and nodular limestone members at the headland and form the greater thickness of exposed Kamishak Formation strata. The Kamishak Formation appears to represent a single upward-deepening succession of late Norian age rocks that rest with an angular unconformity on Permian agglomerate, volcaniclastic rocks (sandstone), and limestone. The precise nature of the contact with the overlying, more clastic-rich Lower Jurassic beds, referred to earlier as the Bidarka Formation by Kellum (1945) or later by others as the Talkeetna Formation, is not yet well defined. Paleobiogeographic affinities of the various faunal elements found in the Kamishak indicate that the Peninsular terrane was probably situated in a tropical to subtropical setting during the Late Triassic and had close faunal ties with the Chulitna, Alexander, and Farewell terranes of southern Alaska, but apparently was separated by a significant distance from the Wrangellia terrane, which was also situated at a warm, low-latitude position during Late Triassic time.
\end{abstract}

\section{INTRODUCTION}

This paper summarizes the complete published record and some unpublished data regarding Upper Triassic fossils from the peninsula bounded by Puale Bay (formerly known as Cold Bay) and Alinchak Bay (figs. 1-3). These rocks have recently been referred to the Kamishak Formation (Detterman and others, 1996), a formation previously established to the north at Kamishak Bay near the upper end of the Alaska Peninsula. The outcrops discussed here are significant in that they represent the only Upper Triassic strata exposed east of the Bruin Bay fault on the Alaska Peninsula. In addition, these rocks have attracted much interest from petroleum explorationists as they have long been considered the

source of most of the potential extractable hydrocarbon resources in the Puale Bay-Becharof Lake-Wide Bay region (Hanna and others, 1937; Molenaar, 1995; Sralla and Blodgett, 2007; Blodgett and Sralla, 2008). The fossils discussed here are derived from a number of sources: Internal unpublished USGS fossil reports (often referred to as E\&R reports) that are mostly summarized in the Alaska Paleontological Database website (http://www.alaskafossil.org), published literature, and newly acquired megafossil collections made by the author during the four days of fieldwork conducted with DGGS August 12-15, 2007. Nearly all known fossils from the Kamishak Formation in the study area are listed

${ }^{1}$ U.S. Geological Survey, Contractor, 4200 University Dr., Anchorage, Alaska 99508 
in the Appendix. The only collections not listed are from private industry sources or reports, which I have not yet received permission to publish.

Upper Triassic (Norian) rocks, referred now to the Kamishak Formation (notably represented by limestone), are widely developed across much of the Peninsular terrane. References to their occurrence can be found in Capps (1923), Detterman and Hartsock (1966), Det-

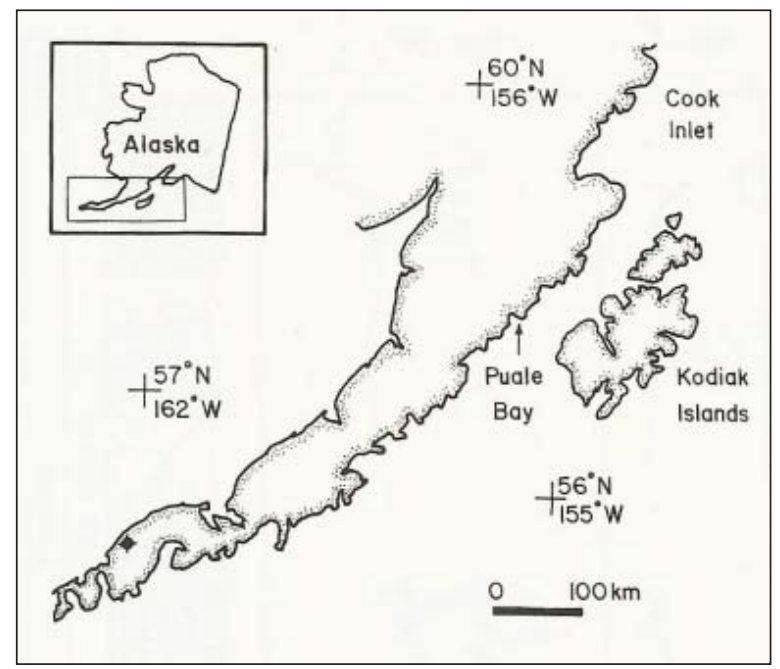

Figure 1. Index map showing location of Puale Bay on the Alaska Peninsula (from Wang and others, 1988). terman and Reed (1980), Detterman and others (1996), Kelley (1980), Martin (1915, 1916, 1921, 1926), Martin and Katz (1912), Newton (1983a, b, 1990), Smith (1925, 1926), Smith and Baker (1924), Stanley (1979), Stanton and Martin (1905), Wang (1987), and Wang and others (1988). The name Kamishak Formation (originally proposed as Kamishak Chert by Martin and Katz [1912] and subsequently changed to Kamishak Formation by Kellum [1945]) is now applied to nearly all exposures of Late Triassic age carbonates on the Alaska Peninsula and in the lower Cook Inlet region. It should be noted that outcrops of the Kamishak Formation occur on both sides of the Bruin Bay fault. Those exposures on its west side (that is, Kamishak Bay) belong to the Iliamna subterrane (name proposed by Wilson and others, 1985), where they are structurally complex and overmature in terms of oil and gas potential. Those included in the Chignik subterrane (also proposed by Wilson and others, 1985) on the east side of the Bruin Bay fault (Puale Bay) are only weakly to moderately folded and are well within the thermal range of oil and gas generation. Other Upper Triassic exposures in the Chignik subterrane can be found in the Port Graham area on the southern end of the Kenai Peninsula, on Ushagat Island (the largest of the Barren Islands), and along the northwestern coast of Kodiak Island. A lack of detailed study has left the latter named exposures poorly known, and strongly deserving of further investigation.

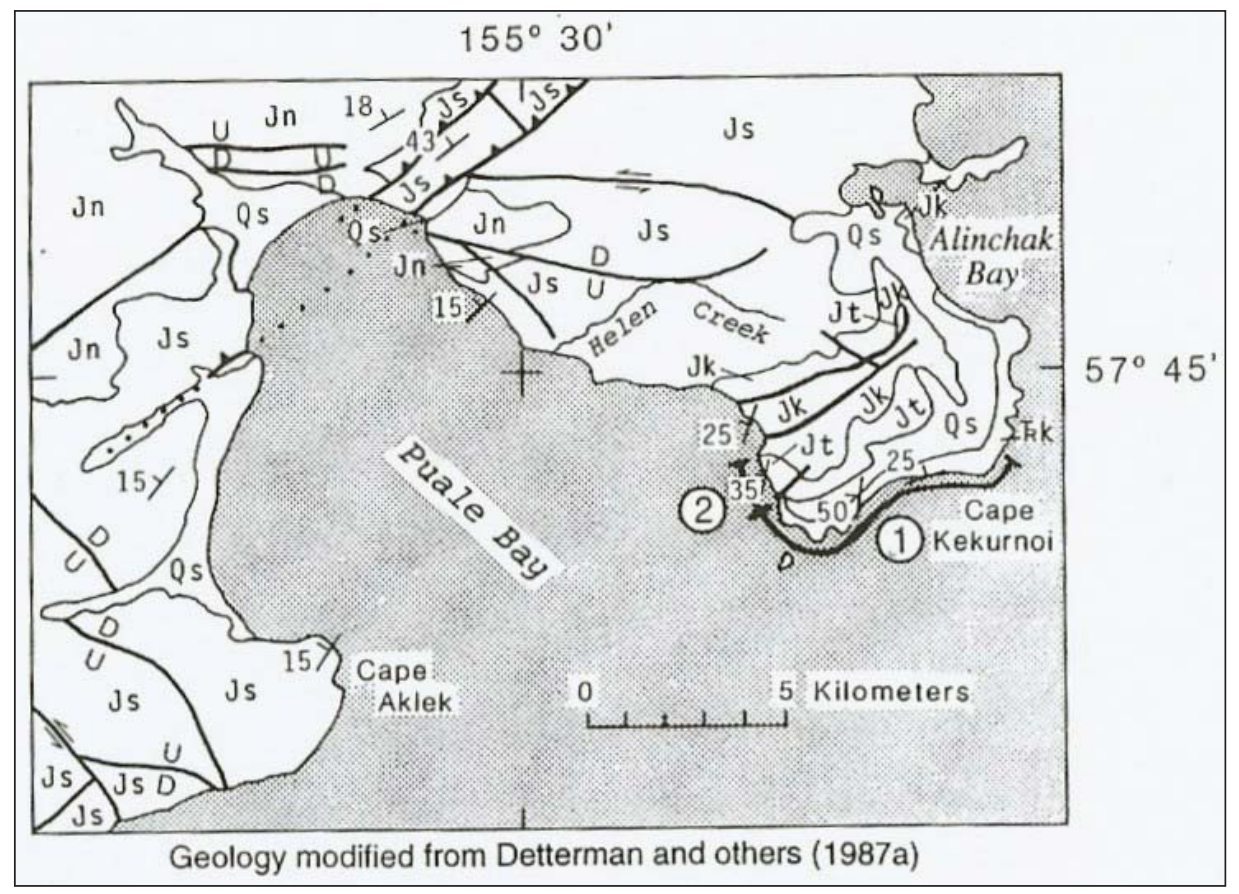

Figure 2. Distribution of the Kamishak Formation (TrK unit) according to Detterman and others (1996). Map shows location of their measured section (Section 1) in this unit (figure from Detterman and others, 1996, fig. 6B). 


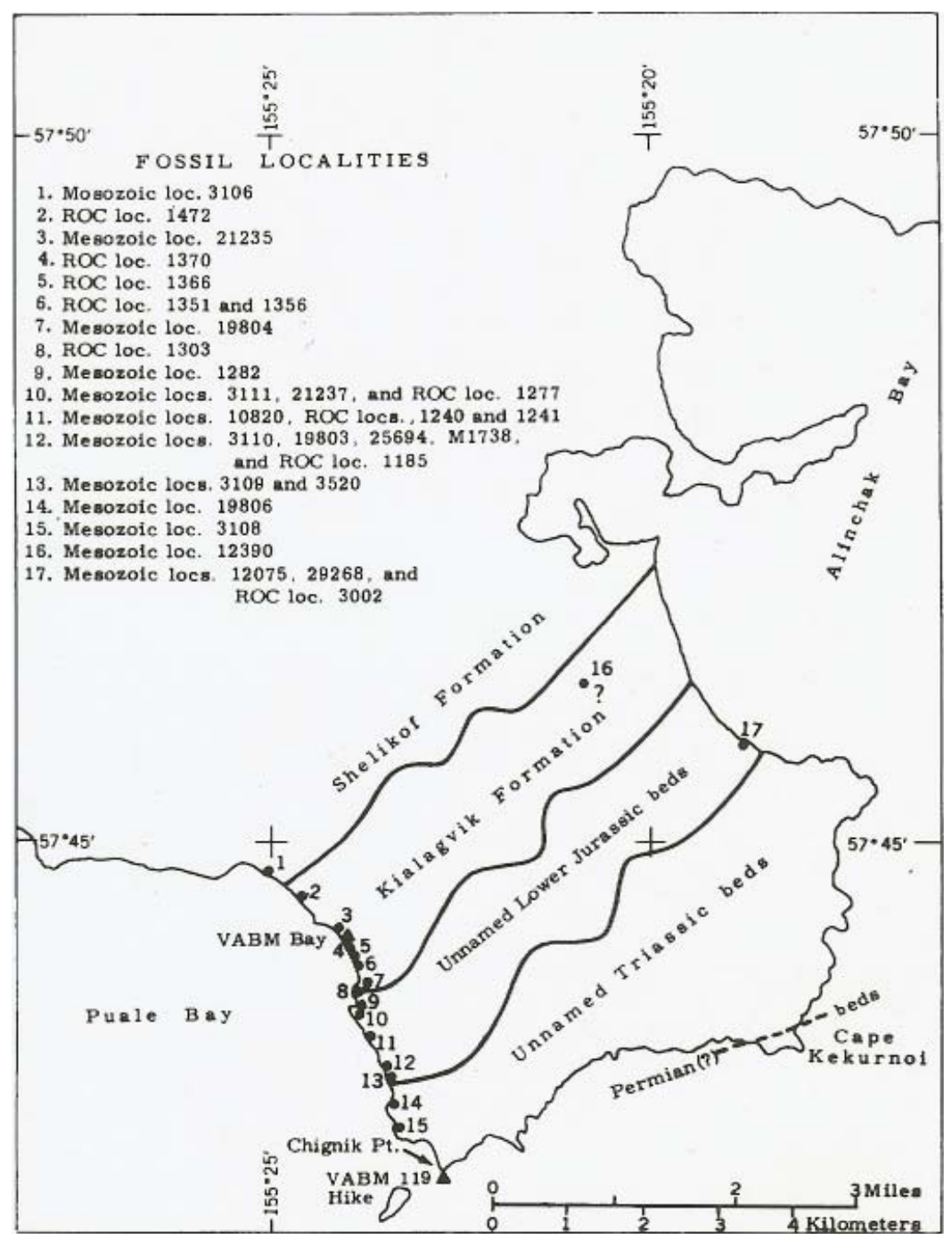

Figure 3. Distribution of unnamed Triassic beds (now referred to Kamishak Formation) according to Imlay and Detterman (1977). This figure more accurately reflects the distribution of Upper Triassic strata than that shown in figure 2. Note the presence of Permian(?) beds shown at Cape Kekurnoi, which were recognized by Hanson (1957).

\section{PREVIOUS WORK}

Alphonse Louis Pinart (a 19 ${ }^{\text {th }}$-century French ethnologist) visited the Alaska Peninsula in 1871 and was the first person to note the presence of Upper Triassic strata in the Puale Bay-Cape Kekurnoi-Alinchak Bay area (he referred to Puale Bay as “Nounakalkhak”) (Pinart, 1873). He collected monotid bivalves that were described in two papers (the latter with illustrations) by Fischer (1872, 1875), who identified them as belonging to the species Monotis salinaria Bronn. These specimens generated considerable interest for their then very remote geographic nature, and were referred to by Teller (1886), who suggested they represent a species of Pseudomonotis related to Pseudomonotis ochotica (Keyserling) ( $P$. ochotica is now referred to the genus Monotis). Mojsisovics (1886) believed this locality represented an occurrence of what he called his "Arctic Pacific Trias province.” Frech (1908) reexamined Pinart's specimens and identified them as including both the typical form of Pseudomonotis ochotica (Keyserling) and also Pseudomonotis ochotica var. sparicostata Teller, the latter taxon being figured. Stanton and Martin (1905, p. 394, 396) make only passing reference to the presence of Upper Triassic strata at Cold (now Puale) Bay, stating that the fauna is "almost limited to the single species Pseudomonotis subcircularis Gabb” but noted that subsequent large collections made from the region indicated that the forms earlier described and illustrated by Fischer as Monotis salinaria should rightfully belong to Gabb's species.

Martin (1916, p. 699-700) makes only a brief comment on the Puale Bay exposures, stating that they consist of limestone and shale, $700 \mathrm{ft}$ (213 m) or more in thickness, and contain Pseudomonotis subcircularis (Gabb) (illustrated on pl. 29, fig. 1 of his publication and reproduced here in fig. 9). He also noted that the beds bearing the monotid bivalves were underlain by contorted cherts, underlain in turn by basic igneous rocks. Martin (1921, p. 57-58) gives a slightly more detailed description of the unnamed Triassic succession 
between Cold (Puale) and Alinchak bays, and noted that at Alinchak Bay contorted cherts (bearing no fossils) underlie limestone and shale containing monotids, and that the cherts are underlain by basic igneous rocks. It is interesting that no subsequent investigations have documented the presence of cherts in this part of the section. The igneous rocks that Martin refers to appear to be part of the volcaniclastic unit that was recognized at Cape Kekurnoi by Hanson (1957) and thought to possibly be part of a Permian-age basement complex. In addition, Martin (1921, p. 58-59) recognized a change upward from calcareous beds beneath into less calcareous beds as one moves from the Upper Triassic into the Lower Jurassic. No definite horizon could be identified by Martin as the Triassic-Jurassic boundary as this appears to occur in a gradual transition in which no fossils were recovered. Capps (1923) made a detailed description of the Upper Triassic beds between Puale Bay and Alinchak Bay. He referred to them as an unnamed unit of "dense thin-bedded limestone and shale" of Late Triassic age (Capps, 1923, pl. II). He estimated the thickness as well over 1,000 ft (305 m), consisting of "hard dense thin-bedded limestone and limy shale, cut by dikes and sills of basalt” (Capps, 1923, p. 92). He also noted that many of the limestone beds were dominated exclusively by a single form of Pseudomonotis (now recognized as Monotis [Pacimonotis] subcircularis Gabb) and the transition into the overlying Jurassic beds was not represented by a structural break, there being "apparently perfect conformity between the Triassic and Jurassic beds” (Capps, 1923, p. 93). Capps regarded the top of the Upper Triassic to "end at the point where the sandy phase begins to appear” (Capps, 1923, p. 93). The Upper Triassic beds were referred to by Smith (1926, p. 65) simply as "massive and thin-bedded limestone of Upper Triassic age" that were overlain conformably by Lower Jurassic limestone, sandstone, and shale. His 1926 paper incorporated his fieldwork conducted in 1924, which updated earlier U.S. Geological Survey mapping done by him, A.A. Baker, and S.R. Capps. In this paper, the lowest beds of the Upper Triassic as exposed at Cold (Puale) Bay were now shown to consist of massive buffcolored limestone $85 \mathrm{ft}(26 \mathrm{~m})$ in thickness, overlain by blue nodular limestone $40 \mathrm{ft}(12 \mathrm{~m})$ in thickness (according to fig. 2 of Smith, 1926, but $30 \mathrm{ft}[9 \mathrm{~m}]$ in text on p. $66)$, overlain in turn by a thicker thin-bedded limestone succession that included a 100-ft- (30-m-) thick interval of basalt (Smith, 1926, fig. 2, shown here as fig. 4). The thin-bedded succession containing Pseudomonotis (now recognized as Monotis) was indicated to be slightly more than $700 \mathrm{ft}(>213 \mathrm{~m}$ ) in thickness (Smith, 1926, p. 69). The Triassic-Jurassic boundary was not determined, but indicated to be within the upper part of Smith's thin-bedded limestone. A total thickness of $900 \mathrm{ft}(275 \mathrm{~m})$ was suggested for the Upper Triassic succession by Smith
(1926). Smith (1926, fig. 2) indicated that the lowest beds of the Upper Triassic consisted of thin-bedded limestone at Alinchak Bay (similar to our observations in 2007 west of Cape Kekurnoi).

The Upper Triassic succession in the study area was shown on the map of Moore (1967) as the Trvm (volcanic and marine sedimentary rocks) unit. On the geologic map of the same area (von Huene and others, 1979, pl. 2) the Upper Triassic was shown as the Trsv (sedimentary and volcanic rocks), with the exception of the rocks at the outermost end of Cape Kekurnoi, which were shown as being assigned to the unit with question. The exposures at Cape Kekurnoi, consisting of basalts, are here considered to be part of the underlying Paleozoic (Permian) basement complex as suggested by Hanson (1957).

Two 1:250,000-scale geologic maps were released by Detterman and others $(1983,1987)$, both of which left the Upper Triassic beds unnamed but represented by a single unit (Trlv) on the map of Detterman and others (1983) and two units (Trls and Trv) on the map of Detterman and others (1987). The Detterman and others (1987) map was the first one to apply the name Talkeetna Formation (a formation established by Martin [1926] for exposures in the southern Talkeetna Mountains) to the previously unnamed Jurassic rocks exposed between Puale and Alinchak bays (see Imlay and Detterman [1977] and Imlay [1981] for detailed faunal lists from the Lower Jurassic of the study area). The name Bidarka Formation was established earlier by Kellum (1945) for rocks he considered to be Early Jurassic in age that were exposed along the east side of Puale Bay. This raises the question of stratigraphic nomenclatorial priority, which needs to be addressed at some point in the future.

Wang (1987) presented the results of his M.S. thesis, emphasizing the sedimentology of the Upper Triassic strata in the study area. He recognized three major facies in his measured section ( 700 $\mathrm{m}[\sim 2,300 \mathrm{ft}]$ ) along the east side of Puale Bay: (1) a basal coralline biomicrite facies $45 \mathrm{~m}(148 \mathrm{~m})$ thick that contains abundant scleractinian corals, spongiomorphs, and terebratulid brachiopods (equivalent to the informal "biostromal member" used here); (2) a carbonate conglomerate facies (overlying the basal biomicrite facies) that is $25 \mathrm{~m}$ (82 ft) thick that contains corals, bivalves, ammonoids, nautiloids, and gastropods in cobble-sized lithoclasts (equivalent to the informal "nodular limestone member" used here); and (3) the uppermost and much thicker rhythmite facies, including calcareous/siliceous shale and siliceous limestone/chert that contains abundant monotid bivalves (equivalent to the informal "limestone and shale member" used here). Wang and others (1988) later presented essentially the same data in the GSA Bulletin. Newton (1990) studied the Triassic-Jurassic boundary section at Puale Bay. She recognized latest 


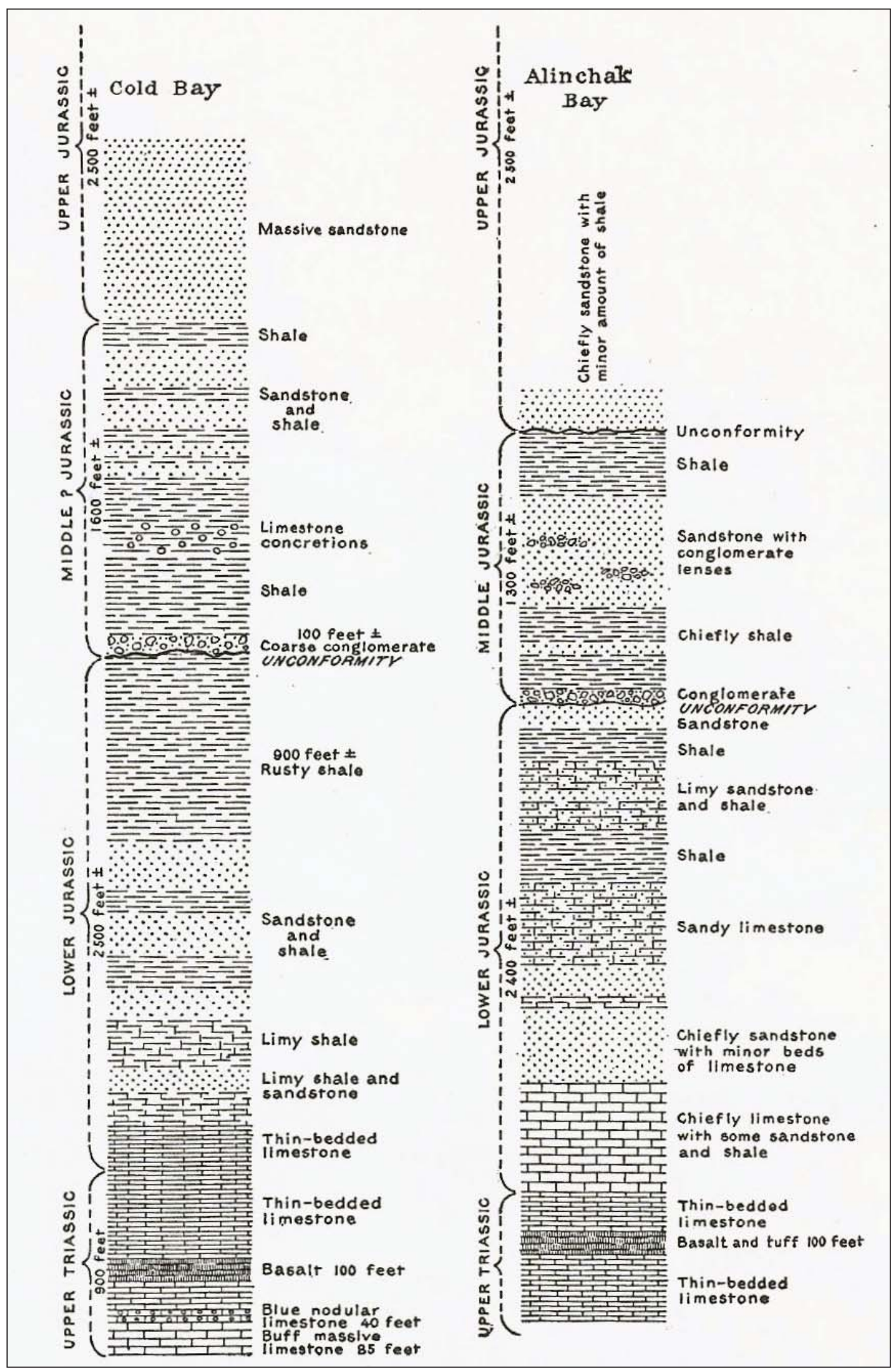

Figure 4. Columnar sections of Upper Triassic and Jurassic strata exposed at Cold (Puale) Bay (left column) and Alinchak Bay (right column) (from Smith, 1926, fig. 2). 
Norian and Hettangian intervals in the section, but noted that they were separated by an approximately 50-m- (164-ft-) thick barren interval (in terms of shelly fauna) containing high concentrations of the trace fossils Thalassinoides and Chondrites. She suggested that this interval included the Triassic-Jurassic boundary that was deposited under dysaerobic conditions.

Detterman and others (1996) were the first to apply the stratigraphic term Kamishak Formation to the previously unnamed Upper Triassic strata exposed in the study area (areal distribution of this unit is shown in fig. 2). They presented a measured section (part of their fig. 6; reproduced here as fig. 5) that comprised a total measured thickness of $799.5 \mathrm{~m}(2,623 \mathrm{ft})$. They also indicated a gradational contact with the overlying Lower Jurassic strata that they assigned to the Talkeetna Formation. They recognized 14 subunits within the Kamishak Formation, of which their lowermost subunit (no. 1) corresponds to the informal nodular limestone member used here.

Pálfy (1997) and Pálfy and others (1999) presented data primarily focused on the Lower Jurassic succession exposed on the east shore of Puale Bay, but differed from earlier investigators in suggesting that the Kamishak Formation extended into the Hettangian, with a boundary between the Kamishak Formation and overlying Talkeetna Formation situated higher in the section. Of interest is the fact that Pálfy and others (1999, fig. 2) showed the lowermost fossiliferous horizon in the Lower Jurassic (middle Hettangian in age) as separated by a normal fault from unfossiliferous, lithologically very similar, presumably uppermost Triassic strata. Barbacka and others (2006) illustrated and described plant macrofossils from middle Hettangian strata on the east shore of Puale Bay, which they assigned to the uppermost part of the Kamishak Formation.

Figure 5. Columnar section of the Kamishak Formation exposed in the Cape KekurnoiPuale Bay area according to Detterman and others (1996; section 1 of their fig. 6). They indicate a total thickness of $799.5 \mathrm{~m}$ (2,623 ft) for the Kamishak Formation.

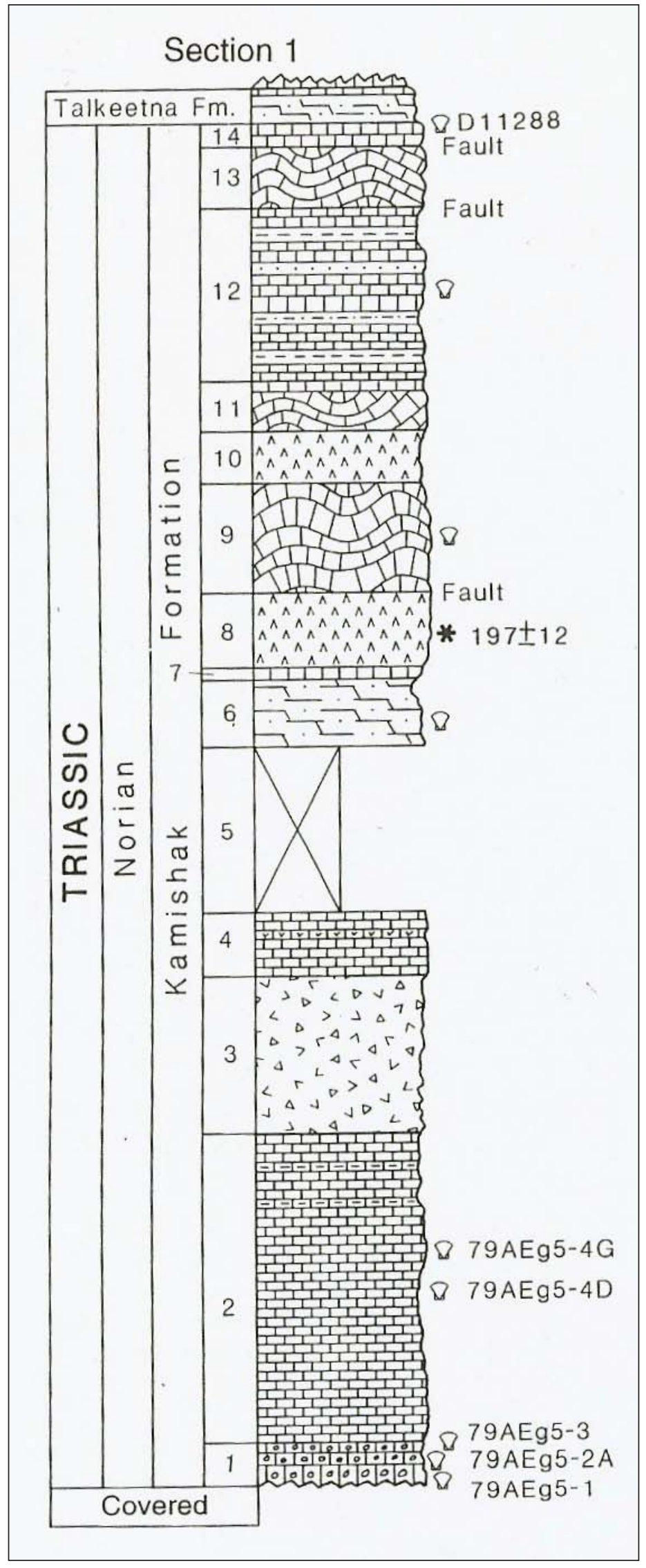




\section{REINTERPRETED STRATIGRAPHY}

The Upper Triassic strata of the study area have only recently been referred to the earlier-named Kamishak Formation by Detterman and others (1996). Only two modern investigators have attempted to illustrate a stratigraphic section of the formation: (1) Wang (1987) and Wang and others (1988), who indicated a total thickness of approximately $700 \mathrm{~m} \mathrm{(2,300} \mathrm{ft} \mathrm{);} \mathrm{and} \mathrm{(2)} \mathrm{Detterman}$ and others (1996), who indicated the thickness to be $799.5 \mathrm{~m}$ (2,623 ft). Neither investigation presented rigid lithostratigraphic evidence for determining the top and bottom of the formation. In neither paper was the base considered exposed onshore in the study area, although the authors suggested that older beds were present offshore on small islands, one of which consisted of limestone yielding mid-Permian fossils (Hanson, 1957; Jeffords, 1977). These islands form part of a pre-Mesozoic complex of volcaniclastic rocks, volcanic rocks, and limestone (the latter yielding Permian fossils). The base of the Kamishak Formation directly overlies volcaniclastic sands of this late Paleozoic complex along the shoreline of the mainland of the peninsula (fig. 6) west of Cape Kekurnoi. The contact is an angular unconformity with quite visible erosional truncation of the underlying volcaniclastic strata. The presence of a Permian unit on the peninsula was suggested earlier (with a questioned age, due to the absence of fossils) on the geologic map presented in Hanson (1957, fig. 1), who indicated the presence of Permian (?) agglomerate onshore. Unfortunately, previous and subsequent investigators missed this contact, perhaps because of the brevity of most fieldwork done in the region, as well as the concentration of study focused on the Upper Triassic exposures on the east side of Puale Bay, resulting in a lack of observations on the exposures near Cape Kekurnoi and Alinchak Bay.

Based on limited time on the Kamishak Formation in the study area, I believe three informal members can be designated that are easily recognizable by a field geologist. The first is the thick- to massive-bedded "biostromal limestone member" (only locally developed). It is equivalent to the basal coralline biomicrite facies of Wang (1987), a unit $45 \mathrm{~m}$ (148 ft) thick and containing abundant scleractinian corals, spongiomorphs, and terebratulid brachiopods. The next highest member, the "nodular limestone member" (again only locally developed), corresponds to the carbonate conglomer-

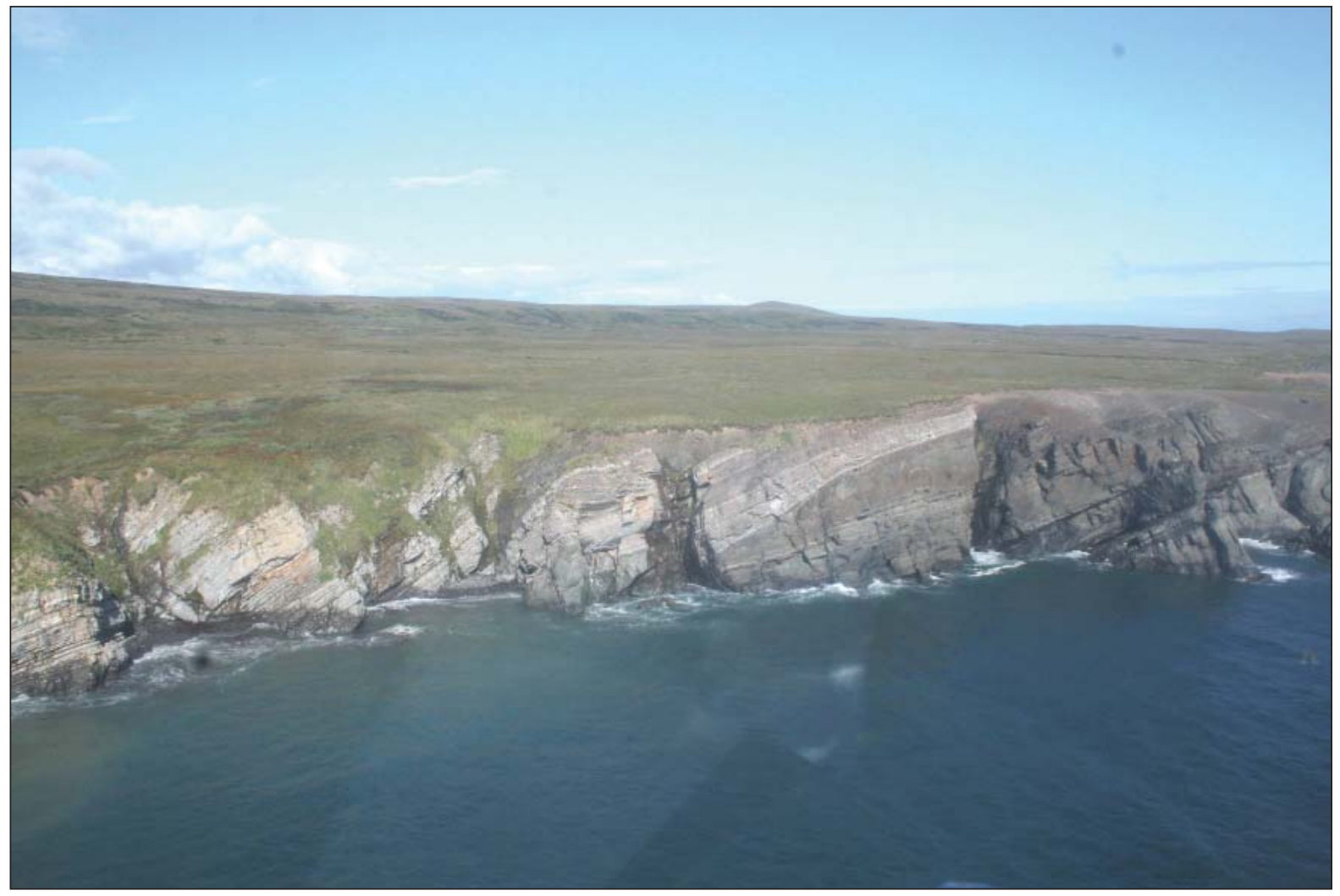

Figure 6. Aerial view of Upper Triassic carbonates of the Kamishak Formation (light-colored rocks) $0.5 \mathrm{mi}$ (0.8 km) west of Cape Kekurnoi, showing lower contact with underlying Permian volcanic agglomerate and volcaniclastic rocks (dark strata). Contact is an angular unconformity with strikingly obvious erosional cutoff of underlying bedded Permian rocks. Photo taken by Bryan Sralla (Fort Worth, TX). Same as figure 2 in Blodgett and Sralla (2008). 
ate facies of Wang (1987), a unit $25 \mathrm{~m}$ (82 ft) thick that contains corals, bivalves, ammonoids, nautiloids, and gastropods in cobble-sized lithoclasts. The highest member, the "limestone and shale member," equivalent to the rhythmite facies of Wang (1987), consists of thin- to medium-bedded calcareous shale, siliceous shale, limestone, and minor volcaniclastic beds. This unit forms the greater part of the formation and on the east of the outcrop belt, from $0.5 \mathrm{mi}(0.8 \mathrm{~km})$ west of Cape Kekurnoi to Alinchak Bay, it composes the entire formation, the lowermost two westerly developed members being absent.

The exposed base of the Kamishak Formation has until now been observed only along the shoreline approximately $0.5 \mathrm{mi}(0.8 \mathrm{~km})$ west of Cape Kekurnoi (fig. 6). Here, probable Permian-age volcaniclastic beds are overlain by thin-bedded limestones of the Kamishak Formation that bear local concentrations of the bivalve Monotis (Pacimonotis) subcircularis Gabb. Farther west, at the east side of the entrance into Puale Bay, the lowest beds of the Kamishak Formation are of somewhat differing character, including the basal, relatively massively bedded biostromal member, developed only near a small headland, which borders the east entrance to Puale Bay, and the overlying nodular limestone member, which likewise is limited to this headland (figs. 7-8). Overlying the nodular limestone member are typical beds of the lower part of the thin- to medium-bedded limestone and shale member of the Kamishak Formation. A rapid facies change appears to exist between the lowermost Kamishak Formation beds at the headland and those to the east near Cape Kekurnoi. No one has seemingly worked out this relationship, which would require careful traversing of shoreline and adjoining exposures between the two areas. Several possibilities readily come to mind: (1) The local development of the biostromal member and nodular limestone member may represent only a locally developed facies, laterally equivalent to the lower part of the limestone and shale member; or (2) the local development of the first two mentioned members may occur as initial fill of an extensively channeled surface, later being covered by deeper-water deposits that covered the entire region during a later rapid transgressive event.

The top of the formation remains to be rigorously defined lithostratigraphically. Both earlier and later workers have recognized that the Upper Triassic beds are gradational in character with those of the overlying Lower Jurassic. Calcareous sediments dominate the lower part of the interval, with a gradual increase of volcanicastic sediments higher in the section. Monospecific accumulations of monotid bivalves (represented primarily by two species of Monotis) typify much of this unit. No biostratigraphically-defined Triassic-Jurassic boundary has yet been identified. Most previous workers have suggested that the Late Triassic beds are part of the Kamishak Formation, while those of Early Jurassic age belong to a different unit. An exception, however, is the work of Pálfy (1997), Pálfy and others (1999), and Barbacka and others (2006) who believe the carbonaterich beds go up into the Hettangian, and assign them to the Kamishak Formation, recognizing the overlying Talkeetna Formation just above where the beds are dominated by non-calcareous clastic rocks.

Age control to date for the Kamishak Formation has relied almost entirely on megafossil invertebrates (primarily monotid bivalves). Conodonts have not yet been reported from the unit, and ammonoids have not been well documented from the formation. In terms of facies and succession of faunal types (communities), the Kamishak Formation appears to represent a transgressive, deepening-upward succession of beds primarily of late Norian age. No Rhaetian- (uppermost Triassic) age beds have been recognized from the succession, and the oldest dated Jurassic fauna is of middle Hettangian age (Imlay, 1981). A detailed study of the Triassic-Jurassic transition from this area would be an invaluable contribution to better understanding the tectonic evolution of the Peninsular terrane.

\section{PALEONTOLOGY}

Ammonoids-Ammonoids are not common in the Kamishak Formation exposures of the study area. In terms of modern taxonomic nomenclature, only four genera have been reported in the literature: Pinacoceras and Trachyceras? from beds probably correlative with the nodular limestone or biostromal members recognized in this report, and Halorites and Metasibirites from higher beds of the platy limestone and shale member.

Bivalves-Bivalves are by far the most common fossil group found in the Kamishak Formation exposures in the study area. Most notably to even the casual observer is the abundance of monotid bivalves throughout most of the Kamishak exposures here. As noted by Silberling and others (1997, p. 11):

"In wave-cut exposures along the shores of Puale and Alinchak Bays, on either side of Cape Kekurnoi, several hundred meters of Upper Triassic, well-bedded, dense limestone, shale and minor volcaniclastic rocks (the "bedded cherts" lithofacies of Wang and others, 1988) overlie platform-carbonates and volcanic rocks, all of which are late Norian in age. Monotis (P.) subcircularis is well represented in collections from relatively low in the well-bedded sequence, however, $\mathrm{M}$. (M.) alaskana occurs near its top. Although the section is disturbed by faults and folds, Detterman and others (1996) reported a minimum stratigraphic separation of about $75 \mathrm{~m}$ between these two species in an unbroken partial section in Alinchak Bay.” 


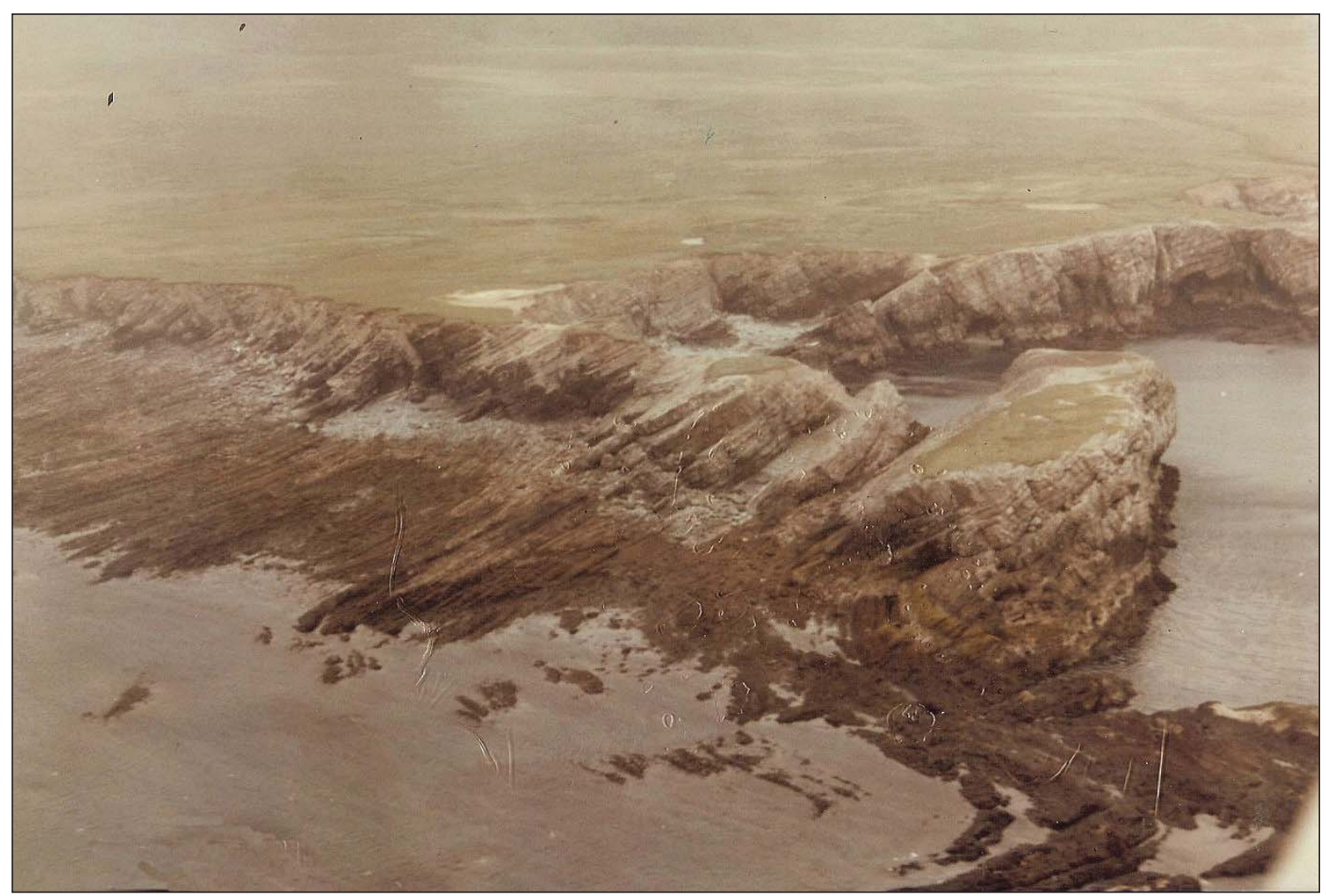

Figure 7. Aerial view of headland situated at the center of the lower margin of Sec. 33, T 28 S, R 37 W, Karluk C-4 and C-5 quadrangle. The prominent massif forming the outermost end of the headland comprises the primary (thickest-known) exposure of the biostromal member. Wang (1987) estimated a minimum thickness for this member at $45 \mathrm{~m}$ (148 ft). Outcrops farther inland (to the left) include the overlying nodular limestone and platy limestone and shale members. Photo, taken at an extremely low minus tide, courtesy of Les Magoon (USGS, Menlo Park, CA).

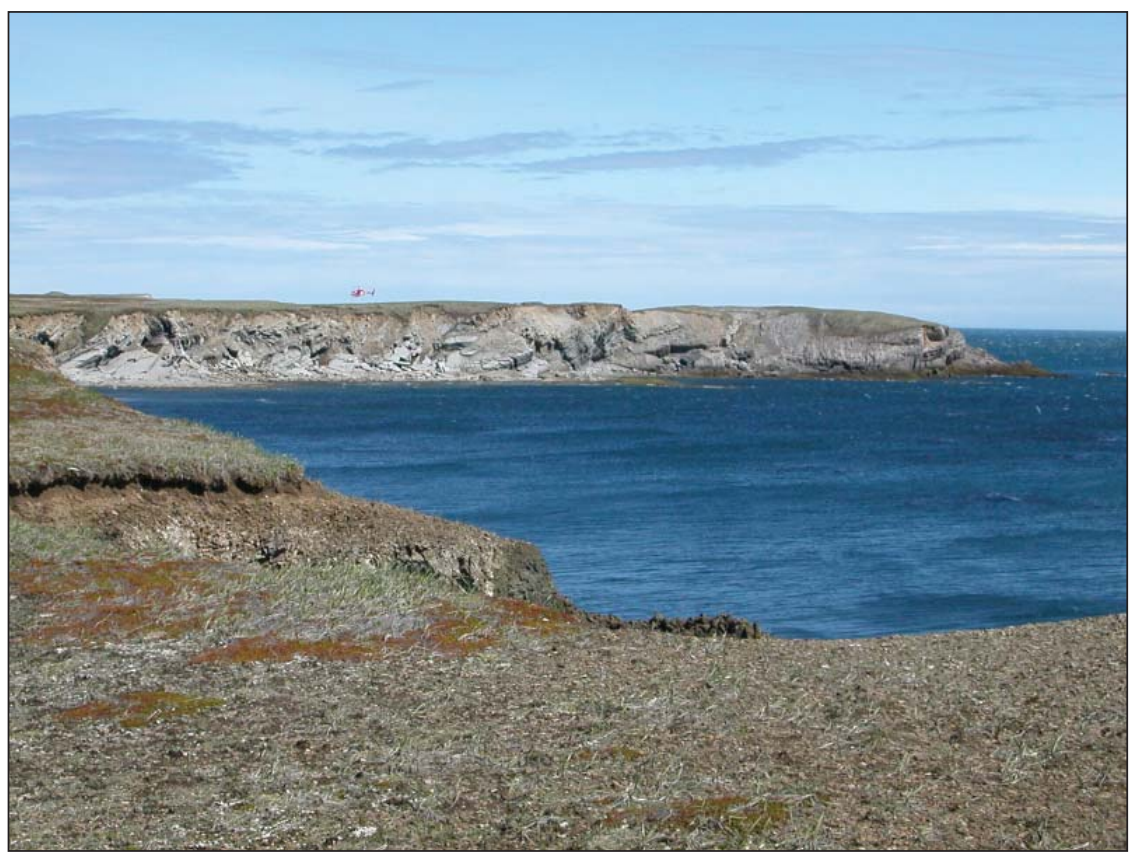

Figure 8. A different view showing the lower part of Kamishak Formation section on the east side of the same headland shown in figure 7. The more massively bedded biostromal and nodular limestone members exposed on the extreme right of the headland and the lower part of the platy limestone and shale member (note finer scale bedding) are exposed on the left side (helicopter for scale). 
Monotis (Pacimonotis) subcircularis Gabb (figs. 9-11) is by far the most abundant bivalve found in the Kamishak Formation, and the typical form that most field geologists have collected in the region. In addition to the two species M. (P.) subcircularis and M. (Monotis) alaskana that typify much of the limestone and shale member, a much rarer third species has been recognized by this author from the Standard Oil Co. of California collections that were donated to the California Academy of Sciences (CAS) in San Francisco. This species is identical to a form illustrated and identified as Monotis (Entomonotis) sp. cf. M. (E.) ochotica densistriata (Teller, 1886) by Silberling and others (1997). This form co-occurs with Monotis (Pacimonotis) subcircularis in the California Academy of Sciences collections.

The absence of any intermediate morphotypes indicates that we are observing two separate taxa. Several left valves of this form are illustrated in figures 12 and 13. This form has previously been recognized in the Alexander terrane of southeast Alaska, where it occurs at USGS Mesozoic locality 1912 on Kuiu Island.

The limestone and shale member is dominated by nearly monospecific accumulations of monotid bivalves. However, both the underlying biostromal and nodular limestone members appear to lack monotids, but rather contain a much more diverse assemblage of bivalves. Pinnid, myophorid, and pectenacid bivalves are most common. Genera previously reported from these lower two members include: Amusium, Cassianella (common in Norian bivalve assemblages elsewhere in southern Alaska), Minetrigonia, Myophoria, Ostrea?, Palaeopharus, Pinna, Pinnigena, Pleuromya, and “Trichites."
Oyster shells, mostly in the form of large fragments (identified in this study as "Ostrea" sp.) are common elements in the nodular limestone member (fig. 14). Oyster shells with somewhat similar laminar shell structure (?Lopha cordillerana) have been illustrated from Norian age strata of the Antomonio Formation of Sonora, Mexico, by McRoberts (1997, fig. 4). A detailed study of the bivalve fauna from the lower Kamishak Formation of the study area would be a fruitful area for future paleontological work in this part of Alaska.

Brachiopods-Brachiopods are common faunal elements in both the biostromal and nodular limestone members. The author knows of no occurrences of brachiopods in the limestone and shale member. Smooth terebratulids seem to be typical for both members (figs. 15-16), with only a few specimens of rhynchonellid or spiriferid brachiopods being noted to date.

The terebratulids are common enough to have formed a monotaxic accumulation of silicified valves in a Standard Oil Co. of California field collection now deposited in the California Academy of Sciences (CAS locality 29823). It would be highly beneficial to have a formal taxonomic study done on these brachiopods, and contact has been made with Dr. Michael R. Sandy (University of Dayton, Dayton, Ohio) to explore the possibility of a joint paper on this subject. Of note is the fact that one terebratulid brachiopod from the author's collection 07RB14 has preserved original color patterns, consisting of radial rays originating on the umbo (fig. 16). This is the first occurrence known by either Dr. Sandy or the author in which color patterns have been preserved in a Triassic brachiopod from North America.
Figure 9. Drawing (from Martin, 1916, pl. 29, fig. 1) showing right valve of Pseudomonotis subcircularis (Gabb) [now referred to Monotis (Pacimonotis) subcircularis Gabb] from USGS Mesozoic locality 3107.

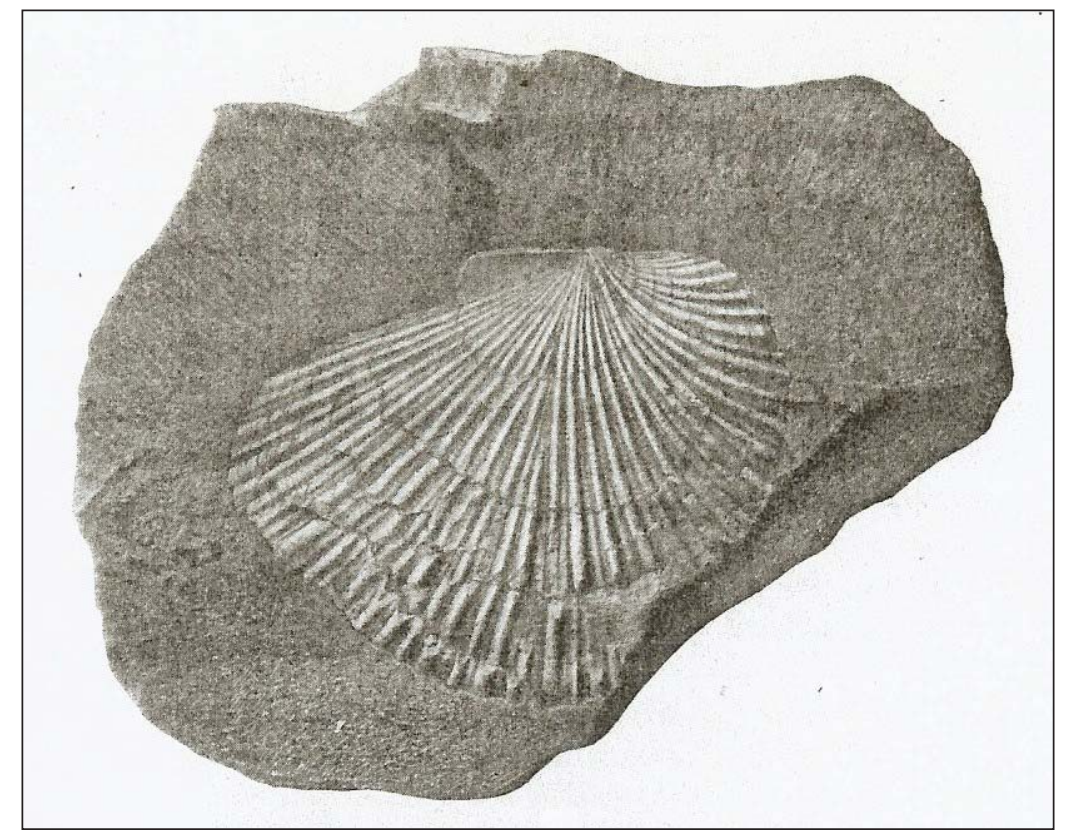




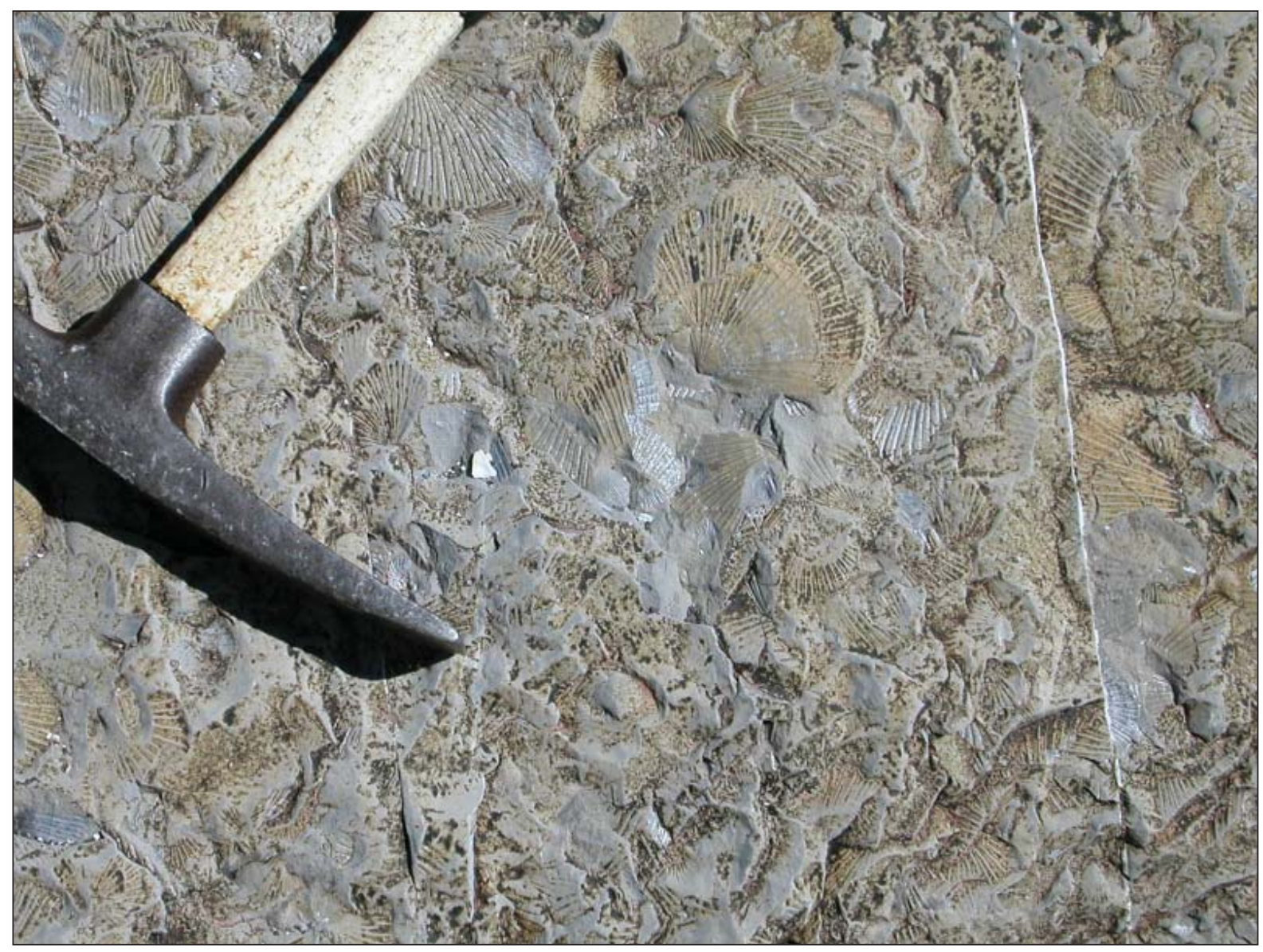

Figure 10. Bedding surface exposure showing typical abundant accumulation of Monotis (Pacimonotis) subcircularis Gabb on bedding plane in lower part of the platy limestone and shale member of the Kamishak Formation.

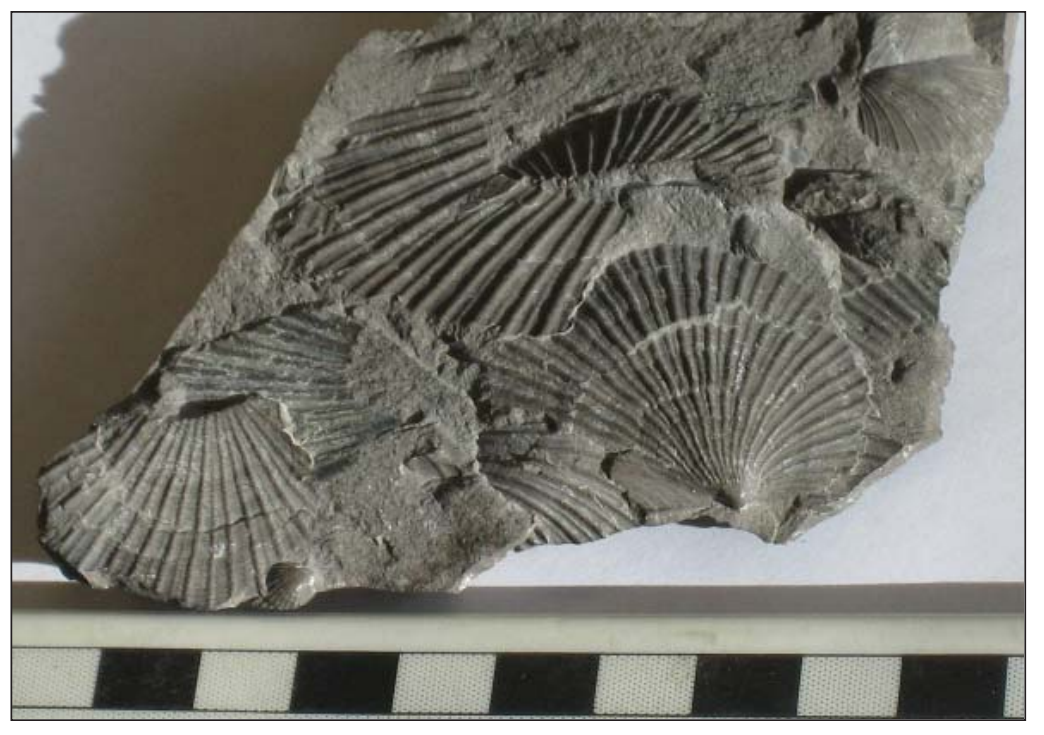

Figure 11. Slab bearing numerous specimens of Monotis (Pacimonotis) subcircularis Gabb. Limestone and shale member of the Kamishak Formation. California Academy of Sciences locality 29039. Scale marked in centimeters. 


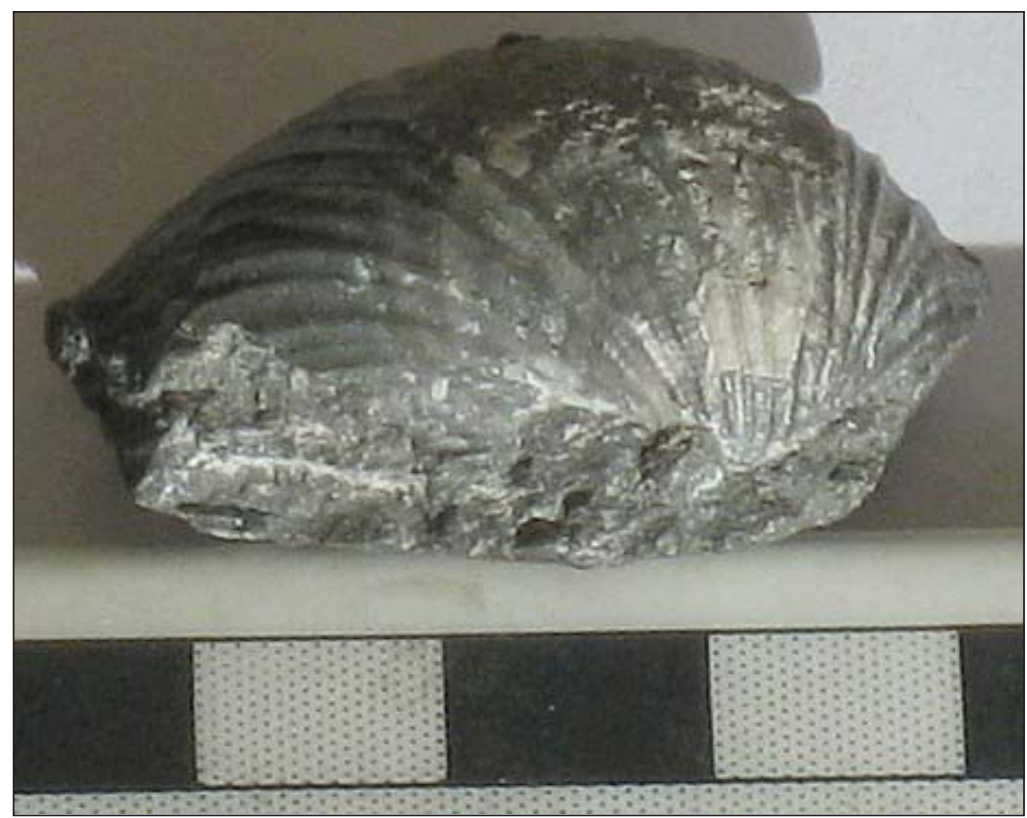

Figure 12. Left valve of Monotis (Entomonotis) sp. $c f$. M. (E.) ochotica densistriata (Teller, 1886) of Silberling and others (1997). Note highly convex nature of valve, which clearly distinguishes this subgenus. California Academy of Sciences locality 29823. Scale bar in centimeters.

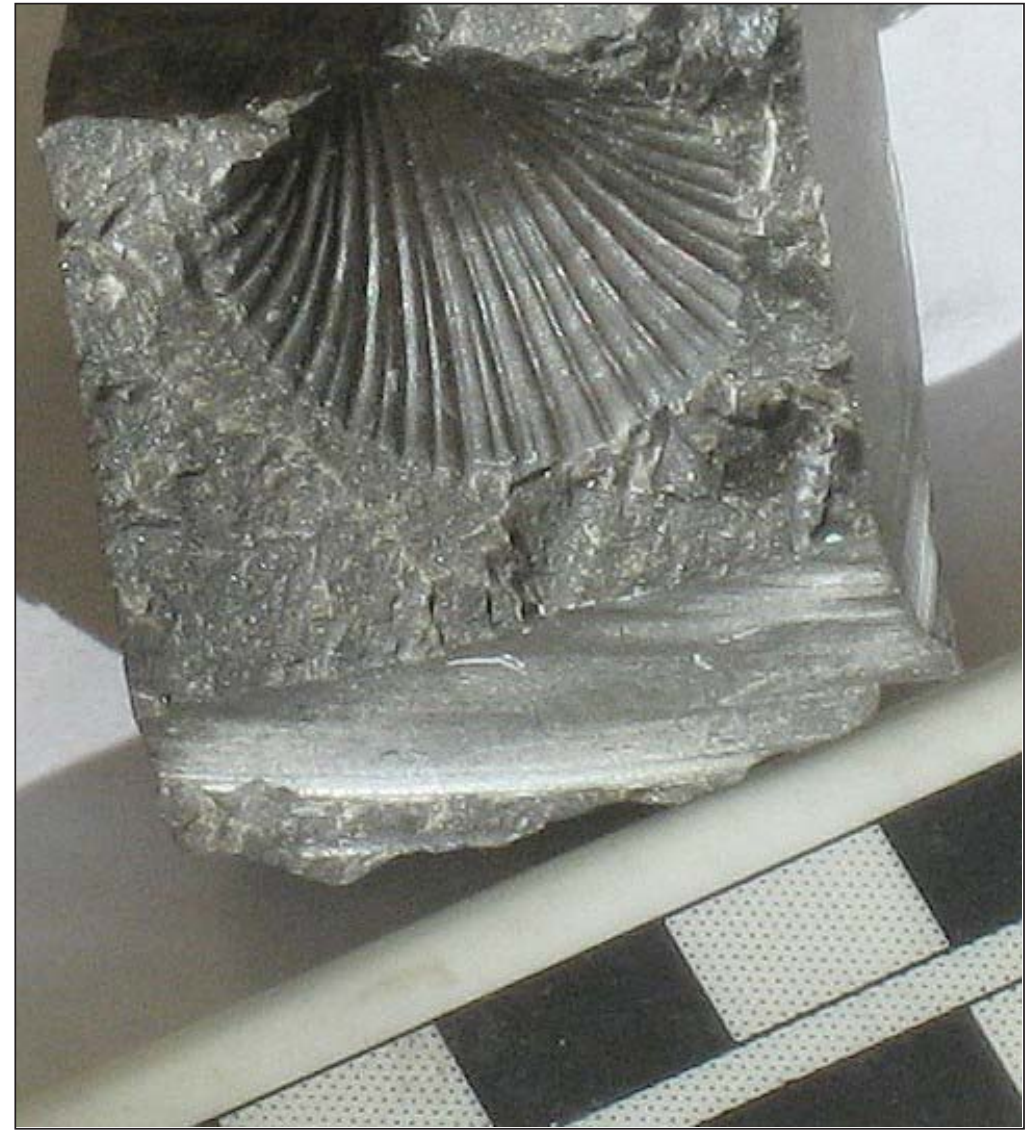

Figure 13. Left valve of Monotis (Entomonotis) sp. cf. M. (E.) ochotica densistriata (Teller, 1886) of Silberling and others (1997) viewed from above. California Academy of Sciences locality 29040. Upper scale bar in centimeters. 


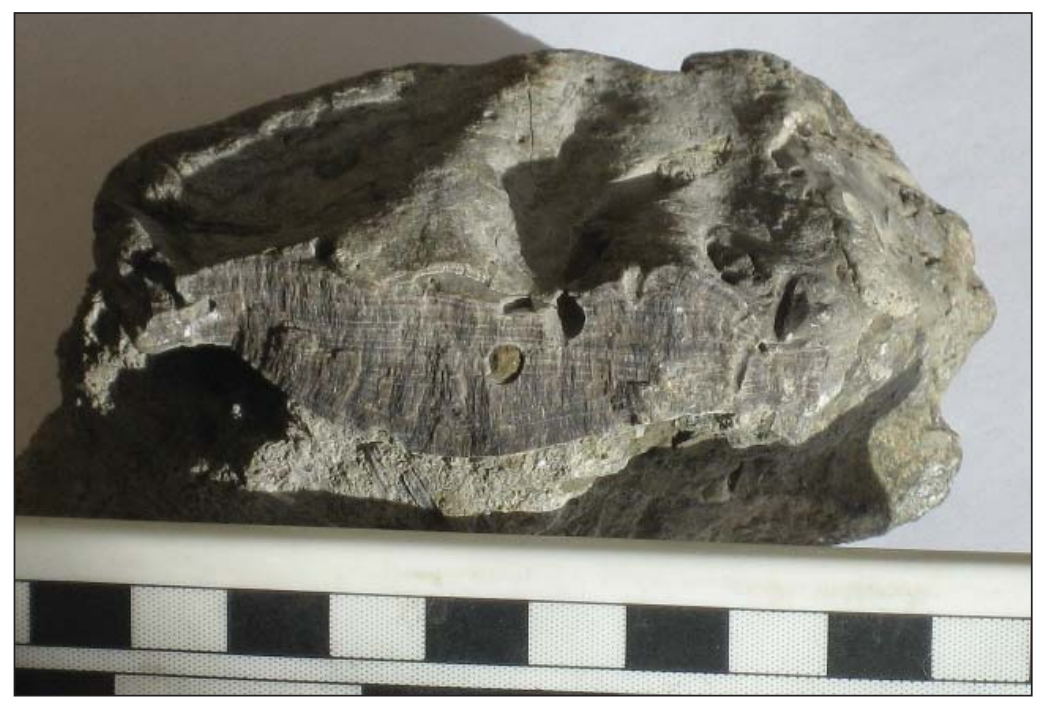

Figure 14. Oblique view of large oyster shell with borings. Note well-developed shell structure. California Academy of Sciences locality 29821. Scale in centimeters.

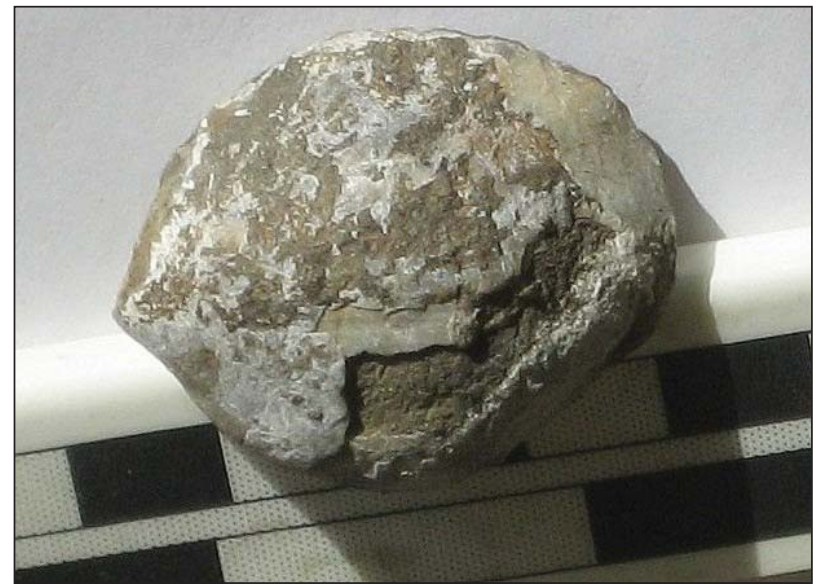

Figure 15. Ventral view of articulated smooth terebratulid brachiopod from California Academy of Sciences locality 29523. Inner scale marked in centimeters.

Figure 16. Smooth terebratulid brachiopod (ventral valve) with well-developed radial color pattern. This is the first time this feature has been observed in a Triassic brachiopod from North America, although they are commonly illustrated in European faunas of the same age. Locality 07RB14, upper part of the nodular limestone member of the Kamishak Formation. Scale in centimeters.

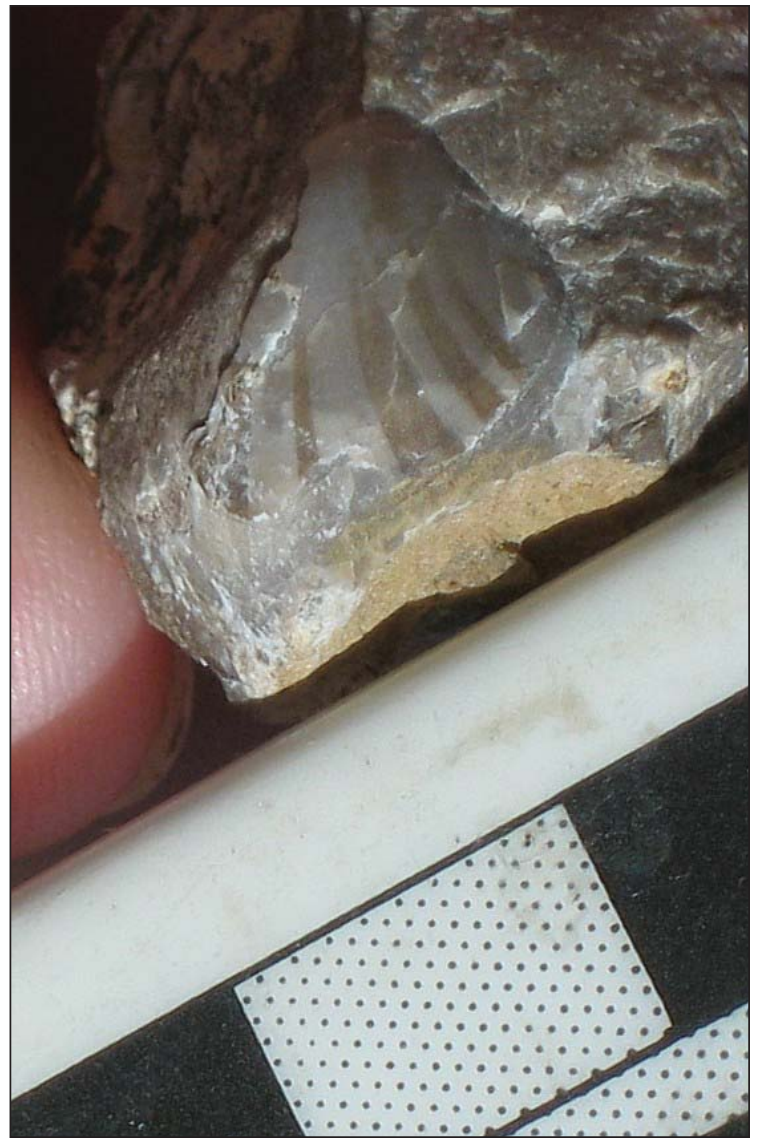


Crinoids-No articulated crinoids are known from the Kamishak Formation in the study area, however, isolated crinoid ossicles are relatively common in the biostromal member of the Kamishak Formation and are present to a lesser degree in the biostromal member. No crinoid ossicles were observed in the platy limestone. The most notable among the ossicle morphotypes include the pentagonal-shaped ossicles of the crinoid genus Pentacrinus (fig.17).

Foraminiferida - No foraminifers have been reported from the Kamishak Formation in the study area, although their presence has been noted in underlying Permian strata (Hanson, 1957; Jeffords, 1957) and overlying Lower Jurassic strata (Amoco Production Co., unpublished internal paleontologic report).

Gastropods-Gastropods are very common in the biostromal member, and slightly less so in the nodular limestone member. Gastropods are not known from the platy limestone and shale member of the Kamishak Formation. Most of the taxa are indeterminate, represented primarily by internal molds (steinkerns), probably due to the non-preservation of the originally aragonitic shell that characterizes most members of this class. However, many differing morphotypes are noted,

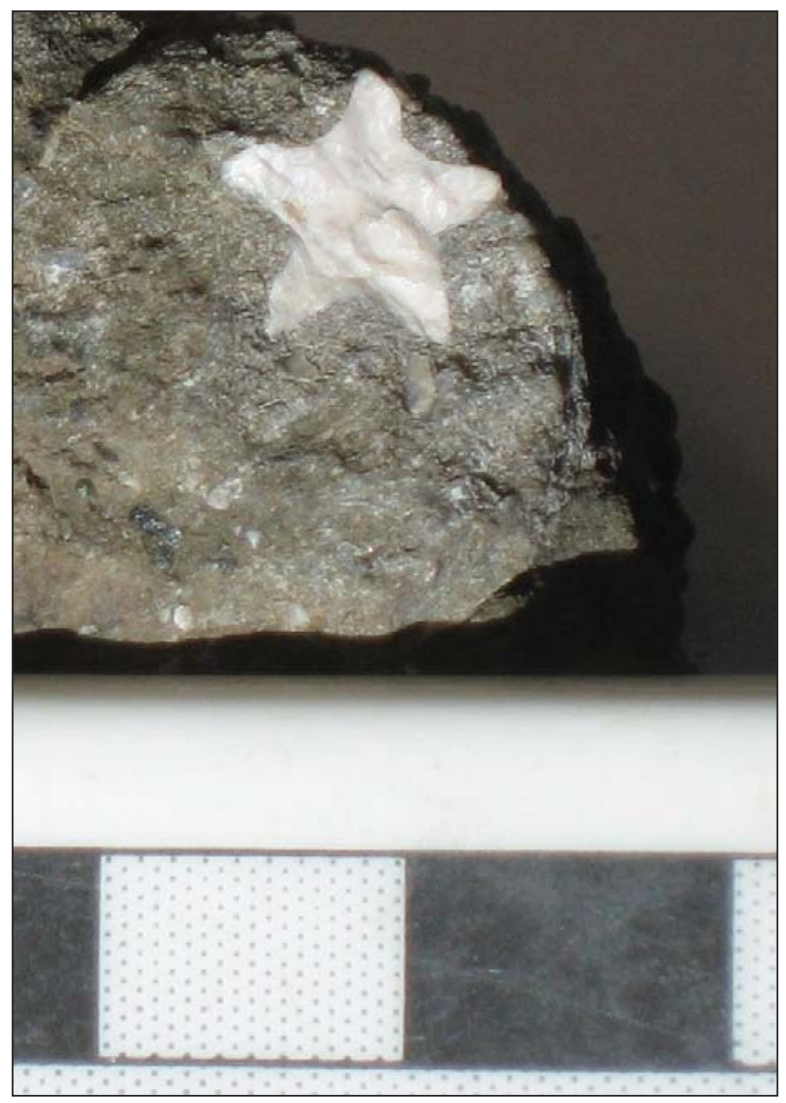

Figure 17. Pentagonal (star) shaped ossicles of the crinoid genus Pentacrinus, California Academy of Sciences locality 29820. Scale marked in centimeters. including both high-spired and low-spired forms. Moldic preservation is rather typical of the nodular limestone member, while preservation of original (or silica-replacement) is more common in the lower biostromal member. The best gastropod material appears to have been collected by geologists of Humble Oil \& Refining Co. These were illustrated in several internal company reports and included a gastropod identified as Protorcula alaskana Smith, 1927. This species is now recognized as the type species of the genus Chulitnacula Frýda and Blodgett, 2001, a genus known from the Chulitna, Alexander, and Farewell terranes of southern Alaska (Frýda and Blodgett, 2001; Blodgett and others, 2000, 2003, 2005, 2006; Blodgett in McRoberts and Blodgett, 2002). Gastropods remain a fruitful target for future paleontological study of the Kamishak Formation. Their utility includes both biostratigraphic and paleoecologic aspects, but is especially useful for determination of paleobiogeographic affinities.

Hydrozoans-The spherical, probably planktonic hydrozoan genus Heterastridium occurs commonly in the lower part of the platy limestone "member" of the Kamishak Formation at Puale Bay. Illustrated in figure 18 are several specimens from collections made by Standard Oil Co. of California geologists (now part of the collections of the California Academy of Sciences in San Francisco).

The earliest reported specimens recognized now as belonging to Heterastridium were by USGS paleontologist T.W. Stanton, who identified them in Capps (1923, p. 93) as Stoliczkaria sp. related to S. granulata. As noted here, Heterastridium commonly occurs in the lower part of the platy limestone and shale member and is the only associated fossil commonly found together with the more abundant Monotis (Pacimonotis) subcircularis Gabb. Heterastridium, a genus restricted to the Upper Triassic, is commonly thought to be indicative of a tropical, warm-water paleoenvironment (Zhang and others, 2003), and is found in a number of accreted terranes of southern Alaska (Chulitna, Wrangellia, Farewell [Nixon Fork subterrane], Alexander, and Peninsular). Its occurrence in Alaska was first noted by Smith (1927) and its most northerly undoubted report in accretionary terrane collage of southern Alaska is from the Nixon Fork subterrane of the Farewell terrane (Silberling and others, 1997).

Nautiloids-Nautiloids have been noted by the writer as being relatively common in the nodular limestone member. The specimens this author has observed are represented by relatively large internal molds. The genus Indonautilus? was reported from the Kamishak Formation exposures in the study area previously by N.J. Silberling (in an E\&R report to G.W. Moore, dated Nov. 23, 1965). In his monographic treatment of American Triassic coiled nautiloids, Kummel (1953, 


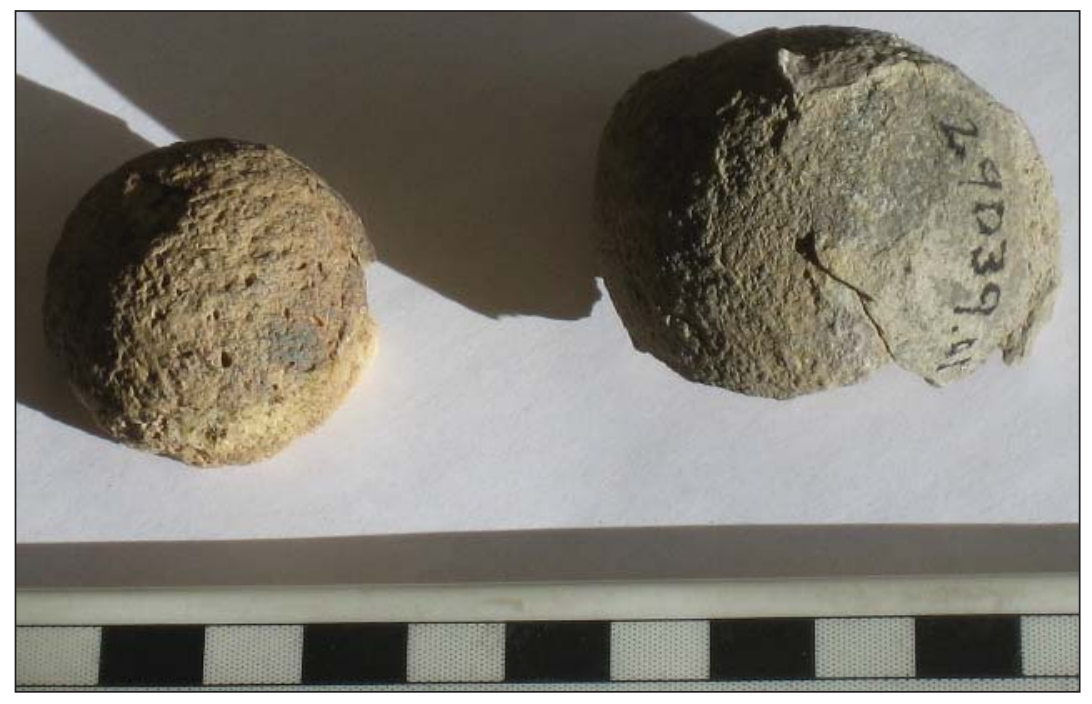

Figure 18. Two specimens of the spherical hydrozoan genus Heterastridium. California Academy of Sciences locality 29039-01. Limestone and shale member of the Kamishak Formation. Scale marked in centimeters.

p. 31) described but did not illustrate a single nautiloid he identified as Germanonautilus sp. His description is as follows:

"Two specimens are available for study from Alaska that clearly belong in Germanonautilus but are too incomplete to warrant specific assignment. The first, U.S.N.M. 107092 (U.S.G.S. loc. 12393), is from the Gold [sic] Bay District, Alaska Peninsula, Alaska and was collected by W.R. Smith in 1924. The specimen is an essentially complete living chamber with part of the crushed phragmocone. The conch is very robust, measuring $57 \mathrm{~mm}$ in width and $54 \mathrm{~mm}$ in height on the most adoral part of the living chamber. The venter is broadly rounded, flanks slightly convex grading on to a rounded and sloping umbilical wall. There is a broad shallow constriction on the flanks and venter about 2 $\mathrm{cm}$ back of the most adoral part of the specimen. The phragmocone is badly crushed but appears to be very much smaller in its general dimensions than the living chamber, indicating a rapidly expanding conch. Only part of a broad lateral lobe of the suture is visible. Position of the siphuncle is not known."

The specimen studied by Kummel was earlier referred to as Nautilus sp. by T.W. Stanton in Smith (1926, p. 68). Several large nautiloids were recovered during the 2007 field season from locality 07RB11 and these are probably conspecific with that described by Kummel as Germanonautilus sp.

Scleractinian corals — Scleractinian corals are known only from the biostromal and nodular members of the Kamishak Formation in the study area. Many of the species appear to belong to colonial forms (fig. 19), and include a form assigned to Elysastraea sp., the only coral taxon yet assigned generically in the study area. Other larger taxonomic entities have been recognized, including thamnasteriid corals, montlivaltid corals, and fungiid? corals. Solitary scleractinian corals have been observed at localities 07RB10 and 07RB12, and $07 \mathrm{RB} 14$.

Spongiomorphs-Spongiomorphs are common in the biostromal member of the Kamishak Formation (Wang, 1987), but have not been reported in the other members. No formal systematic study has yet been undertaken for this group in the study area.

Conodonts-Conodonts had not previously been reported from the Kamishak Formation. Three limestone samples were collected during the 2007 DGGS summer field season for conodont analysis (from 07RB08, 11, and 13B), but only one sample yielded positive results (07RB11). From the latter locality, one indeterminate, possibly juvenile conodont Pa element blade fragment was recovered that had a color alteration index (CAI) value of 1.5-2 (Andrea Krumhardt, written commun., November 14, 2007). This value indicates the host strata were buried to a point lower in the oil window. Conodont color alteration data (Epstein and others, 1977) are highly desired as they would provide another mode of geothermometry to unravel the thermal history of this area.

Vertebrates-No vertebrates have been noted previously from the Triassic rocks of the Peninsular terrane. During the summer 2007 DGGS field program a single large rib fragment approximately 3.9 in $(10 \mathrm{~cm})$ long was recovered from near the base of the nodular limestone member of the Kamishak Formation at the author's locality 07RB11. The specimen consists of a long curved bone that was preserved as an external mold in lime mudstone. Rubber latex casts were made for detailed examination (fig. 20). One cast was sent to Thomas L. Adams, a graduate student at Southern Methodist University, who recently completed a M.S. thesis study of Late Triassic vertebrate (dominantly ichthyosaur) material from middle Norian strata of the Hound Island 


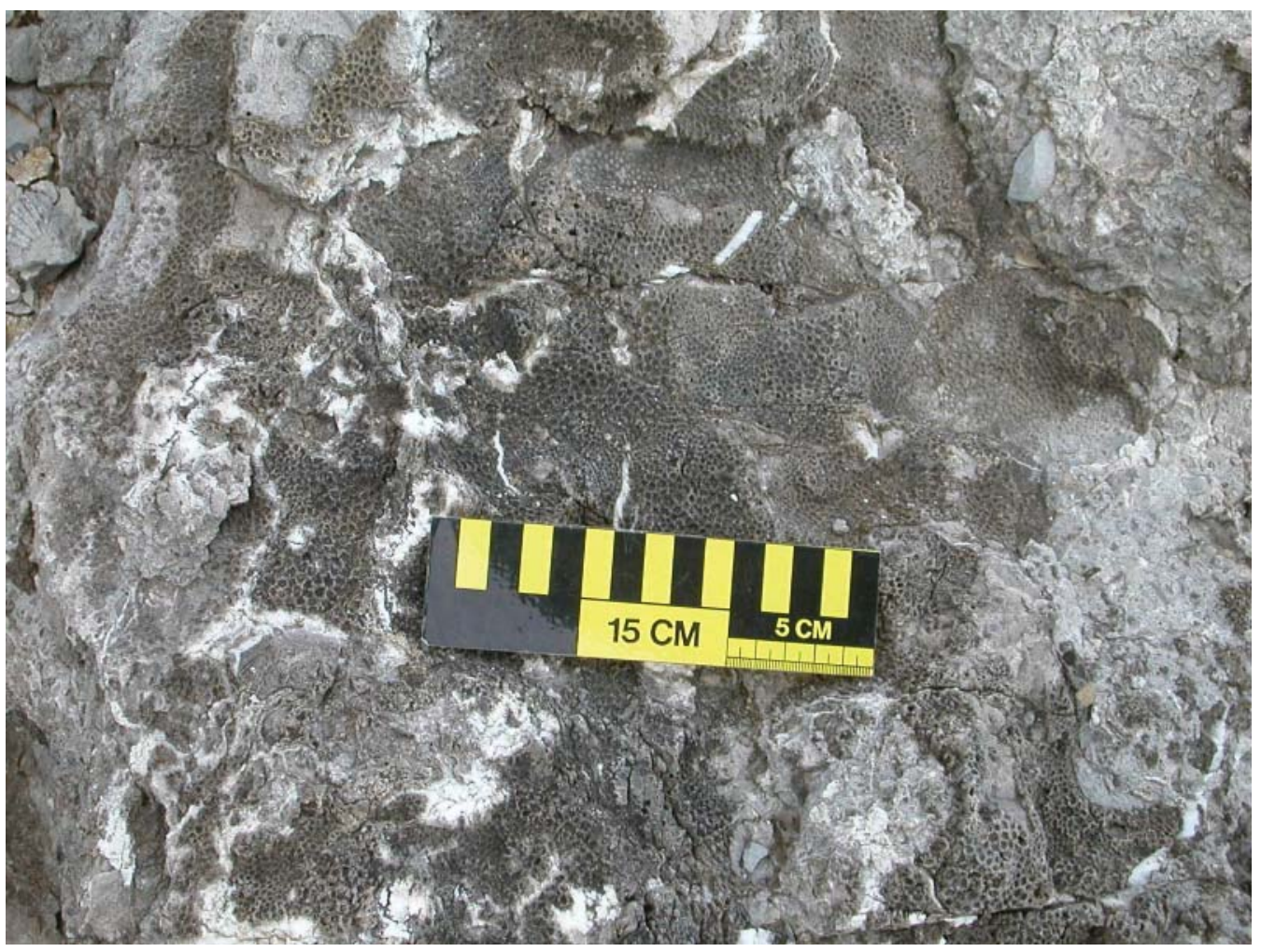

Figure 19. Massive, colonial scleractinian coral head on bedding surface in the uppermost part of the biostromal member of the Kamishak Formation (near fossil locality 07RB10, Lat. 57²42.825’ N, Long. $\left.155^{\circ} 21.712^{\prime} W\right)$.

Volcanics on Hound Island in the Keku Strait region of southeastern Alaska. Based on his preliminary examination of the cast, he reports: "At first inspection, it is definitely a rib. My first guess would be to say that it is ichthyosaur, based on size and the furrow along the upper surface. Beyond that it is hard to say. Ribs are not very diagnostic. Always the chance that it could be thalattosaur or even sauropterygian” (T.L. Adams, written commun., October 2, 2007). Although I am not a vertebrate paleontologist, I would comment further that this specimen reminds me very much of ichthyosaur rib fragments I have seen in the Upper Jurassic Naknek Formation from the east shore of the Island Arm branch of Becharof Lake.

\section{PALEOBIOGEOGRAPHIC AFFINITIES OF THE PENINSULAR TERRANE TRIASSIC FAUNAS}

Determination of the paleobiogeographic affinities of Peninsular terrane faunas and floras through time will shed much light on the wanderings of this terrane during Permian through Jurassic time up to its final accretion into the collage of terranes that comprise Alaska as we now know it. Virtually nothing has previously been published regarding the Peninsular terrane affinities during the Late Triassic, but enough data are now emerging so that some speculation can be made. The remarks made below pertain only to Kamishak Formation fauna recovered to date from the Puale Bay-Alinchak Bay area.

The study of the paleobiogeographic affinities of Late Triassic faunas from Alaska has only recently been undertaken. The first papers to address this issue have focused on monotid bivalves (Silberling, 1985; Grant-Mackie and Silberling, 1990; and Silberling and others, 1997). More recently, publications have appeared that examined the faunal distribution of Late Triassic gastropods within Alaska (Blodgett and Frýda, 2001a, b; Blodgett and others, 2001, 2003, 2005, 2006; Frýda and Blodgett, 2001; Sandy and others, 2001 [the latter also addressed brachiopods]).

The relative abundance of the floating hydrozoan genus Heterastridium (primarily known from late Norian strata in North American, but older Norian records in New Zealand and New Caledonia exist [Jack GrantMackie, written commun., July 24, 2007]) suggest a warm, tropical setting for the terrane. Heterastridium is found in a number of accreted terranes of southern Alaska (Chulitna, Alexander, Wrangellia, Peninsular, Susitna, and Farewell) where it is often closely associated with strata bearing other warm-water elements such as scleractinian corals, spongiomorphs, and 


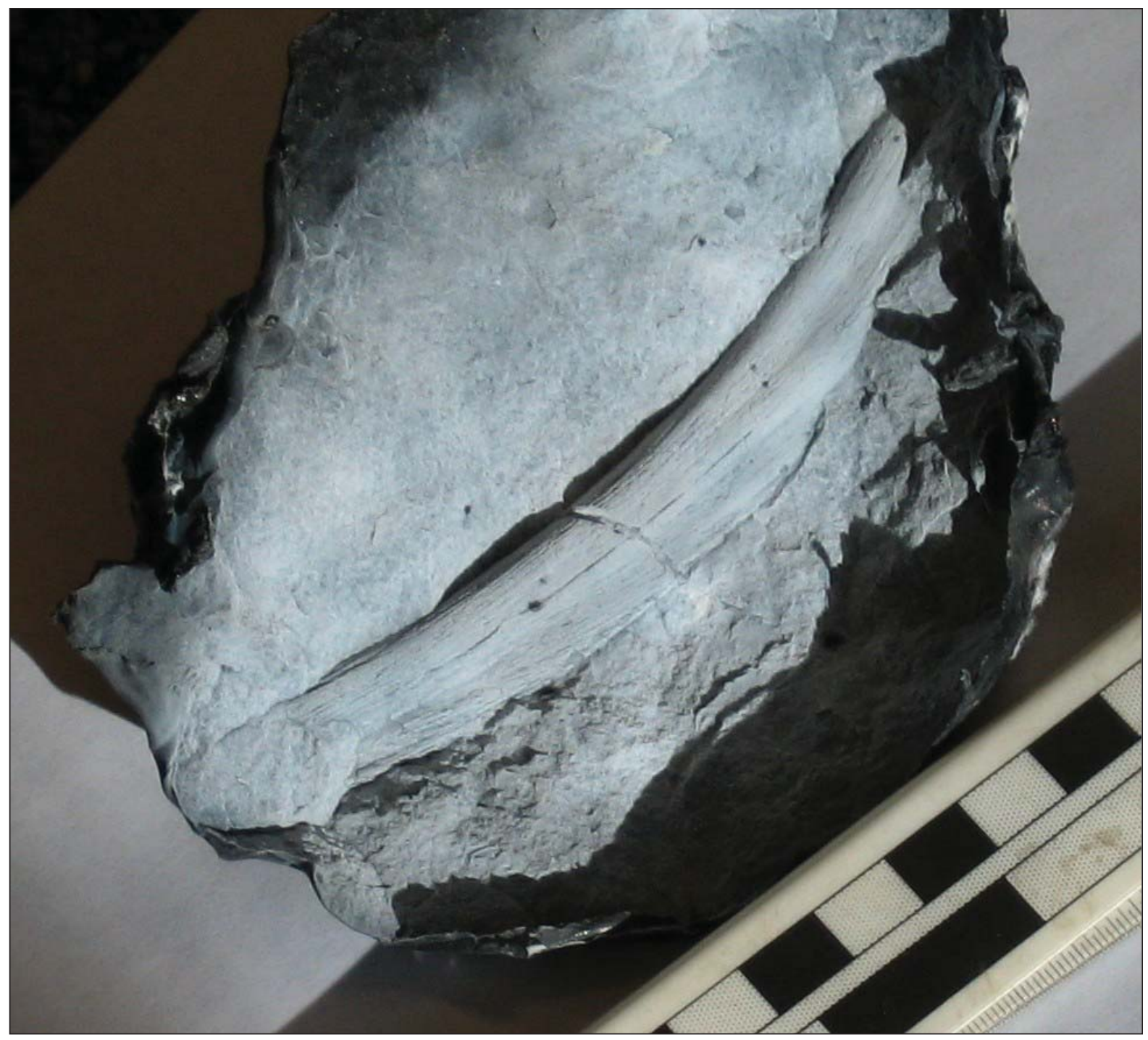

Figure 20. Rubber latex replica of probable ichthyosaur rib fragment from locality 07RB11. Upper scale bar in centimeters.

calcareous green algae (Zhang and others, 2003). The most northerly occurrence of Heterastridium in North America is the accretionary Farewell (Nixon Fork) terrane of west-central Alaska (Silberling and others, 1997, p. 16). Heterastridium, along with scleractinian corals and spongiomorphs, are unknown in the Arctic Alaska terrane, which appears to have been situated at a much more northerly, cool paleolatitude.

Monotid bivalves, the key faunal signature to the upper limestone and shale member of the Kamishak Formation in the study area, have until this investigation been considered to belong to only two species, Monotis (Pacimonotis) subcircularis Gabb, typical of the lower part of this member, with rarer occurrences of Monotis (Monotis) alaskana Smith higher in the section (Detterman and others, 1996; Silberling and others, 1997). Silberling and others (1997, fig. 4) show only four southern Alaskan terranes that contain such a combination of species (present with qualification, or present in the sense of "cf." or "?”): the Susitna, Wrangellia, Peninsular, and Alexander terranes. As noted above, two of the California Academy of Sciences collections (CAS localities 28040 and 29823) recently obtained on loan, contain several left valves of monotid bivalves that are identical to forms illustrated and identified as Monotis (Entomonotis) sp. cf. M. (E.) ochotica densistriata (Teller, 1886) of Silberling, and others, 1997. This taxon has previously been recognized in Alaska only from USGS Mesozoic locality 1912 on Kuiu Island, southeast Alaska (in the Alexander terrane).

Although few gastropods are identified with any confidence from Kamishak Formation in the study area, it is of note that the species Protorcula alaskana was identified and illustrated in an internal report of 
the Humble Oil \& Refining Co. (Levinson and Jeffords, 1956). This species was later designated the type species of the genus Chulitnacula Frýda and Blodgett, 2001, a genus known only from the Chulitna, Alexander, and Farewell terranes of southern Alaska (Frýda and Blodgett, 2001; Blodgett and others, 2000, 2003, 2005, 2006; Blodgett in McRoberts and Blodgett, 2002). It is particularly noteworthy that this distinctive species is, as far as is known, absent from the Wrangellia terrane. Assessment of the Norian gastropod populations (together with other associated fauna and flora) from various parts of southern Alaska suggests that all were probably situated in warm, equatorial settings during this time. However, the Wrangellia terrane (with its own distinctive, highly endemic gastropod fauna) was separated by some significant distance from the Chulitna, Alexander, and Farewell terranes, which appear to have formed a triplet (probably situated close to one another) sharing many of the same, highly endemic gastropod species (see gastropod references cited above for more detailed description). The paleobiogeographic evidence at hand indicates that the Peninsular terrane shares many affinities with the Alexander, Chulitna, and Farewell terrane, rather than with the Wrangellia terrane.

\section{ACKNOWLEDGMENTS}

First, I want to thank Rocky R. Reifenstuhl for involving me in three separate field seasons of fieldwork on the Alaska Peninsula, two of which permitted me to visit the Upper Triassic Kamishak Formation exposures in the area of Puale Bay and Cape Kekurnoi. Many other people have also made contributions that have helped me to better understand the rocks of the area. Les Magoon (USGS, Menlo Park, CA) and Bob Egbert (formerly USGS in Menlo Park, now a consultant in Houston, TX) are gratefully acknowledged for their discussions and sharing with me their notes and photographs from their 1979 fieldwork in the study area. Frederic H. ("Ric") Wilson (USGS, Anchorage, AK) graciously allowed me access to the field sheets and field notes of the late Robert L. ("Buck") Detterman that he made while mapping in the study area. Norman J. Silberling proved very helpful in providing insights in the classification of monotid bivalves and providing me access to the illustrated type specimens from the monographic treatment and overview of this group that he, Jack Grant-Mackie, and Kathy Nichols beautifully documented in their paper (Silberling and others, 1997) on this group. I thank Bryan Sralla (XTO Energy, Inc., Fort Worth, TX) for many fruitful discussions on the Mesozoic stratigraphy and petroleum potential of the region. I also wish to thank the following people for providing access to archived fossil collections and literature of this region: Jean F. DeMouthe (California Academy of Sciences, San Francisco, CA), K.C. (“Casey”) McKinney (USGS, Denver, CO), and
Keith A. Knabe (ExxonMobil Exploration Co., Houston, TX). Kenneth M. Dixon, USGS, Anchorage, Alaska, was most helpful in scanning many old diagrams and in photographing some of the newly collected material reported here. This paper benefited from the thoughtful reviews of Arthur J. Boucot (Dept. Zoology, Oregon State University, Corvallis, OR) and David M. Rohr (Dept. Geology, Sul Ross State University, Alpine, TX). Finally, I thank Herb Mann of Houston, Texas, (formerly with Shell Oil Co.) for sharing his wonderful recollections of fieldwork in the 1950s on the Mesozoic stratigraphy of the Puale Bay area.

\section{REFERENCES CITED}

Barbacka, Maria, Pálfy, J., and Smith, P.L., 2006, Hettangian (Early Jurassic) plant fossils from Puale Bay (Peninsular terrane, Alaska): Review of Palaeobotany and Palynology, v. 142, p. 33-46.

Blodgett, R.B., and Frýda, J., 2001a, On the occurrence of Spinidelphinulopsis whaleni (Late Triassic [early Norian] Gastropoda) in the Cornwallis Limestone, Kuiu Island, southeastern Alaska (Alexander terrane) and its paleobiogeographic significance: Bulletin of the Czech Geological Survey, v. 76, no. 4, p. 235-242.

2001b, Upper Triassic gastropod biogeography of western North America [abs.]: Geological Society of America Abstracts with Programs, v. 33, no. 3, p. A-53.

Blodgett, R.B., and Sralla, Bryan, 2008, A major unconformity between Permian and Triassic strata at Cape Kekurnoi, Alaska Peninsula; Old and new observations on stratigraphy and hydrocarbon potential, in Haeussler, P.J., and Galloway, J.P., eds., Studies by the U.S. Geological Survey in Alaska, 2006: U.S. Geological Survey Professional Paper 1739-E, 13 p. [http://pubs.usgs.gov/pp/pp1739/e/].

Blodgett, R.B., Frýda, J., and Stanley, G.D., Jr., 2001, Delphinulopsidae, a new neritopsoidean gastropod family from the Upper Triassic (upper Carnian or lower Norian) of the Wallowa terrane, northeastern Oregon: Journal of Czech Geological Society, v. 46, no. 3-4, p. 307-318.

2003, Late Triassic gastropod biogeography of southern Alaskan accreted terranes [abs.]: Geological Society of America Abstracts with Programs, v. 35, no. 4, p. 59.

2005, Upper Triassic gastropod fauna from southern Alaska and its implications for terrane accretion [abs.]: Geological Society of America Abstracts with Programs, v. 37, no. 7, p. 82.

2006, Late Triassic gastropod faunas of western North America-A useful tool in terrane analysis [abs.]: Geological Society of America Abstracts with Programs, v. 38, no. 5, p. 81. 
Blodgett, R.B., Wilson, F.H., Stanley, G.D., Jr., McRoberts, C.A., and Sandy, M.R., 2000, Upper Triassic stratigraphy and fauna of the Taylor Mountains D-2 and D-3 quadrangles (SW part of the Farewell terrane), southwest Alaska [abs.]: Geological Society of America Abstracts with Programs, v. 32, no. 6, p. A-4.

Capps, S.R., 1923, The Cold Bay district, in U.S. Geological Survey Staff, Mineral resources of Alaska, report on progress of investigations in 1921: U.S. Geological Survey Bulletin 739, p. 77-116, 1 plate, scale 1:250,000.

Detterman, R.L., and Hartsock, J.K., 1966, Geology of the Iniskin-Tuxedni region, Alaska: U.S. Geological Survey Professional Paper 512, 78 p., 6 plates, scale 1:63,360.

Detterman, R.L., and Reed, B.L., 1980, Stratigraphy, structure, and economic geology of the Iliamna Quadrangle, Alaska: U.S. Geological Survey Bulletin 1368-B, 86 p., 1 plate, scale 1:250,000.

Detterman, R.L., Case, J.E., Miller, J.W., Wilson, F.H., and Yount, M.E., 1996, Stratigraphic framework of the Alaska Peninsula: U.S. Geological Survey Bulletin 1969-A, 74 p.

Detterman, R.L., Case, J.E., Wilson, F.H., and Yount, M.E., 1987, Geologic map of the Ugashik, Bristol Bay, and western part of Karluk quadrangles, Alaska: U.S. Geological Survey Miscellaneous Investigations Series Map 1685, 1 plate, scale 1:250,000.

Detterman, R.L., Case, J.E., Wilson, F.H., Yount, M.E., and Allaway, W.H., Jr., 1983, Generalized geologic map of the Ugashik, Bristol Bay, and part of Karluk quadrangles, Alaska: U.S. Geological Survey Miscellaneous Field Studies Map 1539-A, 1 plate, scale 1:250,000.

Epstein, A.G., Epstein, J.B., and Harris, L.D., 1977, Conodont color alteration-An index to organic metamorphism: U.S. Geological Survey Professional Paper 995, 27 p.

Fischer, P.H., 1872, Sur quelques fossiles de l'Alaska, rapportés par. M.A. Pinart: Comptes Rendus, v. 75, p. 1,784-1,786.

1875, Sur quelques fossiles de l'Alaska, in Pinard, A.L., Voyages à la côte nord-ouest de l'Amérique executés dans les années 1870-1872: Paris, E. Leroux, pt. 1, p. 33-36.

Frech, Fritz, 1908, Die zircumpacifische Trias; Lethaea geognostica, Teil 2, Das Mesozoicum: Band 1, Trias, v. 4, p. 488-509.

Frýda, J., and Blodgett, R. B., 2001, Chulitnacula, a new paleobiogeographically distinctive gastropod genus from Upper Triassic strata in accreted terranes of southern Alaska: Journal of Czech Geological Society, v. 46, no. 3-4, p. 299-306.
Gabb, W.M., 1864, Description of Triassic fossils of California and the adjacent territories: California Geological Survey, Paleontology, v. 1, p. 17-35, plates 3-6.

Grant-Mackie, J.A., and Silberling, N.J., 1990, New data on the Upper Triassic bivalve Monotis in North America and the new subgenus Pacimonotis: Journal of Paleontology, v. 64, no. 2, p. 240-254.

Hanna, G.D., Leach, C.E., Tallant, R.L., Bryan, J.J., and Scott, E.W., 1937, Preliminary geologic report on the Bear Creek Anticline, Alaska-1937: San Francisco, Tide Water Associated Oil Co.-Standard Oil Co. of California-Union Oil Co. of California internal report, $20 \mathrm{p}$.

Hanson, B.M., 1957, Middle Permian limestone on Pacific side of Alaska Peninsula: American Association of Petroleum Geologists Bulletin, v. 41, no. 10, p. 2,376-2,378.

Imlay, R.W., 1981, Early Jurassic ammonites from Alaska: U.S. Geological Survey Professional Paper 1190, 40 p.

Imlay, R.W., and Detterman, R.L., 1977, Some Lower and Middle Jurassic beds in Puale Bay-Alinchak Bay area, Alaska Peninsula: Bulletin of the American Association of Petroleum Geologists, v. 61, no. 4, p. 607-611.

Jeffords, R.M., 1957, Permian fossils from an island in Puale Bay, Alaska: Houston, Humble Oil \& Refining Co. Geologic Research Report 57-24, 6 p.

Kelley, J.S., 1980, Environments of deposition and petrography of Lower Jurassic volcaniclastic rocks, southwestern Kenai Peninsula, Alaska: Davis, University of California, Ph.D. thesis, 304 p.

Kellum, L.B., 1945, Jurassic stratigraphy of Alaska and petroleum exploration in northwest America: Transactions of the New York Academy of Science, ser. 2, v. 7, no. 8, p. 201-209.

Kummel, Bernhard, 1953, American Triassic coiled nautiloids: U.S. Geological Survey Professional Paper 250, 104 p., 19 plates.

Levinson, S.A., and Jeffords, R.M., 1956, Megafossils and spores and pollen from Puale Bay, Alinchak Bay, and Cape Kekurnoi, Alaska: Houston, Humble Oil \& Refining Co. Geologic Research Report, 10 p., 4 plates.

Martin, G.C., 1915, The western part of Kenai Peninsula, in Martin, G.C., Johnson, B.L., and Grant, U.S., Geology and mineral resources of Kenai Peninsula, Alaska: U.S. Geological Survey Bulletin 587, p. 41-112.

Martin, G.C., 1916, Triassic rocks of Alaska: Geological Society of America Bulletin, v. 27, p. 685-718.

Martin, G.C., 1921, Preliminary report on petroleum in Alaska: U.S. Geological Survey Bulletin 719, 83 p., 5 plates, scale 1:125,000. 
Martin, G.C., 1926, The Mesozoic stratigraphy of Alaska: U.S. Geological Survey Bulletin 776, 493 p.

Martin, G.C., and Katz, F.J., 1912, A geologic reconnaissance of the Iliamna region, Alaska: U.S. Geological Survey Bulletin 485, 138 p.

McRoberts, C.A., 1997, Late Triassic (Norian-Rhaetian) bivalves from the Antimonio Formation, northwestern Sonora, Mexico: Revista Mexicana de Ciencias Geológicas, v. 14, no. 2, p. 167-177.

McRoberts, C.A., and Blodgett, R.B., 2002, Upper Triassic (Norian) mollusks from the Taylor Mountains Quadrangle, southwest Alaska, in Wilson, F.H., and Galloway, J.P., eds., Geologic Studies in Alaska by the U.S. Geological Survey, 2000: U.S. Geological Survey Professional Paper 1662, p. 55-75.

Mojsisovics, Edmund, von, 1886, Arktische Triasfaunen: Mémoires de l'Académie Impériale des Sciences de St.-Pétersbourg, 7th ser., v. 33, no. 6, 159 p., 20 plates.

Molenaar, C.M., 1995, Alaska Peninsula, in Magoon, L.B., Molenaar, C.M., Bruns, T.R., Fisher, M.A., Valin, Z.C., Southern Alaska Province (003), in Gautier, D.L., Dolton, G.L., Takahashi, K.I., and Varnes, K.L., eds., 1995 National assessment of United States oil and gas resources-Results, methodology, and supporting data: U.S. Geological Survey Digital Data Series 30, CD-ROM, p. 2-4.

Moore, G.W., 1967, Preliminary geologic map of Kodiak Island and vicinity, Alaska: U.S. Geological Survey Open-file Report 67-161, 1 plate, scale 1:250,000.

Newton, C.R., 1983a, Norian (Late Triassic) mollusks of Cordilleran allochthonous terranes: Paleoecology and paleozoogeography: Santa Cruz, University of California, Ph.D. thesis, 173 p.

1983b, Paleozoogeographic affinities of Norian bivalves from the Wrangellian, Peninsular, and Alexander terranes, northwestern North America, in Stevens, C.H., ed., Pre-Jurassic rocks in western North American suspect terranes: Sacramento, CA, Society of Economic Paleontologists and Mineralogists Symposium, p. 37-48.

Newton, C.R., 1990, Triassic-Jurassic boundary section at Puale Bay, Alaska Peninsula; Comparative diversity patterns of skeletal faunas and trace fossils [abs.]: American Association of Petroleum Geologists Bulletin, v. 74, no. 5, p. 730.

Pálfy, József, 1997, Calibration of the Jurassic time scale: Vancouver, University of British Columbia, Ph.D. dissertation, 180 p.

Pálfy, József, Smith, P.L., Mortensen, J.K., and Friedman, R.M., 1999, Integrated ammonite biochronology and U-Pb geochronometry from a basal Jurassic section in Alaska: Geological Society of America Bulletin, v. 111, no. 10, p. 1,537-1,549.
Pinart, A.L., 1873, Voyage à la côte nord-ouest de l'Amérique d'Ounalashka à Kadiak: Paris, Bulletin de la Société de Géographie, série VI, v. 6, p. 561-580.

Sandy, M.R., Blodgett, R.B., and Frýda, J., 2001, Paleobiogeographic signatures for Upper Triassic brachiopods and gastropods from Kuiu Island and adjacent Keku Strait, SE Alaska [abs.]: Geological Society of America Abstracts with Programs, v. 33, no. 3, p. A-53.

Silberling, N.J., 1985, Biogeographic significance of the Upper Triassic bivalve Monotis in circum-Pacific accreted terranes, in Howell, D.G., ed., Tectonostratigraphic terranes of the Circum-Pacific region: Circum-Pacific Council for Energy and Mineral Resources Earth Sciences Series No. 1, p. 63-70.

Silberling, N.J., Grant-Mackie, J.A., and Nichols, K.M., 1997, The Late Triassic bivalve Monotis in accreted terranes of Alaska: U.S. Geological Survey Bulletin 2151, $21 \mathrm{p}$.

Smith, J.P., 1927, Upper Triassic marine invertebrate faunas of North America: U.S. Geological Survey Professional Paper 141, 262 p.

Smith, W.R., 1925, The Cold Bay-Katmai district, in Mineral resources of Alaska; report on progress of investigations in 1923: U.S. Geological Survey Bulletin 773, p. 183-207.

1926, Geology and oil development of the Cold Bay district, in Mineral Resources of Alaska; Report on progress of investigations in 1924: U.S. Geological Survey Bulletin 783, p. 63-88.

Smith, W.R., and Baker, A.A., 1924, The Cold BayChignik district, in Mineral resources of Alaska; Report on progress of investigations in 1922: U.S. Geological Survey Bulletin 755, p. 151-218.

Sralla, Bryan, and Blodgett, R.B., 2007, Reservoir potential of Late Triassic Kamishak Formation; Puale Bay, Alaska Peninsula [abs.]: American Association of Petroleum Geologists Annual Convention \& Exhibition, Long Beach, CA, 2007, Abstracts, v. 91 (digital), p. 132.

Stanley, G.D., Jr., 1979, Paleoecology, structure, and distribution of Triassic coral buildups in western North America: University of Kansas Paleontological Contributions, v. 65, p. 1-58.

Stanton, T.W., and Martin, G.C., 1905, Mesozoic section on Cook Inlet and Alaska Peninsula: Geological Society of America Bulletin, v. 16, p. 391-410.

Teller, Friedrich, 1886, Die Pelecypod-Fauna von Werchojansk in Ostsiberien, in Mojsisovics, Edmund, von, ed., Arktische Triasfaunen: Mémoires de l'Académie Impériale des Sciences de St.-Pétersbourg, 7th ser., v. 33, no. 6, p. 103-137. 
von Huene, Roland, Moore, J.C., and Moore, G.W., 1979, Cross section of Alaska Peninsula-Kodiak Island-Aleutian Trench: Geological Society of America Map and Chart Series, 1979, v. MC-28A, 2 sheets, scale 1:250,000.

Wang, Jason, 1987, Sedimentology of Norian (Late Triassic) cherts and carbonates from the Peninsular Terrane, Puale Bay, Alaska Peninsula: Syracuse, NY, Syracuse University, unpublished M.S. thesis, $124 \mathrm{p}$.

Wang, Jason, Newton, C.R., and Dunne, L., 1988, Late Triassic transition from biogenic to arc sedimentation on the Peninsular terrane, Puale Bay, Alaska Peninsula: Geological Society of America Bulletin, v. 100 , no. 9 , p. $1,466-1,478$.
Wilson, F.H., Detterman, R.L., and Case, J.E., 1985, The Alaska Peninsula terrane; A definition: U.S. Geological Survey Open-File Report 85-450, 17 p.

Zhang, Ning, Blodgett, R.B., and Stanley, G.D., 2003, Paleontological database applications for Alaskan terrane studies [abs.]: Geological Society of America Abstracts with Programs, v. 35, no. 4, p. 24. 
THIS PAGE INTENTIONALLY LEFT BLANK 


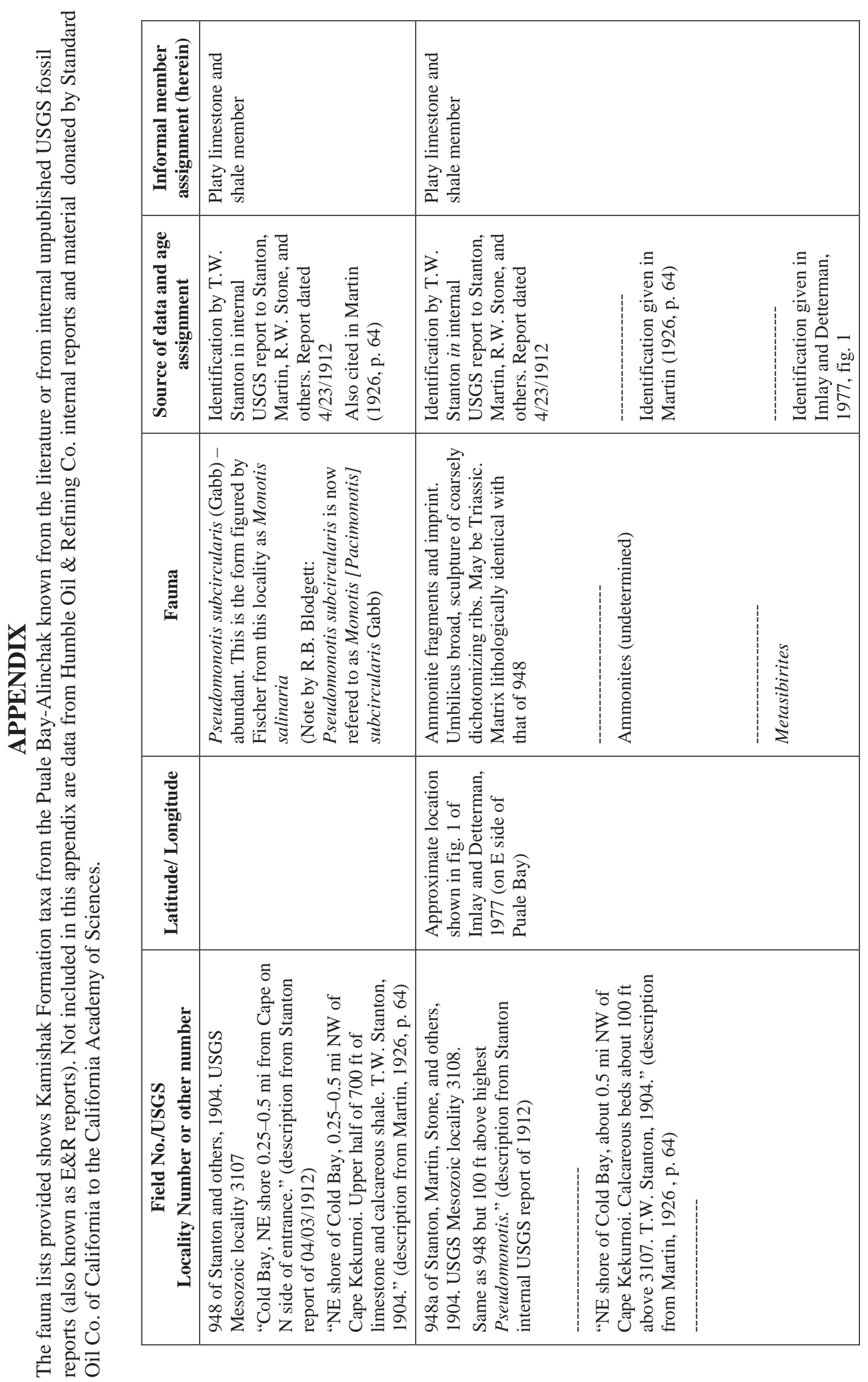




\begin{tabular}{|c|c|c|c|c|}
\hline 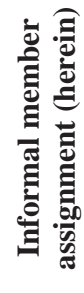 & \multicolumn{2}{|l|}{ 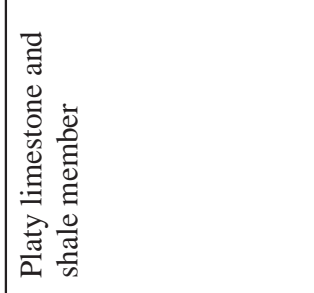 } & 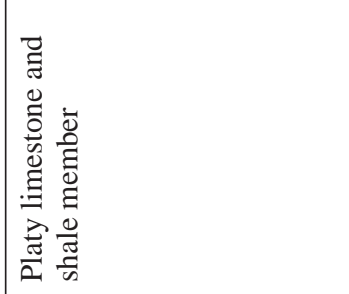 & 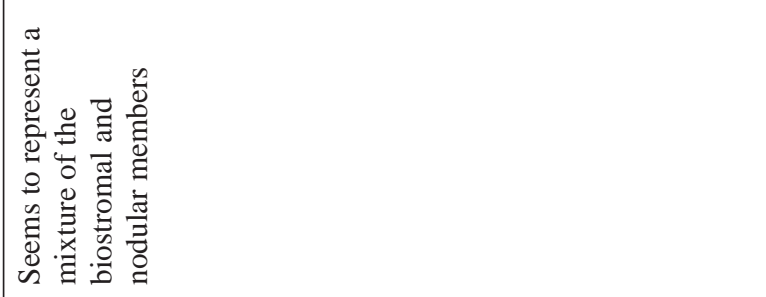 \\
\hline 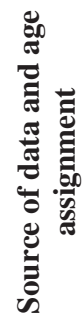 & \multicolumn{2}{|c|}{ 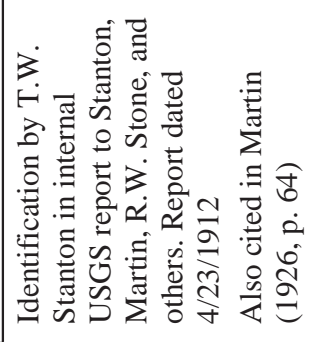 } & 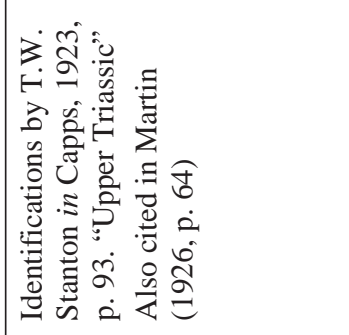 & 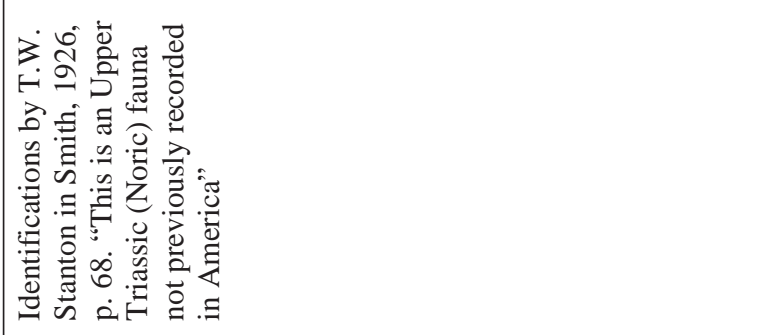 \\
\hline 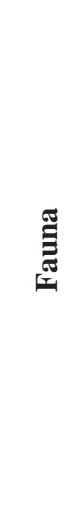 & \multicolumn{2}{|l|}{ 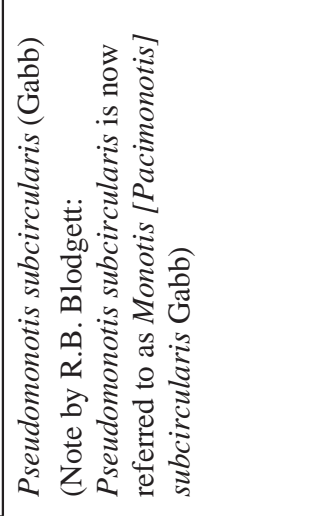 } & 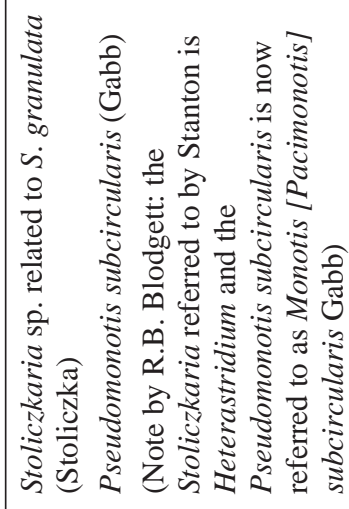 & 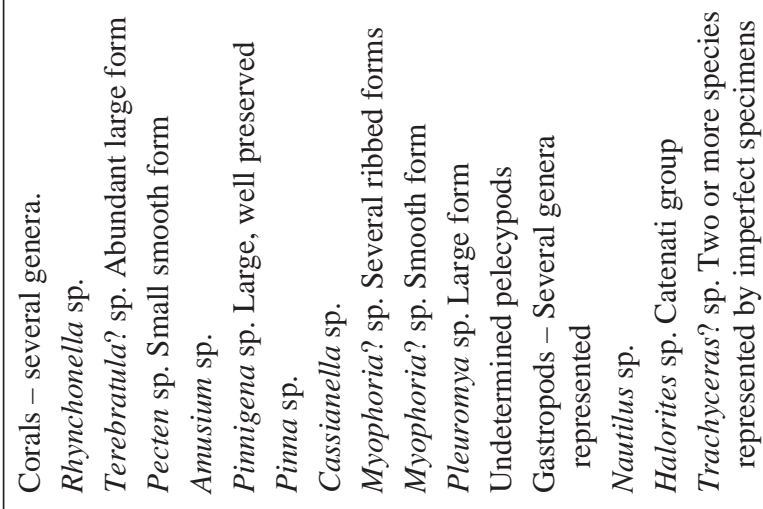 \\
\hline 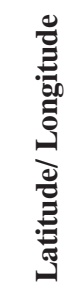 & & & 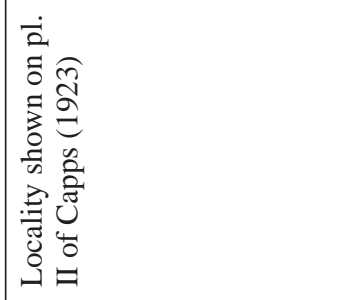 & 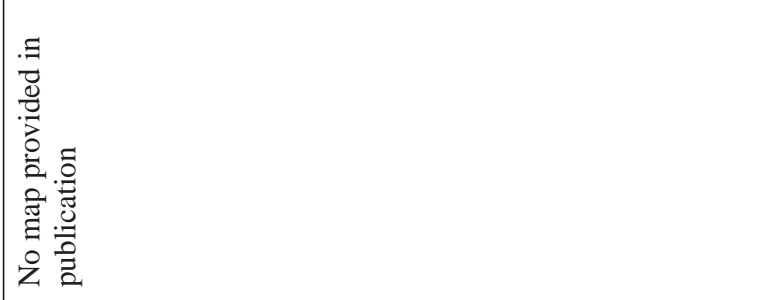 \\
\hline 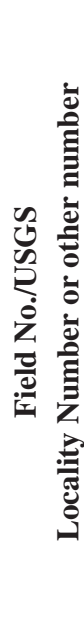 & 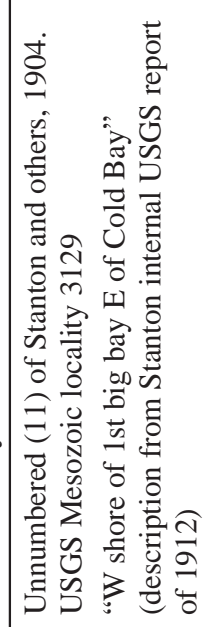 & 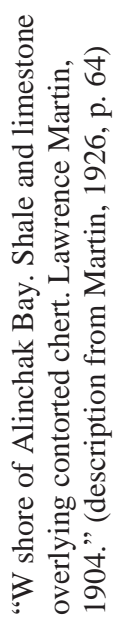 & 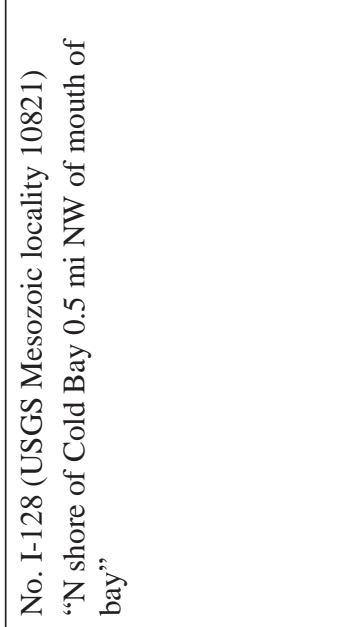 & 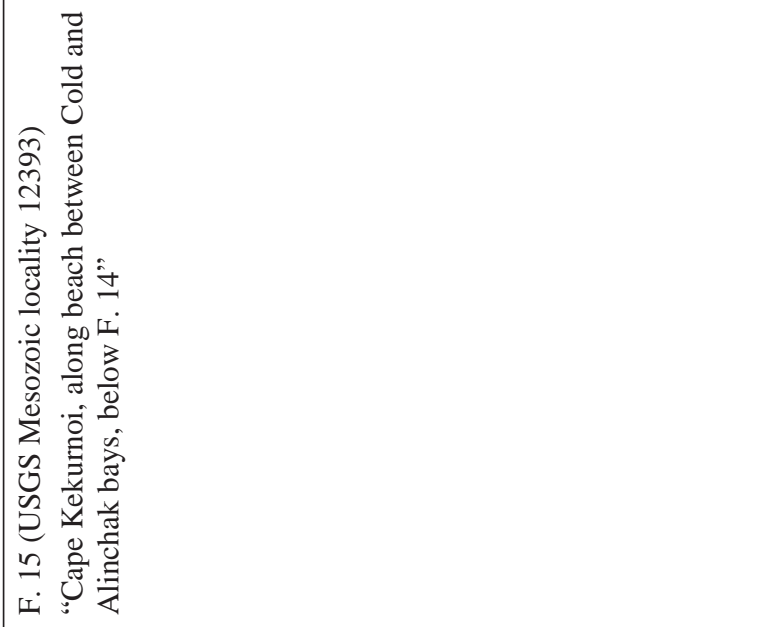 \\
\hline
\end{tabular}




\begin{tabular}{|c|c|c|c|c|}
\hline 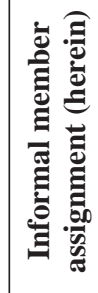 & 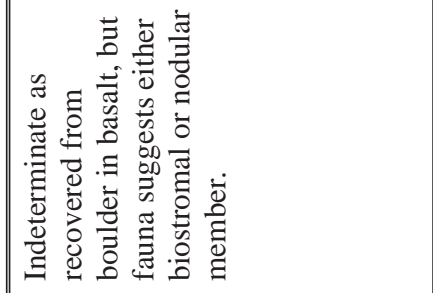 & 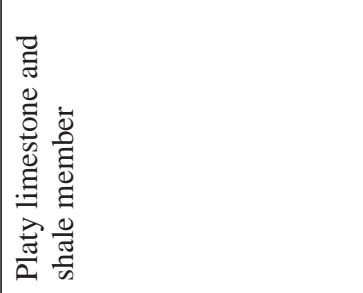 & 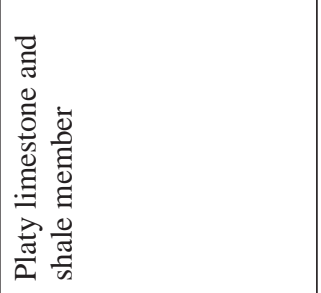 & 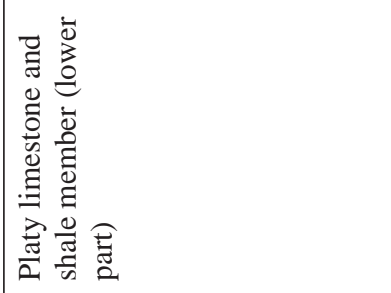 \\
\hline 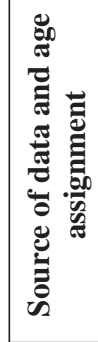 & 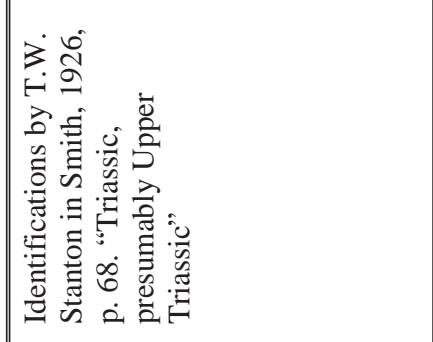 & 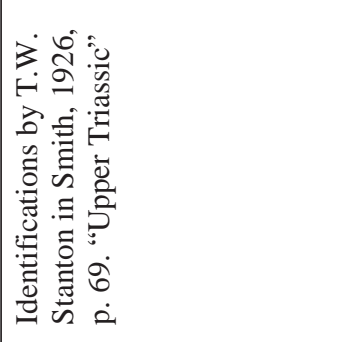 & 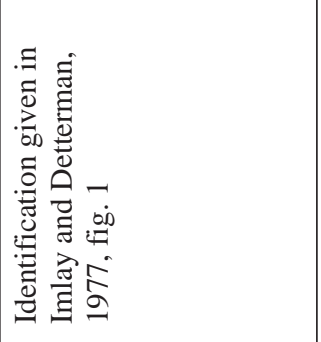 & 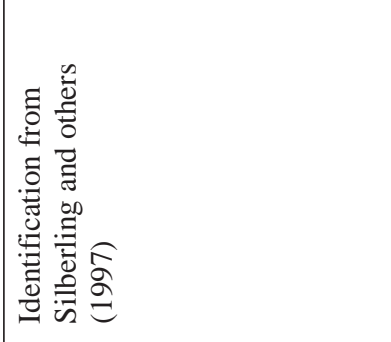 \\
\hline 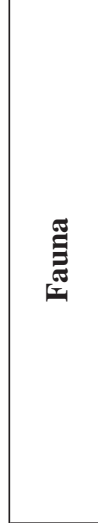 & 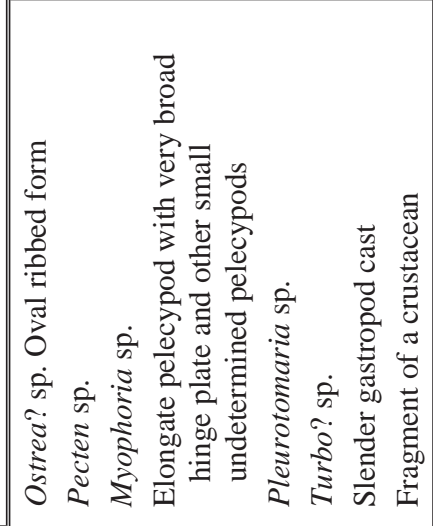 & 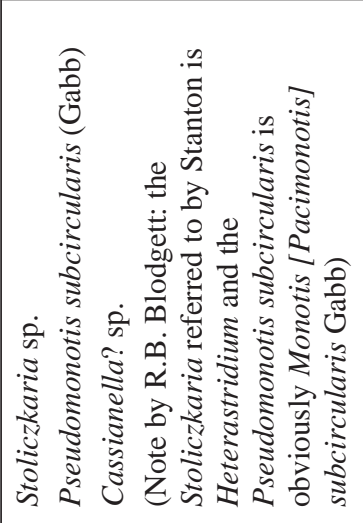 & 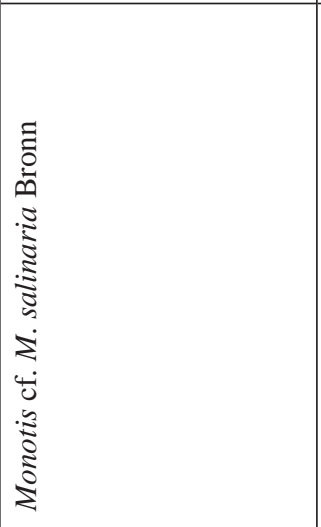 & 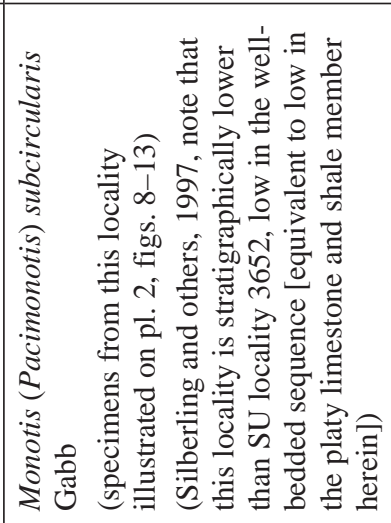 \\
\hline 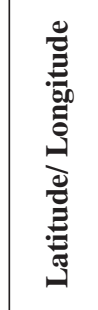 & 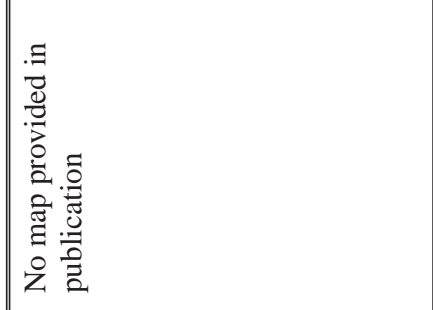 & 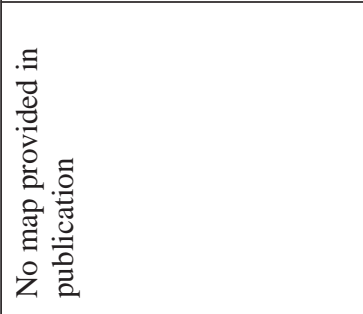 & 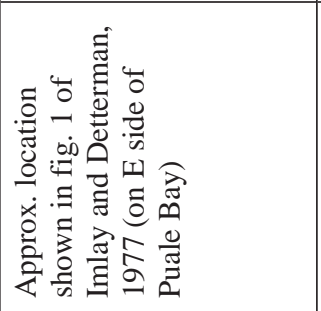 & 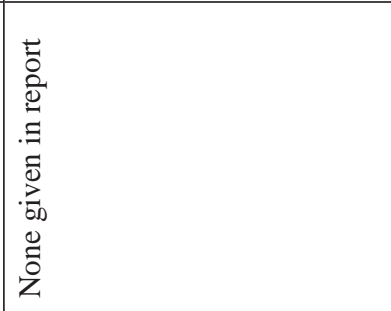 \\
\hline 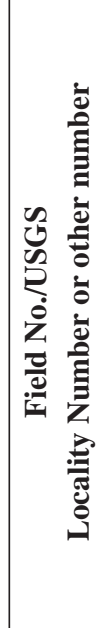 & 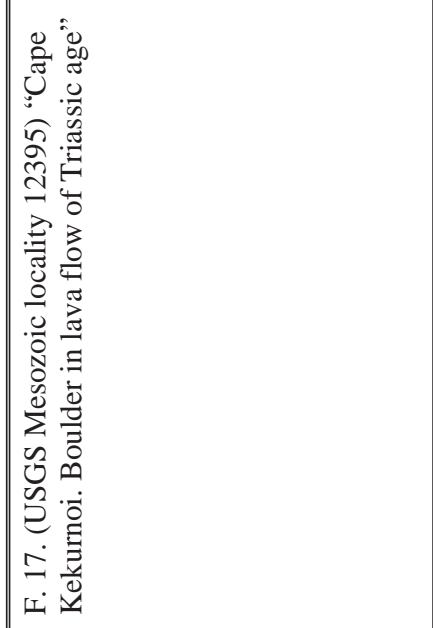 & 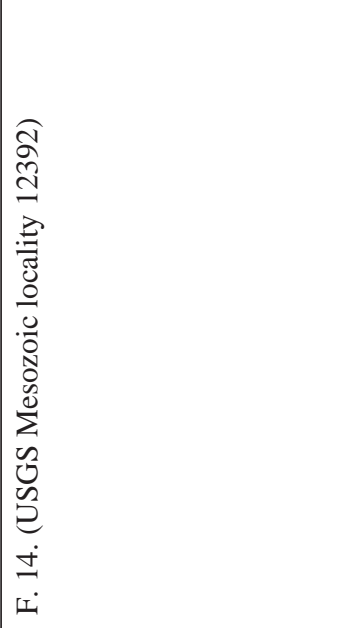 & 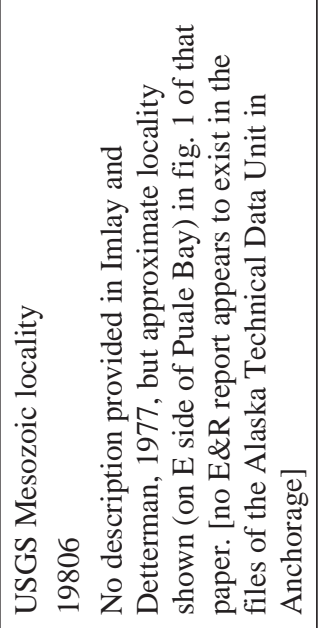 & 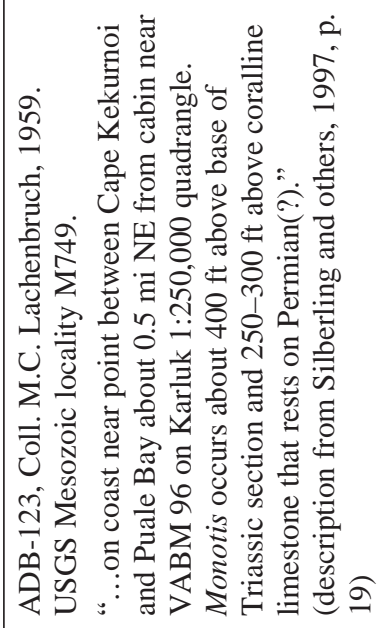 \\
\hline
\end{tabular}




\begin{tabular}{|c|c|c|c|c|c|}
\hline 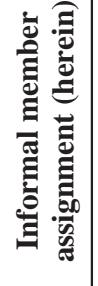 & 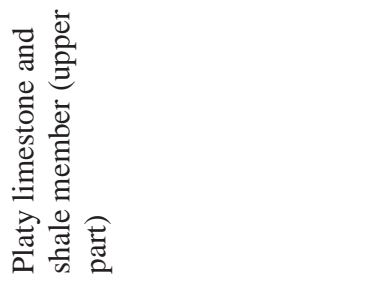 & 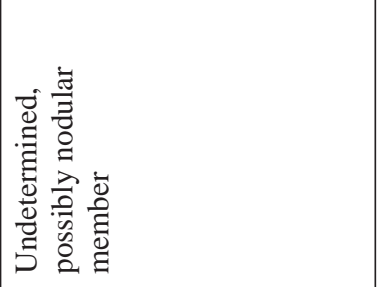 & 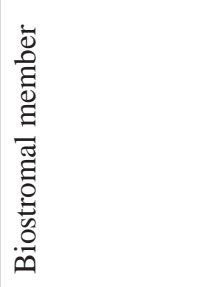 & 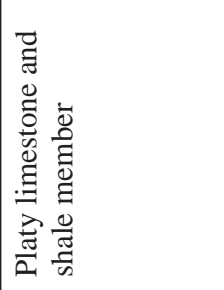 & 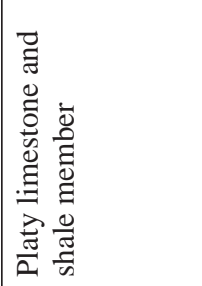 \\
\hline 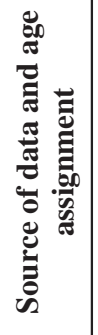 & 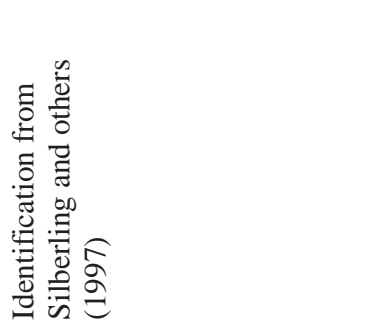 & 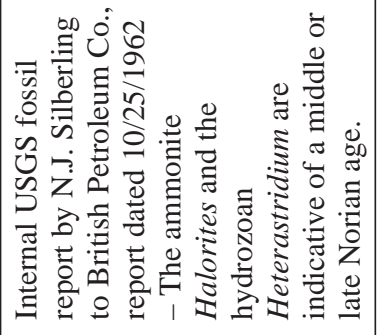 & 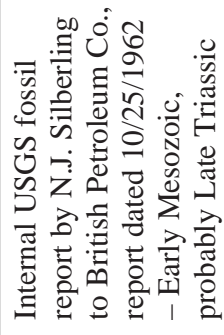 & 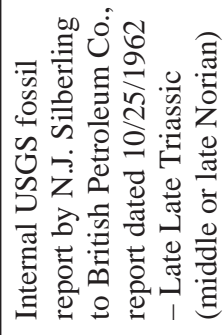 & 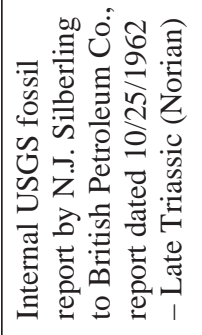 \\
\hline 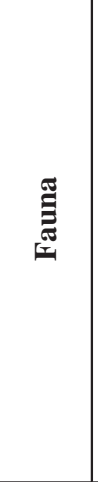 & 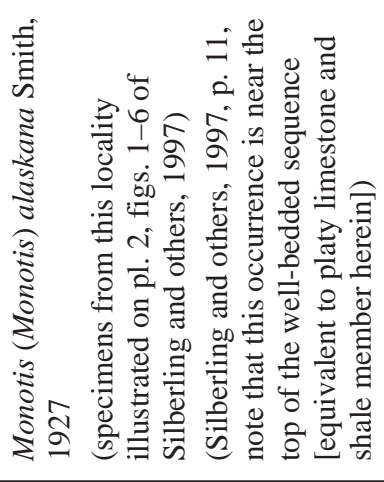 & 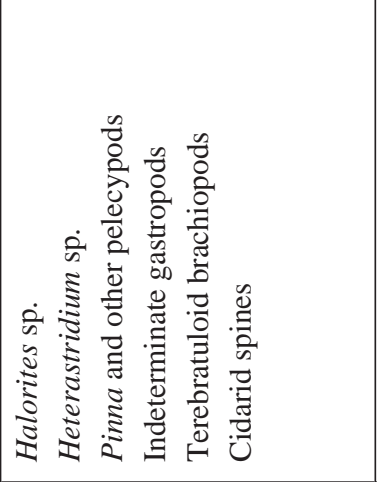 & 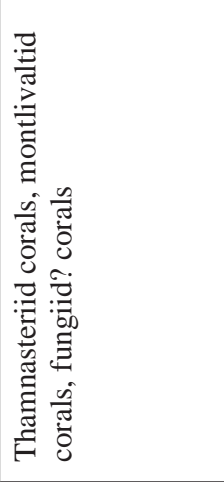 & 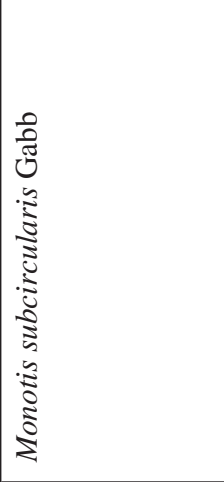 & 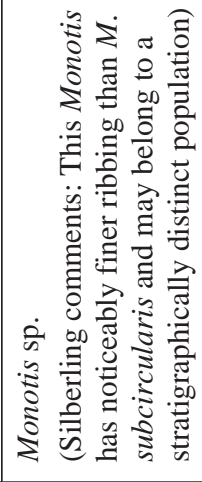 \\
\hline 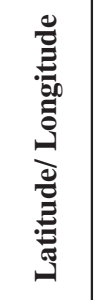 & 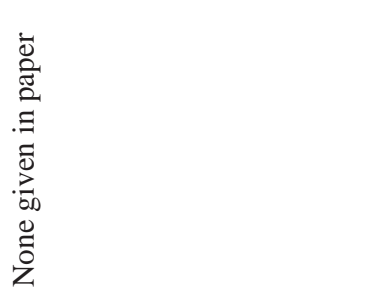 & 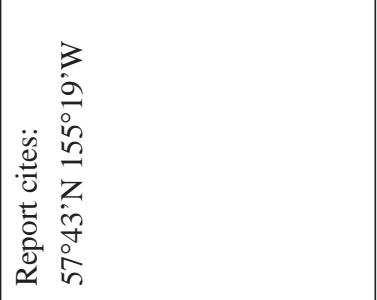 & 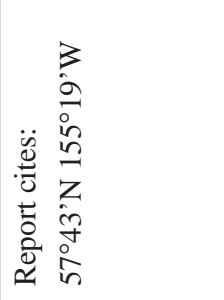 & 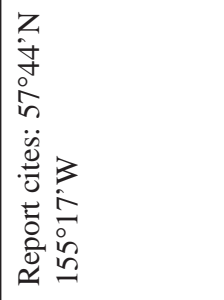 & 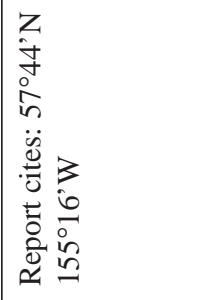 \\
\hline 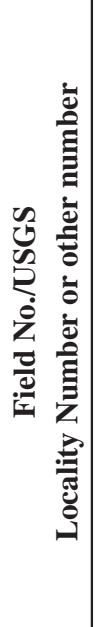 & 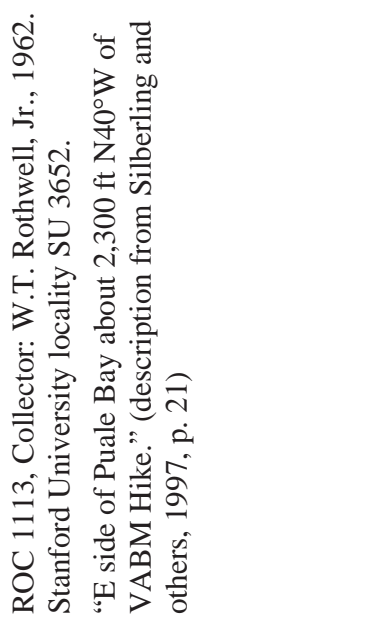 & 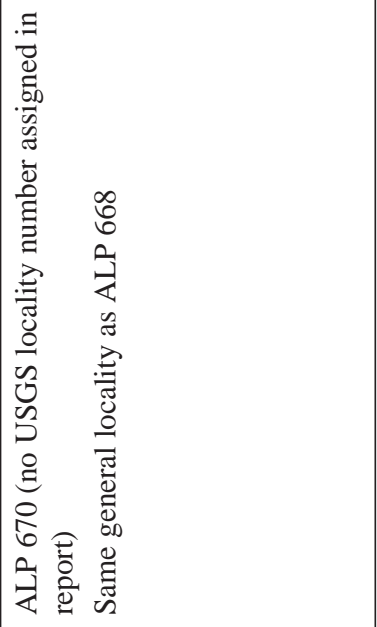 & 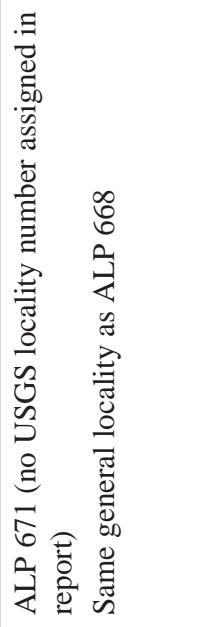 & 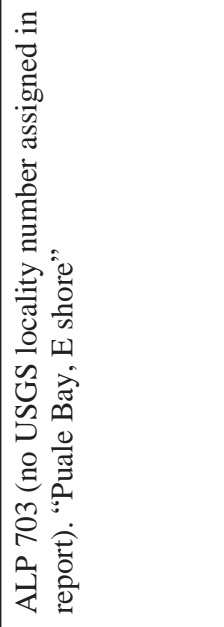 & 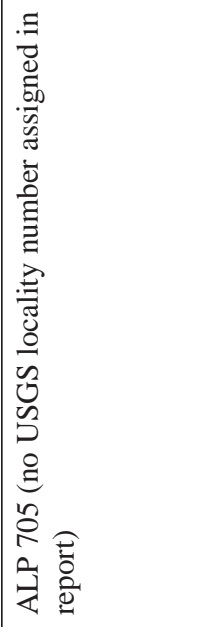 \\
\hline
\end{tabular}




\begin{tabular}{|c|c|c|}
\hline 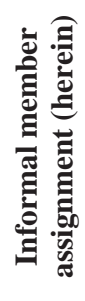 & 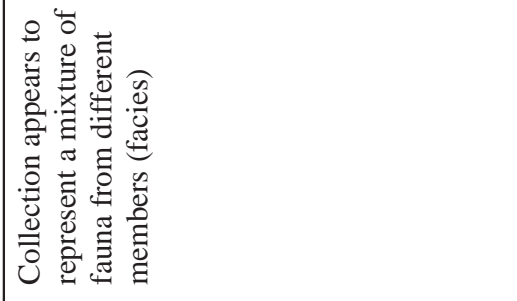 & 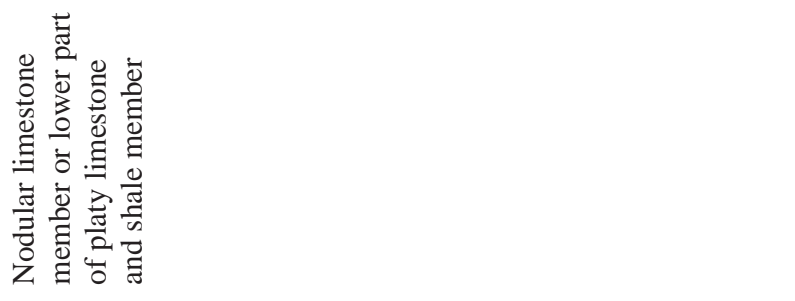 \\
\hline 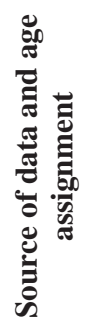 & 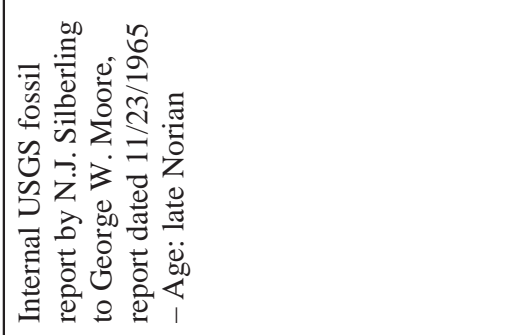 & 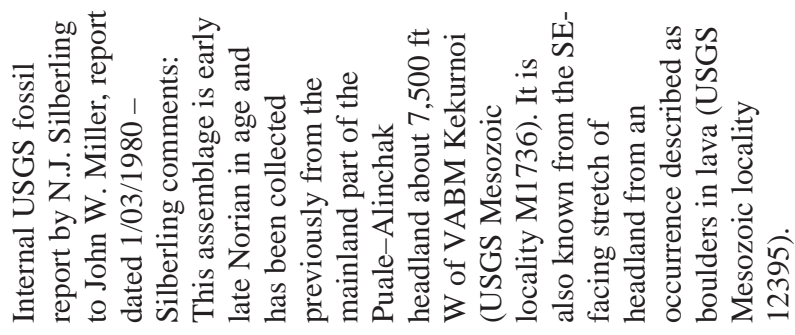 \\
\hline 党 & 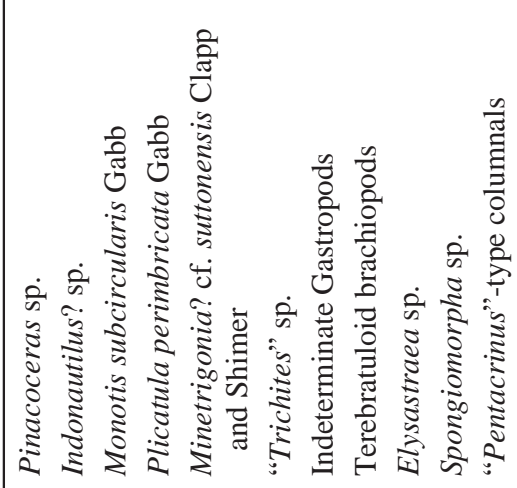 & 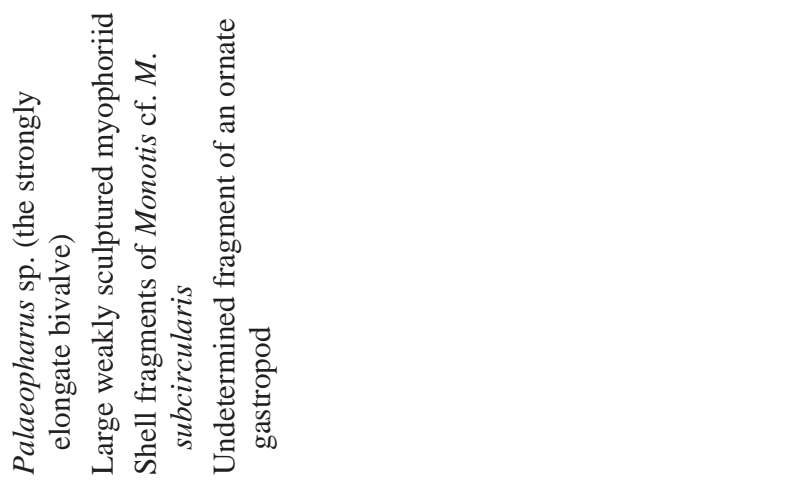 \\
\hline 兽 & 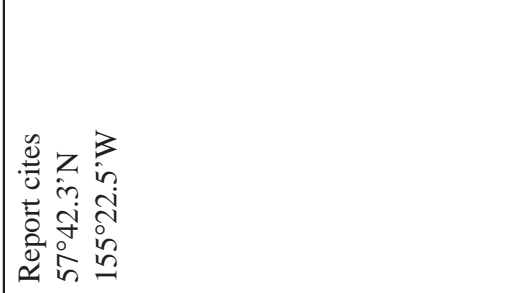 & 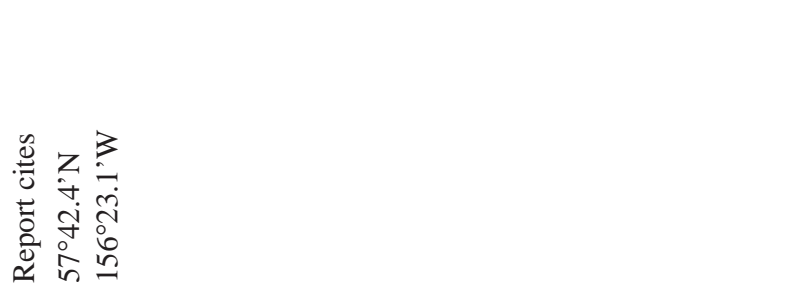 \\
\hline 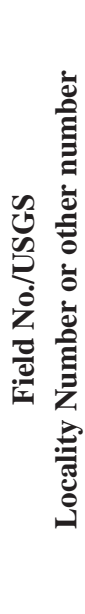 & 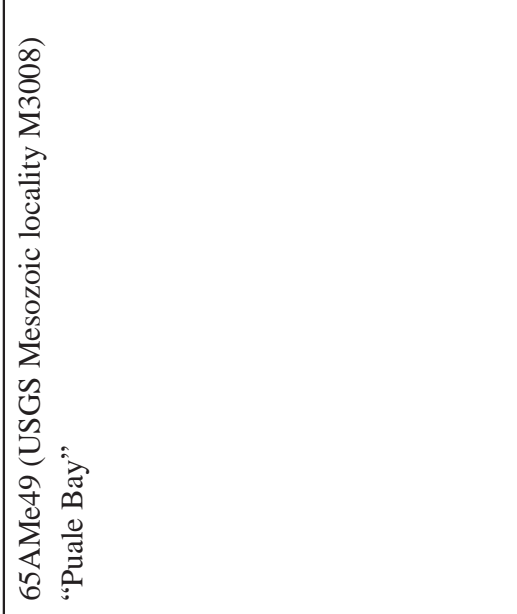 & 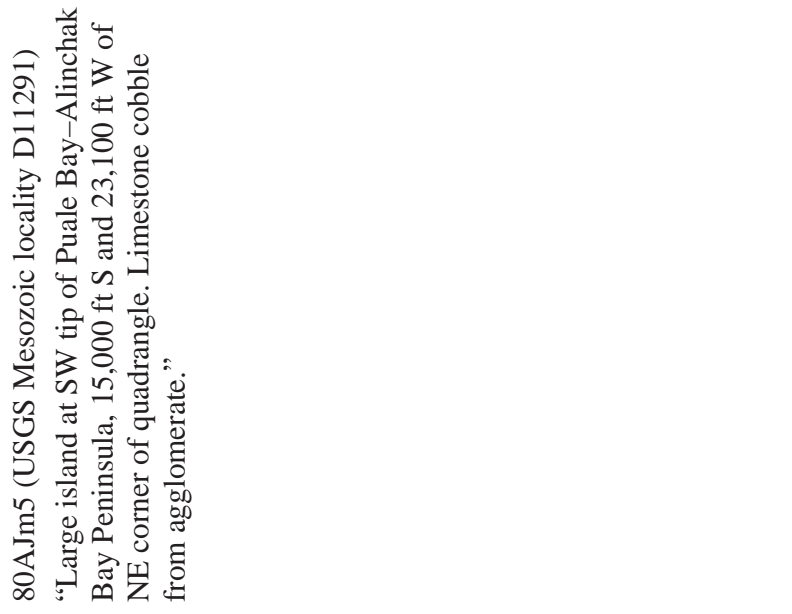 \\
\hline
\end{tabular}




\begin{tabular}{|c|c|c|c|c|c|c|}
\hline 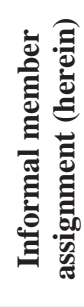 & 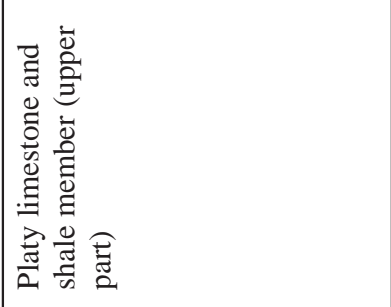 & 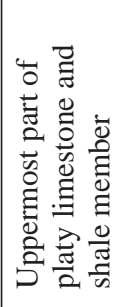 & 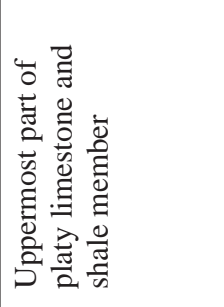 & & & 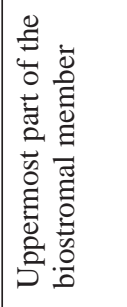 \\
\hline 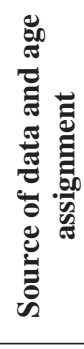 & 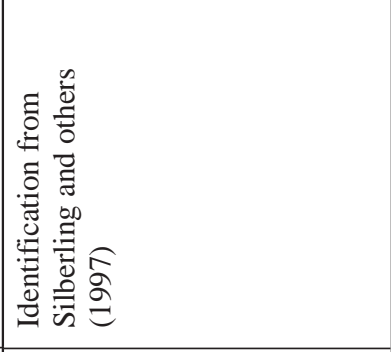 & 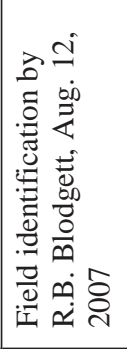 & 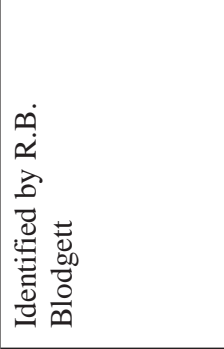 & & 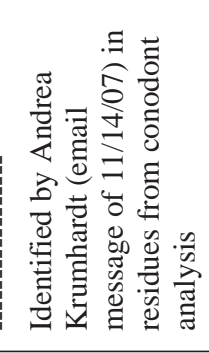 & 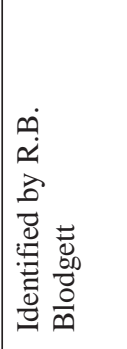 \\
\hline 莬 & 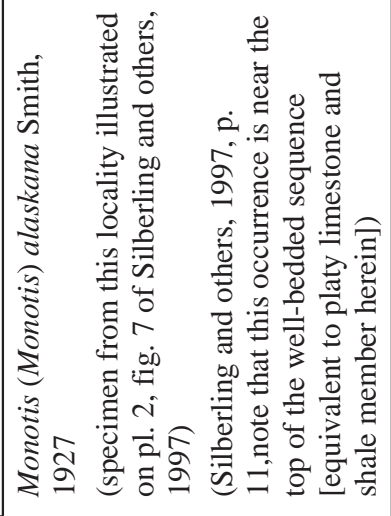 & 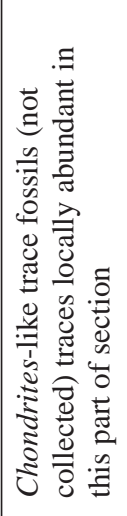 & 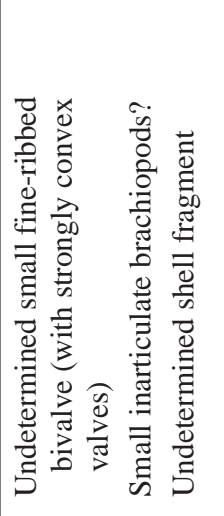 & 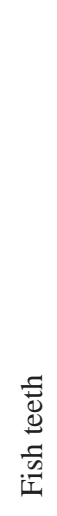 & & 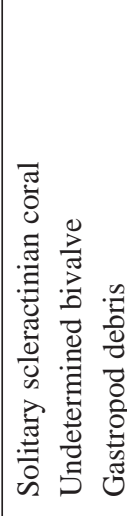 \\
\hline 营 & 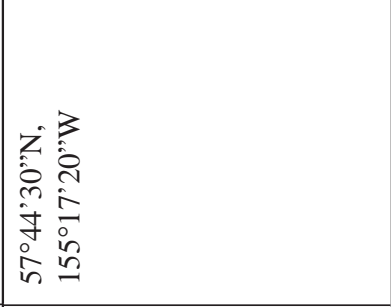 & 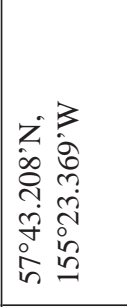 & 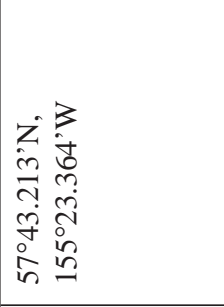 & & & 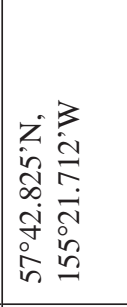 \\
\hline 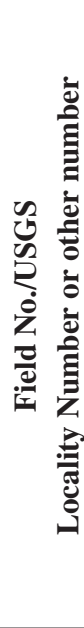 & 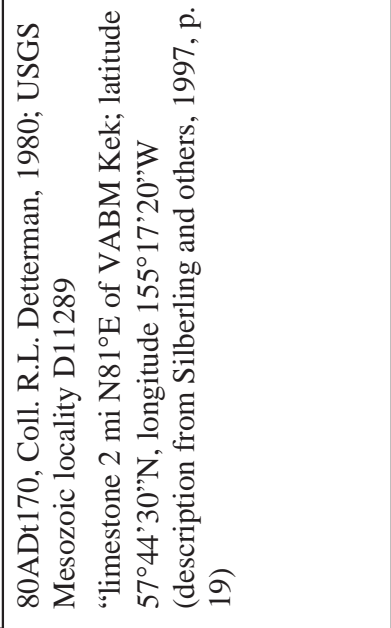 & 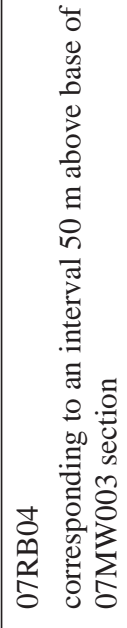 & 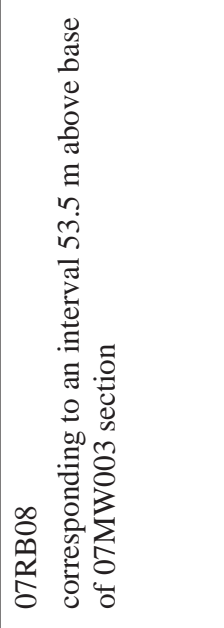 & & & 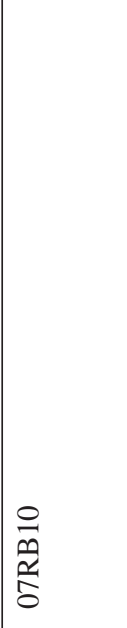 \\
\hline
\end{tabular}




\begin{tabular}{|c|c|c|c|c|}
\hline 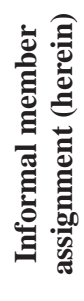 & 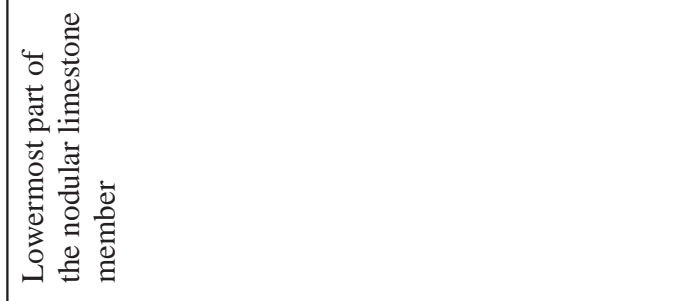 & & & 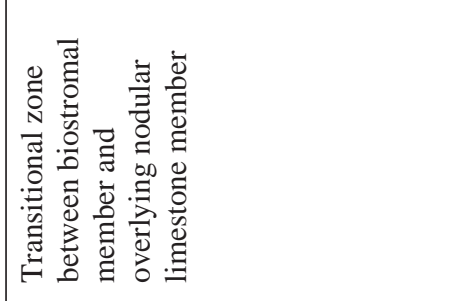 \\
\hline 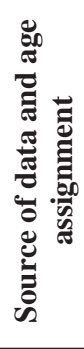 & 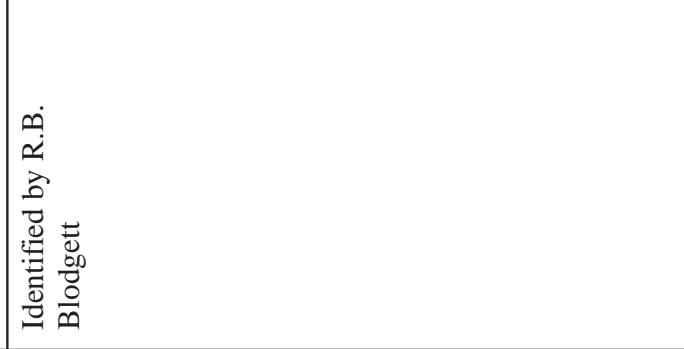 & & 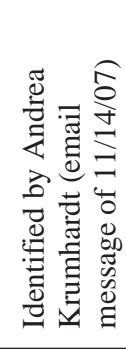 & 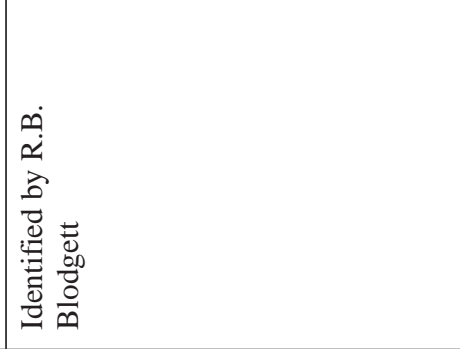 \\
\hline 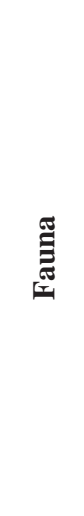 & 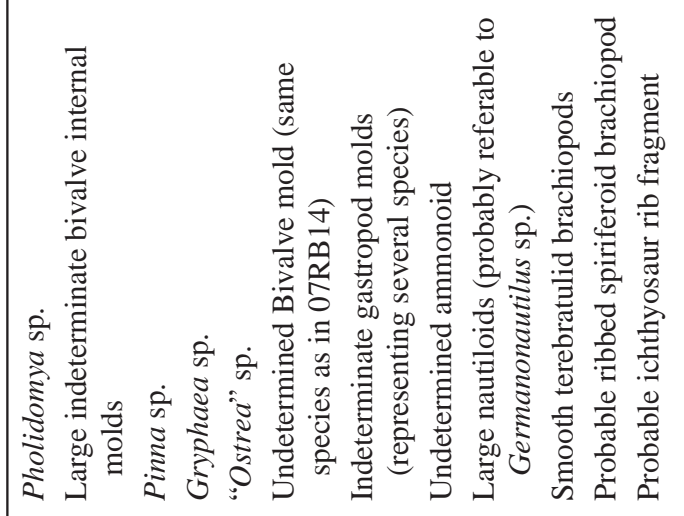 & 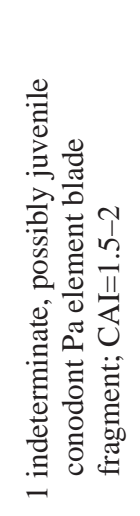 & & 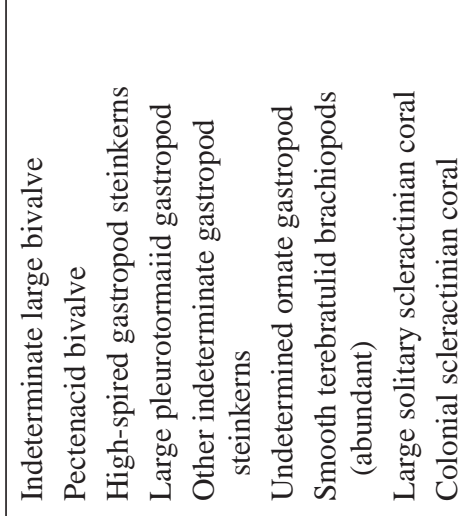 \\
\hline 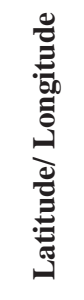 & 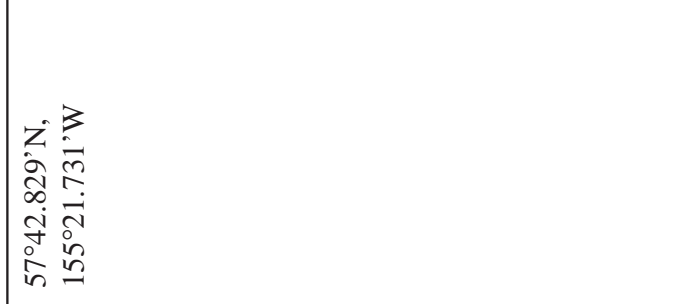 & & & 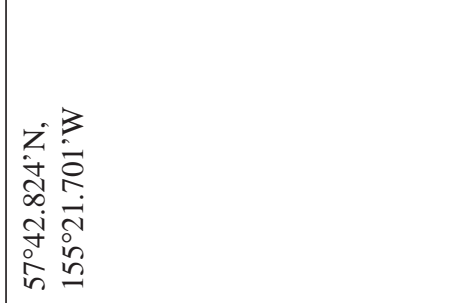 \\
\hline 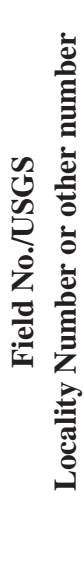 & $\begin{array}{l}\overrightarrow{\vec{p}} \\
\underline{\underline{A}} \\
\underline{\hat{\sigma}}\end{array}$ & & & 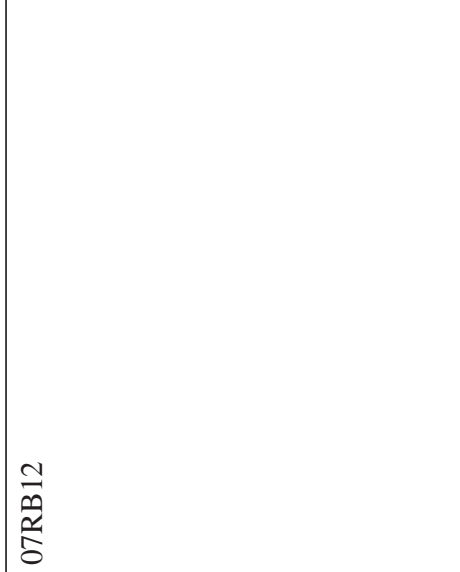 \\
\hline
\end{tabular}




\begin{tabular}{|c|c|c|}
\hline 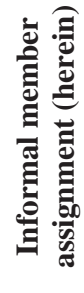 & 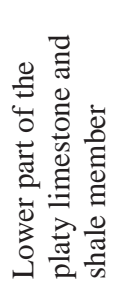 & 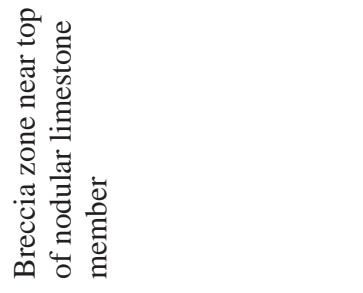 \\
\hline 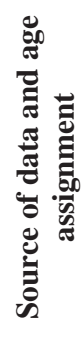 & 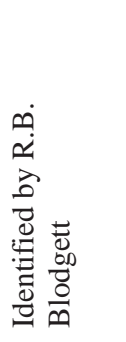 & 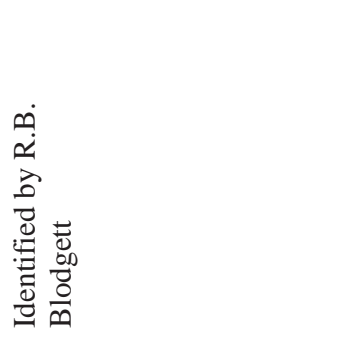 \\
\hline 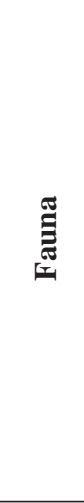 & 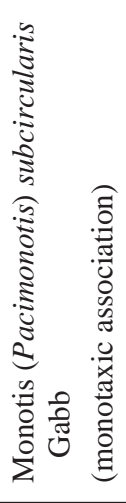 & 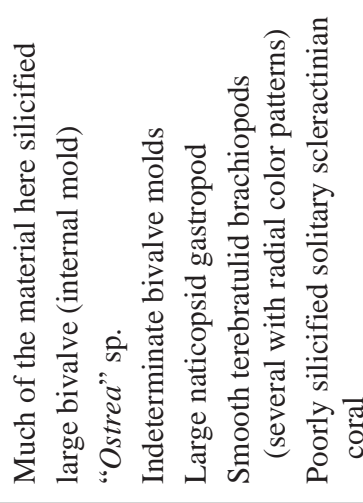 \\
\hline 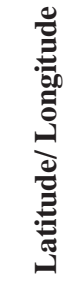 & 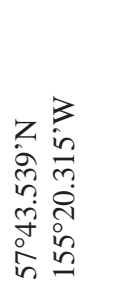 & 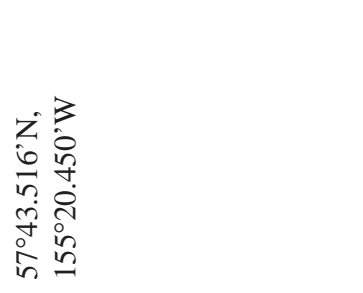 \\
\hline 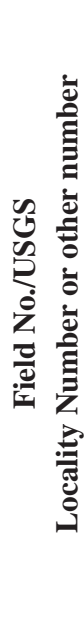 & 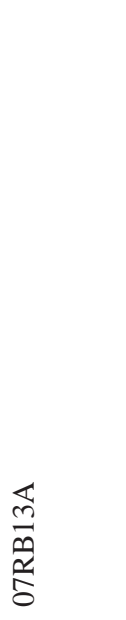 & 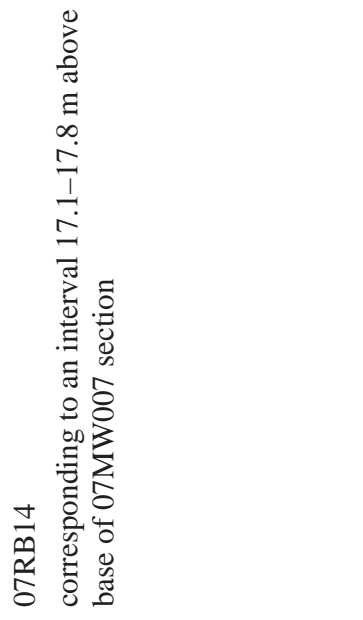 \\
\hline
\end{tabular}




\title{
REVISED GEOLOGIC MAP AND STRUCTURAL MODEL OF THE STANIUKOVICH PENINSULA-HERENDEEN BAY AREA
}

\author{
by
}

Paul L. Decker ${ }^{1}$, Rocky R. Reifenstuhl², Robert J. Gillis², and Andrea Loveland²

\begin{abstract}
Recent geologic mapping provides valuable insights into the structural configuration and hydrocarbon potential south of Port Moller on the northwestern side of the Alaska Peninsula. The study area encompasses most of the onshore lands leased for oil and gas exploration during 2005 and 2006. The region has a polyphase Mesozoic and Cenozoic tectonic history, as reflected by multiple magmatic stages and numerous unconformities in the stratigraphic record. The northwestern part of the map area is a low-relief coastal plain traversed by the David River zone, the southern structural margin of the North Aleutian backarc basin. Both extensional and compressional structures occur in this zone, and faulting is believed to involve a significant right-lateral strike-slip component. Upland areas to the south are dominated by uplifted Mesozoic and Tertiary units. Important differences in structural style and complexity distinguish exposures west of Herendeen Bay (the Sapsuk domain) from rocks of the peninsula between Herendeen Bay and Port Moller (the Staniukovich domain). Although it was not mapped in detail for this study, the Sapsuk domain is dominated by a single, broad uplift cored by a major thrust or reverse fault but traversed by few second-order faults or folds. In contrast, the Staniukovich domain hosts a large, doubly-plunging, complexly faulted rhomboid-shaped uplift (the Staniukovich anticline) as well as narrower, fault-bounded folds to the south. This study finds no structural or stratigraphic evidence for major low-angle overthrusting in the map area, as has been interpreted by previous workers. Instead, kinematic observations indicate deformation occurred through a combination of folding and oblique-slip on at least two sets of steep, intersecting faults, which strike sub-parallel and transverse to the axis of the Staniukovich uplift, respectively. This complex network of longitudinal and transverse faults makes it unlikely that the Staniukovich anticline behaves as a single large hydrocarbon trap, but it may encompass numerous smaller, fault-bounded trapping configurations. Analog experiments on deformation at restraining oversteps in strike-slip regimes generate models that closely resemble the structural styles and patterns mapped in the study area. This supports a structural model for key stages of the area's tectonic history based on right-lateral transpression along left-stepping strands of the David River zone, with the rhomboidal uplift on the Staniukovich peninsula localized within the restraining overstep itself.
\end{abstract}

\section{INTRODUCTION}

The southwestern Alaska Peninsula offers broad areas of relatively well exposed Mesozoic and Tertiary rocks, particularly in the area of this study along the embayed shorelines of Port Moller, Herendeen Bay, and in much of the highlands of the peninsula between these inlets (fig. 1). Informally named in this report after Staniukovich Mountain, its highest point (elevation $\sim 775 \mathrm{~m}[\sim 2,550 \mathrm{ft}]$ ), the Staniukovich peninsula is dominated by a large, doubly-plunging anticlinal uplift with Jurassic Naknek Formation exposed in the core, and rocks as young as the Miocene Bear Lake Formation in scattered outcrops at its flanks. Large anticlines also occur west and southwest of Herendeen Bay. Beyond this basic description, previous geologic maps of the area present strikingly different map patterns corresponding to fundamentally different stratigraphic interpretations and structural implications (Atwood, 1911; Burk, 1965; Amoco, unpublished mapping, 1979, 1983; Wilson and others, 1995; Wilson and others, 1999).

The renewal of oil and gas leasing on the Alaska Peninsula in 2005 attracted independent bidding by two companies, both focused exclusively in the Staniukovich peninsula-Herendeen Bay area (fig. 1), presumably due to a combination of factors. Here, Mesozoic and Tertiary strata are relatively well exposed, revealing the potential for large anticlinal and fault-bounded structural traps in both successions. Shortly before the 2005 sale, analysis of the prolific natural gas seep at Port Moller hot spring near the axis of the anticline on the northeastern Staniukovich peninsula showed it to consist of nearly pure, thermogenic methane (Decker and others, 2005). The integration of outcrop studies with offshore seismic interpretations reveals that the area of industry attention is adjacent to an underexplored probable hydrocarbon source kitchen in the axis of the North Aleutian basin. The area contains an eastern segment of the so-called David River zone (Amoco, 1979), the complex boundary between the Tertiary-filled North Aleutian basin to

${ }^{1}$ Alaska Division of Oil \& Gas, 550 W. 7th Ave., Suite 800, Anchorage, Alaska 99501

${ }^{2}$ Alaska Division of Geological \& Geophysical Surveys, 3354 College Rd., Fairbanks, Alaska 99709-3707 


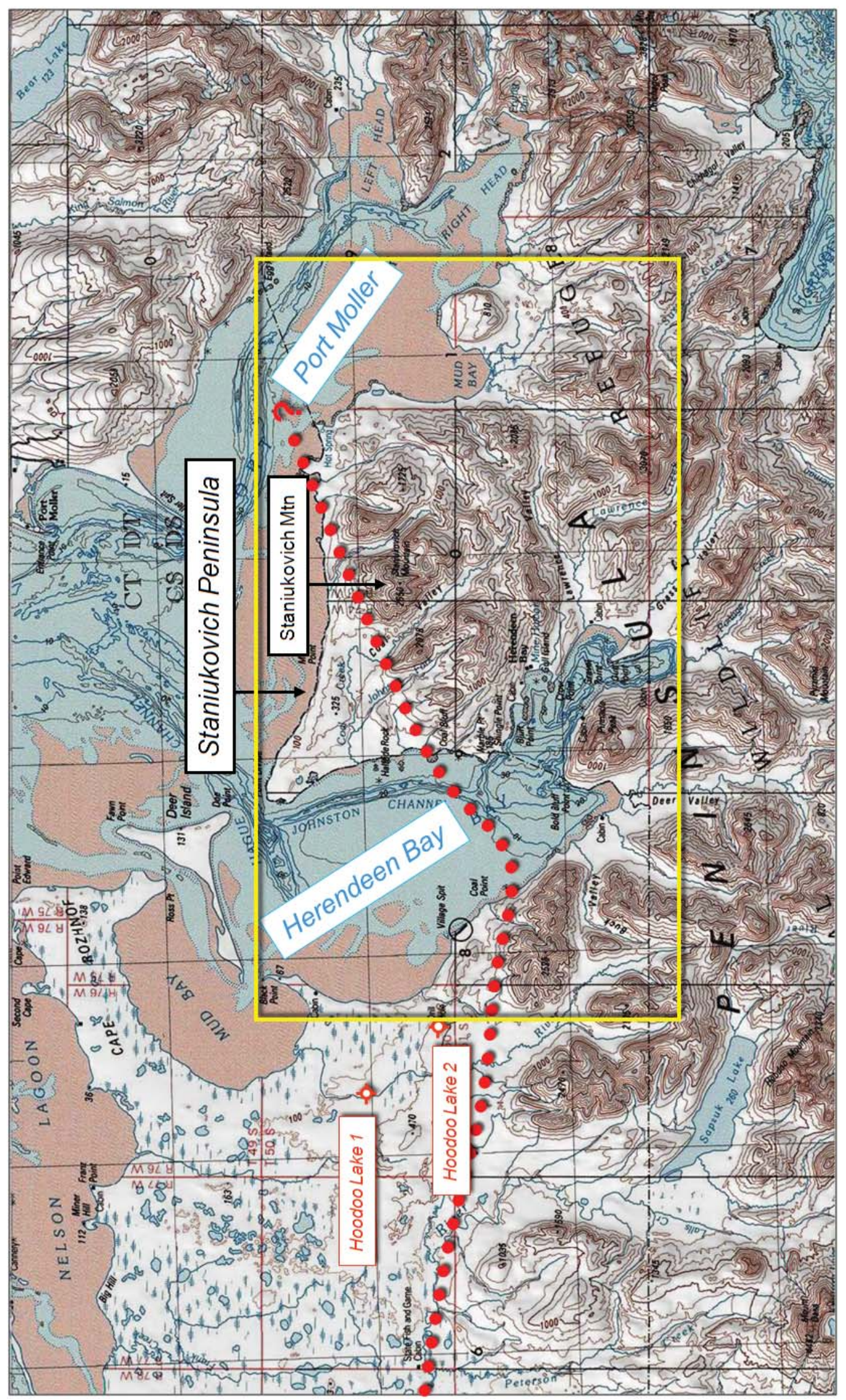

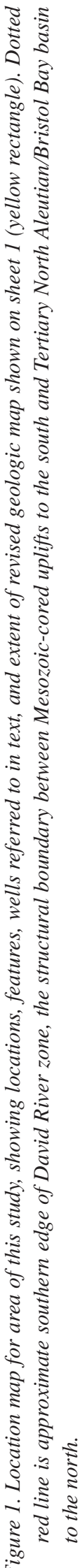


the north and the uplifted Mesozoic rocks to the south (fig. 1; Decker and others, 2005; Finzel and others, 2005; Worrall, 1991).

Given the convergence of geologic potential, industry interest, and widely varying existing interpretations, the State of Alaska required map-based geologic interpretations to evaluate oil and gas resource potential on State lands in this part of the Alaska Peninsula. This report describes geologic mapping and structural studies conducted during 2005 and 2006 to address that need.

\section{PREVIOUS GEOLOGIC MAPPING}

Reporting primarily on coal and other mineral resources of the Alaska Peninsula, Atwood (1911) made valuable structural and stratigraphic contributions and published a highly schematic regional geologic map.
He defined the Lower Cretaceous Staniukovich shale, which he named after the smooth, dull reddish slopes making up much of Staniukovich Mountain. His simplified regional cross section from Port Moller through Unga Island depicts the basic anticlinal structure of the Staniukovich peninsula.

Burk (1965) published a more complete 1:250,000scale map of the Alaska Peninsula southwest of Wide Bay. Ranging widely across the region by helicopter and boat, Burk and a geological assistant conducted three seasons of mapping and stratigraphic studies, and developed a comprehensive geologic history and generalized structural framework. He recognized the doubly-plunging Staniukovich Mountain anticline and adjacent narrower folds to the south, which he mapped as having minor complications due to longitudinal faults (fig. 2). Burk (1965, p. 128) described the Staniukovich

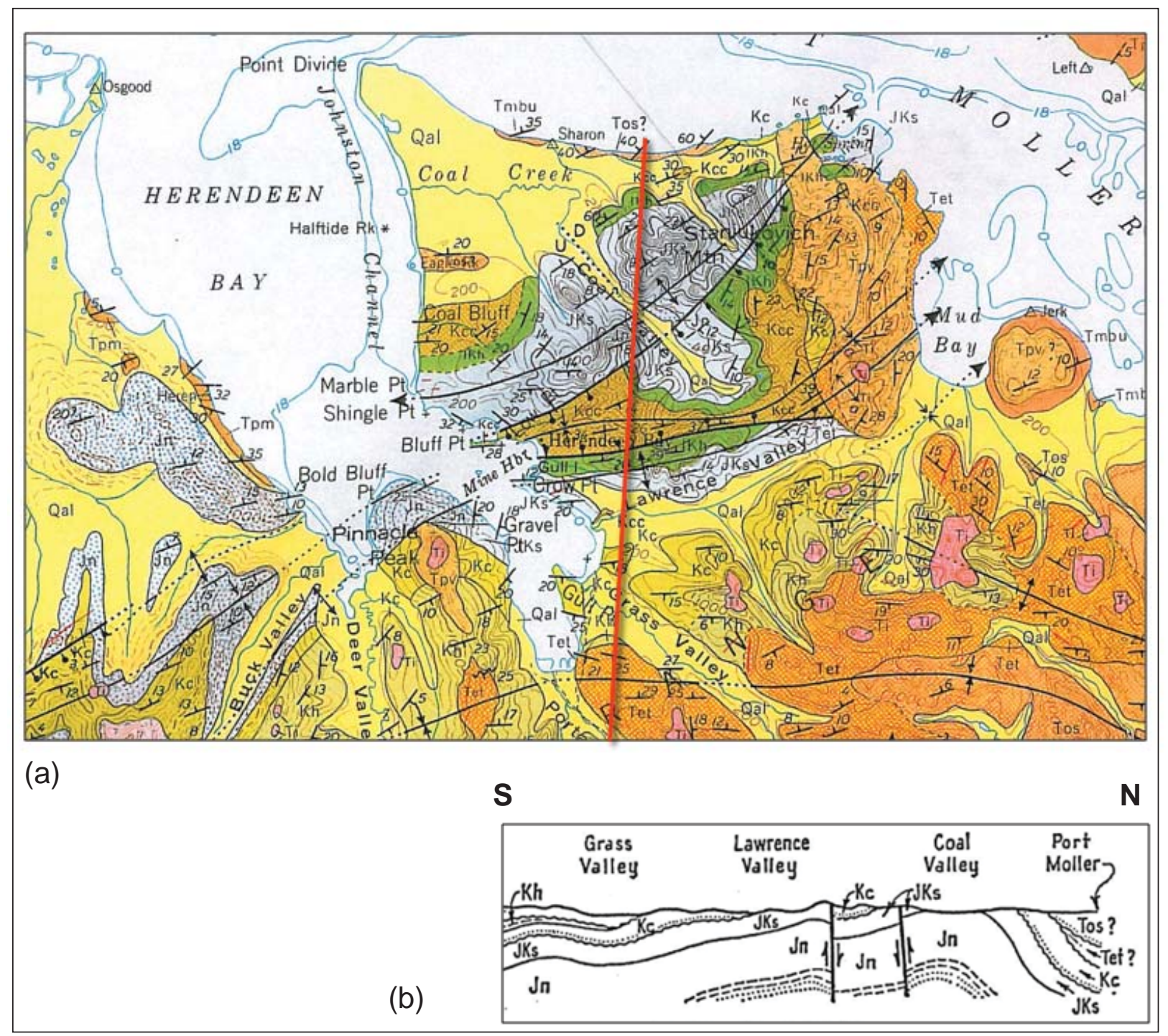

Figure 2. Excerpts from the regional geologic map and figures of Burk (1965). Geologic map (a) and generalized cross section (b) of the present study area in the Staniukovich peninsula-Herendeen Bay area. Compare to figures 3, 4, and sheet 1. 
Mountain anticline and the large uplift west of Herendeen Bay as parts of a continuous, northeast-plunging anticlinal uplift that extends east of Port Moller. He also expanded Atwood's (1911) definition of the Staniukovich Formation to encompass older and coarser-grained rocks, including Upper Jurassic feldspathic sandstones, arkoses, and conglomerates previously assigned to the Naknek Formation (Burk, 1965, p. 39-45). In keeping with his revised definition, Burk mapped no Naknek Formation on the Staniukovich peninsula.
Previously confidential geologic maps and reports generated by Amoco Production Company over the course of several field seasons were publicly released during 2004 and are available for inspection at the Alaska Division of Geological \& Geophysical Surveys Geologic Materials Center in Eagle River, Alaska. Particularly useful is an annotated 1:192,000 (1 inch = 16,000 feet) scale regional geologic map of the entire Alaska Peninsula (fig. 3a; Amoco, 1979) that incorporated interpretations and analytical results from numerous published and

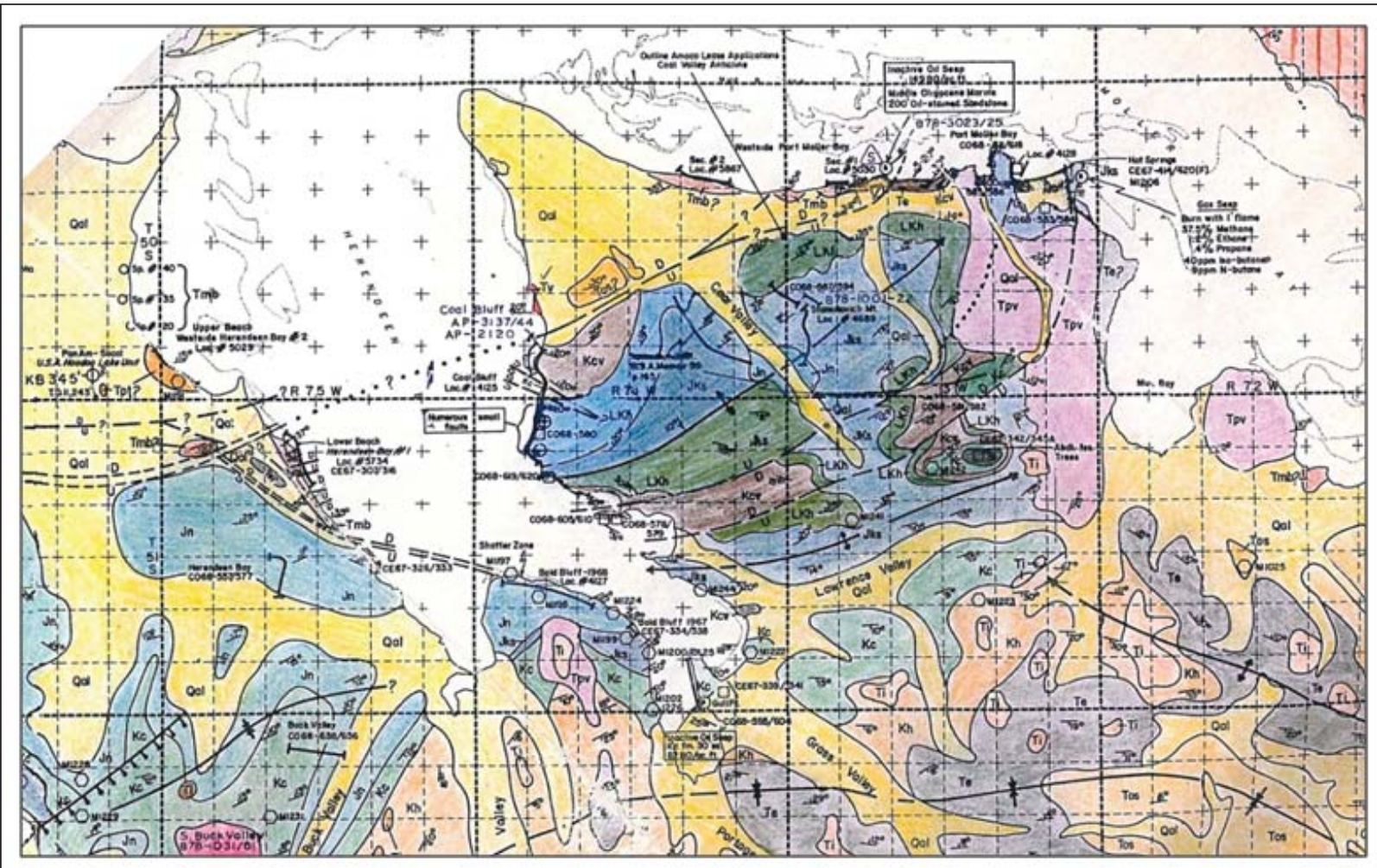

(a)

(b)

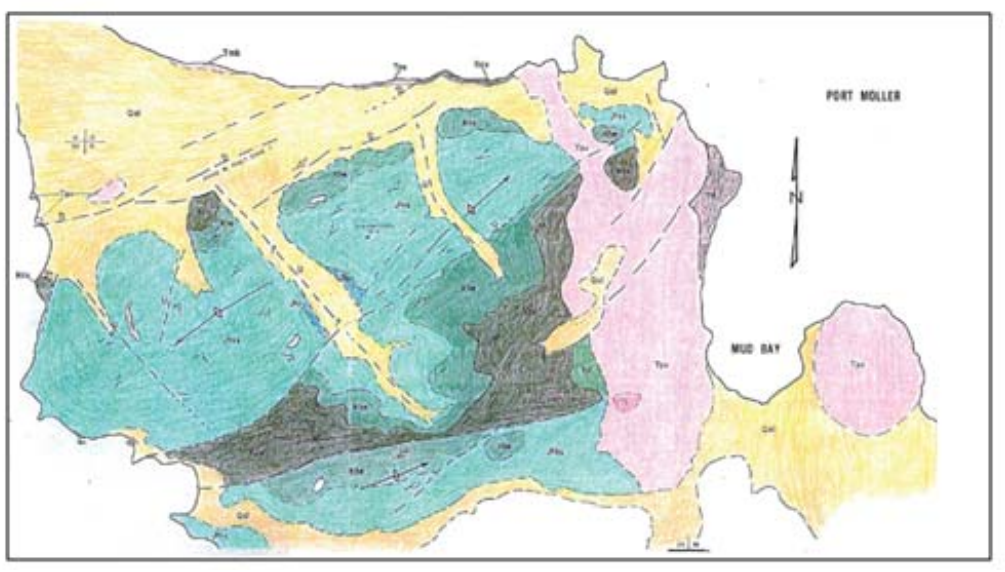

Figure 3. Unpublished geologic maps of the study area in the Staniukovich peninsula-Herendeen Bay area from Amoco Production Company field reports. Figure (a) is excerpted from 1:192,000-scale regional map (Amoco, 1979); (b) is reduced to approximately the same scale from 1:63,360-scale map restricted to the Staniukovich peninsula (Amoco, 1983). Neither included a cross section through the present study area. Compare to figs. 2, 4, and sheet 1. 
unpublished sources. In the present study area, Amoco (1979) made substantial revisions to the map pattern of Burk (1965), and added important outcrop- and geophysically-based structural interpretations, including faults in areas obscured by surficial cover. Subsequent remapping of parts of the Staniukovich peninsula at 1:63,360 ( 1 inch $=1$ mile) scale by Amoco geologists recognized three significant faults nearly perpendicular to and locally offsetting the axis of the Staniukovich Mountain anticline (fig. 3b; Amoco, 1983). This map differed markedly from both Burk's (1965) and Amoco's (1979) previous maps in terms of the distribution of Lower Cretaceous and Upper Jurassic rocks units.

U.S. Geological Survey publications (Wilson and others, 1995; 1999) represent the most comprehensive existing geologic mapping in the study area. The 1:250,000-scale map of Wilson and others (1995) emphasized the structural complexity of the Staniukovich peninsula, depicting numerous relatively straight (high-angle) faults oriented sub-parallel and transverse to the fold axes (fig. 4a). Additionally, USGS geologists inferred the existence of a low-angle thrust fault believed to have emplaced a complexly faulted upper plate consisting of blocks of Jurassic through Paleogene units above a relatively undeformed lower plate that includes Tertiary strata as young as Miocene Bear Lake Formation (fig. 4b; Wilson and others, 1995; Detterman and others, 1996, p. 31).

With important exceptions, the mapping and structural fabric observations of the present study (sheet 1) mostly corroborate the distribution of rock units and high-angle faults mapped by USGS workers (Wilson and others, 1995; 1999). However, our findings do not support the low-angle thrusting interpretation offered by Wilson and others (1995) and Detterman and others (1996). Although the present study significantly revises all previous mapping, we rely largely on the USGS mapping for coverage where we were unable to make our own observations, particularly in the southeastern and southwestern corners of the map (sheet 1 ). In other areas west of Herendeen Bay, we have modified USGS mapping based in part on remote sensing and field observations made by Sralla (2007) on behalf of Hewitt Mineral Corporation following successful bidding in the 2005 lease sale.

\section{REVISED GEOLOGIC MAPPING OF THIS STUDY FIELD METHODS}

The geologic mapping of this study was performed in conjunction with other stratigraphic and structural field objectives (Gillis and others, 2007; Decker and others, 2005; Finzel and others, 2005). Three to four geologists conducted helicopter-supported mapping traverses, beginning with long coastal exposures, and working into more vegetated upland areas as weather permitted. Mapping of formation and fault contacts was complemented by collection of structural orientation and kinematic data (primarily fault planes, slickenlines, and slip sense indicators) where exposures allowed. These data have been plotted in lower hemisphere stereographic projections in figure 6 . The 1:50,000-scale preliminary revised geologic map and cross sections (sheet 1 ) includes these structural fabric stereograms as inset figures. Due to time and logistical constraints, mapping efforts were focused more on the Staniukovich peninsula than on the structurally-simpler areas to the west and south.

\section{MAPPED ROCK UNITS}

Definitive formation calls are often difficult to make in Alaska Peninsula strata, both in the field and from laboratory analyses. The Jurassic through Pliocene sedimentary record is thought to contain as many as ten unconformities (Detterman and others, 1996), and sediments from older units are recycled into younger units, probably more than once in some cases. The framework composition of some sedimentary units varies significantly throughout the region depending on unconformity subcrop and on local variations in the sediment source area. The provenance area consists of arkosic and volcaniclastic sedimentary units and superimposed intermediate to felsic magmatic arcs of Triassic through Quaternary age (for example, Wilson, 1985; Detterman and others, 1996; Wilson and others, 1999). Furthermore, many sedimentary units share a wide range of textures and nonmarine to shallow marine facies associations. Additionally, the megafauna and megaflora assemblages used to characterize some units can be difficult to distinguish without considerable paleontologic expertise. Micropaleontology studies are useful, but they obviously require laboratory preparation and analyses. Volcanic map units of similar composition may be easily mistaken for each other in the field; previous maps are in conflict regarding the age assigned to some lavas. In the absence of diagnostic cross-cutting relationships, age designations for the basaltic and andesitic units are determined better by radiometric methods than by subjective field criteria such as degree of weathering.

These caveats notwithstanding, the preliminary mapping of this study (sheet 1 ) recognizes ten sedimentary bedrock units and four primary igneous units of Upper Jurassic through Pliocene age, and adopts the four Quaternary surficial map units of Wilson and others (1995). Other than as noted in the text, map unit descriptions and outcrop photographs are found on sheet 2. These unit descriptions are adapted from Wilson and others (1995), consisting of excerpted text that has been modified as necessary to reflect the scope and interpretations of our mapping. 


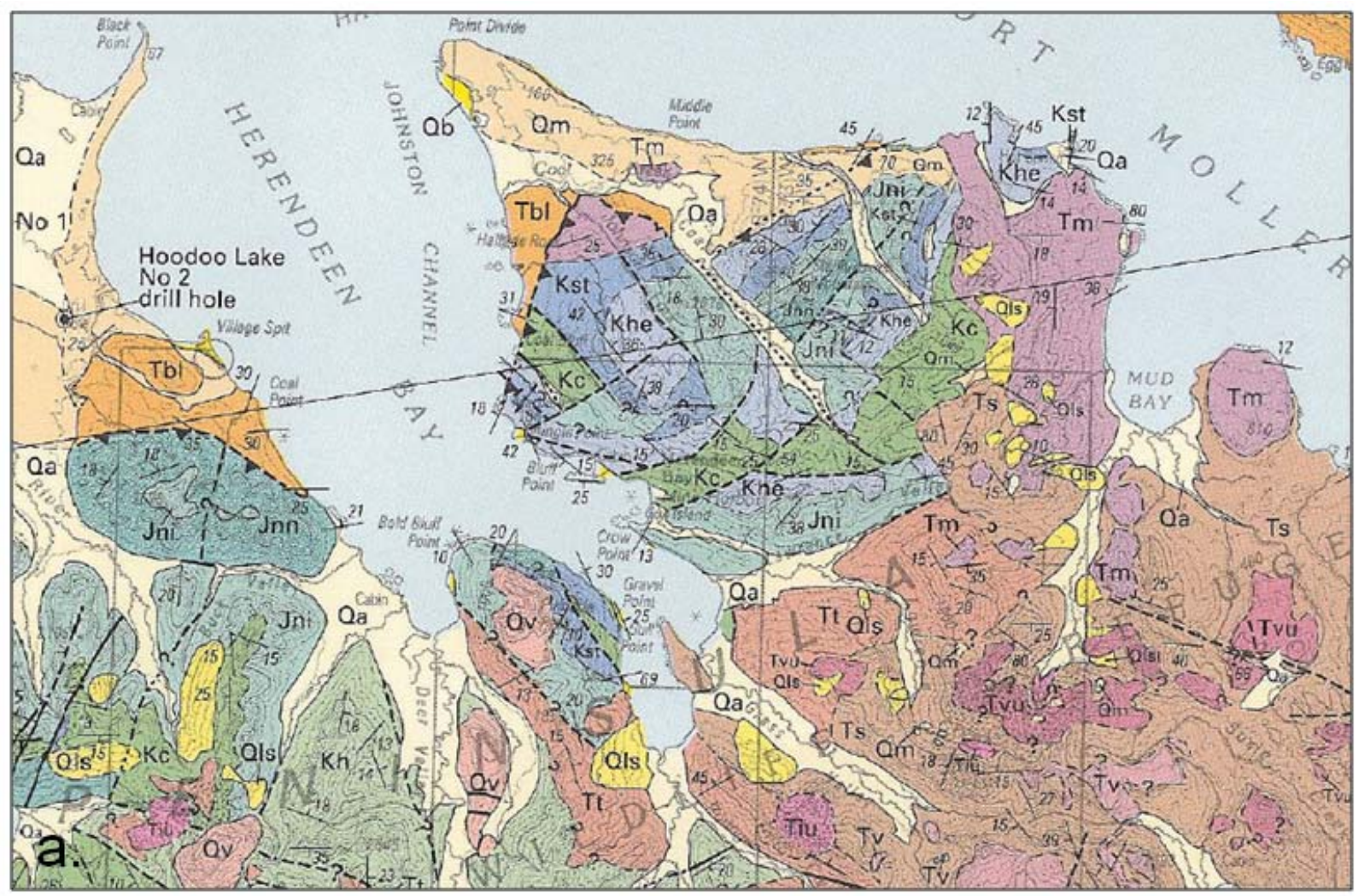

\section{WSW}

ENE

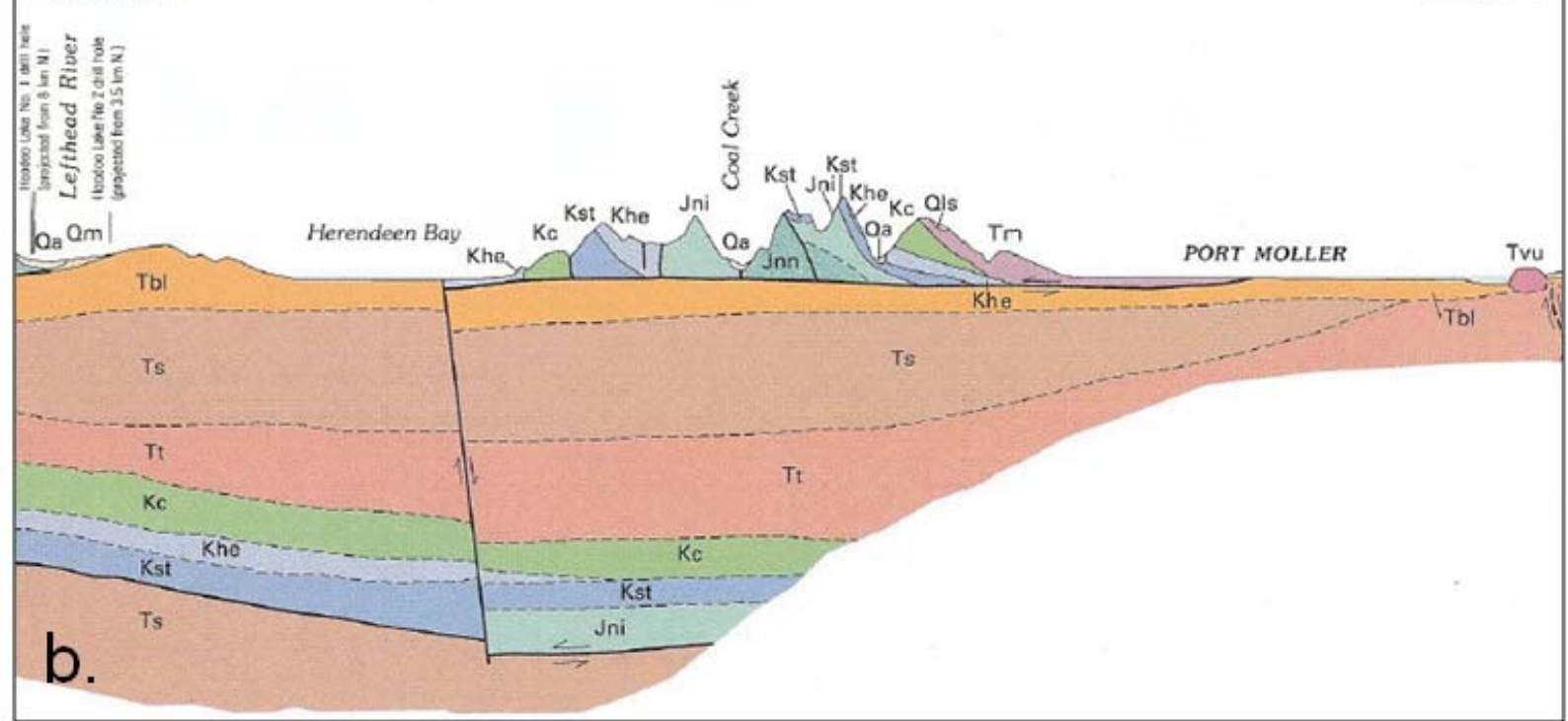

Figure 4. Excerpts from the 1:250,000-scale USGS geologic map (a) and cross section (b) of Wilson and others (1995) in the present study area in the Staniukovich peninsula-Herendeen Bay area. Note interpretation of subhorizontal overthrust placing a sheet consisting of complexly faulted blocks of Jurassic through Paleogene formations over units as young as Miocene Bear Lake Formation (see text for discussion). Compare to figs. 2, 3, and sheet 1. 
The Lower Cretaceous Staniukovich Formation has been variously defined by previous workers (Atwood, 1911; Burk, 1965; Detterman and others, 1996). As mapped in this study (sheet 1), the Staniukovich Formation is restricted to just the distinctive red-brown weathering, smooth-slope-forming siltstone and shale unit constituting most of the Staniukovich Shale originally defined by Atwood (1911). This fine-grained interval represents only the upper part of the Staniukovich Formation as redefined by Detterman and others (1996). Sandstones assigned to the lower part of the formation by Detterman and others (1996) could not be reliably differentiated in the field from lithologically similar, Buchia-rich sandstones of the upper Naknek Formation (Upper Jurassic), particularly in isolated or discontinuous exposures. These Buchia-rich sandstones are here mapped together with the Indecision Creek member (Detterman and others, 1996; Wilson and others, 1995; 1999) in the uppermost Naknek Formation.

The Lower Cretaceous Staniukovich and Herendeen formations are both absent west of Herendeen Bay. This absence might reflect non-deposition due to a local lack of accommodation space during Early Cretaceous time. It is equally possible that the formations were deposited and subsequently eroded west of Herendeen Bay during development of the regional mid-Cretaceous unconformity that underlies the Chignik Formation. During Late Cretaceous time, the area east of Herendeen Bay appears to have been more proximal than the area to the west. This is expressed lithostratigraphically by thick and widespread coarse conglomerates and coals in the Chignik Formation on the Staniukovich peninsula, compared with the thinner Chignik sandstones and time-equivalent sandy mudstones of the deeper water Hoodoo Formation southwest of Herendeen Bay.

\section{STRUCTURAL ELEMENTS}

The main structures that can be confidently recognized from the current mapping are large uplifts of folded and faulted Mesozoic strata. These include the northern part of the Sapsuk uplift west of Herendeen Bay and a more complex anticlinal uplift on the Staniukovich peninsula. These two areas differ strikingly in structural orientation, deformational style, and the northern limit of exposed Mesozoic rocks. This suggests that the map area can be meaningfully divided into two major structural domains here termed the Sapsuk domain to the west and the Staniukovich peninsula domain to the east. Each of these areas can be further subdivided north-to-south. The northern, low-relief coastal plain is underlain by Tertiary and Quaternary units on the south flank of the North Aleutian basin. The southern area has significant topography and is dominated by uplifted Mesozoic rocks.
The boundary between the eastern and western domains is concealed beneath Herendeen Bay. One highly speculative possibility is that Herendeen Bay itself could be controlled by a significant zone of down-to-west or left-lateral strike-slip faulting. Such a zone might represent the offshore continuation of the northweststriking, down-to-southwest faults near Pinnacle Peak, east of Deer Valley at the head of Herendeen Bay. An alternative explanation of the domain boundary will be discussed following a description of the structural style of each of the domains.

\section{SAPSUK DOMAIN}

The broad valleys and highland areas between Herendeen Bay and Sapsuk Lake (formerly named Hoodoo Lake) are dominated by Jurassic and Cretaceous rocks of the Sapsuk uplift. The lower hills and coastal plain to the north near the Hoodoo Lake Unit 1 and 2 wells (fig. 1) locally expose Miocene and younger units accommodated by subsidence at the southern edge of the North Aleutian basin. The southern limit of the Sapsuk domain extends eastward from the east end of Sapsuk Lake to Deer Valley. This excludes the majority of the Tertiary-Quaternary volcanic and hypabyssal intrusive rocks noted farther to the south by Wilson and others (1995). As noted above, we devoted less field time to work in the Sapsuk domain than the Staniukovich peninsula domain, so descriptions included here are based in part on our own field observations, partly on previous mapping (Burk, 1965; Amoco, 1979; Wilson and others, 1995), and partly on recent field observations and remote sensing interpretations of Sralla (2007).

The Sapsuk uplift is a broad, dominantly north-verging fault-cored structure with expansive dip panels of Jurassic and Cretaceous units (sheet 1, section A-A'). These Mesozoic rocks were emplaced above Miocene Bear Lake Formation by north-directed thrusting and/or reverse faulting, as evidenced in relatively continuous outcrops on the western shore of Herendeen Bay (fig. 5). The main fault, mapped here as a thrust, has a southerly dip of 45 degrees where a discrete slip surface was identified in shoreline outcrops. We have no evidence to constrain whether this fault becomes steeper or flatter with depth; Sralla (2007) interprets it as having an overall dip of 70 degrees to the south. Jurassic Naknek Formation in the hangingwall is intensely brecciated in a damage zone tens of meters thick. In a zone of similar thickness directly below the fault, Bear Lake strata were penetratively deformed in a semi-consolidated state by a combination of discrete shearing and plastic, fluidized granular flow. These exposures yielded no kinematic indicators to determine the sense of movement.

Approximately $3 \mathrm{~km}(1.8 \mathrm{mi})$ north of the main fault along the shoreline of Herendeen Bay, beds of the 
Bear Lake Formation are locally reverse faulted and asymmetrically folded. Slightly farther north, these compressional structures abruptly give way to an array of minor, mostly down-to-north normal faults (sheet 1 , section A-A'; Decker and others, 2005). This belt of up-to-south compressional and extensional faults north of the Sapsuk uplift is a segment of the David River zone (DRZ) (Amoco, 1979). Faulting within and adjacent to the DRZ is believed to include three kinematic components. First, there is a significant component of right-lateral strike-slip, which leads to transpressional uplift of the Black Hills west of the current study area (Worrall, 1991). Second, there is extensional subsidence of the basin to the north. Lastly, there is a component of orthogonal convergence, which leads to folding and reverse-faulting of the uplifted Mesozoic units to the south (Decker and others, 2005; Finzel and others, 2005).
The north-verging folds and thrusts involving Bear Lake Formation in this area are evidence of Late Miocene or younger compressional or transpressional deformation within and adjacent to the DRZ.

In the Mesozoic units of the hangingwall, Burk (1965) interpreted the Sapsuk uplift as a relatively simple northeast-trending fold, which he called the Hoodoo Lake anticline. More recently, Sralla (2007) reinterpreted it as a west-northwest-trending, doubly-plunging closure, which he called the Sapsuk Lake anticline. Its axis runs through the Quaternary-covered valleys southwest of Herendeen Bay. The names of several streams and lakes in this area were changed between the publication of Burk's (1965) map and the most recent USGS topographic base maps. In terms of current names (sheet 1), Naknek strata north of the lower Buck Valley and the upper forks of the Lefthead River constitute a gener-
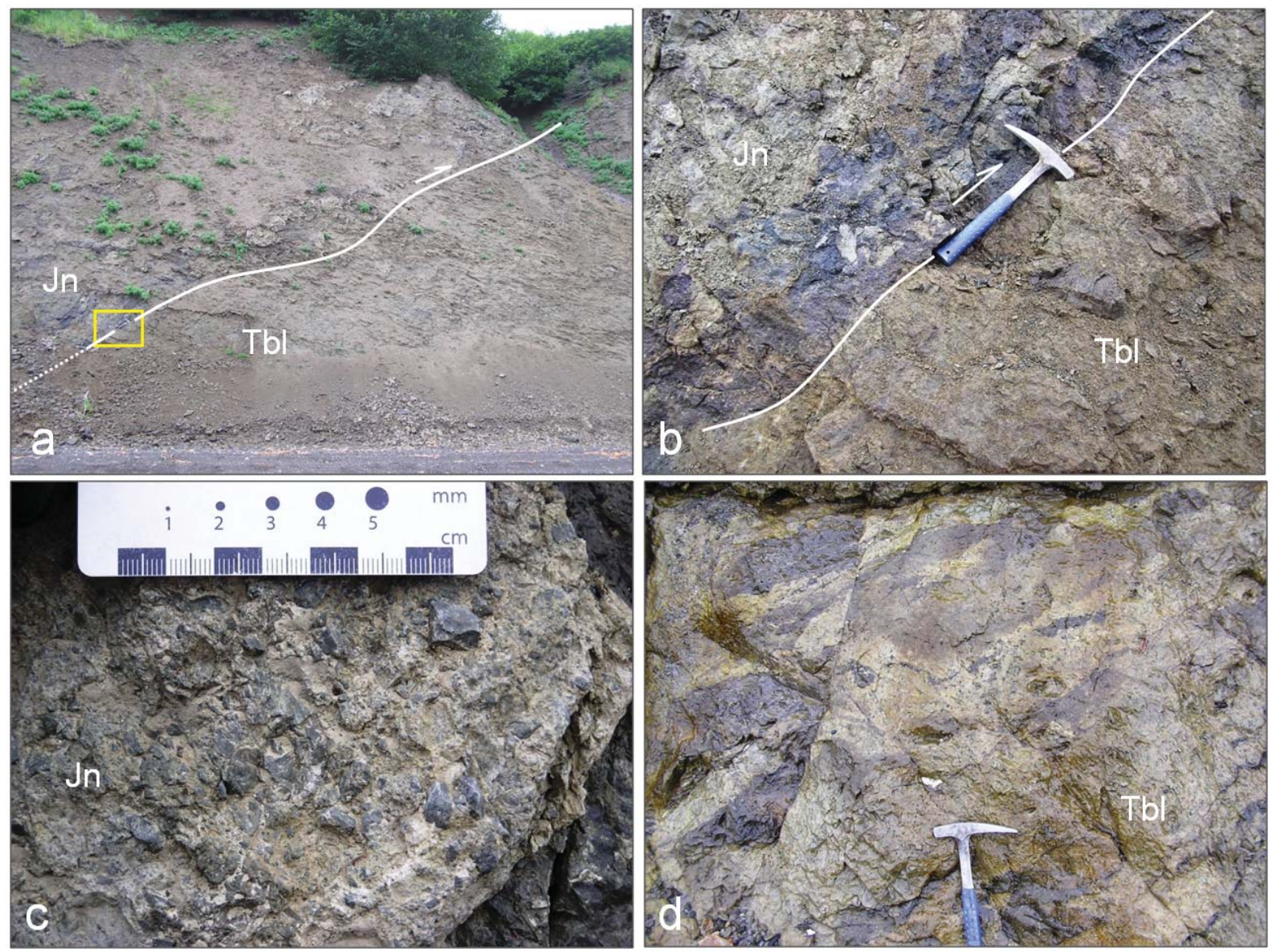

Figure 5. North-verging thrust or reverse fault exposed on western shore of Herendeen Bay places Jurassic Naknek Formation (Jn) over Miocene Bear Lake Formation (Tbl). Photograph in (a) gives outcrop-scale view; yellow rectangle indicates area of close-up in (b). Despite the broad damage zone involving both hangingwall and footwall units, there is remarkably little mixing of the formations across the discrete fault surface marked on the photos. Naknek Formation in the hangingwall is intensely brecciated at the centimeter scale (c), whereas Bear Lake Formation in the footwall tens of meters from the fault (d) was penetratively deformed in a semi-consolidated state, exhibiting characteristics of both discrete shearing and fluidized granular flow. 
ally north-dipping panel with inclinations of up to 20 degrees, whereas Naknek and Cretaceous rocks to the south make up a more gently south- to southeast-dipping panel (Burk, 1965; Sralla, 2007).

The maps of Amoco (1979) and Wilson and others (1995) do not plot an anticlinal axis for this uplift. Wilson and others (1995) showed fewer bedding attitudes than Burk (1965), and mapped most of the Naknek Formation in the highlands north of Buck Valley and the Lefthead River as belonging to the Northeast Creek member, which is stratigraphically lower than the uppermost Naknek Indecision Creek member south of the valleys. Wilson and others (1995) mapped a short east-westtrending fault segment, upthrown to the north. This fault may reconcile the occurrence of the oldest rocks in what is apparently the north flank of the uplift rather than at its core, as defined by the major reversal in dip direction between the northern and southern limbs. In an effort to honor the map unit distribution of Wilson and others (1995), we interpret this as an antithetic (south-verging) reverse fault (sheet 1 , section A-A'). However, without more detailed structural attitude constraints, it is difficult to determine whether this model can be bed-length balanced. Sralla (2007) noted that few faults crosscut the structure, and he interpreted the northern and southern dip panels as consisting of the same member of the Naknek Formation with no substantial fault between them (B. Sralla, oral commun., 2007).

Wilson and others (1995) mapped a cluster of several steep, north-northeast-trending faults at and beyond the southwest corner of our map area near Sapsuk Lake that were not field checked during the current study. As mapped, most show only minor vertical displacement of the Naknek and Chignik Formations, though one appears locally to have up to several hundred feet of stratigraphic separation. Burk (1965) mapped a single northeast-trending down-to-southeast normal fault in the same area. None of these faults were mapped as continuing across the wide valleys into the northern part of the Sapsuk uplift. In any case, they neither significantly disrupt nor compartmentalize the uplift's map pattern.

\section{STANIUKOVICH PENINSULA DOMAIN}

The Staniukovich peninsula between Port Moller and Herendeen Bay received considerably more attention during 2006 field studies than the area west of Herendeen Bay. Preliminary revised geologic mapping focused on developing a better understanding of the major structures in this area, which had been variously represented on previous geologic maps (figs. 2-4). The southern limit of the area described here extends east-northeastward from Deer Valley through Lawrence Valley to Mud Bay near the head of Port Moller, including the smaller peninsula made up of Pinnacle Peak and Bold Bluff Point at the south end of Herendeen Bay.

Perhaps the most obvious geologic features mapped on the Staniukovich peninsula (sheet 1) are the nearly orthogonal, relatively straight, northwest- and northeast-striking faults. Upon further inspection, the large-scale map pattern is that of a complexly faulted, northeast-southwest-trending system of anticlines and synclines (sheet 1 , map and section B-B'). This is a fundamental characteristic of the structure that is not fully expressed by the map or cross section of Wilson and others (1995; fig. 4). Situated immediately south of the coastal plain, the Staniukovich Mountain anticline is the most prominent fold in this area, exposing a thick succession of Upper Jurassic to Lower Cretaceous Naknek and Staniukovich formations in its core. The anticline clearly deforms all units as young as the Upper Cretaceous Chignik Formation. The relationship of Tertiary formations to the folding is less clear, as will be discussed in more detail below.

Burk (1965) and Amoco (1979) depicted the Staniukovich Mountain anticline as a fairly simple northeast-southwest elongated, doubly-plunging closure with only minor complication due to a few steep, northeaststriking (longitudinal) faults (figs. 2, 3a). Amoco (1983) recognized additional steep faults, including several important northwest-striking (transverse) faults that offset the fold axis (fig. 3b). Wilson and others (1995) mapped the area as having still greater fault complexity, showing numerous intersecting strands of two nearly orthogonal fault sets (fig. 4a). These USGS workers further proposed the existence of a large-displacement, low-angle thrust fault, which they believed transported highly disrupted blocks of Mesozoic and Paleogene rocks above little-deformed Neogene footwall strata throughout most of the peninsula (fig. 4b; Wilson and others, 1995; Detterman and others, 1996). Our mapping (sheet 1) recognizes an even greater number of steep, northeast- and northwest-trending faults, but we find no evidence to support the interpretation of major low-angle thrusting on the Staniukovich peninsula.

Faults and shear fractures measured in the Naknek, Staniukovich, Herendeen, and Chignik Formations on the Herendeen Bay shoreline (fig. 6) reflect the two dominant fault trends reflected in the map pattern (sheet 1). Most faults in these populations are steep to moderately dipping. Fault striae indicate that most are oblique-slip faults, with a locally dominant component of strike-slip. Several of the poorly exposed transverse faults that control major northwest-trending drainages are interpreted from stratigraphic juxtapositions to have a significant component of dip-slip. These transverse faults compartmentalize the core and northwestern limb of the Staniukovich Mountain anticline into discrete 
segments marked by varying position and plunge of fold axes, offset positions of the oldest exposed strata, and the type and density of faulting. We interpret them as early-formed tear faults that allowed each sector to respond to further deformation quasi-independently of adjacent compartments. The fold axis has apparent right-lateral separation of nearly $2.5 \mathrm{~km}(1.5 \mathrm{mi})$ across Coal Valley, and approximately $1.3 \mathrm{~km}(0.8 \mathrm{mi})$ across Johnson Fork. The fact that the map pattern is not only laterally offset, but also exposes older stratigraphic units on the northeastern sides of these valleys, indicates that the net slip includes a component of down-to-southwest vertical separation.

The southwestern half of the Staniukovich Mountain anticline is dissected by numerous intersecting transverse and longitudinal fault segments that partition this end of the structure into as many as a dozen mappable blocks. Near the center of the anticline in the block of Naknek and Staniukovich Formations bounded by transverse faults along Coal Valley and Johnson Fork, bedding attitudes indicate the fold axis plunges to the northeast. Immediately to the south, the large block

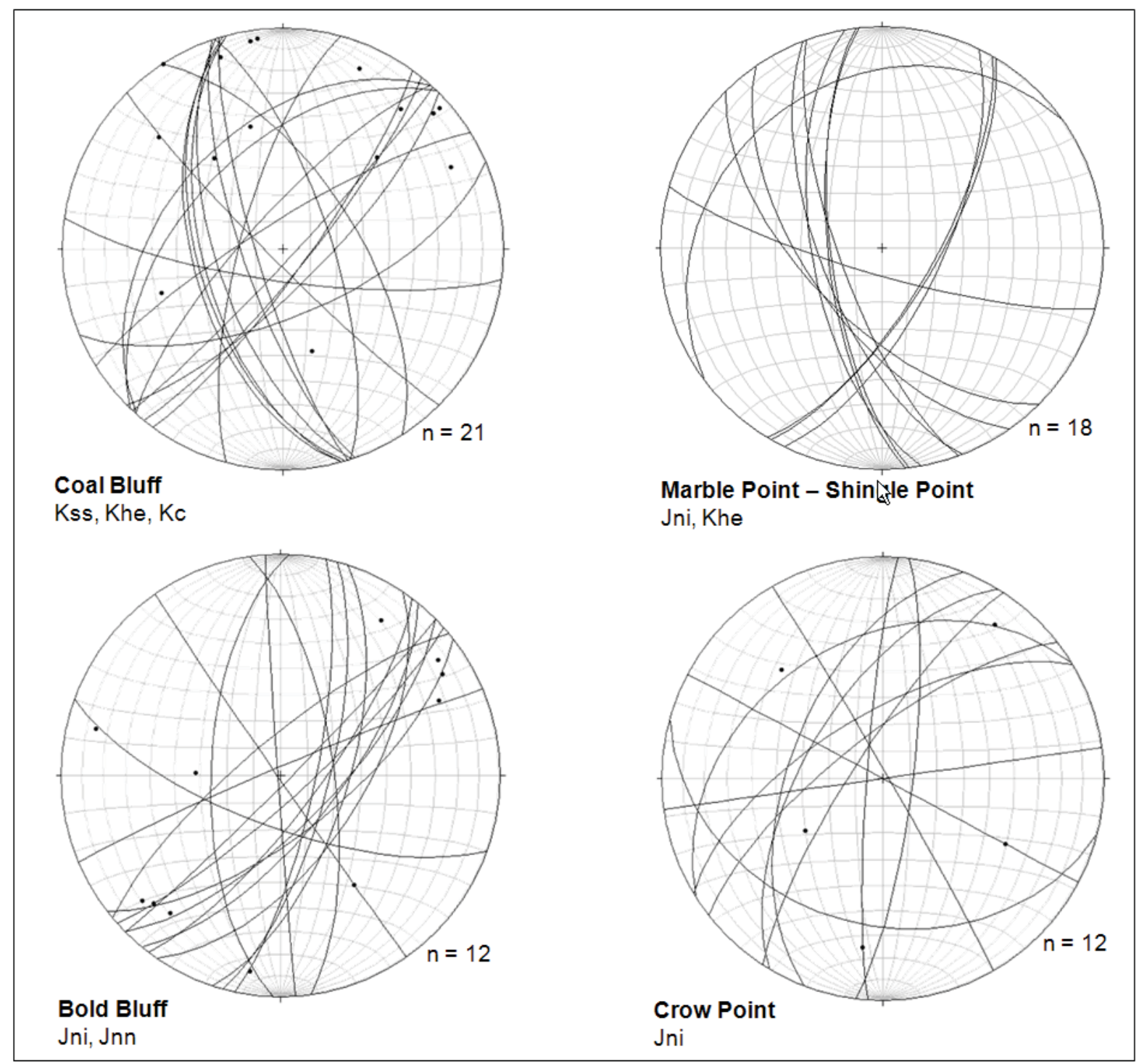

Figure 6. Stereograms of faults (and shear fractures), and slickenside striae in shoreline outcrops, eastern and southern Herendeen Bay. Faults (great circles) are mostly steeply dipping, northeast and northwest striking. Slickenside striae (dots) are mostly gently to moderately plunging, indicating a predominance of oblique-slip faults with a strong strike-slip component. See sheet 1 for localities represented by these populations. Map unit abbreviations as follows: Kc = Chignik Formation, Kss $=$ Staniukovich Formation, Khe = Herendeen Formation, Jni = Indecision Creek member of Naknek Formation, Jnn = Northeast Creek member of Naknek Formation. 
between Lynden Creek and Johnson Fork presented a structural paradox as mapped previously (Wilson and others, 1995), in which a broad, generally synclinal depression cored by Herendeen Formation was mapped at the center of the larger anticline. Based on our observations in this fault-bounded block, we reinterpret it a northeast-plunging anticlinal segment similar to the one just to the north, but with much less Naknek and Staniukovich exposed in its core to the southwest, plunging beneath a broad area of Chignik Formation outcrop to the northeast (sheet 1).

At the far western end of the Staniukovich Mountain anticline, many hilltops have only rubble-crop exposures, rendering the highly compartmentalized fault pattern somewhat interpretive, but mutually cross-cutting relationships suggest that these orthogonal fault sets developed concurrently rather than sequentially. Southwestern plunge beneath Herendeen Bay is most apparent from gentle to moderate southwest dip in the Herendeen Formation along the shoreline between Bluff Point and Marble Point.

The northeastern half of the Staniukovich Mountain anticline is cut by fewer faults than the southwestern half. The major faults recognized in this part of the fold are northeast-striking longitudinal faults that are nearly vertical to steeply southeast-dipping and downthrown to the southeast. A few faults oriented transverse and oblique to the fold axis are interpreted to intersect these longitudinal faults east of Staniukovich Mountain, creating a triangular compartment near the crest of the anticline. In this half of the anticline, the overall convergence of the younger units on the flanks suggests northeast plunge. However, northeast of the unnamed drainage east of Staniukovich Mountain, the axis locally appears to plunge gently in the opposite direction (toward the southwest). The maps of Burk (1965) and Wilson and others (1995) present conflicting strike and dip data in Tertiary lava flows unconformably overlying Mesozoic units near the northeastern end of the anticline on the eastern side of the peninsula, and plunge could not be determined.

The southeastern flank of the Staniukovich Mountain anticline is bounded by a series of relatively continuous longitudinal faults, upthrown relative to the adjacent belt of Chignik Formation in the core of the synclinal trough informally referred to here as the Mine Harbor syncline. This faulted contact is not well exposed between Mine Harbor and Coal Valley, but the curved map trace suggests it is a northwest-dipping reverse fault (sheet 1 , section B-B'). Burk (1965) mapped this structure as a southeast-dipping normal fault. Northeast of Coal Valley, the contact between Chignik and older units is at a very steep, locally anastomosed fault zone, where one fault splays into two sub-parallel strands that continue more than $5 \mathrm{~km}$ (3 mi) to the northeast, separated by just a few hundred meters.

The Mine Harbor syncline is also fault-bounded on its southern side, where the upthrown northern limb and core of the narrow Lawrence Valley anticline exposes Herendeen, Staniukovich, and Naknek Formations. These bounding faults are locally well exposed, but their map traces are only approximately located for much of their length, so their dip and dip directions are uncertain. Burk (1965) mapped this southern edge of the Chignik belt as a single normal fault; we recognize several fault segments, and consider them more likely to have reverse or reverse-oblique displacement. Cretaceous strata are not exposed on the southern limb of the Lawrence Valley anticline; the valley follows a longitudinal fault juxtaposing the Jurassic core against lower Tertiary Tolstoi Formation.

Our remapping finds no positive cross-cutting relationships on the Staniukovich peninsula that demonstrate the late Miocene or younger compressional or transpressional deformation seen in the Sapsuk domain. The contact between Mesozoic and Tertiary units in coastal plain and shoreline outcrops on the northwest flank of the Staniukovich Mountain anticline is mostly covered. It was mapped as conformable by Burk (1965), but was interpreted by Amoco $(1979,1983)$ as multiple parallel or splayed strands of up-to-south faults of the David River zone (DRZ). We map two exposed faults (and one concealed fault) that strike northeast and have down-to-north separation in outcrops on the peninsula's northern shoreline. Following Amoco's lead, we extrapolate this fault system westward along the topographic break between the elevated Mesozoic rocks and the Tertiary rocks of the coastal plain as the probable eastern extension of the David River zone (sheet 1, map and section B-B'). These DRZ faults are evident in coastal outcrops of Chignik and Meshik formations, and are inferred to cut the Stepovak and Bear Lake Formations here as well. The generally northwest dip of Tertiary units in the northern part of the peninsula is conformable with the northwest limb of the Staniukovich Mountain anticline. However, at least some of this dip may relate to extensional faulting and subsidence of the basin to the north rather than solely to compressional uplift and folding to the south.

Relative and radiometric ages from volcanic rocks do provide some constraints on the timing of deformation on the Staniukovich peninsula. Lavas yielding late Middle Eocene to Oligocene radiometric ages (30.2-38.0 Ma) are assigned to the Meshik series, whereas porphyritic volcanics south of Herendeen Bay, capping Pinnacle Peak and the ridge to the southwest, yield Quaternary ages (0.67-0.86 Ma; Wilson and others, 1994, 1995). Of the Meshik exposures, the isolated ridge of columnar 
jointed andesite on the southwestern side of Johnson Fork is the youngest, at $30.2 \mathrm{Ma}$ (Wilson and others, 1994). This rock unit is surrounded by cover and Quaternary sediments, and its fault juxtaposition with folded Mesozoic rocks (sheet 1 ) is only speculative. Better cross-cutting relationships are apparent on the east side of the peninsula, where Meshik volcanics dated within a narrow Middle to Late Eocene age range of 36.1-38.0 Ma (Wilson and others, 1994) unconformably overlie the folded Chignik, Herendeen, and Naknek Formations. Southwest of Mud Bay, Meshik flows exhibit moderate to gentle northeasterly dip that probably reflects substantial paleotopographic relief on the pre-Meshik unconformity. Strike and dip measurements in these lavas are highly variable, and it is difficult to determine whether folding continued after extrusion of the lavas. Clearly, there has been at least local uplift since Late Eocene time; 36.5 Ma leuco-basalt flows interbedded with oyster-bearing volcaniclastic beds (Wilson and others, 1994, sample 84ACe 177) were deposited at or below sea level, but now reside at an elevation of approximately $350 \mathrm{~m}(1,150 \mathrm{ft})$.

Current mapping revealed no evidence for the lowangle late Miocene or younger thrust fault inferred by USGS geologists to place Mesozoic units and locally, Meshik volcanics above Bear Lake Formation across most of the Staniukovich peninsula (fig. 4b; Wilson and others, 1995; 1999; Detterman and others, 1996). The exposures they mapped as Miocene Bear Lake Formation (Wilson and others, 1995; 1999; Detterman and others, 1996, fig. 10) or considered to be "unassigned Tertiary strata" (Detterman and others, 1996, p. 31) at Coal Bluff on the eastern shore of Herendeen Bay are mapped here with a high degree of confidence as Chignik Formation (sheet 1), mostly because of the highly distinctive pebble-cobble conglomerates with pink granitoid clasts containing large, euhedral, zoned potassium feldspar phenocrysts. We concur with Burk's (1965) and Amoco's $(1979,1983)$ mapping of these exposures as Chignik Formation in normal stratigraphic position unconformably overlying the Herendeen Formation. Efforts to locate exposures of Bear Lake Formation mapped by Wilson and others (1995) in the lower plate of their thrust beneath the low ridge of Meshik volcanics near the mouth of Johnson Fork (sheet 1) yielded no exposed bedrock. Furthermore, examination and measurement of numerous fault surfaces in good exposures at Coal Bluff and Marble Point, where the inferred thrust should be most apparent, revealed only steep, oblique- and strikeslip faults, and no observations of low-angle thrusts.

In summary, at least two phases of deformation are recognizable in the Staniukovich peninsula domain. Folding and high-angle faulting of Upper Cretaceous and older strata prior to late Middle Eocene time gave rise to the angular unconformity below the Meshik flows and equivalent Stepovak Formation volcaniclastic strata on the eastern part of the peninsula. Further deformation since Late Eocene time has locally resulted in at least $350 \mathrm{~m}(1,150 \mathrm{ft})$ of local uplift. This phase of Tertiary uplift might correspond to Late Miocene or younger reverse faulting and folding in the Sapsuk domain, but we find no evidence of thrusting with large horizontal displacement on the Staniukovich peninsula.

\section{STRUCTURAL TRAP POTENTIAL}

Though we have not mapped it in detail, the thrustcored Sapsuk uplift appears to exhibit considerably less structural complexity than the intensely faulted, compartmentally-deformed Staniukovich Mountain anticline and the adjacent syncline-anticline pair to the south. Though both areas face significant risks relative to reservoir and seal facies, the broad, gently dipping panels of the Sapsuk uplift may present more favorable conditions for structural trapping. However, this depends on whether there is, in fact, a significant fault near the axis and also depends on there being adequate plunge in both directions. The thick Naknek-Bear Lake gouge zone at the thrust in the north limb of the Sapsuk uplift would very likely provide adequate seal for fault-bounded hydrocarbon accumulations in either the hangingwall or footwall.

Our remapping of the Staniukovich Mountain anticline suggests it is unlikely to behave as a single dome-like trap. More importantly, we consider it highly unlikely that the Mesozoic to Paleogene units at the surface have been thrust-emplaced over little-deformed Tertiary formations. Many of its fault-bounded blocks may harbor potential traps defined by two-way or threeway dip combined with a fault buttress component. In these cases, trap integrity will thus depend on the adequacy of fault seals, which can be compromised by high sandstone:mudstone ratios in the faulted strata, and by reactivation of structures after hydrocarbon migration. If effective fault seals are present in the subsurface, the Staniukovich Mountain anticline would likely host a number of smaller compartmentalized accumulations rather than a single accumulation defined by the larger fold geometry.

\section{STRUCTURAL MODEL}

The fundamental reason for the very different types, orientations, and densities of faulting in uplifted Mesozoic units in the Sapsuk and Staniukovich peninsula domains on opposite sides of Herendeen Bay remains a matter of speculation. Both uplifts are interpreted as immediately adjacent to the east-west-trending southern margin of the North Aleutian basin. This boundary belt (the DRZ) likely has a complex structural history involving compression to the south, extension to the north, 
and a mix of right lateral strike-slip, reverse-oblique (transpression) and normal-oblique (transtension) within it. It is also probable that different segments of this belt have been dominated by different styles of deformation. Strain within transpression zones is commonly partitioned into domains dominated by strike-slip (plane strain, rotational simple shear) and compression (non-rotational pure shear) (for example, Schreurs and Colletta, 2002; Jones and Tanner, 1995; Clegg and Holdsworth, 2005). Outcrop fracture orientation data suggest the ratio of strike-slip to normal convergence increases westward along the DRZ from Herendeen Bay (Decker and others, 2005), and that the Sapsuk uplift area may be dominated by normal convergence.

The fault system in the Staniukovich peninsula domain is similar to that generated in analog models of restraining oversteps in strike-slip fault regimes (fig. 7; McClay and Bonora, 2001). This suggests uplift may be related to transfer of dextral slip from the Sapsuk domain segment of the DRZ to an as-yet unidentified northerly segment beneath Port Moller and farther east. In this context, the Staniukovich Mountain uplift can be interpreted as a broad, antiformal pop-up or positive flower structure, in which the combination of wrenching and shortening generates a more complex pattern of transverse and longitudinal faults, offset fold axes, and compartmentalized blocks than is recognized in the Sapsuk uplift to the west.

As stated previously, the boundary between the Sapsuk and Staniukovich peninsula domains could be a fault hidden beneath Herendeen Bay. The restraining overstep models of McClay and Bonora (2001) suggest an alternative explanation, that the domain boundary may simply reflect the margin of the uplift that develops in the overstep zone, where displacement transfer causes an abrupt change in the orientation, types, and density of

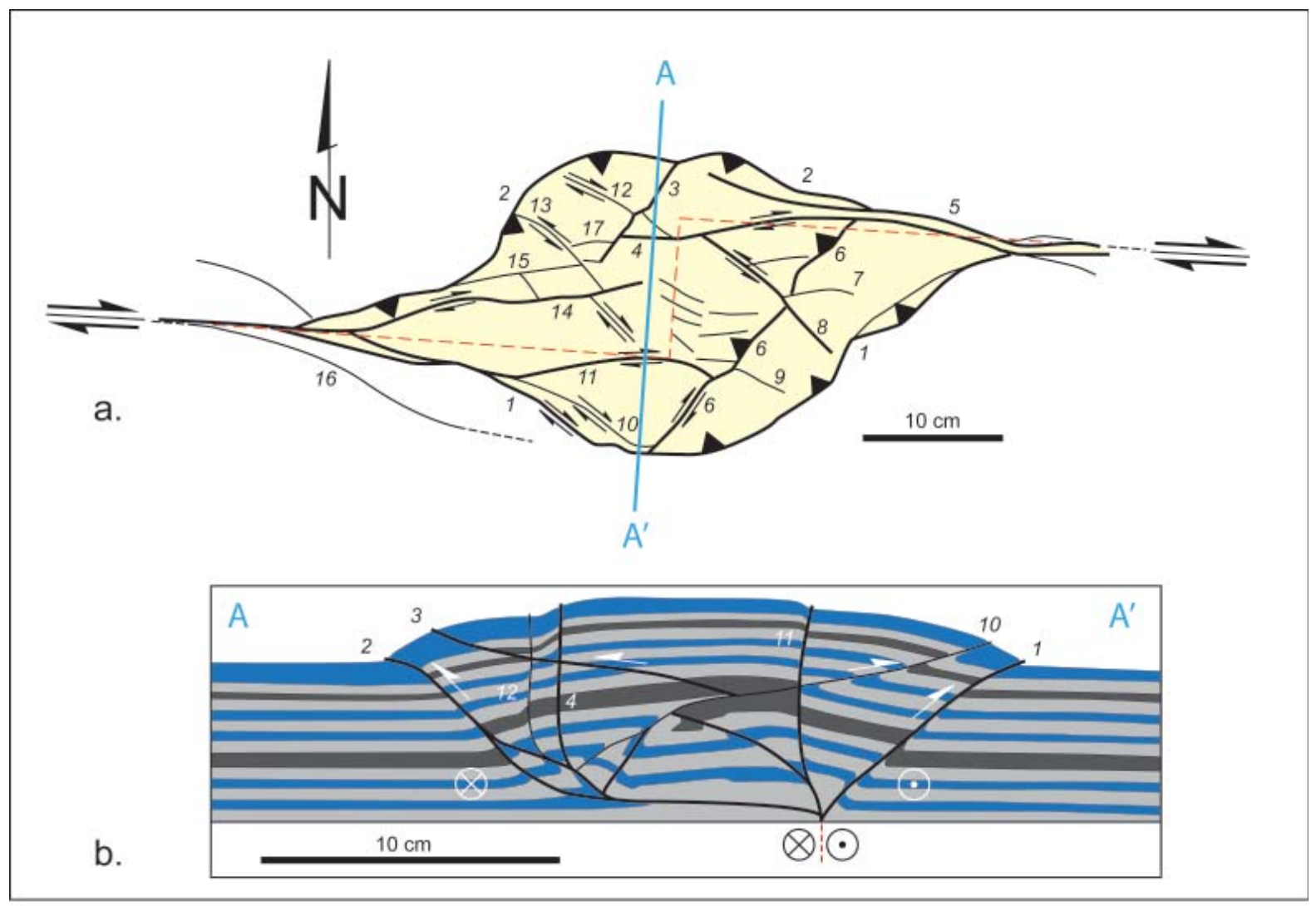

Figure 7. Structural patterns in the Staniukovich peninsula domain have much in common with uplift structures generated in analog modeling of restraining oversteps in strike-slip systems. The plan view (a) and enlarged cross section (b) have been rotated and redrawn in mirror image from the originals (McClay and Bonora, 2001, fig. 6) to show them as they would appear had they been derived from right-lateral instead of left-lateral models to facilitate comparison to the present study area (sheet 1). The overstep is the zone in which strain is transferred between the main strike-slip faults (red dashed lines), which in this case have zero overlap at their tips. Symbols in model cross section mark displacement away $\otimes$ from viewer and toward $\odot$ viewer. Note the northeast-southwest elongated rhomboidal uplift accommodated by northwest-and southeast-verging reverse-oblique faults, and the development of transverse faults with both right and left lateral slip that compartmentalize the overall uplift into differentially uplifted blocks. 
faults and folds. The multiple phases of deformation that have affected this area may well have been accompanied by significant changes in the greater tectonic regime. In this case, it would be unrealistic to expect all the structures to conform to a single suite of structural styles predicted by a given single-stage analog model.

\section{CONCLUSIONS}

Recent field investigations have resulted in substantial revision of pre-existing geologic mapping in the vicinity of recent oil and gas leasing in the Staniukovich peninsula-Herendeen Bay area. Although preliminary in nature, this remapping provides a basis for describing important variations in structural orientation and style, interpreting the deformation history, and addressing the area's hydrocarbon resource potential.

West of Herendeen Bay, the Sapsuk domain is dominated by a large, west-northwest-trending, thrustor reverse-fault-bounded uplift that places Mesozoic rocks in fault contact with Miocene Bear Lake Formation. Sralla (2007) interpreted this uplift as a broad, doubly-plunging anticline devoid of significant fault complications. The map pattern (sheet 1), although inadequately constrained by attitude data, is consistent with this uplift having long, gently- to moderately-dipping flanks. However, the question of whether different members of the Naknek Formation are juxtaposed by faulting near the axis of the structure has implications regarding trap integrity, and merits further investigation. The northward transition from compressional to extensional faulting in the Bear Lake Formation in the coastal belt of the Sapsuk domain reflects syndepositional Miocene subsidence of the offshore North Aleutian backarc basin.

Between Herendeen Bay and Port Moller, the Staniukovich peninsula domain consists of a series of complexly faulted, northeast- to east-northeast-trending folds, including the Staniukovich Mountain anticline, the Mine Harbor syncline, and the Lawrence Valley anticline. Previous workers viewed the Staniukovich Mountain anticline as either a relatively simple dome "broken by several longitudinal and traverse faults" (Burk, 1965, p. 128) or as a chaotic sheet of allochthonous blocks emplaced on nearly undeformed Jurassic through Miocene units (Wilson and others, 1995). Our mapping and structural observations lead us to conclude instead that this structure is best viewed as an extensively faulted basement-cored composite uplift in which numerous compartments developed early on and have responded to continued deformation quasi-independently of one another. As in the Sapsuk domain, the northern coastal plain of the Staniukovich peninsula is underlain by down-to-north faults that mark the northward transition from onshore uplift to offshore subsidence.
Most faults in the map area are relatively steep as indicated by relatively straight map traces and fault fabric measurements. In the Staniukovich peninsula domain, slickenlines indicate a prevalence of obliqueslip movement, and cross-cutting relationships document the co-evolution of the northeast-southwest- and northwest-southeast-trending fault sets that compartmentalize structures.

The structural styles, orientations, and differences between the two domains are consistent with deformation in a right-lateral oblique-convergent setting. The domains may represent different segments of the eastward continuation of the dextral transpressive David River zone as it approaches a left-stepping restraining overstep. In this model, the Sapsuk domain exhibits relatively simple right-lateral transpressional structure along the DRZ, whereas the Staniukovich peninsula domain exemplifies the more complex faulting and folding characteristic of the rhomboidal uplift zone within the restraining overstep itself. Radiometric dating and cross-cutting relationships document at least two main deformational phases in the map area. Substantial folding and faulting occurred on the Staniukovich peninsula between Late Cretaceous and late Middle Eocene time. Subsequent uplift of at least $350 \mathrm{~m}$ is locally documented in this domain, and may be related to late Miocene or younger reverse faulting in the Sapsuk uplift.

The extensive folding and high-angle faulting documented at the surface in the map area suggests a high likelihood that there are structural trapping configurations for hydrocarbons in the subsurface, most of which likely include a fault buttress component. The prevalence of sandstones and conglomerates relative to fine-grained sealing lithologies, considered alongside the area's multi-phase deformation history, suggests many faults may not be reliably sealed. Given the presence of effective fault seals, the structurally compartmentalized Staniukovich Mountain anticline is more likely to host multiple smaller accumulations than a single large oil and gas field.

\section{ACKNOWLEDGMENTS}

Fieldwork for this study was conducted during 2005 and 2006 with funding from multiple sources, including a U.S. Department of Energy grant from the Arctic Energy Technology Development Laboratory at the University of Alaska Fairbanks to Rocky Reifenstuhl (program head) and Paul McCarthy (principal investigator, UAF), Bristol Bay Native Corporation, and Division of Geological \& Geophysical Surveys and Division of Oil and Gas operating and capital improvement project budgets. The authors thank Bryan Sralla for valuable technical discussions. The text, figures, and map benefited from insightful reviews by Robert Swenson and Rick Levinson. 


\section{REFERENCES CITED}

Allison, R.C., and Addicott, W.O., 1973, The Mytilusmiddendorffi group (Bivalvia) of the North American Miocene [abs.]: Geological Society of America Abstracts with Programs, v. 5, p. 2-3.

Amoco, 1979, Geologic map of the Alaska Peninsula: Amoco Production Company Geologic Report FR02-79, (unpublished report of 1977 field season, available through Alaska Geologic Materials Center), scale 1 in = 16,000 ft (1:192,000).

_ 1983, Geologic map of the Staniukovich Mountain area: Amoco Production Company Geologic Report FW-18-81R, (unpublished report of 1981 field season, available through Alaska Geologic Materials Center), scale 1:63,360.

Atwood, W.W., 1911, Geology and mineral resources of parts of the Alaska Peninsula: U.S. Geological Survey Bulletin 467, 137 p.

Brockway, Ronald, Alexander, B., Day, P., Lyle, W.M., Hiles, R., Decker, W., Polski, W., and Reed, B.L., 1975, Bristol Bay region, stratigraphic correlation section, southwest Alaska: Anchorage, The Alaska Geological Society, 1 sheet.

Burk, C.A., 1965, Geology of the Alaska Peninsula-Island Arc and Continental Margin: The Geological Society of America Memoir 99, 250 p., 3 sheets.

Clegg, P., and Holdsworth, R.E., 2005, Complex deformation as a result of strain partitioning in transpression zones; an example from the Leinster Terrane, SE Ireland: Journal of the Geological Society, v. 16.2, p. 187-202.

Decker, P.L., Finzel, E.S., Ridgway, K.D., Reifenstuhl, R.R., and Blodgett, R.B., 2005, Preliminary summary of the 2005 field season; Port Moller, Herendeen Bay, and Dillingham areas, Bristol Bay Basin, Alaska Peninsula: Alaska Division of Geological \& Geophysical Surveys Preliminary Interpretive Report 2005-7, 55 p., 2 sheets.

Detterman, R.L., 1978, Interpretation of depositional environments in the Chignik Formation, Alaska Peninsula, in Johnson, K.M., ed., The United States Geological Survey in Alaska; Accomplishments during 1977: U.S. Geological Survey Circular 772-B, p. B62-B63.

Detterman, R.L., and Reed, B.L., 1980, Stratigraphy, structure, and economic geology of the Iliamna Quadrangle, Alaska: U.S. Geological Survey Bulletin 1368-B, 86 p., 1 plate, scale 1:250,000.

Detterman, R.L., Case, J.E., Miller, J.W., Wilson, F.H., and Yount, M.E., 1996, Stratigraphic framework of the Alaska Peninsula: U.S. Geological Survey Bulletin 1969-A, 74 p.
Detterman, R.L., Miller, T.P., Yount, M.E., and Wilson, F.H., 1981, Geologic map of the Chignik and Sutwik Island quadrangles, Alaska: U.S. Geological Survey Miscellaneous Investigations Series Map I-1229, scale 1:250,000.

Dubois, G.D., Wilson, F.H., and Shew, N.B., 1987, Potassium-argon age determinations from the Port Moller and Stepovak Bay quadrangles, Alaska Peninsula: U.S. Geological Survey Open-File Report 87-191, 1 plate, scale 1:250,000.

Fairchild, D.T., 1977, Paleoenvironments of the Chignik Formation, Alaska Peninsula: Fairbanks, Alaska, University of Alaska Fairbanks, M.S. thesis, 168 p.

Finzel, E.S., Reifenstuhl, R.R., Decker, P.L., and Ridgway, K.D., 2005, Sedimentology, stratigraphy, and hydrocarbon reservoir-source rock potential, using surface and subsurface data, of Tertiary and Mesozoic strata, Bristol Bay Basin and Alaska Peninsula: Alaska Division of Geological \& Geophysical Surveys Preliminary Interpretive Report 2005-4, 67 p.

Galloway, W.E., 1974, Deposition and diagenetic alteration of sandstone in northeast Pacific arc-related basins; Implications for graywacke diagenesis: Geological Society of America Bulletin, v. 85, no. 3, p. 379-390.

Gillis, R.J., Reifenstuhl, R.R., Decker, P.L., Strauch, A.L., and Helmold, K.P., 2007, Onshore Alaska Peninsula petroleum system assessment: preliminary summary of outcrop studies of the Port Moller area, 2006 [abs]: American Association of Petroleum Geologists Bulletin, v. 91, Annual Meeting Program Abstracts (digital), http://www.searchanddiscovery. net/documents/2007/07018annual_abs_Ingbch/abstracts/ lbGillis.htm.

Jones, D.L., and Detterman, R.L., 1966, Cretaceous stratigraphy of the Kamishak Hills, Alaska Peninsula, in Geological Survey research 1966, Chapter D: U.S. Geological Survey Professional Paper 550-D, p. D53-D58.

Jones, R.R., and Tanner, P.W.G., 1995, Strain partitioning in transpression zones: Journal of Structural Geology, v. 17, p. 793-802.

Knappen, R.S., 1929, Geology and mineral resources of the Aniakchak district: U.S. Geological Survey Bulletin 797, p. 161-223.

Mancini, E.A., Deeter, T.M., and Wingate, F.H., 1978, Upper Cretaceous arc-trench gap sedimentation on the Alaska Peninsula: Geology, v. 6, p. 437-439.

Marincovich, Louie, Jr., 1983, Molluscan paleontology, paleoecology, and North Pacific correlations of the Miocene Tachilni Formation, Alaska Peninsula, Alaska: Bulletin of American Paleontology, v. 84, no. 317, p. 59-155, plates 12-23. 
McClay, K., and Bonora, M., 2001, Analog models of restraining stepovers in strike-slip fault systems: American Association of Petroleum Geologists Bulletin, v. 85, p. 233-260.

Nilsen, T.H., 1984, Miocene back-arc tidal deposits of the Bear Lake Formation, Alaska Peninsula, in Reed, K.M., and Bartsch-Winkler, Susan, eds., The United States Geological Survey in Alaska; Accomplishments during 1982: U.S. Geological Survey Circular 939, p. 85-88.

Palache, Charles, 1904, Geology about Chichagof Cove, Stepovak Bay; with notes on Popof and Unga Islands (Alaska): Harriman Alaska Expedition, v. 4, p. 69-88.

Schreurs, G., and Colletta, B., 2002, Analog modelling of continental transpression, in Schellart, P., and Passchier, C., eds., Analogue modelling of large-scale tectonic processes: Journal of the Virtual Explorer, v. 7., p. 67-78.

Spurr, J.E., 1900, A reconnaissance in southwestern Alaska in 1898: U.S. Geological Survey 20th Annual Report, Part 7, p. 31-264.

Sralla, Bryan, 2007, Structural geometry, kinematics, and hydrocarbon exploration potential of Sapsuk Lake anticline, Herendeen Bay region, Alaska Peninsula [abs]: Alaska Geology, v. 38, no. 1, p. 1-2.

Wilson, F.H., 1985, The Meshik arc-An Eocene to earliest Miocene magmatic arc on the Alaska Peninsula: Alaska Division of Geological \& Geophysical Surveys Professional Report 88, 14 p.

Wilson, F.H., and Shew, N., 1992, Map and tables showing geochronology and whole-rock geochemistry of selected samples, Ugashik and part of Karluk quadrangles, Alaska: U.S. Geological Survey Miscellaneous Field Studies Map MF-1539-E, 12 p., 1 plate, scale $1: 250,000$.
Wilson, F.H., Detterman, R.L., and DuBois, Gregory, 1999, Digital data for the geologic framework of the Alaska Peninsula, Southwest Alaska, and the Alaska Peninsula Terrane: U.S. Geological Survey OpenFile Report 99-317, 41 p., 1 plate, scale 1:500,000, http://wrgis.wr.usgs.gov/open-file/of99-317.

Wilson, F.H., Detterman, R.L., Miller, J.W., and Case, J.E., 1995, Geologic map of the Port Moller, Stepovak Bay, and Simeonof Island quadrangles, Alaska Peninsula, Alaska: U.S. Geological Survey Miscellaneous Investigations Series Map I-2272, 2 plates, scale $1: 250,000$.

Wilson, F.H., Shew, N., DuBois, G.D., and Bie, S.W., 1994, Sample locality map and analytical data for potassium-argon ages in the Port Moller, Stepovak Bay, and Simeonof Island quadrangles, Alaska Peninsula: U.S. Geological Survey Miscellaneous Field Studies Map MF-2155-E, 18 p., 1 plate, scale 1:250,000.

Wisehart, R.M., 1971, Paleoenvironmental analysis of the Bear Lake Formation (upper and middle Miocene), Alaska Peninsula, Alaska: Los Angeles, CA, University of California, M.S. thesis, 112 p.

Worrall, D.M., 1991, Tectonic history of the Bering Sea and the evolution of Tertiary strike-slip basins of the Bering Shelf: Geological Society of America Special Paper 257, 120 p., 1 oversize sheet, 4 plates, scale $1: 2,500,000$. 


\title{
FISSION TRACK GEOCHRONOLOGY OF THE NORTH ALEUTIAN COST \#1 WELL (OCS-8218), BRISTOL BAY BASIN, ALASKA
}

\author{
by \\ Steven C. Bergman ${ }^{1}$, John Murphy², and Shari Kelley ${ }^{3}$
}

\begin{abstract}
Zircon and apatite fission-track analyses were performed on six core samples of Eocene to Miocene sedimentary and volcaniclastic rocks from depths of 1,280-5,090 m in the North Aleutian COST \#1 well (NAC), Bristol Bay Basin, Alaska, for the purpose of constraining their thermal history and depositional provenance. Most apatite and zircon populations are complex and reflect mixtures of several age components based on $\mathrm{chi}^{2}$ statistics. Most samples exhibit older zircon fission-track ages than their corresponding apatite fission-track ages, except for two samples at present temperatures $\left(\mathrm{T}_{\mathrm{P}}\right)$ within the apatite partial annealing zone that paradoxically show the opposite relationship.

For the five samples shallower than $3,382 \mathrm{~m}$ at $\mathrm{T}_{\mathrm{p}}=38-104^{\circ} \mathrm{C}$, mean and peak apatite fission-track ages (30-74 Ma) are older than depositional ages (15-43 Ma) and mean track lengths range from 12 to $13 \mu \mathrm{m}$, together indicating that these samples have resided in the fission-track stability zone since deposition $\left(\mathrm{T}<60-90^{\circ} \mathrm{C}\right)$, although a detrital age component would allow partial resetting of the fission-track clock. The deepest sample, from $4,736 \mathrm{~m}$ depth $\left(\mathrm{T}_{\mathrm{P}}=144^{\circ} \mathrm{C}\right)$, displays a nearly totally reset apatite fission-track age of $9 \pm 2$ Ma with a mean track length of $9 \mu \mathrm{m}$, indicating it currently resides at temperatures within the apatite fission-track partial annealing zone $\left(>90-120^{\circ} \mathrm{C}\right)$; the fission-track age and track length distribution reflect significant post-depositional annealing, yet not total annealing, reflecting residence at temperatures below $130-140^{\circ} \mathrm{C}$ for geologic time periods. Although apatite compositions are not available for this sample, we predict they may be enriched in chlorine and hydroxyl $(\mathrm{Cl}-\mathrm{OH})$ and depleted in fluorine $(\mathrm{F})$ anions compared with the Durango apatite standard. Apatite uranium (U) contents show similar depth trends as the zircons where the younger, shallower samples exhibit higher uranium contents, and the deeper samples contain the lowest uranium contents. These apatite and zircon uranium-depth trends indicate a progressive unroofing of an evolving magmatic arc terrane with the deepest samples representing the primitive source magmatic rocks (uranium-depleted) and the shallowest samples representing more evolved magmatic rocks (uranium-enriched).

Corrected estimates of equilibrium bottom-hole temperatures, combined with inferred lithologydependent thermal conductivities, indicate a present-day day heat flow of $56 \mathrm{~mW} / \mathrm{m}^{2}$, corresponding to a mean geothermal gradient of $31^{\circ} \mathrm{C} / \mathrm{km}$ for the section. Both the vitrinite and apatite fission-track data are consistent with a simple Tertiary burial history and a paleo-heat flow similar to or below current values, indicating the stratigraphic section encountered in the North Aleutian COST \#1 well has not experienced higher burial temperatures in the past. The apatite fission-track data indicate minimal erosion has occurred in the penetrated section and that the present-day temperatures have only recently been achieved.
\end{abstract}

\section{INTRODUCTION}

This report presents an analysis and interpretation of zircon and apatite fission-track data from the North Aleutian COST\#1 (NAC) well. The NAC well is situated north of the Aleutian Peninsula in the Bristol Bay Basin (fig. 1). Previous fission-track analyses were performed on wells from the Lower Cook Inlet Basin (synthesized in Murphy and Clough, 1999), but the authors are not aware of any having been reported on wells in the Bristol Bay Basin. The purpose of the present study is to constrain the provenance, depositional age, and thermal history of Cenozoic strata encountered in the NAC well. Logging temperatures and vitrinite reflectance data are integrated to independently derive a geohistory-based

thermal history model within which to interpret the fission-track data. Apatite and zircon fission-track closure temperatures depend on anion and cation composition and cooling rate (for example, Green and others, 1989; Gallagher and others, 1998) with proposed ranges of apatite between 110 and $140^{\circ} \mathrm{C}$, and zircon between 200 and $275^{\circ} \mathrm{C}$.

\section{REGIONAL GEOLOGIC SETTING AND STRATIGRAPHIC OVERVIEW}

The Bristol Bay Basin is located in a back-arc tectonic setting, bounded to the south by the Alaska Peninsula and associated active volcanic arc, approximately

13111 Quenby Avenue, Houston, Texas 77005

${ }^{2} 4687$ Amherst Drive, Fairbanks, Alaska 99709

${ }^{3}$ New Mexico State University, P.O. Box 30001, Las Cruces, New Mexico 88003-8001 
$350 \mathrm{~km}$ north of the Aleutian megatrench, the active plate boundary in which the Pacific plate is being subducted beneath the North American plate at $6.2 \mathrm{~cm} / \mathrm{yr}$ with an azimuth of $344^{\circ}$ (DeMets and others, 1994). The Bristol Bay Basin (figs. 1, 2) is one of several Cenozoic sedimentary basins that formed on the southern margin of the Bering shelf following a subduction zone jump that occurred at approximately 50-60 Ma (Detterman and others, 1969; Scholl and others, 1986; 1987; Finzel and others, 2005). A variety of tectonic models have been proposed for the Bristol Bay Basin, including subsidence caused by varying degrees of right lateral strike-slip faulting (for example, Worrall, 1991), back-arc extension, and flexural loading of the volcanic arc (Bond and others, 1988; Walker and others, 2003). The latter workers proposed that the Bristol Bay Basin formed by right lateral strike-slip faulting that induced early or middle Eocene extension, and late Eocene to middle Miocene flexural subsidence, and a late Miocene-Holocene flexural subsidence related to renewed volcanism on the Alaska Peninsula and a northward prograding deltaic system.
According to Parker and Newman (1995) and Finzel and others (2005), the main Bristol Bay Basin petroleum plays involve Oligocene and Miocene drapes over basement highs, although no regionally extensive seal units have been identified previously. Reservoir potential in the Oligocene and Miocene rocks in the NAC well at depths $<2,900 \mathrm{~m}$ are considered good to excellent, especially in the Tolstoi, Bear Lake, Unga, and Milky River Formations. Porosity and permeability are observed to increase and the degree of consolidation decrease up section. Onshore reservoir quality is generally poor due to the volcanogenic provenance, but the Miocene Bear Lake Formation possesses promising quality. Regional source rocks (mainly gas prone) have been recognized in Paleocene to Miocene age coals and nonmarine shales of the Tolstoi, Stepovak, and Bear Lake Formations. The organic material encountered in the NAC well is mainly type III, humic, gas-prone kerogen. The top of the oil window for hydrocarbon generation was estimated at $3,870 \mathrm{~m}$; the base was projected to be $6,100 \mathrm{~m}$. The main structural traps are thought to be primarily simple anticlines and slightly faulted anticlines. Projected resource means are 0.22 billion barrels oil and 6.7 TCF gas.

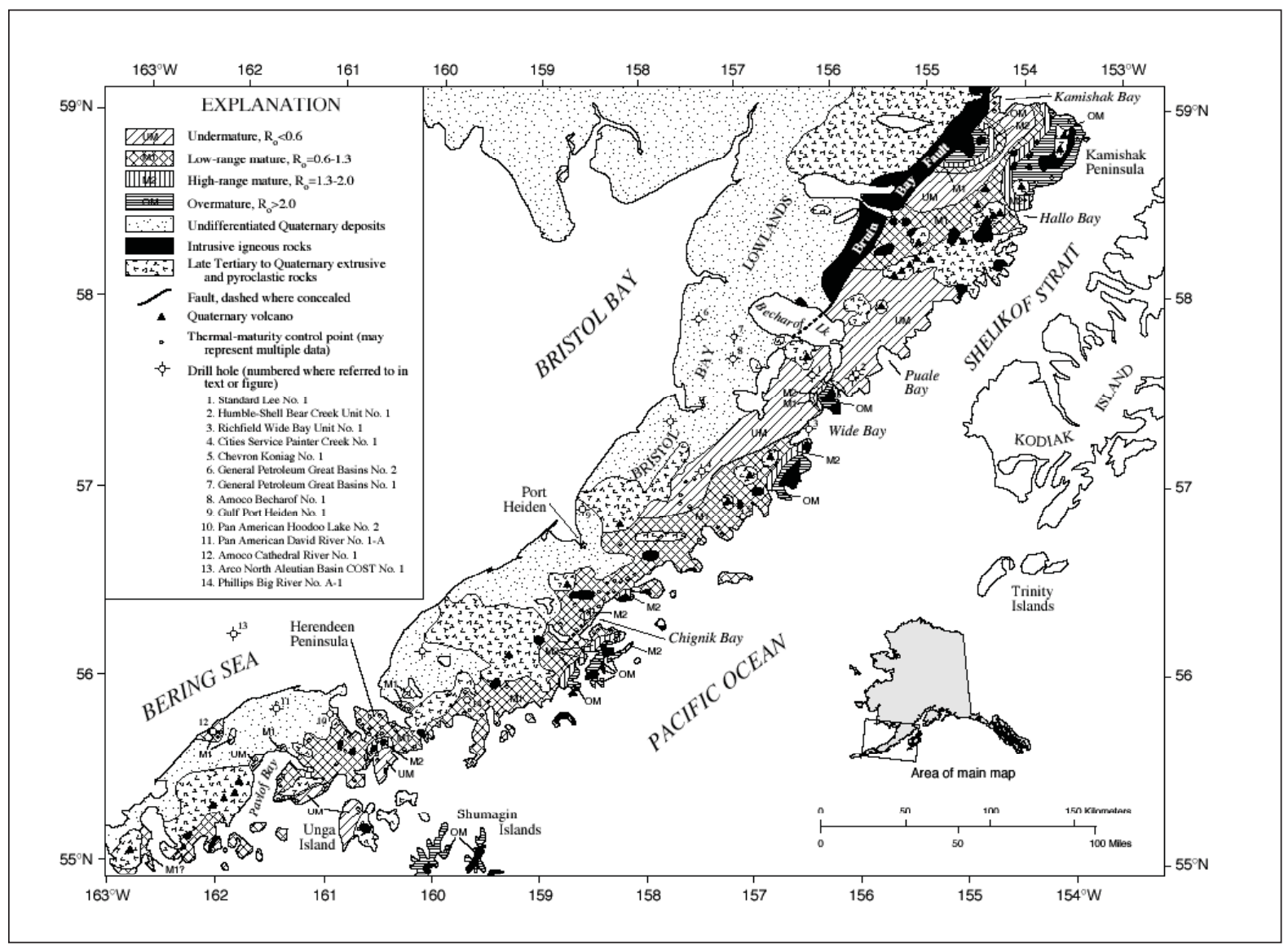

Figure 1a. Map of the Alaska Peninsula and Bristol Bay showing the location of the North Aleutian COST \#1 well (13), as well as distribution of Cenozoic igneous rocks and areas of anomalous thermal maturities; from Molenaar (1996). 


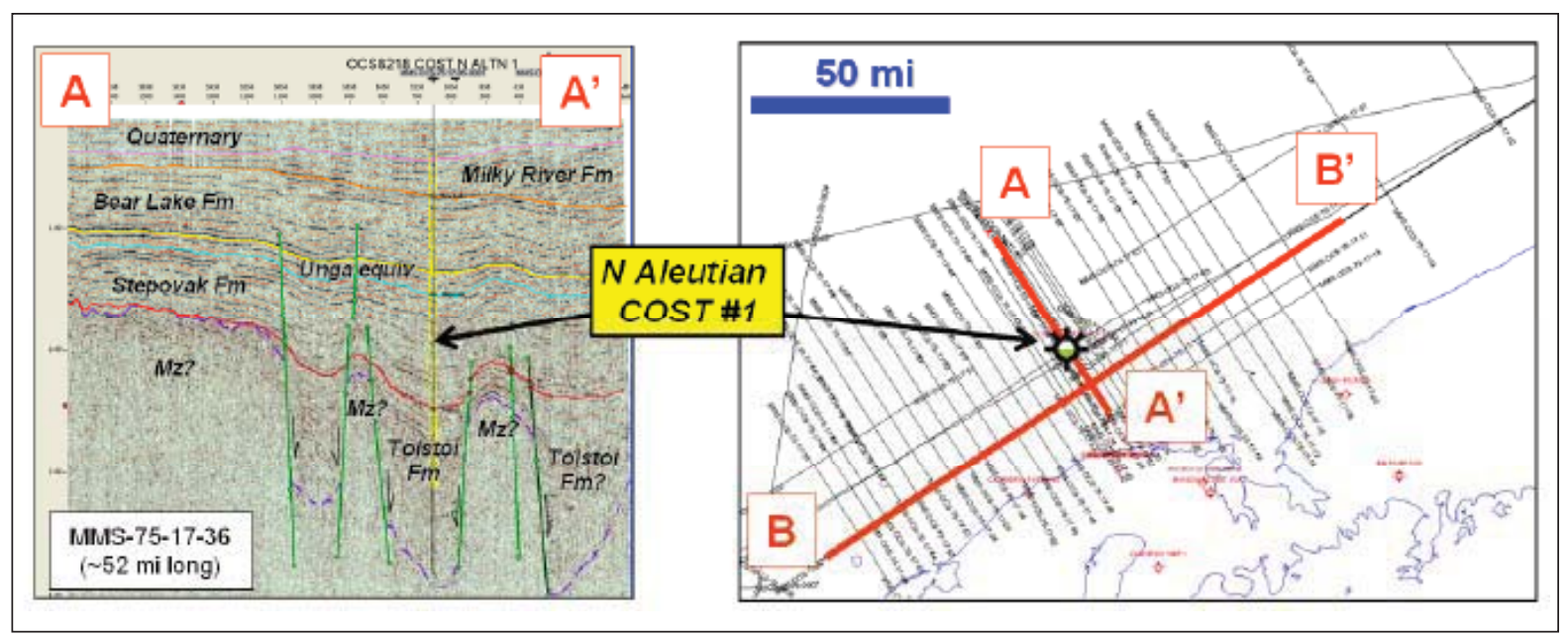

Figure 1b. Northwest-southeast seismic section and map showing the stratigraphic and structural setting of the North Aleutian COST \#1 well; from Finzel and others (2005).

Larson (1988) reported the following conventional $\mathrm{K}-\mathrm{Ar}$ ages on whole rock samples from the NAC well (Teledyne Isotopes, analysts):

$\bullet 4,882 \mathrm{~m}(16,016 \mathrm{ft})$ (core 18), altered volcanic pebble-conglomerate, $31.6 \pm 2 \mathrm{Ma}$;

$\bullet 5,081 \mathrm{~m}$ (16,670 ft; cuttings) devitrified amygdaloidal volcanics, $41 \pm 10 \mathrm{Ma}$;

-5,087-5,090 m(16,690-16,700 ft, cuttings) salt and pepper textured diabase intrusive, $47 \pm 18 \mathrm{Ma}$ (uncertainties not specified, but assumed to be $2 \sigma$ ).

The K-Ar ages show both consistencies and inconsistencies with the biostratigraphic ages reported for the well, and primary analytical data were not provided to evaluate the quality of these data, and because they reflect whole rock and not mineral separate analyses, they should be treated as suspect as evidenced by the sizable relative uncertainties of 20-40 percent.

The NAC well, $\sim 100 \mathrm{~km}$ northwest of Port Moller, was spudded September 8, 1982, to determine the stratigraphic nature of the Bristol Bay Basin in a shallow water ( $87 \mathrm{~m}$ depth) continental shelf domain. It was approximately vertically drilled $\left(<1^{\circ}\right.$ deviation from 0 to $1,749 \mathrm{~m}$ depth, increasing deviation to $3^{\circ}$ at $3,204 \mathrm{~m}$, with a maximum deviation of $4.5^{\circ}$ in the lower third of the well) to a total depth of 5,229 m (completed January 15, 1983); NAC represents one of the deepest wells drilled in Alaska (Turner, 1988). The well encountered Cenozoic strata ranging from Pleistocene/Holocene to Eocene age and was drilled in a small graben floored by Mesozoic rocks near the center of the basin. A total of 19 conventional cores (more than $100 \mathrm{~m}$ of penetrated section) were taken within the interval 1,025-5,100 m. The MMS report by Turner (1988) contains a wealth of data on the lithology, well logs, biostratigraphy, geothermal, and structural and stratigraphic setting of the well. Corrected estimates of equilibrium bottom-hole logging temperature data from three depths were reported by Flett (1988a) and yielded a $2^{\circ} \mathrm{C}$ seafloor temperature and a linear mean thermal gradient of $31^{\circ} \mathrm{C} / \mathrm{km}$. A variety of organic thermal maturity data were reported by Flett (1988b). However, vitrinite reflectance $\left(R_{o}\right)$ and spore coloration indices were difficult to evaluate due to excessive amounts of recycled organic matter. A mainly continuous vitrinite reflectance trend was observed increasing from 0.25 to 1.2 percent with increasing depth except for a possible unconformity recognized near the bottom of the well between 4,684 $\mathrm{m}$ and 4,846 $\mathrm{m}$ where $\mathrm{R}_{\mathrm{o}}$ abruptly increases from 0.6 to 0.8 percent. The corrected bottom-hole temperatures are approximately consistent with the indicated vitrinite thermal maturities, despite the abundance of recycled vitrinite observed in the well samples. Biostratigraphic data did not indicate significant erosional unconformities in the well, although the regional stratigraphy suggests possible unconformities in the middle Miocene, upper Oligocene and middle-upper Eocene sections.

Sedimentary provenance for the NAC section include Cenozoic volcanoplutonic rocks of the Aleutian magmatic arc, Mesozoic magmatic arc rocks of the Beringian Margin-Alaska Range, and Proterozoic younger rocks of interior Alaska (for example, Finzel and others, 2005; Decker and others, 1994).

\section{SAMPLE DETAILS}

Nine core samples $(1,279-5,094 \mathrm{~m}$ core depths) from the NAC well were obtained in May 1994 from the ARCO Bayview core warehouse facility by the first author. Sampled intervals and associated details are listed 
in table 1. Mineral separation followed at Geochron Laboratories (Cambridge, MA) and workable apatite and zircon splits were recovered from six of the nine samples attempted. Fission-track analysis of apatite was performed by John Murphy at the University of Wyoming and of zircon by Shari Kelley at Southern Methodist University to constrain the thermal history and provenance of the section encountered in the NAC well. Detailed analytical methods are described in Appendix 1 and an overview of the fission-track method and discussion of important compositional controls is provided in Appendix 2.

\section{AMBIENT THERMAL STRUCTURE, MATURITY DATA, AND GEOHISTORY ANALYSIS}

Burial history analyses (fig. 2) were performed using the ZetaWare GENESIS software (http://www.zetaware. com) to evaluate the thermal history of the well (Zhiyong He, oral commun., 2004). Three bottom-hole temperatures are available from 1,378 to $4,975 \mathrm{~m}$ depths (Flett, 1988a). On the basis of the well stratigraphy (yielding a mean thermal conductivity of $1.8 \mathrm{~W} / \mathrm{mK}$ ) and observed corrected bottom-hole temperature-derived geothermal gradient of $31^{\circ} \mathrm{C} / \mathrm{km}$, the present-day heat flow in well is estimated at $56 \mathrm{~mW} / \mathrm{m}^{2}$, which is significantly below that estimated for the Bristol Bay area $\left(70-90 \mathrm{~mW} / \mathrm{m}^{2}\right)$ using the recent compilation by Blackwell and Richards (2004). The in-well heat flow is within the range observed for the Alaska Peninsula by Molenaar (1996), who summarized wells in the Bristol Bay Lowland with thermal gradients in the range $29-38^{\circ} \mathrm{C} / \mathrm{km}$. These lower gradients contrast with higher gradients associated with wells to the south along the Alaska Peninsula, near the active magmatic arc, that possess gradients in excess of $34-60^{\circ} \mathrm{C} / \mathrm{km}$.

\section{RESULTS}

Fission-track data are summarized in table 2, comprising six samples in which a total of 181 apatite grains and 154 zircon grains were dated. Fission-track age and length data are summarized on depth plots in figure 3. Apatite fission-track age and length distributions are illustrated in histograms and radial plots in figure 4. Individual grain fission-track age and uranium contents are plotted for the entire core population and individual samples in figure 5. Individual apatite and zircon fission-track grain age data tables, and associated fission-track age and length plots are presented in Appendix 3. Electron microprobe analyses are not available for the NAC apatites, however, many dated apatites from other southern Alaska wells have been analyzed with the electron microprobe and summarized herein to illustrate possible compositional attributes (figs. 6, 7). The detailed discussion of these other samples is beyond the scope of this paper and the summary plots are only presented here to demonstrate some preliminary observations on nearby well samples and to highlight potential for future research.

\section{DISCUSSION \\ PROVENANCE}

All apatite and zircon populations are complex and reflect mixtures of several age components based on chi $^{2}$ statistics, which indicate multiple age populations for four of the six apatite samples and all of the zircon samples. Spectral peak analysis of the zircon fissiontrack ages show the following five peak age groups for the entire sample suite: $12 \pm 3,25 \pm 3,35 \pm 3,48 \pm 3$, and $84 \pm 3 \mathrm{Ma}$. For the deepest two Eocene cores $(3,382$ and 4,681 $\mathrm{m}$ core depths), the zircon fission-track data are consistent with a relatively simple consanguineous volcanoplutonic arc source ( 40 Ma mean zircon fission-

Table 1. Sample details for cores from the North Aleutian COST \#1 well, Alaska

\begin{tabular}{|c|c|c|c|c|c|c|c|c|c|}
\hline & \multirow[b]{2}{*}{ Depth (ft) } & \multicolumn{2}{|c|}{ Ave. Depth } & \multicolumn{2}{|c|}{ Temperature } & \multicolumn{4}{|c|}{ Approx. depositional } \\
\hline & & (ft) & (m) & ${ }^{\circ} \mathbf{C}$ & core\# & Epoch & Ma & Formation & Lithology \\
\hline 94NAC1 & $4,191-4,199$ & 4,195 & 1,279 & 38 & $\mathrm{C} 2$ & $\overline{\text { Middle Miocene }}$ & 15 & Bear Lake/Unga & fg volc ss/tuff \\
\hline 94NAC2 & $5,970-5,999$ & 5,985 & 1,824 & 55 & $\mathrm{C} 4$ & Late Oligocene & 24 & Stepovak & fg volc ss \\
\hline 94NAC3 & $8,056-8,069$ & 8,063 & 2,458 & 75 & $\mathrm{C} 7$ & Early Oligocene & 29 & Stepovak & vfg ss/siltstone \\
\hline 94NAC4 & $8,640-8,648$ & 8,644 & 2,635 & 80 & $\mathrm{C} 8$ & Early Oligocene & 33 & Stepovak & vfg ss \\
\hline 94NAC5 & $9,951-9,959$ & 9,955 & 3,304 & 93 & $\mathrm{C} 10$ & Late Eocene & 38 & Stepovak & vfg volc ss/tuff \\
\hline 94NAC6 & $11,089-11,100$ & 11,095 & 3,382 & 104 & $\mathrm{C} 13$ & Eocene & 40 & Tolstoi & f-mg xl lith tuff \\
\hline 94NAC7 & $12,249-12,257$ & 12,253 & 3,735 & 115 & $\mathrm{C} 14$ & Eocene & 42 & Tolstoi & vfg volc ss/tuff \\
\hline 94NAC8 & $15,355-15,362$ & 15,359 & 4,681 & 144 & $\mathrm{C} 17$ & Eocene & 47 & Tolstoi & f-mg volc ss \\
\hline 94NAC9 & $16,709-16,714$ & 16,712 & 5,094 & 157 & $\mathrm{C} 19$ & Eocene & 50 & Tolstoi & lapilli tuff \\
\hline
\end{tabular}

\footnotetext{
Notes
}

Temperatures interpolated from corrected bottom hole temperatures; subsea temperature $=2{ }^{\circ} \mathrm{C}$; linear geothermal gradient $=31.1^{\circ} \mathrm{C} / \mathrm{km}$. Depositional epoch from Turner (1988); absolute ages approximated using the ICS timescale (http://www.stratigraphy.org).

Formation nomenclature from Finzel and others (2005); lithologies based on thin section inspection.

$\mathrm{v}=$ very, $\mathrm{f}=$ =fine, $\mathrm{m}=$ medium, $\mathrm{g}=$ grained, volc=volcaniclastic, $\mathrm{ss}=$ sandstone. 
Table 2. Summary of apatite and zircon fission-track age data for the North Aleutian COST \#1 well, Alaska

\begin{tabular}{|c|c|c|c|c|c|c|c|c|c|c|}
\hline & $\begin{array}{l}\text { Ave. } \\
\text { (ft) }\end{array}$ & $\begin{array}{r}\text { Depth } \\
\text { (m) }\end{array}$ & $\begin{array}{c}\text { Temp. } \\
{ }^{\circ} \mathrm{C}\end{array}$ & $\begin{array}{c}\text { Depos. } \\
\text { age Ma }\end{array}$ & $\begin{array}{l}\text { Depos. } \\
\text { Epoch }\end{array}$ & $\begin{array}{c}\text { Apatite } \\
\text { age (Ma) } \\
\text { (no. grains) }\end{array}$ & $\begin{array}{c}\text { Apatite } \\
\text { mtl ( } \mu \mathrm{m}) \\
(\mathrm{sd}, \mathrm{ntr})\end{array}$ & $\begin{array}{c}\text { Apatite } \\
\text { U } \\
\text { (ppm) }\end{array}$ & $\begin{array}{c}\text { Zircon } \\
\text { age (Ma) } \\
\text { (no. grains) }\end{array}$ & $\begin{array}{c}\text { Zircon } \\
\mathbf{U} \\
(\mathrm{ppm})\end{array}$ \\
\hline 94NAC1 & 4,195 & 1,279 & 38 & 15 & M Mioc & $30 \pm 4.0(31)$ & $12.2 \pm 0.25(2.2,75)$ & 29 & $69 \pm 10(20)$ & 580 \\
\hline 94NAC2 & 5,985 & 1,824 & 55 & 28 & L Olig & $32 \pm 3.1(31)$ & $12.6 \pm 0.16(1.6,100)$ & 20 & $58 \pm 5.2(30)$ & 617 \\
\hline 94NAC3 & 8,063 & 2,458 & 75 & 33 & E Olig & $74 \pm 7.4(31)$ & $12.5 \pm 0.17(1.7,106)$ & 15 & $50 \pm 5.5(29)$ & 453 \\
\hline 94NAC5 & 9,955 & 3,304 & 93 & 38 & L Eoc & $35 \pm 3.7(31)$ & $13.4 \pm 0.26(2.6,101)$ & 7 & $47 \pm 4(41)$ & 573 \\
\hline 94NAC6 & 11,095 & 3,382 & 104 & 43 & Eoc & $50 \pm 5.6(26)$ & $13.3 \pm 0.24(1.9,63)$ & 3 & $37 \pm 3(20)$ & 515 \\
\hline 94NAC8 & 15,359 & 4,681 & 144 & 50 & Eoc & $8.9 \pm 1.7(31)$ & $9.0 \pm 1.3(3.1,6)$ & 4 & $39 \pm 4(14)$ & 428 \\
\hline
\end{tabular}

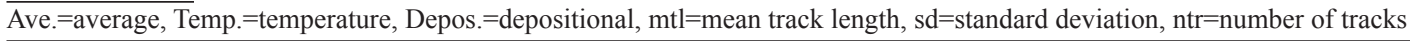

track ages, yet failing the $\mathrm{chi}^{2}$ test for a single population) and a more complex assemblage of Mesozoic plutonic basement rocks and Cenozoic volcanic source terranes for younger Eocene to Miocene deposits based on four cores shallower than 3,034 $\mathrm{m}$. The mean zircon ages of the shallower four cores range from 53 to $82 \mathrm{Ma}$, systematically increasing in age going upsection, with individual grain ages in the range 20-200 Ma. All samples show a broadly negative correlation between zircon fission-track grain age and uranium content. The zircon fission-track ages from Eocene to Miocene cores indicate systematic Mesozoic to Cenozoic source terranes with ages averaging 10-50 m.y. older than depositional ages. Apatite grains are therefore inferred to possess a detrital age component that may be 10-50 m.y. older than depositional ages. The shallowest four samples contain zircons with the widest range in both fission-track age and uranium content, indicating a more complex provenance than that of the deeper two samples, which show very limited age and uranium content ranges.

Apatites display similar, yet slightly contrasting trends, with the shallowest three samples similarly possessing the widest range in both fission-track age and uranium content, whereas the three deeper samples possess apatites with limited uranium contents, but only samples NAC5 and NAC8 show limited fission-track age range (fig. 5). Both zircon fission-track ages and uranium contents both systematically decrease with increasing depth (table 2, figs. 3 and 5). Similarly, apatite uranium content also decreases with increasing depth, whereas apatite fission-track age shows a more complex depth trend due to partial resetting of the deepest sample, NAC8. The zircon and apatite uranium contents are consistent with these phases having been derived by progressive unroofing of an evolving Mesozoic to Cenozoic magmatic arc terrane with the deepest samples representing a more primitive (lower-uranium) source magmatic rocks and the youngest samples representing more evolved (higher-uranium) magmatic rocks. Therefore, initially primitive late Mesozoic- to early
Cenozoic-age mafic to intermediate magmatic rocks represented the dominant provenance during the Eocene deposition, whereas the younger Oligocene to Miocene deposits reflect more diverse provenance including late Mesozoic- to early Cenozoic-age mafic, intermediate, and felsic magmatic rocks.

\section{THERMAL HISTORY}

Five of the six samples possess apatite central fission-track ages within analytical uncertainty of, or older than, depositional ages; mean track lengths vary between 12 and $13 \mu \mathrm{m}$ (fig. 5). These samples currently reside at temperatures of $38-100 \pm 10^{\circ} \mathrm{C}$, below or within the zone of fluorine-rich apatite fission track partial stability $\left(\sim 60-120^{\circ} \mathrm{C}\right)$, hence the ages and track length distributions may reflect minimal post-depositional annealing and age reduction. The deepest sample, NAC8, however, currently resides at a temperature of $144^{\circ} \mathrm{C}$, significantly above the apatite fission-track annealing temperature $\left(120-130^{\circ} \mathrm{C}\right)$, yet displays an apatite fission-track age of $9 \mathrm{Ma}$, reflecting a 75-90 percent age reduction, and a mean track length of $9 \mu \mathrm{m}$, reflecting a 40 percent length reduction. Based on the abundance of chlorine- and hydroxyl-rich apatites observed in southern Alaska wells and apatites in general (figs. 6, 7), the NAC apatites are likely to possess similar diverse anion compositions, and therefore require higher fission-track closure temperatures of $130-150^{\circ} \mathrm{C}$. If NAC8 apatites are fluorine-rich, then the apatite age and length data are more consistent with a sample that has experienced temperatures of $100-120^{\circ} \mathrm{C}$ for the last $1-10 \mathrm{~m} . \mathrm{y}$., significantly below the observed $144^{\circ} \mathrm{C}$ temperature based on the corrected bottom-hole temperatures. It is more likely that the NAC8 apatites contain a significant population of chlorine- and hydroxyl-rich (1-2 wt \%) grains, consistent with the indicated thermal history assuming the present-day heat flow of $56 \mathrm{~mW} / \mathrm{m}^{2}$ has existed in the past. As shown in the apatite fission-track age-chlorine plots in figure $6 \mathrm{a}$, the Lower Cook Inlet COST well and many others in the region contain a majority of apatites with $0.5-2$ wt \% 

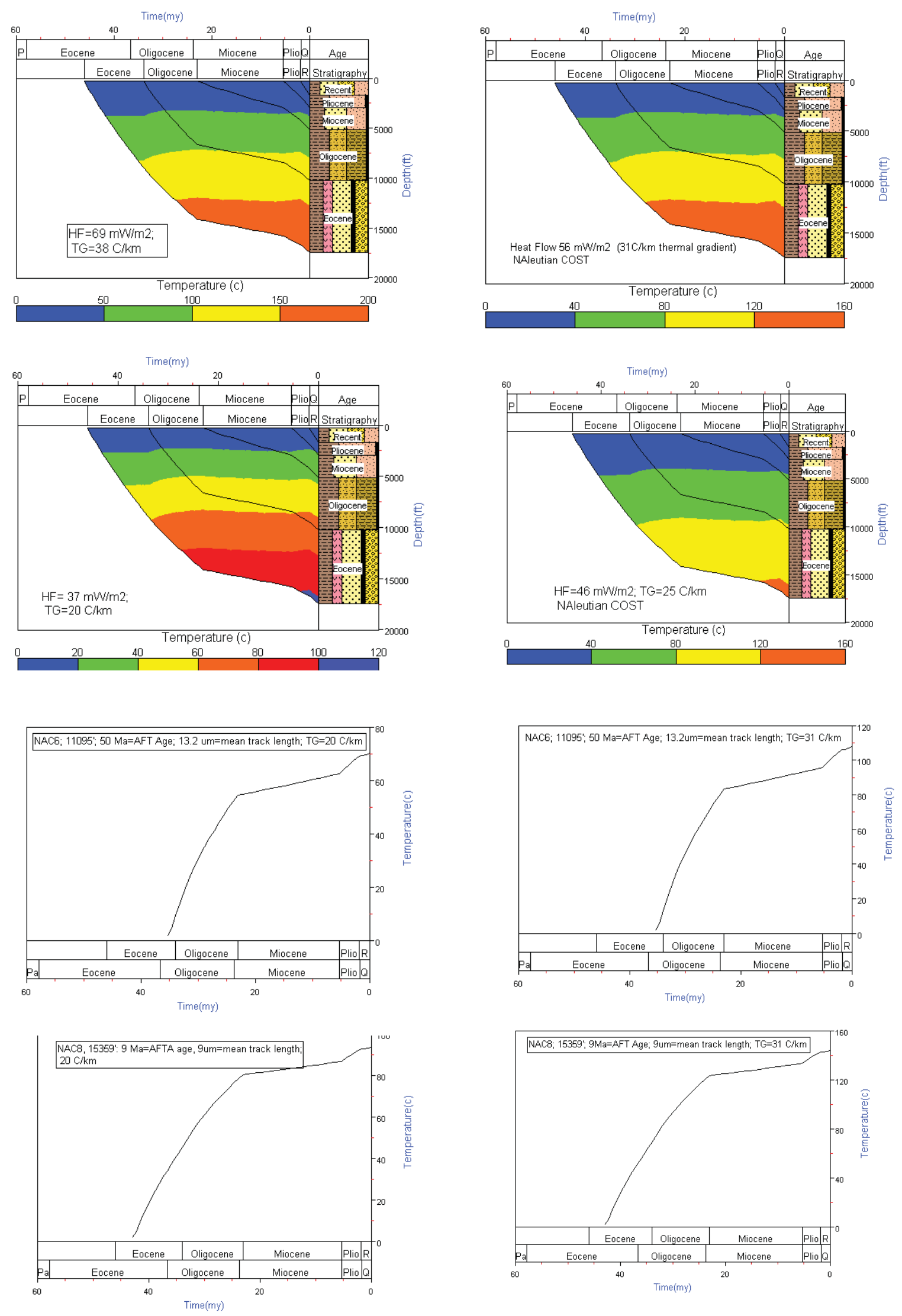

Figure 2. GENESIS burial history plots for the North Aleutian COST \#1 well showing thermal evolution for various heat flow conditions (top four plots); GENESIS-derived thermal evolution plots for the two deepest samples (NAC6 and NAC8) for two possible thermal gradients. 

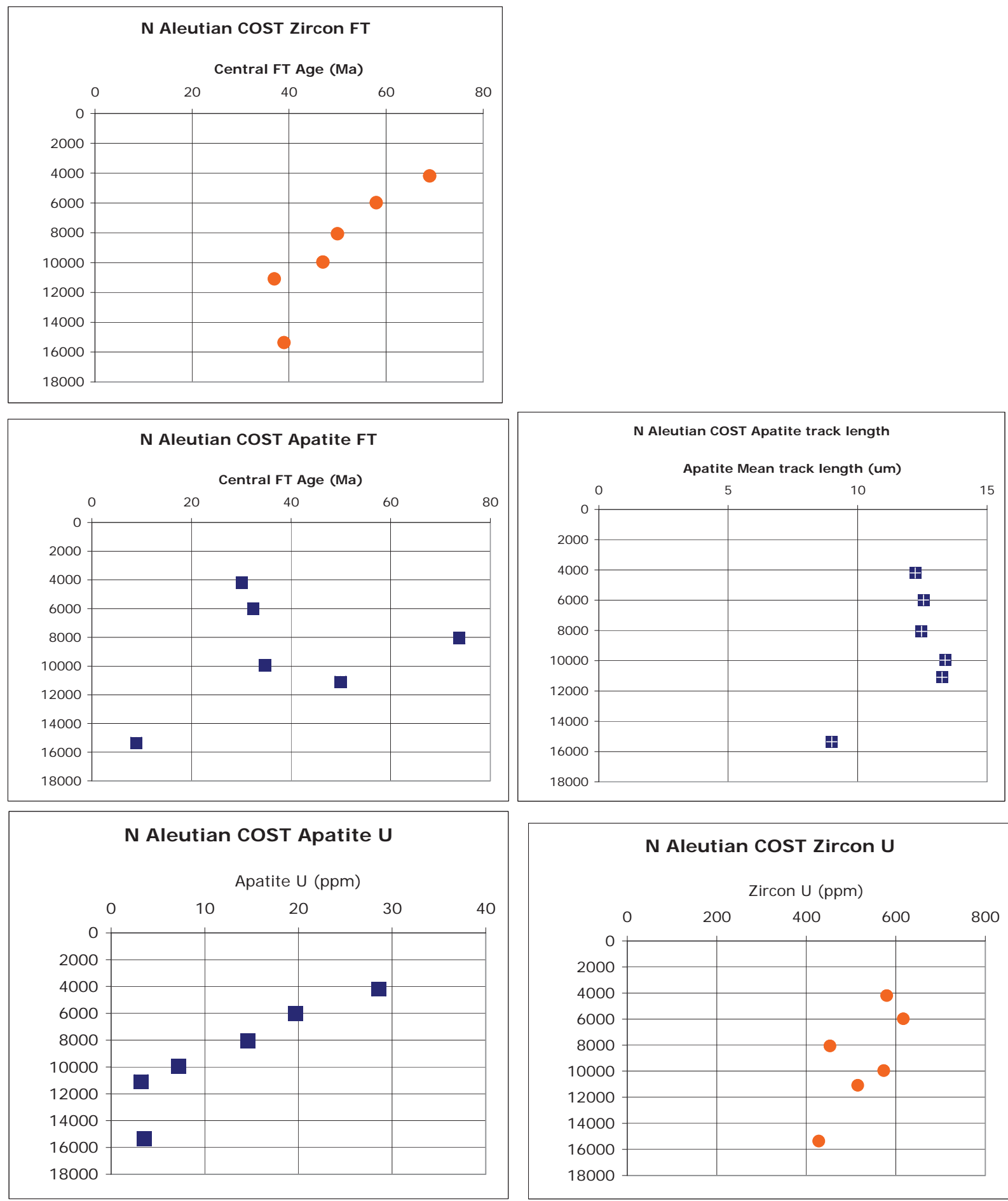

\section{N Aleutian COST Zircon U}

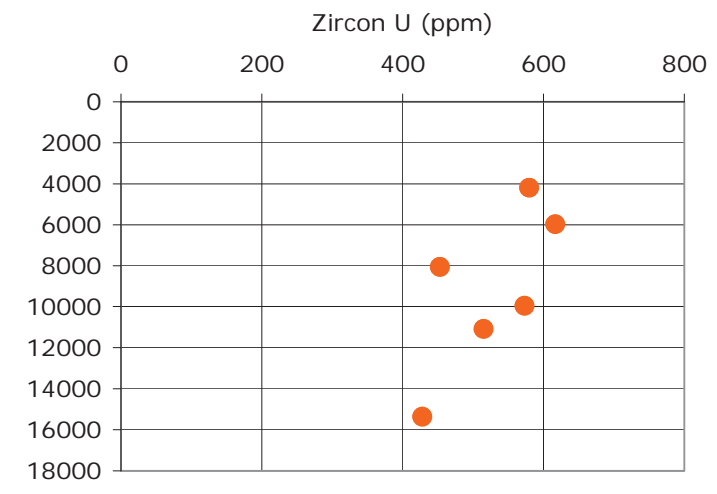

Figure 3. North Aleutian COST \#1 well plots showing the variation in zircon and apatite fission-track age and uranium contents, and apatite mean fission-track length as a function of core depth. Apatite and zircon fission-track age standard deviations are 10 percent relative for a given sample, whereas uranium contents possess more variability, with standard deviations ranging from 10 to 90 percent relative; apatite fission-track length standard errors average $\sim 0.2 \mu \mathrm{m}$, with standard deviations of $\sim 2 \mu \mathrm{m}$. 


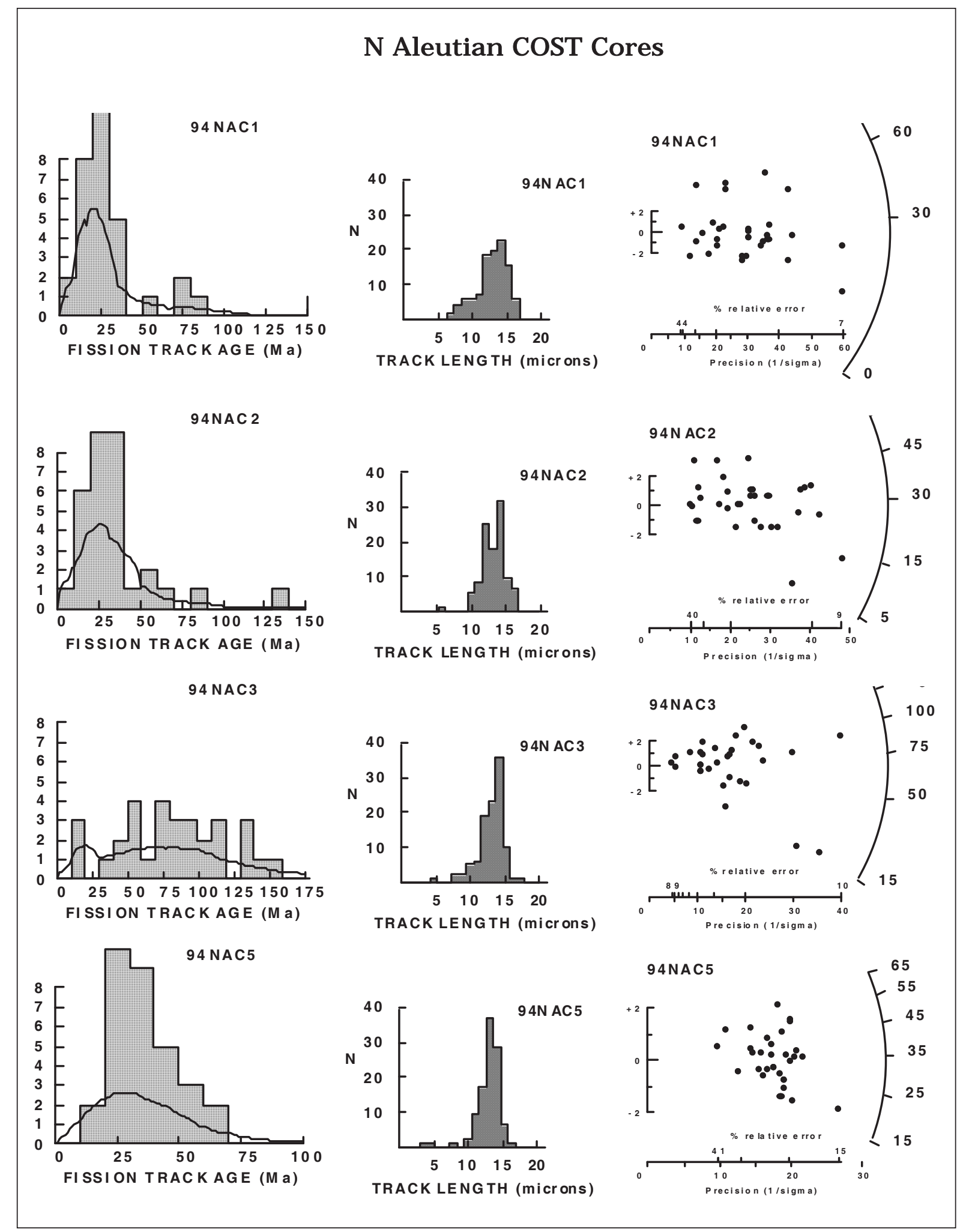

Figure 4. Apatite fission-track age and length histograms and radial plots for the North Aleutian COST \#1 well. 


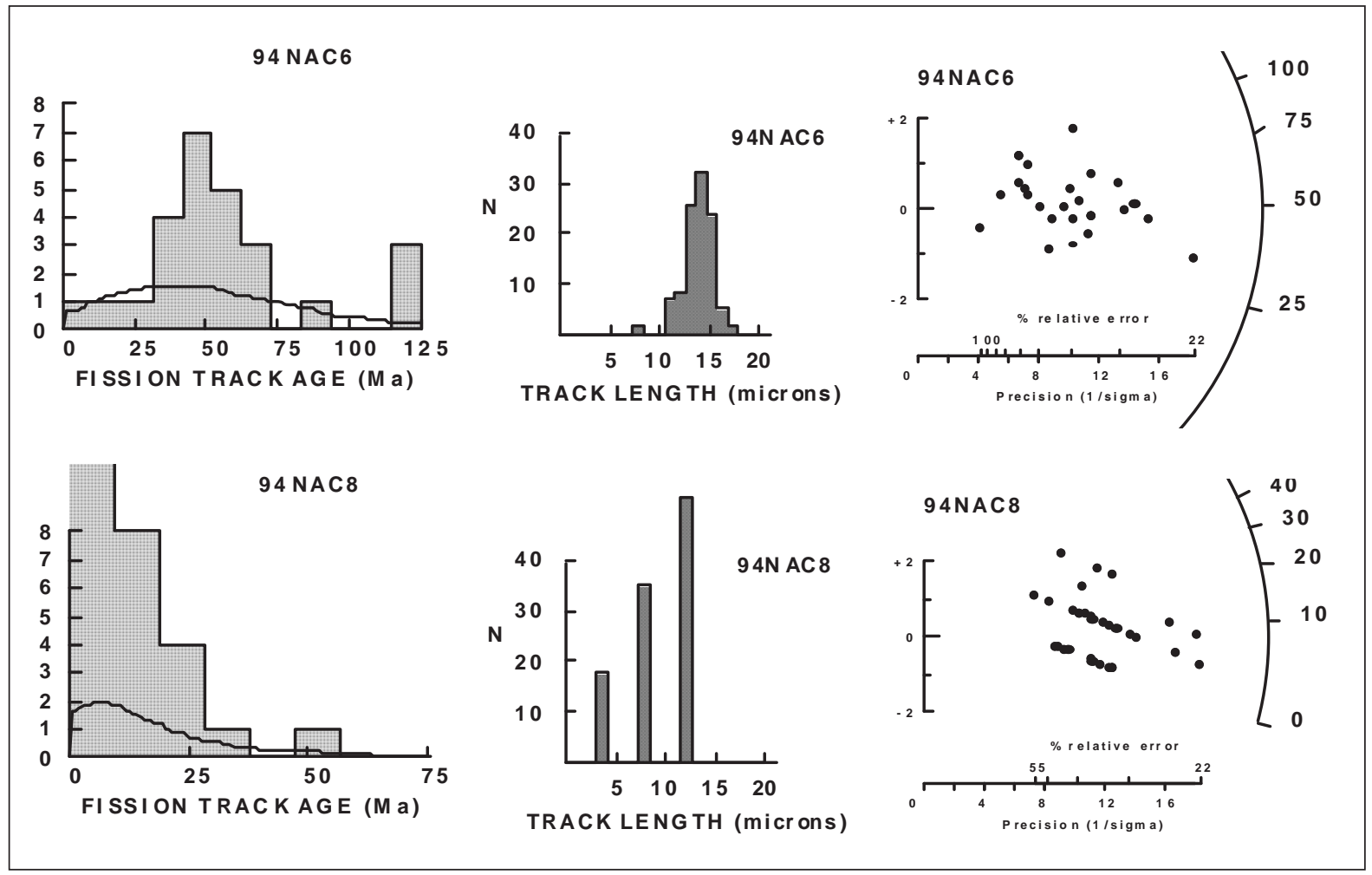

Figure 4 (continued). Apatite fission-track age and length histograms and radial plots for the North Aleutian COST \#1 well.
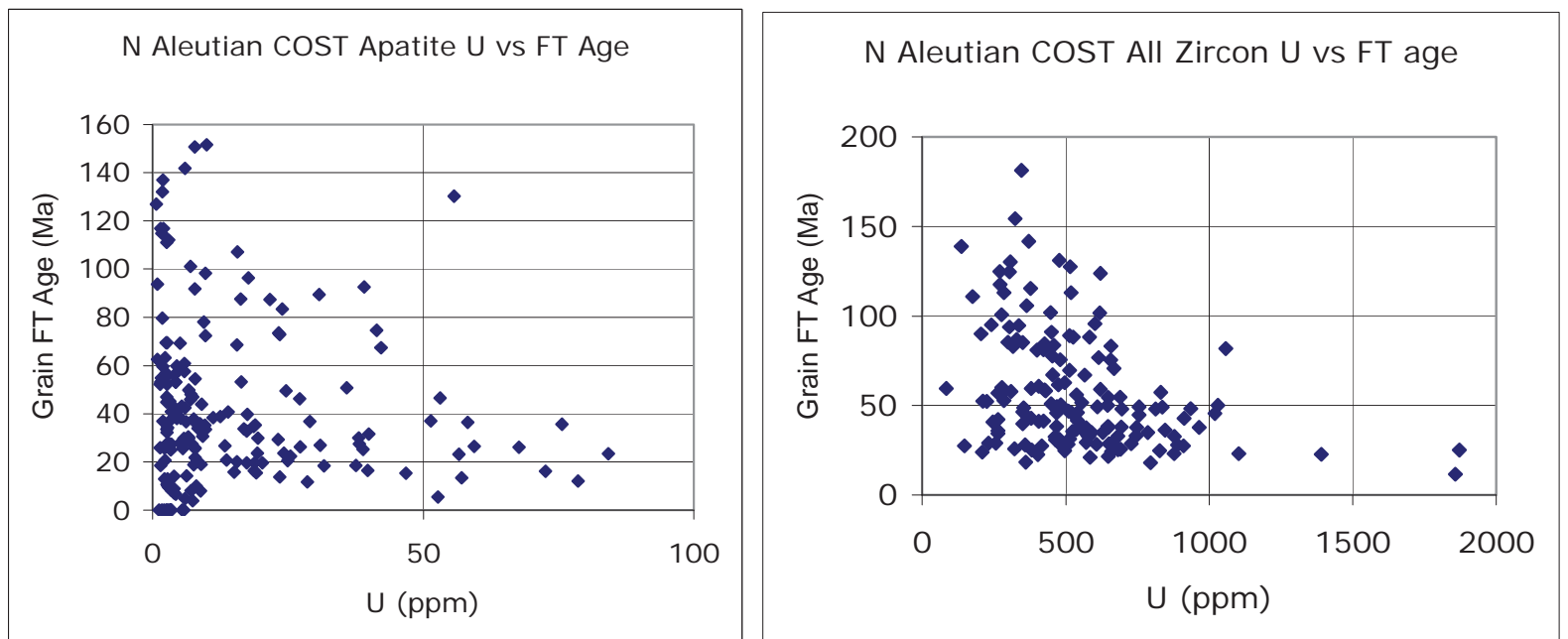

Figure 5a. Individual fission-track grain age versus uranium content for all North Aleutian COST \#1 well apatites (left) and zircons (right). 

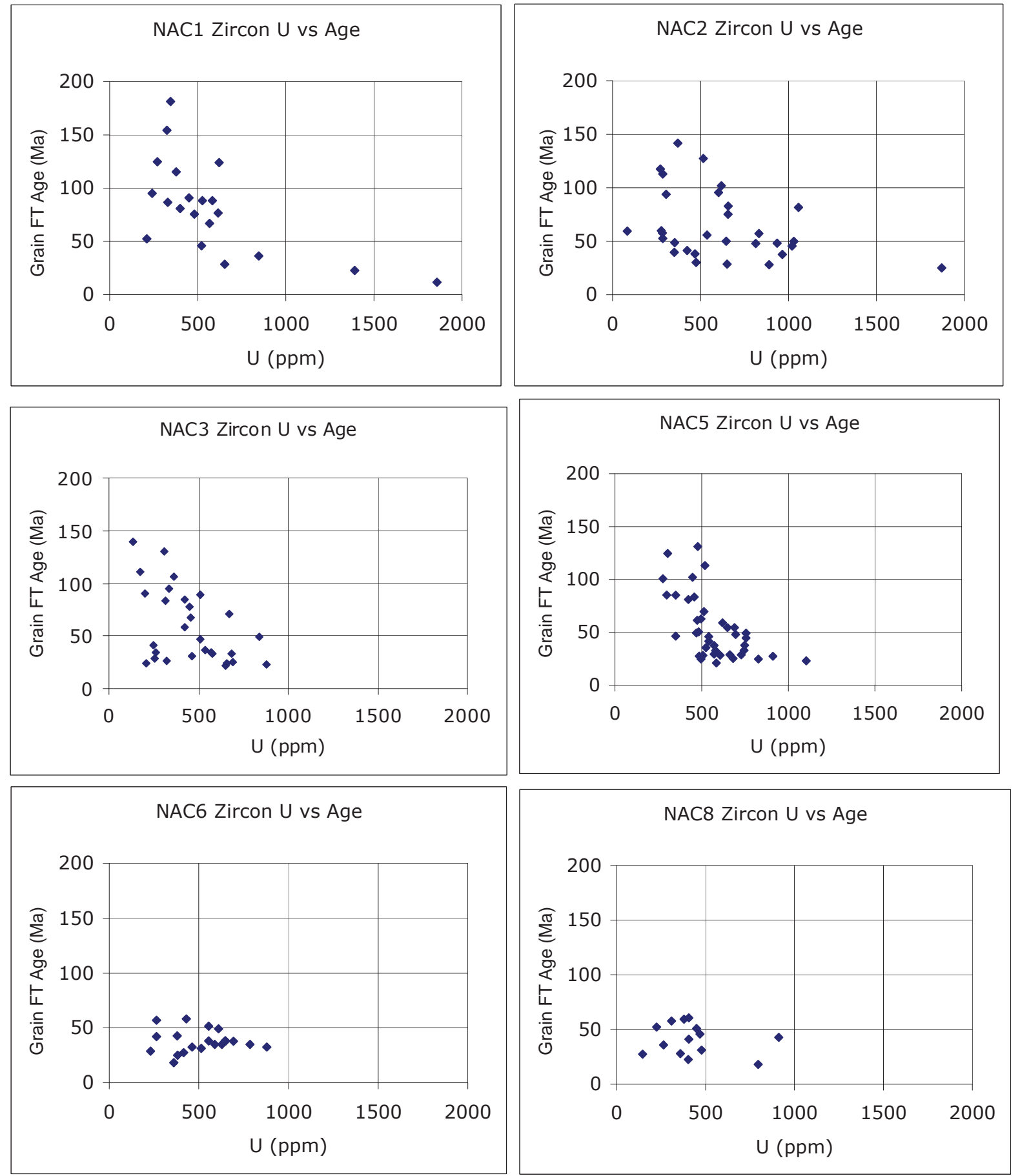

Figure 5b. Individual zircon fission-track grain age versus uranium content for individual North Aleutian COST \#1 well samples. 

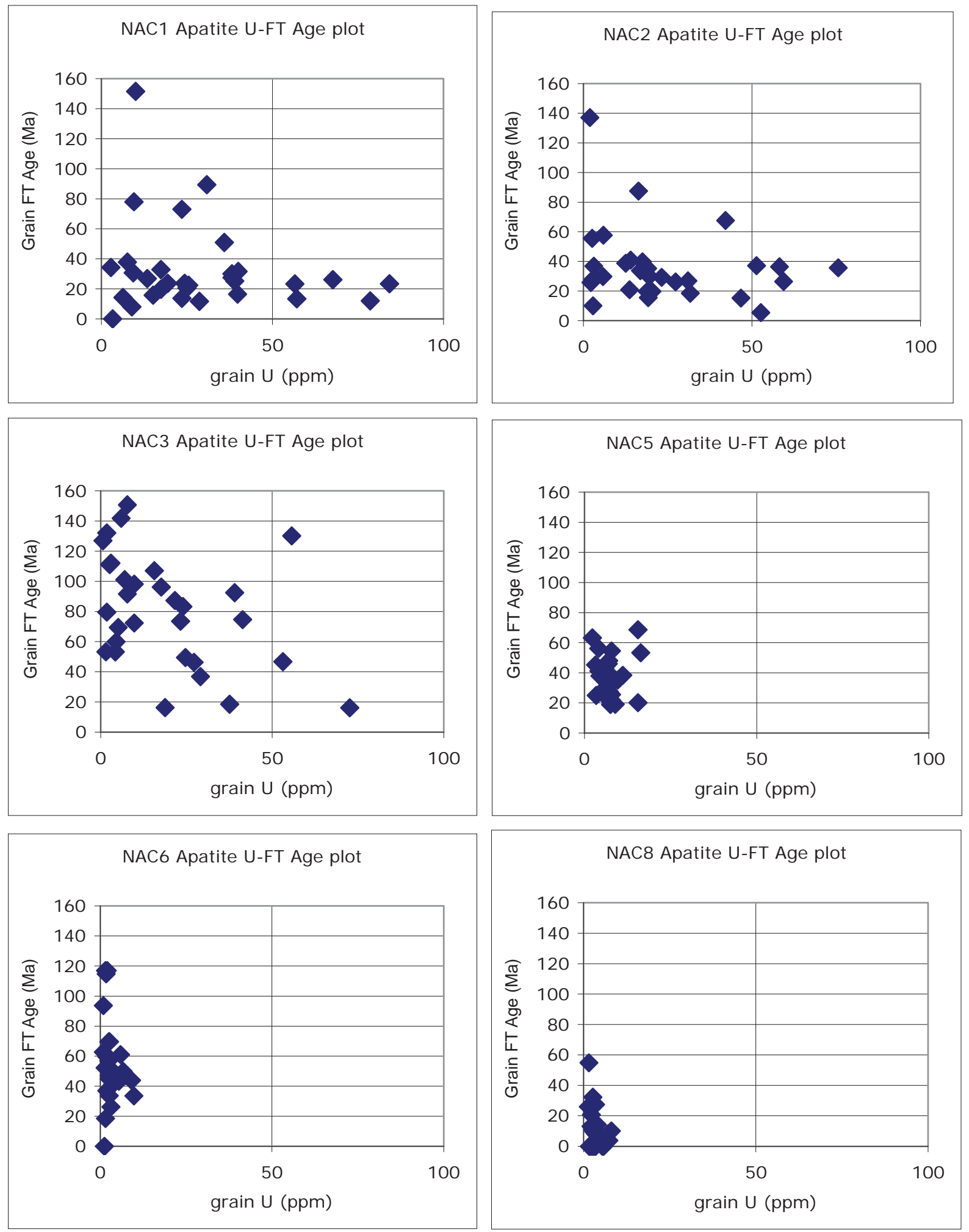

Figure $5 b$ (continued). Individual zircon fission-track grain age versus uranium content for individual North Aleutian COST \#1 well samples. 

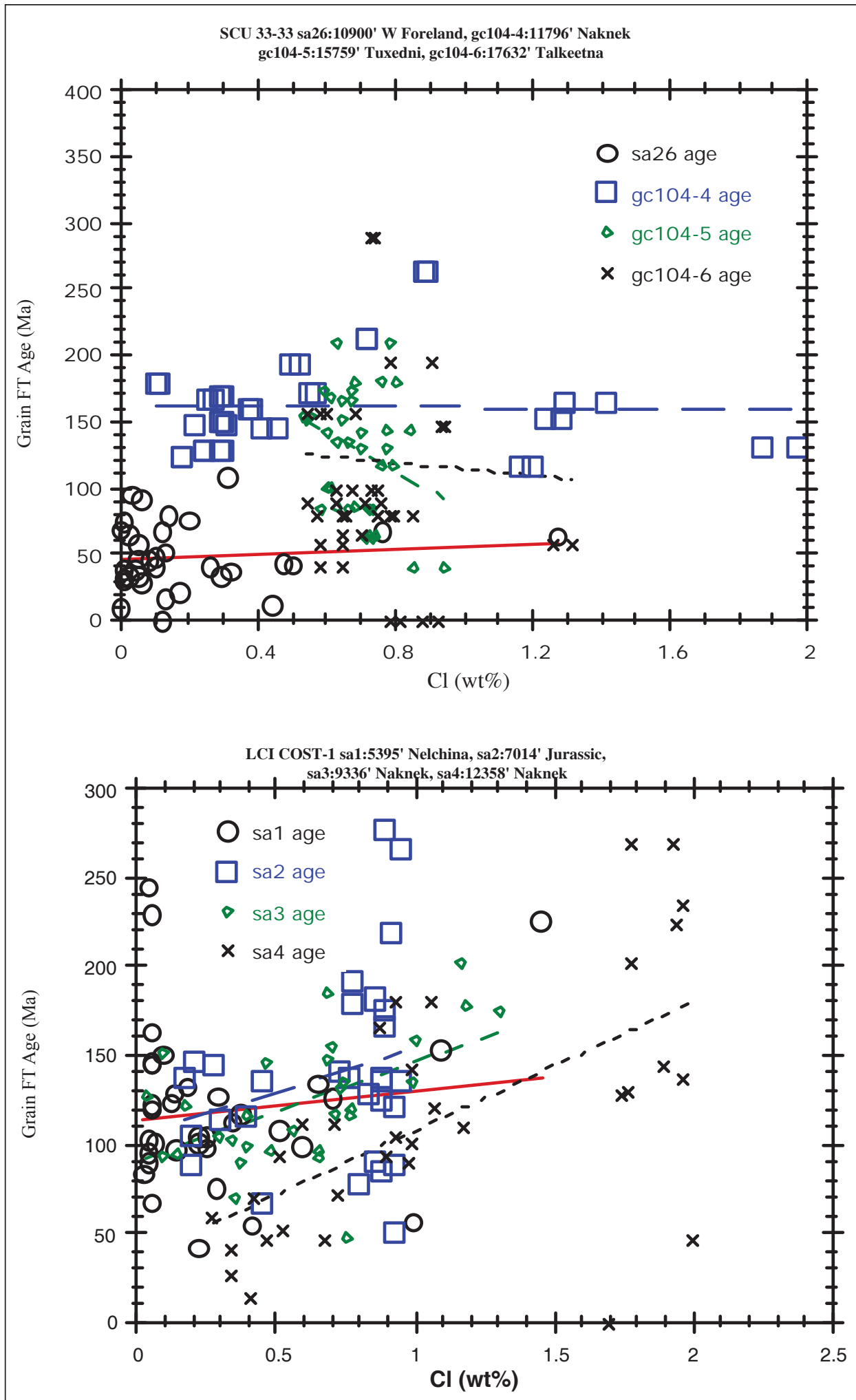

Figure 6a. Apatite fission-track grain age versus grain chlorine content for samples from the Lower Cook Inlet COST \#1 and SCU 33-33 wells, Lower Cook Inlet, Alaska (Cl by wavelength-dispersive electron microprobe analysis of dated grains; Bergman, unpublished data). 


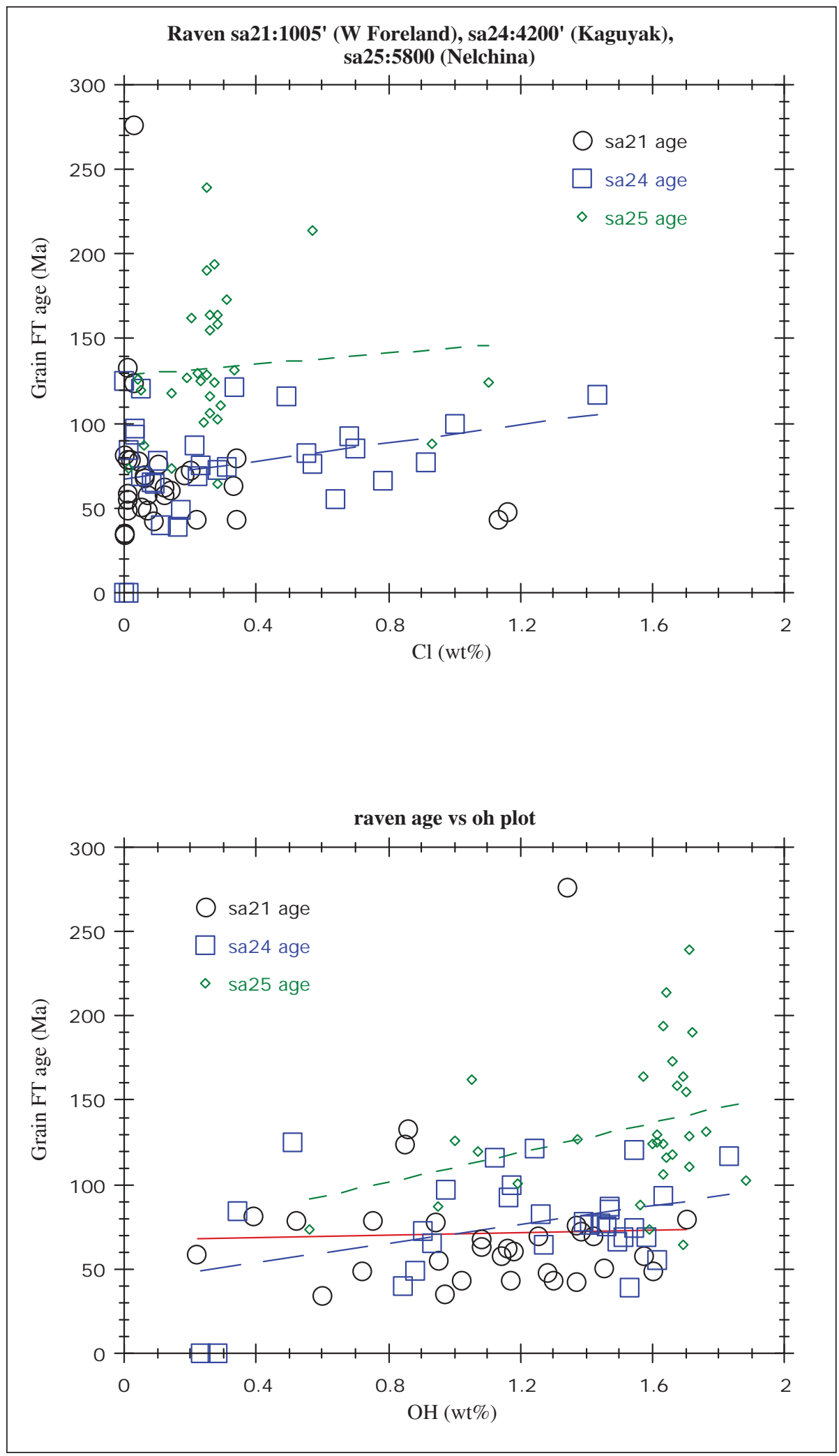

Figure 6b. Apatite fission-track grain age versus grain chlorine and hydroxyl contents for samples from the Raven \#1 well, Lower Cook Inlet, Alaska (Cl and F by wavelength-dispersive electron microprobe analysis of dated grains; OH calculated by difference assuming anion stoichiometry; Bergman, unpublished data). 

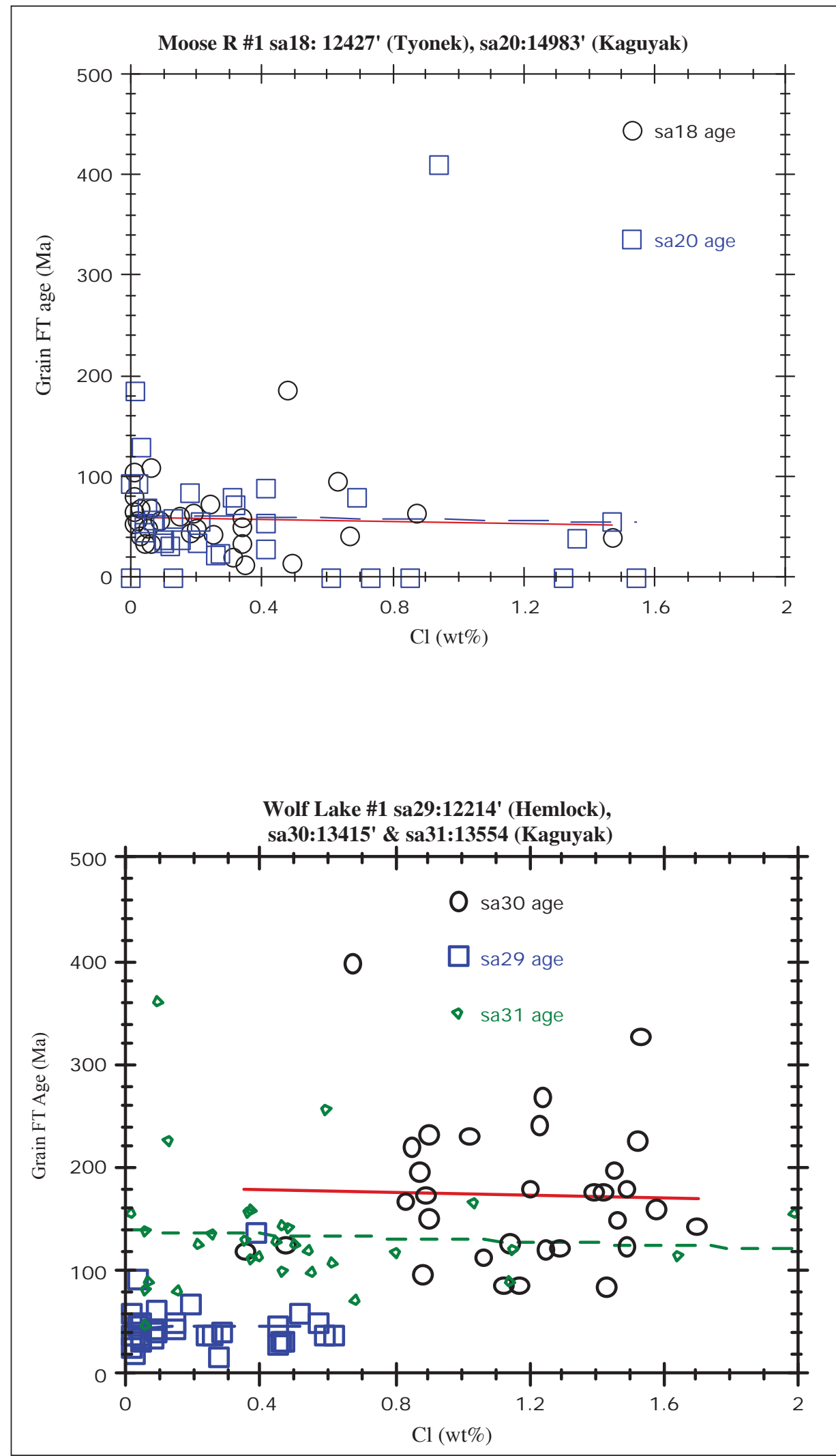

Figure 6c. Apatite fission-track grain age versus grain chlorine content for samples from the Wolf Lake \#1 and Moose River \#1 wells, Lower Cook Inlet, Alaska (Cl by wavelength-dispersive electron microprobe analysis of dated grains; Bergman, unpublished data). 


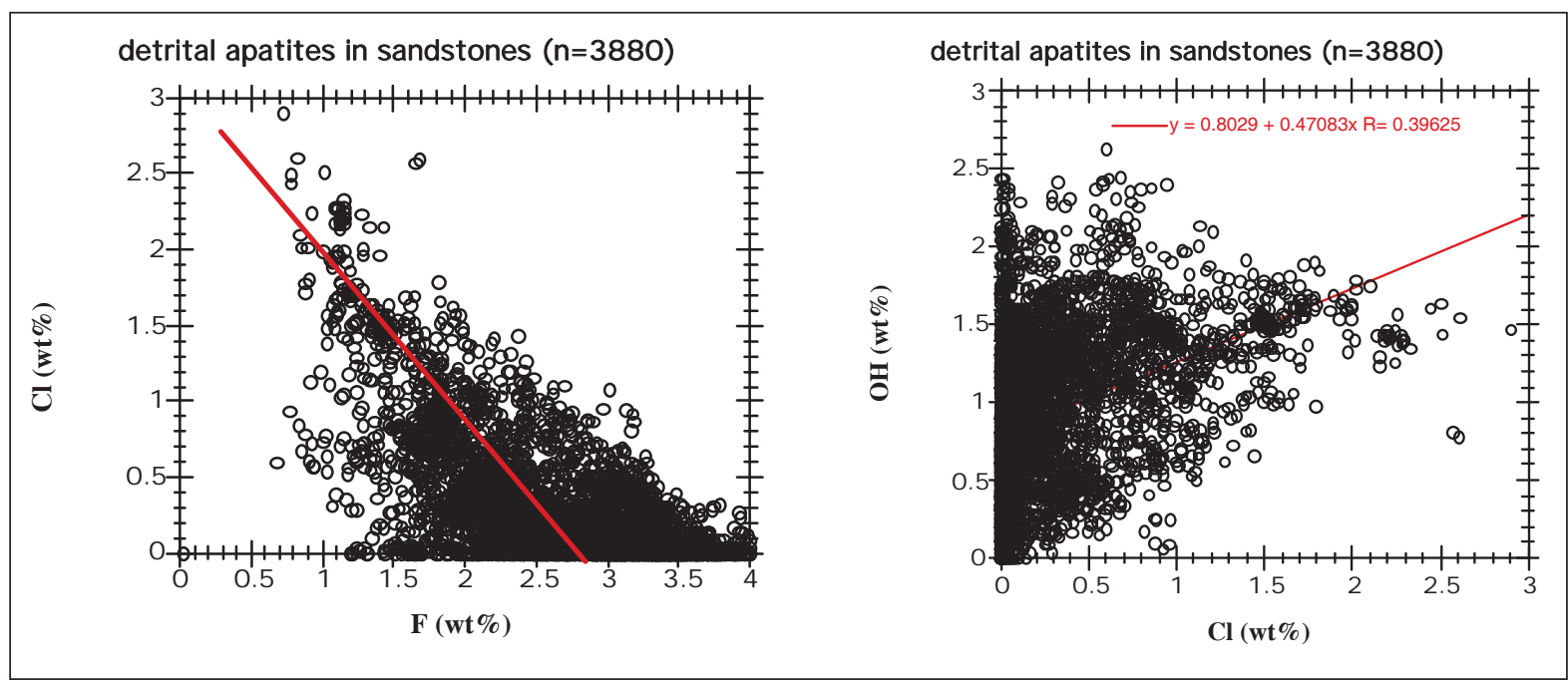

Figure 7a. Plots showing the relationships between various anions in dated apatite from several hundred worldwide sandstone samples showing a wide range in anion composition, and a positive correlation between chlorine and hydroxyl and negative correlation between fluorine and chlorine ( $\mathrm{Cl}$ and $\mathrm{F}$ by wavelength-dispersive electron microprobe analysis of dated grains; OH calculated by difference assuming anion stoichiometry; Bergman, unpublished data).

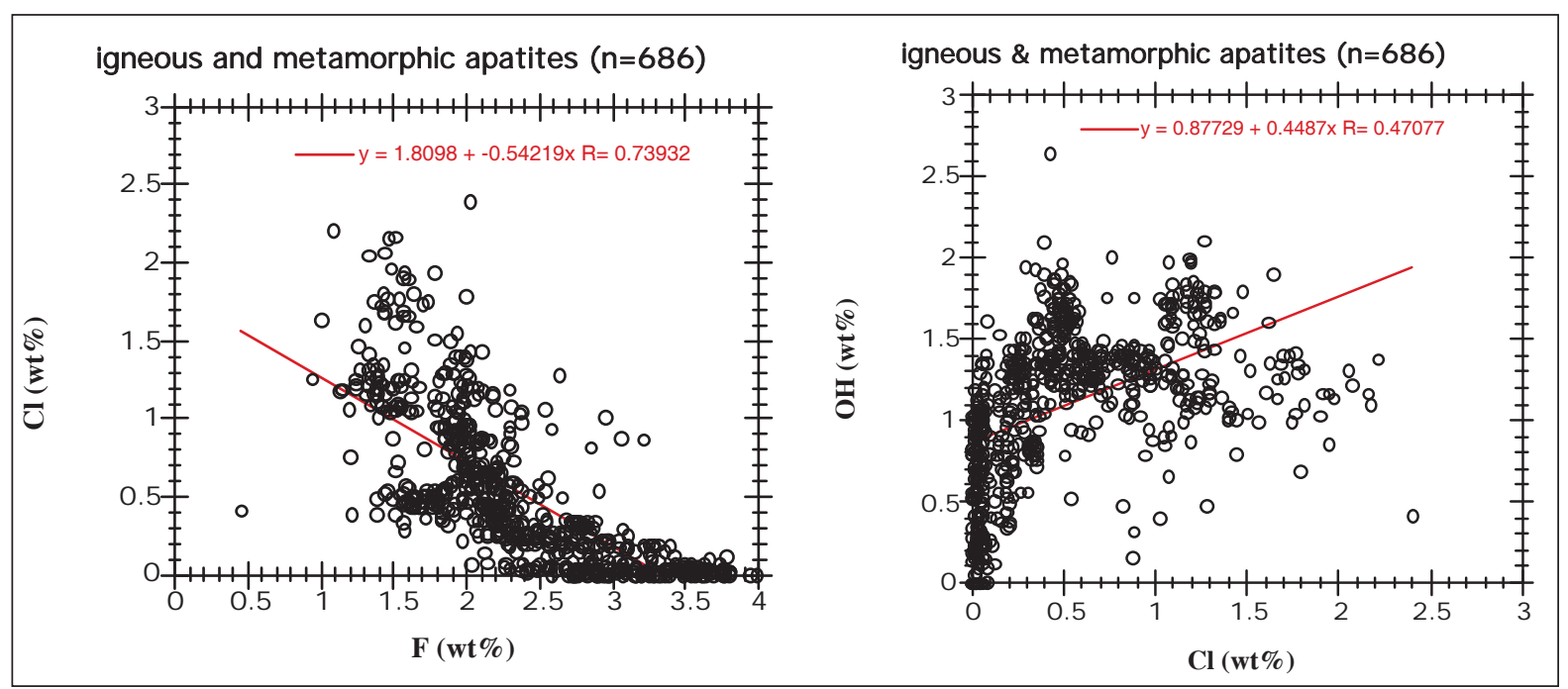

Figure 7b. Plots showing the relationships between the various anions in dated apatite grains from worldwide igneous and metamorphic rock samples showing a wide range in anion composition, and a positive correlation between chlorine and hydroxyl and negative correlation between fluorine and chlorine ( $\mathrm{Cl}$ and $\mathrm{F}$ by wavelength-dispersive electron microprobe analysis of dated grains; OH calculated by difference assuming anion stoichiometry; Bergman, unpublished data). 
chlorine, and positive fission track age-chlorine content correlations, suggesting that higher apatite fission-track closure temperatures of $130-150^{\circ} \mathrm{C}$ may be more appropriate for southern Alaska well apatite fission-track analysis interpretations.

\section{CONCLUSIONS}

Corrected bottom-hole temperatures, combined with inferred lithology-dependent thermal conductivities indicate a present-day day heat flow of $56 \mathrm{~mW} / \mathrm{m}^{2}$ for the NAC well site. The stratigraphic section encountered in the NAC well is currently at or near maximum experienced burial temperatures. Both the vitrinite and apatite fission-track data are consistent with a simple Cenozoic burial history and a Cenozoic heat flow near or below $56 \mathrm{~mW} / \mathrm{m}^{2}$. Due to an abundance of chlorineand hydroxyl-rich apatites observed in southern Alaska wells, slightly higher closure temperatures may be appropriate for the valid interpretation of apatite fission track thermochronology data. New apatite and zircon FT and Uranium data provide constraints on the nature of the provenance of volcaniclastic and sedimentary strata encountered in the Bristol Bay Basin.

\section{ACKNOWLEDGMENTS}

These data were released by ARCO in 2000; many thanks to Barry Davis. The authors thank ARCO Research Thermochronology Lab colleagues Jeff Corrigan and James Talbot, ARCO Alaska colleagues John Decker and Dave Doherty, Alaska Division of Geological \& Geophysical Surveys colleagues Rocky Reifenstuhl and Jim Clough and former colleague Mark Robinson, as well as Alaska Division of Oil \& Gas colleague Paul Decker, for their valued support. Zhiyong He kindly provided access to the Genesis burial modeling software for this study. Paul Layer and Rocky Reifenstuhl provided thoughtful reviews that improved the manuscript and for which the authors are most appreciative.

\section{REFERENCES CITED}

Blackwell, D.D., and Richards, M., editors, 2004, Geothermal Map of North America: Tulsa, OK, American Association of Petroleum Geologists, 1 sheet, scale 1:6,500,000; http://www.smu.edu/geothermal/ 2004NAMap/2004NAmap.htm.

Bond, G.C., Lewis, S.D., Taber, J., Steckler, M.S., and Kominz, M.A., 1988, Evidence for formation of a flexural back arc basin by compression and crustal thickening in the central Alaska Peninsula: Geology, v. 16 , p. $1,147-1,150$.

Carlson, W.D., 1990, Mechanisms and kinetics of apatite fission track annealing: American Mineralogist, v. 75, p. 1,120-1,139.
Carlson, W.D., Donelick, R.A., and Ketcham, R.A., 1999, Variability of apatite fission track annealing kinetics I; Experimental results: American Mineralogist, v. 84 , p. 1,213-1,223.

Crowley, K.D., 1985, Thermal significance of fission track length distributions: Nuclear Tracks, v. 10, p. 311-322.

Decker, J., Bergman, S.C., Blodgett, R.B., Box, S.E., Bundtzen, T.K., Clough, J.G., Coonrad, W.L., Gilbert, W.G., Miller, M.L., Murphy, J.M., Robinson, M.S., and Wallace, W.K., 1994, Geology of southwestern Alaska, in Plafker, G., and Berg, H.C., eds., The geology of Alaska: Boulder, CO, Geological Society of America, The Geology of North America, v. G1, p. 285-310.

DeMets, Charles, Gordon, R.G., Argus, D.F., and Stein, Seth, 1994, Effects of recent revisions to the geomagnetic reversal time scale on estimates of current plate motions: Geophysical Research Letters, v. 21, p. 2,191-2,194.

Detterman, R.L., Case, J.E., Miller, J.W., Wilson, F.H., and Yount, M.E., 1996, Stratigraphic framework of the Alaska Peninsula: U.S. Geological Survey Bulletin 1969-A, $74 \mathrm{p}$.

Dodson, M.H., and McClelland-Brown, E., 1985, Isotopic and paleomagnetic evidence for rates of cooling, uplift, and erosion, in Snelling, N.J., ed., The chronology of the geological record: Geological Society of London, Memoir 10, p. 315-325.

Donelick, R.A., Ketcham, R.A., and Carlson, W.D., 1999, Variability of apatite fission-track annealing kinetics; II, Crystallographic orientation effects: American Mineralogist, v. 84, p. 1,224-1,234.

Donelick, R.A., O'Sullivan, P.B, and Ketcham, R.A., 2005, Apatite fission-track analysis: Reviews in Mineralogy and Geochemistry, v. 58, no. 1, p. 49-94.

Finzel, E.S., Reifenstuhl, R.R., Decker, P.L., and Ridgway, K.D., 2005, Sedimentology, stratigraphy, and hydrocarbon reservoir-source rock potential, using surface and subsurface data, of Tertiary and Mesozoic strata, Bristol Bay Basin and Alaska Peninsula: Alaska Division of Geological \& Geophysical Surveys Preliminary Interpretive Report 2005-4, 67 p.

Fleischer, R.L., Price, P.B., and Walker, R.M., 1975, Nuclear tracks in solids: Los Angeles, University of California Press, 605 p.

Flett, T.O., 1988a, Geothermal gradient, in Turner, R.F., ed., Geological and operational summary, North Aleutian Shelf COST No. 1 well, Bering Sea, Alaska: U.S. Minerals Management Service, OCS Report MMS 88-0089, p. 180-183.

Flett, T.O., 1988b, Organic geochemistry, in Turner, R.F., ed., Geological and operational summary, North Aleutian Shelf COST No. 1 well, Bering Sea, Alaska: U.S. 
Minerals Management Service, OCS Report MMS 88-0089, p. 184-202.

Gallagher, K., Brown, R.W., and Johnson, C., 1998, Fission track analysis and its applications to geological problems: Annual Reviews of Earth and Planetary Sciences, v. 26, p. 519-572.

Gleadow, A.J.W., and Duddy, I.R., 1981, A natural long term annealing experiment for apatite: Nuclear Tracks, v. 5, p. 169-174.

Gleadow, A.J.W., Duddy, I.R., and Lovering, J.F., 1983. Fission track analysis; A new tool for the evaluation of thermal histories and hydrocarbon potential: Australian Petroleum Association Journal, v. 23, p. $93-102$.

Gradstein, F.M., Ogg, J.G., Smith, A.G., Agterberg, F.P., Bleeker, W., Cooper, R.A., Davydov, V., Gibbard, P., Hinnov, L.A., House, M.R., Lourens, L., Luterbacher, H.P., McArthur, J., Melchin, M.J., Robb, L.J., Shergold, J., Villeneuve, M., Wardlaw, B.R., Ali, J., Brinkhuis, H., Hilgen, F.J., Hooker, J., Howarth, R.J., Knoll, A.H., Laskar, J., Monechi, S., Plumb, K.A., Powell, J., Raffi, I., Röhl, U., Sadler, P., Sanfilippo, A., Schmitz, B., Shackleton, N.J., Shields, G.A., Strauss, H., Van Dam, J., van Kolfschoten, T., Veizer, J., and Wilson, D., 2004, A geologic time scale 2004: Cambridge University Press, 589 p.

Green, P.F., Duddy, I.R., Gleadow, A.J.W., and Lovering, J.F., 1989, Apatite fission track analysis as a paleotemperature indicator for hydrocarbon exploration, in Naeser, N.D., and McCulloch, T.H., eds., Thermal history of sedimentary basins; methods and case histories: New York, Springer-Verlag, p. 181-195.

Green, P.F., Duddy, I.R., Laslett, G.M., Hegarty, K.A., Gleadow, A.J.W., and Lovering, J.F., 1989, Thermal annealing of fission tracks in apatite; 4, Quantitative modeling techniques and extension to geological timescales: Chemical Geology (Isotope Geoscience Section), v. 79, no. 2, p. 155-182.

Larson, J.A., 1988, Paleontology and Biostratigraphy, in Turner, R.F., ed., Geological and operational summary, North Aleutian Shelf COST No. 1 well, Bering Sea, Alaska: U.S. Minerals Management Service, OCS Report MMS 88-0089, p. 159-179.

Laslett, G.M., Green, P.F., Duddy, I.R., and Gleadow, A.J.W., 1987, Thermal modeling of fission tracks in apatite: 2. A quantitative analysis: Chemical Geology, v. 65, p. $1-13$.

Molenaar, C.M., 1996, Thermal-maturity patterns and geothermal gradients on the Alaska Peninsula, in Johnsson, M.J., and Howell, D.G., eds., Thermal evolution of sedimentary basins in Alaska: U.S. Geological Survey Bulletin 2142, p. 11-19.

Murphy J.M., and Clough, J.G., 1999, Low-temperature thermal history using fission track dating in three wells in southern Alaska offshore basins; Lower Cook Inlet,
Shelikof Strait, and Stevenson Trough: Marine Georesources and Geotechnology, v. 17, p. 271-281.

Naeser, C.W., 1979. Fission track dating and geological annealing of fission tracks, in Jager, E. and Hunziker, J.C., eds., Lectures in Isotope Geology: New York, Springer-Verlag, p. 154-169.

Naeser, C.W., 1981. The fading of fission tracks in the geologic environment; Data from deep drill holes: Nuclear Tracks, v. 5, p. 248-250.

Naeser, C.W., and Faul, H., 1969, Fission track annealing in apatite and sphene: Journal of Geophysical Research, v. 74, p. 705-710.

Parker, J., and Newman, R., 1995, Alaska federal offshore; descriptions of geologic plays; 1995 national resource assessment: U.S. Minerals Management Service, North Aleutian Basin Assessment Province http://www. mms.gov/alaska/re/asmtdata/naleutia/naleplay.htm

Paul, T.A., and Fitzgerald, P.G., 1992, Transmission electron microscopic investigation of fission tracks in fluorapatite: American Mineralogist, v. 77, p. 336-344.

Price, P.B., and Walker, R.M., 1963, Fossil tracks of charged particles in gneiss and the age of minerals: Journal of Geophysical Research, v. 68, p. 4,847-4,862.

Scholl, D.W., Vallier, T.L., and Stevenson, A.J., 1986, Terrane accretion, production, and continental growth; A perspective based on the origin and tectonic fate of the Aleutian-Bering Sea region: Geology, v. 14, p. 43-47.

Scholl, D.W., Vallier, T.L., and Stevenson, A.J., 1987, Geologic evolution and petroleum geology of the Aleutian Ridge, in Scholl, D.W., Grantz, Arthur, and Vedder, J.G., eds., Geology and resource potential of the continental margin of western North America and adjacent ocean basins, Beaufort Sea to Baja California: Houston, TX, Circum-Pacific Council For Energy and Mineral Resources, Houston, TX, p. 73-102.

Tagami, T., and O'Sullivan, P.B., 2005, Fundamentals of fission-track thermochronology: Reviews in Mineralogy and Geochemistry, v. 58, p. 19-47.

Turner, R.F., ed., 1988, Geological and operational summary, North Aleutian Shelf COST No. 1 well, Bering Sea, Alaska: U.S. Minerals Management Service, OCS Report MMS 88-0089, 256 p., 2 plates.

Walker, K.T., McGeary, S.E., and Klemperer, S.L., 2003, Tectonic evolution of the Bristol Bay basin, southeast Bering Sea: Constraints from seismic reflection and potential field data: Tectonics, v. 22, no. 5, p. 19

Worrall, D.M., 1991, Tectonic history of the Bering Sea and the evolution of Tertiary strike-slip basins of the Bering Shelf: Geological Society of America Special Paper 257, 120 p., 1 oversize sheet, 4 plates. 
THIS PAGE INTENTIONALLY LEFT BLANK 


\section{APPENDIX 1 ANALYTICAL METHODS}

Core slabs from nine different $5 \mathrm{ft}$ to $29 \mathrm{ft}$ intervals (see table 1), each weighing a total of 2-4 kg, were aggregated, crushed and washed.Apatite and zircon concentrates were prepared in the laboratories of Geochron Inc., Cambridge, MA, using conventional isodynamic magnetic (Frantz barrier separator) and heavy liquid (tetrabromoethane and methylene iodide) techniques. The apatite yields were generally very poor (three samples: NAC4 from 8,644 ft, NAC7 from 12,253 ft, and NAC9 from 16,712 ft lacked workable apatite) to excellent.Many samples contained abundant pyrite.Those splits with excessive pyrite and barite were treated with aqua regia to concentrate zircon.

The external detector method was used for single grain apatite and zircon fission track dating in the laboratories of John Murphy at the University of Wyoming and Shari Kelley at Southern Methodist University Department of Geological Sciences, respectively.Apatite and zircon mounts were covered with low-U muscovite detectors, apatites sandwiched between standards including Durango apatite, NBS glass SRM692, and Corning glass CN-6, and zircons between Fish Canyon and Myalla Road syenite zircon age standards as well as the two glasses.Both packages were irradiated at the Texas A \& M reactor at fluences in the range 6.4-7.0 x $10^{15}$ neutrons $/ \mathrm{cm}^{2}$, and apatites at $0.7-1.4 \times 10^{16}$ neutrons $/ \mathrm{cm}^{2}$. Reactor neutron fluence was calculated using accepted ages of 27.9, 172.8, and 31.4 Ma for Fish Canyon, Myalla Road, and Durango standards and the flux gradient was verified using the glass standards.Muscovite detectors were etched for 13 minutes in 48 percent $\mathrm{HF}$ to reveal induced ${ }^{235} \mathrm{U}$ fission tracks.Individual grain ages were calculated using the zeta correction formulation of Price and Walker (1963); age uncertainty calculations of grains with non-zero ages are those of Hurford and others. (1984). Small fragments of the Durango apatite were mounted with the samples and analyzed as internal standards. The resulting zeta calibration factors for eight grains (assuming an age of $31.4 \mathrm{Ma}$ ) average $352 \pm 45$, compared with the zeta factor for SRM612 of $349 \pm 14$.

Apatite confined track length measurements were made on those samples yielding sufficient quantities of workable apatite using a 100x air objective, digitizing tablet, and a camera-lucida tube.Mounted and polished length mounts were irradiated prior to etching with vertical ${ }^{252} \mathrm{Cf}$ fragments (induced density approximately $10^{6}$ tracks $/ \mathrm{cm}^{2}$ ) at the ARCO Plano fission track laboratory in order to increase the etchable spontaneous confined track yields. The means of spontaneous and induced confined tracks analyzed in the Durango apatite standard concurrent with these analyses were: $14.36 \pm 0.07 \mu \mathrm{m}(1$ sigma $=0.88 \mu \mathrm{m}, \mathrm{n}=150)$ and $16.15 \pm 0.07 \mu \mathrm{m}(1$ sigma $=0.80 \mu \mathrm{m}, \mathrm{n}=150)$, respectively. 


\section{APPENDIX 2 OVERVIEW OF THE FISSION TRACK GEOCHRONOLOGY TECHNIQUE}

Fission track analysis is a geothermochronologic technique for constraining the thermal history of rocks (Fleischer others, 1975; Naeser, 1979; Gleadow others, 1983; Gallagher others, 1998). Detrital grains of apatite and zircon in sedimentary rocks contain minor to trace amounts of ${ }^{238} \mathrm{U}$. Each year, about one in 10 billion ${ }^{238} \mathrm{U}$ atoms decays and one in a million of those undergoes spontaneous fission, or splits into two fragments. Fission tracks are zones of radiation damage in crystals produced by the destructive interaction (creating defects, ionizing atoms, and stripping their electrons) of highly energetic (100-200 Mev), highly charged (>+20e) fission particles (atoms such as $\mathrm{Rb}, \mathrm{Sr}, \mathrm{Ba}, \mathrm{Yb}, \mathrm{Zr}$ ) of variable mass (ca. 85-110, 125-155 amu) (Price and Walker, 1963). Fission tracks are only preserved in dielectric (non-conducting: $>2000 \mathrm{ohm}-\mathrm{cm}$ resistivity) solids (crystals or glasses); conducting solids immediately repair the fragment damage since an abundance of free electrons exist in metals. Although the true identity of fission tracks remains an enigma, recent TEM imaging studies suggest they are probably glassy zones of defects in crystalline matter which are on the order of 50-100 $\AA$ in diameter and $<20 \mu \mathrm{m}$ long in natural oxide minerals such as apatite and zircon (Paul and Fitzgerald, 1992). This damage zone can be enlarged (to $>1-5 \mu \mathrm{m}$ diameter) by etching with a solvent such as nitric acid (apatite) and $\mathrm{NaOH}-\mathrm{KOH}$ (zircon) and studied with an optical microscope.

Since the fission damage zones heal as a function of time and temperature and are rendered unetchable, each mineral possesses a characteristic blocking temperature (usually expressed for a given time scale and cooling rate; Dodson, 1973), above which tracks form but spontaneously anneal, and below which tracks shorten at very slow rates (Naeser, 1979). For rapid cooling rates $\left(30^{\circ} \mathrm{C} / \mathrm{m} . \mathrm{y}\right.$.) and geologic time scales $(1-10 \mathrm{~m} . \mathrm{y}$.$) , the respective$ blocking temperatures for apatite and zircon are approximately $120 \pm 10^{\circ} \mathrm{C}$ and $200 \pm 30^{\circ} \mathrm{C}$ (Naeser, 1979 ; Gleadow others, 1983). Therefore, fission track analysis of apatite and zircon are useful for constraining the low temperature $\left(<200^{\circ} \mathrm{C}\right)$, shallow $(<6 \mathrm{~km})$ thermal history of the upper crust.

Etchable fission tracks in apatite are initially long, ca $16.5 \mu \mathrm{m}$, and shorten by annealing as a function of time and temperature. Apatites that rapidly cool $\left(>10-100^{\circ} \mathrm{C} / \mathrm{m}\right.$.y.) through temperatures $>150^{\circ} \mathrm{C}$ to $<60^{\circ} \mathrm{C}$, possess long tracks $(14-15 \mu \mathrm{m})$, whereas those that experienced a protracted cooling history $\left(<1{ }^{\circ} \mathrm{C} / \mathrm{m} . \mathrm{y}\right.$. $)$ possess shorter tracks $(<13 \mu \mathrm{m})$. Fission tracks in apatite fade and are rendered unetchable if subjected to temperatures $>100$ to $>130^{\circ} \mathrm{C}$ for time scales of 100 to 10 m.y., respectively. The age of a given mineral grain is a function of the fission track density, the length of fission tracks relative to those of the age standard, and uranium concentration. The fissiontrack age in apatite may represent a geologic event, if the apatite cooled rapidly and the tracks are long $(>13.5 \mu \mathrm{m})$, or alternatively some complicated thermal history in the temperature range $60-130^{\circ} \mathrm{C}$, if the apatite cooled slowly and the tracks are short $(<13.5 \mu \mathrm{m})$.

A large body of high temperature $\left(100-400^{\circ} \mathrm{C}\right)$, short term $(<1.5 \mathrm{yr})$ experimental data is available that describes the effect of time and temperature on track shortening and age reduction in apatite (Zimmerman, 1977; Naeser and Faul, 1969, Green others, 1986; Crowley others, 1991). Longer term constraints on track annealing include well documented subsurface samples from wells thought to be at maximum thermal conditions (Naeser, 1981; Gleadow and Duddy, 1981). Kinetic models have been developed by many workers (Crowley, 1985; Laslett others, 1987; Carlson, 1990) that predict the degree of length and age reduction as a function of time and temperature. A compositional effect of annealing kinetics has been recognized by Duddy others (1988) and Green others (1989) and many subsequent workers in which apatites from the Otway Basin with $>1 \mathrm{wt} \% \mathrm{Cl}$ possess higher effective blocking temperatures than F-rich varieties $(<0.4 \mathrm{wt} \% \mathrm{Cl})$. It is thought that $1-3 \mathrm{wt} \% \mathrm{Cl}$ in apatite produces a $10-30^{\circ} \mathrm{C}$ increase in fission track blocking temperature. Alternatively, $\mathrm{Cl}$-rich apatites may possess longer tracks and older ages because they etch at greater rates than Cl-poor varieties. Figure 6 shows the relationship between anion composition and apatite FT age for Mesozoic and Cenozoic samples from five selected wells in the Lower Cook Inlet Alaska. Figure 7 shows that several thousand worldwide apatites from igneous, metamorphic and sedimentary rocks vary widely in anion composition, with a positive correlation between $\mathrm{Cl}$ and $\mathrm{OH}$ and negative correlation between $\mathrm{F}$ and $\mathrm{Cl}$ (Bergman, unpublished data). $\mathrm{As} \mathrm{Cl}$ and $\mathrm{OH}$ are positively correlated, either $\mathrm{OH}$ or $\mathrm{Cl}$ may be the cause of the higher blocking temperatures for those apatites depleted in Fluorine. 


\section{APPENDIX 3 \\ FISSION TRACK DATA TABLES}

94NAC1 Apatite

IRRADIATION WY94-4-1 COUNTED BY: JMM

\begin{tabular}{|c|c|c|c|c|c|c|c|c|c|c|}
\hline No. & Ns & $\mathrm{Ni}$ & $\mathrm{Na}$ & RATIO & $\begin{array}{c}U \\
(\mathrm{ppm})\end{array}$ & RHOS & RHOi & $\begin{array}{l}\text { F.T.AGE } \\
\text { (Ma) }\end{array}$ & & \\
\hline 1 & 16 & 34 & 30 & 0.471 & 10.0 & $8.141 \mathrm{E}+05$ & $1.730 \mathrm{E}+06$ & 151.6 & $+/-$ & 46.1 \\
\hline 2 & 2 & 46 & 64 & 0.043 & 6.3 & $4.770 \mathrm{E}+04$ & $1.097 \mathrm{E}+06$ & 14.2 & $+/-$ & 10.2 \\
\hline 3 & 10 & 106 & 100 & 0.094 & 9.3 & $1.526 \mathrm{E}+05$ & $1.618 \mathrm{E}+06$ & 30.7 & $+/-$ & 10.2 \\
\hline 4 & 12 & 119 & 60 & 0.101 & 17.4 & $3.053 E+05$ & $3.028 \mathrm{E}+06$ & 32.8 & $+/-$ & 10.0 \\
\hline 5 & 9 & 214 & 80 & 0.042 & 23.5 & $1.717 \mathrm{E}+05$ & $4.083 E+06$ & 13.7 & $+/-$ & 4.7 \\
\hline 6 & 2 & 19 & 60 & 0.105 & 2.8 & $5.088 \mathrm{E}+04$ & $4.834 \mathrm{E}+05$ & 34.2 & $+/-$ & 25.5 \\
\hline 7 & 0 & 37 & 100 & 0.000 & 3.3 & $0.000 \mathrm{E}+00$ & $5.648 \mathrm{E}+05$ & 0.0 & $+/-$ & 0.0 \\
\hline 8 & 24 & 310 & 70 & 0.077 & 38.9 & $5.234 \mathrm{E}+05$ & $6.760 \mathrm{E}+06$ & 25.2 & $+/-$ & 5.4 \\
\hline 9 & 60 & 267 & 100 & 0.225 & 23.5 & $9.159 \mathrm{E}+05$ & $4.076 \mathrm{E}+06$ & 72.9 & $+/-$ & 10.5 \\
\hline 10 & 18 & 285 & 100 & 0.063 & 25.0 & $2.748 \mathrm{E}+05$ & $4.350 \mathrm{E}+06$ & 20.6 & $+/-$ & 5.0 \\
\hline 11 & 6 & 99 & 50 & 0.061 & 17.4 & $1.832 \mathrm{E}+05$ & $3.022 \mathrm{E}+06$ & 19.7 & $+/-$ & 8.3 \\
\hline 12 & 16 & 221 & 80 & 0.072 & 24.3 & $3.053 \mathrm{E}+05$ & $4.217 \mathrm{E}+06$ & 23.6 & $+/-$ & 6.1 \\
\hline 13 & 16 & 221 & 100 & 0.072 & 19.4 & $2.442 \mathrm{E}+05$ & $3.374 \mathrm{E}+06$ & 23.6 & $+/-$ & 6.1 \\
\hline 14 & 7 & 195 & 60 & 0.036 & 28.6 & $1.781 \mathrm{E}+05$ & $4.961 E+06$ & 11.7 & $+/-$ & 4.5 \\
\hline 15 & 31 & 319 & 70 & 0.097 & 40.0 & $6.760 \mathrm{E}+05$ & $6.956 \mathrm{E}+06$ & 31.6 & $+/-$ & 6.0 \\
\hline 16 & 23 & 453 & 100 & 0.051 & 39.8 & $3.511 E+05$ & $6.915 \mathrm{E}+06$ & 16.5 & $+/-$ & 3.6 \\
\hline 17 & 20 & 217 & 50 & 0.092 & 38.1 & $6.106 \mathrm{E}+05$ & $6.625 E+06$ & 30.0 & $+/-$ & 7.0 \\
\hline 18 & 23 & 322 & 50 & 0.071 & 56.6 & $7.022 \mathrm{E}+05$ & $9.831 \mathrm{E}+06$ & 23.2 & $+/-$ & 5.0 \\
\hline 19 & 20 & 290 & 100 & 0.069 & 25.5 & $3.053 \mathrm{E}+05$ & $4.427 \mathrm{E}+06$ & 22.4 & $+/-$ & 5.2 \\
\hline 20 & 18 & 213 & 49 & 0.084 & 38.2 & $5.607 \mathrm{E}+05$ & $6.636 \mathrm{E}+06$ & 27.5 & $+/-$ & 6.8 \\
\hline 21 & 10 & 86 & 100 & 0.116 & 7.6 & $1.526 \mathrm{E}+05$ & $1.313 \mathrm{E}+06$ & 37.8 & $+/-$ & 12.7 \\
\hline 22 & 64 & 409 & 100 & 0.156 & 35.9 & $9.770 \mathrm{E}+05$ & $6.243 \mathrm{E}+06$ & 50.8 & $+/-$ & 6.9 \\
\hline 23 & 29 & 105 & 30 & 0.276 & 30.8 & $1.476 \mathrm{E}+06$ & $5.343 \mathrm{E}+06$ & 89.4 & $+/-$ & 18.9 \\
\hline 24 & 37 & 462 & 60 & 0.080 & 67.7 & $9.413 \mathrm{E}+05$ & $1.175 \mathrm{E}+07$ & 26.1 & $+/-$ & 4.5 \\
\hline 25 & 8 & 195 & 30 & 0.041 & 57.1 & $4.071 E+05$ & $9.922 \mathrm{E}+06$ & 13.4 & $+/-$ & 4.8 \\
\hline 26 & 5 & 61 & 40 & 0.082 & 13.4 & $1.908 \mathrm{E}+05$ & $2.328 \mathrm{E}+06$ & 26.7 & $+/-$ & 12.4 \\
\hline 27 & 33 & 895 & 100 & 0.037 & 78.6 & $5.037 \mathrm{E}+05$ & $1.366 \mathrm{E}+07$ & 12.0 & $+/-$ & 2.1 \\
\hline 28 & 2 & 81 & 80 & 0.025 & 8.9 & $3.816 \mathrm{E}+04$ & $1.546 \mathrm{E}+06$ & 8.0 & $+/-$ & 5.8 \\
\hline 29 & 5 & 103 & 60 & 0.049 & 15.1 & $1.272 \mathrm{E}+05$ & $2.620 \mathrm{E}+06$ & 15.8 & $+/-$ & 7.2 \\
\hline 30 & 26 & 108 & 100 & 0.241 & 9.5 & $3.969 \mathrm{E}+05$ & $1.649 \mathrm{E}+06$ & 78.0 & $+/-$ & 17.1 \\
\hline \multirow[t]{2}{*}{31} & 62 & 862 & 90 & 0.072 & 84.2 & $1.052 \mathrm{E}+06$ & $1.462 \mathrm{E}+07$ & 23.4 & $+/-$ & 3.1 \\
\hline & 614 & 7354 & & & 28.6 & $4.142 \mathrm{E}+05$ & $4.961 E+06$ & & & \\
\hline
\end{tabular}

Area of basic unit $=6.551 \mathrm{E}-07 \mathrm{~cm}-2$

CHI SQUARED $=118.0924$ WITH 30 DEGREES OF FREEDOM

$\mathrm{P}($ chi squared $)=0.0 \%$

CORRELATION COEFFICIENT $=0.687$

VARIANCE OF SQR(Ns) $=3.706818$

VARIANCE OF SQR $(\mathrm{Ni})=38.24873$

$\mathrm{Ns} / \mathrm{Ni}=0.083+/-0.004$

MEAN RATIO $=0.100+/-0.017$

Pooled Age $=27.2+/-1.3 \mathrm{Ma}$

Mean Age $=32.6+/-5.4 \mathrm{Ma}$

Central Age $=30.1+/-4.0 \mathrm{Ma}$

$\%$ Variation $=67.85 \%$

Ages calculated using a zeta of $12250+/-1000$ for SRM963a glass

$\mathrm{RHO} D=5.323 \mathrm{E}+04 \mathrm{~cm}-2 ; \mathrm{ND}=2561$ 
94NAC2 Apatite

IRRADIATION WY94-4-2 COUNTED BY: JMM

\begin{tabular}{|c|c|c|c|c|c|c|c|c|c|c|}
\hline No. & Ns & $\mathrm{Ni}$ & $\mathrm{Na}$ & RATIO & $\underset{(p p m)}{U}$ & RHOS & RHOi & $\begin{array}{l}\text { F.T.AGE } \\
\text { (Ma) }\end{array}$ & & \\
\hline 1 & 40 & 348 & 60 & 0.115 & 51.4 & $1.018 \mathrm{E}+06$ & $8.854 \mathrm{E}+06$ & 37.0 & $+1-$ & 6.2 \\
\hline 2 & 15 & 55 & 30 & 0.273 & 16.3 & $7.632 \mathrm{E}+05$ & $2.799 \mathrm{E}+06$ & 87.5 & $+1-$ & 25.6 \\
\hline 3 & 7 & 84 & 24 & 0.083 & 31.0 & $4.452 \mathrm{E}+05$ & $5.343 \mathrm{E}+06$ & 26.9 & $+1-$ & 10.6 \\
\hline 4 & 5 & 104 & 48 & 0.048 & 19.2 & $1.590 \mathrm{E}+05$ & $3.307 \mathrm{E}+06$ & 15.5 & $+/-$ & 7.1 \\
\hline 5 & 1 & 32 & 100 & 0.031 & 2.8 & $1.526 \mathrm{E}+04$ & $4.885 \mathrm{E}+05$ & 10.1 & $+1-$ & 10.2 \\
\hline 6 & 33 & 402 & 60 & 0.082 & 59.4 & $8.396 \mathrm{E}+05$ & $1.023 \mathrm{E}+07$ & 26.5 & $+1-$ & 4.8 \\
\hline 7 & 25 & 528 & 100 & 0.047 & 46.8 & $3.816 \mathrm{E}+05$ & $8.060 \mathrm{E}+06$ & 15.3 & $+1-$ & 3.1 \\
\hline 8 & 15 & 137 & 64 & 0.109 & 19.0 & $3.578 \mathrm{E}+05$ & $3.268 \mathrm{E}+06$ & 35.3 & $+/-$ & 9.6 \\
\hline 9 & 2 & 25 & 100 & 0.080 & 2.2 & $3.053 \mathrm{E}+04$ & $3.816 \mathrm{E}+05$ & 25.8 & $+1-$ & 19.0 \\
\hline 10 & 2 & 23 & 70 & 0.087 & 2.9 & $4.361 \mathrm{E}+04$ & $5.016 \mathrm{E}+05$ & 28.0 & $+1-$ & 20.7 \\
\hline 11 & 5 & 297 & 50 & 0.017 & 52.7 & $1.526 \mathrm{E}+05$ & $9.067 \mathrm{E}+06$ & 5.4 & $+/-$ & 2.5 \\
\hline 12 & 9 & 21 & 100 & 0.429 & 1.9 & $1.374 \mathrm{E}+05$ & $3.206 \mathrm{E}+05$ & 137.0 & $+1-$ & 54.7 \\
\hline 13 & 4 & 35 & 100 & 0.114 & 3.1 & $6.106 \mathrm{E}+04$ & $5.343 \mathrm{E}+05$ & 36.8 & $+1-$ & 19.5 \\
\hline 14 & 37 & 328 & 50 & 0.113 & 58.2 & $1.130 \mathrm{E}+06$ & $1.001 \mathrm{E}+07$ & 36.4 & $+/-$ & 6.4 \\
\hline 15 & 20 & 191 & 100 & 0.105 & 16.9 & $3.053 \mathrm{E}+05$ & $2.916 \mathrm{E}+06$ & 33.7 & $+/-$ & 8.0 \\
\hline 16 & 12 & 67 & 100 & 0.179 & 5.9 & $1.832 \mathrm{E}+05$ & $1.023 \mathrm{E}+06$ & 57.6 & $+1-$ & 18.1 \\
\hline 17 & 10 & 175 & 49 & 0.057 & 31.7 & $3.115 \mathrm{E}+05$ & $5.452 \mathrm{E}+06$ & 18.4 & $+1-$ & 6.0 \\
\hline 18 & 10 & 110 & 42 & 0.091 & 23.2 & $3.634 \mathrm{E}+05$ & $3.998 \mathrm{E}+06$ & 29.3 & $+1-$ & 9.7 \\
\hline 19 & 16 & 148 & 70 & 0.108 & 18.7 & $3.489 \mathrm{E}+05$ & $3.227 \mathrm{E}+06$ & 34.8 & $+1-$ & 9.2 \\
\hline 20 & 17 & 138 & 70 & 0.123 & 17.5 & $3.707 \mathrm{E}+05$ & $3.009 \mathrm{E}+06$ & 39.7 & $+/-$ & 10.2 \\
\hline 21 & 5 & 29 & 100 & 0.172 & 2.6 & $7.632 \mathrm{E}+04$ & $4.427 \mathrm{E}+05$ & 55.5 & $+/-$ & 26.9 \\
\hline 22 & 10 & 79 & 50 & 0.127 & 14.0 & $3.053 \mathrm{E}+05$ & $2.412 \mathrm{E}+06$ & 40.8 & $+/-$ & 13.7 \\
\hline 23 & 17 & 141 & 100 & 0.121 & 12.5 & $2.595 \mathrm{E}+05$ & $2.152 \mathrm{E}+06$ & 38.8 & $+/-$ & 10.0 \\
\hline 24 & 10 & 155 & 100 & 0.065 & 13.7 & $1.526 \mathrm{E}+05$ & $2.366 \mathrm{E}+06$ & 20.8 & $+/-$ & 6.8 \\
\hline 25 & 13 & 213 & 100 & 0.061 & 18.9 & 1.984E+05 & $3.251 \mathrm{E}+06$ & 19.7 & $+1-$ & 5.6 \\
\hline 26 & 34 & 307 & 36 & 0.111 & 75.6 & $1.442 \mathrm{E}+06$ & $1.302 \mathrm{E}+07$ & 35.7 & $+1-$ & 6.5 \\
\hline 27 & 6 & 65 & 100 & 0.092 & 5.8 & $9.159 \mathrm{E}+04$ & $9.922 \mathrm{E}+05$ & 29.8 & $+/-$ & 12.7 \\
\hline 28 & 10 & 108 & 49 & 0.093 & 19.5 & $3.115 \mathrm{E}+05$ & $3.364 \mathrm{E}+06$ & 29.9 & $+1-$ & 9.9 \\
\hline 29 & 25 & 119 & 25 & 0.210 & 42.2 & $1.526 \mathrm{E}+06$ & $7.266 \mathrm{E}+06$ & 67.5 & $+1-$ & 14.9 \\
\hline 30 & 14 & 229 & 100 & 0.061 & 20.3 & $2.137 \mathrm{E}+05$ & $3.496 \mathrm{E}+06$ & 19.7 & $+1-$ & 5.4 \\
\hline \multirow[t]{2}{*}{31} & 25 & 308 & 100 & 0.081 & 27.3 & $3.816 \mathrm{E}+05$ & $4.702 \mathrm{E}+06$ & 26.2 & $+1-$ & 5.5 \\
\hline & 454 & 5001 & & & 19.7 & $3.084 E+05$ & $3.397 \mathrm{E}+06$ & & & \\
\hline
\end{tabular}

Area of basic unit $=6.551 \mathrm{E}-07 \mathrm{~cm}-2$

CHI SQUARED $=52.7205$ WITH 30 DEGREES OF FREEDOM

$P($ chi squared $)=0.0 \%$

CORRELATION COEFFICIENT $=0.758$

VARIANCE OF SQR(Ns) $=1.956051$

VARIANCE OF SQR(Ni) $=24.34258$

$\mathrm{Ns} / \mathrm{Ni}=0.091+/-0.004$

MEAN RATIO $=0.112+/-0.014$

Pooled Age = 29.3+/- 1.6 Ma

Mean Age $=36.2+/-4.6 \mathrm{Ma}$

Central Age $=32.4+/-3.1 \mathrm{Ma}$

$\%$ Variation $=40.65 \%$

Ages calculated using a zeta of $12250+/-1000$ for SRM963a glass

$\mathrm{RHO} D=5.276 \mathrm{E}+04 \mathrm{~cm}-2 ; \mathrm{ND}=2561$ 
94NAC3 Apatite

IRRADIATION WY94-4-3 COUNTED BY: JMM

\begin{tabular}{|c|c|c|c|c|c|c|c|c|c|c|}
\hline $\begin{array}{l}\mathrm{N} \\
\mathrm{O} .\end{array}$ & Ns & $\mathrm{Ni}$ & $\mathrm{Na}$ & RATIO & $\underset{(\mathrm{ppm})}{\mathbf{U}}$ & RHOS & RHOi & $\begin{array}{c}\text { F.T.AGE } \\
\text { (Ma) }\end{array}$ & & \\
\hline 1 & 29 & 86 & 49 & 0.337 & 15.7 & $9.034 \mathrm{E}+05$ & $2.679 \mathrm{E}+06$ & 107.1 & $+/-$ & 24.7 \\
\hline 2 & 2 & 5 & 64 & 0.400 & 0.7 & $4.770 \mathrm{E}+04$ & $1.193 E+05$ & 126.9 & $+/-$ & 106.7 \\
\hline 3 & 13 & 89 & 15 & 0.146 & 53.1 & $1.323 \mathrm{E}+06$ & $9.057 \mathrm{E}+06$ & 46.6 & $+/-$ & 14.4 \\
\hline 4 & 1 & 6 & 36 & 0.167 & 1.5 & $4.240 \mathrm{E}+04$ & $2.544 \mathrm{E}+05$ & 53.2 & $+/-$ & 57.6 \\
\hline 5 & 11 & 76 & 25 & 0.145 & 27.2 & $6.717 \mathrm{E}+05$ & $4.641 \mathrm{E}+06$ & 46.2 & $+/-$ & 15.4 \\
\hline 6 & 89 & 306 & 70 & 0.291 & 39.1 & $1.941 \mathrm{E}+06$ & $6.673 \mathrm{E}+06$ & 92.5 & $+/-$ & 13.6 \\
\hline 7 & 6 & 52 & 16 & 0.115 & 29.1 & $5.724 \mathrm{E}+05$ & $4.961 \mathrm{E}+06$ & 36.8 & $+/-$ & 16.2 \\
\hline 8 & 17 & 55 & 50 & 0.309 & 9.8 & $5.190 \mathrm{E}+05$ & $1.679 \mathrm{E}+06$ & 98.2 & $+/-$ & 28.5 \\
\hline 9 & 7 & 20 & 70 & 0.350 & 2.6 & $1.526 \mathrm{E}+05$ & $4.361 \mathrm{E}+05$ & 111.1 & $+/-$ & 49.7 \\
\hline 10 & 5 & 22 & 20 & 0.227 & 9.8 & $3.816 \mathrm{E}+05$ & $1.679 \mathrm{E}+06$ & 72.4 & $+/-$ & 36.4 \\
\hline 11 & 1 & 4 & 20 & 0.250 & 1.8 & $7.632 \mathrm{E}+04$ & $3.053 \mathrm{E}+05$ & 79.6 & $+/-$ & 89.2 \\
\hline 12 & 5 & 23 & 40 & 0.217 & 5.1 & $1.908 \mathrm{E}+05$ & $8.777 \mathrm{E}+05$ & 69.3 & $+/-$ & 34.7 \\
\hline 13 & 5 & 12 & 60 & 0.417 & 1.8 & $1.272 \mathrm{E}+05$ & $3.053 \mathrm{E}+05$ & 132.1 & $+/-$ & 71.2 \\
\hline 14 & 26 & 111 & 24 & 0.234 & 41.4 & $1.654 \mathrm{E}+06$ & $7.060 \mathrm{E}+06$ & 74.6 & $+/-$ & 17.4 \\
\hline 15 & 11 & 219 & 27 & 0.050 & 72.6 & $6.219 \mathrm{E}+05$ & $1.238 \mathrm{E}+07$ & 16.1 & $+/-$ & 5.1 \\
\hline 16 & 30 & 99 & 50 & 0.303 & 17.7 & $9.159 E+05$ & $3.022 \mathrm{E}+06$ & 96.3 & $+/-$ & 21.6 \\
\hline 17 & 3 & 59 & 28 & 0.051 & 18.8 & $1.636 \mathrm{E}+05$ & $3.217 \mathrm{E}+06$ & 16.3 & $+/-$ & 9.7 \\
\hline 18 & 9 & 39 & 15 & 0.231 & 23.3 & $9.159 \mathrm{E}+05$ & $3.969 \mathrm{E}+06$ & 73.5 & $+/-$ & 27.9 \\
\hline 19 & 10 & 21 & 24 & 0.476 & 7.8 & $6.360 \mathrm{E}+05$ & $1.336 \mathrm{E}+06$ & 150.7 & $+/-$ & 59.3 \\
\hline 20 & 4 & 24 & 50 & 0.167 & 4.3 & $1.221 \mathrm{E}+05$ & 7.327E+05 & 53.2 & $+/-$ & 29.1 \\
\hline 21 & 45 & 172 & 64 & 0.262 & 24.0 & $1.073 \mathrm{E}+06$ & $4.102 \mathrm{E}+06$ & 83.3 & $+/-$ & 15.6 \\
\hline 22 & 15 & 52 & 60 & 0.288 & 7.8 & $3.816 \mathrm{E}+05$ & $1.323 \mathrm{E}+06$ & 91.7 & $+/-$ & 28.0 \\
\hline 23 & 7 & 22 & 28 & 0.318 & 7.0 & $3.816 \mathrm{E}+05$ & $1.199 \mathrm{E}+06$ & 101.1 & $+/-$ & 44.7 \\
\hline 24 & 14 & 51 & 21 & 0.274 & 21.7 & $1.018 \mathrm{E}+06$ & $3.707 \mathrm{E}+06$ & 87.3 & $+/-$ & 27.3 \\
\hline 25 & 23 & 56 & 9 & 0.411 & 55.7 & $3.901 \mathrm{E}+06$ & $9.498 \mathrm{E}+06$ & 130.2 & $+/-$ & 34.1 \\
\hline 26 & 6 & 32 & 64 & 0.188 & 4.5 & $1.431 \mathrm{E}+05$ & $7.632 \mathrm{E}+05$ & 59.8 & $+/-$ & 27.1 \\
\hline 27 & 9 & 58 & 21 & 0.155 & 24.7 & $6.542 \mathrm{E}+05$ & $4.216 \mathrm{E}+06$ & 49.5 & $+/-$ & 18.2 \\
\hline 28 & 17 & 294 & 70 & 0.058 & 37.6 & 3.707E+05 & $6.411 \mathrm{E}+06$ & 18.5 & $+/-$ & 4.9 \\
\hline 29 & 30 & 67 & 100 & 0.448 & 6.0 & $4.579 \mathrm{E}+05$ & $1.023 \mathrm{E}+06$ & 141.8 & $+/-$ & 33.4 \\
\hline 30 & 12 & 34 & 100 & 0.353 & 3.0 & 1.832E+05 & $5.190 \mathrm{E}+05$ & 112.1 & $+/-$ & 38.8 \\
\hline \multirow[t]{2}{*}{31} & 4 & 24 & 50 & 0.167 & 4.3 & $1.221 \mathrm{E}+05$ & 7.327E+05 & 53.2 & $+/-$ & 29.1 \\
\hline & 466 & 2190 & & & 14.6 & $5.309 \mathrm{E}+05$ & $2.495 E+06$ & & & \\
\hline
\end{tabular}

Area of basic unit $=6.551 \mathrm{E}-07 \mathrm{~cm}-2$

CHI SQUARED $=60.58839$ WITH 30 DEGREES OF FREEDOM

$\mathrm{P}($ chi squared $)=0.0 \%$

CORRELATION COEFFICIENT $=0.714$

VARIANCE OF SQR(NS) $=3.188586$

VARIANCE OF SQR(Ni) $=15.46305$

$\mathrm{Ns} / \mathrm{Ni}=0.213+/-0.011$

MEAN RATIO $=0.252+/-0.021$

Pooled Age $=67.8+/-6.7 \mathrm{Ma}$

Mean Age $=80.1+/-9.4 \mathrm{Ma}$

Central Age $=73.8+/-7.4 \mathrm{Ma}$

$\%$ Variation $=41.81 \%$

Ages calculated using a zeta of $12250+/-1000$ for SRM963a glass

$\mathrm{RHO} D=5.229 \mathrm{E}+04 \mathrm{~cm}-2 ; \mathrm{ND}=2561$ 
94NAC5 Apatite

IRRADIATION WY94-4-4 COUNTED BY: JMM

\begin{tabular}{|c|c|c|c|c|c|c|c|c|c|c|}
\hline No. & Ns & $\mathrm{Ni}$ & $\mathrm{Na}$ & RATIO & $\underset{(p p m)}{U}$ & RHOS & RHOi & $\begin{array}{c}\text { F.T.AGE } \\
(\mathrm{Ma})\end{array}$ & & \\
\hline 1 & 6 & 46 & 100 & 0.130 & 4.2 & $9.159 \mathrm{E}+04$ & $7.022 \mathrm{E}+05$ & 41.3 & $+/-$ & 18.2 \\
\hline 2 & 6 & 50 & 100 & 0.120 & 4.5 & $9.159 \mathrm{E}+04$ & $7.632 \mathrm{E}+05$ & 38.0 & $+/-$ & 16.7 \\
\hline 3 & 7 & 58 & 100 & 0.121 & 5.2 & $1.069 \mathrm{E}+05$ & $8.854 \mathrm{E}+05$ & 38.2 & $+/-$ & 15.6 \\
\hline 4 & 3 & 21 & 60 & 0.143 & 3.2 & $7.632 \mathrm{E}+04$ & $5.343 \mathrm{E}+05$ & 45.2 & $+/-$ & 28.1 \\
\hline 5 & 7 & 73 & 100 & 0.096 & 6.6 & $1.069 \mathrm{E}+05$ & $1.114 \mathrm{E}+06$ & 30.4 & $+/-$ & 12.3 \\
\hline 6 & 8 & 45 & 100 & 0.178 & 4.1 & $1.221 \mathrm{E}+05$ & $6.869 \mathrm{E}+05$ & 56.2 & $+/-$ & 22.1 \\
\hline 7 & 15 & 69 & 40 & 0.217 & 15.6 & $5.724 \mathrm{E}+05$ & $2.633 \mathrm{E}+06$ & 68.6 & $+/-$ & 20.4 \\
\hline 8 & 5 & 25 & 100 & 0.200 & 2.3 & $7.632 \mathrm{E}+04$ & $3.816 \mathrm{E}+05$ & 63.2 & $+/-$ & 31.4 \\
\hline 9 & 7 & 74 & 100 & 0.095 & 6.7 & $1.069 \mathrm{E}+05$ & $1.130 \mathrm{E}+06$ & 29.9 & $+/-$ & 12.1 \\
\hline 10 & 12 & 99 & 80 & 0.121 & 11.2 & $2.290 \mathrm{E}+05$ & $1.889 \mathrm{E}+06$ & 38.4 & $+/-$ & 12.2 \\
\hline 11 & 6 & 67 & 100 & 0.090 & 6.0 & $9.159 \mathrm{E}+04$ & $1.023 \mathrm{E}+06$ & 28.4 & $+/-$ & 12.3 \\
\hline 12 & 9 & 62 & 80 & 0.145 & 7.0 & 1.717E+05 & $1.183 \mathrm{E}+06$ & 45.9 & $+/-$ & 16.8 \\
\hline 13 & 12 & 79 & 100 & 0.152 & 7.1 & $1.832 \mathrm{E}+05$ & $1.206 \mathrm{E}+06$ & 48.0 & $+/-$ & 15.4 \\
\hline 14 & 7 & 87 & 100 & 0.080 & 7.9 & $1.069 \mathrm{E}+05$ & $1.328 \mathrm{E}+06$ & 25.5 & $+/-$ & 10.2 \\
\hline 15 & 3 & 38 & 100 & 0.079 & 3.4 & $4.579 \mathrm{E}+04$ & $5.801 \mathrm{E}+05$ & 25.0 & $+/-$ & 15.1 \\
\hline 16 & 7 & 86 & 100 & 0.081 & 7.8 & $1.069 \mathrm{E}+05$ & $1.313 \mathrm{E}+06$ & 25.8 & $+/-$ & 10.4 \\
\hline 17 & 9 & 67 & 100 & 0.134 & 6.0 & $1.374 \mathrm{E}+05$ & $1.023 \mathrm{E}+06$ & 42.5 & $+/-$ & 15.5 \\
\hline 18 & 10 & 93 & 100 & 0.108 & 8.4 & $1.526 \mathrm{E}+05$ & $1.420 \mathrm{E}+06$ & 34.0 & $+/-$ & 11.7 \\
\hline 19 & 10 & 87 & 100 & 0.115 & 7.9 & $1.526 \mathrm{E}+05$ & $1.328 \mathrm{E}+06$ & 36.4 & $+/-$ & 12.5 \\
\hline 20 & 11 & 97 & 100 & 0.113 & 8.8 & $1.679 \mathrm{E}+05$ & $1.481 \mathrm{E}+06$ & 35.9 & $+/-$ & 11.8 \\
\hline 21 & 15 & 87 & 100 & 0.172 & 7.9 & $2.290 \mathrm{E}+05$ & $1.328 \mathrm{E}+06$ & 54.5 & $+/-$ & 15.9 \\
\hline 22 & 12 & 108 & 100 & 0.111 & 9.7 & $1.832 \mathrm{E}+05$ & $1.649 \mathrm{E}+06$ & 35.2 & $+/-$ & 11.1 \\
\hline 23 & 5 & 84 & 100 & 0.060 & 7.6 & $7.632 \mathrm{E}+04$ & $1.282 \mathrm{E}+06$ & 18.9 & $+/-$ & 8.8 \\
\hline 24 & 5 & 57 & 100 & 0.088 & 5.1 & $7.632 \mathrm{E}+04$ & $8.701 \mathrm{E}+05$ & 27.8 & $+/-$ & 13.2 \\
\hline 25 & 11 & 173 & 100 & 0.064 & 15.6 & $1.679 \mathrm{E}+05$ & $2.641 \mathrm{E}+06$ & 20.1 & $+/-$ & 6.5 \\
\hline 26 & 8 & 69 & 100 & 0.116 & 6.2 & $1.221 \mathrm{E}+05$ & $1.053 \mathrm{E}+06$ & 36.7 & $+/-$ & 14.0 \\
\hline 27 & 15 & 89 & 49 & 0.169 & 16.4 & $4.673 \mathrm{E}+05$ & $2.773 \mathrm{E}+06$ & 53.3 & $+/-$ & 15.5 \\
\hline 28 & 6 & 87 & 100 & 0.069 & 7.9 & $9.159 \mathrm{E}+04$ & $1.328 \mathrm{E}+06$ & 21.8 & $+/-$ & 9.4 \\
\hline 29 & 5 & 62 & 100 & 0.081 & 5.6 & $7.632 \mathrm{E}+04$ & $9.464 \mathrm{E}+05$ & 25.5 & $+/-$ & 12.1 \\
\hline 30 & 6 & 100 & 100 & 0.060 & 9.0 & $9.159 \mathrm{E}+04$ & $1.526 \mathrm{E}+06$ & 19.0 & $+/-$ & 8.1 \\
\hline \multirow[t]{2}{*}{31} & 7 & 81 & 100 & 0.086 & 7.3 & $1.069 \mathrm{E}+05$ & $1.236 \mathrm{E}+06$ & 27.4 & $+/-$ & 11.0 \\
\hline & 255 & 2320 & & & 7.2 & $1.338 \mathrm{E}+05$ & 1.217E+06 & & & \\
\hline
\end{tabular}

Area of basic unit $=6.551 \mathrm{E}-07 \mathrm{~cm}-2$

CHI SQUARED $=14.10372$ WITH 30 DEGREES OF FREEDOM

$P($ chi squared $)=55.9 \%$

CORRELATION COEFFICIENT $=0.529$

VARIANCE OF SQR(NS) $=.3320277$

VARIANCE OF SQR $(\mathrm{Ni})=2.725667$

$\mathrm{Ns} / \mathrm{Ni}=0.110+/-0.007$

MEAN RATIO $=0.116+/-0.007$

Pooled Age $=34.8+/-3.7 \mathrm{Ma}$

Mean Age $=36.7+/-3.9 \mathrm{Ma}$

Central Age $=34.9+/-2.5 \mathrm{Ma}$

$\%$ Variation $=7.98 \%$

Ages calculated using a zeta of $12250+/-1000$ for SRM963a glass

$\mathrm{RHO} D=5.181 \mathrm{E}+04 \mathrm{~cm}-2 ; \mathrm{ND}=2561$ 
94NAC6 Apatite

IRRADIATION WY94-4-5 COUNTED BY: JMM

\begin{tabular}{|c|c|c|c|c|c|c|c|c|c|c|}
\hline No. & Ns & $\mathrm{Ni}$ & $\mathrm{Na}$ & RATIO & $\begin{array}{c}U \\
(\mathrm{ppm})\end{array}$ & RHOS & RHOi & $\begin{array}{l}\text { F.T.AGE } \\
(\mathrm{Ma})\end{array}$ & & \\
\hline 1 & 3 & 10 & 100 & 0.300 & 0.9 & $4.579 \mathrm{E}+04$ & $1.526 \mathrm{E}+05$ & 93.7 & $+/-$ & 62.1 \\
\hline 2 & 7 & 19 & 100 & 0.368 & 1.7 & $1.069 \mathrm{E}+05$ & $2.900 \mathrm{E}+05$ & 114.8 & $+/-$ & 51.7 \\
\hline 3 & 6 & 40 & 49 & 0.150 & 7.4 & $1.869 \mathrm{E}+05$ & $1.246 \mathrm{E}+06$ & 47.0 & $+/-$ & 21.0 \\
\hline 4 & 3 & 8 & 36 & 0.375 & 2.0 & $1.272 \mathrm{E}+05$ & $3.392 \mathrm{E}+05$ & 116.9 & $+/-$ & 79.7 \\
\hline 5 & 2 & 9 & 30 & 0.222 & 2.7 & $1.018 \mathrm{E}+05$ & $4.579 \mathrm{E}+05$ & 69.5 & $+/-$ & 54.6 \\
\hline 6 & 2 & 10 & 100 & 0.200 & 0.9 & $3.053 \mathrm{E}+04$ & $1.526 \mathrm{E}+05$ & 62.6 & $+/-$ & 48.8 \\
\hline 7 & 3 & 28 & 100 & 0.107 & 2.6 & $4.579 \mathrm{E}+04$ & $4.274 \mathrm{E}+05$ & 33.6 & $+/-$ & 20.6 \\
\hline 8 & 4 & 21 & 100 & 0.190 & 1.9 & $6.106 \mathrm{E}+04$ & $3.206 \mathrm{E}+05$ & 59.6 & $+/-$ & 32.9 \\
\hline 9 & 3 & 8 & 50 & 0.375 & 1.5 & $9.159 \mathrm{E}+04$ & $2.442 \mathrm{E}+05$ & 116.9 & $+/-$ & 79.7 \\
\hline 10 & 1 & 17 & 100 & 0.059 & 1.5 & $1.526 \mathrm{E}+04$ & $2.595 \mathrm{E}+05$ & 18.5 & $+/-$ & 19.1 \\
\hline 11 & 6 & 27 & 100 & 0.222 & 2.5 & $9.159 \mathrm{E}+04$ & $4.122 \mathrm{E}+05$ & 69.5 & $+/-$ & 31.9 \\
\hline 12 & 3 & 20 & 70 & 0.150 & 2.6 & $6.542 \mathrm{E}+04$ & $4.361 \mathrm{E}+05$ & 47.0 & $+/-$ & 29.4 \\
\hline 13 & 7 & 44 & 60 & 0.159 & 6.7 & $1.781 \mathrm{E}+05$ & $1.119 \mathrm{E}+06$ & 49.8 & $+/-$ & 20.7 \\
\hline 14 & 4 & 29 & 70 & 0.138 & 3.8 & $8.723 \mathrm{E}+04$ & $6.324 \mathrm{E}+05$ & 43.2 & $+/-$ & 23.3 \\
\hline 15 & 2 & 24 & 70 & 0.083 & 3.1 & $4.361 \mathrm{E}+04$ & $5.234 \mathrm{E}+05$ & 26.2 & $+/-$ & 19.4 \\
\hline 16 & 8 & 75 & 70 & 0.107 & 9.8 & $1.745 E+05$ & $1.636 \mathrm{E}+06$ & 33.5 & $+/-$ & 12.8 \\
\hline 17 & 4 & 24 & 80 & 0.167 & 2.7 & $7.632 \mathrm{E}+04$ & $4.579 \mathrm{E}+05$ & 52.2 & $+/-$ & 28.5 \\
\hline 18 & 7 & 50 & 50 & 0.140 & 9.1 & $2.137 \mathrm{E}+05$ & $1.526 \mathrm{E}+06$ & 43.9 & $+/-$ & 18.1 \\
\hline 19 & 4 & 29 & 49 & 0.138 & 5.4 & $1.246 \mathrm{E}+05$ & $9.034 \mathrm{E}+05$ & 43.2 & $+/-$ & 23.3 \\
\hline 20 & 2 & 11 & 40 & 0.182 & 2.5 & $7.632 \mathrm{E}+04$ & $4.198 \mathrm{E}+05$ & 56.9 & $+/-$ & 44.0 \\
\hline 21 & 1 & 6 & 40 & 0.167 & 1.4 & $3.816 \mathrm{E}+04$ & $2.290 \mathrm{E}+05$ & 52.2 & $+/-$ & 56.6 \\
\hline 22 & 3 & 23 & 60 & 0.130 & 3.5 & $7.632 \mathrm{E}+04$ & $5.852 \mathrm{E}+05$ & 40.9 & $+/-$ & 25.3 \\
\hline 23 & 0 & 4 & 30 & 0.000 & 1.2 & $0.000 \mathrm{E}+00$ & $2.035 E+05$ & 0.0 & $+/-$ & 0.0 \\
\hline 24 & 2 & 14 & 49 & 0.143 & 2.6 & $6.231 \mathrm{E}+04$ & $4.361 \mathrm{E}+05$ & 44.8 & $+/-$ & 34.0 \\
\hline 25 & 2 & 17 & 80 & 0.118 & 1.9 & $3.816 \mathrm{E}+04$ & $3.244 \mathrm{E}+05$ & 36.9 & $+/-$ & 27.7 \\
\hline \multirow[t]{2}{*}{26} & 7 & 36 & 56 & 0.194 & 5.9 & $1.908 \mathrm{E}+05$ & $9.813 \mathrm{E}+05$ & 60.9 & $+/-$ & 25.7 \\
\hline & 96 & 603 & & & 3.2 & 8.427E+04 & $5.293 E+05$ & & & \\
\hline
\end{tabular}

Area of basic unit $=6.551 \mathrm{E}-07 \mathrm{~cm}-2$

CHI SQUARED = 7.004144 WITH 25 DEGREES OF FREEDOM

$P($ chi squared $)=96.2 \%$

CORRELATION COEFFICIENT $=0.810$

VARIANCE OF SQR(Ns) $=.4142963$

VARIANCE OF SQR(Ni) $=2.447244$

$\mathrm{Ns} / \mathrm{Ni}=0.159+/-0.017$

MEAN RATIO = $0.176+/-0.018$

Pooled Age $=49.9+/-6.9 \mathrm{Ma}$

Mean Age $=55.2+/-7.3 \mathrm{Ma}$

Central Age $=49.9+/-5.6 \mathrm{Ma}$

$\%$ Variation $=0.02 \%$

Ages calculated using a zeta of $12250+/-1000$ for SRM963a glass

$\mathrm{RHO} D=5.134 \mathrm{E}+04 \mathrm{~cm}-2 ; \mathrm{ND}=2561$ 
94NAC8 Apatite

IRRADIATION WY94-4-6 COUNTED BY: JMM

\begin{tabular}{|c|c|c|c|c|c|c|c|c|c|c|}
\hline No. & Ns & $\mathrm{Ni}$ & $\mathrm{Na}$ & RATIO & $\underset{(p p m)}{U}$ & RHOS & RHOi & $\begin{array}{l}\text { F.T.AGE } \\
\text { (Ma) }\end{array}$ & & \\
\hline 1 & 3 & 29 & 100 & 0.103 & 2.7 & $4.579 \mathrm{E}+04$ & $4.427 \mathrm{E}+05$ & 32.2 & $+/-$ & 19.7 \\
\hline 2 & 3 & 17 & 100 & 0.176 & 1.6 & $4.579 \mathrm{E}+04$ & $2.595 \mathrm{E}+05$ & 54.8 & $+/-$ & 34.6 \\
\hline 3 & 1 & 15 & 60 & 0.067 & 2.3 & $2.544 \mathrm{E}+04$ & $3.816 \mathrm{E}+05$ & 20.7 & $+/-$ & 21.5 \\
\hline 4 & 1 & 80 & 100 & 0.012 & 7.4 & $1.526 \mathrm{E}+04$ & $1.221 \mathrm{E}+06$ & 3.9 & $+/-$ & 3.9 \\
\hline 5 & 1 & 44 & 100 & 0.023 & 4.0 & $1.526 \mathrm{E}+04$ & $6.717 \mathrm{E}+05$ & 7.1 & $+/-$ & 7.2 \\
\hline 6 & 1 & 12 & 80 & 0.083 & 1.4 & $1.908 \mathrm{E}+04$ & $2.290 \mathrm{E}+05$ & 25.9 & $+/-$ & 27.1 \\
\hline 7 & 0 & 18 & 100 & 0.000 & 1.7 & $0.000 \mathrm{E}+00$ & $2.748 \mathrm{E}+05$ & 0.0 & $+1-$ & 0.0 \\
\hline 8 & 1 & 35 & 80 & 0.029 & 4.0 & +04 & $6.678 \mathrm{E}+05$ & 8.9 & $+/-$ & 9.1 \\
\hline 9 & 1 & 38 & 100 & 0.026 & 3.5 & $1.526 \mathrm{E}+04$ & $5.801 \mathrm{E}+05$ & 8.2 & $+/-$ & 8.3 \\
\hline 10 & 1 & 24 & 100 & 0.042 & 2.2 & $1.526 \mathrm{E}+04$ & $3.664 \mathrm{E}+05$ & 13.0 & $+/-$ & 13.3 \\
\hline 11 & 2 & 62 & 70 & 0.032 & 8.1 & $4.361 \mathrm{E}+04$ & $1.352 \mathrm{E}+06$ & 10.0 & $+/-$ & 7.3 \\
\hline 12 & 1 & 22 & 50 & 0.045 & 4.0 & $3.053 \mathrm{E}+04$ & $6.717 \mathrm{E}+05$ & 14.1 & $+/-$ & 14.5 \\
\hline 13 & 1 & 28 & 90 & 0.036 & 2.9 & $1.696 \mathrm{E}+04$ & 4.749E+05 & 11.1 & $+/-$ & 11.4 \\
\hline 14 & 1 & 33 & 100 & 0.030 & 3.0 & $E+04$ & $5.037 \mathrm{E}+05$ & 9.4 & $+/-$ & 9.6 \\
\hline 15 & 2 & 77 & 100 & 0.026 & 7.1 & $3.053 \mathrm{E}+04$ & $1.175 \mathrm{E}+06$ & 8.1 & $+/-$ & 5.8 \\
\hline 16 & 0 & 36 & 100 & 0.000 & 3.3 & $0.000 \mathrm{E}+00$ & $5.495 \mathrm{E}+05$ & 0.0 & $+/-$ & 0.0 \\
\hline 17 & 2 & 24 & 100 & 0.083 & 2.2 & $3.053 \mathrm{E}+04$ & $3.664 \mathrm{E}+05$ & 25.9 & $+/-$ & 19.2 \\
\hline 18 & 0 & 33 & 100 & 0.000 & 3.0 & $0.000 \mathrm{E}+00$ & $5.037 \mathrm{E}+05$ & 0.0 & $+1-$ & 0.0 \\
\hline 19 & 1 & 26 & 80 & 0.038 & 3.0 & $1.908 \mathrm{E}+04$ & $4.961 \mathrm{E}+05$ & 12.0 & $+/-$ & 12.2 \\
\hline 20 & 0 & 37 & 100 & 0.000 & 3.4 & $0.000 \mathrm{E}+00$ & $5.648 \mathrm{E}+05$ & 0.0 & $+1-$ & 0.0 \\
\hline 21 & 1 & 65 & 100 & 0.015 & 6.0 & $1.526 \mathrm{E}+04$ & $9.922 \mathrm{E}+05$ & 4.8 & $+/-$ & 4.8 \\
\hline 22 & 1 & 24 & 80 & 0.042 & 2.8 & $1.908 \mathrm{E}+04$ & $4.579 \mathrm{E}+05$ & 13.0 & $+1-$ & 13.3 \\
\hline 23 & 3 & 34 & 90 & 0.088 & 3.5 & $5.088 \mathrm{E}+04$ & $5.767 \mathrm{E}+05$ & 27.4 & $+/-$ & 16.7 \\
\hline 24 & 0 & 38 & 100 & 0.000 & 3.5 & $0.000 \mathrm{E}+00$ & $5.801 \mathrm{E}+05$ & 0.0 & $+/-$ & 0.0 \\
\hline 25 & 0 & 21 & 90 & & 2.1 & 0.0 & $3.562 \mathrm{E}+05$ & 0.0 & $+/-$ & 0.0 \\
\hline 26 & 1 & 47 & 100 & 0.021 & 4.3 & $1.526 \mathrm{E}+04$ & $7.174 \mathrm{E}+05$ & 6.6 & $+1-$ & 6.7 \\
\hline 27 & 1 & 29 & 100 & 0.034 & 2.7 & $1.526 \mathrm{E}+04$ & $4.427 \mathrm{E}+05$ & 10.7 & $+1-$ & 11.0 \\
\hline 28 & 0 & 22 & 80 & 0.000 & 2.5 & $0.000 \mathrm{E}+00$ & $4.198 \mathrm{E}+05$ & 0.0 & $+/-$ & 0.0 \\
\hline 29 & 0 & 19 & 30 & 0.000 & 5.8 & $0.000 \mathrm{E}+00$ & $9.668 \mathrm{E}+05$ & 0.0 & $+/-$ & 0.0 \\
\hline 30 & 0 & 29 & 100 & 0.000 & 2.7 & $0.000 \mathrm{E}+00$ & $4.427 \mathrm{E}+05$ & 0.0 & $+/-$ & 0.0 \\
\hline \multirow[t]{2}{*}{31} & 0 & 30 & 50 & 0.000 & 5.5 & $0.000 \mathrm{E}+00$ & $9.159 \mathrm{E}+05$ & 0.0 & $+1-$ & 0.0 \\
\hline & 30 & 1048 & & & 3.5 & 1.677E+04 & $5.860 \mathrm{E}+05$ & & & \\
\hline
\end{tabular}

Area of basic unit $=6.551 \mathrm{E}-07 \mathrm{~cm}-2$

CHI SQUARED = 17.14536 WITH 30 DEGREES OF FREEDOM

$\mathrm{P}($ chi squared $)=7.8 \%$

CORRELATION COEFFICIENT $=0.159$

VARIANCE OF SQR(Ns) $=.3577907$

VARIANCE OF SQR(Ni) $=1.800645$

$\mathrm{Ns} / \mathrm{Ni}=0.029+/-0.005$

MEAN RATIO $=0.034+/-0.007$

Pooled Age $=8.9+/-1.8 \mathrm{Ma}$

Mean Age $=10.6+/-2.4 \mathrm{Ma}$

Central Age $=8.9+/-1.7 \mathrm{Ma}$

$\%$ Variation $=10.48 \%$

Ages calculated using a zeta of $12250+/$ - 1000 for SRM963a glass

$\mathrm{RHO} D=5.087 \mathrm{E}+04 \mathrm{~cm}-2 ; \mathrm{ND}=2561$ 
N Aleutian COST \#1 well Zircon FT data summary

\begin{tabular}{|c|c|c|c|c|c|c|c|c|c|c|c|c|}
\hline 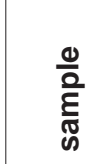 & 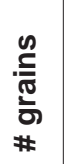 & n & $\bar{z}$ & 㐘 & 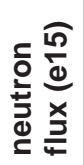 & 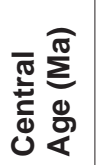 & 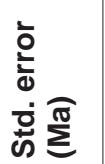 & 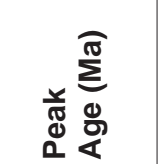 & 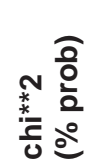 & $\supset$ & 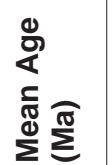 & 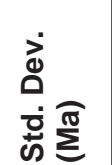 \\
\hline $\mathrm{AC1}$ & 20 & 2661 & 2152 & & 1.78 & 68.6 & 9.9 & $\begin{array}{r}82,12,23 \\
36,47\end{array}$ & $<1$ & 580 & 82 & 44 \\
\hline NAC2 & 30 & 3858 & 3554 & 4 & 1.77 & 57.5 & 5.2 & $48,28,83$ & $<1$ & 535 & 59 & 32 \\
\hline NAC3 & 29 & 1960 & 2065 & 5.20 & 1.76 & 50.2 & 5.5 & 25,82 & $<1$ & 437 & 64 & 35 \\
\hline NAC5 & 40 & 4981 & 5363 & & 1.74 & 46.9 & & $27,50,85$ & $<$ & 57 & 53 & 30 \\
\hline NAC6 & 20 & 827 & 1161 & $2.50 \mathrm{E}-04$ & 1.73 & 36.7 & 2.5 & 35 & $<1$ & 508 & 38 & 10 \\
\hline NAC8 & 14 & 591 & 757 & $2.10 \mathrm{E}-04$ & 1.71 & 39.2 & 4.2 & 32 & $<1$ & 406 & 41 & 14 \\
\hline
\end{tabular}

Individual Zircon Grain Data

\begin{tabular}{|c|c|c|c|c|c|c|c|c|c|c|}
\hline Sample & Flux & Grain \# & color & shape & $\begin{array}{c}\text { Area } \\
\left(\mathrm{cm}^{* * 2}\right)\end{array}$ & Ns & $\mathrm{Ni}$ & U (ppm) & $\begin{array}{l}\text { FT Age } \\
\text { (Ma) }\end{array}$ & $\begin{array}{l}\text { Std.Error } \\
\text { (Ma) }\end{array}$ \\
\hline 94NAC1 & $1.78 \mathrm{E}+15$ & 1 & B & $\mathrm{SH}$ & 8.00E-06 & 65 & 39 & 526 & 88.1 & 18.1 \\
\hline 94NAC1 & $1.78 \mathrm{E}+15$ & 2 & YB & $\mathrm{SH}$ & 1.20E-05 & 162 & 69 & 620 & 123.8 & 18.3 \\
\hline 94NAC1 & $1.78 \mathrm{E}+15$ & 3 & $B$ & SR & $2.00 \mathrm{E}-05$ & 153 & 70 & 378 & 115.4 & 17.1 \\
\hline 94NAC1 & $1.78 \mathrm{E}+15$ & 4 & $\mathrm{Y}$ & $E$ & 4.00E-05 & 160 & 89 & 240 & 95.0 & 13.0 \\
\hline 94NAC1 & $1.78 \mathrm{E}+15$ & 5 & $\mathrm{Y}$ & $\mathrm{SH}$ & 4.00E-05 & 77 & 78 & 210 & 52.4 & 8.6 \\
\hline 94NAC1 & $1.78 \mathrm{E}+15$ & 6 & YB & $\mathrm{SH}$ & $2.00 \mathrm{E}-05$ & 127 & 89 & 480 & 75.5 & 10.8 \\
\hline 94NAC1 & $1.78 \mathrm{E}+15$ & 7 & $B$ & $\mathrm{SH}$ & $2.00 \mathrm{E}-05$ & 165 & 114 & 615 & 76.6 & 9.7 \\
\hline 94NAC1 & $1.78 \mathrm{E}+15$ & 8 & $B$ & $E$ & 2.00E-05 & 110 & 258 & 1391 & 22.7 & 2.7 \\
\hline 94NAC1 & $1.78 \mathrm{E}+15$ & 9 & $\mathrm{Y}$ & $\mathrm{SH}$ & $2.00 \mathrm{E}-05$ & 100 & 61 & 329 & 86.7 & 14.4 \\
\hline 94NAC1 & $1.78 \mathrm{E}+15$ & 10 & $\mathrm{Y}$ & $E$ & $2.00 \mathrm{E}-05$ & 65 & 121 & 653 & 28.5 & 4.5 \\
\hline 94NAC1 & $1.78 \mathrm{E}+15$ & 11 & $\mathrm{O}$ & $E$ & 4.00E-05 & 167 & 193 & 520 & 45.9 & 5.1 \\
\hline 94NAC1 & $1.78 \mathrm{E}+15$ & 12 & B & SR & 3.20E-05 & 171 & 251 & 846 & 36.2 & 3.8 \\
\hline 94NAC1 & $1.78 \mathrm{E}+15$ & 13 & $\mathrm{Y}$ & $\mathrm{SH}$ & 4.00E-05 & 265 & 210 & 566 & 66.8 & 6.6 \\
\hline 94NAC1 & $1.78 \mathrm{E}+15$ & 14 & $\mathrm{O}$ & SR & 2.00E-05 & 221 & 64 & 345 & 181.3 & 26.5 \\
\hline 94NAC1 & $1.78 \mathrm{E}+15$ & 15 & YB & $\mathrm{SH}$ & $2.00 \mathrm{E}-05$ & 176 & 60 & 324 & 154.3 & 23.7 \\
\hline 94NAC1 & $1.78 \mathrm{E}+15$ & 16 & 0 & $\mathrm{SH}$ & $1.20 \mathrm{E}-05$ & 86 & 50 & 449 & 90.9 & 16.5 \\
\hline 94NAC1 & $1.78 \mathrm{E}+15$ & 17 & $\mathrm{Y}$ & $\mathrm{SH}$ & 1.20E-05 & 71 & 30 & 270 & 124.8 & 27.5 \\
\hline 94NAC1 & $1.78 \mathrm{E}+15$ & 18 & $B$ & $E$ & 7.20E-06 & 27 & 124 & 1858 & 11.6 & 2.5 \\
\hline 94NAC1 & $1.78 \mathrm{E}+15$ & 19 & $B$ & SR & $2.00 \mathrm{E}-05$ & 113 & 74 & 399 & 80.8 & 12.4 \\
\hline 94NAC1 & $1.78 \mathrm{E}+15$ & 20 & $\mathrm{Y}$ & $E$ & $2.00 \mathrm{E}-05$ & 180 & 108 & 582 & 88.1 & 11.1 \\
\hline NAC2 & $1.77 \mathrm{E}+15$ & 1 & B & $\mathrm{SH}$ & 1.60E-05 & 153 & 97 & 658 & 83.0 & 11.1 \\
\hline NAC2 & $1.77 \mathrm{E}+15$ & 2 & $B$ & $\mathrm{SH}$ & 1.20E-05 & 82 & 90 & 814 & 48.1 & 7.5 \\
\hline NAC2 & $1.77 \mathrm{E}+15$ & 3 & YB & $\mathrm{SH}$ & $1.20 \mathrm{E}-05$ & 100 & 92 & 832 & 57.3 & 8.5 \\
\hline NAC2 & $1.77 \mathrm{E}+15$ & 4 & $B$ & $E$ & $2.00 \mathrm{E}-05$ & 57 & 52 & 282 & 57.8 & 11.3 \\
\hline NAC2 & $1.77 \mathrm{E}+15$ & 5 & $\mathrm{Y}$ & $E$ & 3.20E-05 & 84 & 84 & 285 & 52.7 & 8.3 \\
\hline NAC2 & $1.77 \mathrm{E}+15$ & 6 & $\mathrm{Y}$ & $\mathrm{SH}$ & $2.00 \mathrm{E}-05$ & 303 & 195 & 1058 & 81.8 & 8.0 \\
\hline NAC2 & $1.77 \mathrm{E}+15$ & 7 & $\mathrm{Y}$ & $\mathrm{SH}$ & $2.00 \mathrm{E}-05$ & 162 & 188 & 1020 & 45.5 & 5.1 \\
\hline NAC2 & $1.77 \mathrm{E}+15$ & 8 & YB & $\mathrm{SH}$ & 2.00E-05 & 231 & 95 & 515 & 127.5 & 16.1 \\
\hline NAC2 & $1.77 \mathrm{E}+15$ & 9 & YB & $E$ & 2.00E-05 & 180 & 190 & 1031 & 50.0 & 5.5 \\
\hline NAC2 & $1.77 \mathrm{E}+15$ & 10 & $\mathrm{Y}$ & $\mathrm{SH}$ & 4.00E-05 & 200 & 112 & 304 & 93.9 & 11.5 \\
\hline NAC2 & $1.77 \mathrm{E}+15$ & 11 & $\mathrm{Y}$ & $E$ & 8.00E-06 & 63 & 69 & 936 & 48.2 & 8.6 \\
\hline NAC2 & $1.77 \mathrm{E}+15$ & 12 & YB & $E$ & 2.00E-05 & 202 & 111 & 602 & 95.6 & 11.8 \\
\hline NAC2 & $1.77 \mathrm{E}+15$ & 13 & $\mathrm{Y}$ & $\mathrm{SH}$ & 2.00E-05 & 112 & 50 & 271 & 117.5 & 20.4 \\
\hline NAC2 & $1.77 \mathrm{E}+15$ & 14 & RB & $\mathrm{SH}$ & 2.00E-05 & 58 & 51 & 277 & 59.9 & 11.7 \\
\hline
\end{tabular}




\begin{tabular}{|c|c|c|c|c|c|c|c|c|c|c|}
\hline Sample & Flux & Grain \# & color & shape & $\begin{array}{c}\text { Area } \\
\left(\mathrm{cm}^{\star *} 2\right)\end{array}$ & Ns & $\mathrm{Ni}$ & U (ppm) & $\begin{array}{l}\text { FT Age } \\
\text { (Ma) }\end{array}$ & $\begin{array}{l}\text { Std.Error } \\
\text { (Ma) }\end{array}$ \\
\hline NAC2 & $1.77 \mathrm{E}+15$ & 15 & $\mathrm{Y}$ & SR & 1.60E-05 & 50 & 69 & 468 & 38.3 & 7.2 \\
\hline NAC2 & $1.77 \mathrm{E}+15$ & 16 & $\mathrm{Y}$ & $\mathrm{SH}$ & 1.20E-05 & 36 & 39 & 353 & 48.7 & 11.4 \\
\hline NAC2 & $1.77 \mathrm{E}+15$ & 17 & $\mathrm{O}$ & $\mathrm{SH}$ & $2.00 \mathrm{E}-05$ & 87 & 164 & 889 & 28.0 & 3.8 \\
\hline NAC2 & $1.77 \mathrm{E}+15$ & 18 & $\bar{Y}$ & SR & $2.00 \mathrm{E}-05$ & 164 & 345 & 1871 & 25.1 & 2.5 \\
\hline NAC2 & $1.77 \mathrm{E}+15$ & 19 & $\mathrm{Y}$ & $\mathrm{SH}$ & 2.00E-05 & 105 & 99 & 537 & 55.9 & 8.1 \\
\hline NAC2 & $1.77 \mathrm{E}+15$ & 20 & $B$ & $\mathrm{SH}$ & 4.00E-05 & 130 & 240 & 651 & 28.6 & 3.3 \\
\hline NAC2 & $1.77 \mathrm{E}+15$ & 21 & RB & $E$ & 4.00E-05 & 226 & 105 & 285 & 113.0 & 13.9 \\
\hline NAC2 & $1.77 \mathrm{E}+15$ & 22 & $B$ & $\mathrm{SH}$ & 2.00E-05 & 127 & 178 & 965 & 37.7 & 4.6 \\
\hline NAC2 & $1.77 \mathrm{E}+15$ & 23 & YB & $E$ & 8.00E-05 & 70 & 62 & 84 & 59.5 & 10.6 \\
\hline NAC2 & $1.77 \mathrm{E}+15$ & 24 & $\bar{Y}$ & $E$ & $2.00 \mathrm{E}-05$ & 61 & 78 & 423 & 41.3 & 7.2 \\
\hline NAC2 & $1.77 \mathrm{E}+15$ & 25 & & $\mathrm{E}$ & 4.00E-05 & 97 & 129 & 350 & 39.7 & 5.5 \\
\hline NAC2 & $1.77 \mathrm{E}+15$ & 26 & $\bar{Y}$ & $\mathrm{SH}$ & $2.00 \mathrm{E}-05$ & 113 & 119 & 645 & 50.1 & 6.8 \\
\hline NAC2 & $1.77 \mathrm{E}+15$ & 27 & $B$ & $\mathrm{SH}$ & $2.00 \mathrm{E}-05$ & 221 & 114 & 618 & 101.8 & 12.2 \\
\hline NAC2 & $1.77 \mathrm{E}+15$ & 28 & YB & $E$ & $2.00 \mathrm{E}-05$ & 173 & 121 & 656 & 75.3 & 9.3 \\
\hline NAC2 & $1.77 \mathrm{E}+15$ & 29 & $\bar{Y}$ & $E$ & 4.00E-05 & 100 & 175 & 475 & 30.2 & 3.9 \\
\hline NAC2 & $1.77 \mathrm{E}+15$ & 30 & $B$ & $E$ & 1.20E-05 & 111 & 41 & 371 & 141.8 & 26.4 \\
\hline NAC3 & $1.76 \mathrm{E}+15$ & 1 & $\bar{Y}$ & $\mathrm{SH}$ & $2.40 \mathrm{E}-05$ & 85 & 193 & 877 & 23.1 & 3.1 \\
\hline NAC3 & $1.76 \mathrm{E}+15$ & 2 & $\mathrm{Y}$ & $\mathrm{SH}$ & $1.20 \mathrm{E}-05$ & 19 & 29 & 264 & 34.4 & 10.2 \\
\hline NAC3 & $1.76 \mathrm{E}+15$ & 3 & $\mathrm{Y}$ & $\mathrm{E}$ & 2.00E-05 & 126 & 78 & 425 & 84.5 & 12.5 \\
\hline NAC3 & $1.76 \mathrm{E}+15$ & 4 & $\mathrm{Y}$ & $\mathrm{SH}$ & 1.20E-05 & 86 & 92 & 836 & 49.0 & 7.5 \\
\hline NAC3 & $1.76 \mathrm{E}+15$ & 5 & YB & $\mathrm{SH}$ & 2.00E-05 & 160 & 94 & 513 & 89.0 & 12.0 \\
\hline NAC3 & $1.76 \mathrm{E}+15$ & 6 & $\mathrm{O}$ & $E$ & 2.00E-05 & 56 & 121 & 660 & 24.3 & 4.0 \\
\hline NAC3 & $1.76 \mathrm{E}+15$ & 7 & B & $\mathrm{SH}$ & 1.20E-05 & 67 & 37 & 336 & 94.6 & 19.7 \\
\hline NAC3 & $1.76 \mathrm{E}+15$ & 8 & $\bar{Y}$ & $E$ & 1.20E-05 & 21 & 27 & 245 & 40.8 & 12.0 \\
\hline NAC3 & $1.76 \mathrm{E}+15$ & 9 & $\bar{Y}$ & $\mathrm{SH}$ & $1.28 \mathrm{E}-05$ & 50 & 80 & 682 & 32.8 & 6.0 \\
\hline NAC3 & $1.76 \mathrm{E}+15$ & 10 & $\mathrm{O}$ & $E$ & 8.00E-06 & 66 & 49 & 668 & 70.5 & 13.5 \\
\hline NAC3 & $1.76 \mathrm{E}+15$ & 11 & $\mathrm{O}$ & $E$ & 1.20E-05 & 40 & 15 & 136 & 138.9 & 42.3 \\
\hline NAC3 & $1.76 \mathrm{E}+15$ & 12 & $\mathrm{Y}$ & $\mathrm{SH}$ & 1.20E-05 & 81 & 40 & 364 & 105.7 & 20.8 \\
\hline NAC3 & $1.76 \mathrm{E}+15$ & 13 & YB & SR & 1.20E-05 & 64 & 50 & 455 & 67.0 & 12.9 \\
\hline NAC3 & $1.76 \mathrm{E}+15$ & 14 & $\mathrm{O}$ & $\mathrm{SH}$ & $2.40 \mathrm{E}-05$ & 21 & 46 & 209 & 24.0 & 6.4 \\
\hline NAC3 & $1.76 \mathrm{E}+15$ & 15 & $\mathrm{O}$ & $E$ & 2.00E-05 & 92 & 58 & 316 & 83.0 & 14.2 \\
\hline NAC3 & $1.76 \mathrm{E}+15$ & 16 & $\mathrm{O}$ & $\mathrm{SH}$ & $1.28 \mathrm{E}-05$ & 56 & 50 & 426 & 58.7 & 11.6 \\
\hline NAC3 & $1.76 \mathrm{E}+15$ & 17 & $\mathrm{O}$ & $\mathrm{SH}$ & 1.20E-05 & 41 & 59 & 536 & 36.5 & 7.5 \\
\hline NAC3 & $1.76 \mathrm{E}+15$ & 18 & $\mathrm{O}$ & $\mathrm{SH}$ & 4.00E-05 & 135 & 211 & 575 & 33.6 & 3.9 \\
\hline NAC3 & $1.76 \mathrm{E}+15$ & 19 & $Y$ & $E$ & 2.00E-05 & 68 & 32 & 175 & 110.9 & 24.1 \\
\hline NAC3 & $1.76 \mathrm{E}+15$ & 20 & $\mathrm{O}$ & $\mathrm{SH}$ & 4.00E-05 & 58 & 118 & 322 & 25.8 & 4.2 \\
\hline NAC3 & $1.76 \mathrm{E}+15$ & 21 & YB & $\mathrm{SH}$ & 2.00E-05 & 123 & 83 & 453 & 77.6 & 11.3 \\
\hline NAC3 & $1.76 \mathrm{E}+15$ & 22 & $B$ & $E$ & 1.28E-05 & 44 & 67 & 571 & 34.5 & 6.8 \\
\hline NAC3 & $1.76 \mathrm{E}+15$ & 23 & $\bar{Y}$ & $\mathrm{SH}$ & 1.20E-05 & 30 & 51 & 464 & 30.9 & 7.2 \\
\hline NAC3 & $1.76 \mathrm{E}+15$ & 24 & YB & $E$ & $1.28 \mathrm{E}-05$ & 90 & 36 & 307 & 130.3 & 26.1 \\
\hline NAC3 & $1.76 \mathrm{E}+15$ & 25 & YB & $E$ & 1.60E-05 & 39 & 95 & 648 & 21.6 & 4.2 \\
\hline NAC3 & $1.76 \mathrm{E}+15$ & 26 & YB & $E$ & $2.00 \mathrm{E}-05$ & 26 & 47 & 256 & 29.1 & 7.2 \\
\hline NAC3 & $1.76 \mathrm{E}+15$ & 27 & YB & $\mathrm{SH}$ & 4.00E-05 & 129 & 75 & 205 & 89.9 & 13.4 \\
\hline NAC3 & $1.76 \mathrm{E}+15$ & 28 & $B$ & SR & 1.20E-05 & 50 & 56 & 509 & 46.8 & 9.3 \\
\hline NAC3 & $1.76 \mathrm{E}+15$ & 29 & $\bar{Y}$ & $\mathrm{SH}$ & 1.20E-05 & 37 & 76 & 691 & 25.6 & 5.2 \\
\hline NAC5 & $1.74 \mathrm{E}+15$ & 1 & $E$ & $B$ & 2.00E-05 & 60 & 110 & 607 & 28.3 & 4.6 \\
\hline NAC5 & $1.74 \mathrm{E}+15$ & 2 & YB & $E$ & 2.00E-05 & 125 & 93 & 513 & 69.6 & 9.8 \\
\hline NAC5 & $1.74 \mathrm{E}+15$ & 3 & B & $\mathrm{SH}$ & $4.00 \mathrm{E}-05$ & 440 & 173 & 477 & 131.0 & 12.6 \\
\hline NAC5 & $1.74 \mathrm{E}+15$ & 4 & YB & $\mathrm{SH}$ & 1.20E-05 & 72 & 46 & 423 & 81.0 & 15.5 \\
\hline NAC5 & $1.74 \mathrm{E}+15$ & 5 & B & $\mathrm{SH}$ & 1.60E-05 & 68 & 70 & 483 & 50.4 & 8.7 \\
\hline NAC5 & $1.74 \mathrm{E}+15$ & 6 & YB & $\mathrm{SH}$ & 2.00E-05 & 87 & 98 & 541 & 46.0 & 7.0 \\
\hline NAC5 & $1.74 \mathrm{E}+15$ & 7 & YB & $\mathrm{SH}$ & 4.00E-05 & 197 & 271 & 748 & 37.7 & 3.8 \\
\hline NAC5 & $1.74 \mathrm{E}+15$ & 8 & YB & $\mathrm{SH}$ & 4.00E-05 & 120 & 247 & 681 & 25.2 & 2.9 \\
\hline
\end{tabular}




\begin{tabular}{|c|c|c|c|c|c|c|c|c|c|c|}
\hline Sample & Flux & Grain \# & color & shape & $\begin{array}{c}\text { Area } \\
\left(\mathrm{cm}^{\star *} 2\right)\end{array}$ & Ns & $\mathrm{Ni}$ & $\mathrm{U}(\mathrm{ppm})$ & $\begin{array}{c}\text { FT Age } \\
(\mathrm{Ma})\end{array}$ & $\begin{array}{c}\text { Std.Error } \\
\text { (Ma) }\end{array}$ \\
\hline NAC5 & $1.74 \mathrm{E}+15$ & 9 & B & $\mathrm{SH}$ & $2.00 \mathrm{E}-05$ & 87 & 165 & 910 & 27.4 & 3.7 \\
\hline NAC5 & $1.74 \mathrm{E}+15$ & 10 & $\mathrm{Y}$ & $\mathrm{SH}$ & 2.00E-05 & 66 & 105 & 579 & 32.6 & 5.2 \\
\hline NAC5 & $1.74 \mathrm{E}+15$ & 11 & $\mathrm{Y}$ & $\mathrm{E}$ & 2.00E-05 & 86 & 135 & 745 & 33.1 & 4.7 \\
\hline NAC5 & $1.74 \mathrm{E}+15$ & 12 & YB & $E$ & 1.20E-05 & 40 & 72 & 662 & 28.9 & 5.8 \\
\hline NAC5 & $1.74 \mathrm{E}+15$ & 13 & B & $\mathrm{SH}$ & 1.20E-05 & 43 & 90 & 828 & 24.8 & 4.7 \\
\hline NAC5 & $1.74 \mathrm{E}+15$ & 14 & YB & $\mathrm{SH}$ & $2.00 \mathrm{E}-05$ & 89 & 54 & 298 & 85.2 & 15.0 \\
\hline NAC5 & $1.74 \mathrm{E}+15$ & 15 & $\mathrm{Y}$ & $\mathrm{SH}$ & $2.00 \mathrm{E}-05$ & 89 & 200 & 1103 & 23.1 & 3.1 \\
\hline NAC5 & $1.74 \mathrm{E}+15$ & 16 & $B$ & $\mathrm{SH}$ & 4.00E-05 & 150 & 207 & 571 & 37.6 & 4.2 \\
\hline NAC5 & $1.74 \mathrm{E}+15$ & 17 & $\mathrm{O}$ & $\mathrm{SH}$ & $2.00 \mathrm{E}-05$ & 130 & 137 & 756 & 49.2 & 6.3 \\
\hline NAC5 & $1.74 \mathrm{E}+15$ & 18 & B & $\mathrm{SH}$ & 8.00E-05 & 186 & 352 & 486 & 27.4 & 2.7 \\
\hline NAC5 & $1.74 \mathrm{E}+15$ & 19 & $B$ & $\mathrm{SH}$ & 4.00E-05 & 233 & 252 & 695 & 48.0 & 4.7 \\
\hline NAC5 & $1.74 \mathrm{E}+15$ & 20 & $\mathrm{Y}$ & $\mathrm{SH}$ & 4.00E-05 & 117 & 207 & 571 & 29.4 & 3.5 \\
\hline NAC5 & $1.74 \mathrm{E}+15$ & 21 & YB & $\mathrm{SH}$ & $2.00 \mathrm{E}-05$ & 102 & 86 & 474 & 61.4 & 9.2 \\
\hline NAC5 & $1.74 \mathrm{E}+15$ & 22 & $\mathrm{O}$ & $\mathrm{SH}$ & 4.00E-05 & 247 & 235 & 648 & 54.5 & 5.3 \\
\hline NAC5 & $1.74 \mathrm{E}+15$ & 23 & $B$ & $E$ & 2.00E-05 & 134 & 83 & 458 & 83.5 & 12.0 \\
\hline NAC5 & $1.74 \mathrm{E}+15$ & 24 & $\mathrm{Y}$ & $\mathrm{SH}$ & 8.00E-06 & 39 & 20 & 276 & 100.7 & 27.9 \\
\hline NAC5 & $1.74 \mathrm{E}+15$ & 25 & $\mathrm{Y}$ & $\mathrm{SH}$ & 1.20E-05 & 34 & 38 & 349 & 46.4 & 11.1 \\
\hline NAC5 & $1.74 \mathrm{E}+15$ & 26 & $B$ & $\mathrm{SH}$ & 4.00E-05 & 263 & 250 & 690 & 54.5 & 5.2 \\
\hline NAC5 & $1.74 \mathrm{E}+15$ & 27 & $\mathrm{Y}$ & $\mathrm{SH}$ & 2.00E-05 & 43 & 90 & 497 & 24.8 & 4.7 \\
\hline NAC5 & $1.74 \mathrm{E}+15$ & 28 & YB & $\mathrm{R}$ & 4.00E-05 & 209 & 127 & 350 & 85.1 & 10.0 \\
\hline NAC5 & $1.74 \mathrm{E}+15$ & 29 & YB & $\mathrm{SH}$ & 2.00E-05 & 206 & \begin{tabular}{|l|}
94 \\
\end{tabular} & 519 & 113.1 & 14.6 \\
\hline NAC5 & $1.74 \mathrm{E}+15$ & 30 & $\mathrm{~B}$ & $E$ & $1.20 \mathrm{E}-05$ & 39 & 57 & 524 & 35.5 & 7.5 \\
\hline NAC5 & $1.74 \mathrm{E}+15$ & 31 & $\mathrm{Y}$ & $\bar{E}$ & $2.00 \mathrm{E}-05$ & 43 & 106 & 585 & 21.1 & 3.9 \\
\hline NAC5 & $1.74 \mathrm{E}+15$ & 32 & YB & $\mathrm{SH}$ & 2.00E-05 & 81 & 85 & 469 & 49.4 & 7.9 \\
\hline NAC5 & $1.74 \mathrm{E}+15$ & 33 & $\mathrm{Y}$ & $\mathrm{SH}$ & $2.00 \mathrm{E}-05$ & 109 & 90 & 497 & 62.7 & 9.2 \\
\hline NAC5 & $1.74 \mathrm{E}+15$ & 34 & $B$ & $\mathrm{SH}$ & 4.00E-05 & 157 & 196 & 541 & 41.6 & 4.7 \\
\hline NAC5 & $1.74 \mathrm{E}+15$ & 35 & YB & $\mathrm{SH}$ & $2.00 \mathrm{E}-05$ & 73 & 132 & 728 & 28.7 & 4.3 \\
\hline NAC5 & $1.74 \mathrm{E}+15$ & 36 & YB & $\mathrm{SH}$ & $2.00 \mathrm{E}-05$ & 50 & \begin{tabular}{|l|}
92 \\
\end{tabular} & 508 & 28.2 & 5.1 \\
\hline NAC5 & $1.74 \mathrm{E}+15$ & 37 & YB & $E$ & 4.00E-05 & 256 & 225 & 621 & 59.0 & 5.8 \\
\hline NAC5 & $1.74 \mathrm{E}+15$ & 38 & YB & SR & 2.00E-05 & 133 & 55 & 303 & 124.7 & 20.4 \\
\hline NAC5 & $1.74 \mathrm{E}+15$ & 39 & $\mathrm{Y}$ & $E$ & 2.00E-05 & 160 & 81 & 447 & 102.0 & 14.3 \\
\hline NAC5 & $1.74 \mathrm{E}+15$ & 40 & $\mathrm{Y}$ & $\mathrm{SH}$ & $2.00 \mathrm{E}-05$ & 118 & 137 & 756 & 44.7 & 5.8 \\
\hline NAC6 & $1.73 \mathrm{E}+15$ & 1 & B & $\mathrm{SH}$ & 8.00E-06 & 16 & 30 & 416 & 27.5 & 8.6 \\
\hline NAC6 & $1.73 \mathrm{E}+15$ & 2 & $B$ & $E$ & $2.40 \mathrm{E}-05$ & 63 & 100 & 462 & 32.5 & 5.3 \\
\hline NAC6 & $1.73 \mathrm{E}+15$ & 3 & B & SR & -05 & 60 & 95 & 879 & 32.6 & 5.5 \\
\hline NAC6 & $1.73 \mathrm{E}+15$ & 4 & YB & $E$ & 1.60E-05 & 45 & 74 & 513 & 31.4 & 6.0 \\
\hline NAC6 & $1.73 \mathrm{E}+15$ & 5 & YB & $\mathrm{SH}$ & 6.00E-06 & 23 & 34 & 629 & 34.9 & 9.5 \\
\hline NAC6 & $1.73 \mathrm{E}+15$ & 6 & YB & $\mathrm{SH}$ & 1.60E-05 & 31 & 38 & 264 & 42.1 & 10.3 \\
\hline NAC6 & $1.73 \mathrm{E}+15$ & 7 & YB & SR & 1.20E-05 & 14 & 25 & 231 & 28.9 & 9.7 \\
\hline NAC6 & $1.73 \mathrm{E}+15$ & 8 & B & SR & 1.28E-05 & 46 & 68 & 590 & 34.9 & 6.8 \\
\hline NAC6 & $1.73 \mathrm{E}+15$ & 9 & $B$ & $\mathrm{SH}$ & 1.20E-05 & 34 & 41 & 379 & 42.8 & 10.0 \\
\hline NAC6 & $1.73 \mathrm{E}+15$ & 10 & YB & SR & 1.60E-05 & 84 & 88 & 610 & 49.2 & 7.7 \\
\hline NAC6 & $1.73 \mathrm{E}+15$ & 11 & YB & $\mathrm{SH}$ & 2.00E-05 & 23 & 65 & 361 & 18.3 & 4.5 \\
\hline NAC6 & $1.73 \mathrm{E}+15$ & 12 & YB & $\mathrm{SH}$ & 9.60E-06 & 46 & 68 & 786 & 34.9 & 6.8 \\
\hline NAC6 & $1.73 \mathrm{E}+15$ & 13 & YB & $\mathrm{SH}$ & 6.00E-06 & 26 & 35 & 647 & 38.3 & 10.0 \\
\hline NAC6 & $1.73 \mathrm{E}+15$ & 14 & YB & $\mathrm{SH}$ & 9.60E-06 & 16 & 33 & 382 & 25.0 & 7.7 \\
\hline NAC6 & $1.73 \mathrm{E}+15$ & 15 & $\mathrm{O}$ & $\mathrm{E}$ & 9.60E-06 & 44 & 60 & 694 & 37.8 & 7.6 \\
\hline NAC6 & $1.73 \mathrm{E}+15$ & 16 & $B$ & $\mathrm{SH}$ & 8.00E-06 & 40 & 40 & 555 & 51.5 & 11.7 \\
\hline NAC6 & $1.73 \mathrm{E}+15$ & 17 & $Y$ & $\mathrm{SH}$ & 8.00E-06 & 21 & 19 & 264 & 56.9 & 18.1 \\
\hline NAC6 & $1.73 \mathrm{E}+15$ & 18 & $\mathrm{Y}$ & $E$ & $2.00 \mathrm{E}-05$ & 74 & 100 & 555 & 38.2 & 6.0 \\
\hline NAC6 & $1.73 \mathrm{E}+15$ & 19 & $B$ & $\mathrm{R}$ & $2.00 \mathrm{E}-05$ & 86 & 117 & 649 & 37.9 & 5.5 \\
\hline NAC6 & $1.73 \mathrm{E}+15$ & 20 & B & SR & 8.00E-06 & 35 & 31 & 430 & 58.2 & 14.5 \\
\hline NAC8 & $1.71 \mathrm{E}+15$ & 1 & $B$ & $\mathrm{SH}$ & 1.20E-05 & 30 & 85 & 795 & 18.0 & 3.9 \\
\hline
\end{tabular}




\begin{tabular}{|l|c|c|c|c|c|c|c|c|c|c|}
\hline Sample & Flux & Grain \# & color & shape & $\begin{array}{c}\text { Area } \\
\left(\mathbf{c m}^{* *} \mathbf{2}\right)\end{array}$ & $\mathbf{N s}$ & $\mathbf{N i}$ & $\mathbf{U}(\mathbf{p p m})$ & $\begin{array}{c}\text { FT Age } \\
\mathbf{( M a )}\end{array}$ & $\begin{array}{c}\text { Std.Error } \\
\mathbf{( M a})\end{array}$ \\
\hline NAC8 & $1.71 \mathrm{E}+15$ & 2 & $\mathrm{YB}$ & $\mathrm{SH}$ & $1.60 \mathrm{E}-05$ & 109 & 130 & 912 & 42.8 & 5.7 \\
\hline NAC8 & $1.71 \mathrm{E}+15$ & 3 & $\mathrm{Y}$ & $\mathrm{SH}$ & $1.20 \mathrm{E}-05$ & 19 & 43 & 402 & 22.6 & 6.3 \\
\hline NAC8 & $1.71 \mathrm{E}+15$ & 4 & $\mathrm{Y}$ & $\mathrm{E}$ & $2.40 \mathrm{E}-05$ & 75 & 66 & 309 & 57.9 & 10.0 \\
\hline NAC8 & $1.71 \mathrm{E}+15$ & 5 & $\mathrm{Y}$ & $\mathrm{SH}$ & $7.20 \mathrm{E}-06$ & 21 & 26 & 405 & 41.2 & 12.2 \\
\hline NAC8 & $1.71 \mathrm{E}+15$ & 6 & $\mathrm{Y}$ & $\mathrm{SH}$ & $1.60 \mathrm{E}-05$ & 63 & 54 & 379 & 59.4 & 11.2 \\
\hline NAC8 & $1.71 \mathrm{E}+15$ & 7 & $\mathrm{YB}$ & $\mathrm{E}$ & $2.00 \mathrm{E}-05$ & 41 & 40 & 225 & 52.2 & 11.7 \\
\hline NAC8 & $1.71 \mathrm{E}+15$ & 8 & $\mathrm{~B}$ & $\mathrm{SR}$ & $2.00 \mathrm{E}-05$ & 52 & 85 & 477 & 31.2 & 5.6 \\
\hline NAC8 & $1.71 \mathrm{E}+15$ & 9 & $\mathrm{YB}$ & $\mathrm{E}$ & $7.20 \mathrm{E}-06$ & 31 & 26 & 405 & 60.7 & 16.3 \\
\hline NAC8 & $1.71 \mathrm{E}+15$ & 10 & $\mathrm{YB}$ & $\mathrm{SH}$ & $1.20 \mathrm{E}-05$ & 48 & 48 & 449 & 51.0 & 10.5 \\
\hline NAC8 & $1.71 \mathrm{E}+15$ & 11 & $\mathrm{O}$ & $\mathrm{SH}$ & $2.00 \mathrm{E}-05$ & 14 & 26 & 146 & 27.5 & 9.2 \\
\hline NAC8 & $1.71 \mathrm{E}+15$ & 12 & $\mathrm{Y}$ & $\mathrm{SH}$ & $1.60 \mathrm{E}-05$ & 28 & 51 & 358 & 28.0 & 6.7 \\
\hline NAC8 & $1.71 \mathrm{E}+15$ & 13 & $\mathrm{~B}$ & $\mathrm{E}$ & $2.00 \mathrm{E}-05$ & 33 & 47 & 264 & 35.8 & 8.2 \\
\hline NAC8 & $1.71 \mathrm{E}+15$ & 14 & $\mathrm{O}$ & $\mathrm{SH}$ & $7.20 \mathrm{E}-06$ & 27 & 30 & 468 & 45.9 & 12.3 \\
\hline
\end{tabular}

Notes:

Color abbreviations: $\mathrm{Y}=$ yellow, $\mathrm{B}=$ brown, $\mathrm{O}=$ orange;

Shape: SH=subhedral, SR=subrounded, E=euhedral, R=rounded. 


\section{BRISTOL BAY-ALASKA PENINSULA BIBLIOGRAPHY OF SELECTED REFERENCES}

Addicott, W.O., 1971, Tertiary marine mollusks of Alaska; An annotated bibliography: U.S. Geological Survey Bulletin 1343, $30 \mathrm{p}$.

Alaska Department of Natural Resources, 1971, Aeromagnetic map, Northwest Nushagak Bay Quadrangle: BBNC files, data set index no. 461, 1 sheet, scale 1:1,250,000.

1971, Aeromagnetic survey, Goodnews Bay Quadrangle: BBNC files, data set index no. 488, 1 sheet, scale $1: 250,000$.

Alaska Department of Natural Resources and Bristol Bay Native Corporation, 2003, Memorandum of Understanding Between the Alaska Department of Natural Resources and Bristol Bay Native Corporation to Facilitate Oil and Gas Lease Sales on State and BBNC Land in the Bristol Bay Region, 3 p.

Alaska Division of Geological \& Geophysical Surveys staff, 1986, Summary of existing data and potential for commercial hydrocarbon accumulations, Bristol Bay, Alaska: Alaska Division of Geological \& Geophysical Surveys Public-Data File 86-13, 20 p.

Alaska Division of Oil \& Gas, 2004, General information and digital well data—Alaska Peninsula areawide lease sale and Bristol Bay Basin exploration license area: Information and data Compilation, v. 1.

_2004, Seismic data—Alaska Peninsula areawide lease sale and Bristol Bay basin exploration license area: Information and data compilation, v. 3.

_2004, Scanned electric well logs_-Alaska Peninsula areawide lease sale and Bristol Bay basin exploration license area: Information and data compilation, v. 2.

2004, Alaska Peninsula areawide oil and gas lease sale and Bristol Bay basin exploration license area, information and data compilation: Alaska Division of Oil \& Gas, Alaska Peninsula oil and gas resource series, 3 volume CD-ROM.

Alaska Oil and Gas Conservation Commission (AOGCC), 2004, Alaska exploratory wells list: http://www.state. ak.us/local/akpages/ADMIN/ogc/homeogc.shtml

Albanese, M.D., and Goff, K.M., 1987, Petrified wood occurrences in Alaska: Alaska Division of Geological \& Geophysical Surveys Public-Data File 87-26, 11 p.

Allaway, W.H., Jr., 1982, Sedimentology and petrography of the Shelikof Formation, Alaska Peninsula: San Jose, CA, unpublished M.S. thesis, San Jose State University, 81 p.

Allaway, W.H., Jr., and Miller, J.W., 1984, Newly recognized sedimentary environments in the Shelikof Formation, in Coonrad, W.L, and Elliot, R.L., eds., The United States Geological Survey in Alaska; Accomplishments during 1981: U.S. Geological Survey Circular 868, p. 34-37.

Allaway, W.H., Jr., Detterman, R.L, Miller, J.W., and Magoon, L.B., 1984, Stratigraphic clarification of the Shelikof Formation, Alaska Peninsula, in Stratigraphic notes, 1983: U.S. Geological Survey Bulletin 1537-A, p. A21-A27.

Allison, R.C., 1978, Late Oligocene through Pleistocene molluscan faunas in the Gulf of Alaska region: The Veliger, v. 21, p. 171-188.

Allison, R.C., and Addicott, W.O., 1973, The Mytilus-middendorffi group (Bivalvia) of the North American Miocene [abs.]: Geological Society of America Abstracts with Programs, v. 5, p. 2-3.

1976, The North Pacific Miocene record of Mytilus (Plicatomytilus), a new subgenus of Bivalvia: U.S. Geological Survey Professional Paper 962, 22 p.

Amoco, 1979, Geologic map of the Alaska Peninsula: Amoco Production Company Geologic Report FR-02-79, (unpublished report of 1977 field season, available through Alaska Geologic Materials Center), scale 1 in = $16,000 \mathrm{ft}(1: 192,000)$.

1979, High sensitivity magnetometer survey of the Alaska Peninsula, upper half: BBNC files, data set index no. 703, 1 sheet, scale 1:96,000.

1979, High sensitivity magnetometer survey of the Alaska Peninsula, lower half: BBNC files, data set index no. 704, 1 sheet, scale 1:96,000.

1979, High sensitivity magnetometer survey of the Alaska Peninsula: BBNC files, data set index no. 771, 1 sheet, scale 1:96,000.

1980, Bouguer gravity map, Bristol Bay: BBNC files, data set index no. 705, 1 sheet, scale 1:250,000.

1982, Seismic map of shallow unconformity, east and southeast of Egegik Bay, Alaska Peninsula: BBNC files, data set index no. 688, 1 sheet, scale 1:48,000. 
Amoco, 1982, Seismic map of deep unconformity, east and southeast of Egegik Bay, Alaska Peninsula: BBNC files, data set index no. 687, 1 sheet, scale 1:48,000.

1982, ANM shotpoints; Bristol Bay, southern peninsula, Egegik Bay: BBNC files, data set index no. 689, 1 sheet, various scales.

1982, Alaska Peninsula, Bouguer gravity, density 2.67: BBNC files, data set index no. 702, 2 sheets, scale 1:250,000.

1983, Geologic map of the Staniukovich Mountain area: Amoco Production Company Geologic Report FW-18-81R, (unpublished report of 1981 field season, available through Alaska Geologic Materials Center), scale 1:63,360.

1983, Top of unconformity (time-structure); Bristol Bay, southern peninsula, Ugashik: BBNC files, data set index no. 686, 1 sheet, scale 1:48,000.

1983, Deep unconformity; Bristol Bay, southern peninsula, Egegik Bay: BBNC files, data set index no. 687, 1 sheet, scale 1:48,000.

-1983, Shallow unconformity; Bristol Bay, southern peninsula, Egegik Bay: BBNC files, data set index no. 688,1 sheet, scale 1:48,000.

1983, BBNC southern peninsula, seismic base for gravity and magnetics, base map 3: BBNC files, data set index no. 727, 1 sheet, scale 1:250,000.

1985, Post drilling appraisal of the Amoco Becharof State No. 1 well: BBNC files, data set index no. 623, $35 \mathrm{p}$.

Atwood, W.W., 1911, Geology and mineral resources of parts of the Alaska Peninsula: U.S. Geological Survey Bulletin 467, $137 \mathrm{p}$.

Barbacka, Maria, Pálfy, J., and Smith, P.L., 2006, Hettangian (Early Jurassic) plant fossils from Puale Bay (Peninsular terrane, Alaska): Review of Palaeobotany and Palynology, v. 142, p. 33-46.

Barnes, I., and McCoy, G.A., 1979, Possible role of mantle-derived $\mathrm{CO}_{2}$ in causing two "phreatic" explosions in Alaska: Geology, v. 7, p. 434-435.

Bascle, R., Evans, D., Seidlitz, A., and Borkowske, J., 1987, Alaska Peninsula/Becharof National Wildlife Refuge oil and gas assessment: Bureau of Land Management, 83 p., http://www.blm.gov/pgdata/etc/medialib/blm/ak/aktest/ energy/egy_pubs.Par.81720.File.dat/ak_peninsula_becharof_oga.pdf

Beeman, W.R., Obuch, R.C., and Brewton, J.D., 1996, Digital map data, text, and graphical images in support of the 1995 National Assessment of United States Oil and Gas Resources: U.S. Geological Survey Digital Data Series DDS-35, 1 disk, http://pubs.usgs.gov/dds/dds-035/DDS-35.html

Beikman, H.M., 1980, Geologic map of Alaska: U.S. Geological Survey Professional Paper 171, 1 plate, scale 1:2,500,000.

Bergman, S.C., Murphy, John, and Kelley, Shari, this volume.

Bishop, W.C., 1985, History, geology, energy, and mineral resources of Bristol Bay area: Bristol Bay Native Corporation, Internal Report, 145 p.

Blackwell, D.D., and Richards, M., editors, 2004, Geothermal Map of North America: Tulsa, OK, American Association of Petroleum Geologists, 1 sheet, scale 1:6,500,000; http://www.smu.edu/geothermal/2004NAMap/2004NAmap. htm.

Blasko, D.P., 1976, Oil and gas seeps in Alaska: Alaska Peninsula, western Gulf of Alaska: U.S. Department of the Interior, Bureau of Mines Report of Investigations no. 8122, 78 p.

Blodgett, R.B., this volume.

Blodgett, R.B., and Clautice, K.H., 2005, Oil and gas seeps of the Puale Bay-Becharof Lake-Wide Bay region, northern Alaska Peninsula: Alaska Division of Geological \& Geophysical Surveys Preliminary Interpretive Report 2005-6, 13 p., 1 sheet.

Blodgett, R.B., and Frýda, J., 2001, On the occurrence of Spinidelphinulopsis whaleni (Late Triassic [early Norian] Gastropoda) in the Cornwallis Limestone, Kuiu Island, southeastern Alaska (Alexander terrane) and its paleobiogeographic significance: Bulletin of the Czech Geological Survey, v. 76, no. 4, p. 235-242.

2001, Upper Triassic gastropod biogeography of western North America [abs.]: Geological Society of America Abstracts with Programs, v. 33, no. 3, p. A-53.

Blodgett, R.B., and Sralla, Bryan, 2008, A major unconformity between Permian and Triassic strata at Cape Kekurnoi, Alaska Peninsula; Old and new observations on stratigraphy and hydrocarbon potential, in Haeussler, P.J., and Galloway, J.P., eds., Studies by the U.S. Geological Survey in Alaska, 2006: U.S. Geological Survey Professional Paper 1739-E, 13 p. [http://pubs.usgs.gov/pp/pp1739/e/]. 
Blodgett, R.B., Finzel, E.S., Reifenstuhl, R.R., Clautice, K.H., Ridgway, K.D., and Gillis, R.J., 2008, Jurassic through Pliocene age megafossil samples collected in 2005 by the Alaska Division of Geological \& Geophysical Surveys from the Bristol Bay-Port Moller area, Alaska Peninsula: Alaska Division of Geological \& Geophysical Surveys Preliminary Interpretive Report 2008-2, 12 p.

Blodgett, R.B., Frýda, J., and Stanley, G.D., Jr., 2001, Delphinulopsidae, a new neritopsoidean gastropod family from the Upper Triassic (upper Carnian or lower Norian) of the Wallowa terrane, northeastern Oregon: Journal of Czech Geological Society, v. 46, no. 3-4, p. 307-318.

2003, Late Triassic gastropod biogeography of southern Alaskan accreted terranes [abs.]: Geological Society of America Abstracts with Programs, v. 35, no. 4, p. 59.

2005, Upper Triassic gastropod fauna from southern Alaska and its implications for terrane accretion [abs.]: Geological Society of America Abstracts with Programs, v. 37, no. 7, p. 82.

_2006, Late Triassic gastropod faunas of western North America-A useful tool in terrane analysis [abs.]: Geological Society of America Abstracts with Programs, v. 38, no. 5, p. 81.

Blodgett, R.B., Weems, R.E., and Wilson, F.H., 1995, Upper Jurassic reptiles from the Naknek Formation, Alaska Peninsula; A glimpse into Alaska’s own “Jurassic Park”: Geological Society of America, Abstracts with Programs, v. 27, no. 5, p. 6.

Blodgett, R.B., Wilson, F.H., Stanley, G.D., Jr., McRoberts, C.A., and Sandy, M.R., 2000, Upper Triassic stratigraphy and fauna of the Taylor Mountains D-2 and D-3 quadrangles (SW part of the Farewell terrane), southwest Alaska [abs.]: Geological Society of America Abstracts with Programs, v. 32, no. 6, p. A-4.

Bolger, G.W., and Reifenstuhl, R.R., this volume.

Bond, G.C., Lewis, S.D., Taber, J., Steckler, M.S., and Kominz, M.A., 1988, Evidence for formation of a flexural back arc basin by compression and crustal thickening in the central Alaska Peninsula: Geology, v. 16, p. 1,147-1,150.

Boreham, C.J., and Powell, T.G., 1993; Petroleum source rock potential of coal and associated sediments—qualitative and quantitative aspects, in Law, B.E., and Rice, D.D., eds., Hydrocarbons from coal: American Association of Petroleum Geologists Studies in Geology 38, p. 133-157.

Bristol Bay Native Corporation, 2003, Regional Land Status Map: Bristol Bay Native Corporation, Bristol Environmental \& Engineering Services Corporation, 1 sheet.

2004, Bristol Bay Native Corporation Oil and Gas Files: 5 p.

Brockway, Ronald, Alexander, B., Day, P., Lyle, W.M., Hiles, R., Decker, W., Polski, W., and Reed, B.L., 1975, Bristol Bay region, stratigraphic correlation section, southwest Alaska: Anchorage, The Alaska Geological Society, 1 sheet.

Burk, C.A., 1965, Geology of the Alaska Peninsula-Island Arc and Continental Margin: The Geological Society of America Memoir 99, 250 p., 3 sheets.

Capps, S.R., 1921, Preliminary report on petroleum in Alaska: U.S. Geological Survey Bulletin 719, 83 p. 1923, The Cold Bay district, in U.S. Geological Survey Staff, Mineral resources of Alaska, report on progress of investigations in 1921: U.S. Geological Survey Bulletin 739, p. 77-116, 1 plate, scale 1:250,000.

1937, Kodiak and vicinity, Alaska: U.S. Geological Survey Bulletin 868-B, p. 93-134, 2 plates, scale $1: 250,000$.

Carlson, W.D., 1990, Mechanisms and kinetics of apatite fission track annealing: American Mineralogist, v. 75, p. $1,120-1,139$.

Carlson, W.D., Donelick, R.A., and Ketcham, R.A., 1999, Variability of apatite fission track annealing kinetics I; Experimental results: American Mineralogist, v. 84, p. 1,213-1,223.

Case, J.E., Detterman, R.L., Wilson, F.H., Chuchel, B.A., and Yount, M.E., 1988, Maps showing aeromagnetic survey and geologic interpretation of parts of the Ugashik and Karluk Quadrangles, Alaska: U.S. Geological Survey, Miscellaneous Field Studies Map 1539-D, 12 p., 2 plates, scale 1:250,000.

Citron, G.P, Kay, R.W., Mahlburg Kay, S., Snee, L.W., and Sutter, J.F., 1980, Tectonic significance of early Oligocene plutonism on Adak Island, central Aleutian Islands, Alaska: Geology, v. 8, p. 375-379.

Clayton, J.L., 1993, Composition of crude oils generated from coals and coaly organic matter in shales, in Law, B.E., and Rice, D.D., eds., Hydrocarbons from coal: American Association of Petroleum Geologists Studies in Geology 38, p. 185-201.

Clegg, P., and Holdsworth, R.E., 2005, Complex deformation as a result of strain partitioning in transpression zones; an example from the Leinster Terrane, SE Ireland: Journal of the Geological Society, v. 16.2, p. 187-202.

Comer, C.D., and Martin, G.C., 1994, Petroleum potential of Mesozoic strata of the Cook Inlet outer continental shelf planning area, Alaska, Third Symposium on Studies Related to Continental Margins-A Summary of Year Five and Year Six Activities: Austin, TX, p. 172-180. 
Connelly, William, and Moore, J.C., 1979, Geologic map of the northwest side of the Kodiak Islands, Alaska: U.S. Geological Survey Miscellaneous Field Studies Map 1057, 2 plates, scales 1:250,000 and 1:63,360. [See USGS Open-File Report 77-382]

Conwell, C.N., and Triplehorn, D.M., 1978, Herendeen Bay-Chignik coals, southern Alaska Peninsula: Alaska Division of Geological \& Geophysical Surveys Special Report 8, 15 p., 2 sheets.

Cronin, M.A., Brannon, Ernie, and Moulton, Larry, 1999, Natural oil seeps in the Puale Bay area of the Becharof National Wildlife Refuge, and the Blue Creek area of the Alaska Peninsula National Wildlife Refuge, Alaska—A report to Refuge Manager, Becharof National Wildlife Refuge (dated 27 September 1999).

Crowley, K.D., 1985, Thermal significance of fission track length distributions: Nuclear Tracks, v. 10, p. 311-322.

Csejtey, B., Jr., and St. Aubin, D.R., 1981, Evidence for northwestward thrusting of the Talkeetna Superterrane, and its regional significance, in Albert, N.R.D., and Hudson, T., eds., 1981, The U.S. Geological Survey in Alaska; Accomplishments during 1979: U.S. Geological Survey Circular 823-B, p. B49-B51.

Dall, W.H., 1882, Notes on Alaska Cenozoic deposits: American Journal of Science, 3rd Series, v. 24, p. 67-68.

Decker, P.L., this volume.

Decker, J., Bergman, S.C., Blodgett, R.B., Box, S.E., Bundtzen, T.K., Clough, J.G., Coonrad, W.L., Gilbert, W.G., Miller, M.L., Murphy, J.M., Robinson, M.S., and Wallace, W.K., 1994, Geology of southwestern Alaska, in Plafker, G., and Berg, H.C., eds., The geology of Alaska: Boulder, CO, Geological Society of America, The Geology of North America, v. G1, p. 285-310.

Decker, P.L., Finzel, E.S., Ridgway, K.D., Reifenstuhl, R.R., and Blodgett, R.B., 2005, Preliminary summary of the 2005 field season; Port Moller, Herendeen Bay, and Dillingham areas, Bristol Bay Basin, Alaska Peninsula: Alaska Division of Geological \& Geophysical Surveys Preliminary Interpretive Report 2005-7, 55 p., 2 sheets.

Decker, P.L., Reifenstuhl, R.R., Finzel, E.S., and Helmold, K.P., 2006, Play concepts for reopening the Bristol Bay basin; Tertiary and Mesozoic petroleum systems of the Alaska Peninsula, (abs): American Association of Petroleum Geologists Bulletin, v. 90, Program Abstracts (digital).

Decker, P.L., Reifenstuhl, R.R., and Gillis, R.J., this volume.

Demaison, G., and Huizinga, B.J., 1994, Genetic classification of petroleum systems using three factors; Charge, migration and entrapment, in Magoon, L.B., and Dow, W.G., eds., The petroleum system — from source to trap: American Association of Petroleum Geologists Memoir 60, p.73-89.

DeMets, Charles, Gordon, R.G., Argus, D.F., and Stein, Seth, 1994, Effects of recent revisions to the geomagnetic reversal time scale on estimates of current plate motions: Geophysical Research Letters, v. 21, p. 2,191-2,194.

Detterman, R.L., 1978, Interpretation of depositional environments in the Chignik Formation, Alaska Peninsula, in Johnson, K.M., ed., The United States Geological Survey in Alaska; Accomplishments during 1977: U.S. Geological Survey Circular 772-B, p. B62-B63.

1990, Stratigraphic correlation and interpretation of exploratory wells, Alaska Peninsula: U.S. Geological Survey Open-File Report 90-279, 51 p.

Detterman, R.L., and Hartsock, J.K., 1966, Geology of the Iniskin-Tuxedni region, Alaska: U.S. Geological Survey Professional Paper 512, 78 p., 6 plates, scale 1:63,360.

Detterman, R.L., and Miller, R.L., 1985, Kaguyak Formation-An Upper Cretaceous flysch deposit, in BartschWinkler, Susan, and Reed, K.M., eds., United States Geological Survey in Alaska: Accomplishments during 1983: U.S. Geological Survey Circular 945, p. 49-51.

Detterman, R.L., and Reed, B.L., 1980, Stratigraphy, structure, and economic geology of the Iliamna Quadrangle, Alaska: U.S. Geological Survey Bulletin 1368-B, 86 p., 1 plate, scale 1:250,000.

Detterman, R.L., Case, J.E., Church, Stanley E., Frisken, J.G., Wilson, F.H., and Yount, M.E., 1990, The Alaska Mineral Resource Assessment Program (AMRAP); background information to accompany folio of geologic and resource maps of the Ugashik, Bristol Bay, and western part of Karluk quadrangles, Alaska, U.S. Geological Survey Circular 1046, 14 p.

Detterman, R.L., Case, J.E., Miller, J.W., Wilson, F.H., and Yount, M.E., 1996, Stratigraphic framework of the Alaska Peninsula: U.S. Geological Survey Bulletin 1969-A, 74 p.

Detterman, R.L., Case, J.E., Wilson, F.H., and Yount, M.E., 1987, Geologic map of the Ugashik, Bristol Bay, and western part of Karluk quadrangles, Alaska: U.S. Geological Survey Miscellaneous Investigations Series Map 1685, 1 plate, scale 1:250,000. 
Detterman, R.L., Case, J.E., Wilson, F.H., Yount, M.E., and Allaway, W.H., Jr., 1983, Generalized geologic map of the Ugashik, Bristol Bay, and part of Karluk quadrangles, Alaska: U.S. Geological Survey Miscellaneous Field Studies Map 1539-A, 1 plate, scale 1:250,000.

Detterman, R.L., Hudson, Travis, Plafker, George, Tysdal, R.G., and Hoare, J.M., 1976, Reconaissance geologic map along Bruin Bay and Lake Clark faults in Kenai and Tyonek quadrangles, Alaska: U.S. Geological Survey Open-File Map 76-477, 4 p., 1 plate, scale 1:250,000.

Detterman, R.L., Miller, J.W., and Case, J.E., 1985, Megafossil locality map, checklists, and pre-Quaternary stratigraphic sections of Ugashik, Bristol Bay, and part of Karluk quadrangles, Alaska: U.S. Geological Survey Miscellaneous Field Studies Map 1539-B, 3 plates, scale 1:250,000.

Detterman, R.L., Miller, T.P., Yount, M.E., and Wilson, F.H., 1979, Generalized geologic map of the Chignik and Sutwik Island quadrangles, Alaska: U.S. Geological Survey Miscellaneous Field Studies Map 1053-A, 1 plate, scale 1:250,000.

Detterman, R.L., Miller, T.P., Yount, M.E., and Wilson, F.H., 1981, Geologic map of the Chignik and Sutwik Island quadrangles, Alaska: U.S. Geological Survey Miscellaneous Investigations Series Map 1229, 1 plate, scale 1:250,000.

1981, Quaternary geologic map of the Chignik and Sutwik Island quadrangles, Alaska: U.S. Geological Survey Miscellaneous Investigations Series Map 1292, 1 plate, scale 1:250,000.

Detterman, R.L., Wilson, F.H., Yount, M.E., and Miller, T.P., 1987, Quaternary geologic map of the Ugashik, Bristol Bay, and western part of the Karluk quadrangles, Alaska: U.S. Geological Survey Miscellaneous Investigations Series Map 1801, 1 plate, scale 1:250,000.

Detterman, R.L., Yount, M.E., and Case, J.E., 1981, Megafossil sample locality map, checklists, and stratigraphic sections of the Chignik and Sutwik Island quadrangles, Alaska: U.S. Geological Survey Miscellaneous field Studies Map MF-1053-N, 2 plates, scale 1:250,000.

Dickinson, W.R., 1970, Interpreting detrital modes of graywacke and arkose, Journal of Sedimentary Petrology, v. 40, p. 695-707.

Dickinson, W.R. and Suczek, C.A., 1979, Plate tectonics and sandstone compositions: American Association of Petroleum Geologists, v. 63, p. 2,164-2,182.

Dickson, J.A.D., 1965, A modified staining technique for carbonates in thin section: Nature, v. 205, p.587. 1966, Carbonate identification and genesis as revealed by staining: Journal of Sedimentary Petrology, v. 36, p. 491-505.

Dodson, M.H., and McClelland-Brown, E., 1985, Isotopic and paleomagnetic evidence for rates of cooling, uplift, and erosion, in Snelling, N.J., ed., The chronology of the geological record: Geological Society of London, Memoir 10, p. 315-325.

Donelick, R.A., Ketcham, R.A., and Carlson, W.D., 1999, Variability of apatite fission-track annealing kinetics; II, Crystallographic orientation effects: American Mineralogist, v. 84, p. 1,224-1,234.

Donelick, R.A., O’Sullivan, P.B., and Ketcham, R.A., 2005, Apatite fission-track analysis: Reviews in Mineralogy and Geochemistry, v. 58, no. 1, p. 49-94.

Dow, W.G., 1977, Kerogen studies and geological interpretations: Journal of Geochemical Exploration, v. 7, p. 79-99.

-1977, Petroleum source beds on continental slopes and rises, in Geology of continental margins: American Association of Petroleum Geologists Short Course Note Series No. 6, p. D1-D37.

-1983, Geochemical analysis of North Aleutian Shelf Cost No. 1 well, Alaska: U.S. Minerals Management Service public well files - Robertson Research Report No. 823/135, 315 p.

Dubois, G.D., Wilson, F.H., and Shew, N.B., 1987, Potassium-argon age determinations from the Port Moller and Stepovak Bay quadrangles, Alaska Peninsula: U.S. Geological Survey Open-File Report 87-191, 1 plate, scale 1:250,000.

Dumoulin, J.A., Whalen, M.T., and Harris, A.G., 2008, Lithofacies, age, and sequence stratigraphy of the Carboniferous Lisburne Group in the Skimo Creek area, central Brooks Range, in Haeussler, Peter J., and Galloway, John P., eds., Studies by the U.S. Geological Survey in Alaska, 2006: U.S. Geological Survey Professional Paper 1739-B, 64 p. [http://pubs.usgs.gov/pp/pp1739/b/].

Dunham, R.J., 1962, Classification of carbonate rocks according to texture, in Ham, W.E., ed., Classification of carbonate rocks: American Association of Petroleum Geologists Memoir 1, p. 108-121.

Eakins, G.R., 1970, A petrified forest on Unga Island, Alaska, Alaska Division of Mines and Geology, Special Report 3, 19 p. 
Eckdale, A.A., Bromley, R.G., and Pemberton, S.G., 1984, Ichnology trace fossils in sedimentology and stratigraphy: Society of Economic Paleontologists and Mineralogists Short Course 15, 317 p.

Elder, W.P., and Miller, J.W., 1991, Maps showing fossil localities and checklists of Jurassic and Cretaceous macrofauna of western Alaska: U.S. Geological Survey Open-File Report 91-629, 71 p., 3 plates, scale 1:500,000.

Embry, A.F., and Klovan, J.E., 1972, Absolute water depth limits of late Devonian paleoecological zones: Geological Research, v. 61, p. 672-686.

Epstein, A.G., Epstein, J.B., and Harris, L.D., 1977, Conodont color alteration-An index to organic metamorphism: U.S. Geological Survey Professional Paper 995, 27 p.

Espitalié, J., Deroo, G., and Marquis, F., 1985, La pyrolyse Rock-Eval et ses applications: Revue de l’Institut Français du Pétrole, v. 40, p. 563-579 and 755-784.

Espitalié, J., Laporte, J.L., Madec, M., Marquis, F., Leplat, P., Paulet, J., Boutefeu, A., 1977, Methode rapide de caracterisation des roches meres, de leur potential petrolier et de leur degree d'evolution: Revue de l'Institut Français du Pétrole, v. 32, p. 23-42.

Espitalié, J., Madec, M., and Tissot, B., 1977, Source rock characterization method for petroleum exploration: Proceedings of the 9th Annual Offshore Technology Conference, v. 3, p. 439-448.

Fairchild, D.T., 1977, Paleoenvironments of the Chignik Formation, Alaska Peninsula: Fairbanks, Alaska, University of Alaska Fairbanks, M.S. thesis, 168 p.

Finzel, E.S., Reifenstuhl, R.R., Decker, P.L., and Ridgway, K.D., 2005, Sedimentology, stratigraphy, and hydrocarbon reservoir-source rock potential, using surface and subsurface data, of Tertiary and Mesozoic strata, Bristol Bay Basin and Alaska Peninsula: Alaska Division of Geological \& Geophysical Surveys Preliminary Interpretive Report 2005-4, 67 p.

Finzel, E.S., Ridgway, K.D., Reifenstuhl, R.R., Blodgett, R.B., White, J., and Decker, P.L., in press, Stratigraphic framework and estuarine depositional environments of the Miocene Bear Lake Formation, Bristol Bay basin, Alaska: Onshore equivalents to potential reservoir strata in a frontier gas-rich basin: American Association of Petroleum Geologists Bulletin.

Fiorillo, A.R., Website showing hadrosaur footprint from Cretaceous rocks at Aniakchak crater: http://www.uaf. edu/seagrant/NewsMedia/01ASJ/09.21.01dinosaur.html (accessed August 20, 2008).

Fischer, P.H., 1872, Sur quelques fossiles de l’Alaska, rapportés par. M.A. Pinart: Comptes Rendus, v. 75, p. $1,784-1,786$.

-1875, Sur quelques fossiles de l’Alaska, in Pinard, A.L., Voyages à la côte nord-ouest de l'Amérique executés dans les années 1870-1872: Paris, E. Leroux, pt. 1, p. 33-36.

Fleet, A.J., and Scott, A.C., 1994, Coal and coal-bearing strata as oil-prone source rocks; An overview, in Scott, A.C., and Fleet, A.J., eds., Coal and coal-bearing strata as oil-prone source rocks?: Geological Society Special Publication No. 77, p. 1-8.

Fleischer, R.L., Price, P.B., and Walker, R.M., 1975, Nuclear tracks in solids: Los Angeles, University of California Press, $605 \mathrm{p}$.

Flett, T.O., 1988, Geothermal gradient, in Turner, R.F., ed., Geological and operational summary, North Aleutian Shelf COST No. 1 well, Bering Sea, Alaska: U.S. Minerals Management Service, OCS Report MMS 88-0089, p. 180-183.

1988, Organic geochemistry, in Turner, R.F., ed., Geological and operational summary, North Aleutian Shelf COST No. 1 well, Bering Sea, Alaska: U.S. Minerals Management Service, OCS Report MMS 88-0089, p. 184-202.

Flügel, E., 2004, Microfacies of carbonate rocks; Analysis, interpretation, and application: Berlin-Heidelberg, Springer-Verlag, 976 p.

Franks, S.G., and Hite, D.M., 1980, Controls on zeolite cementation in Upper Jurassic sandstones, lower Cook Inlet, Alaska: AAPG Bulletin, v. 64, no. 5, p. 708-709.

Frech, Fritz, 1908, Die zircumpacifische Trias; Lethaea geognostica, Teil 2, Das Mesozoicum: Band 1, Trias, v. 4, p. 488-509.

Frýda, J., and Blodgett, R. B., 2001, Chulitnacula, a new paleobiogeographically distinctive gastropod genus from Upper Triassic strata in accreted terranes of southern Alaska: Journal of Czech Geological Society, v. 46, no. 3-4, p. 299-306.

Gabb, W.M., 1864, Description of Triassic fossils of California and the adjacent territories: California Geological Survey, Paleontology, v. 1, p. 17-35, plates 3-6.

Gallagher, K., Brown, R.W., and Johnson, C., 1998, Fission track analysis and its applications to geological problems: Annual Reviews of Earth and Planetary Sciences, v. 26, p. 519-572. 
Galloway, W.E., 1974, Deposition and diagenetic alteration of sandstone in northeast Pacific arc-related basins; Implications for graywacke diagenesis: Geological Society of America Bulletin, v. 85, no. 3, p. 379-390.

Gillis, R.J., Reifenstuhl, R.R., and Decker, P.L., 2008, Implications of new apatite and zircon fission-track thermochronology for Mesozoic and Tertiary basin margin exhumation, upper Alaska Peninsula [abs.], in Garver, J.I., and Montario, M.J., eds., Extended Abstract Volume: FT 2008 - The 11th International Conference on Thermochronometry, Anchorage Alaska, Sept. 15-19, 2008, p. 95, http://www.union.edu/ft2008/Abstract_volume.html.

Gillis, R.J., Reifenstuhl, R.R., Decker, P.L., Strauch, A.L., and Helmold, K.P., 2007, Onshore Alaska Peninsula petroleum system assessment: preliminary summary of outcrop studies of the Port Moller area, 2006 [abs]: American Association of Petroleum Geologists Bulletin, v. 91, Annual Meeting Program Abstracts (digital), http://www.searchanddiscovery.net/documents/2007/07018annual_abs_Ingbch/abstracts/lbGillis.htm.

Gleadow, A.J.W., and Duddy, I.R., 1981, A natural long term annealing experiment for apatite: Nuclear Tracks, v. 5, p. 169-174.

Gleadow, A.J.W., Duddy, I.R., and Lovering, J.F., 1983. Fission track analysis; A new tool for the evaluation of thermal histories and hydrocarbon potential: Australian Petroleum Association Journal, v. 23, p. 93-102.

Gluyas, J.G., 1984, Early carbonate diagenesis within Phanerozoic shales and sandstones of the northwest European shelf: Clay Minerals, v. 19, p. 309-321.

Gradstein, F.M., Ogg, J.G., Smith, A.G., Agterberg, F.P., Bleeker, W., Cooper, R.A., Davydov, V., Gibbard, P., Hinnov, L.A., House, M.R., Lourens, L., Luterbacher, H.P., McArthur, J., Melchin, M.J., Robb, L.J., Shergold, J., Villeneuve, M., Wardlaw, B.R., Ali, J., Brinkhuis, H., Hilgen, F.J., Hooker, J., Howarth, R.J., Knoll, A.H., Laskar, J., Monechi, S., Plumb, K.A., Powell, J., Raffi, I., Röhl, U., Sadler, P., Sanfilippo, A., Schmitz, B., Shackleton, N.J., Shields, G.A., Strauss, H., Van Dam, J., van Kolfschoten, T., Veizer, J., and Wilson, D., 2004, A geologic time scale 2004: Cambridge University Press, 589 p.

Grant-Mackie, J.A., and Silberling, N.J., 1990, New data on the Upper Triassic bivalve Monotis in North America and the new subgenus Pacimonotis: Journal of Paleontology, v. 64, no. 2, p. 240-254.

Green, P.F., Duddy, I.R., Gleadow, A.J.W., and Lovering, J.F., 1989, Apatite fission track analysis as a paleotemperature indicator for hydrocarbon exploration, in Naeser, N.D., and McCulloch, T.H., eds., Thermal history of sedimentary basins; methods and case histories: New York, Springer-Verlag, p. 181-195.

Green, P.F., Duddy, I.R., Laslett, G.M., Hegarty, K.A., Gleadow, A.J.W., and Lovering, J.F., 1989, Thermal annealing of fission tracks in apatite; 4, Quantitative modeling techniques and extension to geological timescales: Chemical Geology (Isotope Geoscience Section), v. 79, no. 2, p. 155-182.

Gulf Oil, 1962, Total magnetic contours, Port Moller area: BBNC files, data set index no. 695, 1 sheet, scale $1: 8,000$.

1962, Gravity meter survey, Port Moller-Port Heiden area, Alaska: BBNC files, data set index no.693, 1 sheet, scale 1:8,000.

1964, Port Moller project; Fireweed and Sandy River area, Deep Phantom Horizon \#2: BBNC files, data set index no. 694, 1 sheet, scale 1:8,000.

1969, Port Moller project, Fireweed and Sandy River area, Deep Phantom Horizon \# 2: Interpretive seismic map, BBNC files, data set index no. 694, 1 sheet, scale 1:8,000.

Hanna, G.D., Leach, C.E., Tallant, R.L., Bryan, J.J., and Scott, E.W., 1937, Preliminary geologic report on the Bear Creek Anticline, Alaska_1937: San Francisco, Tide Water Associated Oil Co.-Standard Oil Co. of California-Union Oil Co. of California internal report, 20 p.

Hanson, B.M., 1957, Middle Permian limestone on Pacific side of Alaska Peninsula: American Association of Petroleum Geologists Bulletin, v. 41, no. 10, p. 2,376-2,378.

Hazzard, J.C., Borax, E., Bryan, J.J., and Shoemaker, R.W., 1950, Cretaceous rocks in the Kamishak Bay area, Cook Inlet, Alaska: Science, v. 112, no. 2904, p. 226-227.

Helmold, K.P., and Brizzolara, D.W., 2005, Reservoir quality of Tertiary sandstones from Bristol Bay basin, Alaska Peninsula: preliminary report: Alaska Division of Oil and Gas internal report; http://www.dog.dnr.state. ak.us/oil/products/publications/akpeninsula/reservoir_quality_report.pdf

Helmold, K.P., Brizzolara, D.W., and Reifenstuhl, R.R., this volume.

Hill, M.D., 1979, Volcanic and plutonic rocks of the Kodiak-Shumagin shelf, Alaska; Subduction deposits and near-trench magmatism: Santa Cruz, CA, University of California Santa Cruz, Ph.D. Dissertation, 259 p.

Hite, David, 2004, Bristol Bay Native Corporation-Hydrocarbon potential of Native lands in the Bristol Bay area, southern Alaska: BBNC files, Data Set Index No. 774. 
Hite, David, 2004, Hydrocarbon potential of the Alaska Peninsula and Bristol Bay basin, southern Alaska, - Emphasis on Bristol Bay Native Corporation lands, 8 p.

Hoare, H.J., and Coonrad, W.L., 1961, Geologic map of the Hagemeister Island Quadrangle, Alaska: U.S. Geological Survey Miscellaneous Geologic Investigations, Map 321, 1 plate, scale 1:250,000.

1961, Geologic map of the Goodnews Quadrangle, Alaska: U.S. Geological Survey Miscellaneous Geologic Investigations, Map 339, 1 plate, scale 1:250,000.

1978, Geologic Map of the Goodnews and Hagemeister Island Quadrangles region, southwestern Alaska: U.S. Geological Survey Open-File Report 78-9B, 2 plates, scale 1:250,000.

Hollick, A., 1930, The Upper Cretaceous floras of Alaska: U.S. Geological Survey Professional Paper 182, 185 p.

Hoose, P.J., and Whitney, John, 1980, Map showing selected geologic features of the outer continental shelf, Shelikof Strait, Alaska: U.S. Geological Survey Open-File Report 80-2035, 1 plate, scale 1:250,000.

Hunt, J.M., 1991, Generation of gas and oil from coal and other terrestrial organic matter: Organic Geochemistry, v. 17, p. 673-680.

Imlay, R.W., 1953, Callovian (Jurassic) ammonites from the United States and Alaska, Part 2. Alaska Peninsula and Cook Inlet regions: U.S. Geological Survey Professional Paper 249-B, p. 41-108.

1975, Stratigraphic distribution and zonation of Jurassic (Callovian) ammonites in southern Alaska: U.S. Geological Survey Professional Paper 836, 28 p.

1981, Early Jurassic ammonites from Alaska: U.S. Geological Survey Professional Paper 1148, 49 p.

1981, Early Jurassic ammonites from Alaska: U.S. Geological Survey Professional Paper 1190, 40 p.

1984, Early and middle Bajocian (Middle Jurassic) ammonites from southern Alaska: U.S. Geological Survey Professional Paper 1322, 38 p.

Imlay, R.W., and Detterman, R.L., 1977, Some Lower and Middle Jurassic beds in Puale Bay-Alinchak Bay area, Alaska Peninsula: Bulletin of the American Association of Petroleum Geologists, v. 61, no. 4, p. 607-611.

Iriondo, Alexander, Kunk, M.J., and Wilson, F.H., 2003, ${ }^{40} \mathrm{Ar} /{ }^{39} \mathrm{Ar}$ geochronology of igneous rocks in the Taylor Mountains and Dillingham quadrangles in southwestern Alaska: U.S. Geological Survey Open-File Report 03-0421, 32 p.

Jeffords, R.M., 1957, Permian fossils from an island in Puale Bay, Alaska: Houston, Humble Oil \& Refining Co. Geologic Research Report 57-24, 6 p.

Jones, D.L., 1973, Structural elements and biostratigraphic framework of Lower Cretaceous rocks in southern Alaska, in The Boreal Lower Cretaceous: Liverpool, England, Seel House Press, p. 1-18.

Jones, D.L., and Detterman, R.L., 1966, Cretaceous stratigraphy of the Kamishak Hills, Alaska Peninsula, in Geological Survey research 1966, Chapter D: U.S. Geological Survey Professional Paper 550-D, p. D53-D58.

Jones, D.L., and Miller, J.W., 1976, Preliminary geologic map of the Alaska Peninsula showing post-Callovian Mesozoic fossil localities: U.S. Geological Survey Open-File Report 76-76, 2 plates, scale 1:500,000.

Jones, D.L., and Silberling, N.J., 1979, Mesozoic stratigraphy - the key to tectonic analysis of southern and central Alaska: U.S. Geological Survey Open-File Report 79-1200, 37 p.

Jones, D.L., Silberling, N.J., and Hillhouse, John, 1977, Wrangellia-A displaced terrane in northwestern North America: Canadian Journal of Earth Science, v. 14, p. 2565-2577.

Jones, R.R., and Tanner, P.W.G., 1995, Strain partitioning in transpression zones: Journal of Structural Geology, v. 17, p. 793-802.

Katz, B.J., 1983, Limitations of 'Rock-Eval’ pyrolysis for typing organic matter: Organic Geochemistry, v. 4, p. 195-199.

Keller, A.S., and Reiser, H.N., 1959, Geology of the Mt. Katmai area, Alaska: U.S. Geological Survey Bulletin 1058-G, p. 261-298, 1 plate, scale 1:250,000.

Kelley, J.S., 1980, Environments of deposition and petrography of Lower Jurassic volcaniclastic rocks, southwestern Kenai Peninsula, Alaska: Davis, University of California, Ph.D. thesis, 304 p.

Kelley, J.S., and Denman, J.M., 1972, Geological literature on the Alaska Peninsula and adjacent area: Alaska Division of Geological \& Geophysical Surveys Special Report 20, 64 p.

Kellum, L.B., 1945, Jurassic stratigraphy of Alaska and petroleum exploration in northwest America: Transactions of the New York Academy of Science, ser. 2, v. 7, no. 8, p. 201-209.

Kellum, L.B., Daviess, S.N., and Swinney, C.M., 1945, Geology and oil possibilities of the southeastern part of the Wide Bay anticline, Alaska, U.S. Geological Survey Open-File Report, 17 p. 
Kennedy, G.C., and Waldron, H.H., 1955, Geology of Pavlof volcano and vicinity, Alaska: Bulletin 1028-A, p. 1-19, scale 1:100,000.

Kirschner, C.L., 1988, Map showing sedimentary basins of offshore and continental shelf areas, Alaska: U.S. Geological Survey Miscellaneous Investigations Series 1873, 1 plate, scale 1:2,500,000.

Knappen, R.S., 1929, Geology and mineral resources of the Aniakchak district: U.S. Geological Survey Bulletin 797, p. 161-223.

Kummel, Bernhard, 1953, American Triassic coiled nautiloids: U.S. Geological Survey Professional Paper 250, 104 p., 19 plates.

Langford, F.F., and Blanc-Valleron, M.-M., 1990, Interpreting Rock-Eval pyrolysis data using graphs of pyrolyzable hydrocarbons vs. total organic carbon: American Association of Petroleum Geologists Bulletin, v. 74, p. 799-804.

Laniz, R.V., Stevens, R.E., and Norman, M.B., 1964, Staining of plagioclase feldspar and other minerals: U.S. Geological Survey Professional Paper 501-B, p. B152-B153.

Lankford, S.M., and Magoon, L.B., 1977, Petrography of the Upper Jurassic through Oligocene sandstones in the Cape Douglas-Kamishak Hills area, lower Cook Inlet in Johnson, K.M., ed., The United States Geological Survey in Alaska, Accomplishments during 1977, U.S. Geological Survey Circular 772-B, p. B60-B62.

Larson, J.A., 1988, Paleontology and Biostratigraphy, in Turner, R.F., ed., Geological and operational summary, North Aleutian Shelf COST No. 1 well, Bering Sea, Alaska: U.S. Minerals Management Service, OCS Report MMS 88-0089, p. 159-179.

Laslett, G.M., Green, P.F., Duddy, I.R., and Gleadow, A.J.W., 1987, Thermal modeling of fission tracks in apatite: 2. A quantitative analysis: Chemical Geology, v. 65, p. 1-13.

Levinson, S.A., and Jeffords, R.M., 1956, Megafossils and spores and pollen from Puale Bay, Alinchak Bay, and Cape Kekurnoi, Alaska: Houston, Humble Oil \& Refining Co. Geologic Research Report, 10 p., 4 plates.

Lindholm, R.C., and Finkelman, R.B., 1972, Calcite staining; Semiquantitative determination of ferrous iron: Journal of Sedimentary Petrology, v. 42, p. 239-242.

Loveland, A.M., Reifenstuhl, R.R., Gillis, R.J., and Decker, P.L., 2007, Outcrop sample results from mercury injection capillary pressure analyses, Bristol Bay, Alaska Peninsula: Alaska Division of Geological \& Geophysical Surveys Raw Data File 2007-3, 11 p.

Lyle, W.M., and Dobey, P.M., 1973, Geologic and mineral evaluation of the Aniakchak River drainage, Alaska Peninsula, for wild and scenic river study: Alaska Division of Geological \& Geophysical Surveys Open-File Report 26, 21 p., 1 sheet, scale 1:63,360.

-1974, Geologic evaluation of the Herendeen Bay area, Alaska Peninsula: Alaska Division of Geological \& Geophysical Surveys Open-File Report 48, 22 p., 3 sheets.

Lyle, W.M., Morehouse, J.A., Palmer, I.F., Jr., and Bolm, J.G., 1979, Tertiary formations and associated Mesozoic rocks in the Alaska Peninsula area, Alaska, and their petroleum reservoir and source-rock potential: Alaska Division of Geological \& Geophysical Surveys Geologic Report 62, 69 p., 19 sheets.

Mackevett, E.M., Jr., and Plafker, G., 1974, The Border Ranges Fault in southcentral Alaska: U.S. Geological Survey Journal of Research, v. 2, no. 3, p. 323-329.

MacNeil, F.S., 1970, New Pliocene Chlamys (Swiftopecten) and Beringius from the Alaska Peninsula: Nautilus, v. 84, p. 69-74.

1973, Marine fossils from the Unga Conglomerate Member of the Bear Lake Formation, Cape Aliaksin, Alaska Peninsula, Alaska: Science Reports of the Tohoku University, Series 2, Geology Tohoku Daigaku Rika Hokoku, Dai 2: Shu Chishitsugaku v. 6, no. 6, p. 117-123.

Magoon, L.B., 1994, Tuxedni-Hemlock(!) petroleum system in Cook Inlet, Alaska, U.S.A., in Magoon, L.B., and Dow, W.G., eds., The petroleum system-from source to trap: American Association of Petroleum Geologists Memoir 60, p. 359-370.

Magoon, L.B., and Anders, D.E., 1990, Oil-source rock correlation using carbon isotope data and biological marker compounds, Cook Inlet-Alaska Peninsula [abs.]: American Association of Petroleum Geologists Bulletin, v. 74, p. 711.

Magoon, L.B., and Anders, D.E., 1992, Oil-to-source rock correlation using carbon-isotopic data and biological marker compounds, Cook Inlet-Alaska Peninsula, Alaska, in Moldowan, J.M., Albrecht, P., and Philip, R.P., eds., Biological Markers in Sediments and Petroleum: Prentice Hall, Englewood Cliffs, New Jersey, p. 241-274.

Magoon, L.B., and Claypool, G.E., 1981, Petroleum geology of Cook Inlet basin; an exploration model: American Association of Petroleum Geologists Bulletin, v. 65, p. 1,043-1,061. 
Magoon, L.B., Adkison, W.L., Chmelik, F.B., Dolton, G.L., Fischer, M.A., Hampton, M.A., Sable, E.G., and Smith, R.A., 1976, Hydrocarbon potential, geologic hazards, and infrastructure for exploration and development of the lower Cook Inlet, Alaska: U.S. Geological Survey Open-File Report 76-449, 132 p.

Magoon, L.B., Egbert, R.M., and Petering, George, 1978, Upper Jurassic and Cretaceous rocks of the Kamishak Hills-Douglas River area, lower Cook Inlet, in Johnson, K.M., ed., The United States Geological Survey in Alaska: Accomplishments during 1977: U.S. Geological Survey Circular 772-B, p. B57-B59.

Magoon, L.B., Griesbach, F.B., and Egbert, R.M., 1980, Nonmarine Upper Cretaceous rocks, Cook Inlet, Alaska: AAPG Bulletin, v.64, p. 1259-1266.

Magoon, L.B., Molenaar, C.M., Bruns, T.R., Fisher, M.A., and Valin, Z.C., 1995, Southern Alaska Province (003), in Gautier, D.L., Dolton, G.L., Takahashi, K.I., and Varnes, K.L., eds., 1995 National Assessment of United States Oil and Gas Resources on CD-ROM: U.S. Geological Survey Digital Data Series 30 (CD-ROM), 21 p.

Mancini, E.A., and Deeter, T.M., 1977, Alaska Peninsula Late Cretaceous fore-arc deposition [abs.]: American Association of Petroleum Geologists Bulletin, v. 61, no. 5, p. 811.

Mancini, E.A., Deeter, T.M., and Wingate, F.H., 1978, Upper Cretaceous arc-trench gap sedimentation on the Alaska Peninsula: Geology, v. 6, p. 437-439.

Marincovich, Louie, Jr., 1981, Tyrannoberingius rex, a new genus and species of Miocene gastropod from Alaska: Journal of Paleontology, v. 55, p. 176-179.

1981, Fossils from the Bear Lake Formation and fossils from the Meshik Formation, in Detterman, R.L., Yount, E., and Case, J., eds., Megafossil localities, checklists, and stratigraphic sections, Chignik and Sutwik Island Quadrangles, Alaska: U.S. Geological Survey Miscellaneous Field Studies Map 103-N, 2 plates.

1983, Molluscan paleontology, paleoecology, and North Pacific correlations of the Miocene Tachilni Formation, Alaska Peninsula, Alaska: Bulletin of American Paleontology, v. 84, no. 317, p. 59-155, plates 12-23.

1984, Asiatic mollusks in Miocene faunas of the Alaska Peninsula: U.S. Geological Survey Professional Paper 1375, p. 179-180.

1988, Miocene mollusks from the lower part of the Bear Lake Formation on Ukolnoi Island, Alaska Peninsula, Alaska: Natural History Museum of Los Angeles County, Contributions to Sciences, no. 397, 20 p.

Marincovich, Louie, Jr., and Kase, Tomoki, 1986, An occurrence of Turritella (Hataiella) sagai in Alaska; implications for the age of the Bear Lake Formation: Tokyo, Japan, Bulletin of the National Science Museum, Series C, Geology and Paleontology, v. 12, no. 2, p. 61-66.

Marincovich, Louie, Jr., and Powell, C.L., II, 1989, Preliminary Tertiary molluscan biostratigraphy of the Alaska Peninsula, southwestern Alaska: U.S. Geological Survey Open-File Report 89-674, 2 plates.

Marincovich, Louie, Jr., Barinov, K.B., and Oleinik, A.E., 2002, The Astarte (Bivalvia: Astartidae) that document the earliest opening of Bering Strait: Journal of Paleontology, v. 76, p. 239-245.

Martin, G.C., 1915, The western part of Kenai Peninsula, in Martin, G.C., Johnson, B.L., and Grant, U.S., Geology and mineral resources of Kenai Peninsula, Alaska: U.S. Geological Survey Bulletin 587, p. 41-112.

1916, Triassic rocks of Alaska: Geological Society of America Bulletin, v. 27, p. 685-718

1921, Preliminary report on petroleum in Alaska: U.S. Geological Survey Bulletin 719, 83 p., 5 plates, scale $1: 125,000$.

1924, Correlation and paleogeography of the Cretaceous of Alaska: Pan-Pacific Scientific Congress, Australia, 1923, Proceedings, v. 2, p. 1,345-1,359.

1926, The Mesozoic stratigraphy of Alaska. U.S. Geological Survey Bulletin 776, 493 p.

Martin, G.C., and Katz, F.J., 1912, A geologic reconnaissance of the Iliamna region, Alaska: U.S. Geological Survey Bulletin 485, 138 p.

McClay, K., and Bonora, M., 2001, Analog models of restraining stepovers in strike-slip fault systems: American Association of Petroleum Geologists Bulletin, v. 85, p. 233-260.

McGee, D.L., 1973, Gulf of Alaska petroleum seeps: Alaska Division of Geological \& Geophysical Surveys Open-File Report 32, 9 p.

McGimsey, R.G., Neal, C.A., and Girina, O., 2003, 1998 volcanic activity in Alaska and Kamchatka: summary of events and response of the Alaska Volcano Observatory: U.S. Geological Survey Open-File Report 03-423, $35 \mathrm{p}$.

McLean, H., 1977, Organic geochemistry, lithology, and paleontology of Tertiary and Mesozoic rocks from wells on the Alaska Peninsula: U.S. Geological Survey Open-File Report 77-813, 63 p.

1979, Sandstone petrology: Upper Jurassic Naknek Formation of the Alaska Peninsula and coeval rocks on the Bering Shelf: Journal of Sedimentary Petrology, v. 49, no. 4, p. 1263-1268. 
McLean, Hugh, Engelhardt, C.L., and Howell, D.G., 1978, Reconnaissance geologic map of the Cold Bay and False Pass quadrangles, Alaska: U.S. Geological Survey Open-File Report 78-323, 1 plate, scale 1:250,000.

McRoberts, C.A., 1997, Late Triassic (Norian-Rhaetian) bivalves from the Antimonio Formation, northwestern Sonora, Mexico: Revista Mexicana de Ciencias Geológicas, v. 14, no. 2, p. 167-177.

McRoberts, C.A., and Blodgett, R.B., 2002, Upper Triassic (Norian) mollusks from the Taylor Mountains Quadrangle, southwest Alaska, in Wilson, F.H., and Galloway, J.P., eds., Geologic Studies in Alaska by the U.S. Geological Survey, 2000: U.S. Geological Survey Professional Paper 1662, p. 55-75.

Melim, L.A., Swart, P.K., and Maliva, R.G., 1995, Meteoric like fabrics forming in marine waters; Implications for the use of petrography to identify diagenetic environments: Geology, v. 23, p. 755-758.

Melim, L.A., Westphal, H., Swart, P.K., Eberli, G.P., and Munnecke, A., 2002, Questioning carbonate diagenetic paradigms; Evidence from the Neogene of the Bahamas: Marine Geology, v. 185, p. 24-54.

Merritt, R.D., 1986, Coal resources of the Miocene Unga Conglomerate Member, Bear Lake Formation, Unga Island, Alaska Peninsula: Alaska Division of Geological \& Geophysical Surveys Public-Data File 86-69, 33 p.

Merritt, R.D., and McGee, D.L., 1986, Depositional environments and resource potential of Cretaceous coal-bearing strata at Chignik and Herendeen Bay, Alaska Peninsula: Alaska Division of Geological \& Geophysical Surveys Public-Data File 86-72, 44 p.

Merritt, R.D., McGee, D.L., Clough, J.G., and Belowich, M.A., 1987, Coal Atlas of the Alaska Peninsula: Alaska Division of Geological \& Geophysical Surveys unpublished report.

Mertie, J.B., Jr., 1938, The Nushagak district, Alaska: U.S. Geological Survey Bulletin 903, 96 p., 1 plate, scale $1: 250,000$.

Meyer, J.F., Jr., 2007, Total intensity magnetic anomaly for the Bristol Bay region and Alaska Peninsula: Alaska Department of Natural Resources, Division of Oil \& Gas, Alaska Peninsula Oil and Gas Field Map Series, plate 3 of 3 , scale 1:500,000.

Meyer, J.F., Jr., Hansen, J.J., Brizzolara, D. W., Pritchard, M.E., Boggess, P.L., Beaty, C.J., Dirks, K.L., Gumpert, J.D., Bolin, K.A., Gibler, K.I., and Phillipson, E.M., 2004, Bristol Bay region and Alaska Peninsula oil and gas programs: Alaska Department of Natural Resources, Division of Oil \& Gas, Alaska Peninsula Resource Series, plate 1 of 4 .

2004, Regional geology of the Bristol Bay region and Alaska Peninsula: Alaska Department of Natural Resources, Division of Oil \& Gas, Alaska Peninsula Resource Series, plate 2 of 4.

2004, Oil and gas well data for the Alaska Peninsula and Bristol Bay region: Alaska Department of Natural Resources, Division of Oil \& Gas, Alaska Peninsula Resource Series, plate 3 of 4.

2004, Seismic data availability for the Bristol Bay region and the Alaska Peninsula: Alaska Department of Natural Resources, Division of Oil \& Gas, Alaska Peninsula Resource Series, plate 4 of 4. 2004, Alaska aeromagnetic compilation, Ugashik quadrangle: Alaska Department of Natural Resources, Division of Oil \& Gas, Alaska Peninsula Resource Series, plate 10 of 19, scale 1:250,000. 2004, Oil and gas resource map series legend: Alaska Department of Natural Resources, Division of Oil \& Gas, Alaska Peninsula Resource Series, plate 19 of 19, Scale 1:250,000.

2004, Alaska Peninsula areawide oil and gas lease sale: information and data compilation industry packet: Alaska Division of Oil \& Gas Alaska Peninsula Resource Series (digital, updated 2007).

Mickey, M.B., Haga, H. Boettcher, R.S., and Kling, S.A., 2005, Northwestern Alaska Peninsula-Bristol Bay basin biostratigraphy study: Micropaleo Consultants Job No. 25-104, 287 p., 4 oversize plates, 40 oversize figures, Alaska Division of Oil \& Gas online publication http://www.dog.dnr.state.ak.us/oil/products/publications/akpeninsula/ biostrat.htm

Micropaleo Consultants, Inc., 2005, North Aleutian shelf public biostratigraphic data set; 11-well study with cross sections correlating the COST well with Alaska Peninsula wells, 286 p., 18 sheets.

Miller, D.J., Payne, T.G., and Gryc, G., 1959, Geology of possible petroleum provinces in Alaska: U.S. Geological Survey Bulletin 1094, $131 \mathrm{p}$.

Miller, J.W., and Jones, D.L., 1981, A field guide to some common megafossils from post-Callovian Mesozoic rocks of the Alaska Peninsula: U.S. Geological Survey Open-File 81-745, 15 p., 1 plate.

Mobil Oil, 1959, Kuskokwim district, Bristol Bay project: Interpretative seismic map, BBNC files, data set index no. 698,1 sheet, scale 1:8,000.

1963, Exhibit 4, structure contour map, seismic phantom horizon of probably late Miocene: BBNC files, data set index no. 697, 1 sheet, scale 1:8,000. 
Mojsisovics, Edmund, von, 1886, Arktische Triasfaunen: Mémoires de l’Académie Impériale des Sciences de St.-Pétersbourg, 7th ser., v. 33, no. 6, 159 p., 20 plates.

Molenaar, C.M., 1995, Alaska Peninsula, in Magoon, L.B., Molenaar, C.M., Bruns, T.R., Fisher, M.A., Valin, Z.C., Southern Alaska Province (003), in Gautier, D.L., Dolton, G.L., Takahashi, K.I., and Varnes, K.L., eds., 1995 National assessment of United States oil and gas resources-Results, methodology, and supporting data: U.S. Geological Survey Digital Data Series 30, CD-ROM, p. 2-4.

1996, Thermal-maturity patterns and geothermal gradients on the Alaska Peninsula, in Johnsson, M.J., and Howell, D.G., eds., Thermal evolution of sedimentary basins in Alaska: U.S. Geological Survey Bulletin 2142, p. 11-19.

Möller, N.K., and Kvingan, K., 1988, The genesis of nodular limestones in the Ordovician and Silurian of the Oslo Region (Norway): Sedimentology, v. 35, p. 405-420.

Moore, D.M., and Reynolds, R.C., Jr., 1989, X-ray diffraction and the identification and analysis of clay minerals: Oxford University Press, 332 p.

Moore, G.W., 1967, Preliminary geologic map of Kodiak Island and vicinity, Alaska: U.S. Geological Survey Open-File Report 67-161, 1 plate, scale 1:250,000.

-1967, Preliminary geologic map of the Kodiak Islands and vicinity: U.S. Geological Survey Open File Report 271, 1 plate, scale 1:250,000.

Motyka, R.J., Liss, S.A., Nye, C.J., and Moorman, M.A., 1993, Geothermal resources of the Aleutian Arc, Alaska: Alaska Division of Geological \& Geophysical Surveys Professional Report 114, 17 p.

Murphy J.M., and Clough, J.G., 1999, Low-temperature thermal history using fission track dating in three wells in southern Alaska offshore basins; Lower Cook Inlet, Shelikof Strait, and Stevenson Trough: Marine Georesources and Geotechnology, v. 17, p. 271-281.

Naeser, C.W., 1979. Fission track dating and geological annealing of fission tracks, in Jager, E. and Hunziker, J.C., eds., Lectures in Isotope Geology: New York, Springer-Verlag, p. 154-169.

1981. The fading of fission tracks in the geologic environment; Data from deep drill holes: Nuclear Tracks, v. 5, p. 248-250.

Naeser, C.W., and Faul, H., 1969, Fission track annealing in apatite and sphene: Journal of Geophysical Research, v. 74, p. 705-710.

Newton, C.R., 1983, Paleozoogeographic affinities of Norian bivalves from the Wrangellian, Peninsular, and Alexander terranes, northwestern North America, in Stevens, C.H., ed., Pre-Jurassic rocks in western North American suspect terranes: Society of Economic Paleontologists and Mineralogists Symposium, Sacramento, CA, 1983, p. 37-48.

1983, Norian (Late Triassic) mollusks of Cordilleran allochthonous terranes: Paleoecology and paleozoogeography: Santa Cruz, University of California, Ph.D. thesis, 173 p.

1983, Paleozoogeographic affinities of Norian bivalves from the Wrangellian, Peninsular, and Alexander terranes, northwestern North America, in Stevens, C.H., ed., Pre-Jurassic rocks in western North American suspect terranes: Sacramento, CA, Society of Economic Paleontologists and Mineralogists Symposium, p. 37-48.

1989, Triassic-Jurassic boundary section at Puale Bay, Alaska Peninsula; Comparative diversity patterns of skeletal faunas and trace fossils: American Association of Petroleum Geologists Bulletin, v. 74, p. 730.

1990, Triassic-Jurassic boundary section at Puale Bay, Alaska Peninsula; Comparative diversity patterns of skeletal faunas and trace fossils [abs.]: American Association of Petroleum Geologists Bulletin, v. 74, no. 5, p. 730.

Nilsen, T., 1985, Sedimentology of tidally deposited Miocene Bear Lake Formation, Alaska Peninsula: American Association of Petroleum Geologists, Bulletin, v. 69, no. 4, p. 673.

Nilsen, T.H., 1984, Miocene back-arc tidal deposits of the Bear Lake Formation, Alaska Peninsula, in Reed, K.M., and Bartsch-Winkler, Susan, eds., The United States Geological Survey in Alaska; Accomplishments during 1982: U.S. Geological Survey Circular 939, p. 85-88.

Palache, Charles, 1904, Geology about Chichagof Cove, Stepovak Bay; with notes on Popof and Unga Islands (Alaska): Harriman Alaska Expedition, v. 4, p. 69-88.

Pálfy, József, 1997, Calibration of the Jurassic time scale: Vancouver, University of British Columbia, Ph.D. dissertation, $180 \mathrm{p}$.

Pálfy, József,, Smith, P.L., Mortensen, J.K., and Friedman, R.M., 1999, Integrated ammonite biochronology and U-Pb geochronometry from a basal Jurassic section in Alaska: Geological Society of America Bulletin, v. 111, no. 10 , p. 1,537-1,549. 
Pálfy, József,, Smith, P.L., Mortensen, J.K., and Friedman, R.M., 1999, Integrated ammonite biochronology and U-Pb geochronometry from a basal Jurassic section in Alaska: Geological Society of America Bulletin, v. 111, no. 10, p. 1,537-1,549.

Parker, J., and Newman, R., 1995, Alaska federal offshore; descriptions of geologic plays; 1995 national resource assessment: U.S. Minerals Management Service, North Aleutian Basin Assessment Province http://www.mms. gov/alaska/re/asmtdata/naleutia/naleplay.htm

Paul, T.A., and Fitzgerald, P.G., 1992, Transmission electron microscopic investigation of fission tracks in fluorapatite: American Mineralogist, v. 77, p. 336-344.

Peters, K.E., 1986, Guidelines for evaluating petroleum source rock using programmed pyrolysis: American Association of Petroleum Geologists Bulletin, v. 70, p. 318-329.

Peters, K.E., and Cassa, M.R., 1994, Applied source rock geochemistry, in Magoon, L.B., and Dow, W.G., eds., The petroleum system-from source to trap: American Association of Petroleum Geologists Memoir 60, p. 93-117.

Phillips Petroleum, 1974, Seismic program maps: BBNC files, data set index no. 422, 1 sheet, scale 1:250,000.

1974, Aeromagnetic interpretation, Chignik area: BBNC files, data set index no. 661, several sheets, multiple scales.

1974, BBNC program map, seismic; Nugashak, Dillingham, Naknek, Ugashik: BBNC files, data set index no. 668, several sheets, various scales.

1974, BBNC program map, seismic; Chignik, Sutwik Island, Stepovak Bay: BBNC files, data set index no. 669, several sheets, various scales.

1974, Chignik Bay and Mitrofinia shot points, BBNC files, data set index no. 712, 1 sheet, scale 1:8,000. 1974, Chignik Bay seismic interpretation: BBNC files, data set Index No. 711, 1 sheet, scale 1:8,000.

1974, Total magnetic intensity, Nushagak Basin, Alaska: BBNC files, data set index no. 744, 1 sheet, scale $1: 16,000$.

1975, Petrology report, Alaska Peninsula-Nushagak area for Bristol Bay Native Corporation: BBNC files, data set index no. 423, 73 p.

1975, Bouguer gravity maps, Mitrofinia area, Alaska: BBNC files, data set Index No. 560, 2 sheets, scale 1:63,360.

Pinart, A.L., 1873, Voyage à la côte nord-ouest de l'Amérique d’Ounalashka à Kadiak: Paris, Bulletin de la Société de Géographie, série VI, v. 6, p. 561-580.

Powell, T.G., and Boreham, C.J., 1994, Terrestrially sourced oils; Where do they exist and what are our limits of knowledge? - A geochemical perspective, in Scott, A.C., and Fleet, A.J., eds., Coal and coal-bearing strata as oil-prone source rocks?: Geological Society Special Publication No. 77, p. 11-29.

Price, P.B., and Walker, R.M., 1963, Fossil tracks of charged particles in gneiss and the age of minerals: Journal of Geophysical Research, v. 68, p. 4,847-4,862.

Reed, B.L., and Lanphere, M.A., 1973, Alaska-Aleutian Range batholith: Geochronology, chemistry, and relation to circum-Pacific plutonism: Geological Society of America Bulletin 84: p. 2,583-2,610.

Reed, B.L., Miesch, A.T., and Lanphere, M.A., 1983, Plutonic rocks of Jurassic age in the Alaska-Aleutian Range batholith: chemical variations and polarity: Geological Society of American Bulletin, v. 94, p. 1232-1240.

Reifenstuhl, R.R., and McCarthy, Paul, 2004, Petroleum reservoir characterization, source rock potential, fossil fuel resources, and basin analyses, Bristol Bay Basin, Alaska: AETDL Quarterly Report, October, 2004,1 p.

Reifenstuhl, R.R., Bailey, R.D., and Finzel, E.S., 2005, Bristol Bay and Alaska Peninsula 2004: Fieldwork and sample analyses compilation report: Alaska Division of Geological \& Geophysical Surveys Preliminary Interpretive Report 2005-1, 20 p.

Reifenstuhl, R.R., Decker, P.L., Gillis, R.J., Helmold, K.P., and Strauch, A., 2007, Hydrocarbon systems, basin analyses, and 2006 field and subsurface data; Bristol Bay, Alaska Peninsula, Frontier Basin [abs.]: American Association of Petroleum Geologists Bulletin, v. 91, Program Abstracts (digital).

Reifenstuhl, R.R., Shafer, D.C., Ryherd, T.J., Brizzolara, D.W., and Blodgett, R.B., 2004, Summary of May 25-June 4, 2004, field notes and samples, Puale Bay and Wide Bay areas, Alaska Peninsula: Alaska Division of Geological \& Geophysical Surveys Raw Data File 2004-3, 16 p.

Riehle, J.R., and Detterman, R.L., 1993, Quaternary geologic map of the Mount Katmai quadrangle and adjacent parts of the Naknek and Afognak quadrangles, Alaska: U.S. Geological Survey Miscellaneous Investigations Series Map 2032, 1 plate, scale 1:250,000. 
Riehle, J.R., Detterman, R.L., Yount, M.E., and Miller, J.W., 1993, Geologic map of the Mt. Katmai quadrangle and portions of the Naknek and Afognak quadrangles, Alaska: U.S. Geological Survey Miscellaneous Investigations Series Map I-2204, 1 plate, scale 1:250,000. [see USGS Open-File Report 87-593]

Riehle, J.R., Wilson, F.H., Shew, Nora, and White, W.H., 1999, Geology of Unga Island and the northwestern part of Popof Island, in Riehle, J.R., ed., A geological and geophysical study of the Gold-Silver vein systems of Unga Island, southwestern Alaska: U.S. Geological Survey Open-File Report 99-136, CD-ROM.

Saltus, R.W., Connard, G.G., and Hill, P.L., 1999, Alaska aeromagnetic compilation-digital grids and survey data: U.S. Geological Survey Open-File Report 99-502, CD-ROM.

Saltus, R.W., Haeussler, P.J., Bracken, R.E., Doucette, J.P., and Jachens, R.C., 2001, Anchorage Urban Region Aeromagnetics (AURA) Project - preliminary geophysical results: U.S. Geological Survey Open-File Report 01-0085, $21 \mathrm{p}$.

Saltus, R.W., Hudson, T.L., Wilson, F.H., 2003, Geophysical identification and geological implications of the southern Alaska magnetic trough, U.S. Geological Survey Open-File Report 03-200, 1 plate (poster).

Sandy, M.R., Blodgett, R.B., and Frýda, J., 2001, Paleobiogeographic signatures for Upper Triassic brachiopods and gastropods from Kuiu Island and adjacent Keku Strait, SE Alaska [abs.]: Geological Society of America Abstracts with Programs, v. 33, no. 3, p. A-53.

Scholl, D.W., Vallier, T.L., and Stevenson, A.J., 1986, Terrane accretion, production, and continental growth; A perspective based on the origin and tectonic fate of the Aleutian-Bering Sea region: Geology, v. 14, p. 43-47.

1987, Geologic evolution and petroleum geology of the Aleutian Ridge, in Scholl, D.W., Grantz, Arthur, and Vedder, J.G., eds., Geology and resource potential of the continental margin of western North America and adjacent ocean basins, Beaufort Sea to Baja California: Houston, TX, Circum-Pacific Council For Energy and Mineral Resources, Houston, TX, p. 73-102.

Schreurs, G., and Colletta, B., 2002, Analog modelling of continental transpression, in Schellart, P., and Passchier, C., eds., Analogue modelling of large-scale tectonic processes: Journal of the Virtual Explorer, v. 7., p. 67-78.

Sherwood, K.W., and Craig, J.D., 2001, Prospects for development of Alaska natural gas—A review: U.S. Minerals Management Service, Resource Evaluation Office, 135 p.

Sherwood, K.W., Comer, D., and Larson, J., 2003, Review of geologic model for North Aleutian Basin: U.S. Minerals Management Service, "Handout," 25 p.

Sherwood, K.W., Craig, J.D., and Cooke, L.W., 1996, Endowments of undiscovered conventionally recoverable and economically recoverable oil and gas in the Alaska federal offshore: U.S. Minerals Management Service, Alaska Outer Continental Shelf Region, OCS Report MMS 96-0033, 6 p.

Sherwood, K.W., Larson, J., Comer, C.D., Craig, J.D., and Reitmeier, C., 2006, North Aleutian basin OCS planning area assessment of undiscovered technically-recoverable oil and gas: U.S. Minerals Management Service Alaska OCS Region report, 138 p., 4 plates, www.mms.gov/alaska/re/reports/rereport.htm

Silberling, N.J., 1985, Biogeographic significance of the Upper Triassic bivalve Monotis in circum-Pacific accreted terranes, in Howell, D.G., ed., Tectonostratigraphic terranes of the Circum-Pacific region: Circum-Pacific Council for Energy and Mineral Resources Earth Sciences Series No. 1, p. 63-70.

Silberling, N.J., Grant-Mackie, J.A., and Nichols, K.M., 1997, The Late Triassic bivalve Monotis in accreted terranes of Alaska: U.S. Geological Survey Bulletin 2151, 21 p.

Smith, J.P., 1927, Upper Triassic marine invertebrate faunas of North America: U.S. Geological Survey Professional Paper 141, 262 p.

Smith, W.R., 1924, The Upper Cretaceous invertebrate fauna of Alaska: Baltimore, MD, The Johns Hopkins University, unpublished Ph.D. dissertation, $178 \mathrm{p}$.

1925, The Cold Bay-Katmai district, in Mineral resources of Alaska; report on progress of investigations in 1923: U.S. Geological Survey Bulletin 773, p. 183-207.

1926, Geology and oil development of the Cold Bay district, in Mineral Resources of Alaska; Report on progress of investigations in 1924: U.S. Geological Survey Bulletin 783, p. 63-88.

Smith, W.R., and Baker, A.A., 1924, The Cold Bay-Chignik district, in Mineral resources of Alaska; Report on progress of investigations in 1922: U.S. Geological Survey Bulletin 755, p. 151-218.

Sneider, R.M., 1997, Petrophysical properties of seals, in Surdam, R.C., ed., Seals, traps and the petroleum system: Tulsa, OK, American Association of Petroleum Geologists Memoir 67, 317 p.

Spicer, R.A., 1987, Late Cretaceous floras and terrestrial environment of northern Alaska, in Tailleur, Irv, and Weimer, Paul, eds., Arctic North Slope Geology, Volume 1: Pacific Section, SEPM, and The Alaska Geological Society, p. 497-512. [Mentions floras from Chignik area, Nelson Island, Nunivak Island, Yukon River, North Slope; see fig. 2 for location] 
Spurr, J.E., 1900, A reconnaissance in southwestern Alaska in 1898: U.S. Geological Survey 20th Annual Report, Part 7, p. 31-264.

Sralla, Bryan, 2007, Structural geometry, kinematics, and hydrocarbon exploration potential of Sapsuk Lake anticline, Herendeen Bay region, Alaska Peninsula [abs]: Alaska Geology, v. 38, no. 1, p. 1-2.

Sralla, Bryan, and Blodgett, R.B., 2007, Reservoir potential of Late Triassic Kamishak Formation; Puale Bay, Alaska Peninsula [abs.]: American Association of Petroleum Geologists Annual Convention \& Exhibition, Long Beach, CA, 2007, Abstracts, v. 91 (digital), p. 132.

Stanley, G.D., Jr., 1979, Paleoecology, structure, and distribution of Triassic coral buildups in western North America: University of Kansas Paleontological Contributions, v. 65, p. 1-58.

Stanton, T.W., and Martin, G.C., 1905, Mesozoic section on Cook Inlet and Alaska Peninsula: Geological Society of America Bulletin, v. 16, p. 391-410.

Strauch, A.L., Gillis, R.J., Reifenstuhl, R.R., and Decker, P.L., 2006, 2006 Bristol Bay, Alaska Peninsula field summary and outcrop sample results from porosity \& permeability and mercury injection capillary pressure analyses: Alaska Division of Geological \& Geophysical Surveys Raw Data File 2006-1, 65 p.-

Streckeisen, A., 1976, To each plutonic rock its proper name: Earth Science Review, v. 12, p. 1-33.

Swanson, B.F., 1981, A simple correlation between permeabilities and mercury capillary pressures: Journal of Petroleum Technology, p. 2,498-2,504.

Symonds, R.B., Ritchie, B.E., McGimsey, R.G., Ort, M.H., Poreda, R.J., Evans, W.C., and Janik, C.J., 1997, Investigations of gas seeps and springs in the vicinity of The Gas Rocks, south shore Becharof Lake, Alaska: U.S. Geological Survey Open-File Report 97-0127, 27 p.

Tagami, T., and O’Sullivan, P.B., 2005, Fundamentals of fission-track thermochronology: Reviews in Mineralogy and Geochemistry, v. 58, p. 19-47.

Teller, Friedrich, 1886, Die Pelecypod-Fauna von Werchojansk in Ostsiberien, in Mojsisovics, Edmund, von, ed., Arktische Triasfaunen: Mémoires de l'Académie Impériale des Sciences de St.-Pétersbourg, 7th ser., v. 33, no. 6, p. 103-137.

Thomas, C.P., Doughty, T.C., Faulder, D.D., and Hite, D.M., 2004, South-central Alaska natural gas study: U.S. Department of Energy, National Energy Technology Laboratory-Arctic Energy Office, www.netl.doe.gov, 207 p.

Tissot, B.P., and Welte, D.H., 1984, Petroleum formation and occurrence, 2nd ed.: Berlin, Springer-Verlag, 699 p.

Triplehorn, D.M., 1976, Large kaolinite crystals in the Chignik Formation (Upper Cretaceous), Herendeen Bay, in Short Notes on Alaskan Geology 1976: Alaska Division of Geological \& Geophysical Surveys Geologic Report 51F, p. 23-25.

Troutman, S.M., and Stanley, R.G., 2003, Maps showing sedimentary basins, surface thermal maturity, and indications of petroleum in the Central Alaska Province, U.S. Geological Survey Miscellaneous Field Studies Map 2428, pamphlet, 2 plates, scale 1:2,500,000.

Tucker, M.E., and Wright, V.P., 1990, Carbonate Sedimentology: Oxford, England, Blackwell Publishing, 482 p. Turner, R.F., ed., 1988, Geological and operational summary, North Aleutian Shelf COST No. 1 well, Bering Sea, Alaska:U.S. Minerals Management Service, OCS Report MMS 88-0089, 256 p., 2 plates.

U.S. Geological Survey, 1963, Aeromagnetic survey of parts of the Ugashik and Karluk quadrangles: BBNC files, data set index no. 526, 1 plate, scale 1:125,000.

1963, Aeromagnetic map of parts of the Dillingham quadrangle: BBNC files, data set index no. 727, 1 plate, scale $1: 125,000$.

1971, Aeromagnetic survey, Goodnews area, Bethel A-1 through A-5 quadrangles: BBNC files, data set index no. 528, 1 plate, scale 1:63,360.

U.S. Geological Survey, 1971, Aeromagnetic survey, Goodnews area, Hagemeister C-3 through C-7 and D-1 through D-6 quadrangles: BBNC files, data set index no. 529, 11 sheets, plate 1:63,360.

1971, Aeromagnetic survey, Goodnews area, Goodnews Bay A-1 through A-8, B-1 through B-8, and C-1 through C-8 quadrangles: BBNC files, data set index no. 530, 24 plates, scale 1:63,360.

1971, Aeromagnetic survey, Goodnews area, Nushagak Bay B-4, C-4, and D-4 through D-8 quadrangles: BBNC files, data set index no. 531, 5 plates, scale 1:63,360.

1975, Aeromagnetic map of part of the Naknek quadrangle, Alaska: BBNC files, data set index no. 505, 1 plate, scale 1:250,000.

1978, Aeromagnetic map of Chignik and Sutwik Island quadrangles, Alaska: U.S. Geological Survey Open-File Report 78-262, 1 plate, scale 1:250,000. 
U.S. Geological Survey, 1978, Aeromagnetic maps of the Chignik and Sutwik Island quadrangles: BBNC files, data set index no. 556, 11 plates, scale 1:63,360.

1978, Aeromagnetic map of the Chignik and Sutwik Island quadrangles: BBNC files, data set index no. 557, 1 plate, scale 1:250,000.

1995, 1995 national assessment of the United States oil and gas resources: U.S. Geological Survey National Oil and Gas Resource Assessment Team, U.S. Geological Survey Circular 1118, 20 p.

U.S. Minerals Management Service, 1985, Final Environmental Impact Statement, North Aleutian Basin Sale No. 92, OCS EIS/EA MMS 85-0052, v. 1, 583 p., http://www.mms.gov/alaska/ref/EIS\%20EA/N_Aleutian_Basin_FEIS_92/ mms85_0052Volume1.pdf

2000, Undiscovered Oil and Gas Resources, Alaska Federal Offshore, December 2000 Update, U.S. Minerals Management Service, 5 p., http://www.mms.gov/alaska/re/uogr/uogr.pdf.

2006, North Aleutian Basin planning area (Alaska); Province summary, 2006 oil and gas assessment, (http://www.mms.gov/alaska/re/reports/2006Asmt/NAGA/naga.HTM), 24 p.

Union Oil, 1974, Plate 2B, Seismic project map, Nushagak Project: BBNC files, data set index no. 670, 1 sheet, scale $1: 63,360$.

Vacquier, V., 1963, General principles, in Vacquier, V., Steenland, N. C., Henderson, R.G., and Zietz, I., Interpretation of aeromagnetic maps: Geological Society of America Memoir 47, 151 p., 14 plates.

Van Kooten, G.K., Short, J.W., and Kolak, J.J., 2002, Low-maturity Kulthieth Formation coal; A possible source of the polycyclic aromatic hydrocarbons in benthic sediments of the northern Gulf of Alaska: Environmental Forensics, v. 3, p. 227-241.

Veach, N.J., 1973, Aeromagnetic map, northeastern part of Hagemeister Island Quadrangle: Alaska Division of Geological \& Geophysical Surveys Alaska Open-File Report 16, 5 p., 1 sheet, scale 1:250,000.

von Huene, Roland, Moore, J.C., and Moore, G.W., 1979, Cross section of Alaska Peninsula-Kodiak Island-Aleutian Trench: Geological Society of America Map and Chart Series, 1979, v. MC-28A, 2 sheets, scale 1:250,000.

Waldron, H.H., 1961, Geologic reconnaissance of Frosty Peak Volcano and vicinity, Alaska: U.S. Geological Survey Bulletin 1028-T, p. 677-708, 1 plate, scale 1:250,000.

Walker, K.T., McGeary, S.E., and Klemperer, S.L., 2003, Tectonic evolution of the Bristol Bay basin, southeast Bering Sea: Constraints from seismic reflection and potential field data: Tectonics, v. 22, no. 5, p. 19.

Wang, Jason, 1987, Sedimentology of Norian (Late Triassic) cherts and carbonates from the Peninsular Terrane, Puale Bay, Alaska Peninsula: Syracuse, NY, Syracuse University, unpublished M.S. thesis, 124 p.

Wang, Jason, Newton, C.R., and Dunne, L., 1988, Late Triassic transition from biogenic to arc sedimentation on the Peninsular terrane, Puale Bay, Alaska Peninsula: Geological Society of America Bulletin, v. 100, no. 9, p. $1,466-1,478$.

Waples, D., 1981, Organic geochemistry for exploration geologists: Minneapolis, Minnesota, Burgess Publishing Company, $151 \mathrm{p}$.

Weems, R.E., and Blodgett, R.B., 1996, The Pliosaurid Megalneusaurus; A newly recognized occurrence in the Upper Jurassic Naknek Formation of the Alaska Peninsula, in Moore, T.E., and Dumoulin, J.A., eds., Geologic studies in Alaska by the U.S. Geological Survey, 1994: U.S. Geological Survey Bulletin 2152, p. 169-175.

Westermann, G.E.G., 1964, The ammonite fauna of the Kialagvik Formation at Wide Bay, Alaska Peninsula, Part 1, Lower Bajocian (Aalenian): Bulletins of American Paleontology, v. 47, no. 216, p. 327-503.

1969, The ammonite fauna of the Kialagvik Formation at Wide Bay, Alaska Peninsula, Part 2, Sonninia Sowerbyi Zone (Bajocian): Bulletins of American Paleontology, v. 57, no. 255, p. 4-226.

_1978, Alaskinia nom. nov. for Alaskoceras Westermann, 1969 non Miller and Kummel, 1945; Jurassic Ammonitina: Journal of Paleontology, v. 52, p. 604.

Wetzel, A., and Werner, F., 1980, Morphology and ecological significance of Zoophycos in deep-sea sediments off northwest Africa: Palaeogeography, Palaeoclimatology, Palaeoecology, v. 32, p. 185-212.

Whalen, M., this volume.

Whalen, M.T., Eberli, G.P., van Buchem, F.S.P., Mountjoy, E.W., and Homewood, P.W., 2000, Bypass margins, basin-restricted wedges and platform-to-basin correlation, upper Devonian, Canadian Rocky Mountains; Implications for sequence stratigraphy of carbonate platform systems: Journal of Sedimentary Research, v. 70, p. 913-936.

White, C.A., 1889, Mesozoic molluscs from the southern coast of the Alaskan Peninsula: U.S. Geological Survey Bulletin 51, p. 64-70. 
Whitney, John, Hoose, P.J., Smith, L.M., and Lybeck, Lynn, 1980, Geologic cross sections of the Outer Continental Shelf of Shelikof Strait, Alaska: U.S. Geological Survey Open-File Report 80-2036, 1 plate, scale 1:250,000.

Wilson, F.H., 1977, Some plutonic rocks of southwestern Alaska, a data compilation: U.S. Geological Survey Open-File Report 77-501, 7 p., 4 plates, scale 1:1,000,000.

-1985, The Meshik arc - An Eocene to earliest Miocene magmatic arc on the Alaska Peninsula: Alaska Division of Geological \& Geophysical Surveys Professional Report 88, 14 p.

1989, Geologic setting, petrology, and age of Pliocene to Holocene volcanoes of the Stepovak Bay area, western Alaska Peninsula, in Dover, J.H., and Galloway, J.P., eds., Geologic studies in Alaska by the U.S. Geological Survey, 1988: U.S. Geological Survey Bulletin 1903, p. 84-95.

Wilson, F.H., and Coonrad, W.L., 2005, The Togiak-Tikchik Complex of southwestern Alaska, a replacement for the Gemuk Group: Stratigraphic nomenclature that has outlived its time: U.S. Geological Survey Scientific Investigations Report 2005-5019, 12 p.

Wilson, F.H., and Shew, N., 1992, Map and tables showing geochronology and whole-rock geochemistry of selected samples, Ugashik and part of Karluk quadrangles, Alaska: U.S. Geological Survey Miscellaneous Field Studies Map MF-1539-E, 12 p., 1 plate, scale 1:250,000.

Wilson, F.H., and Weber, F.R., 2001, Quaternary geology, Cold Bay and False Pass quadrangles, Alaska Peninsula, in Gough, L.P., and Wilson, F.H., eds., Geologic studies in Alaska by the U.S. Geological Survey, 1999: U.S. Geological Survey Professional Paper 1633, p. 51-71.

Wilson, F.H., Case, J.E., and Detterman, R.L., 1985, Preliminary description of a Miocene zone of structural complexity in the Port Moller and Stepovak Bay quadrangles, Alaska, in Bartsch-Winkler, Susan, and Reed, K.M., eds., The United States Geological Survey in Alaska, Accomplishments during 1983: U.S. Geological Survey Circular, 945, p. 55-56.

Wilson, F.H., Detterman, R.L., and Case, J.E., 1985, The Alaska Peninsula terrane; A definition: U.S. Geological Survey Open-File Report 85-450, 17 p.

Wilson, F.H., Detterman, R.L., and DuBois, Gregory, 1999, Digital data for the geologic framework of the Alaska Peninsula, Southwest Alaska, and the Alaska Peninsula Terrane: U.S. Geological Survey Open-File Report 99-317, 41 p., 1 plate, scale 1:500,000, http://wrgis.wr.usgs.gov/open-file/of99-317.

Wilson, F.H., Detterman, R.L., Miller, J.W., and Case, J.E., 1995, Geologic map of the Port Moller, Stepovak Bay, and Simeonof Island quadrangles, Alaska Peninsula, Alaska: U.S. Geological Survey Miscellaneous Investigations Series Map I-2272, 2 plates, scale 1:250,000.

Wilson, F.H., Gajewski, S.Z., and Angeloni, L.M., 1986, Geological literature of the Alaska Peninsula to 1985: U.S. Geological Survey Open-File Report 86-176, 113 p.

Wilson, F.H., Gaum, W.C., and Herzon, P.L., 1981, Maps and tables showing geochronology and whole-rock geochemistry, Chignik and Sutwik Island quadrangles, Alaska: U.S. Geological Survey Miscellaneous Field Studies Map MF-1053-M, 3 plates, scale 1:250,000.

Wilson, F.H., Hudson, T.L., Grybeck, Donald, Stoeser, D.B., Preller, C.C., Bickerstaff, Damon, Labay, Keith, and Miller, M.L., 2003, Preliminary geologic map of the northeast Dillingham quadrangle (D-1, D-2, C-1, and C-2), Alaska: U.S. Geological Survey Open-File Report 03-105, 13 p., 1 plate, scale 1:100,000.

Wilson, F.H., Shew, N., DuBois, G.D., and Bie, S.W., 1994, Sample locality map and analytical data for potassium-argon ages in the Port Moller, Stepovak Bay, and Simeonof Island quadrangles, Alaska Peninsula: U.S. Geological Survey Miscellaneous Field Studies Map MF-2155-E, 18 p., 1 plate, scale 1:250,000.

Wilson, F.H., Weber, F.R., Dochat, T.M., Miller, T.P., and Detterman, R.L., 1997, Revised geologic map of the Cold Bay and False Pass quadrangles, Alaska Peninsula: U.S. Geological Survey Open-File Report 97-866, 34 p., 1 plate, scale 1:250,000.

Wisehart, R.M., 1971, Paleoenvironmental analysis of the Bear Lake Formation (upper and middle Miocene), Alaska Peninsula, Alaska: Los Angeles, CA, University of California, M.S. thesis, 112 p.

Worrall, D.M., 1991, Tectonic history of the Bering Sea and the evolution of Tertiary strike-slip basins of the Bering Shelf: Geological Society of America Special Paper 257, 120 p., 1 oversize sheet, 4 plates, scale 1:2,500,000.

Yount, M.E., Wilson, F.H., and Miller, J.W., 1985, Newly discovered Holocene volcanic vents, Port Moller and Stepovak Bay quadrangles, Alaska Peninsula, in Bartsch-Winkler, Susan, and Reed, K.M., eds., The United States Geological Survey in Alaska, Accomplishments during 1983: U.S. Geological Survey Circular, 945, p. 60-62.

Zhang, Ning, Blodgett, R.B., and Stanley, G.D., 2003, Paleontological database applications for Alaskan terrane studies [abs.]: Geological Society of America Abstracts with Programs, v. 35, no. 4, p. 24. 